\title{
SCHLICH'S
}

Manual of Forestry

Vol. IV.

FOREST PROTECTION

W. R. FISHER 


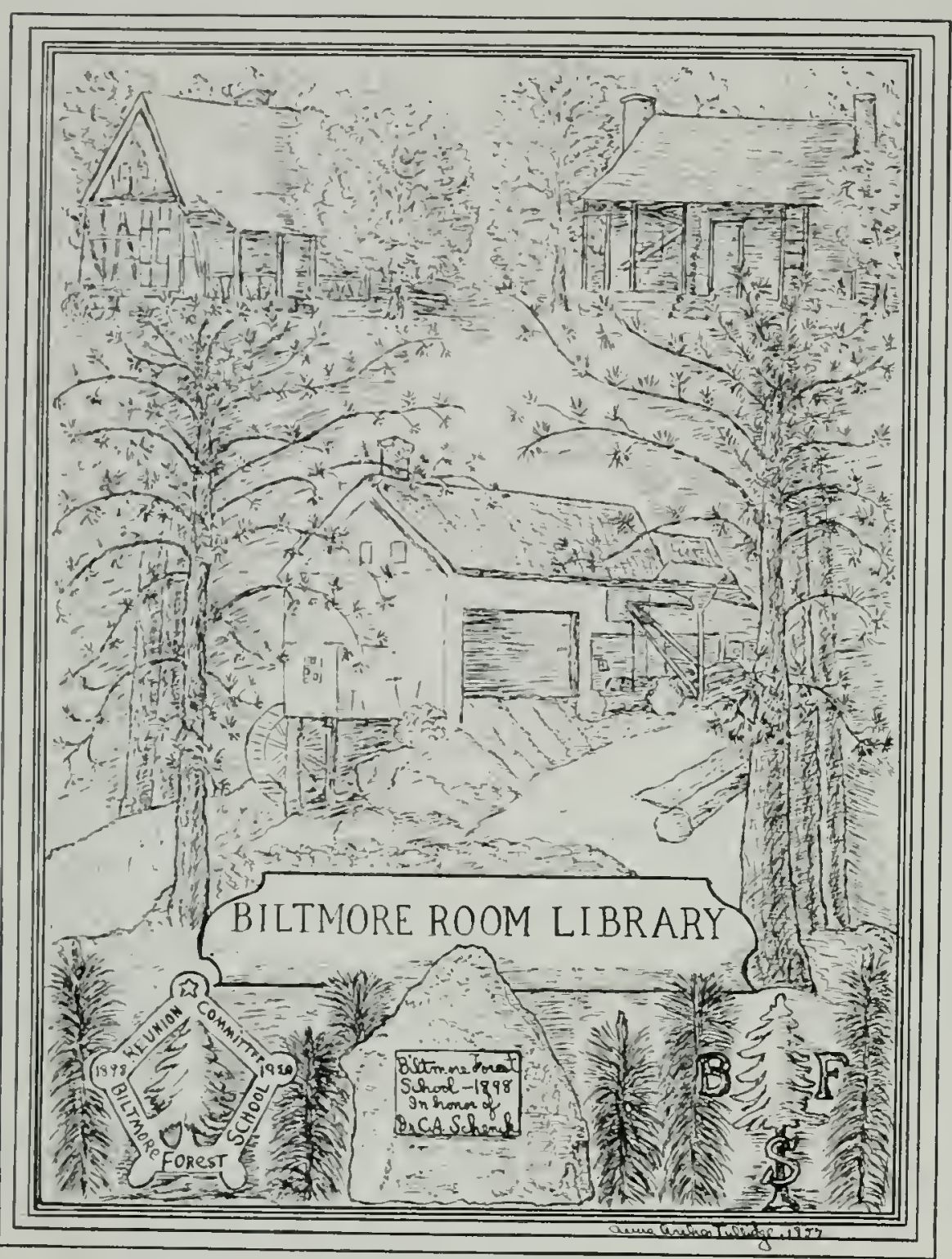




\title{
DR. SCHLICH'S
}

\section{MANUAL OF FORESTRY.}

VOLUME IV.

\section{FOREST PROTECTION,}

$\mathrm{BY}$

\author{
W. R. FISHER, B.A., \\ ASEISTANT PROFESSOR OF FORESTRT, Ri)YAL INDIAN ENGINEERING COLLEGE, \\ COOPERS HILL; \\ LATE COXSERYATOR OF FORESTS TO THE GOVERNMEXT OF IXDIA;
}

WITH 259 ILLUSTRATIONS,

BEIsG

AN ENGLISH ADAPTATION OF

"DER FORSTSCHUTZ," вY DR. RICHARD HESS, PROFESSOR OF FORESTRY AT THE CXIVERSITY OF GIESSEN.

LONDON :

BRADBURT, AGNEW, \& CO. LD., 8, 9, 10, BOUVERIE STREET. 1895. 
<smiles>CCCCCCC</smiles> 


\section{PREFACE.}

Dr. W. Schlich, C.I.E., has allowed the present book to form Volume IV. of his Manual of Forestry. For this favour I have therefore to thank him, as well as for the kind advice and assistance he has always readily afforded me during the progress of the work. This treatise on Forest Protection, the full scope of which is explained in the Introduction, is an adaptation for English readers of the well-known German Forstschutz, by Dr. Richard Hess, Professor of Forestry at the University of Giessen, in Hesse Darmstadt, to whom I am most grateful for permission to utilize his book and its illustrative plates. I have found it at times necessary to deviate from the original, especially in the chapters on Forest Offences and Rights and Forest Insects, so as to render them more serviceable for English readers. I have also, wherever practicable, exemplified the subject-matter from Britain and India, so that the book might be specially useful to British and Indian foresters.

Mr. B. H. Baden Powell, C.I.E., Instructor in Forest Law at the Royal Indian Engineering College, and late Judge of the Chief Court of the Punjab, has very kindly revised Chapters III. and IV. of Part I., which deal with Forest Offences and Rights, and has rewritten the pages on forest property and the general account of forest rights, so as to make them concordant with English law. My own knowledge of insects is too inadequate to enable me to deal properly with Part II., Chapters IV. to VIII. which treat of Forest Insects; I have therefore submitted my translation of this portion of the Fonstschutz to Mr. W. F. H. Blandford, F.Z.S., lecturer on Entomology at the Royal Indian Engineering College, and I here express my great obligation to 
him for revising these chapter's and rewriting many pages of them, so as to make them more distinetly applicable to British insects. While those portions of the work of Dr. Hess which deal with insects unknown in the British Isles have been largely abridged or entirely omitted, it has not been found possible or advisable to remodel the ehapters on insects from an entirely British point of view. The scientific names of the insects referred to hare been altered, wherever this was required, so as to conform with the nomenclature adopted in the best modern systematic works on British entomology.

Dr. H. Marshall Ward, F.R.S., has very kindly looked over Part III. which deals with forest weeds and fungi, in which he has made some corrections. The scientific names of the forest weeds follow Hooker's and Bentham's British Flora, 1892, and those of the fungi, R. Hartig's Lenrbuch Der BaumIranineiten, being nearly all the same as those adopted by Dr. Hess.

My colleagne Dr.F. E. Matthews, F.I.C., has very kindly assisted me wherever any special knowledge of chemistry was required, as in the last chapter dealing with the effects of acid fumes on trees, and also in eorrecting proofs of the whole book. I have to thank Mr. J. W. Sowerby, of the Botanic Gardens, Regent's Park, for information supplied regarding the effects of London smoke on the growth of trees.

Niss E. Ormerod has lindly placed at my disposal three plates (tigs. 135, 136, 137) from her "Manual of Injurions Insects;" Dr. Maxwell T. Masters, F.R.S., has lent me a plate (fig. 233), taken from the Gardeners' Chronicle; and Dr. H. Marshall Ward two plates (figs. 258 and 259), taken from his Croonian lecture, and published in Vol. 47. of the Proceedings of the Royal Society.

Dne reference will be found in the footnotes to the anthors whose works I have consulted.

C'OOpers Hill C'Oldege, W. R. FISHER. May 1st, 1895. 


\section{TABLE OF CONTENTS.}

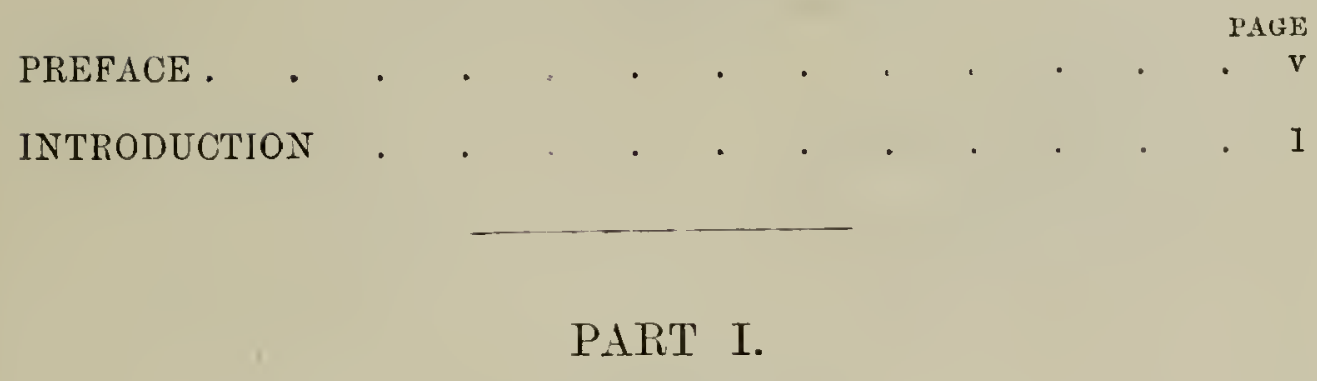

PROTECTION OF FORESTS AGAINST MAN.

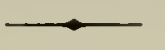

CHAPTER I.

FOREST BOUNDARIES.

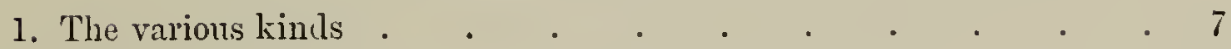

2. Settlement . . . . . . . . 8

3. Demarcation . . . . . . . . . . 9

4. Survey . . . . . . . . . 16

5. Description . . . . . . . . . . 16

6. Legalisation . . . . . . . . . . . 16

7. Upkeep . . . . . . . . . . . . 17

8. Cost . . . . . . . . . . . . 17

9. Improvement . . . . . . . . . . . 18

\section{CHAPTER II.}

PROTECTION OF FORESTS AGAINST IRREGULARITIES IN UTILIZING FOREST PRODUCE.

Section I.-Principal Prodtce.

1. General account . . . . . . . . . 19

2. Overfelling . . . . . . . . . 19

3. Unscientific felling . . . . . . . . . 20

4. Careless conversion . . . . . . . . . . 21

5. Bad stacking . . . . . . . . . . . 22

6. Careless transport . . . . . . . . . . 22 
Section II. - Misol: Pronucl.

1. General account . . . . . . . . . . 22

2. Bark . . . . . . . . . . . . 23

3. Turpentine, resin, and gums . . . . . . . . . . 23

4. Leares and branches of forest trees . . . . . . . 25

5. Fruits of forest trees (collection) . . . . . . . . . 26

,,$\quad$ (pannage) . . . . . . . . 26

6. Grass and herbage (grass-cuttings) . . . . . . . . . 29

8. Dead branch-wood . . . . . . . . . . 45

9. Stones, gravel, sand, Sc. . . . . . . . . . . 46

10. Other produce. . . . . . . . . . 46 46

11. Game and fisheries . . . . . . . . 47

\section{CHAPTER III.}

PROTECTION OF THE FOREST AGAINST OFFENCES.

1. General account . . . . . . . . . 48

2. Definition of forest offences . . . . . . . . 48

3. Classification of forest offences. . . . . . . . . . . . 49

4. Protective rules . . . . . . . . . . 52

CHAPTER IV.

PROTECTION AGAINST FOREST RIGHTS.

Sectior I. -Gexeral View of Eniest's as "Estates" or Pieces of Prolerty . . . . . . . . 56

" II.-Geveral Account of Forest Rights . • . . 59

2. III.-Sprecial Accoust of Follest Rights . . . . . 68 


\section{PART II.}

PROTEOTION OF THE FOREST AGANST ANIMALS.

Introductory remarks .

PAGE 82

\section{CHAPTER I.}

\section{PROTECTION AGAINST GAME.}

Section I.-Gexeral Account . . . . . . . . . 84

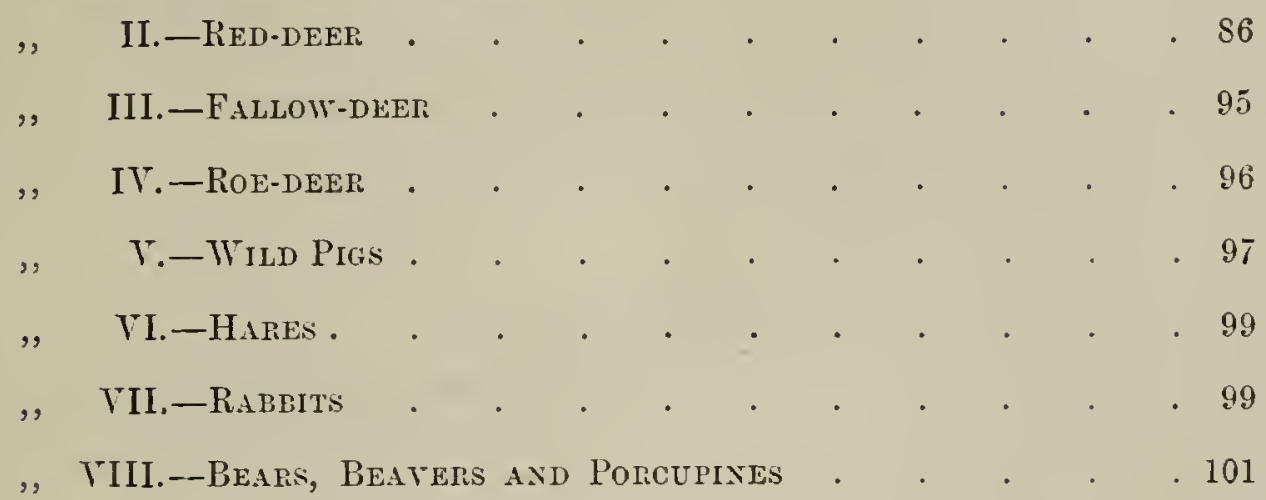

\section{CHAPTER II.}

PROTECTION AGAINST OTHER RODENTS.

Secliox I.-Gexelial Accourt . . . . . . . . 102

,, II.-SQUIRkels . . . . . . . . . 103

, III.-DORMIICE . . . . . . . . . . . . . . . 107

IV. - MICE . . . . . . . . . . . . . 108

, T.-TOLES . . . . . . . . . . . . . 109

CHAPTER III.

PROTECTION AGAINST BIRDS.

Section I.-Gexeral Accoust . . . . . . . . . 120

„ II.-Capercallie, Grouse axd Pheasists • • • . 121

,. III._PIgEONS AND Dores . . . . . . . . 122

, IV.-JAYs AND NtTcrackers . . . . . . . . 123

,. Y.-Fisches axd other Simal Birds . . . . . 124

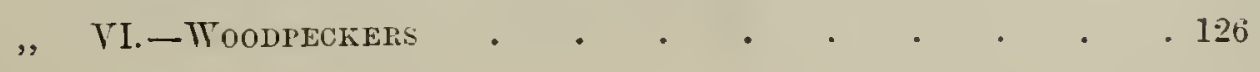


CHAPTER IV.

FOREST INSECTS (GENERAL ACCOUNT).

Sectioy I -Ciassificatios -

" Il.-Distimibution . . . . . . . . . . 136

", III.-Life-History . . . . . . , 137

") IV.-Number . . . . . . . . . 141

" V.-Useful Foriest Ixsects . . . . . . . . 141

,. VI.-Injurious Forest INwiets . . . . . . . 142

1. Damage done . . . . . . . . . . . 142

2. Preventive rules (Protection of insectivorons birds, \&c.) . . . 144

3. Remedial measures . . . . . . . . . . . 152

4. Treatment of injured woods . . . . . . . . 156

\section{CHAPTER V.}

INSECTS USEFUL TO FORESTS (SPECIAL ACCOUNT).

Order I.-Coleottera. . . . . . . . . . 158

, II.-HYMexopterA . . . . . . . . . 162

, III.-Dipteita . . . . . . . . . . . 171

IV.-NeUroptera . . . . . . . . . . 172

" V.-Orthoptera (Pseudoneutioltera) . . . . . . 174

", VI.-Heniptera . . . . . . . . . . 174

\section{CHAPTER VI.}

INJURIOUS FOREST INSIECTS (SPECIAL ACCOUNT OF COLEOPT'ELA).

Family I. - Scatrabeide.

1. Helolontha vulgaris (Common cockclafer) . . . . . . 177

2. M. hippocesteni . . . . . . . . . . . 154

3. Rhizotrogues solstitictlis (June chafer) . . . . . . . . 185

Fanily II.-Buprestide.

1. Agrilus viridis . . . . . . . . . . . 186

2. Other species . . . . . . . . . . . . . . 158

Fanim III.-Elattidide (Click-beetles) . . . . . . . 189

$" \quad$ IV.-LYMEXYLONid.e.

Lymexylon navale . • . . . • . . . . . . 190 
FAMILy V.-AพовHDe.

Iestobium tesselatum

Family VI.-Curculionide (Weevils).

1. Apoderus coryli . . . . . . . . . . 193

2. Rhynchites betule . . . . . . . . . . . 193

3. Strophosomus coryli. . . . . . . . . . 194

4. Balaninus nucum (Nut-weevil) . . . . . . . . 195

5. Orchestes fagii . . . . . . . . . . . . . 196

6. O. quercus . . . . . . . . . . . . . 197

7. Cryptorrhynehus lapathi . . . . . . . . . 198

8. Hylobius abictis (Pine-weevil) . . . . . . . . 199

9. Pissodes notatus . . . . . . . . . . . . 205

10. Other species . . . . . . . . . . 208

FAMILY VII. -Scolytide (Bark-beetles).

(a) Subfamily Tomicini.

1. Tomicus typographus . . . . . . . . . 210

2. T. amitinus . . . . . . . . . . 218

3. T. chalcographus . . . . . . . . . 219

4. T. sexdentalus. . . . . . . . . . 221

万. T. Tericis . . . . . . . . . . . . . . 223

6. T. bidentatus . . . . . . . . . . . . . 226

7. T. acuminatus. . . . . . . . . . . . 228

8. Trypodcudron lincatum . . . . . . . . . . 228

9. T. domestieum . . . . . . . . . . . . . . 231

10. Nyleborus dispar . . . . . . . . . . . 232

(b) Subfamily Hylesinini.

1. Hylastes pallicatres . . . . . . . . . . 234

2. H. ater . . . . . . . . . . . 236

3. Hylurgus piniperda (Pine-beetle) . . . . . . . 237

4. H. minor . . . . 243

5. Hylesinus forctini (Ash-bark beetle) . . . . . . 245

6. H. vittatus . . . . . . . . . . . . 246

7. H. erenatus . . . . . . . . . . 247

(c) Subfamily Scolytini.

1. Scolytus destructor (Elin-bark beetle) . . . . . . 248

2. S. intricatus . . . . . . . . . . . 250

Fanily Viti.-Cerambreine (Longicorns).

1. Scaperda carcharias (Large poplar longicorn) . . . . . . 252

2. S. populnea (Small poplar longricorn) . . . . . . 253

Fanily IX.-Cirrysonelide (Leaf-beetles).

1. Melasoma populi (Red poplar-leaf beetle). . . . . . 255

2. Phratora vitcllince (Willow-beetle) . . . . . . . . 256 


\section{CHAPTER VII.}

LEPIDOPTERA (Heterocera, Moths).

FAMILY I.-SESHDE.

PAGE

1. Sesic apiformis (Hornet clearwing-moth) . . . . . 260

FAMILY II.-COsSIDE.

1. Cossus ligniperde (Goat-moth) . . . . . . • . 262

2. Zenvere crsculi (Wood leopard-moth) . . . . . 264

FaMLY III.-BOMBYCLD.

1. Gastropacha pini (Pine-moth) . . . . . . . . 265

2. Bombye neustria (Lackey-moth) . . . . . . . . 272

3. Dasychira pudibunda (Pale tussock moth) . . . . . . 274

4. Porthesia chrysorrhaen (Brown-tail moth). . . . . . . 278

5. Liparis monaclea (Black-arches or Nun moth) . . . . . 280

FaMLY IY.-Noctuide (Night-moths).

1. Punolis piniperde (Pine noctua) . . . . . . . 288

2. Agrotis vestigialis . . . . . . . . . . . 290

3. A. seyetum (Turnip dart-moth) . . . . . . . . . 292

F.nim V.-Geometride (Loopers).

1. Bupalus piniurius (Pine looper-1110t1) . . . . . . . 294

2. Cheimatobia brumata (Winter-moth) . . . . . . 296

Fanily TI. - Tontricide (Leaf-roller moths).

1. Eurias chlorana (Green willow leaf-roller) . . . . . . 299

2. Tortrix viridana (Oak-leaf roller) . . . . . . . . 299

3. Retinia buoliana (Pine-shoot tortrix) . . . . . . 301

4. R. turionance. . . . . . . . . . . 304

5. H. resinclla . . . . . . . . . . . . . . . . . . . .

6. Pecdisere mefinitrene . . . . . . . . . . . . . . . . . . . . . . . . .

7. P. occultana . . . . . . . . . . . . . . . . . . . .

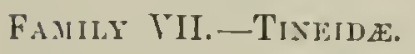

1. Hyponomeute padelle . . . . . . . . . 309

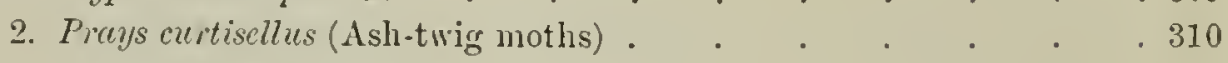

3. Colcophora larieclla (Larch-miner moth) . . . . . . . 311

\section{CHAP'TER VIII.}

\section{OTHER ORDERS OF DESTRUCTIVE INSECTS.}

\section{(i) Hymenoptera.}

Fanily I.-Textmindxide (Sawflies).

1. Lophyrus pini (Pine sawfly). 
FAMILY II. -UroceirIdE (Wood-wasps).

PAGE

1. Sirex jurencus (Steel-blue wool-wasp) . . . . . . 320

2. S. gigas (Yellow wood-wasp) . . . . . . . . . . . . . . . .

Fayily III.-Cryipide (Gall-wasps).

\section{(b) Diptera.}

Fanily I.-Cecinomyides (Gall-gnats).

1. Cecidomyia saliciperda (Willow gall-gnat) .

\section{(c) Hemiptera.}

Fanily I. - APHIDIde (Plant-lice).

1. Chermcs abietis (Spruce-gall Aphis) . . . . . . . 325

2. Chermcs laricis (Larch Aphis) . . . . . . . . 327

FAMILY II.—Coccide (Scale-insects).

1. Lccanium racemosum .

(d) Orthoptera.

Family I.-Grillide (Crickets).

1. Gryllotalpa vulgaris (Mole-cricket) 329

Fanily II.-ACrinidde (Locusts).

1. Pachytylus migratorius (Migratory locust)

(e) List of Trees with the Insects which attack them.

\section{PART III.}

\section{PRO'IECIION AGAINST PLANTS.}

CHAPTER I.

PRO'TECTION AGAINST FOREST WEEDS.

Section I. - General Account.

1. Definition

2. Classification .

3. Utility of certain weeds

4. Daunage done by forest weeds

5. Protentive rules

6. Remedial measures .

Sectiox II.-Special Accourt.

1. List of forest weeds

2. Light-demanding weeds . . . . . . . . . . . . 355

3. Half-shadebearing weeds • . . . • . . . . 359 
Shectios II. - Special Account (continued).

PACE

4. Shadebearing weeds .

363

5. Weeds of wet peaty soil . . . . . . . . . . . . 364

6. Climbing plants . . . . . . . . . . . 364

7. Parasitic phanerograms . . . . . . . . . . . 366

8. Weeds acting as hosts to injurions fungi . . . . . . . 369

9. Classification of weerls in order of injurionsness . . . . . 372

CHAPTER II.

\section{PROTECTION AGAINST FENGI.}

Section 1.-Gexeral Account.

1. Position of fungi in vegetable kingdom 374

2. Classification and importance . . . . . . . . . 375

3. Mode of life . . . . . . . . . . . . . . . . . . . . . . . . . . . .

4. Distribution . . . . . . . . . . . . . . . 379

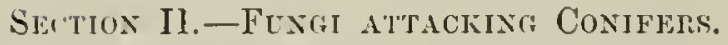

1. Aguriens mellous . . . . . . . . . . . 382

2. Trametes radiciperda . . . . . . . . . . . . . . . . . . .

3. T. Pini. . . . . . . . . 387

4. Fungi causing red or white-rot . . . . . . . . . 389

5. Peridermium Pini (corticola) (Yine-blister) . . . . . 390

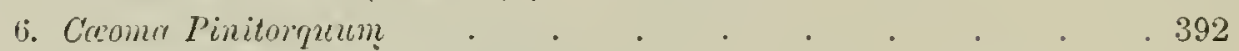

7. Ceoma Laricis (Larch needle-p'ust) . . . . . . . . . . 395

8. Fungi cansing witches' broom . . . . . . . . 395

9. Ecidium clatinum (Silver-fir canker) . . . . . . 395

10. Nectria Cucurbitula . . . . . . . . . 399

11. Pe i: Willkommii (Iarch-blister) . . . . . . . 401

12. Pestalowia Hartigii. . . . . . . . . . 404

13. Pcridermium Pini (acicole) . . . . . . . . 404

14. Ascidinm abictinum . . . . . . . . 405

15. E. columnare. . . . . . . . . . 405

16. Chrysomyxa Abictis . . . . . . . . . 406

17. Hystcrium Pincstri . . . . . . . . . . 407

18. H. macrosporium . . . . . . . . . . 409

19. H. nervisequium . . . . . . . . . . 410

20. Trichospharia parasitica. . . . . . . . . 411

21. Ecidium strobilinum . . . . . . . . 412

Section III. - Fungi atracking Brond-leaven Trees.

1. Rosellinia quercine . . . . . . . . . . . 413

2. Polyporus sulpluzercus . . . . . . . . . 414

3. Other wound-parasites . . . . . . . . . . 415

4. Nectria ditissima . . . . . . . . . . . 416

5. N. cimabarine . . . . . . . . . . 417

6. Phytophthore omivore . . . . . . . . . 419

7. Rheytisma accrinum. . . . . . . . . . . . . 420

8. Mclempsoia Heartigia 


\title{
PART TY.
}

PROTECTION AGAINST ATMOSPHERIC INFLUENCES.

\author{
CHAPTER I. \\ PROTECTION AGAINST FROST.
}

Section I.-Frozfa Plant-Orgaxs.

1. External appearance

.425

2. Explanation of the action of frost on plants . . . . . . 426

3. Damage done . . . . . . . . . . . . 427

4. Register of severe frosts . . . . . . . . . . . . . 433

5. Protective measures . . . . . . . . . . . 433

SECTION I1.-Frost-Crack . . . . . . . . . 435

" III.-Frost-CANKer . . . . . . . . . . . . 439

$\therefore \quad$ IT.-Uphootixg of SeedLixgs bY Frost . . . . . 430

\section{CHAPTER II.}

PROTECTION AGAINST INSOLATION.

Section I. -Dhought.

1. Appearance and cause of injury . . . . . . . . 443

2. Damage done . . . . . . . . . . . . 443

3. Register of dry years . . . . . . . . . . . . . . . . . . . . . 447

4. Protective rules . . . . . . . . . . . . . . 448

SECTION II.-BARK-SCORCHING . . . . . . . . . 450

, III.-HEAT-CRACK . . . . . . . . . . 454

CHAPTER III.

PROTECTION AGAINST WIND.

Sectiox I.-Puevalext Winds.

1. Damage done .

2. Protective rules . . . . . . . . . . . . . . 457

SEUTION II.-STORMS.

1. Origin . . . . . . . . . . . . 458

2. Damage done . . . . . . . . . . . 460 
PAGE

Sfotion II.-s'toris (continucd).

3. Register of storms . . . . . . . . . . . . . 465

4. Protective rules . . . . . . . . . . . . 467

5. Treatment of windfalls . . . . . . . . . . . . 474

6. Treatment of injured woods . . . . . . . . . . 474

CHAPTER IV.

PROTECTION AGAINST VIOLENT RAIN.

1. Damage done . . . . . . . . . . 477

2. Protective rules . . . . . . . . . . 477

\section{CHAPTER V. \\ PROTECTION AGAINST HAIL.}

1. Damage done . . . . . . . . . . . 479

2. Prevalence of hail-storms. . . . . . . . . . . 480

3. Protective rules . . . . . . . . . . 481

CHAPTER VI.

PROTECTION AGAINST SNOW.

1. Dimage done .

2. Record of bad years. . . . . . . . . . . 489

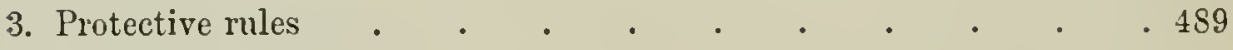

4. Treatment of injured woorls . . . . . . . . . . . . . . . .

\section{CHAPTER VII.}

PROTECTION AGAINST RIME.

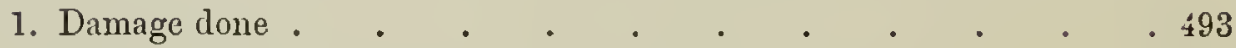

2. liecord of bad years . . . . . . . . . . 494

3. Protective rules . . . . . . . . . . 495

4. Treatment of injured woods . . . . . . . . . . . . 495 


\title{
PART V.
}

\section{PROTECTION · AGAINST NON-ATMOSPHERIC NATURAL PHENOMENA.}

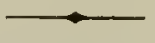 \\ CHAPTER I. \\ PROTECTION AGAINST DAMAGE BY WATER.
}

Section I.-Soll-Denudatiox . . . . . . . . . . 496

" II.-Inundations. . . . . . . . . . . . . 499

,, III.-Swamis.

1. Formation . . . . . . . . . . . . 504

2. Damage done . . . . . . . . . . . . 506

3. Protective rules . . . . . . . . . . . . 509

Sectiox IV.-Dralnage.

1. Vertical drainage

2. Open ditches . . . . . . . . . . . . 512

3. Covered drains . . . . . . . . . . . 516

CHAPTER II.

PROTECTION AGAINST AVALANCHES . . . . 520

CHAPTER III.

PROTECTION AGAINS'I SHIFTING SAND.

Section I.--Sand Dunes.

1. Description . . . . . . . . . . . 524

2. Construction of littoral dune . . . . . . . . . . 526

3. Material for fixing the sand . . . . . . . . . 527

4. Naintenance of the littoral dime . . . . . . . . . . . . 528

5. Protective coast forest zone . . . . . . . . . . . . . 528

Section II.-InLand SAND.

1. Description . . . . . . . . . . . . 532

2. Frotective rules $. \quad . \quad . \quad . \quad . \quad . \quad . \quad . \quad . \quad .533$

3. Firation of the sand . . . . . . . . . . . . . . . 533

4. Stocking the area . . . . . . . . . . . . 536

VOL. IV. 


\title{
CHAP'TER IV. \\ PROTECTION AGAINST FOREST FIRES.
}

Section I.-Fonest Fires caused by Humax Agexcy.

PAGE

1. Causes . . . . . . . . . . 539

2. Kinds of forest fires. . . . . . . . . . 540

3. Damage done . . . . . . . . . . . . . . . .

4. Register of fires . . . . . . . . . . . 54t

5. Protective mensures . . . . . . . . . . 546

6. Rules for extinguishing forest fires . . . . . . . . . 552

7. Wateling site of fire . . . . . . . . . . . . 555

8. Treatment of injured woods . . . . . . . . . . . . . . . . . . .

Sectiox II.-Effects of Lightrixg on Trees . . . . . 556

\begin{abstract}
PART VI.
PROTECTION AGAINST CERTAIN DISEASES.
\end{abstract}

\section{CHAPTER I.}

GENERAL ACCOUNT

CHAPTER II.

RED-ROT.

1. Deseription . . . . . . . . . 564

2. Modifying factors . . . . . . . . . . 565

3. Causes . . . . . . . . . . . . 566

4. Damage done . . . . . . . . . . . . . . . . . . . . .

5. Treatment . . . . . . . . . . . 568

CHAPTER III.

WHITE-ROT

CHAP'TER IV.

STAG-HEADEDNESS.

1. Deseription and causes . . . . . . . . 570

2. Treatment . . . . . . . . . . . . . . . . 


\section{CHAPTER V.}

ABNORMAL NEEDLE-SHEDDING.

1. Description

2. Modifying factors

3. Geographical range .

4. Causes

5. Damage done

6. Treatment

PAGE

.573

.574

.575

. 576

.578

. 578

\section{CHAPTER VI.}

DAHAGE BY ACID FUMES FRON FURNACES, \&c.

1. Description of injury . . . . . . . . . . . . . . . . . . . . . . 582

2. Injurious components of smoke . . . . . . . . . . 58

3. Danage done . . . . . . . . . . . . . 586

4 Remedial measures . . . . . . . . . . . . . 592 



\section{FOREST PROTECTION.}

\section{INTRODUCTION.}

\section{Definition of the term Forest Protection.}

Forests may be protected by two agencies:-

By the State, through laws and regulations made for the general welfare of the country and forming the subject of Forest Law.

By the Ouner of the forest, in his private capacity, and only this part of the subject comes under the term Forest Protection, which may therefore be defined as follows:-

Forest Protection has for its object the security of forests against unfarourable external influences, as far as lies within the poucer of their owners.

The measures to be taken in order to protect a forest may be:-

Preventive or remedial, according as their object is to ward off certain dangers, or to remedy evils which the forest has already incurred.

The essential conditions of successful Forest Protection are :-

Knowledge of the phenomena and causes of all damage which may threaten forests.

Knowledge of the available preventive and remedial measures.

A proper application of the above knowledge to any special case of damage which may arise. 


\section{Position of Forest Protection in Forestri.}

The position of Forest Protection in the science of forestry will be seen from the following considerations :-

Sylviculture teaches us how to form, tend, and regenerate forests; Forest Protection, how to guard them against injurious external influences, and is followed by Forest Utilization, which shows how to utilize a forest in the most suitable manner. These three branches of Forestry are also included in the term Forest Production, while the remaining branches are comprised under Forest Management, which includes Mensuration and Valuation of Forests, Worling-Plans, and Political Economy applied to forests, which may be termed Forest Policy.

\section{Historical Notice.}

The first trace in history of forest protection consists in that afforded to sacred groves and trees. We read of such groves in the Bible and in Tacitus, and they still exist in India, especially in the hill-tracts south of Assam. In Europe, the oak and lime appear to have been the trees looked upon as most sacred, and in the Himalayas, the deodara (God's tree).

The Ban forests of the middle ages established by the Emperors of Germany and other royal or noble personages who wished to secure sufficient tracts of forest for the preservation of deer and other game, formed the next stage. The Windsor, Epping and Dean forests, the New Forest and some other smaller forest areas are the relies of former extensive tracts reserved as hunting-grounds by the Norman kings of England.

The forest laws of the middle ages, besides being chiefly concerned in the preservation of game, contain many provisions regarding boundaries, forest fires, mast, forest pasture, damage to trees, \&c. In the Salzburg Forest Ordinance* of 1524, for instance, directions are given regarding boundary marks. In a Bavarian forest ordinance of 1568 , the influence of the west wind on the natural regeneration of forests is referred to, and

* H. Fding, Die Rechtsverhältnisse des Waldes. Berlin, 1S74, p. 36. 
directions are given to leave a protective belt of trees to the west of a felling-area.

In 1665, the famous Ordonnance des forêts proposed by Colbert was sanctioned by Louis XIV., and amongst other improvements put an end to the grazing of sheep and goats in the French Crown forests.

Hans von Carlowitz in 1713, in his classical work Sylvicultura Economica, which is chiefly deroted to sylviculture, describes several measures of forest protection, including a regulation made in 1680 against caterpillar's.

As regards damage by game, Burgsdorf wrote in 1796 concerning the peeling of bark by deer. At the commencement of the present century, the damage done to forests by game was very considerable; in a battue held by King Frederick of Würtemberg in 1812 in the beech-forests near Tübingen, 823 deer and wild pigs were lilled in 2 hour's. Only since the eventful year 1848 has damage by yame to forests in Germany considerably diminished, and become more localised by the constitution of special parks for game. Such was the forest of Compiègne under Napoleon III., where all the forest revenues were absorbed by the cost of feucing the young woods, and where in 1870, several hundred red-deer and thousands of roes, besides much smaller game, were lilled.

In England, James the First was the first monarch who con- sidered forest trees of more importance than game; he obtained much unpopularity by enclosing part of Windsor Forest, and put an end to the pollarding of maiden oak-trees, which were lopped in winter to enable the deer to browse off the bark of the lopped branches. None but pollard oak have been lopped in this way since 1608 , and most of the hollow old oak pollards in the Windsor Forest were in existence before that date. That King's fondness* for knocking rabbits on the head with a stick would, however, be amply satisfied were he now at Windsor, as rabbits have increased in the most alarming manner during the last 20 years, and have destroyed the valuable undergrowth orer large areas of the forest. They render the reproduction of the trees exceedingly difficult and expensive, and altogether nullify the proper management of the large area of oak forest

* Hepworth Dixon, "Royal Windsor." 
planted for the nation in 1816-25. Such wholesale destruction of valuable woods by rabbits would not be allowed in any other European Crown forest.

Forest grazing was regulated in 1585 by the ordinance of Mansfeld, which prescribed a 5 years close season for all coppice woods with 12 years rotation. Grazing and pannage, or the eating of mast by pigs, in forests have greatly fallen off in importance of late years, but in earlier times these forest usages vied in importance with that of hunting.

The great damage done to forests by insects was first noted in Germany in 1780, and between that date and 1830 several works on Forest Entomology appeared. That by Ratzebourg was published in 1837, and that by Altum in 1872 .

The engineer Brémontier proposed the fixing of the shifting sands on the west coast of France in 1800, and a French law on that subject was passed in 1810. Oberforster von Kropf did a similar service for Germany at about the same time.

The' great damage done in 1856 by floods in the Rhone Valley, induced the French to pass in 1860 a law for "reboisement des montagnes."

Forest fires were formerly of frequent occurrence in France and Germany, but are now looked upon as national calamities, and rarely allowed to extend over considerable areas. A special law against forest fires in Dauphiny was passed in 1872, and revised in 1893. They are still prevalent on a large scale. in Russia and Greece, and in North America. In British India, for the last 30 years, a steadily increasing success has been attained by the Government in its efforts to reduce the area of State forests burned annually, and 24,000 square miles of endangered State forcsts were successfully protected from fire in 1893.

The preserration of birds useful in forestry and agriculture has been furthered by the naturalists of different European countries and by the enactment of special laws. At the same time the British gamekeeper by indiscriminately destroying birds of prey and the smaller carnivora has allowed rabbits and roodpigeons to increase so enormously, as to become a reritable scourge to forestry and agriculture, to say nothing of eren greater danger from mice and voles.

Lastly, the researches of Willkomm in 1866, and of Robert 
Hartig in 1874, have brought to light the causes of many diseases of forest trees which are due to fungi.

\section{Arrangement of Material.}

The measures to be taken by the owner for the protection of his forests may be arranged under the following heads:-

Protection of the forests against man, animals, plants, atmospheric influences (frost, heat, wind, rain, hail, snow and rime); against extraordinary natural phenomena (inundations, avalanches, shifting sand and forest-fires); and against certain diseases the causes of which are doubtful, stagheadedness, and factory fumes.

A detailed list of the headings are given at the commencement of this book.

It will be noticed that some of the protective measures suggested in certain cases are conflicting; thus woods should be cut from west to east in order to protect them against cutting east winds, but from east to west, when liable to be thrown by strong westerly gales. Stumps must be extracted to prevent the breeding of certain insects, but should be left on hill-sides, when there is danger of erosion. The forester will, however, have little difficulty in deciding, for any case, which is the greater danger, and will bear that chiefly in mind in protecting his woods.

5. List of Sciences on which Forest Protection is based.

Jurisprudence, chiefly as regards property and servitudes.

Zoology, chiefly of game and forest insects.

Botany chiefly physiological, and Mycology.

Physiography and Meteorology.

Other branches of Forestry (Sylviculture, Forest Utilization, and Forest Policy).

A knowledge of forest legislation and of game laws will also be useful. 


\section{PAPT I. \\ PROTECTION OF FORESTS AGAINST MAN.}

THe damage which may be caused to forests by our fellorrcreatures may be classified as follows:-

Injuries to forest boundaries.

Irregularities in utilising forest produce.

Theft of forest produce and damage to forests, or forest offences.

Excesses by holders of forest servitudes.

It is the duty of the forester to maintain the boundaries of the forest entrusted to his care, to counteract irregularities in utilizing it, to prevent theft of forest produce and damage to the forest, and also excesses in the exercise of forest servitudes. 


\section{CHAPTER I. \\ PROTECTION OF FOREST BOUNDARIES.**}

A Clearly defined and permanent demarcation of a forest stands in the first rank of the protective measures for forest property. It protects the forest against fraud and damage, and affords security for all the details of forest management.

The different points which require consideration under this heading are :-

The various kinds of forest boundaries.

Settlement of

Demarcation of

Survey of

Description of

Legalisation of

Upkeep of

Cost of

Improvement of do.

do.

do.

do.

do.

do.

do.

do.

\section{The Various Kinds of Forest Boundaries.}

Boundaries are of two principal kinds, property and administrative boundaries.

By the term property boundaries is meant those of separate estates, or of portions of the same estate subject to servitudes.

Property boundaries may be either external or may surround enclosures. Boundaries of servitudes separate those parts of an estate which are affected by rights of third parties from those which are not so subject.

Administrative boundaries may indicate :-

Administrative units, such as beats, ranges, divisions, \&c., or,

Working units, as compartments, periodic blocks, workingsections, working-circles, \&c.

* Eding, H., Die Rechtsverhältnisse des Waldes : Berlin, 1874. Kalk, R., Die Sicherung der Forstgrenzen: Eberswalde, 1879. 


\section{Settlement of Boundaries.}

The procedure for settling boundaries differs according as they are property or administrative boundaries. Administrative boundaries depend merely on the will and pleasure of the owner of the estate, and the details regarding them are dealt with under Worling-Plans.

Property boundaries must be accurately defined. This is of the greatest importance to the ouner and also to the public, so as to prevent uncertainty, and unnecessary work for the executive and legal machinery of the State. Hence in all civilized countries the procedure for settling property boundaries is laid down by law. Evidence as to the correct boundary consists in existing

FIG. 1.

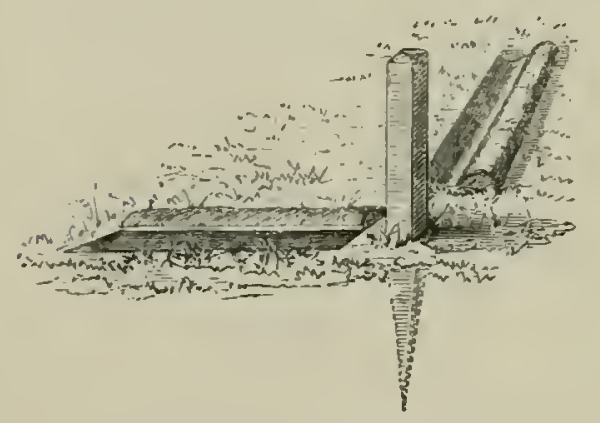

FIG. 2.

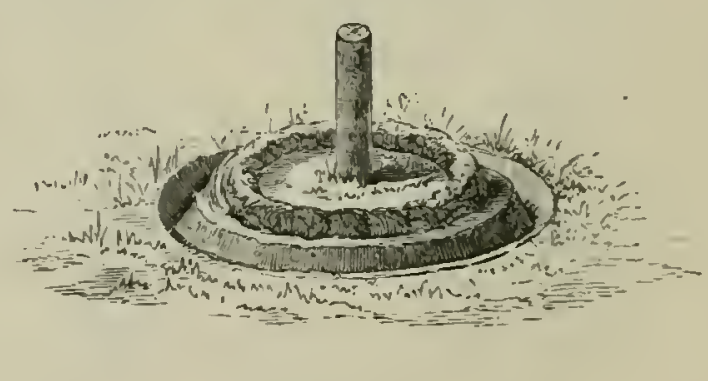

boundary pillars or traces of where they have been, statements of old people who know the boundaries, and boundary maps. The settlement is best done by a public surreyor, who may be either chosen by the parties concerned, the adjacent owners, or by the executive State or Local authority.

During the boundary settlement the adjacent proprietors should be present personally, or by their legally appointed agents, and boundaries which may be regulated in their absence after a formal summons to be present will be held to have been duly accepted by them. The surveyor should endearour to lay down the boundary on the ground by friendly agreement between the parties; if he does not succeed, the competent lari-courts or officials must decide disputed points.

The surveyor should fix the boundary lines as long and straight as possible, in order to render the estates more ralutble, and to keep down the cost of demarcating and maintaining the 
boundary. This maxim should not, however, be carried too far, when by so doing, boundary points would be situated in impassible places, such as swamps, \&c.

All boundary points which have been finally settled should at once be marked by durable posts, and by digging narrow trenches in the direction of the boundary lines (fig. 1), or in a circle round each post (fig. 2). During the progress of the boundary settlement, the surveyor should make a rough plan of the boundary line, and keep notes of the evidence brought before him.

FIG. 3.

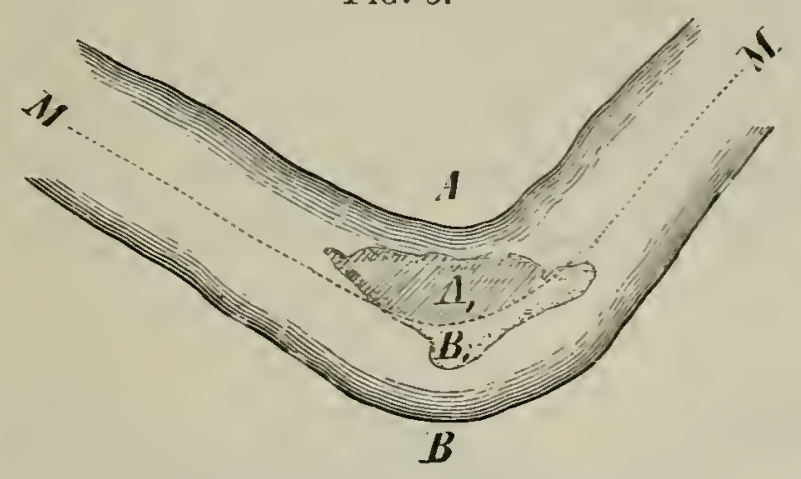

Partition of an island by the line MI M, mid-stream, between two adjacent owners, $A$ and $B$, into two parts $A, B$.

\section{FIG. 4.}

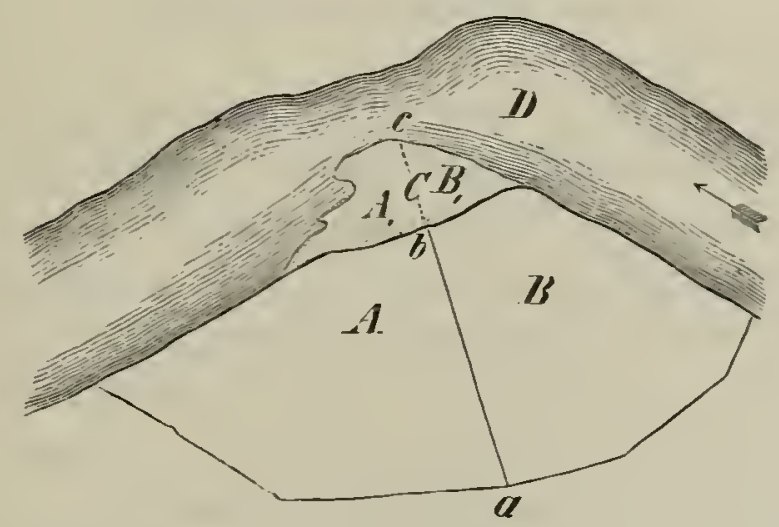

Partition of a river-side accretion $\mathrm{C}$, by the line $a b c$.

\section{Demarcation of Boundaries.}

The demarcation of boundaries is effected by natural, artificial, or mixed boundaries.

Property boundaries require to be more permanently marked than administrative boundaries. 


\section{(a) Natural Boundaries.}

Natural boundaries are :-

Water-partings,

Water-cour'ses,

Marked trees, \&c.

With the exception of the first, all these natural boundaries are liable to changes. Streams frequently alter their course, and trees are liable to die or be blown orer or cut down. At the same time, whererer the cour'se of a stream is fairly well fixed, as in a deep valley, such a natural feature forms a good and economical boundary between two properties. In the case of water-courses, mid-stream is generally considered the boundary as in fig. 5 . Where deposits of new land occur, they belong as a rule to the proprietor who owns the shore along which they occur. If sereral

FIG. 5.

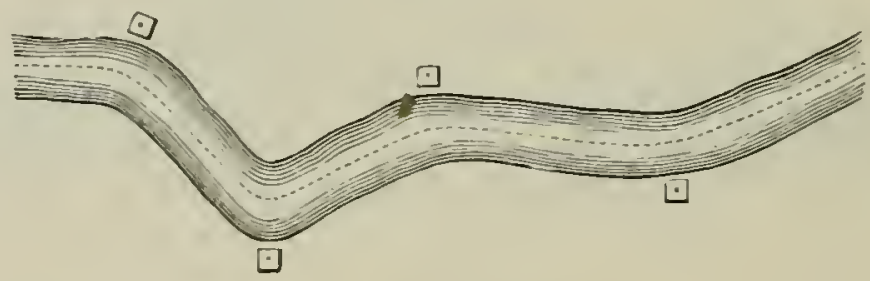

Tater-course with boundary marks.

ouner's participate in the shore, the new boundaries are indicated by producing the original boundary line through the new accretion to the water-side as shown in fig. 4. In the case of erosion and re-deposit, laws differ ; in some cases, the owner's can claim the area thus lost and re-deposited. In other cases, as in certain parts of British India, new islands formed in the middle of a river belong to the State. Owners are allowed to prevent erosion by artificial works, fixing the banks, \&c. It is not, however, permissible to induce deposits by artificial means.

For greater security natural boundary lines may be marked by numbered marks similar to those described below for artificial boundaries. If the centre of a stream is the boundary, the boundary marks are placed alternately on either side of it, as in fig. 5, but only on one side of it if the bank be the boundary. 


\section{(b) Artificial Boundaries.}

Artificial boundary lines consist of :-

Roads, or lines of boundary marks.

The line of a road may have to be changed, especially at certain points to reduce too steep a gradient, and this may be an objection in some cases to a road as a permanent boundary, but a well alligned road forms an excellent and economical forest boundary, and facilitates the export of produce from the forests on either side of it.

Lines of boundary marks may be demarcated by mounds of earth or stones; by wooden or iron posts, masonry pillar's, or cut stone blocks. All boundary marks should be numbered consecutirely, and the numbers on them painted black or white according to the colour of the marks. The marks for each separate forest property are usnally numbered from north to west and by south to east, and on property boundary marks the initial letter of the ormer's name may be added. Every enclosure in a forest belonging to another owner than that of the forest should be surrounded by similarly numbered boundary marks.

In case of any addition to a forest involving fresh boundary marks being interposed between two formerly existing marks, letters A, B, \&c., may be added to the earlier number to denote their position.

Fig. 6 shows the usual mode of representing a line of boundary marks, on a map.

The nature of the boundary will differ according as the adjoining estate is woodland, or cleared for agriculture. In the former case, a strip of a certain breadth inside the boundary may have to be liept clear of forest growth. The choice of the lind of boundary mark depends on circumstances, but stone or masonry pillars are generally to be preferred. In cases where a rapid 
demarcation is necessary, and cut stones or eren bricks are not easily procurable, as in some backward districts in India, conical mounds of earth or of stones, with posts in the centre, are sometimes used, at any rate until more permanent marks can be supplied.

In constructing such mounds, the post made of heartwood only, and of the most durable timber available, is first planted in the

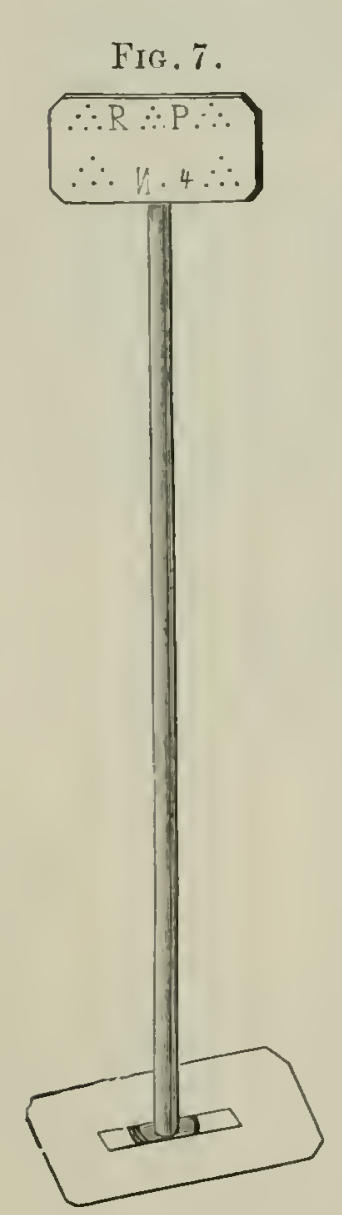
soil, the portion in the ground having been charred, or the whole post tarred so as to ensure greater durability. Round the post two circles are then traced in the ground, and earth to be heaped up must be dug from beyond the outer circle and placed within the inner one. Otherwise the heap would soon settle down into the treuch. The mounds may be made of stones if available. The slope of the mounds will correspond with the natural angle of repose for the class of material employed, and their height should be about four feet. Earthen mounds should be carefully protected by placing sods on their surface. Wooden

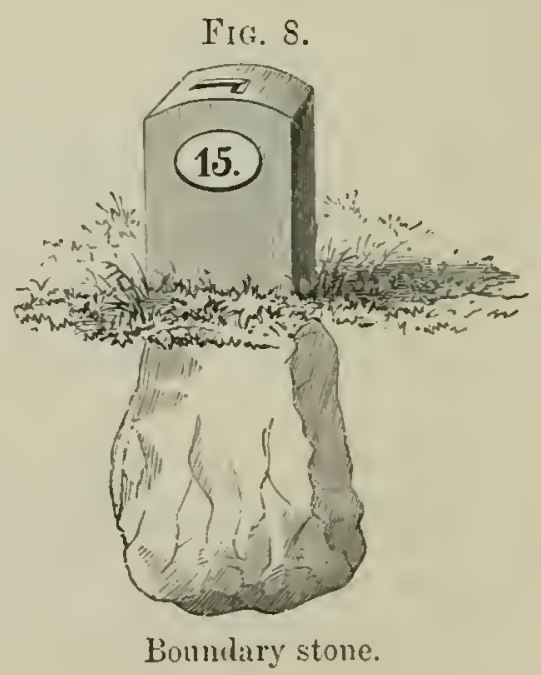

posts without mounds may also be used as boundary marks, but they are then more liable to be thrown down by cattle, or wild animals, or to be removed. In either case the posts should bear current numbers, a very durable form being a cast iron plate, in which the number has been cut ont, or the numbers may be painted on the posts.

Hess gives a useful kind of iron boundary mark as shown in fig. 7. The lower and upper plates can be remored to facilitate transport. Stnnes are heaped on the lower plate after it has been put into the ground to the required depth. 
The best of all boundary marks are generally hewn stones (fig. 8), or masonry pillars. The former may be prismatic, or rectangular with a rounded top. The lower portion to be placed in the ground should be left rough and be of larger bulk than the cut portion, so as to ensure stability.

A line should be cut in the top of the pillar to show the direction of the boundary, and serial numbers cut on one of its faces.

Care should be taken to select durable material such as granite, basalt or quartzite for these stones.

Where herm stones are not available, pillars of brick and mortar masonry may be erected, a sufficient foundation being of course provided.

The current number is carved on a small flat piece of stone or slate inserted in the sloping top of the pillar. This is greatly preferable to inserting the number on a prismatic piece of stone let into the apex of the pillar, as is sometimes done. Such pieces are easily loosened by boys engaged in tending cattle or sheep near the forest boundary. These pillars should be formed of cubes with a side of $2 \frac{1}{2}$ to 3 feet, surmounted by a pyramid 6 to 9 inches high.

It is customary in India to bury a quantity of charcoal under boundary pillars, so as to assist detection of any fraudulent change in their position.

In all lines of boundary marks, one mark should be placed at each angle, and whenever two angular points of the boundary are too distant to be seen from one another, a sufficient number of intermediate pillars should be erected.

If the boundary is merely a line, the pillars are placed along its centre, but if pillars are placed along a road, the middle of which forms the boundary, they should be alternately on either side of it.

After boundary lines have been laid out, their exact position may be more clearly defined by rows of trees, hedges, fences, ditches, walls or forest rides.

Rous of trees are injurious to neighbouring fields by their shade and the spread of their roots. Hedges are difficult to keep in order, and rarely answer their purpose in keeping out cattle along a lengthy forest boundary. Fenees are expensive, but their use is sometimes unaroidable where browsing by game, or 
grazing is to be feared. Details as to the different linds of fences are given in Schlich's Sylviculture, Vol. II., pages $12-20$.

Walls may be used where stones can be collected on the spot, and where ditches are not practicable on account of the steepness of the slopes. Such walls should be 1 yard broad at the base and from a height of 18 inches should gradually taper off to the top. The stones should be placed with the thick end outside. Forest boundary rides as well as boundary marks are necessary where two forests adjoin. Unless the ride is also to be used as a road, a breadth of 4 to 8 feet will suffice. Along

FIG. 9. FIG. 10.

FIG. 12. FIG. 13.

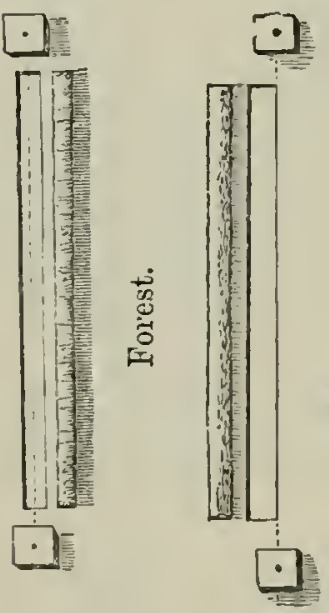

FIG. 11.
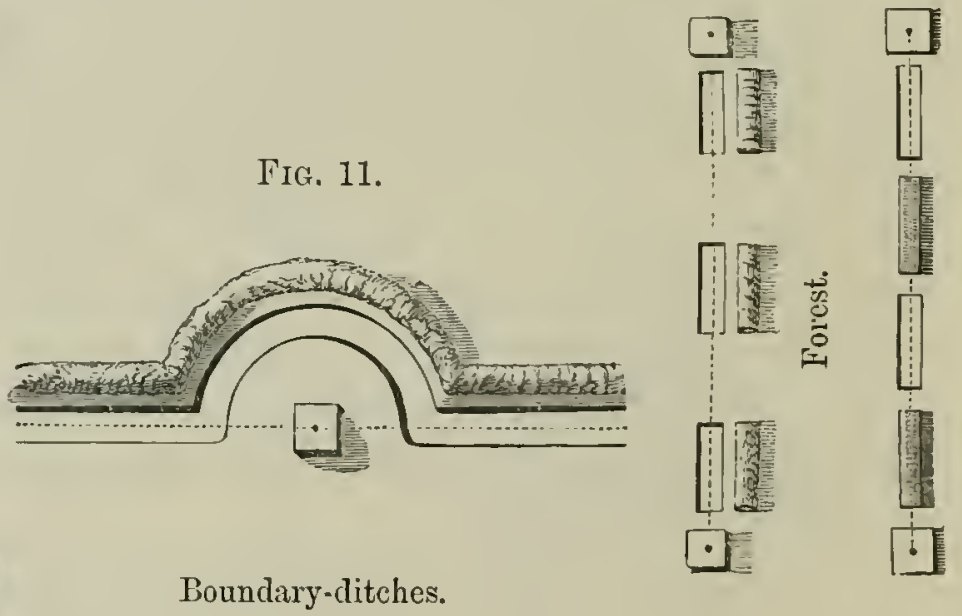

such rides it may be advisable to dig out all stumps, to prevent the growth of coppice-shoots, and the ground may be roughly levelled and drained, and even narrow bridges erected, so as to convert the ride into a bridle-path to facilitate inspection.

Boundary ditches (figs. 9 to 13) give a clearly cut line and prevent encroachment by ploughing or grazing when the forest boundary runs along a field or meadow. Such ditches can be dug everywhere except on very stony ground; they either run along the entire boundary line from point to point or are intermittent. In either case they should stop a few feet from the boundary marlis.

The earth dug out of the ditches should be placed on the 
forest side of the ditch and a few feet from it (fig. 10), or in the case of intermittent ditches it may be placed between them as shom in fig. 13.

Intermittent ditches (figs. 12 and 13) are usual on slopes to prevent the formation of ravines.

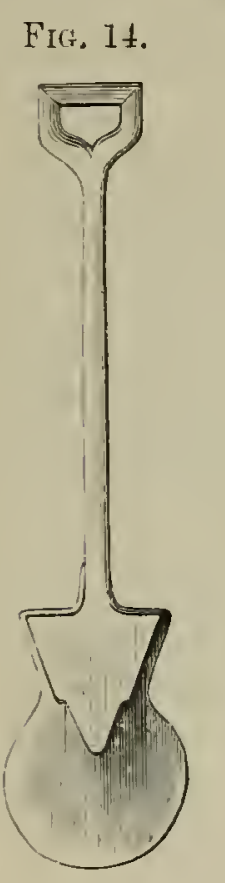

$$
\text { FIG. } 15 .
$$

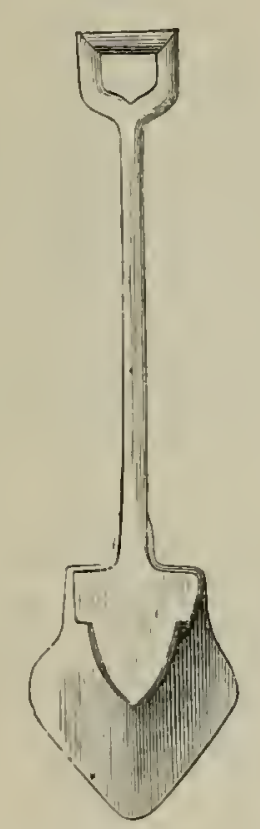

Fig. 16.

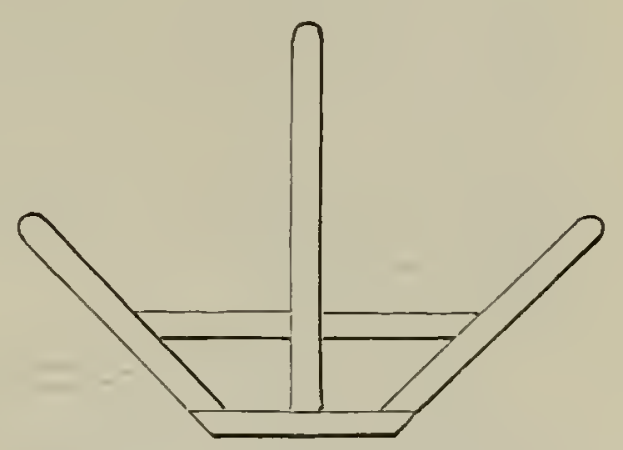

Template or mould-frame for ditch.

The section of the ditches depends on the nature of the soil, but is generally $2-2 \frac{1}{2}$ feet wide at the top and $8-10$ inches at the bottom and the same depth. The boundary line may be the centre of the ditch, or one of its sides; in the latter case the

\section{FIG. 17.}
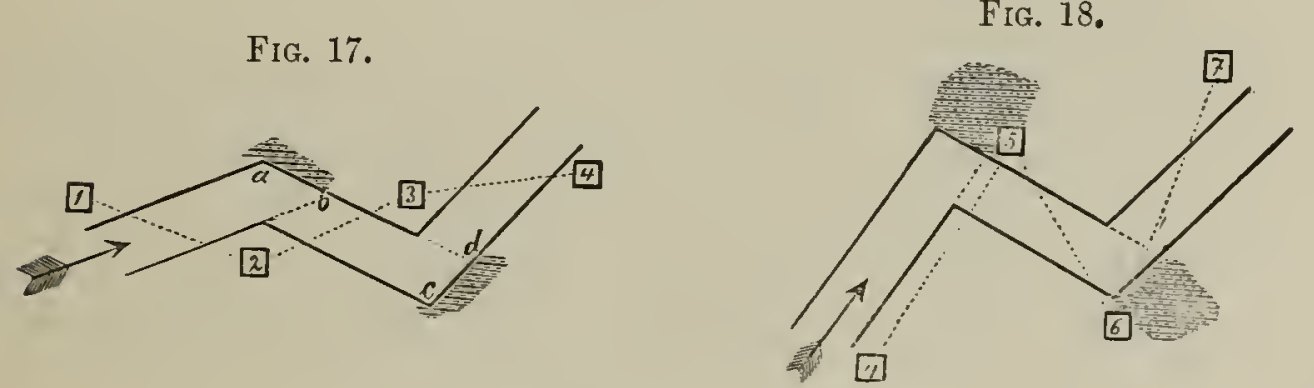

Boundary-ditch serving as a drain.

ditch belongs to the proprietor on whose land the earth from it is thrown, which is generally towards the forest. Special kinds of spades are used for ditching, as shown in figs. 14 and 15 . 
A wooden model of the ditch-profile is also useful (fig. 16), and is termed template or mould-fiame.

In case the ditches are also used as drains, care must be taken not to allow the boundary marlis to be undermined. Thus the arrangement shown in fig. 17 should be followed to protect the boundary marks from erosion, and not that shewn in fig. 18 .

\section{Survey of Boundaries.}

The best survey is that carried out by the theodolite and a chain, or measuring staff, but for preliminary work a less accurate instrument, such as the plane-table or prismatic compass, will suffice. From the survey a boundary map should be drawn up, the usual scale of such maps being 18 or 36 inches to the mile in Germany.

These maps should show:-

All boundary marks with their numbers.

The course of the boundary lines.

The names of adjoining properties, and the nature of their cultivation, or otherwise.

\section{Description of Boundaries.}

This should be prepared in a tabular form, and should show : Name of forest and of proprietor.

Names of adjoining estates and of their proprietors.

Current number and nature of boundary marks.

Angle at each corner in degrees.

Distance from one mark to the next.

Direction of boundary line from mark to mark with reference either to that of the magnetic needle, or true north.

Other remarks worth recording, such as crossing points of streams and roads, or reference to any permanent objects near the line, such as trigonometrical pillars, \&c.

\section{Legalisation of Boundaries.}

It is desirable to cause the boundary map and description to be recognized by the proper State authority, according to the law in force. 


\section{Upheep of Boundaries.}

The boundaries once laid down must be maintained in good order; the following measures being specially necessary:-

(a) Periodic clearing of the boundary line, so that one mark may be visible from the next. In case the boundary line be a road, bridle-path or ditch, repairs to these become necessary from time to time.

(b) Periodic inspection of the lines by the forest officials, to whose charge definite lengths of boundary should be allotted according to their rank, and each official should from time to time submit reports to his superiors, on the condition of the boundaries.

(c) Immediate repair of all defects in the marks, repainting fading numbers, etc., before any point becomes doubtful. Marks which may have been removed can only be replaced with the consent of both owners or by order of a Court of Law.

(d) Immediate report of all tampering with established boundaries and prosecution of the offenders.

\section{Cost.}

The cost of erecting and maintaining forest boundaries should be divided between the adjacent owners, unless there is any legal provision to the contrary.

These costs vary so much according to circumstances, that it is difficult to lay down any general estimates; the following figures may be considered approximate. One man can erect in one day au earth boundary mound 4 to 5 feet in diameter and 3 to 4 feet high, and can sod about 3 to 6 such mounds, and repair from 6 to 9 of them.

Hewn limestone boundary stones cost 2 to 3 shillings each, and 20 such stones can be carted by two horses. Iron boundary posts cost from $1 s .6 d$. to $2 s .6 d$. each.

In loam, a man ean dig in one day 30 to 40 yards of boundary trench, 10 inches wide at the base, and of the same depth. In light soils, the labour is from 10 to 15 per cent. heavier. 
Boundary works are generally done by contract, and on the continent of Europe repairs to forest ditches are frequently executed by petty offenders in lieu of fines.

\section{Inprovenient of Boundaries.}

Advantage should be takes of every opportunity to consolidate forest property and thereby to improve its boundaries. This can be done by purchase, disposal or exchange of land, so as to cut off inconvenient corners or narrow strips, to alienate detached pieces, or to acquire enclosures belonging to other proprietor's.

Some of the advantages of consolidation are:-

(a) Greater facility for keeping the boundary line in order, and at a reduced cost.

(b) Saving in protection expenses, in work of staff, and less liability to cases of misappropriation and damage by outsiders, especially in the case of danger from fire.

(c) Increase in the productiveness of the forest. Fewer roads are required; damage is reduced, whether it is caused to the forest by frost, storms, etc. or to adjoining farm-land by overhanging trees, or by game sheltering in the forest. 


\section{CHAPTER II.}

PROTECTION OF THE FOREST AGAINST IRREGULARITIES IN THE UTILIZATION OF FOREST PRODUCE.

Section I.-Principal Produce.

1. General Account of Damage done.

The standing-crop or soil of a forest may be endangered during fellings and in the conversion and transport of timber in the following ways:-By overfelling, bad felling, careless conversion or bad stacking of timber and firewood, and careless transport.

The methods for fixing the annual yield of a forest are explained under Worling-Plans, and how timber should be felled and converted under Forest Utilization; here, only the preventive measures necessary to obviate irregularities will be considered.

Irregularities of wood-cutters, cartmen, etc., may be dealt with either by regulations made by the forest owner, or by the forest laws of the country.

In a general way, it should be noted that some damage must be done during fellings, conversion and transport, and it is only by experience that a forester learns how much damage is unavoidable. Too stringent conditions should not be enforced on woodcutters or timber purchasers.

\section{Overfelling.}

All forest operations must be carefully watched, and their results recorded, so that only the fixed yield prescribed by the working-plan is cut amnually. At the same time, at least in 
private forests, it may be advisable to cut more than the fixed yield in seasons when the price of timber is exceptionally high, and reduce the fellings when it is low.

In order to keep within the limits of the fixed annual yield, trees to be felled should be properly marked in accordance with administrative rules, and after the fellings, the stumps of felled trees should be examined and counted in order to detect possible irregularities. In some cases, as in Coppice-with-Standards, the trees to be reserved are marked instead of those to be felled. The practice in France of marking such trees by cutting off a portion of the bark and stamping on them with a steel hammer may give rise to attacks of fungi and defects in the wood at the base of the tree.

In the case of large felling-areas, it may be necessary to employ an extra forest"guard in addition to the guard of the beat to supervise the woodmen, and when trees are sold standing, the purchaser may be allowed to appoint a special guard with temporary police powers and a badge of office. This necessity for special supervision applies to all the succeeding sections, referring both to the removal of principal and minor produce.

\section{Bad Felling.}

Measures for the prevention of mischief are :-

(a) Employment of competent and trustworthy roodeutters, and careful supervision of their work. It is generally advisable to employ the same men year after year, and to withdraw from the gang all those who fell badly, and encourage the best men by instruction and higher wages.

(b) Cessation of the work during unfavourable seasons or weather; for instance, when the trees are in sap, except where bark is being harvested; during absence of snow on the ground to break the fall of the trees and spare natural regeneration; during seasons of hard frost, when the stems may be broken, or during strong winds, when the direction of the fall of the trees is uncertain. In northern India, fellings are frequently stopped during the hot dry months of May and June, from fear of forest fires which may be caused by the workmen.

(c) Avoidance of damage to seed-bearing trees in regeneration fellings, and to standards. 
(d) Throwing trees on to bare spots and not amongst young growth.

(c) Removal of branches and crowns of trees before felling, to prevent the trees from crushing valuable undergrowth.

$(f)$ Preservation of young growth during the removal of stumps, and putting earth into holes thus caused to prevent their being filled with water.

(g) Careful felling of coppice with sharp instruments and with a clean and sloping cut.

(h) Leaving stools on steep slopes where erosion is to be feared, and also on shifting sands.

(i) Avoidance of throwing felled trees on to rocks, stones or other stems; felling uphill or sideways so that there may be a minimum of breakage.

(j) Tropical woody climbers should be cut two years before a felling is to take place, as otherwise they bind trees together, and the fall of any tree may involve that of a group of surrounding ones. The soft-wooded climber's, however, rot in about two years' time.

(k) Trees are sometimes, as in the case of teak in Burma, girdled two or three years before being felled, so that the wood may dry and lose weight, and become floatable. Care must be taken that this is not done to trees liable after girdling to be bored by insects.

\section{Careless Contersion.}

Here may be mentioned :-

(1) Quick conversion and removal of felled trees, especially in the case of natural regeneration and in coppice; protection of young growth in both cases.

(b) Use of the saw instead of the axe to prevent waste.

(c) Quick removal of bark to prevent insect-attacks.

(d) Repairs of any damage done to young plants, which, if of broad-leaved species, may, when injured, be cut back close to the ground so as to get a strong regrowth. Otherwise, replanting must be effected with strong transplants after the felling-area has been cleared. 


\section{Bad Stacking of Timber and Firevood.}

Employ specially trained men for stacking firewood, as ordinary woodcutters generally stack loosely.

Stacking should be done on blanks, or along the edges of felling-areas, on roadsides, \&c.

Withes for binding up faggots should be cut from suppressed stems, or taken from cleanings or special plantations.

\section{Careless 'Transport of 'T'imber and Firewood.}

Attend to the timely construction and repairs of the necessary roads, slides, etc., which should be ready when the fellings commence.

Remove material from the felling-area at farourable seasons, when snow is on the ground; not in hard frosts, nor when the trees are in sap and the bark of standing trees is ensily abraded by the wheels of the carts, etc.

Avoid damaging methods, such as rolling, etc., among young growth.

Fix a period during which the material must be remored, say from November of one year to the end of winter in the next, so that the ground may be cleared in time for the spring-growth of the second year. At the end of this period, all injured plants should be cut-back, blanks planted-up, and all ruts on temporary cart-tracks filled-in.

Certain rules should be made for the protection of roads and other means of transport. These are, that new roads should not be used until the earth has settled, and they have, if possible, been macadamised. Notices closing roads under construction or repair should be posted up, and bars put across such roads. Dragging along ordinary roads should be disallowed.

All transport should be carefully superrised, if necessary, by extra forest guards.

\section{Section II.-Irregularitifes in vtilizing Minor Forest Produce.}

\section{General Aceomit of Damage done.}

Whenever the minor produce is less important than the principal produce of a forest, it should be harrested in such a 
way as not to endanger or diminish the supply of the latter. The following are the chief items of minor forest produce:Burk, turpentine, resin and gums, leaves, fruits of forest trees, dead branch-urood, grass and herbage, litter, stones, grarel, sand and earth, peat, forest cultivation of cereals, berries, edible fungi, game, fish, wild honey and wax, etc., etc.

\section{Bark.}

Bark is chiefly used for tanning, or for dyes, but the bark of certain species, such as the paper-mulberry (Broussonctia papyrifer(a), may be made into paper-pulp, or, as in the case of Betula Bhojpatra in India, into hats and umbrellas. The inner bark of the lime and of many tropical trees is used for ropemaking or mats.

In the case of oak-bark used for tanning, the following rules should be observed:-

(a) Secure a clean and slanting cut of the stems in order to protect the stools against moisture.

(b) Prevent any tearing of bark from the stool, by making a clean cut near the ground, before the bark is peeled from standing poles.

(c) Remove peeled stems expeditiously, so that the new shoots may harden before early frosts occur.

(d) Carefully stack and quickly dry the bark, so as to aroid loss of tannin by rain, and ensure rapid clearance of the fellingarea.

Wherever bark is used for any of the other purposes above referred to, similar rules, modified for the species in question, should be observed.

\section{Turpentine, Resin and Gums.}

The present chief sources of the supply of turpentine and resin are the pitch pine $(P$. anstralis $)$ and other pine-trees in the Southern States of North America, and the cluster pine (Pinus Pinaster) forests in the west of France. Tappings for turpentine and resin on a moderate scale have, however, been started in the forests of the long-needled and blue pines of the Himalayas ( $P$. longifolia and excelsa). Some turpentine is still obtained from the spruce in Germany and the north of 
Europe, but as this tree only yields it in small quantities and the process of tapping it is extremely injurious to spruce timber, its tapping should be absolutely prohibited.

The following remarks, therefore, only apply to species of pine which yield turpentine abundantly, and to the extraction of gums and caoutchouc from several species of trees in hot countries.

(a) Lessees of turpentine or gum must be pecuniarily responsible for all damage done in forests by their workmen.

(b) Tapping should generally be confined either to trees like the Ficus elastica, which are hardly of any value except for the gum they yield, or to trees too remote from means of transport for their timber to be of any marketable value as compared with the value of the turpentine or gum which may be extracted from them. In other cases, it should be confined to trees which will be felled for timber within a period of from ten to twenty years, as when young trees are tapped no considerable increment of growth may be expected. For the same reason the best shaped and most promising trees should not be tapped.

In seeding-fellings, a certain number of the seed-bearers should remain untapped, as tapping is prejudicial to both the quantity and quality of the seed.

(c) Rules regarding the size and number of cuts and the depth of cut to be made in each tree will vary with the species, and are given in detail under Forest Utilization. In tapping pines for resin, there should not be more than two points of attack, unless it is intended to kill the tree, when as many as six may be opened. There should be from 8 to 12 inches betrieen each cut, and the cuts should not be more than 2 inches broad and in one yearr only about 3 feet long.

(d) Tapping must be intermittent, so as to allow recovery of the trees before a fresh tapping is allowed, unless it is intended to tap the tree to death before felling it. The interval between successive tappings will of course vary with the species in question. In Europe, all tapping should cease with the first early frost in August or September, and not be resumed till the spring.

(c) Tapping should rarely be attempted on poor soils. 


\section{Leares and Branches of Forest Trees.}

Leaves of forest trees are used for fodder, mamure, thatching, tanning, dyes, \&c. Leaf-fodder is extensively used for cattle in countries where sufficient grass is not available, as in the centre and south of France, where hedge-row oaks are annually pollarded for this purpose. A similar practice prevails in the Himalayan districts of India during winter, evergreen oaks, elms and species of Celtis, Prumus, \&c., being thus utilized. During the season of rest, leaves of evergreen trees are rich in reserve nutrient material, and afford valuable fodder. In seasons of drought in Central and Western Europe, as in 1893, leaffodder from hornbeam and other decidnous trees is also extensively used instead of grass.

In the north of India, camels, buffalos and elephants are chiefly fed on branches and leares of trees during the cold and dry seasons. Oaks and other forest trees were also formerly extensively pollarded in European deer-forests to afford fodder for the deer, which ate the bark of these branches when the ground was covered with snow.

The important points where the use of leaf-fodder prevails are: to allow trees to be lopped only after the principal growth of the year is orer, to restrict lopping, as much as possible, to inferior species of little or no value as timber trees, and to prevent the lopping of trees until they have attained a certain size. Wherever the restriction is practicable, only side-shoots should be lopped and the leaders spared, and the trees lopped only every third year. In forests, lopping should, if possible, be restricted to compartments which will be shortly cut over.

Where the demands for leaf-fodder are large and cannot otherwise be met, a regular system of pollarding should be introduced, with a fixed rotation, the length of which will be decided by local experience.

In India and other hot countries, the foliage of woody climbers may be used for leaf-fodder to the actual benefit of the forests. In certain parts of India, green branches and leaves of trees are used to manure the rice-fields, under the term of $r a b$; this subject will be referred to again under the heading Forest Servitudes. In hot countries, leaves of various 
forest species are used for tamning, dỵes, drugs, hat and umbrella making, plates, and for feeding silkworms. The last is a very important and valuable industry, and the trees utilized are generally of much less value for timber than for their leaves, and therefore rules should be made which will afford the greatest possible quantity of leares at the time required, and in a way most easily accessible to the silk producer's. Thus pure coppice is adopted with very short rotations, even of one year in the case of the mulberry in Bengal. As regards the other demands for leaves, forest officers would do well not to be pedantic in stopping industries dependent on their forests which can be supplied without serious injury to the trees by the exercise of a little ingenuity and suitable control.

\section{Fruits of Forest Trees.}

Fruits of forest trees are collected for sowing; for the food of men or animals; for extracting oil, dyes, tamin, \&c., or they may be eaten on the ground in the forest by swine (pannage), or by deer. The rules for the protection of the forest are as follows :-

\section{A. Collection by Hand.}

Where regeneration by seed is expected, or where swine or deer are to be fed in a forest, fruits should not be collected for other purposes.

All injuries to the trees during the collection of the seed must be strictly forbidden. These are : beating trees with axes; dragging down fruit-laden branches; use of climbing irons, dre. The bad effects of the latter on the quality of the wood may be seen from fig. 19, each wound made by the iron introducing decay into the timber. Smooth-barked species such as beech and Weymouth pine suffer most in this way.

The work must be stopped during frost, when the branches are easily broken.

\section{B. Pannage.}

I'annage, or the feeding of swine on the mast of a forest, consisting of fallen acorns, beech-uuts, chestnuts, dic., was formerly a rery important industry, but is now becoming less frequent 
in the forests of Europe. It still prevails in Epping Forest, where about fifty pigs are turned into the roods annually from the 14th Sept. to the 8th Nor.

Swine damage forests in the following ways:-

(a) Eating-up mast in seeding-fellings.

(b) Uprooting young plants, breaking off weak stems, abrading the bark off poles, and exposing and gnawing roots of raluable forest species. All these injuries are chiefly felt in natural regeneration-fellings, and in thinnings in young woods, on loose sandy or shallow soils, on steep slopes, ic.

FIG. 19.

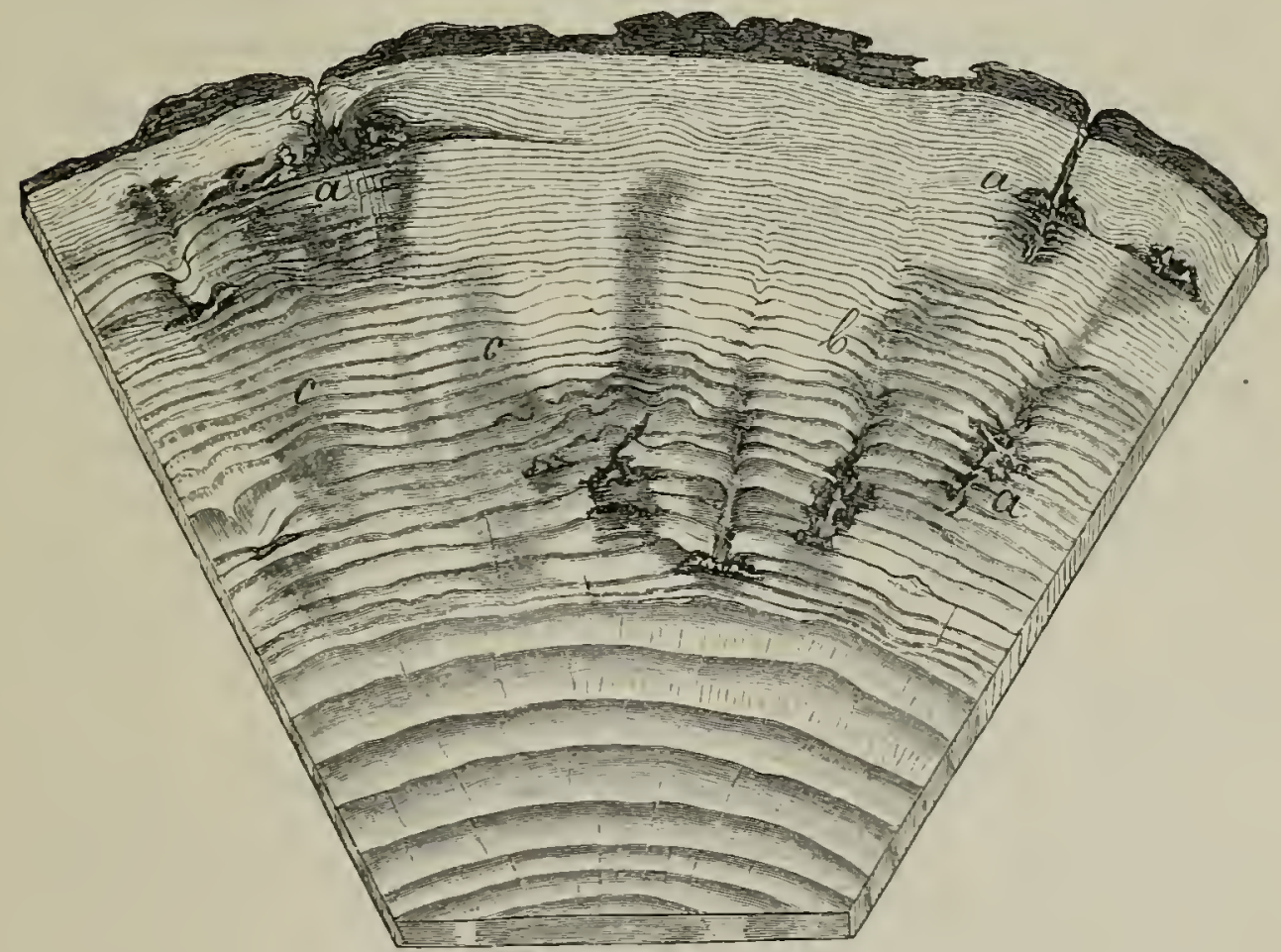

Section of a Scotch pine injured by climbing irons.

(a) Points of injury.

(b) Concare annual rings of woorl occluding wounds.

(c) Brown-coloured wood below the wounds, showing consequent decay.

Swine are useful to forests in the preparation of the soil for seed, by removing the covering of dead leaves and exposing the mineral soil, and by burying acorns and other fruits; also by trampling dead leaves into the soil, which is of importance in places exposed to winds, and by destroying mice and certain insects hibernating or moring in the soil-covering. 
The protective rules for pannage arc:-

(a) Exclusion from the following places: Seeding-fellings; dry loose soils in the case of swine driven in to feed exclusively on fungi, worms, insects, \&c.; places where the mast is reserved for deer or wild-pigs.

(b) Compartments opened for pannage should as nearly as possible adjoin one another, so that the swine may not wander uselessly through the forest. They should not be allowed to remain long in compartments without mast, as they then proceed to bark the trees.

(c) The place where the swine pass the night should be carefully selected. In such places scarcely a root escapes injury.

(d) The number of swine to be allowed in a forest must depend on the quantity of mast available. Each full-grown animal requires from two-and-a-lalf to seven-and-a-half acres of forest.

(c) Limitation of pammage to the period of the year from the middle of October till the end of January. It should not commence till sufficient mast has fallen, as otherwise the swine become thin from much wandering about, are not easily kept together, and do much mischief. On the other hand, it must cease when the mast is no longer sufficiently plentiful, and it is in the spring that the greatest damage is done by peeling the bark and roots. During the aftermast, after Christmas, the acorns become more digestible, and are specially suitable for breeding-animals.

(f) The admission of swine into a forest should only be on condition that they are perfectly healthy, and guarded by trustworthy swineherds; two hundred swine for each man, and an assistant for every hundred additional swine.

(g) The owners of the swine should be made collectively responsible for all damage which may be done to the forest. In Epping Forest all swine admitted to pamnage are ringed.

\section{Grass and Herbage.}

Grass and herbage, dry ferus, heather, \&c., may either be cut and removed from the forest and used for fodder, or litter for cattle, or, with the exception of the ferns, may be utilized on the spot as pasture by grazing animals. 


\section{A. Grass-cutting.}

Grass and herbage may be cut for fodder, or to form thatching material, paper-pulp, \&c. Dead ferns, especially bracken, are largely used for litter, and heather for litter or thatching.

The protective rules are:-

(1) Limitation to persons who have obtained a formal permit from the forest manager, and, as a general rule, on certain fixed days, when the forest guards can supervise the cutting.

When a number of people are together cutting herbage in the forest, they should be held collectively responsible for any damage which may be done.

(2) Restriction of cutting to places with a moist fertile soil, which can bear the removal of the mineral constituents of the grass, \&c. In such places, planting in lines between which grass can easily be cut is more suitable than natural regeneration. In some cases, heather and broom protect young plants from frost and insolation and should be left intact. High grass, on the contrary, as will be seen further on, greatly increases radiation, the intensity of frost and the drying-up of the soil by the sun, so that it is frequently more advantageous to have it removed. Its removal also furnishes additional security against forest fires.

(3) The use of scythes should not be permitted amongst young growth, where grass should be cut with sickles or pulled up by hand. In India, a flat cutting-instrument called a likurpa is frequently used by grass-cutter's to scrape out the rhizomes of the grass, which are highly nutritious; this practice should not be allowed in forests. Scythes may be used in older plantations, but on the condition of leaving a narrow zone of grass round each plant. On rides, extensive blanks, road-sides, \&c., there need be no restriction as regards the instruments used for grass-cutting.

(4) In hot countries, grass which springs up after forests have been burned furnishes better thatching or paper-material than when cut from unburned forest containing much dead and decayed grass, dead leaves, \&c. Hence, in forests under fire protection, grass can only be used with advantage from off roads, fire-traces or blanks which are cut erery year. 


\section{B. Forest Pasture.*}

\section{(1) General Account.}

Forest pasture, except in mountainous districts, where the area of cultivable land is very limited, is no longer so important as formerly; cultivators object to their cattle becoming thin and wiry in roaming about the forests, to their cows yielding less milk than when kept at home, to the loss of valuable manure, and to the increased danger from disease.

In backward countries, however, forest pasture is still prevalent, and it is therefore necessary to draw up rules for its exercise with the least possible amount of injury to forests, as, when unrestricted, it is incompatible with the existence of forests. 'To a certain extent, however, some good may be done to forests by cattie, by keeping down a rank growth of grass and herbage, which interferes with reproduction, and by breaking through and scattering the dense layer of needles in coniferous forests, and exposing the mineral soil for the roots of seedlings. Browsing on advance-growth of subsidiary species, or softwoods which it is desirable to keep in check in favour of more valuable species, may also be sometimes useful. +

The damage done to forests by the grazing and browsing of domestic animals extends to the soil, especially on slopes, and standing-crop; to the roads and other means of communication, and the boundaries, ditches, fences, \&c.

The soil of a forest suffer's chemically, becoming impoverished in potash, phosphorus, and nitrogen, by the removal of the grass ; and physically, becoming hardened owing to the tread of the grazing animals, and the consequent insufficient aëration of the humus in process of formation. The woods are injured by the animals browsing on young plants; biting-off buds, leaves, and shoots; brealing-off coppice-shoots and gnawing the bark of trees ; trampling on, bending down and breaking young growth; exposing and destroying roots, ic.

* Hundeshagen, J. C., Die Waldweide u. Waldstren: Tübingen, 1830.

f In Forest Utilization, p. 137, Fernandez states that goats are useful to regeneration in mature Acacia arabica (babnt?) forests. When the pols are falling, the seeds swallowed by the goats and exereted germinate without delay, whilst other seeds require at least a whole year to spront, during which they are exposed to destruction, chiefly by insects. 
Roads, ditches, slopes, hedges, and fences, are especially liable to injury by grazing animals.

The extent of the damage done by grazing depends on a number of factors. Among the chief of these are:-Species of tree, age of tree; system of management, nature of locality, species of grazing animal, number of animals, season of the year, state of the weather. The amount of damage varies greatly according to circumstances. Thus Hundeshagen * estimates the ordinary loss of increment due to cattle-grazing at one-tenth. Krain states that goats in 15 - to 35 -years-old spruce, Scotch pines and hormbeams prevent almost any growth from taking place.

(2) According to Specics of Tree.

Broad-leaved species are more exposed than conifers, but recover more readily from browsing than the latter. Most exposed to damage are: ash, maples, hornbeam, beech. Next to them : lime, sallow, and poplars. Less still : oaks, elms, Pyrus sp. Least of all: birch, alder, horse-chestnut and robinia.

Of conifers, the silver-fir suffers most, then larch, the different species of pine, and the spruce.

The above scale is drawn-up chiefly as regards horned cattle, but if we consider the preferences shown by other grazing animals, it should be noted that-horses prefer oak-foliage and aroid that of the lime; sheep appear to prefer light-demanding species, even the birch and Scotch pine; young lambs, the leares of robinia; goats are not particular, and even browse on the poisonous yew without injury, in India, however, they succumb to the foliage of Rhododendron campanulatum.

Another peculiarity of horned cattle is to prefer plants introduced into pure woods, such as ash or hornbeam in beech forests, or exotics planted among native woods.

The vegetable monstrosities resulting from browsing are very striking to the eye; rounded bushes, which sometimes broaden out till some leading shoots in their centre escape and grow into trees, are frequent eyesores wherever forest grazing is practised.

* Encyclopädie der Forstwissenschaft. I. Forstliche Productionslehre, 3 Aufl. Tübingen, 1835 , p. 512. 
Shallow-rooted plants such as the spruce, in spring, suffer most from the tread of the animals.

\section{(3) Age of 'Tree.}

Young plants suffer most. In older woods, without undergrowth, the chief injury is done by the hardening of the soil owing to the tread of the animals. The trees suffer from browsing until the foliage is beyond the reach of the animals, and the age at which this happens depends on the rate of growth, the conditions of the locality and the kind of animal.

\section{(4) System of Management.}

In the case of the Selection system, grazing is most dangerous; then come in descending order of danger: Group system, Coppic-with-Standards, Coppice, Shelter-uood Compartment and Clear-cutting systems. Pollarding is the most farourable system to adopt on land open to grazing, as young pollardshoots are out of the reach of the cattle; pollards are regenerated by planting taller transplants, or cuttings, than in other systems, and the plants shonld at first be securely fenced against cattle, which might injure them by rubbing against them, or gnawing their bark. The meven-aged systems of High Forest, such as the Selection and Group systems, suffer most of all, as in the former, young growth is scattered all over the forest, and in the latter, it is scattered in patches over very large areas. If grazing be allowed under the Selection system, regeneration can usually be effected only by fencing-in patches of ground where large trees have been felled, and planting them with strong transplants, which will be out of the reach of the cattle by the time the fences are no longer effectual.

Coppice-with-standards suffers more than pure coppice, on account of the necessity for proserving numerous seedling plants to replace the standards as they are felled. Coppice suffers more than even-aged High Forest, because stuol-shoots branch out lower, and are less firmly rooted than High Forest poles; in the even-aged systems of High Forest all pole-woods can be opened to caltle withont mnch danger. In regular plantations, damage done by grazing is less than in irregular artificial, or 
natural reproduction, and planting in lines somewhat far apart in one direction is most favourable, as the cattle can readily graze between the rows. It has also been observed in grazed forests in hill-tracts, that mound-planting gives better results than pit-planting.

\section{(5) Locality.}

On moist and fertile soil, the damage done by grazing is minimised, because a strong growth of herbage generally springs up on such localities, and the cattle have less inclination to attack woody growth, moreover the trees grow faster, and are sooner out of their reach. Binding or heavy soil becomes all the more compact by the tread of the animals, and less susceptible to the entrance of air and water, and the roots lying immediately below the soil-covering are exposed to damage. Very loose soil becomes still looser from the tread of cattle, as they destroy the herbage which binds the soil together. The greatest damage by grazing animals is on shifting sands.

On level ground, damage is less than among hills, where it is increased if the soil be loose, or the slopes steep; rery wet slopes are also endangered by the sliding of the feet of the cattle. The steeper a slope, up to a certain point, the more erosion is caused; larger plants are also reached by cattle from above, on slopes, than on level ground, and the damage by browsing, bending and breaking is greater.

Scantily wooded, dry, hot aspects are obviously unsuited for grazing.

\section{(6) Density of Forest Growth.}

In dense woods, little or no grass is to be found, so that more damage is done to woody growth than in more open forests, where herbage grows under the trees.

\section{(7) Species of Grazing Animal.}

Among European animals, goats show the greatest preference for woody plants, and their mode of feeding is most injurious. They even devour woody plants when there is plenty of herbage

vOL. IV. 
available, and beat down saplings with their forelegs till they can reach the leading shoots, on which they browse; they can thus reach plants 12 feet in height. They also peel the bark from stems in spring. Their constant movement on the steepest slopes is another great source of damage. To take some out of many instances of the destruction of forests by goats:In the Tyrol and southern Switzerland, and in the Himalayas, fine forests have been completely destroyed by them, and in Ajmere and Merwara, whole hill-sides where regetation once flourished have been laid almost bare, with nothing left but deformed, thorny shrubs. In France, since 1665, goats have been excluded from all forests managed by the State Forest Department, and no legal right can be enforced to graze goats in private forests, as the grazing of these animals is considered incompatible with the maintenance of the underwood.

The sheep is less injurious than the goat, holding its head low, and preferring grass, but sheep browse freely on woody plants, and injure forest soil and the roots of shallow-rooted species by their short tread and sharp feet.

Horned cattle generally confine themselves to grass and herbage, and only attack woody plants in the absence or scarcity of the former. The buffalo in India is, however, frequently fed during the cold season by loppings of evergreen or winter-green trees. Cattle do much injury to forest soil, slopes, roads, and ditches owing to their weight and size, and also break down seedlings and saplings; these injuries are aggravated in the case of the buffalo, which is a hearier animal than common cattle. Oxen are more destructive than cows, and young beasts are worse than older ones, as they gnaw woody growth, partly out of pure mischief and partly to develop the formation of their teeth, and are much more active.

Horses can reach higher, and are fonder of leaf-fodder than cattle, and do much damage to roots by their tread. Foals occasionally peel the bark from trees.

Camels eat almost everything that grows within their reach, to a considerable height, and can feed readily on thorny species owing to their hard mouths. Much damage has been done to forest growth in Northern and Central India by camels. 
Elephants are chiefly fed by loppings from species of Ficus and other trees, as well as on grass and herbage, but the number of tame elephants admitted to a forest is limited, and their browsing can be easily controlled. Wild elephants are very destructive in bamboo forests.

The relative damage done to forests by European grazing animals has been estimated as follows by Hundeshagen :-

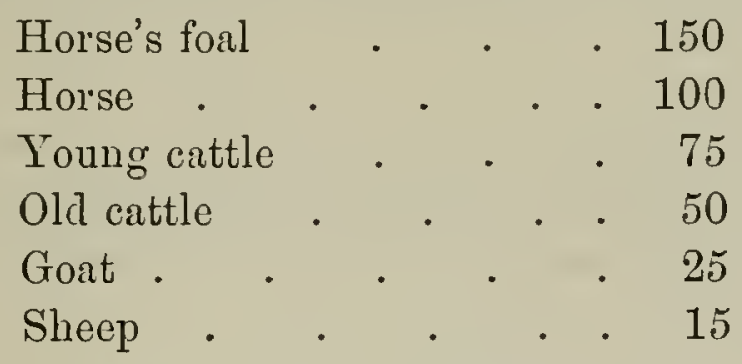

This list is drawn up on the understanding that the animals are freely grazing in forests where the cromus of the trees have grown beyond their reach. The fact that the goat is only estimated to do a quarter the damage of the horse does not controvert the former statement of its being relatively to its size the most harmful beast, for its weight is only about 1-14th of that of the horse.

(8) Number of Cattle admitted to the Forest.

The number of cattle admitted to graze in a forest must be regulated by the species and amount of herbage arailable; it should be so fixed that the latter is sufficient to nourish the cattle, or else they are certain to attack the trees.

Hundeshagen has calculated for the complete nourishment of large milch cattle for the whole summer, night and day, that 10 to $12 \frac{1}{2}$ acres of good pasture is required; for merely grazing by day, $2 \frac{1}{2}-5$ acres, and he reckons 2 to 3 young cattle or 10 sheep as equivalent to one head of full-grown cattle. He esti-. mates for their daily requirements, $18-20 \mathrm{lbs}$. of hay for a cow weighing four hundredweight, 10 to $12 \frac{1}{2} \mathrm{lbs}$. per head of young cattle, and $1 \frac{1}{2}-2 \mathrm{lbs}$. for a sheep.

\section{(9) Season of the Year.}

In Europe the greatest amount of damage is done to forests by grazing in the spring, when the young leaves and shoots are most tempting and the herbage scanty. The strong 
appetite and restlessness of the beasts after the long winter stalling has also to be considered. The least damage is done in the autumn, but as the grass at that season is hard and umnutritious, forest-pasture is chiefly used when the herbage is best and most plentiful, from the end of May till the middle of July.

In the plains and lower hills of extra-tropical India, forest grazing is chiefly confined to the cold and dry seasons, but varies with localities.

In the Himalayas, grazing is carried on in the upper forests from 8,000 to 10,000 feet above sea-level, between May and September, the animals coming down below the snow-level in the cold season.

(10) State of the Weather.

During very dry or very wet weather, or in the morning, while heavy dew is on the ground, cattle prefer the leaves of trees to herbage. The damage done to the roots of trees by the tread of cattle is also greatest in wet weather.

\section{(11) Other Considerations.}

Milch cattle require the best grazing grounds, and those nearest to the villages; then come young cattle. Beasts of dranglit can go further and put up with inferior pasture. Sheep can go furthest of all.

Horned cattle and especially buffaloes like moist pastures, and the latter will eat very coarse herbage. Horses prefer short grass on old roads to that grown on ioose forest soil. Sheep prefer even drier herbage, in elevated lands exposed to full light, such as heather-land, and are very liable to disease if fed on moister lands.

Horned cattle will not graze readily after sheep, and attack woody growth in preference to grass where sheep have been grazing.

Cattle accustomed to forest grazing do more damage than others which seldom come into the forest. Less damage is done when the herds are kept well together, and this is most difficult to secure in the case of goats. 
When one considers all the various circumstances which affect the damage done by grazing, it is not surprising that practical foresters should differ greatly in their estimates of its amount in different cases. Whilst a forester having coppicewith-standards to deal with may consider the amount of damage done as very considerable, another in charge of spruce forest under the clear-cutting system may look upon it as quite trifling.

It is, however, clear that from the experience of grazing in so many mountain forests in the Hartz, Black Forest, \&c., where thousands of head of cattle have grazed for centuries, and the forests are still flourishing, that well-regulated forest grazing may be admitted wherever its necessity for the welfare of the people is very pressing; a great resource in times of drought may also be secured to the people by opening portions of State and other forests for pasture at such seasous.

Under certain circumstances, where the grom under a seeding-felling is covered with tall herbage, or a dense mass of dead leaves and moss, temporary driving-in of cattle may prove useful, and also in the case of a plague of mice, or of insects, when their larvæ or pupæ are on the ground.

\section{(12) Protective Measures.}

The regulation of forest pasture may be considered under the headings: close-time, arrangement of grazing areas, duration of grazing, species of animal, number of animals, control, and protective staff.

\section{(a) Close-time.}

Close-time is the period during which a wood should not be opened to grazing. It commences with the regeneration of the wood, and terminates when the young trees can no longer be reached by the animals, in the pole stage. The length of the close-time depends on the species of tree, the system of management, the circumstances of the locality, and the kind of grazing animal.

Broad-leaved species, especially slow-growing ones, require a longer close-time than conifers; high forests, a longer 
close-time than coppice. In the case of mixed woods, the length of the close-time will depend on the most endangered species.

On poor soil, in exposed places, longer close-periods are required than for good soils, sheltered positions, and mild climates, since trees then grow faster. Sheep can be driven into a forest earlier than cattle or horses.

The calculation of the open area in a forest is given in the following formula :-

$$
\text { Let } \begin{aligned}
\mathrm{F} & =\text { area of forest, } \\
f & =\text { closed area, } \\
f_{1} & =\mathrm{F}-f=\text { open area, } \\
s & =\text { close-time, } \\
r & =\text { rotation of forest. }
\end{aligned}
$$

$$
\begin{array}{r}
\text { Then, } f=\mathrm{F} \frac{s}{r} \\
f_{1}=\mathrm{F}-f=\mathrm{F}\left(1-\frac{s}{r}\right)=\mathrm{F}\left(\frac{r-s}{r}\right) \ldots \mathrm{II} \text {. }
\end{array}
$$

For example, a forest of 1,000 acres area, with a rotation of 100 years, and a close-time of 25 years :

$$
\text { The closed area }=1000 \frac{25}{100}=250 \text { acres. }
$$$$
\text { The open area }=1000 \frac{75}{100}=750 \text { acres. }
$$

Speaking generally, according to G. L. Hartig, the following areas should be closed :-

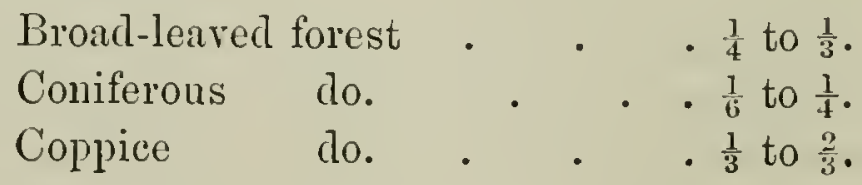

According to Hundeshagen, the close-time should be as follows :- 
Systey of Managenent.

\begin{tabular}{|c|c|c|c|c|}
\hline $\begin{array}{l}\text { Species } \\
\text { of } \\
\text { Cattle. }\end{array}$ & $\begin{array}{l}\text { Broad-leaved } \\
\text { High Forest. }\end{array}$ & $\begin{array}{l}\text { Coniferous } \\
\text { Forest. }\end{array}$ & $\begin{array}{l}\text { Coppice } \\
\text { with } \\
\text { Standards. }\end{array}$ & Coppice. \\
\hline & Years. & Years. & Years. & Years. \\
\hline $\begin{array}{l}\text { Horses and } \\
\text { horned cattle }\end{array}$ & \} $18-24$ & $12-20$ & $14-18$ & $6-14$ \\
\hline Sheep . . & $14-18$ & $9-16$ & $10-12$ & $4-10$ \\
\hline
\end{tabular}

In this table the minima are for good localities, and for species not much endangered by grazing, and the maxima for inferior localities, and for species preferred by the animals.

When the animals are simply driven through a forest, much younger woods can be opened, but in such cases the gradient of the slopes and the consistence of the soil should be considered.

\section{(b) Location of Grazing Areas.}

Every year a new tabular form showing the areas opened to grazing should be drawn-up and publicly advertised amongst the grazing villages which use the forest. In preparing such a form, the open compartments should be arranged so as to make it possible for the animals to pass through old woods from one grazing ground to the next, or drift-roads should be laidout between them wherever young woods intervene, and sufficient time allowed for the grass to grow in a grazed area before its turn for opening recurs. Marshy places, loose soil and steep slopes are to be excluded. Localities with undergrowth which is valued for regeneration must not be opened to sheep. Where trampling is to be dreaded, horned cattle must also be excluded. Attention to the requirements of the animals when drawing up the plan of grazing will also tend to restrict damage.

The closed areas must be marlied on the ground with notice boards, or protected with fences or ditches, the latter to be 3 feet 
wide and $1 \frac{1}{2}$ feet deep, with the earth thrown up on the side of the closed area.

If drift-roads are required from one part of the forest to another, they should be from 15 to 24 feet wide, according to the number and species of grazing animals. Wherever these roads pass through very young growth, ditches, earth or stone walls, or dry thorn hedges, should be placed on either side. The earth from the ditches should be thrown up towards the closed area to assist in keeping out the cattle.

Wherever such protective works are not made along a drift road, the nearest rows of young plants should be protected, as in

FIf. 20.

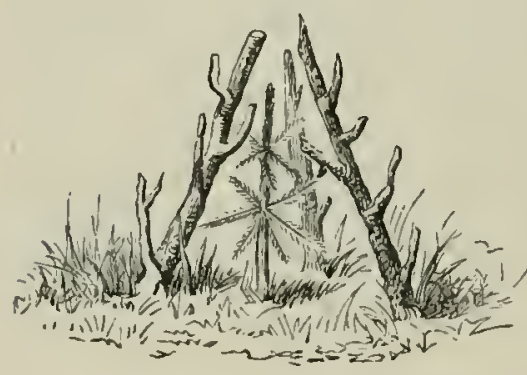

Protection for young plants. fig. 20, each with three rough stakes with the jagged sides pointing outwards. When for the removal of a strong growth of herbage, or other reasons, pasture in young growth is considered advisable, this should be allowed only from the 1st of July after the year's shoots have commenced hardening, and in dry weather. By multiple planting at each spot, in threes or more, there is more chance of success in grazed forests, than when single plants are used. In grazed selection forests, the only certain system of reproduction is to plant in groups where old trees have been removed, and fence-in each group until the plants require no further protection.

\section{(c) Duration of Pasture.}

The usual duration of pasture in Europe is from May till September. The period for grazing varies in different countries, being, however, much the same in the mountainous parts of Northern India as in Europe. In hot countries a great difficulty consists in the custom of firing the dry grass in forests for spring-grazing, in order to get fresh young shoots from the rhizomes of the grass, as the dead cold-weather grass is unnutritious. In certain forests, however, some of the grasses remann green, long after the grass outside the forests has dried 
up, especially when the forests are at a certain altitude and on northern aspects.

Owing to unsuitability of the unburned grass for pasture, certain inferior areas of forest and blanks may have to be given up as grazing-grounds, and burned amnually for this purpose. It is found by experience, that, owing to constant grazing, coarse grasses gradually disappear from these areas, so that eventually they need not be burned, the non-inflammability of the finer grasses then assists in the protection of the valuable parts of the forest from fire. It is, however, always preferable to try and induce the people to cut and remove the grass before it has become dried-up, and preserve it as hay or ensilage for use during the dry season. This plan has had great success in Ajmir, in India.

In the Alps, forest pasture only lasts for ten or twelve weeks, and sheep-grazing on the high forest pastures of the Himalayas is of a similar nature, these pastures not being burned. The winter pastures in the N.-W. Himalayas, in forests of Pirus longifolia, are generally burned, both in order to destroy the dead needles, and to produce a fresh crop of grass. Forests so treated must eventually disappear, and the magnificent reproduction of Pinus excelsa in the middle altitudes of the Himalayas between 6,000 and $s, 000$ feet, since fire protection has been introduced into the forests, is most remarkable.

In wet weather, forest grazing must be stopped, or only carried on in old woods. The usual daily grazing should only commence after the sun has dried the dew, and uight-grazing is not generally allowable. If cattle are to be driven through young growth, this should be in the afternoon, after they have already had a good meal.

(d) Species of Grazing Animals.

Goats, horses, and camels must not be allowed to browse in valuable forests, but their fodder should be cut and brought to them. The French Govermment excludes sheep as well as goats from all forests managed by the State Forest Department, but sheep may be admitted to graze in forests in certain localities under special sanction. Elephants may be admitted into forests with their keeper, and their fodder cut and brought in by them. A 
list of climbers and inferior forest trees suitable for the fodder of goats, camels, elephants and buffaloes should be drawn-up and circulated amongst all keepers of these animals who obtain fodder from a forest, and the fodder, as far as it consists of woody plants, should be restricted to these species.

As regards other grazing animals, the number to be admitted into forests must be carefully controlled. This number will be determined by considering the amount of their requirements and the available quantity and quality of the herbage in the forest. Wherever tender grasses are arailable, these are exclusively grazed on.

No diseased or sick cattle should be admitted, and from onetenth to one-fifteenth of the animals should be provided with bells, those inclined to wander from the herd being chosen.

The animals should only be driven into the forest in flocks or herds under the care of trustworthy herdsmen, who must see that they do not crowd together, nor stray too far apart. A few horses may be attached to a herd of cattle, but cattle and sheep should never be kept together to graze. The herds must not be too great, not above 100 to 150 head. All crowding and fast driving, and especially driving cattle with dogs through young growth, must be forbidden.

On slopes grazing animals are driven straight up from below, and very slowly, in order, as much as possible, to aroid damage by their tread.

Shady places in old woods without undergrowth should be selected for rest in the middle of the day, and must be near water for the animals to drink.

\section{(e) Herdsmen.}

Well-reputed, trustworthy people must be selected as herdsmen, and the owners of the cattle held responsible for damage or breach of regulations, any failing in this respect being at once reported.

The forest manager should secure for himself a certain influence in the appointment of the herdsmen, and endeavour to get them to take interest in the welfare of the forest, by rewards for good behaviour, and disconragement if they are careless. If 
the herdsman chooses the proper moment, when the beasts show an inclination to attack woody plants, to drive them on to another pasture, and when to graze in young woods, and selects old woods in wet weather-in fact, if he has the necessary power of observation and will use it for the benefit of the forest, the damage done by grazing may become quite inconsiderable.

\section{(13) Greese, etc.}

As regards domestic birds, geese, forvls and pigeons may damage a forest, the former spoiling the pasturage, and the latter devouring forest seeds; but certain blanks may be found suitable for geese, and the damage done by fowls and pigeons is inconsiderable.

\section{Forest Litter.*}

As the removal of litter consisting either of the soil-covering of dead leaves, needles, humus, moss, etc., or of branches of forest trees in full foliage, is the most hurtful form of utilization of minor forest produce, its permission must be looked upon as altogether exceptional, and only to be granted under the most pressing necessity (scarcity of straw, etc.).

The then requisite protective measures are :-

Limitation of the quantity of litter to be removed to what is absolutely required by local farmers and peasants. Not a word should be heard in favour of selling the litter to others.

If the rides, roads, ditches, places from which the wind would inevitably blow away the litter, and hollow places where it becomes heaped up unnecessarily deep do not suffice for the requisite supply of litter, then felling-areas with high herbage should be opened, but growing woods only as a last resort.

Only places with fertile, deep and fresh soil can bear a limited deprivation of litter. On poor, shallow, easily dried, hot soils and on sunny aspects, the collection of litter must be unconditionally refused.

Woods which have not yet attained their maximum heightgrowth must be closed against the removal of litter. The neces-

* For an account of the value of humus in the soil of a forest, see Schlich, Sylviculture, Vol. I., pl. 129 and 143. 
sary close-time depends on the species, the locality, and the length of rotation $(r)$; it should be at least $\frac{1}{3} r$ for High Forest and Coppice-with-Standards, $\frac{1}{2} r$ for Coppice, but for exacting species, such as the beech, we must wait up to $\frac{1}{2} r$ even in high forest.

Woods the quality of which is under $0 \cdot 7$, where unity stands for best quality, must not be used for litter.

The repetition of the ntilization of litter is only allowable after a certain close-time, which varies from five to ten years according to species of wood, quality of locality, rate of growth, ete.

Remoral of leares should not be permitted two years before or after a thinning, and in the case of natural regeneration there must be a close-time for litter some years before and after a seeding-felling. This, however, implies such a state of decomposition of the soil-covering, that seedlings can strike their tap-roots into the mineral soil. Wherever deep layers of undecomposed humus prevent this, they must be remored so as to expose the mineral soil.

The most suitable time for removing litter in Europe is on sumny dry days in September and October, shortly before the fall of the leaf. This rule will require modifying where, as in hot countries, some of the trees lose their leaves in the spring.

Iron rakes must not be used for collecting litter, as they go in too deep and may injure the roots of the trees; brooms also remore too much litter. Only the uppermost undecomposed layer of litter should be remored. Cutting and remoral of sods of grass with the roots must be forbidden.

As regards moss, species of Hypmum should be removed only in strips during the spring, so that the regeneration of the moss on the bare places may be facilitated from the strips left untouched; this happens, when the soil is fertile and moist, in about six years. Then the old strips of moss may be removed, and another six years left for the bare places to recorer, and so on. Species of Polytrichum and Sphagmum, which generally grow in patches on wet soil, eause swamps and are hurtful rather than useful, and ean therefore always be removed.

Branch loppings for litter, best from silver-fir, should be conceded only from felled trees or from those just about to be felled. 
During removal of the litter, the forest must be carefully watched, and wherever annual permission for litter is given, a scheme must be drawn up, allotting the open areas for successive years.

By careful economy in the preservation and use of all manures and by the use of straw and provision of fodder-crops for stock, the demand for forest litter may be reduced; it is the duty of the State to impart public instruction in this respect, and in the extreme impoverishment of forest soil by the constant removal of litter. Among the worst instances of damage to the soil by the remoral of litter are the State forests near Nuremburg in Bavaria, where even Scotch pine, in the worst parts of the forest, can now only grow as a dwarfed scrubby tree almost useless except for fuel.

\section{Dead Branch-urood.}

Wherever the removal of dead branch-wood is not a right of usage, but is permitted under certain conditions by the forest manager, the following rules apply :-

Written or priuted permits for the removal of the dead wood must be held by each person so engaged in order to prevent the concession from becoming a right, and generally, people too poor to purchase fuel should be faroured in this respect, but they should not be allowed to sell the wood.

Very poor or exposed localities in the forest should be excluded from the use of this concession, as the dead branches increase the humus in the soil.

As a rule, no tools should be used, but where removal of dead branches from standing trees is allowed, they should be sawn off close to the stem.

In order to facilitate control, the removal of dead wood should be allowed only on certain days, and not between sumset and sumrise, and the forest carefully watched on those days.

Wherever game is of importance, the privilege must be suspended during the breeding season.

It may be necessary to prescribe the removal by certain roads in order to facilitate control.

The removal of falleu dead wood is not so harmless as many 
people think, as a considerable amount of humus is formed from it. Thus saprood, of which young branches are chiefly composed, contains far more potash than heartwood.

In the Crown forests of Hesse the privilege of collecting dead wood gratis is subject to the following rules:-

All dry fallen wood which in the opinion of the forest manager is unsuitable for sale, may be taken. Also dead branches which can be broken off by hand by one person without climbing the

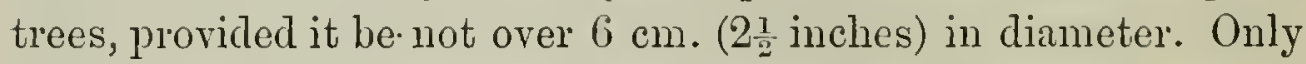
poor people provided with formal permits are admitted between sumrise and sumset to this privilege. All tools are excluded, and no sale of the wood allowed. Transport is by head-loads, or in hand-sledges. The privilege is stopped during May and Jure.

\section{Remoral of Stones, Gravel, Sand, ete.}

'The following rules should be enforced :-

All quarries, sand, clay and gravel pits must be properly demarcated, and the boundaries strongly walled or fenced to prevent accidents. Proper precautions must be taken that neither roads, nor streams, wor the forest outside the quarry are imperilled by quarrying.

Stones lying about on the ground should be collected only where their removal is not prejudicial to the forest, and when removed, the ground where they were lying should be levelled. Removal of loose stones should not generally be allowed on the sites of fellings, especially on loose sand or calcareous soil which dry up easily, as stones retain moisture in the soil. Places must be assigned where the stones may be stored and roads designated for their removal.

Sand, clay, and gravel pits which have been abandoned should be levelled or sloped-off to prevent accidents, and if possible planted-up. This rule is especially applicable to experimental pits abandoned as not sufficiently profitable.

10. Collection of other Items of Minor Produce.

Collecting berries, such as those of bilberries, wild strawberries, raspberries, etc.; edible fungi; empty cones lying 
on the ground; grass-seeds; medicinal herbs or fruits, and other such produce, the collection of which is not worth the trouble of the forest owner, must be so regulated that only persons provided with formally written or printed permits should be admitted, and the period of collection should be fixed. In hot countries, some of those products attain a much greater importance than in temperate regions, and certain special rules may be necessary, as in the collection of wild honey and wax in India, where care must be taken to prevent the collectors from firing the forest, so that it may be necessary to prolibit the collection altogether except during seasons when the grass and soil-covering in the forest will not burn.

\section{Game and Fisheries.}

Leases in forests of the right to hunt or shoot game and of fisheries frequently produce consideruble annual revenues, but whilst little or no damage is done by pheasants and other birds, deer and ground-game (hares and rabbits) may do a great amount of harm to a forest. The measures to protect forests against these animals will be given further on.

The protection of game and fisheries is dealt with in special treatises, and would take up too much space in the present book. In most civilised countries there are special laws relating to game and fisheries, and these should be so framed as not only to prevent wholesale destruction of useful wild animals and fish, especially during their breeding season, but also to afford compensation to owners or tenants of land bordering on a forest, for damage done to their crops by any excessive head of game which may be preserved in the forest. They should also fix a minimum limit to the area on which a man may claim the exclusive right of shooting on his own land; this is especially required in countries where landed property is much subdivided. 


\section{CHAP'TER III.}

PROTECTION OF THE FOREST AGAINST OFFENCES.

\section{General Account of the Subject.}

The theory of forest legislation and the law of forest police is dealt with under Forest Law.*

There are of course a number of acts which constitute an infringement of the rights of the owner in a forest, which may be only remediable by a ciril court:-either by a suit for an injunction to the offender not to repeat his act, or for damages. Of such cases it is not necessary to speak in detail; but a word may be said about "trespass." Ordinarily an entry on a man's property which is not lawfully warrantable gives rise to an action for damages; but under the English law (and so in India) trespass camnot be prosecuted criminally, unless there is proof that the entry was with intention to do "mischief" or commit a legal offence of some kind. When, therefore, in forests, it is desirable (owing to the special circumstances) to make penal the mere act of climbing a fence and aimlessly wandering (off regular paths) in a compartment, or a young plantation, it can only be done by an express enactment of a suitable prohibition and (light) penalty.

\section{Definition of a Forest Offence.}

Under the term "forest offence" is here included any act done in a forest which is punishable under an existing forest or other law, and by which damage is done to the forest or the interests of its owner are threatened. Offences which affect or threaten forests (or the produce of them when converted and stored, or in transit) or which interfere with control, are naturally sometimes of a kind which might occur in respect of any property,

* Reference may be made to "Forest Law," by B. H. Baden-Powell, C.I.E., London (Bradbury, Agnew, \& Co. Ld.), 1893, which also refers to the principal works on the subject. 
and sometimes of a special character: i.e. they only happen in forests and are not attempted elsewhere; or else are exceptionally dangerons or injurious when done in a forest (or with regard to forest property generally). Hence in most systems of law, "offences" are partly punishable under the provisions of a forest lav, and partly under the ordinary "Penal Code" or the statute and common law of the comntry.

In India, for example, such ofiences will sometimes come under the Forest Acts; sometimes under the Penal Code; sometimes under either. And it is a matter for the law manuals to tell us when one law or the other should be had recourse to. In the British Istes there is no special forest law ; accordingly all "offences" that are punishable (as distinguished from acts which give rise to a claim for damages) are so under the ordinary (Criminal) Common and Statute Law.

\section{Classification of Forest Offences.}

Forest offences may, therefore, be classified as follows :-

(a) Damage :

Unintentional.

Wilful.

(b) Misappropriation :

Simple.

Accompanied by damage.

(c) Contraventions of forest police.

The subjects of forest offences are sometimes the forest soil, or its covering; the stack of wood or minor produce, whether standing or converted; houses, roads and other works and appliances used in forest business.

\section{(a) Damage.}

Unintentional damage occurs in a variety of ways, as for instance:-damage to standing trees through clumsy felling of other trees, to young growth during fellings or removal of material; cutting up valuable timber into firewood in ignorance of its value; cutting seedlings during grass-cutting; driving carts over boundary marks, through ditches, down embankments, etc. The number of cases which may occur is so great, that to VOL. IV. 
draw up a complete list here is impossible. In many cases no legal offence is committed which is punishable criminally; but the doer of the damage is liable to make reparation.

In the case of wilful damage, the motives may be wantonness, revenge, selfishness, even superstition.*

Damage of this kind includes:-peeling the bark from standing trees, girdling, cutting-off leading shoots, lopping branches or exposed roots; lopping branches from trees yielding mast, or from cone-bearing trees in order to facilitate the removal of their fruit; wilful damage to boundary marks, fences, forest nurseries, or other forest appurtenances.

\section{(b) Misappropriation.}

Under this heading is understood illegal appropriation of forest property still belonging to the forest owner.

In most systems of law "theft" and "larceny" refer to "personal" or " moveable" property: such as a watch, firewood in a stack, a log, or a beam; and there is (or may be) a difficulty about prosecuting cases of lopping, or the offence of cutting a standing or growing tree, bush, or sapling; generally, therefore, the forest law (if there is one) will specially provide for these cases, and will leave "theft" of forest produce (stored), cut timber, etc., to the ordinary law. $t$ Where there is no special forest law, the cutting of standing trees would at any rate coustitute "wilful damage" or " mischief."

Simple misappropriation (in the general sense of the term) is unaccompanied by any damage to the forest, so that no loss of increment, no impoverishment of the soil, results from the offence, but merely the loss of the property illegally taken away. In this is included the illegal removal of dead standing trees (provided no damage is thus done to living trees); of dead branches or windfalls; of fruits not required for natural reproduction; of

* About thirty years ago a deodar forest in Jaunsar, in the N. W. Himalayas, was deliberately burned to propitiate the goddess of small-pox.

t In India, a technical distinction is drawn between "theft" and "misappro. priation," for which see "Forest Law" (p1. 118, 426). It is provided, how. ever, in the Indian law, that though "theft" can only be of "moveable" property, - and a standing tree is not such, - still the act of cutting and severing the trec from the soil may make the object moveable and also effect the lnoving with dishonest intention that is necessary to constitnte "theft." 
grass from rides, or roads; of stones lying on the ground, berries, edible fungi, etc.

Misappropriation accompanied by damage is committed when the forest owner, in addition to the loss of the articles abstracted, suffers physical damage to his property, which may differ greatly in degree according to circumstances (species, age of wood, system of management, density of growth, locality, etc.).

To offences of this class belong, as regards principal produce:cutting and removal of standing timber, or parts of standing trees, involving loss of increment and irregularity of management, or introducing decay into the wood; removal of mother-trees in regeneration-fellings, or of standards in stored coppice, resulting in delay in the reproduction of the wood, deprivation of shelter against atmospheric influences for the young growth, exposure of the soil, etc. Some of the most harmful of these offences are digging up green stools from coppice, and removal of young plants from plantations, as thus the care taken to restock a wood is frustrated.

As regards minnr produce:-peeling bark, tapping for turpentine or gum, lopping branches for fodder, grazing, raking-up litter, cutting sods, and appropriation of the resulting produce, are common offences.

In many of these cases, as for instance in the removal of litter, the damage done to the forest far exceeds the value of the material abstracted.

\section{(c) Contrarention of Forest Police Regulations.}

The offences comprised under the above heading are infractions of police regulations made for the public welfare, or in the interests of forest conservancy.. No damage need result from such offences, as for instance from lindling a fire in a forest which may become extinguished without causing a forest fire, although there is an imminent probability that such a calamity will happen, and this necessitates the stringent prohibition of such an act. Offences of this nature may be placed in the following groups :-

(i) Offences against forest control.-Examples: removal of wood without permission, at a forbidden time, or by a closed 
road; collection of dead fallen wood without a permit, on forbidden days, or with prolibited tools, etc.

(ii) Offences endungering the forest.-Examples: lighting a fire; leaving unextinguished a fire lighted with permission of the forest manager; carelessness in burning charcoal or lime; smoking pipes without covers; going into a forest with torches, etc.

(iii) Acts preperatory to "forest offence, which are consequently prohibited:-Examples: trespass by climbing over fences, carrying axes or saws in a forest without permission, injury to notices, etc. Forest trespass (in closed places, off regular paths, etc.) where this is made penal by law.

Many forest offences comprise damage or misappropriation, as well as contravention of regulations; as for instance injury to growing trees by transport on a prohibited road, kindling a fire in a forest with misappropriated wood, etc.

Such complications may involve several heads of charge in the prosecution case, or call for severer punishment than offences of a simpler nature.

\section{Protective Measures.}

Protective measures against forest offences may be either direct or indirect. The latter chiefly involve removal of the cause of offences, and the former are directed against the offence itself ; it is, however, difficult to draw the line between them.

Unfortunately forest offences are always considered less culpable than those against the penal code, as many German proverbs show. This results from the former communal possession of many forests, and the small value of forest produce in earlier times. Even now, the appropriation of Christmas trees, birches for Whitsuntide and sallow branches in bloom for Palm Sunday, are frequently considered justifiable. The forester should not be too exacting regarding certain innocent practices ingrained in the popular mind, and he should endeavour to become acquainted with all local customs which prevail near his forests.

The following are the protective measures against fores'i offences :-

\section{(a) Remocal of Causes of Offence.}

Want of occupation and consequent poverty often leads to an 
increase of forest offences. As a population increases, without more opportunities for employment arising, and as the clearance of communal and private forests causes a rise in the price of forest produce, the temptation to commit offences is increased. They are also more frequent near populous towns than elsewhere, as the trade in stolen forest produce is thus facilitated. At Hardwar in N.-W. India, in 1882, unmarked forest produce brought into the town was regularly priced lower than properly certificated produce, as the former was suspected of having been misappropriated and might get the purchaser into trouble. Insufficient education, careless watching of a forest, bad forest legislation, and a feeble execution of justice on the part of magistrates, may all combine to increase forest offences.

The subject of Forest Policy comprises a study of the above factors, and only the energetic action of the State can ensure thorough protection to forests against forest offences. Under Forest Protection, we can rely only on means within the power of the private forest owner, which are as follows :-

(i) Careful utilization of all forest produce, so that all local wants may as far as possible be supplied. Frequent sales of produce, and in small lots, and credit given for a certain part of the purchase-money until the purchaser can begin to realize the value of his purchase, are useful measures.

(ii) Provision should also be made for the sale, by printed or written permit, of kinds of principal forest produce which frequently form the object of misappropriation, such as hop-poles, props for fruit-trees, cart-axles, wood for ploughs, pea-sticks, thorny bushes or stakes for fences, bast for rope-making, Christmas trees, faggots, etc.

(iii) Permits, if necessary without payment, to remove certain minor forest produce as far as is consistent with the safety of the forest, should also be obtainable throughout the year. For instance, to cut grass; for dead fallen fuel; to collect berries, edible fungi, cones; to utilize some kinds of litter the removal of which is not harmful ; in certain cases for the temporary cultivation of crops. Tall coarse grasses may frequently be removed to the advantage of a forest, and thus may be secured less danger from frost and fire, more heat and moisture in the soil, and loosening of the surface, all of which are important for plantations. 
In the case of temporary cultivation, potatoes are to be preferred to cereal crops, as they impoverish the soil less.

(iv) Supplying labour in the forest in bad times. Roads, drainage, ditching and remoral of stumps, will furnish employment, in addition to the ordinary felling and planting work in a forest.

(v) In the case of communal forests we have moreover to secure economy in the use of firewood by introducing the use of improved stoves, ovens, etc. The firewood store-depots should be centrally situated, so as to facilitate removal of the material by the householders. The wood should be delivered dry and in the smallest quantities in demand.

(vi) Improvement of agricultural methods, so that agriculture may depend as little as possible on the forest. Common-land should be used to the best advantage; technical instruction in agriculture should be afforded, etc.

(vii) Something may be done by the exercise of tact and kindness in the administration of a forest, to prevent the ignorant peasantry from feeling the forest to be a hostile institution in their neighbourhood. This need not impair the effectireness with which important rules are enforced and the safety of the forest ensured. It is possible so to act as to make the people not dislike the control, by using discretion in enforcing particular prohibitions. Ignorant peasantry will always dislike forest conservancy; but they need not feel it a grievance : there is an irritating lind of exactness which tends to provoke a spirit of malice and a desire to injure the forest; whereas, a judicious management will in time disseminate the idea that the forest is after all a benefit, and that the forester is not the enemy of the people.

\section{(b) Direct Dealing with Frorest Offences.}

(i) The forest should be subdivided into beats of suitable size and shape for patrollin! and leeping watch against trespassers, or against the causes or origin of fire; in Germany, the area of a beat ranges between 500 and 1,800 acres, the latter in Würtemberg, the mean area being 1,150 acres. Trustworthy forest guards should be appointed, who sbould be allowed sufficient pay and houses well situated as regards their beat, also allot- 
ments for a garden and potato-field, and pasture for one or two cows on forest rides and blanks. Proper control of the guards, and promotion and reward of good men must be seen to by the forest managers.

(ii) Wood-cutters and contractors employed on work generally should be induced to participate in the protection of the forest.

The forest should be constantly inspected, and all workmen employed in it supervised. Proper rules regarding forest fires must be duly made known and strictly enforced.

(iii) All forest offences must be promptly reported, and the offenders prosecuted. There are some particular offences against which special remedies may be adopted. Where tappings for turpentine have been illegally effected, they may be smeared with lime-water, which stops the flow of turpentine. Where removal of litter is to be feared, stumps may be left somewhat high at the thinnings, or stakes driven into the ground to impede progress. All stumps of stolen trees should, on discovery, be marked with a special hammer to facilitate control. 


\section{CHAPTER IV.}

PROTECTION AGAINST DANGER FRON FOREST RIGHTS.

Section I.-General View of Forests as "Estates" or Pieces of Property.

\section{What is Property?}

A Discussion cannot here be attempted of the legal definitions of property, or the questions involved in legal possession, and so forth, with which the whole subject is bound up. We commence with the practical consideration, that in modern times most things that are available for use have, or are presumed to have, an owner. In particular all land (in countries where there is a civilized goverument) has come to be recoguized as the "property" of someone: even an open moor or waste is owned by someone. This ownership implies the following elements :-

(a) That within certain limits or boundaries,

(b) the "owner" has certain positive rights: which other people have not.

(c) He has also the negative right that other persons are bound not to interfere with his rights.

In either case there is a legal remedy, which the owner can invoke in the case of an infringement of lis right.

(d) It is possible that some other persons (without actually infringing the owner's right) may have certain rights of their own which limit the enjoyment of the owner; if so, these rights must be known and certain.

Where these conditions are not yet legally existing there cannot be, for any practical purposes of management or control, an estate or moperty.

Where the owner's right ( $a$ and $b$ above) is not limited by the 
existence of other rights under $(d)$, the lawyers shortly express the sum of his rights as ouncr, by saying that he has the use (every possible advantage from the estate); the abuse (the right to destroy and make it a waste, unless some express law prevents him); the fruits, i.e. all produce and accessories; and lastly, the right to let, lire, alienate, and maintain any kind of legal action necessary to defend his property.

\section{Of the I'ersons who are Ouners.}

Forest property may belong to an individual owner, or to a partnership or body of co-owners, or to the State; or to what is called an artificial or legal person, namely, some body of men, or individual holding a peculiar position, or even an official trust, or some institution, which the law regards as if it were one single person, taking (as regards the property owned) no thought of the individual member or members composing it.

The corporation, as a legal person is called, is exemplified by the "Crown," the "rector of a parish," a town corporation, a college, charitable, or other body, which is by law, or by a Royal Charter declared to be corporate. In such cases the law or charter specifies the officer (chairman, secretary, \&c.) who is to represent the corporation: the act of the whole body is signified by a common seal.* The individual members of a corporation have no interest in or liability for the property whatever, nor can they take any action regarding it. Thus corporate property differs from property where the owner is a company (not being a corporation), or a partnership, or a set of two or more joint owners: for all these have separate rights and individual interest, although until partition, no one of them alone can deal with any portion of the estate.

\section{Limitation of Ouner's Right.}

In the short enumeration of the characteristics of property it was noted that sometimes, though there was an owner to the

* This has nothing to do with the departmental official seal used by a forest department or government secretariat, etc. "I'he "State" or "the gorermment" as owner of forests and so forth, is not exactly a corporation-but it is analogous. State property is always provided to be managed and held by someone-e.y. the Secretary of State for India in Council, in the case of prblic property in India. 
estate, whose right extended over the whole, within its proper boundaries, there might be third persons, having rights within the boundaries also. When this is the case it is often popularly (but inaccurately) said that the ownership is limited. Ownership in itself is an ultimate and indivisible right; if a person is owmer at all, he is simply owner, he cannot be something more or less, so long as he retains the legal title at all. But around the right of ownership cluster also a number of subsidiary rights and enjoyments, some of which can be broken off, so to speak, and come into the hunds of other persons. Hence, though the ownership remains, the enjoyment of it may be either absolute and unfettered or may be limited. One obvious way in which such limitation arises, is by some contract-such as a lease, pledge, or mortgage, or loan of the estate; with that kind, however, the present work is not concerned. There is another class of rights of third parties which do not arise out of any lease or temporary contract, and their existence often causes a very considerable limitation of a forest owner's enjoyment and control of his property.

\section{Rules of Protecting Forest Property.}

Before discussing the nature of these rights, some bricf rules may be given, which apply to the protection of the forest property or estate as such; to secure the area, general title, and legal position of the property.

(a) See that the forest is regularly and permanently demarcated, both as to its general outer boundaries and as to all inner boundaries - which mark the limits to which certain rights extend, or in which there are no rights other than the owner's.

(b) Exercise the rights of ownership in the forest, especially near its outer boundaries; let no one have an excuse for saying it conld not be known that any one was in possession, or was owner of the place.

(c) Carefully prevent damage to the estate, its roads, fences, works, etc., especially if caused by the removal of forest produce.

(d) Carefully watch against encroachments, and all kinds of forest offences, injury to boundary pillars and other marks. 
(e) When any licences or concessions are allowed, see that it is always done by written or printed permission so worded as to make it clear that no right of a prescriptive character can arise.

$(f)$ Exercise any rights the forest estate may possess over other estates, and all claims to labour, or payments, all rights of receiving help in case of forest fire or other calamity, or receiving information (which may be imposed by the forest or other law).

\section{Section II.-General Account of Forest Rights or SERVITUdes.}

\section{Nature and Origin of Forest Rights.}

As already stated, it frequently happens that persons (sometimes individuals, sometimes legal persons or corporations) possess rights orer a forest (or other) property which belongs to someone else. These are permanent rights, which have nothing to do with a contract, or temporary lease, mortgage, etc. In that case the forest or other estate over which the limited right exists is called the serrient estate-it is burdened with the right. These rights are called by various names. The Roman lawyers called them servitudes (because the burdened property was made to serre the purpose of the holder of the right). In English some were called easements (i.e. one kind of them were so, of which presently), others rights of common. In India, the Legislature (abandoning this distinction) has called them all "easements." "Such rights

* Origin of forest rights. - In Germany these rights often arose out of the old agricnltural communities whose territory or .Mark had a portion or borderland of waste and forest which (in some sense, at any rate) belonged to the inlrabitants. From the time of Charlemagne these border-forests were appropriated by the empire or by powerful landowners and town corporations, and the original owners became mere right-holders. Waste lands attached to villages in India have also had something of the same history ; but under the effects of the land settlements such areas have mostly been freely given over to the villages. In the Garo Hills (Assam), where tribal settlements in the ancient model still can be observel, it is only within the last 30 years that fighting has ceased when one village group tried to encroach on the border-forest of the next. Forest rights also arose by grant of the baron or lord : aud still more grow up by local custom, and long nser of the neighbours, partly because the modes of agriculture then known suggesterl forest grazing, lannage, etc., as the most desirable, and wood fuel was rernuired before coal was obtainable. In those times, too, lorests were abundant in comparison with the number of the population : and no one cared to interfere with people habitnally taking what was so abundant and had so little value. 
depend partly on gronts, or some form of written title, perhaps a judgment of some Court, and partly on what is called mescription. By this latter term we mean, that though the exact origin is not known, yet as a matter of fuct the right has been exercised for a long time-the term of years (usually 20 or 30) is fixed by the law of cach comntry-and also has been exercised openly (not by frand and unknown to the owner), peaceably (not by violence), and as of right (not by mere leave or sufferance, acknowledging that the owner could put a stop to the practice). When these conditions concur, there is a full legal right by prescription. It is also possible the rights may be regarded as (in a way) prescriptize, by reason of their being admittedly matters of ancient local custom or on other equituble grounds, even when the precise terms of a legal prescription, as above stated, are not established.

\section{Rights or Serritudes classified into Kinds.}

The lawyers in various countries have classified these rights in different ways in consequence of particular legal distinctions. For example, such rights are said to be negative when the estate which bears the right is merely under the continuous obligation not to do something-i.e. not to dig a liole so as to endanger the right-holder's foundations, not to stop the flow of water, etc.; and positive, when it is obliged to allow the right-holder to do or take sometling, as to drive his cattle across a field, take wood, or drive-in pigs to feed on acorns, etc. Rights are also said to be continuous or discontinuons (intermittent); the former in their nature are continually in operation at every moment (as a right to light and air by ancient windows*); the latter are used from time to time, either at fixed intervals (e.g. a right to have 10 beams for repairs once every 5 years), or on occasion (as to cut brushwood for fuel when wanted). This latter feature (discontinnity) may give rise to a further question, which will be noticed presently.

On the subject of classification of rights of user, only two points have a practical bearing on protection. One concerns the nature of the right, the other concerns the nature of the right-holder.

* And in general all negatire servitudes are necessarily contimuous. 
As regards the nature of the right, there is an obvious distinction between rights which (whether negative or positive) only imply some use of the servient estate (as walking over it, letting water flow across it, having the support of soil for foundations, having a beam resting on a (servient) neighbouring wall, etc.,-in all which cases nothing is taken out of or from the servient estate; and those rights which do take something; e.g. rights of pasture, wood rights, rights to dig sand, litter, etc.) [It is the former only that the English lawyers call easements; the latter are rights of common, or profits i premlre in older books.] And then as to the holder of the right: this may be a person A. B. aud his heirs; it is always understood that the person camnot alienate the right or servitude. Such rights are said to be personal rights, or as English lawyers say, rights in gross. But very often the right is held not by a person (natural or artificial) as such, but by a certain house, farm, or other building or estate; so that the right is exercised by the person who happens to be the holder of the estate or farm, etc., for the time being. Should the present holder go away and sell the farm, etc., he would cease to have any right; but the right might pass with the farm by sale. Rights of this lind are called real rights (real in a technical sense), and the estate, house, farm, etc., to which they are attached is called the dominant estate, just as the estate which bears the right is called the serrient estate.

Different systems of law have different ideas regarding these rights. For instance, in France and Germany forest rights (to pasture, wood, etc.) are always real rights-they are always attached to some farm, building, etc., for the benefit of which the right exists. But this is not always the case in Britain or in India (except in some few cases which in their nature imply some (dominant) house or building or land to which the right is attached); it is quite possible for an individual to have a customary right as such individual.* It is not necessary then to

\footnotetext{
* A brief note may be useful as to village rights in India : it cannot be sail, or can only be true in particular cases, that a village is in any sense a corloration, or that it, regarded as a single (artificial) person, can loold rights of user or common; nor can it in general be regarded as a single dominant estate possessing rights. If (though not warranted by the Indian forest law) a right is set down in a public record as existing in favour of "village C." - this merely means that all nulubitants (or perhaps only anl landholders) of village C., for the time being, can exercise the right in question.
} 
pursue this classification further, except to be sure that when a right is so attached, the record of it makes it quite clear exactly where, what and of what extent, is the house, farm, or estate, which is the dominant or right-holding property.

It need only be mentioned that personal rights may be granted or become prescriptive to a person and his heirs for ever, or may be (granted) for life or lives only.

\section{Forest Rights which are Undefined.}

Returning for one moment to the prescriptive origin of rights, one very important matter has to be noticed. Such rights are nearly always undefined or indefinite-indeed, it is possible that some rights by the terms of a grant are also left undefined; but most commonly it is prescriptive rights that are so.

The custom is that the right-holder may graze "his cattle" in forest A. (how many and of what kind, and at what season is not stated); or that he may have power to build and repair "his house"; or he has "common of estovers"- - a right to fuel-but of what kind (brushwood or billets) and for what purposes, does not expressly appear.

In all systems of law there are rules for determining how such undefined rights can either be brought formally to record in a definite shape (e.g. the Indian Forest Act*), or at least there are provisions for fixing the number of cattle, quantity of timber or firewood, etc., to be claimed under the right. These principles are detailed in law manuals. $t$ No system of law allows such a thing as an unlimited right-for that might swallow up the entire ownership-a thing contrary to the very nature of a right of this kind which, it should be always remembered, is a permanent right (not arising out of contract) of one person or estate, which exists over the property of another person, to have some use, or take some part of the produce of the other property.

It is true that sometimes a number of separate rights may exist, the aggregate demands of which form a serious burden on

In all fully-constituted State forests in India, the law requires crery right claimed to be brought before a public officer appointed for that purpose and not only recorded, but made as definite in number, extent, kind, ete., as circumstances allow.

+ "For instance, in Danckehnamn's -Ablösung und licgclung, 3 rols.: Berlin, 1Sso. baden-l'owell, "Forest Law," 1. 31s, ff. 
the forest property ; but there is no infringement of the principle. It is also to be mentioned in passing, that sometimes there is a lind of right over property of a special nature, called the usufruct, which implies that the whole of the normal produce and the general enjoyment of the property passes for life to the usufructuary; but even then, the holder of such a right is not owner, nor can he do anything that alters or injures the property in its substance, or affects the ownership right*-a fortiori, therefore, a mere holder of a right of common is bound to respect the estate on which his right subsists, and treat it civiliter et modeste according to Roman Law, or en bon père de famille, in French Law, and cannot demand an unlimited, or abusive enjoyment of it.

\section{How Forest Rights may Terminate.}

As we have considered how such rights may grow up, so a few words will be appropriate as to how they come to an end.

(a) It may be naturally: as where the dominant estate disappears (e.g. river diluvion), or where the personal right-holder dies without heirs.

(b) It may be that the forest is unable to satisfy the requirements of the right; here the right must remain in abeyance, till the forest has recovered from the calamity which caused the inability. Where the rights are permanently in excess of the yield-power of a normal forest, then the law usually provides express terms for dealing with the difficulty. ${ }^{+}$

(c) When the right-holder becomes (by will, purchase, etc.) owner of the servient estate, or where the dominant estate is acquired by the servient estate, the lesser right merges into the greater.

(d) Where the right-holder submits to an interruption, or acquiesces in an act on the part of the servient owner who prevents the exercise (of course having notice of the interruption),

* The usufrnct is always for life (see Broillard: Le Traitement des Bois en France : Paris : Berger, Levrault et Cie. (i.e. 1894: pl). 627-654). If there is a prescribed working-plan the usufructuary must carry it out and only take such produce as comes within its directions, and he must carry ont all works, such as new planting, sowing, keeping forest works and roads in order. Such a usufruct arises in the case of entailer forests, or those comprised in a family settlement ; also it may be that part of the glebe lands of a rectory in which the parson las a life-intcrest, is stocked with trees, and may come under this head.

+ See Baden-Powell, "Forest Law," pp. 293, 369, 378. 
the right will be lost if no action is taken for one year.* It may be that the right-holder himself discontinues or intermits the exercise of his right. In England, it is a question of fact for the jury, whether the discontinuance was long enough or under such circumstances, as to give rise to a conclusion that the right was abandoned. In India, the matter has been settled by legislation (Act XY of 1877, sect. 26 Exp.). Two years' intermission (under the conditions stated in the Act) will cause the right to terminate.

Of course in all cases, as a right can be gained by prescription so it can be lost by complete non-nser for the whole legal period of prescription.

(e) Lastly, the right may terminate when, either by friendly agreement, or (if the law prescribes) by compulsory process, the right is commuted or bought-out on paying compensation. +

\section{Practical Principles of Law regarding Forest Rights.}

The following short statement of legal principles, all oi which are based on broad rules recognized in all systems of civilized law, will be found useful :-

(1) There can be no such thing as a right to destroy the estate or do wanton mischief (e.\%. burn a forest).

(b) The right-holder is in no sense a part-owner of the forest. When a part of the forest is separated and given over to him, such a proceeding is at the option of the owner, - as a means of compensating for and getting rid of the right.

(c) The right is always a limited one; it can only be exercised so as while fully and fairly enjoyed it does not attack the sulstance of the forest: it can never exceed the normal regular yield of the forest nor its capacity to bear the right without deterioration in the case of grazing, soil-litter, etc. etc.

(d) When a right is undefined in its character, and has not been reduced to definite terms, it is always understood to be

\footnotetext{
* For England, see $2 \& 3$ Will. 4, c. 71. The Indian law is similar : see sect. 26 , Aet XV of 1877.

† Kxplained in Danekelmann's Die Ablösung und Fiegelung der Waldirundyrreclitigkeiten. Cooke's "Wingrove on Enclosures," 1864 (referring to the multitudinous and complieated Enelosure Aets). Baden-Powell, "Forest Law," pp. $357-393$ (where ali abstract of the German law is criven). Meamme, Usuge Forestier (reprinted from the liépertoire de Ligislution: Naney, 1861).
} 
limited to the actual needs of the person, or the dominant estate (as the case may be), in his or its normal condition as it was whell the right originated. If a peasant has a right to rood for "building his house," it means such a house as is usual in the locality, not a large villa or whole range of farm-buildings.*

(c) The right must be exercised so as to interfere as little as possible with the regular management proper to forests of the normally existing class or kind: it cannot prevent the restoration of an ill-used forest, or the proper planting operations and production of young growth.

$(f)$ On the other hand, the forest owner cannot claim to alter the character of the forest, or its general destination so as to affect rights; and where one mode of proper working would provide for the rights while another would not, the owner must make his rorking-plan so as to proride for the rights. $\dagger$

\section{The Disadrantages Arising from Forest Serritudes.}

The chief disadrantages to forests, from the existence of rights of commou are :-

(a) Limitation of the owner's power of managing the forest in the best possible manner, or of converting it, and so forth. Some servitudes affect the control more than others.

And it is noteworthy, that it is generally not any one right that is objectionable; the difficulty arises from the aggregate demand for a number of right-holders, both as to the quantity of produce, area of grazing, \&c., which they require, and also

* See Jaden-Powell, "Forest Law," p. 290 .f7, 328.

+ See "Frrest. Law," p. 294 „ff. In England we have a recent example which illustrates the rule that a forest owner cannot alter the entire destination and character of his estate to the prejudice of right-holders ; and at the same time is a rare instance of forest rights being beneficial (from a forest point of view). In the case of Epling Forest, the right possessed by the commoners to lop the trees was enforcel when the lords of the manors wished to enclose the forest areas, included in their manors, and had eren proceeded so far as to clear a thousand acres of forest and subdivide it into building allotments. They claimed the power to purchase the right of lopping from the right-holders within their own manors. The right-holders, on the other hand, claimed that their right extended over the whole forest, and not orer any particnlar manor, and this view of the matter was eventually accepted by the High Court of Justice after a protracted judicial enquiry. Thus it was decided that the lords of the manors conld not free their respective manors from the rights withont satisfying all the right-holders, in whatever manor they might reside. This decision saved Epping Forest from being converted into building-sites, and the City of London eventually purehased all the manorial and lopping rights in the forest, the latter for $£ 7,000$, and $110 \mathrm{~W}$ only rights of pasture and panuage are exercised by the commoner's.

YOL. IV. 
the number of persons introduced, to graze flocls, gather wood, sc.

(b) Even rights-of-way and other rights which talie nothing from the forest, give occasion to accidental trespass, to forest fires, and perhaps to wilful offences.

(c) The forest owner is tempted to be less careful of his forest, and is deterred from expending capital on its improrement.

(d) Both the labour and cost of protection are considerably increased when forest rights are numerous.

(c) And so are the risks of offences, and forest fires.

(f) Disputes arise, and risk of litigation, and of ill-feeling culminating in revengeful attempts to burn or otherwise injure the forest. Forest right-holders are also tempted to presume on their position and encroach on the rights of the owners.*

Looking at the question from the broad point of view of political economy, forest servitudes encourage extravagance in the use of wood, and establish a backward style of agriculture, as regards the use of litter for manure, loppings for fodder, and forest grazing, which may in the end overtax the forest and result in serious forest destruction and consequent injuries to the country, from floods, landslips, and other physical evils against which forests are a natural and often effective protection.

The degree of danger incurred, irrespectively of the character of the serritude, depends on the conditions of the locality and the density of the standing crop. A completely stocked rood, on favourable site (as regards slope, exposure, \&c.), and with a mild climate, suffer's (proportionately) least of all.

\section{Equitalle Principles in Dealing with Rirglets.}

Where forest laws exist, there is usually provision for the record of all forest rights, and for the definition of those which

* In the New Forest, the present tendency is for commoners to exargerate their rights at the expense of those of the Cromn : and they are attempting to prevent the Crown from erecting a saw-mill and exereising other rights of ownership in the forest. In the Forest of Dean, since 1857, owing to the indiflerence of the Commissioners of Woods and Forests, grazing lyy sheep is largely practised; and it remains to be seen whether the Commissioners will be able to stop this practice, which is fast ruining the Forest of Dean, for centuries the most productive oak forest in Britain. Sheep are not heasts of common by Encrish law (see Williams on Rights of Common. 1850, p. 232), and no prescriptive right to sheep-grazing can arise in England ; but it remains to be seen whether local feeling in favour of the commoners will be allowed to orerride the national interest in this matter. 
are claimed in indefinite terms. It is hardly necessary to remark, that every claim must be proved: the natural presumption is that the owner's enjoyment is not limited-it is for the person who asserts a right to any use or produce limiting the enjoyment, to prove it.

The forest estate should always possess the means of referring to documents conferring rights, and if there is a serious doubt about terms, the sooner a judicial decision is obtained the better. Nothing is gained by "letting sleeping dogs lie "-for in this case uncertain rights are not "sleeping"; they always tend to grow more difficult to settle, and are ultimately fixed in a form that perhaps was never contemplated.

It may be confidently stated that where indefinite rights exist all rational management is impossible until they are properly defined.

The forest owner has, in general, a right to share in the produce of the forest, along with the right-holder's.*

Attention should be paid (p. 64) to the legal principles stated, especially as regards the limitation of undefined rights to the actual needs of the person or dominant estate, and to there being no right (in general) to a surplus which may be sold or turned to an extra profit. Also to the limit that camnot be exceeded, when the yield-power (possibitité) of the forest is in question.

On the other hand it must be borne in mind that while the forest right-holder has his obligations and must submit to those reasonable restrictions which are necessitated by proper conservative management, the forest owner has a duty on his side. He cannot adopt special methods of management (however desirable in themselves) that would destroy the rights; and the working-plans should be prepared with the express object of providing for such rights as exist, and which (especially in certain localities) are almost indispensable to the welfare of the present population. $\dagger$

New rights ought never to be allowed (by neglect, \&c.) to grou up in forests even when there is no forest law which ex-

* See Baden-Powell, "Forest Law," p. 397.

$\dagger$ See "Forest Law," l'. $294 . f 7$, where the correlative rights and duties of the right-holder and forest-holder are discussed. 
pressly forbids such growths. Nor can the State or other owner grant new forest rights to the prejudice of old and existing ones.

\section{Protective Measures.}

From the point of view of the forest owner, the following measures are desirable :-

(a) Clear demarcation of the portions of the forest burdened with rights, and those free from them or closed against them; and maintenance of distinct boundary lines; also indication by ditches or sign-posts, \&c., of lines of right-of-way for cattle, \&c.

(b) Careful record of rights-of-way, \&c., use of water, as well as those to produce. Where there is a forest law, it is probably provicled how this is to be done. Besides which all working-plans of the forest must contain a schedule of the rights showing :-

(i) Title-deed, or other origin of the right.

(ii) Exact description of personal holder or dominant estate; and the exact name, \&c., of the servient estate or part of it affected.

(iii) The extent of the right, kind, number, quantity, quality, season of exercise, Sc., \&c.

(iv) The mode and conditions of exercise, and whether any particular duty is laid on either side (e.\%. providing a competent herdsman for the cattle, proriding cattle-bells, or the forestorner maintaining culverts, \&c., for a roadway).

(v) Any payments, or returns in labour, due to the forestowner for the exercise of the right.

(vi) A notice of any obscure or disputed points.

(c) Careful watching of the exercise of forest rights by the guardians and inspecting officers. But the caution already give! about irritating and vexatious interference should be borne in mind.

It is only necessary to add that where the rights are such that the forest is seriously threatened, then efforts must be made to get rid of them by commutation.

Section III.-Special Account of the several Forest Pights.

This section is concerued with some rules applicable to each 
particular kind of right, for which purpose the following list of "forest rights" is given :-

\section{Wood-Rights.}

(a) Building-timber.

(b) Tood for industrial purposes and agricultural implements.

(c) Firewood.

(d) Softwoods.

(e) Dead, or fallen wood.

( $f$ ) Lop and top.

(g) Stumps and roots.

(h) Windfalls and broken trees.

(i) Dead standing trees.

\section{Rights to Minor Produce.}

(a) Bark.

(b) Turpentine and tar.

(c) Leaf-fodder.

(d) Grass (cutting or gathering).

(c) Pasture.

$(f)$ Collecting acorns and beech-mast.

(g) Pannage.

(h) Litter.

(i) Quarrying or digging pits for sand, gravel, turf, \&c.

(j) Gathering berries, wild fruit, hazel-nuts, fungi, \&c.

(li) Shooting and fishing.

\section{Sundry Rights (Easements).}

(a) Rights-of-way.

(b) Rights to water, water-channels, use of springs or wells, to water cattle at streams, \&c.

(c) Rights to float timber.

(d) Right to burn charcoal, to stack wood, \&c.

\section{WOOD-RIGHTS.}

Under the above term is muderstood either a right to claim from a forest a certain fixed quantity of rood, or as much as may be necessary for certain purposes. Such rights may, or may not, be subject to certain payments to the owner of the forest. It is generally stated what lind of rood is the subject 
of the right, thus, it may be building-timber, timber for implements, or firewood. Sometimes the title-deed merely mentions " necessary wood," under which term firewood is generally understood. The forest manager has the right of delivering the wood, and certain days may be fixed for its removal.

A defined right to wood is fixed as regards quantity and form, and sometimes as regards species.

When the species is not mentioned, the right-holder must be satisfied with wood of the prevailing species, provided it is suitable for the purpose required.

An undefined right to wood is limited to the requirements of. the right-holder or the dominant estate; for instance, the actual house of the right-holder, not his sheds and farm-buildings (unless those are equitably included).

The owner of the burdened forest must manage it so that the wood which is the subject of the right may continue to be produced. For instance, where there is a right to buildingtimber, the forest cannot be converted to coppice.

The right-holder may not sell his wood, but must use it for the purpose for which it has been granted to him.

\section{(a) Building-Timber.}

The supply of building timber to right-holders should be fairly proportional to the number and size of the buildings which existed at the time of the acquisition of the right. Often the right only applies to wood for the exterior of the house, but may include wood for wainscoats, windows and doors.

When repairs to a building become necessary, a regular estimate of the requisite amount of timber should be drawn up ; and the rood must be used within a fixed period. When a new house is being built, all still serviceable wood from the old house must be deducted from the estimate. It is usual for the right-holder to pay the cost of extraction of the rood, even though he pays nothing for the wood itself. In the Himalayan forests, right-holders usually fell the trees and convert the timber for themselves; in some cases the rightholder is allotted annually a certain number of trees for houserepairs or building; in other cases the right-holder is put down 
as being entitled to what is needed on application, for the particular work. Account has here to be taken of the ignorance of the people, and their ancient but wasteful habit of preparing beams with the axe or adze-chipping away a whole stem for one beam. By loan of saws, and by issuing suitable beams ready prepared, it is hoped to overcome this defect, which leads of course to much waste of material.

The work of the forest staff is considerably burdened by rights to building-timber, as the correctness of the estimates has to be tested, and the amount of wood granted to be entered on special registers. It is clearly the duty of forest officers who manage large areas of State or municipal forests subject to rights for building-timber, to know thoroughly the customary forms of building of the locality and the proper dimensious of beams and other timbers used in the construction of houses, or they may be called upon to grant much larger quantities of timber than is necessary in particular cases.

\section{(b) Wood for Industrial Purposes.}

This right (as claimed) may be defined, or not, in its nature and extent. In general, it comprises timber required for ordinary agricultural and domestic objects, such as wood for carts, ploughs, hop-poles, vine-props, Sc. Wherever the right is undefined, the quantity should be fixed, so as to correspond to the amount required at the time of acquisition of the right, extent of hopgarden, vineyard, \&c. This right, if indefinite, interferes greatly with the development of the revenue of a forest.

\section{(c) Firewood.}

Rights to firewood (as claimed) may be either defined or indefinite, and in the latter case the amount granted would be only what is required for the household of the right-holder, including such ordinary household requirements as heating, cooling, washing, baking, drying fruit, \&c. Requirement for industrial purposes such as distilling, \&c., is not included. As a rule, the wood is prepared by order of the owner of the forest, and must be taken from all classes of firewood in due proportion, split and round wood, dead wood, stump-wood and faggots. Occasionally the right-holder is permitted to cut and remove the wood, especially where it is brushwood or small coppice stuff. 
In case a forest burdened with this right sbould be damaged by some calamity (storm, insects, \&c.), which causes an excessive yield in any particular year, then several years' supply of firewood may be granted to the right-holder, in advance, but the latter cannot claim this as a right.

\section{(d) Softuroods.}

Where the right is to "softwoods," termed in France bois bluncs, in Germany Weichloolz, the question is to decide on the meaning of the term. It may be interpreted as including inferior soft-wooded species which are not the object of the management of the forest, and therefore only appear in trifling quantity, and can never get the upper hand under a proper treatment. The following species are generally included under this head:-Aspen and other poplars, the sallow and other willows, limes, hazel, thorns and other shrubs, sometimes also alder and birch, even Scotch pine; mostly trees which spring up amongst young growth, and are cut-out in the cleanings.

\section{(e) Fallen Dead Wood.}

All dead branches and twigs lying on the ground, and refuse from fellings which the owner does not require, are generally included under this heading. In some cases dead branches are also included, which can be broken off by hand from standing trees. In many forests, dead standing stems up to a certain girth are also included, and stump-wood as well. The meaning of the term fallen dead wood must therefore be decided locally, but it is rarely taken to include saleable fallen timber. This distinction is thoroughly recognized in North-Western India. Cutting tools must generally be prohibited, but a wooden rake may be allowed for collecting the fallen dead wood on the ground. If there is only a small quantity of dead wood available in a forest, the right-holder cannot claim other wood to make up a full supply. The sale of such wood is not usually permissible, as the servitude is for household requirements.

Within properly regulated limits this usage is only slightly hurtful to a forest. 


\section{(f) Lop and 'Top.}

This right is generally to the crown of a felled tree from the place where the stem is cut off by the woodman, at a certain fixed girth, and to the lower branches lopped off the stem. The right-holder cannot take possession of the wood until the stem has been severed from the crown. The only serious disadvantage cansed by this right to the owner is that he cannot well manage his forest as Coppice, or Coppice-withStandards, as the greater part of his produce would then go to the right-holder.

If, however, the right-holder has the right of lopping the crown from standing trees, great injury will accrue to the forest. In such a case the right must not be exercised during the growing season, and only in compartments where the trees are ripe for the axe, and at a certain height from the ground. A particular form of this servitude is the right existing in certain forests to lop birch-trees for brooms.

\section{(g) Stumps and Roots.}

This right is only admissible in High Forest, and the owner cannot then convert his forest into Coppice, or Coppice-withStandards.

Unless it is distinctly laid down to the contrary, the owner can fell his trees as low as he likes. The right must be suspended wherever its exercise would damage the forest, as for instance in seeding-fellings well stocked with young seedlings, on steep slopes where landslips or erosion are to be feared, or on shifting sands. Sometimes the right-holder is under the obligation to fill up the holes made in extracting the stumps, and to sow or plant-up the ground. The right may also be limited to certain months, days, or hours.

\section{(h) Windfalls and Broken Trees.}

The right may be to all or merely to certain categories of this material, wood broken by wind, by snow, or rime (see p. 494). 
Trees which are bent down, but may recover themselres, are not included, nor are portions of trees still rooted in the ground. The right ean only extend to single trees broken here and there, not to whole woods broken down and uprooted, as occasionally happens by an exceptional storm or calamity which is not in the contemplation (naturally) either of custom or a grant. The right-holders may use implements to convert the timber. This servitude is not of sylvicultural importance.

\section{(i) Dead Standing Trees.}

Poles and trees which have died naturally are included in this class, and care must be taken to exclude all those which may have been lilled intentionally by damage, girdling, \&c. This usage gives rise to trouble between the right-holder and the ormer, as the latter will endearour to remove dying trees before they are actually dead, and the former to claim trees not yet quite dead. To prevent such contentions it is better to fix definitely the period at which thimnings of dead wood can be commenced.

As in the former case, when a large extent of rood is lilled by injuries from storms, ice, the produce is not the property of the right-holder.

\section{Rights to Minon Pronuce.}

(a) Bark.

In Europe this right is generally restricted to the bark of trees yielding tannin, such as oak, spruce, larch and bireh.

The bark ean be claimed by the right-holders only from felled trees in regular fellings. The rigint may be either by quantity or by number of trees, or commensurate with the requirements of the right-holder. The owner must fell during the growing season when the bark ean be easily removed.

Lime-bur or bast for cordage and matting is sometimes the subject of a right, and then similar rules must be followed. In India, bark of Betule Bhojpatra is used for making umbrellas and paper, and the barlik of many species of trees for ropes and cords; all these may be subjects of rights. 


\section{(b) Turpentine and Tar.}

Rights to tap the spruce or the Austrian pine for turpentine frequently exist. The number and size of the trees to be tapped, as well as of the cuts to be made in each, may be defined, or not. In any case the usage must be restricted to nearly mature woods, and there should be a close-time between successive tappings of the same tree, the season during which the usage is permissible must also be fixed. As turpentine is usually an article of commerce, it may be in the nature of the right that there is no restriction to household requirements, nor as to the sale of the produce.

This is a most hurtful servitude, as tapping for turpentine, especially in the case of the spruce, results in a loss of increment, and lessens the quantity of timber in the base of the tree, and also introduces spores of fungi and insects into the wood, causing disease.

\section{(c) Leares for Fodder, etc.}

This is the right to pluck leaves from trees, especially for feeding cattle in stored and simple coppice. Implements may not be used, nor can twigs be broken-off. If the demand for leaves camnot be supplied from the regular fellings, then certain compartments may be opened for plucking leaves as far from the ground as the hands can reach, but only after late summer.

In various parts of India leaves of forest species are used for cattle-fodder, for thatching, for wrapping up goods at a market, as plates, for making umbrellas, cigarettes, etc., or for manure, and sometimes these customs may have become prescriptive rights. In such cases protective rules similar to the abore should be enforced.

Where foliage and branches are lopped for litter or fodder, as in the Himalayas and in other parts of India, where, owing to the absence during winter of fodder-crops or natural herbage, leaf-fodder is wanted, and a prescriptive right has been acquired, it is by custom limited to certain species, and certain protective measures can be adopterl. Thiese are:-

(i) No lopping to take place till after the principal growth of the year is over. 
(ii) To restrict the usage, as much as possible, to woody climbers and species of little value as timber-trees.

(iii) To forbid the lopping of the leading shoots of the trees, and to restrict the lopping of side-shoots till they have attained certain dimensions and only to a certain height up to the stem.

(iv) 'Io give the trees a rest so that the same tree is not lopped in two consecutive years.

(v) Should the right apply to more valuable timber trees it should be restricted to compartments which will shortly be cut over. The use of leafy twigs and branches of trees felled in the ordinary course camot harm the forest.

(vi) Where the demands for this kind of fodder or cattle-litter are large, and cannot otherwise be met, a regular system of pollarding should be introduced, with a fixed rotation giving the trees time to recover between successive cuttings. Such a system prevailed in Epping Forest prior to 1878, when the right was commuted. The loppings of hornbeam-pollards, of which this forest is chiefly composed, were not, however, only used for litter, but also for making fences, hurdles, etc., and then a rotation of ten years was fixed; in the former case annual loppings were the practice. There is now a marked difference between the pollards in the two cases, to the adrantage of those lopped with a ten year's' rotation.

Another case in Western India is the use of green branches, termed rab, as manure in rice-fields. Here similar rules should be adopted as long as this practice is allowed.

(vii) In every case where leaf-fodder is used by right-holders, the people should be induced, as far as possible, to cut and preserve hay or ensilage, or to grow root-crops for the winterfodder of their animals. Leaf-fodder from forests will always prove a valuable resource when other fodder fails, as was the case in France and Germany during the drought of 1893.

\section{(d) Grass for Fodder, Thatch, etc.}

Rights of cutting grass are also of rery common occurrence mnder the coppice systems, and they should be limited according to locality, time, and mode of exercise, the limitations which prevail varying according to local law or custom. They can only 
commence at a certain age of the wood, and the close-time must be regulated according to species, and to specified days, when the forest guard can supervise the grass-cutting. Sometimes the grass must be plucked by hand, or sickles or scythes may be used; the latter instrument is evidently not admissible amongst young plants. If properly regulated and supervised, this usage does little or no harm on moist fertile soil, and may even assist in fire-conservancy by removing a great source of danger, and also prove useful during the reproduction of the forest. It is also often usefully allowed as a compromise for grazing when that cannot be allowed, and yet the stoppage is a hardship.

\section{(e) Forest Pasture.}

This right allows the holder to graze his own cattle in a forest belonging to some other person, on the grasses and other herbage springing up in it. The right to cut grass is not included. The forest owner has the power of closing certain tracts in his forest, but cannot introduce changes of the system of management which will prejudice the right.

The species and number of grazing beasts may be defined, or not. If the species is not mentioned, animals such as the goat* and sheep, which are highly detrimental to forest growth, must be excluded, as in France they are by law, in spite of any right to the contrary. If the number of beasts is limited, sncklings are not counted in the total number admitted to graze. Should the number be undefined, as is generally the case, only so many head should be admitted into the forest as can be provided for without serious injury to the forest.t Unless specially stated, cattle intended for trade camnot share in this right. The rightholder must engage a herdsman to look after his cattle and is responsible for his conduct. The beasts can only enter and leare the forest by authorised paths. The fencing of closed areas is not obligatory on the forest owner, although fences prevent much contention and further his interests. The right of grazing his own cattle in his forest appertains, in every case, to the forest owner, unless the contrary is specially laid down; but he camnot graze

* The possibility of prohibiting goats in India is discussed in "Forest Law," p. 349.70 .

† See p. 332 "Forest Law" as to the rules for fixing the number 
them in portions of the forest which are closed to the rightholder's' cattle.

\section{(f) Acorns, Beech-Mast and Fruits generally.}

The kinds of fruits to be collected will ordinarily be specified in the deeds regarding the right. The fallen fruit can be picked-up only in compartments opened to the right, and on fixed days; the right-holder is held responsible for all damage done to the standing-crop. Plucking the fruits, and the use of iron rakes to collect it, are forbidden, and the usage must be limited to household requirements. Compartments, the fruit of which is required for natural regeneration, can be closed against this right, which does not include the right of pamnage.

These rights do little or no damage to the forest.

\section{(g) Pannage.}

This is the right to drive pigs into another person's forest to feed off the acorns and beech-nuts, sc., lying on the ground, but the right of collecting the fruit by hand is not included.

An estimate of the quantity of mast in any year on which the number of pigs to be admitted into a forest should be based must be prepared by an expert. The right-holder can only drive his own pigs into the forest, and the forest owner has an equal right. The pigs should be withdrawn when most of the acorns are eaten, or they will damage the forest. This servitude does little harm, but is becoming rare in Europe, as stall-feeding of pigs is more profitable. Pannage is still practised in Epping Forest, about fifty pigs being turned into the forest every Michaelmas; they are all ringed.

\section{(h) Litter.}

Litter to which right-liolders are entitled may be defined or indefinite in amount, and may also be of special linds; dead leaves and moss, weeds, \&c.-in short, the right to strip the surface of its covering down to the soil may be implied.

An undefined right to litter means the right to take what is sufficient for the requirements of the right-holder, and in this amount, straw from his own lands must be reckoned. Owing to the prejudicial nature of this right on the fertility of the forest, 
it must never be stretched so far as to include the whole of the litter a forest may contain.

The necessary limitations as regards locality, time and manner of exercise of the right have been already given.* Sodcutting should never be allowed, except from blanks, as where trees are standing, the roots would be exposed by this practice. The exceptional hurtfulness of this right to the productiveness of a forest, and the possibility that it may lead to its complete ruin, render it most essential that the forest should be freed from it by purchase or otherwise.

(i) Quarrying or Digging Pits for Sand, Grarel, Turf, etc.

Rights to stones, gravel, sand, turf, etc., in another's forest can only extend to places where the stancing-crop and roads are in no danger from the right. Places for reception of refuse from the works, and export-roads must be designated.

These rights, if properly regulated, can do no injury worth mentioning, to the forest.

\section{(j) Collecting Berries, etc.}

This right is always unlimited in amount, and cannot be limited, as the produce is generally collected for sale. Except in the case of digging up truffles it is quite harmless to the forest, and need not be interfered-with beyond fixing dates for its commencement and termination in any year.

Truffle-hunting, which is carried on with the help of a special breed of dogs resembling poodles, must be prohibited on the site of fellings, or amongst young growth.

\section{(k) Shooting and Fishing.}

'The right to kill game on another's property has been abolished by law in Germany. This right is not there bound up with the ownership of the land, but is only permitted to an owner when his estate exceeds a certain area. It frequently happens, therefore, that the right of shooting on a number of small estates is leased in one lot, and the proceeds divided by the owners. In England, the Crown possessed 
rights to the game in certain manors, after it had parted with the other manorial rights, or actual property of the land, but these rights have now been surrendered, as in the Epping Forest. Baden Powell* states that in India no prescriptive rights to hunt in the State forests have ever been admitted; though people have always lilled game in the forests: no right can have ordinarily become customary, as it is not necessary to the existence of agricultural villages, or communities, as is the case with grazing or wood rights. The question of hunting, with rules for the protection of game during the breeding season and when immature, is dealt with in different countries under special laws.

Fishing rightst in forest streams may exist, and are dealt with by special laws regarding fisheries. These have chiefly reference to close-times during the breeding season; and to protecting immature fish by fixing a minimum-sized mesh where nets are allowed; also to prohibiting the poisoning of streams, and other unsportsmanlike ways of catching fish.

\section{Sundri Rights (Easements).}

(a) Rights-of-Thay.

Rights-of-way if too mumerous in a forest may tend to hamper the management, especially by causing danger from fire, and increasing the cost of fire-protection. It is therefore important to prevent new rights-of-way from arising by prescription, and where the law permits, to close altogether roads or paths which may have gone out of use, or other's for which a more convenient substitute may be found. These rights may be subdivided into rights to footpaths, cart-roads, or drift-roads, $t$ the second category sometimes including the third.

In all these cases the question arises as to the legal breadth of the way, and whenever this is uncertain, it should be determined with reference to the breadth of the way required by the circumstances of the case, and according to local custom. The right-holder whose cattle pass along a road to pasture, is responsible for any damage done to the forest growtl beyond

* "Forest Law," pp. 338, 364.

+ Regulations for the protection of game and fish in the State forests of India have been framed by the Iocal Governments of the diflerent Provinces.

¥ See "Forest Law," p. 315.ff. 
the limits of the road; and, the owner of the forest according to circumstances may or may not be compelled to protect his forest by ditches, fences, or hedges.

\section{(b) Rights to Water.}

Rights to water-course generally refer, to the servient estate rcceiving the drainage water for a dominant estate, or allowing (not obstructing) the flow of (useful) water from the servient to the dominant. Sometimes it includes allowing a canal cut, or irrigation channel being taken across the servient estate, in which case the maintenance of the water-channel is the business of the right-holder. Rights to use springs or wells in another person's forest, or to water cattle at them, all of which involve lights-of-way through the forest to the source of the water, are also included.

\section{(c) Riglit to float Timber.}

The kinds of timber to be floated should be specified and the owner of the stream has the same rights as the right-holders. The right of footpath along the bank of the stream may be also combined with this right, the breadth of the path being determined by custom. In India this right is always exerciseable only under the control of the State.

(d) Rights of burning Charcoal, stacking Wood, de.

The sites where the charcoal is to be burned or the wood stacked, must be pointed out to the right-holder, and also the roads to be used for export, which should be as convenient as circumstances will allow. 


\section{PAR'T II. \\ PROTECTION AGAINST MNIILAL. \\ INTroductori Remarlis.}

The question of the usefulness or hurtfulness of wild animals indigenous in Europe may be considered from a forest, agricultural, or sporting point of view. Under Forest Protection only the forest point of view will be considered, but even under this heading some difficulty will be experienced, for the following reasons:-

1. The degree of utility or harm done by one and the same animal differs according to its age, to local circumstances (season of the year, condition of the woods, \&c.,) so that it is hardly possible to lay down definitely that certain animals are absolutely injurious, or useful. Thus, the fox, though a great enemy to barn-door fowls and game, may be very useful, especially in a broad-leaved forest, which suffers more from rodents than coniferous woods. Thrushes and blackbjrds in spring and summer feed mainly on worms and insects, but in autumn chiefly on berries. The cuckoo and bats are always useful, while bark-beetles, the Nun-moth and other insects are absolutely injurious to forests.

2. The utility of certain animals to forests may be direct, or indirect. Thus the jay may be directly useful by carrying about acorns, and dropping them in the forest, while certain mammals and many birds are indirectly useful by destroying injurious mice and insects.

3. The injury done may also be direct or indirect; the former consisting in damage or destruction to forest produce, the latter in lilling useful species. Most destructive kinds of animals are either mammals or insects, while birds are generally useful. 
4. The amount of damage done to the forest depends on the species causing it, the local conditions, the season, \&c. It is generally in inverse proportion to the size of the animal; the little bark-beetle, on account of its rapid increase and steady working, doing more damage to a forest than the large red-deer. The woodpecker is a good instance of the difficulties of deciding as to the amount of harm or good done to a forest by a particular species. This bird is useful in destroying numerous insects living in wood, but it sometimes damages healthy trees by boring holes into them, while these holes may be useful if subsequently occupied by bats or starlings, but injurious if occupied by ring-dores.

Protective measures in the case of animals may be either preventive or remedial, and will be dealt with under the following heads :-

Mammals $\left\{\begin{array}{l}\text { Game animals. } \\ \text { Rodents other than ground-game. }\end{array}\right.$

Birds.

Insects.

As already stated the present work can only deal in detail with European animals, but it may be mentioned that in India the Nilgai (Portax pictus) and the common antelope (Antilope bezoartica) do much damage in coppices aud plantations adjoining agricultural land; whilst among birds, the pheasants and game fowls do similar damage to that by grouse in Europe. For a fuller account and especially of Indian forest insects the reader is referred to "Indian Forest Zoology," * by E. C. Cotes, lecturer" in Zoology at Dehra Dun Forest School.

* Published by the Superiutendent of Government Printing, Calcutta, 1893. 


\section{CHAPTER I.}

PROTECTION AGAINST GAIE.

\section{Section I.-General Account.}

1. List of Injurious Species.

Red-deer (Cervus claphus, L.)

Fallow-deer (Damus vulyuris, Brook).

Roe-deer (Cervus caprenlus, L.).

Wild pig (Sus scrofa, L.).

Hare (Lepus timiclus, I.).

Rabbit (Lepus cuniculus, L.).

\section{Damage by Game.}

The above-named animals injure the forest by eating the fruit of trees, biting-off buds and young shoots, trampling-down seedlings, breaking-off leaders, bending-down stems, barking poles, exposing and gnawing roots, and undermining the ground with burrows. Further details regarding the damage will be given under the headings of each species.

The cousequences of damage done by game consist in loss of increment, stunted growth, diminution of timber as compared with firewood, increased danger from insects, fungi, storms, snow, \&c.

\section{Preventive Measures.}

The chief preventive measures are :-

(a) Formation in High Forest of large, connected, regenerationareas; small clearings in which game has not sufficicnt room, and strip-fellings near thickets or poles where the game habitually remains, suffer most of all. For sylvicultural reasons, however, very large felling-areas are not permissible. 
(b) Corering endangered fruits, acorns, \&c., in seedingfellings.

(c) Avoidance when possible of autumn-sowings, and preference of planting to sowing, the former with large and strong transplants.

(d) Avoidance of the introduction of species specially liked by the game.

(e) Careful choice of system and great care in the management of forests containing game.

( $f$ ) Care for the nourishment of the game by :-

Introduction of mast-producing species, oaks, chestnuts, \&c., wherever the locality is suitable for them.

Protection of softwoods (aspen, willows, \&c.) in cuttings frequented by game, and introduction of these if necessary.

Cultivation of fodder-crops for the game. Oats, buckwheat, turnips, potatoes, clover, \&c., according to the species of game which is prevalent.

Encouragement of a growth of grass in the forest; stopping grass-cutting and pasture.

Feeding the game in the depth of winter, and when there is much snow on the ground. Loppings of aspen, willows, limes, or other softwoods form suitable food in winter. The animals peel the bark from these loppings, and eat the buds and young shoots.

\section{Remedial Mectsures.}

(a) Substantial fencing of forest murseries and cultivations, or of the game-preserve. The kind and height of the fence to be used depends on the mode of life and size of the game. The fences must always be kept in good order. Digging a ditch outside the fence will afford additional security.

(b) Specially valuable trees should be separately fenced-in, or protected by rough stakes with the jagged ends of branches outside. Thorns, bad-smelling substances, or wire-netting may also be used.

(c) Scarecrows may be set-up in endangered localities, or dogs brought-in, blank-cartridges fired, \&c. The scarecrows must be altered from time to time, as the animals get accustomed to them.

(d) Shooting-down the game to a restricted number which 
the forest can bear. Game need not be exterminated, and the chief difference between modern and old times consists in the fact that formerly the forest was managed for the game, but now it is recognised that the admissible quantity of game must be proportioned to the interests of the forest.

\section{Section II.-Red-Deer.}

\section{Damage done.}

The damage done by red-decr consists in eating fruits, browsing, peeling, rubbing, trampling, dc.

\section{(a) Eating Forest Fruits.}

The red-deer eats all kinds of fruits, but especially acorns, beech-nuts, chestnuts, mountain-ash berries, \&c. Acorns are often beaten-ont by the deer with their fore-feet and eaten, and sowings may be thus completely ruined.

\section{(b) Brousing.}

The deer bite-off buds and young shoots, chiefly from late autumn till spring, and occasionally devour foliage in the summer.

The following species are preferred by red-deer : aspen, sallow, ash, oak, hormbeam, beech,* maple, hazel, and amongst conifers the silver-fir and lar'ch; the birch, alder, Scotch pine, and spruce are least liked, but different circumstances, such as a mixture of species, system of management, growth of grass or supply of fodder, greatly influence the degree of damage done in any particular case. Deer and cattle are fond of tasting new and foreign species introduced into a wood.

In times of scarcity of fodder, young plants protruding through the snow may be completely browsed-down; in mound-planting this is especially noticeable.

Orershadowed plants are less freely browsed compared with those growing in the open. Old stags and hinds do more dimage than fawns, as they can reach higher. Southern and

\footnotetext{
* In the Ardemes, red-deer apparently leave beech alone.
} 
western aspects suffer more than northern and eastern ones, as the deer frequent the former in the winter. The lower parts of the warm aspects bordering on fields suffer most, as during winter the deer crowd together into such places. Here may be found those rounded, bush-like plants due to the annual formation of numerous side-shoots, exposed every year to the bite of the deer. The young plants also suffer much in frost localities, on account of their slow growth. Of great influence on the amount of damage done are the degrees of recovery shown by certain species, dne to power of reproduction, rapid growth, and also to local circumstances. Beech and hornbeam recover well from browsing, although the former does not reproduce well from the stool. The ash shows less power of recovery, and so does the maple when bitten, also conifers, among which the silver-fir has the best power of recovery. The bite is, however, never clean, the deer having no lower incisor's, so that recovery is difficult. Obriously, quick-growing trees on a rich soil, make the best recovery.

\section{(c) Pecling Bark.}

The worst lind of damage done by red-deel consists in peeling the bark of trees, which is generally, but not always, eaten.

The following species are thus attacked:-

Chiefly spruce and oak.

Less, the ash, silver-fir, beech, hornbeam, maple, hazel.

Least of all, Scotch and black pines, larch, alder, and birch. Spruce, from 20 to 40 years old, and 15 to 20 yearsold oak coppice-shoots are preferred, but spruce up to 60 years old are also attacked. In the case of Scotch pine, after 20 years the bark becomes too thick to be injured. Wellthinned compartments are preferred, as the deer can get abont better in them, and prefer a sappy bark dereloped in the light. 'The stag does the most damage in this way. The stem may be girdled, or merely long strips of bark torn-off; several strips may be torn from a single stem, but in the case of spruce, one strip only is generally torn from its sunny side. In the case of the oak and beech, the bark is often stripped-off in patches one above the other, as shown in fig. 20 . 
The bark may be peeled in winter or summer. In the latter case, the deer bite through the strip of bark from below, hold it with their teeth, and then, walking hackwards, and raising the head, strip it off in long pieces, which cause serious wounds in the tree. Their length may be 6 feet, and breadth from 2 to

FIr., 21.

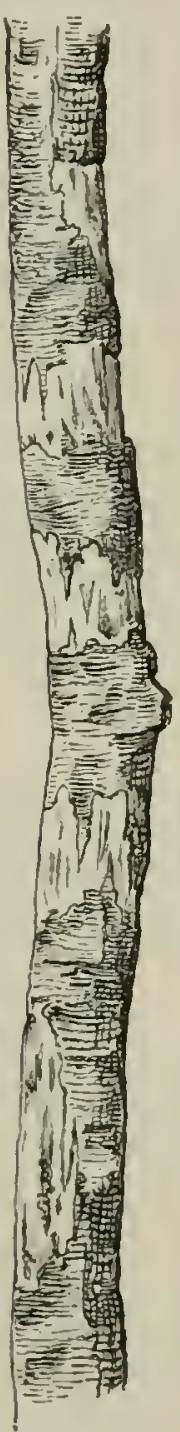

(reduced.)

Oak sapling. 18-20 years old, preeled by red-deer.
Fig. 22 .

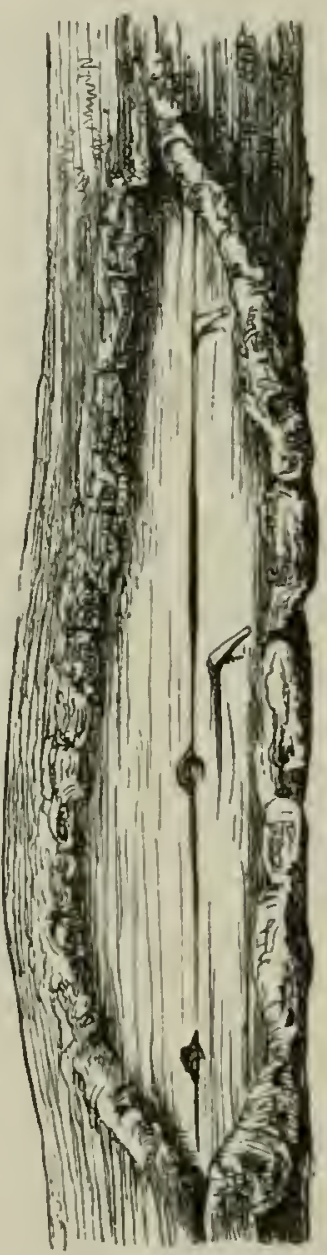

(reduced.)

Summer-peeling.
FIG. 23.

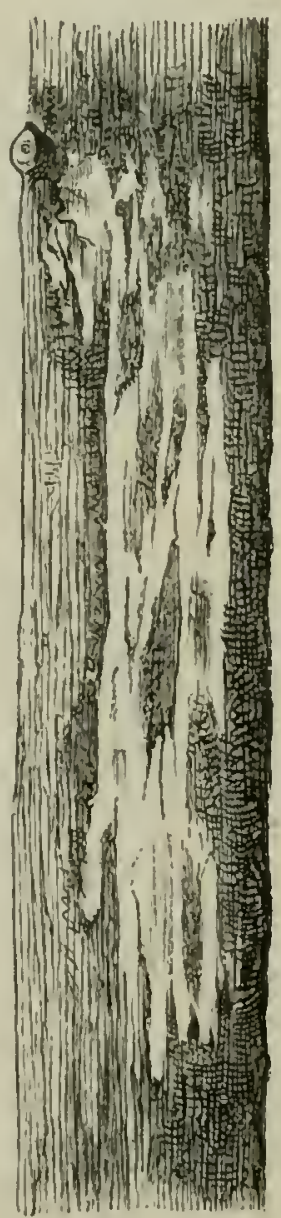

Winter-peeling on $40-$ 50 -rear-old spruce.

6 inches, and they may reach down to the roots, but generally stop at about two feet above them.

Winter-peeling is generally less serious, the deer gnawing off and eating pieces of the outer bark, leaving the bast and part of 
the bark between the bared strips. When deep snow is on the ground these wounds may be pretty high up the stem.

Peeling is generally done in the morning after the deer have eaten a meal, and after rain, which softens the bark.

The disastrous consequences of peeling consist in loss of increment and the formation of badly-shaped boles by the bulg-

FIG. 24 .

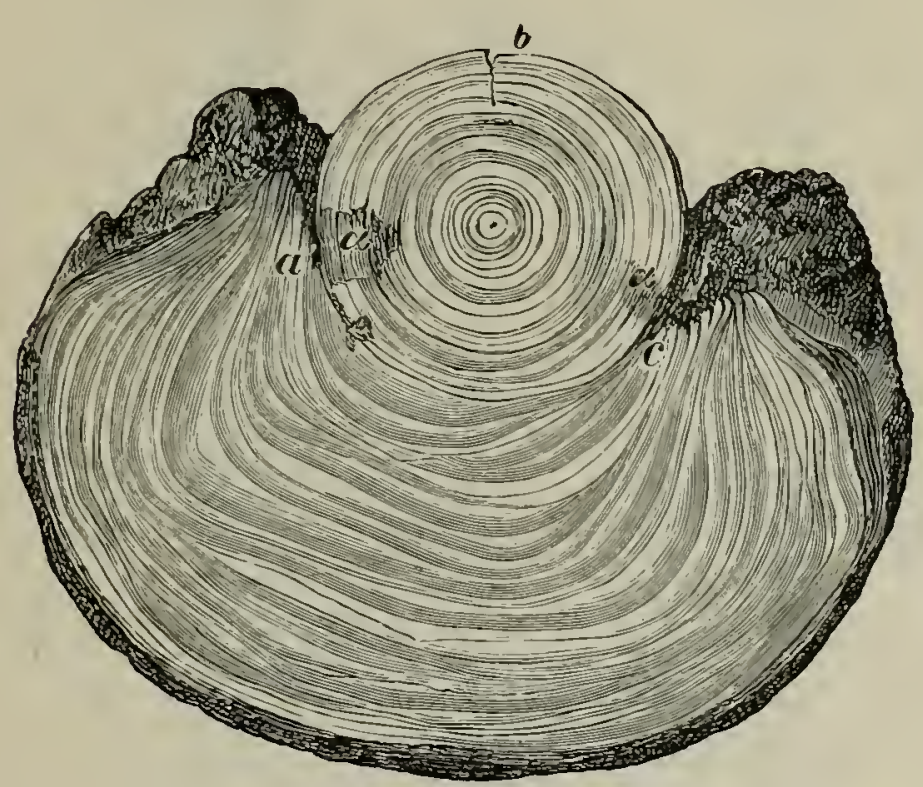

Transverse section of a spruce-stem peeled in summer (rectueed).

ing-out of the annual rings of wood, which may render the trees lop-sided as shown in fig. 24 .

Occasionally peeling gives rise to the formation of adventitions buds from below the wound, and frequently to decay, such as red-rot in spruce, or Peziza Williommii in larch. The stems which have been attacked become unserviceable except for fuel, and the tree often gets broken by wind or snow at or just above its injured portion. Insects, such as bark-beetles and woodwasps, frequently attack the tree, which will die if completely girdled.

Such injuries to broad-leaved species are soonest healed in the case of the oak. In farourable cases only little damage may be done, leaving small local traces of decay (figs. 25 and 26).

The newly formed rings of wood, however, never completely repair the damage when the sapwood has been exposed, 
though they may occlude it. Wounds of the ash also recover FIG. 25.

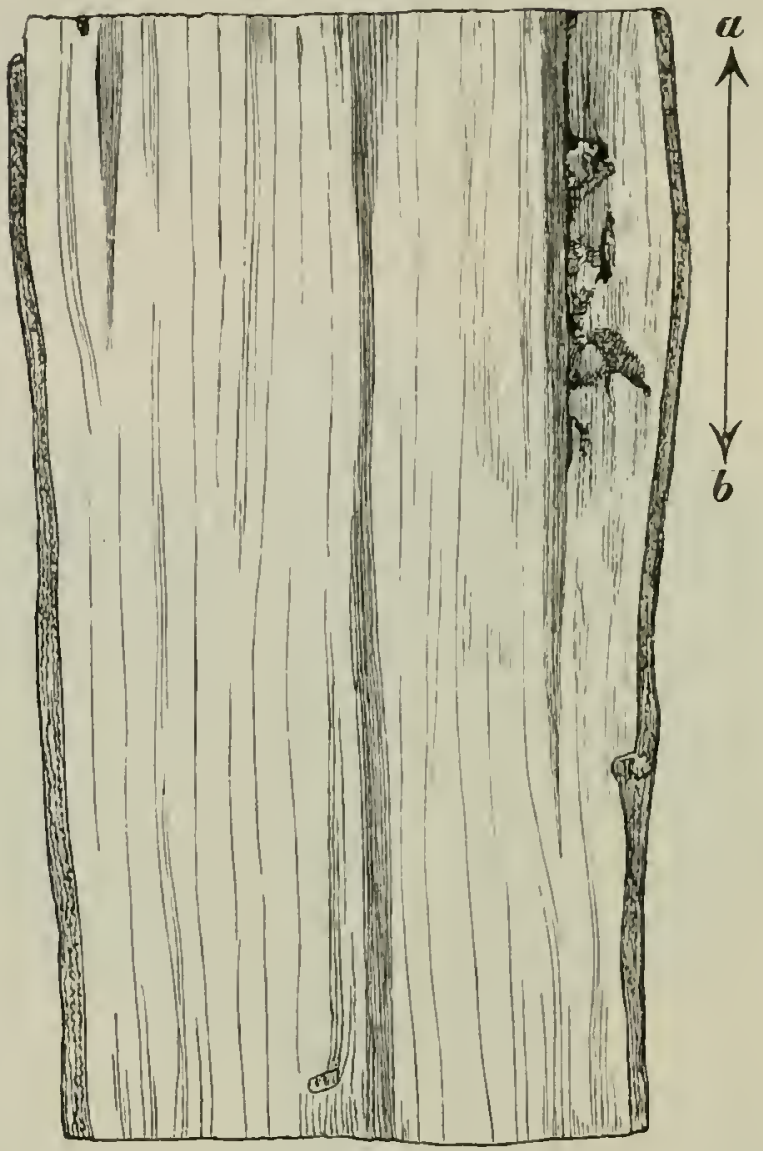

Longitudinal section of an oak-stem peeled from $\iota$ to $b$, and occludel. (Nett. sizc.)

FIG. 26.

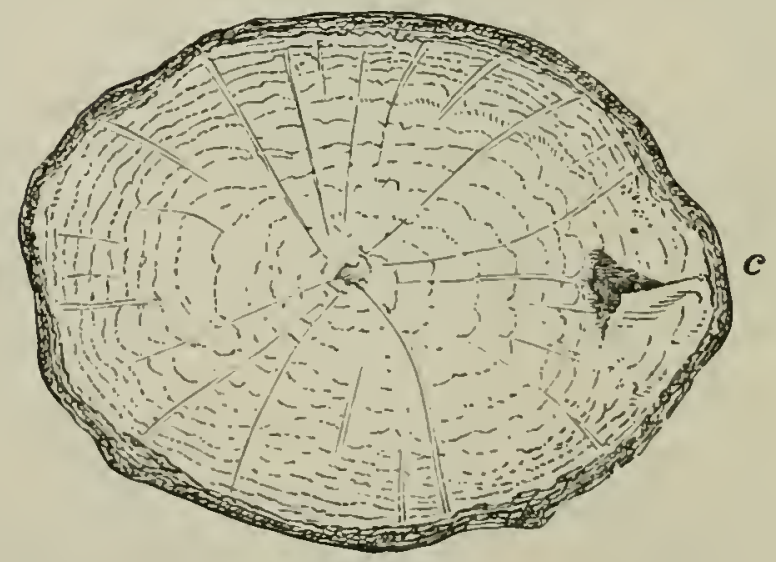

Trinsverse section of same oak. c. Injuresl sjot.

lapidly, although the wood of this species is easily injured. 
Beech and hornbeam recover with greater difficulty, and the maple more slowly still.

Amongst conifer's the following scale is in descending order of power of recovery:-

Silver-fir, larch, Weymouth and Scotch pines, spruce. Such a thorough recorery as is shown in fig. 27 is very rare.

The gravity of the damage done depends, in other respects,

FIC. 27.

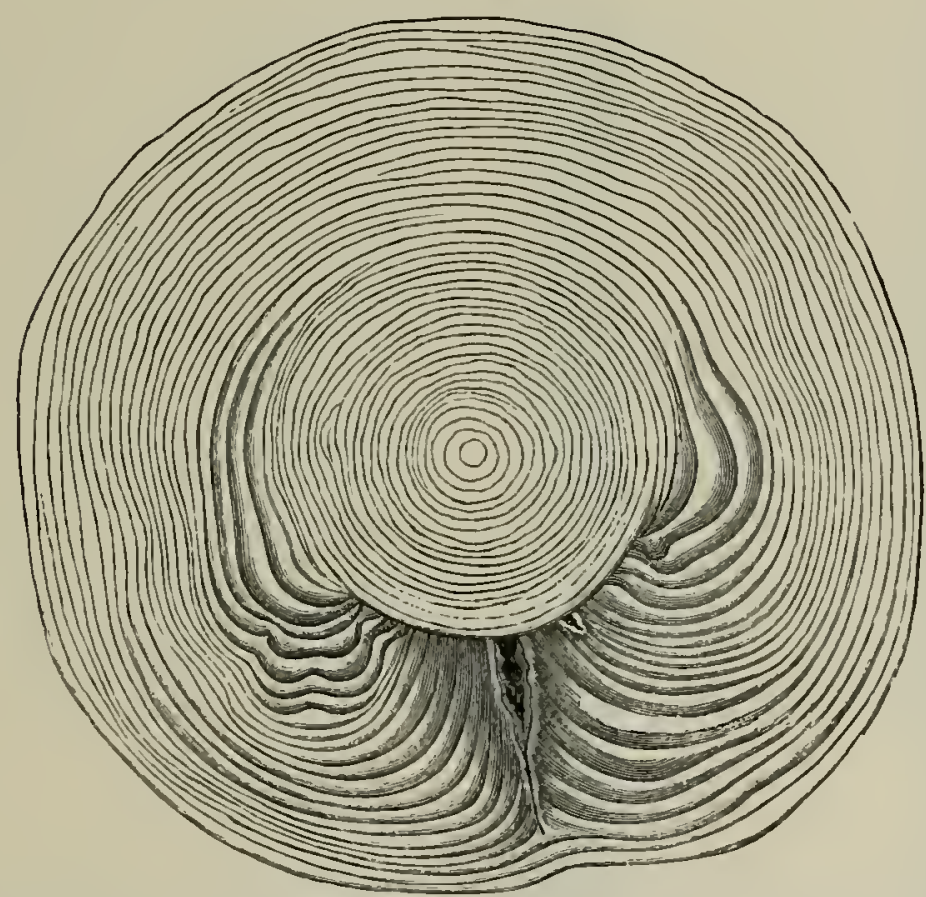

Transverse section of a $60-80$-year-old spruce, which has been occluded after being peeled by red-deer.

on the size of the wounds, the season, repetition of the injury to the same tree, age of the wood, and nature of locality. Summer-peeling is more injurious than winter-peeling, although in the former case the antiseptic nature of the outflow of turpentine is to some extent a compensation.

At the commencement of spring most damage is done in this way. The younger the wood, the more fertile and moister the soil, the quicker the damage is repaired.

Bark-peeling by red-deer is a new habit; as long as mixed woods under the Selection system offered plenty of nourishment, the deer left the bark alone, but the present density of growth, which excludes grass, and the substitution of conifer's for broadleaved species, have rendered fodder scarce in the forests, and it 
FIG. 28.

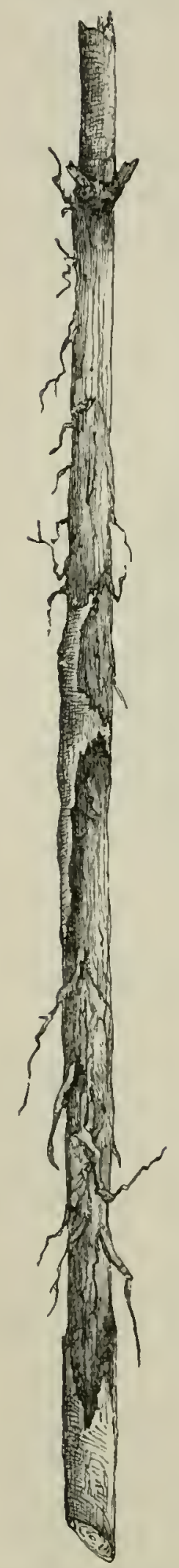

Fig. 29.

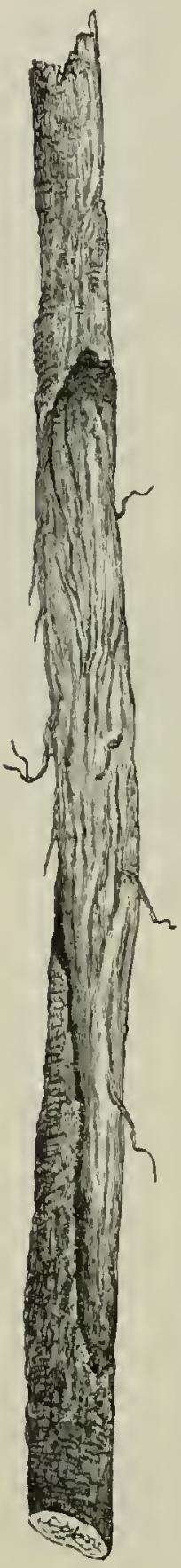

is possible that the deer eat the bark medicinally, as well as from hunger, and also partly from sportiveness.

\section{(d) Rubbing and Striking.}

The stags rub their' antlers against trees to remore the relvet at the end of July and August, generally by night, and they select for the purpose slender smooth poles of lime, aspen, sallow, larch, Weymouth-pine, silver-fir', maple, \&c., especially when these species are scattered among other forest growth. Scotch pine poles are also much injured in this way by deer in the Ardenues.

They also strike their antlers against trees at rutting time in September and October, and before they lose them in March and April. The damage done in this way is less than by peeling, as the same trees serve over and over again for the jurpose. It can readily be distinguished from peeling by the filaments of bark which occur on the wound, and by the hair's of the deer adhering to it, from the deer's habit of rubbing its neck on the peeled stem. 


\section{(e) Trampling.}

Damage done by trampling is confined to young growth and sowings of conifers ; 1 and 2-years-old plants on steep slopes with loose soil suffer most of all, being frequently uprooted.

\section{(f) Total Amount of Damage.}

More experience is required regarding the total amount of damage done to forests by red-deer. A forester who is at the same time a sportsman, should endearour to ascertain clearly the amount of sacrifice of income his sport involves, so that he may be able to keep the number of deer within proper limits. Until the damage done under certain circumstances has been properly observed, sympathy with sport, or antipatly to it, give the question a wide range. It may not be possible to estimate the proportional amount of damage done respectively by browsing, peeling, trampling, \&c., but in a forest frequented by deer, certain compartments might be fenced and others left open, and comparative yield-figures ascertained, from which the extent of the damage done, in the latter case, may be deduced.

\section{Protective Measures.}

Besides the general rules given above (p. s4), the following special rules relate to red-deer :-

\section{(a) Maintenance of a Moderate Number of Deer.}

As the term moderate varies with the species of tree grown, the system of management, locality, nature of boundaries and grass-production, it is impossible to give good average figures.

According to Hartig, on 2,500 acres of forest the stock of deer in the spring, before the young are bo!n (May to June) may be as follows :-

\begin{tabular}{|c|c|c|c|}
\hline & Broad-leaved & Coniferous. & Remarks. \\
\hline Forests bordering on other forests & $\begin{array}{l}\text { Forest. } \\
\text { Red-deer. } \\
\mathrm{s}\end{array}$ & $\begin{array}{l}\text { Forest. } \\
\text { Ricd-deer. } \\
12\end{array}$ & $\begin{array}{l}\text { Besides a certain } \\
\text { number of roe- } \\
\text { deer and wild }\end{array}$ \\
\hline $\begin{array}{l}\text { Forests bordering on fields } \\
\text { Forests surrounded by fields }\end{array}$ & $\begin{array}{c}\text { licd-decr. Roes. } \\
4 \text { and } 8 \\
2 \text { and } 8\end{array}$ & $\begin{array}{l}\text { Red-deer. Roes } \\
\quad 4 \text { and } 16 \\
2 \text { and } 12\end{array}$ & pigs. \\
\hline
\end{tabular}


Ratzeburg considers 16 red-deer per 2,500 acres the proper number.

Prince Charles of Schwartzenburg states that in Bohemia 15 to 35 head of red-deer are admissible, and places one reddeer as equal to two fallow-deer or four roe-deer; but these figures approach those for a forest overstocked with deer.

(b) Sufficient Fodder must be Supplied to the Deer in Winter.

Oats, turnips, acorns and chestnuts are best. Feeding only with hay or leaf-fodder causes the deer to fall-off in health, and prevents the formation of good antlers, whilst acorns are best for the latter. The fodder should not be given on felling-areas, nor near recent thinnings, as the deer loiter about near the feeding-places and cause damage.

\section{(c) Hences against Red-Deer.}

Should not be less than 7 feet in height, and on slopes another foot may be added to prevent the deer from leaping the fences.

\section{(d) To prevent brousing}

Young forest growth may be sprinkled with blood and cowdung, or open jars full of blood buried in the gronnd. Coaltar may be lightly painted on strong young conifers, excepting the buds. It is best done by passing the shoots lightly throngh the hand covered by a tarred glove. This should be done from September till November, and repeated when necessary. The spruce stands this treatment less well than the Scotch pine, and broak-leaved species suffer from the practice. The cost is not high, about $2 s .6 d$. an acre, including the purchase of $6 \mathrm{lbs}$. of tar. A woman can tar 300 plants in an hour.

Broad-leaved species may be daubed with the following mixture :-

Carriage grease . . . $5 \mathrm{lbs}$.

Petroleum . . . 21 quarts.

Alum . . . $\frac{3}{4} \mathrm{lb}$.

Tallow. . . . $\frac{3}{4} \mathrm{lb}$. 
This gires enough for 600 plants. Plants may also be limed, the terminal buds being smeared with a brush dipped in whitewash. This costs for silver-fir $1 s$. $6 c$. per 1,000 plants, or $2 s .4 d$. an acre; $10 \mathrm{lbs}$. of lime are required for 1,000 plants. A woman can lime about 500 plants in a day on a slope, and 3,000 plants on level ground. This gives better results than tarring the plants, and the lime apparently does them no injury. Refuse hemp may also be lightly placed orer plants, as it clogs the teeth of the deer and has proved efficacious.

\section{(e) Mectsures to prevent peeling.}

Delay thinnings, so that deer cannot penetrate amongst saplings.

Pieces of rock-salt should be scattered about for the stags to lick, or the following composition :-

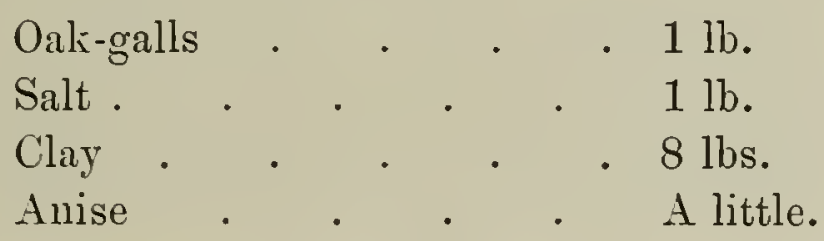

The galls should be Istrian, which cost 50s. a cwt. Each piece suffices for 100 acres of forest.

Beasts detected peeling bark should be shot, as young deer soon follow their example.

(f) Measures to prerent rubbing, etc.

Taluable exotics, etc., can be protected against rubbing by smearing them with certain compositions up to 5 feet in height. Such a composition is a mixture of lime, blood and sulphur.

\section{Section III.-Fallow-Deer.}

The damage done by the fallow-deer is of a similar nature to that by the red-deer; it perhaps does more harm by bruising and trampling, as it is rery restless, and particular about its food. However, it never peels in a wild state, only sometimes in fenced parks. The fallow-deer rubs its antlers at the end of August and in September, and strikes the same species as the 
red-deer. The protective rules are the same, except that precautions against peeling are unnecessary.

\section{SECTION IV.-Roe-DEER.}

\section{Damage cione.}

Besides herbage, the roe eats becch-mast, acorns, wild fruit, and the cotyledons of beech and oak seedlings, and in winter browses on the buds and shoots of nearly erery species of tree, especially young plants, and in summer on fresh young shoots and tender foliage.

The following species are preferred:-Oak, beech, maple, ash, elm, hornbeam, aspen, sallow and silver-fir, and least of all birch and alder. Young plants one or two years old may be entirely devonred. Exotic species and those occurring rarely in a wood are preferred.

Sunny aspects where the roe stays in winter suffer most, especially on poor soils. The roe rubs its horns in Narch and April on smooth-barked saplings about a finger's thickness, and strikes its horns on poles in rutting-time at the end of July and August, and before losing them in November. Larch, Weymouth-pine, aspen, lime, and mountain-ash are most exposed to these injuries.

In places where roe-decr crowd together, they trample-down many seedlings. The roe is relatively worse as a forest browser than the red-deer, as it is very dainty and tears the shoots like a goat; but on account of its small size, and as it abstains from peeling trees, it does a less absolute amount of damage.

\section{Protective Rules.}

Irrespective of the general rules given, the following hold good for roe-deer.

Suitable fodder are oats, acorns and foliage; they eat hay only as a last resource, when it is given quite dry and hung up in little bundles under the shelter of trees or thatched corerings and not strewn on the ground. Lopping branches of silver-fir, aspen, sallow, etc., in winter is very useful.

Fences against roe-deer need only be 5 to 6 feet high.

Scare-crows are of little good, as the roes soon become accustomed to them. 
Smearing dung, petroleum, or asafootida on cultivations is useful.

Young coniferous cultivations may be tarred, as for red-deer, but with deep snow it is better to lime them. The cost of tarring is $5 d$. to $8 \frac{1}{2} d$. per 1000 plants, at a daily wage of $7 d$. to $y d$., and tar at $1 s .9 d$. per ewt.

To protect exoties (Douglas-fir, \&c.), saplings may be encireled at about $1 \frac{1}{2}$ feet from the ground with a piece of paper as broad as the hand, fastened with string, or they may be surrounded with thorns, or by three jagged stakes.

\section{Section V.-Wild Pigs.}

\section{Damage done.}

The wild pig does damage similar to that done by the tame pig, which has been already described, besides pulling-up fresh transplants, and destroying mound-planting, and birds-nests. As regards sport, it does much harm by killing fawns, leverets, etc.

Of late, in the Lower Rhine districts, pigs have so largely increased in the forests, and do so much damage to the agricultural crops, that it has become necessary to hold battues, and fix a price for their destruction. From a forest point of view, howerer, wild pigs do much less damage than other game.

They may, however, do a considerable amount of good by brealing-up the soil, burying fruits and seeds and by the destruction of mice and hurtful insects.

\section{Protectire Rules.}

Feeding with turnips, potatoes, oats, peas, acorns, wild fruit, etc., so as to keep the pigs from injuring forest plants.

Fences against pigs should be about 6 feet high and strongly built.

Traps can be used to catch pigs. A pit about 6 feet deep and broad is dug with walls vertical or eren sloping inwards. A light covering of poles, brushwood and moss is covered with soil, dead leaves, etc., resembling the litter

voL. IV. 
on the ground. Such traps should be made near wallowing places in the breeding season (November to January). In making these traps the greatest care must be taken, the workmen must not smoke nor eat their food near the trap, and the earth dug out must be removed to some distance. Another excellent

Fig. 30 .

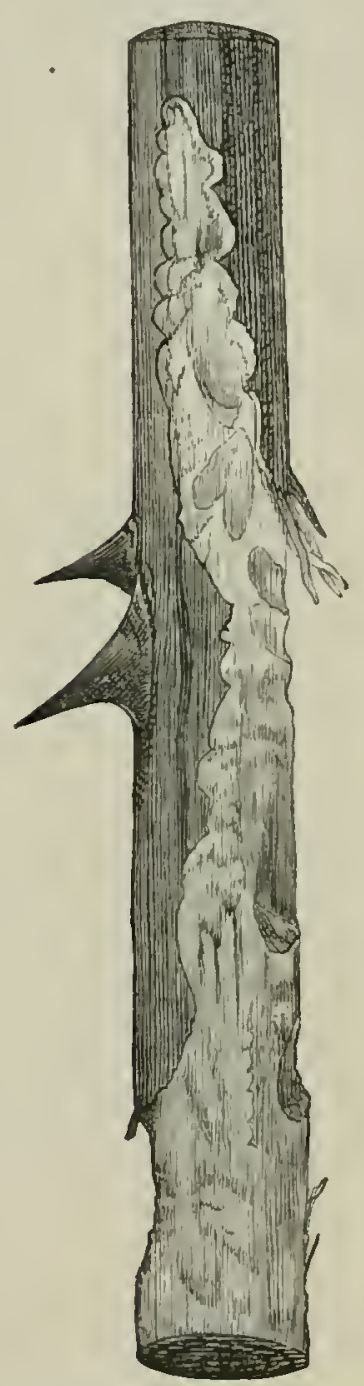

Robinia gnawed by hare (nat. size).
Fir. 31 .

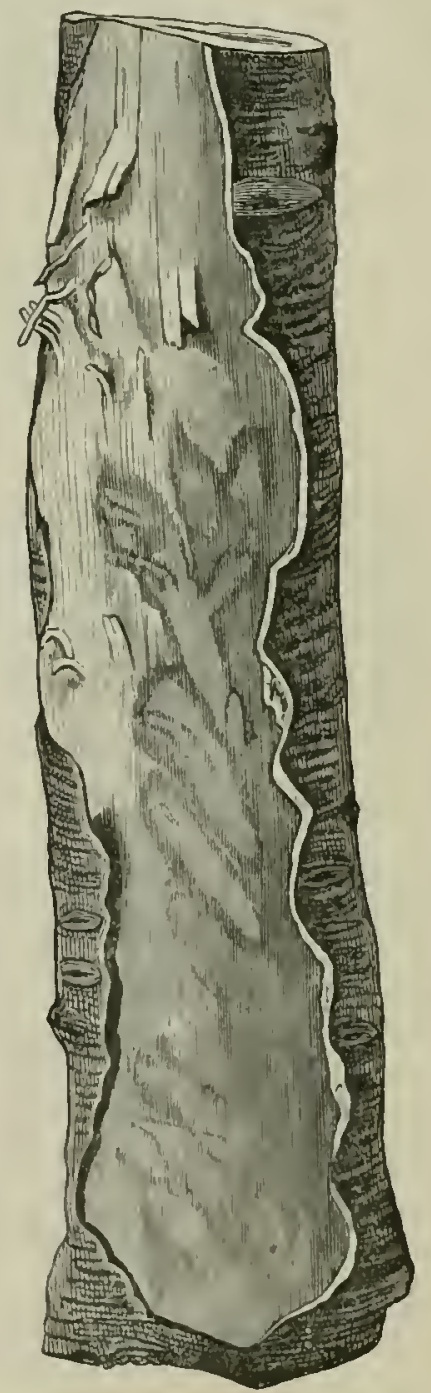

Beech gnawed by hare (nut. size).

method for catching wild pigs is described in the "Indian Forester," vol, xi., p. 530.

Pigs, when numerous in woods bordering on fields, must be kept down by shooting. 


\section{Section VI.-Hares.}

\section{Damage done.}

The hare injures woody plants in winter by biting and gnawing their bark. Buds and young shoots of beech, hornbeam, elm, ash, maple and aspen are chiefly bitten, the conifers less, and spruce and Scotch pine least of all.

As the hare affects certain localities, the damage is restricted in area, but very extensive where it prevails; so that a single hungry hare may cause considerable damage in young growth of veech on sunny situations, which it frequents in winter. The sharp teeth, cutting in pairs, give very distinct markings on plants attacked by hares.

As regards peeling, the one-year-old shoots of the robinia are frequently stripped of bark, and the wood gnawed as shown in fig. 30. The hare frequently damages fruit-trees in orchards, chiefly the apple, next the cherry, and least of all the pear.

\section{Protective Rules.}

(a) Fence-in nurseries with liedges or dead thorns, or with wire netting 4 feet high.

(b) Bind fruit-trees from November till April with thorns, branches of conifers or wheat straw.

(c) Fruit-trees may be smeared with stinking substances. A mixture of 10 quarts of bullock's blood, $\frac{1}{4} 1 \mathrm{~b}$. of asafœida dissolved in warm water, and some lime and cow-dung may be used.

\section{Section VII.-Rabbits.}

\section{Damage done.}

Rabbits, which are chiefly found on hilly and sandy ground, do the same kind of damage to young growth as hares, besides injuring the roots of plants by burrowing. They are not nearly so destructive in biting off young shoots as by gnawing at the bark of plants. The seedlings of the Scotch pine, the chief 
species on sandy soils, suffer most of all, and next to this spruce.

As regards gnawing, nearly all species suffer', chiefly hor'nbeam, ash, robinia, aspen, sallow, hazel and fruit trees. Not only is young growth attacked, but

Fir. 32.

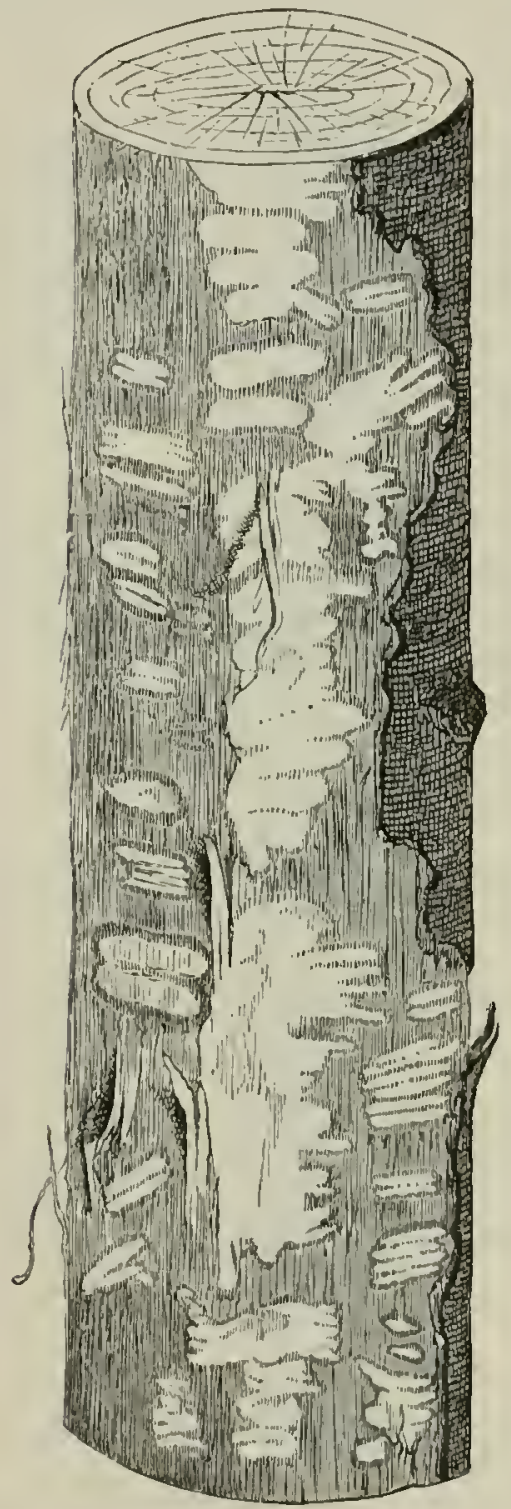

Willow gnawed by rabbits (nat, sizc). where rabbits are numerous, and when the ground is frozen or covered with snow, the base of large beech and other trees is barked, and the trees may be completely girdled. From experience in Windsor Forest, which is overrun with these pests, so that the underwood, so valuable in oak forests, which was plentiful twenty-five years ago, has now disappeared over large areas, the sycamore appear's to suffer less than other species, and rabbits will not touch Rihododendron ponticum, which sometimes forms a dense underwood in parts of the forest infested by them.

By burrowing, rabbits do much har'm to cultivations and young seedlings. Hares avoid places frequented by rabbits.

2. Protectire Measures.

(a) Protection of foxes, pole-cats, martens, stoats and weasels, which are the natural enemies of rabbits.

(b) Careful fencing 4 feet high, and use of wire-netting buried partly in the ground and sloping ontside the area to be protected.

(c) Valnable trees may be bound round with thorns or wirenetting, or their bases smeared with coal tar.

(d.) Use of traps or poisons, or smoling-ont the burrows with sulphur. 
(e) Ferreting, the ferret being merely a domesticated variety of pole-cat. This is usually followed from October till the end of February, when rabbits do not generally have young. The ferret is sent into the burrow, and a net placed at its opening into which the rabbits run, or they may be shot when driven by the ferret out of their burrows.

\section{Section VIII.-Bears, Beavers and Porcupines.}

The bear and the beaver are two animals now almost extinct in Central Europe, but which formerly did much damage to forest trees.

In the Himalayas, the black bear (Ursus tibetamus) peels the bark from pines during the winter. Beavers (Castor, fiber, L.) are still pretty numerous in Pussia and Scandinavia, in North America, and a few still exist in France in the Rhone Valley. They fell and bark many species of trees up to 9 inches in diameter, chiefly willows and poplars, but also ash, oak, and elm growing near streams. The trees felled are used by them in constructing dams to protect their dwellings, and they also eat the bark. 'The porcupine (Hystrix sp.) is very common in Indian forests, and girdles saplings and poles of various species, especially of Leguminose; it does much damage in forest nurseries by burrowing, and by devouring seedlings and vegetables. It should be excluded by strong mire-netting, partly buried at the foot of a fence, as in the case of rabbits. 


\section{CHAPTER II.}

PROTECTION AGAINST OTHER RODENTY.

\section{Section I.-General Account.}

1. List of Injurious Species.

Squirrels (Sciuride).

The common squirrel (Sciurus vulgaris, L.).

Dormice (Nyoxide).

The loir (Myoxus glis, Scbreb.)

The common dormouse (M. acellanarius, L.).

The garden dormouse (M. quercinus, L.).

Mice (Muride).

The common wood-mouse (Mus silvaticus, L.).

The long-tailed field mouse (M. agrarius, Pall.).

$$
\text { Voles (Arvicolide). }
$$

The water-rat (Arricola amphilinu, Desm.).

'The field vole, or short-tailed field mouse (A. agrestis, Blas.). The southern field vole (A. arralis, Selys.).

The bank vole (Hypudceus (A.) glareolus, Wagn.).

\section{Damage done.}

The above-mentioned animals damage the forest by eating fruits and seeds, and gnawing young growth, breaking-off young shoots, eating buds, peeling bark, and burrowing in the ground. Mice and voles do most harm, on account of their destructive voracity and their enormous powers of breeding. Young growth, sowings and plantations are often completely destroyed by them. 
The damage done by squirrels and dormice is not so great, being confined to individual plants, and these animals do not become so numerous as mice and voles.

\section{Protective Rules.}

Proper precantions must be taken in the reproduction, tending and utilization of woods. Enemies of these animals must be spared. Shooting, trapping, poisoning may be resorted to. More detail is given separately for each kind.

\section{Section II.-The Squirrel.}

\section{Damage done.}

The damage done by squirrels is greater than is generally imagined. They eat fruits and seeds, cotyledons and buds, and bite off young shoots, remove bark, and destroy eggs and young birds. Their utility in destroying beetles, larvæ of saw-flies and other insects, does not compensate for the harm they do.

\section{(a) Destruction of Frnits and Seedlings.}

Beech-nuts, acorns, hazel-nuts and seeds of spruce constitute the chief food of the squirrel. Besides these, it eats seeds of other conifers, fruits of hornbeam and maple and of mountain-ash, and walnuts, apples and other garden fruits. A large proportion of the annual supply of fruit may thus be lost, and in coniferous woods, natural reproduction may be greatly reduced.

Fig. 33 shows how the hazel-nut is attacked by this little animal, and figs. 34 and 35 how the scales are stripped from the spruce cones so that it can get at the seeds. Heaps

FIG. 33.

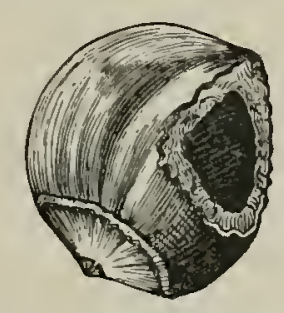

Hazel-nut opened by squirrel. of broken scales from cones lying under the trees show how busy the squirrel has been.

More harm again is done by the squirrel digging out seeds and cotyledons from the ground, and biting off cotyledons of the beech in seed-beds and reproduction-areas. It also uproots young oak-plants to get at the remains of the acorns. 
Indian squirrels have similar proclivities to the above-mentioned species and sometimes completely strip trees of their fruit, besides being very destructive to peas, \&c., in regetable-gardens.

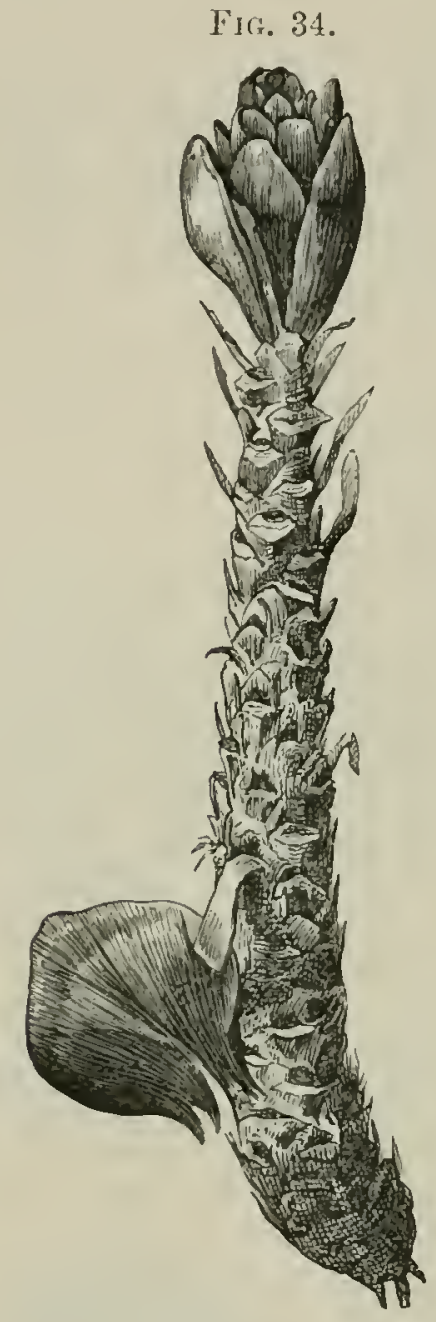

Spruce-cone stripped of scales by squirrel.

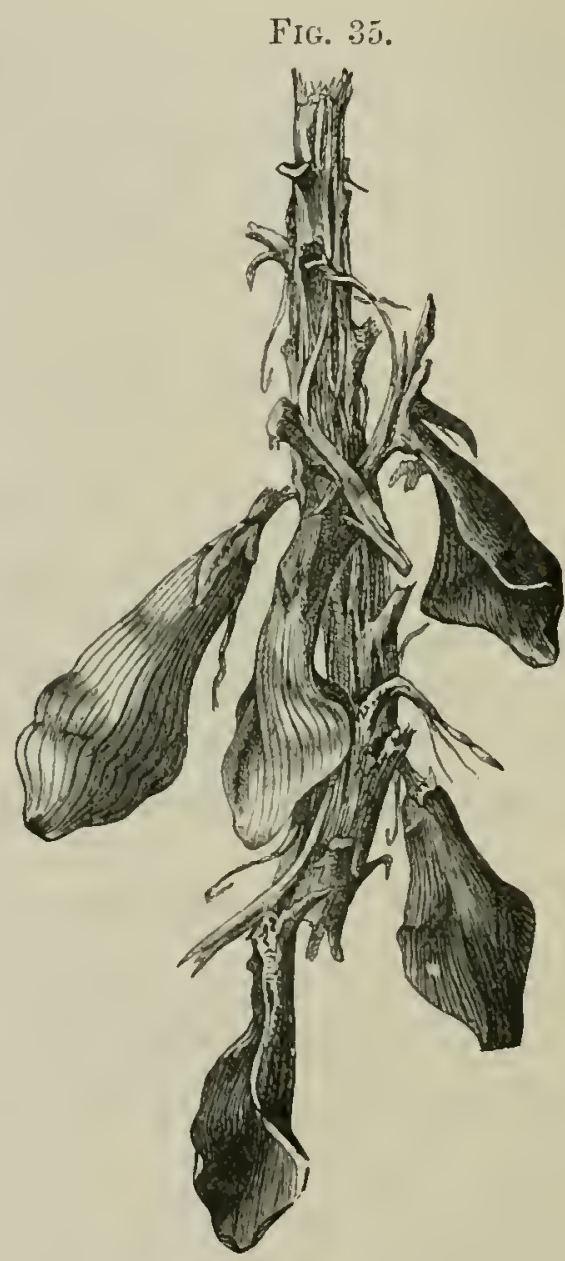

Portion of spruce-cone attacked by squirrel.

(b) Eating Buds and Biting off Tuigs.

As regards buds, the squirrel prefers those of the inflorescence, which are richer in nitrogenous substances and more nomrishing than the foliage-buds. Spruce and Scotch pine are preferred, but silver-fir is also attacked in this way. The destruction of these buds, in snowy winters, may entirely prevent seed from being produced. The methods pursued by the squirrel in cating the buds differ according to the age, height, and strength of the plants attacked. In plantations and thickets from 1 to 6 
feet high, which are not yet provided with flowering buds, the squirrels bite-off the top of the previous year's shoot, and the side-shoots of the last verticil, the buds of which are also eaten. Scotch pine injured in this way, develop new leaders from buds just below the point of attack, whilst in the case of spruce, an uninjured side-shoot from the last verticil becomes a leader. In

FIG. 36.

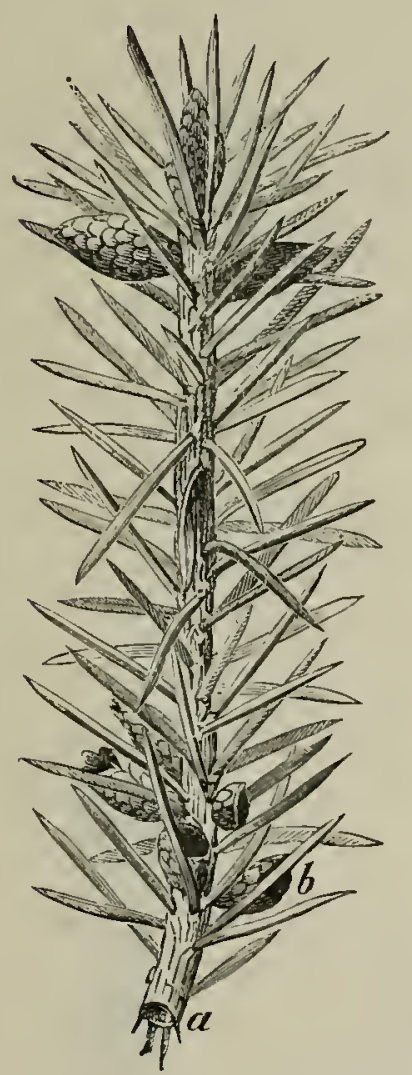

Fir. 37.

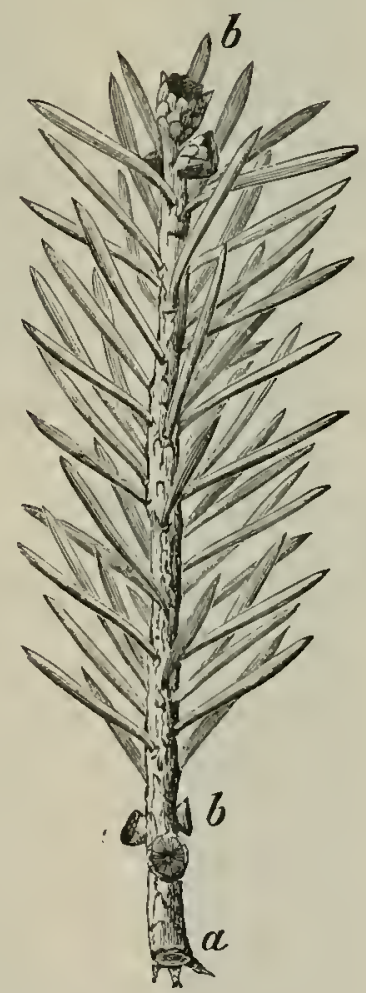

Twigs bitten off by squirrel ( $n a t$. size).

$a$. Points where twigs are bitten-off. $b$. Bases of bitten-off buds.

the case of poles and trees of these species, the squirrel bites-off the most external little shoots on which are the male inflorescencebuds, and then, holding the twig with its fore feet, goes back to the branch to eat the buds. It then lets the twig fall to the ground. Probably the female inflorescence-buds are eaten as well, and very few cones are formed on trees where squirrels have lived during the winter.

In the summer also, shoots of various lengths up to 8 inches are bitten off spruce trees by the squirrel and gnawed, as at this time there are no seeds or buds to eat. 


\section{(c) Peeling and Girdling.}

The peeling and girdling of young plants of larch, Scotch

Fig. 40.

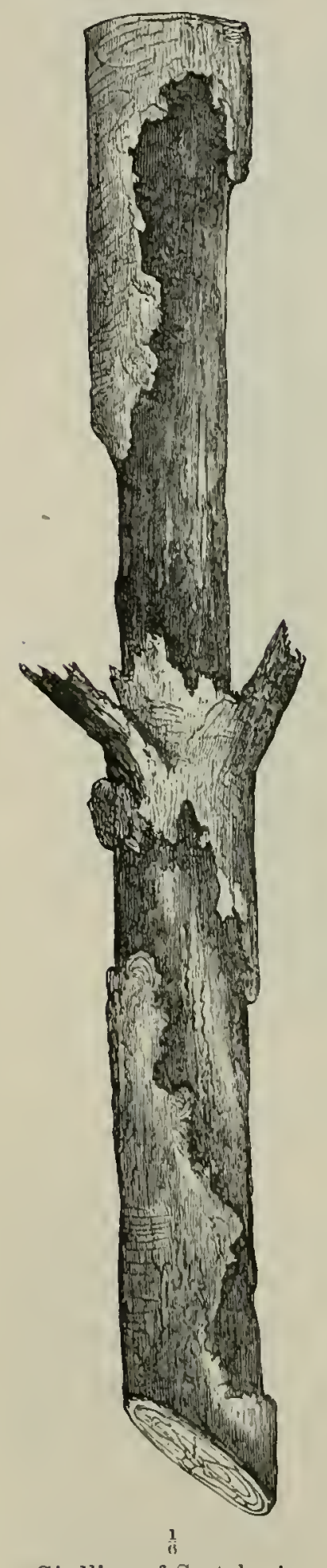

Girdling of Scotch pine by squirrel. pine and silver-fir, also of beech, hornbeam, aspen, willows and oak have been noticed, but are fortunately rare. Plants fifteen to thirty years old suffer most, but also sixty-years-old woods. This is done from May to July chiefly in dry years. The damage is done to the stem in the crown where the squirrel sits, and is sometimes in rings or spirals, at other times quite irregular; as it goes down to the sapwood, the injured stems may die above the peeled place, as they do sometimes by hundreds.

Fig. 38.

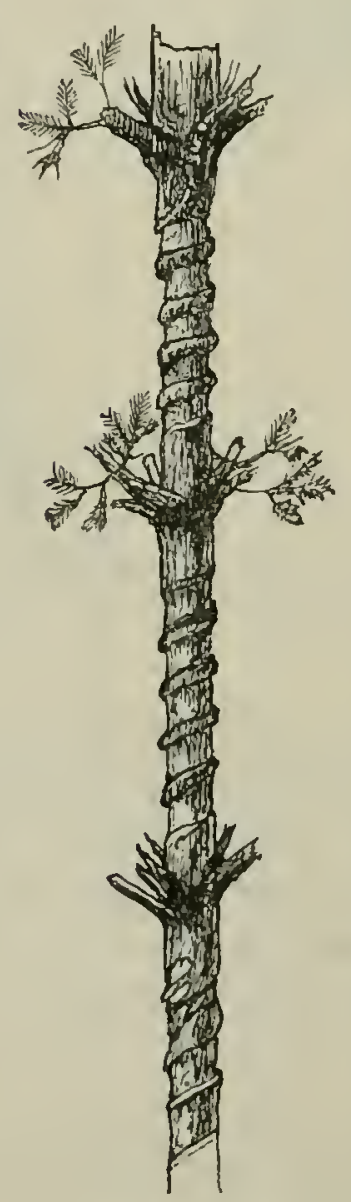

FIG. 39.

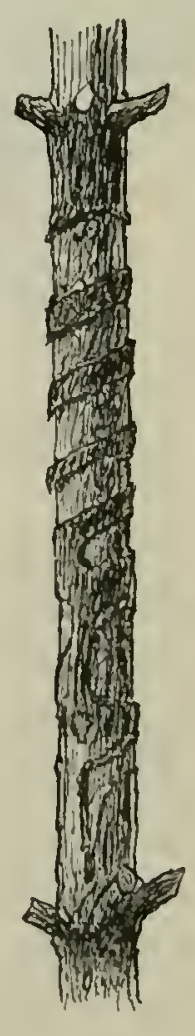

Spiral girdlings of Scotch pine by squirrel. 


\section{(d) Destruction of Young Birds.}

During the breeding season of birds, the squirrel frequently attacks their young, lilling them and eating their heads.

(e) Protective Rules.

Protection of the pine-marten (Mrustela martes), a great enemy of the squirrel.

Shooting, in spruce seedyears, and near nurseries.

\section{Section III.-Dormice.}

\section{Damage done.}

Dormice are squirrel-like animals, with bushy tails, and as they move about at night, chiefly in broadleaved forest, it is difficult to state precisely the amount of damage they do.

The loir (Myoxus glis, in German, Siebenschlïfer), the largest European species of dormouse, is found in southern Europe, but not in the British Isles. It feeds on mast of all kinds and also on spruce and other seeds, and orchard-fruit, bites-off the leading shoots of beech

FIgs. $41 \& 42$.

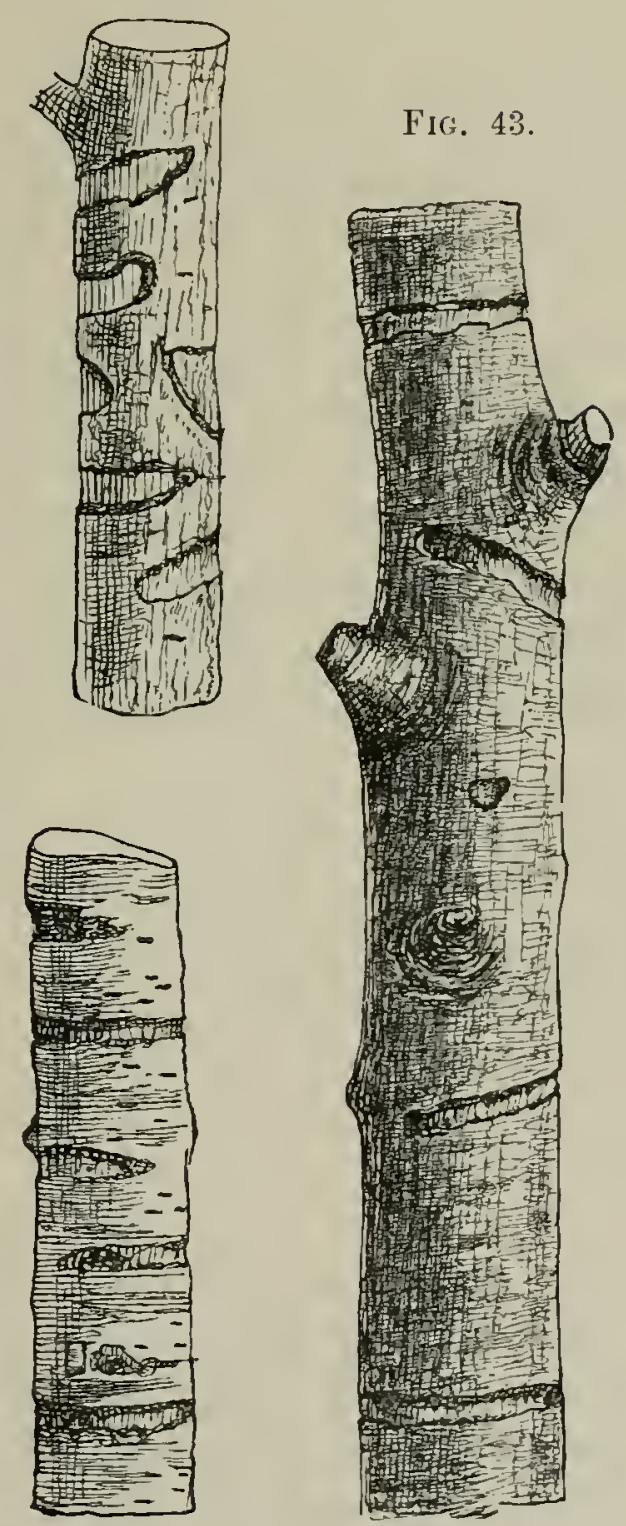

Girdling of alder (41), birch (4:2) and beech $(43)$ by dormice. and silver-fir, and in spring, barks young stems, and robs birds' nests, doing injury of a similar nature to squirrels.

It collects a provision for the winter in holes, but passes most of this season asleep. Barking is done in strips, or rings, on ten to twenty-five-years-old trees of beech, hornbeam, hazel, etc., also larch and silver-fir. 
'The loir also bites-off' spruce-shoots in order to strip them of their needles and chew them, spitting out the débris.

The garden-dormouse ( $M$. quercinus, L.) is rarer than the former, but has a similar habitat, going, howerer, further north; it is fond of orchard-fruit, and also attaclis forest fruits like the loir.

The common dormouse ( $M$. arellanarins, L.) chiefly inhabits coppice, especially hazel-coppice, and is found all over Europe, from Sweden to Northeru Turkey, but is less common in the south than the other two species. It does similar damage to them, but on a smaller scale, and owing to its fonchess for hazel-nuts, is termed Hazelmans in Germany.

\section{Protectire Rules.}

Protection of the pine- and beech-martens (Mustcla foina). Dormice may be caught like rats in iron traps baited with bacon, or for the last species, in wire traps with almonds as a bait.

In Carinthia, the capture of the loir is actively pursued, its flesh, which becomes very fat in autumn, being eaten, while the skins are exported, as many as 800,000 being captured in good years of beech-mast.

\section{SECTION IV.-MicF.}

\section{Damage done.}

Forest mice, especially the long-tailed field-mouse (Mus silvaticus, L.), and to a less degree Mus agrarius, Pall., are very destructive by eating forest fruits and seeds, biting and gnawing, burrowing in the ground and lilling small birds.

Beech and oak-mast and hazel-nuts are chiefly eaten, and antumn-sowings suffer more than those made in the spring.

In winter, and when the snow is on the ground, they gnaw buds, tender shoots, bark and sapwood of young forest plants, from 2 to 15 years old. Broad-leaved species chiefly suffer, such as hormbeam, beech, ash, maple, hizel, sallow, and also oak, elm, aspen, ete. Handsome thorn-trees are often girdled by them. They gnaw the bark of plants up to 3 feet and higher from the greund, somerhat higher than roles, from 
which they can be distinguished in this way. Young stems up to 2 inches in diameter at the base are often gnawed through, and promising cultivations are thus ruined.

By their burrowing, many plants are uprooted and die, but this lind of damage is dowe on a much greater scale by voles.

Nice are chiefly destructive on sunny aspects in young woods full of grass undergrowth. Their powers of reproduction in dry summers are quite extraordinary.

\section{Protective Rules.}

These are about the same as against voles, and will therefore be given in full further on, but as the long-tailed field-monse lives in forests throughout the year, it is more difficult to ward against its attacks than against those of voles, which come from the fields into the forest during winter. The chief remedy is to protect its enemies, the stoat, weasel, fox, owls, etc.

\section{SECTION V.-Voles.}

Toles are distinguished from mice by their thicker, shorter head, by haring ears buried in their fur, short legs and tail, true mice having a pointed head, large ears and a long tail.

\section{Damage dome.}

Voles in daytime live chiefly in the soil, into which they burrow in all directions. Their burrows are just below the surface of the ground, and by burrowing in forest nurseries, plantations and natural regeneration-areas, they uproot thousands of plants and injure drains and ditches. They are chiefly vegetable eaters, devouring fruits and seeds, cutting throngh the roots of young plants in the ground, gnawing their shoots, but they also attack young birds.

During winter they gnaw the bark of plants chiefly of broadleared species from the collum up to ten inches, or as far as the grass reaches, in strips or rings.

Voles breed much more rapidly than mice, the southern field- 
vole (Arricolaartalis, Selys.) $)^{*}$ being especially reproductive.

The water-vole (A. amphibius, Desm.), and the common field-role ( $A$. argrestis, Blas.), do the most damage. The water-vole lives not only near water, but also in the forest, and does much damage by burrowing, and by cutting-off the tap-root of stems up to the thickness

FIG. 44.

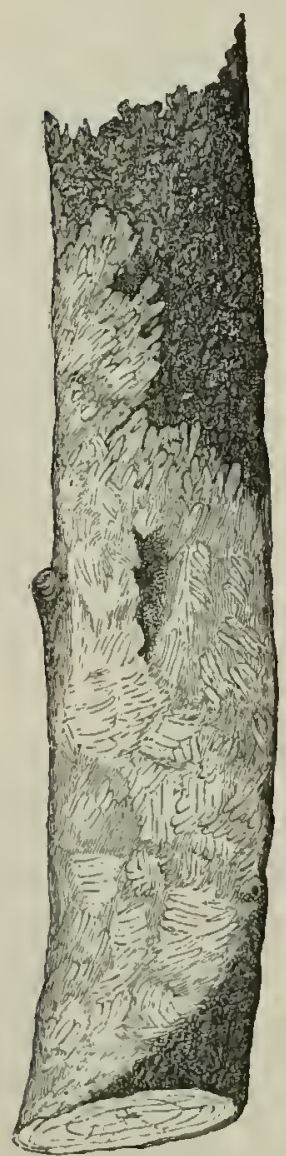

Beech gnawed by nice (nat. sizc).
FIG. 45.

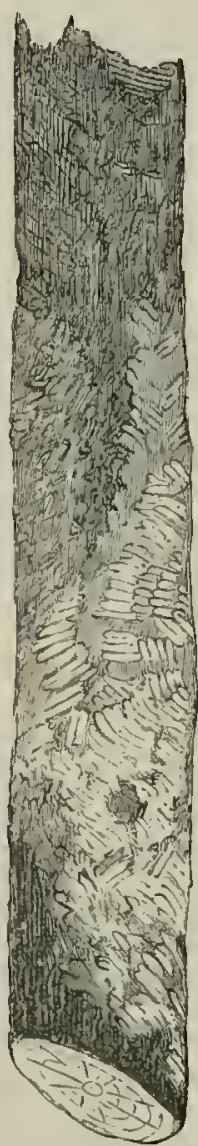

Alder gnawed by mice (nat. size).
FIf. 46.

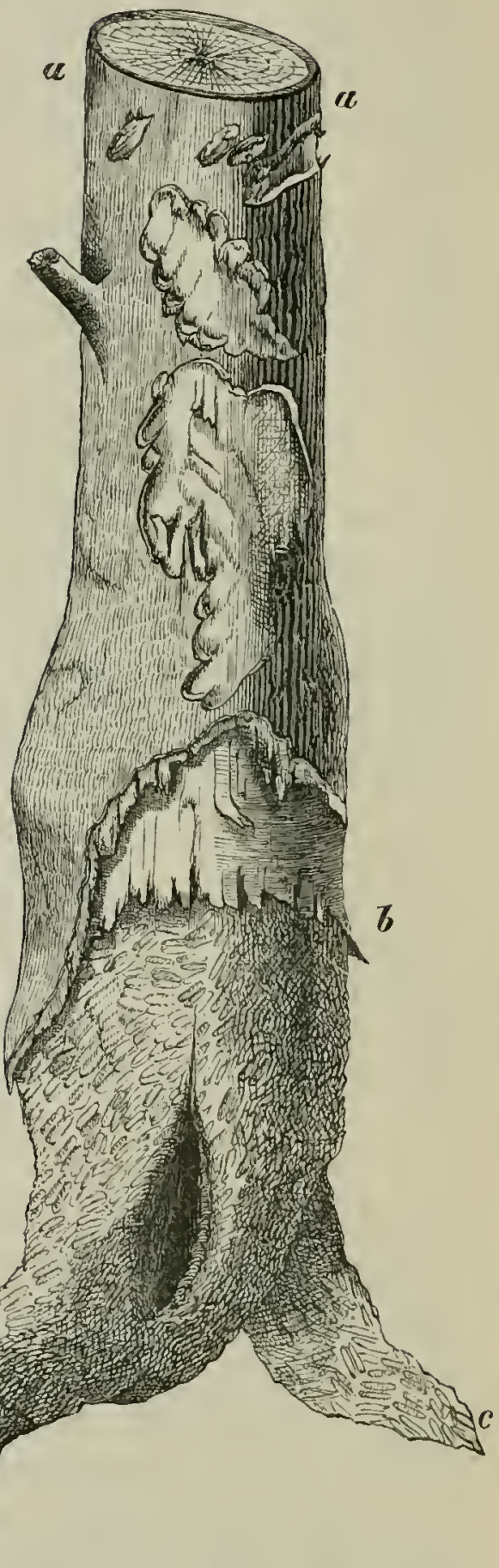

Apple-tree gnawed by hares $(a b)$, and by nice $(b e)$ (nat. size).

* About seventy-five per cent. of them are $q$, and a mother volc has eight tc ten young every six to eight weeks, from March till late in autumn. A o begins breeding when eight weeks old, and may have 10,000 descendants in a year. 
of a man's arm, which naturally kills them. Oak and ash suffer most in this way, also poplars, willows, apple-trees, etc., less beech and conifers. The water-vole also frequently injures banks and dams; it has done much damage in the forests occasionally inundated by the Danube, but is fortunately never very numerous.

The bank-vole (Hypudeus glareolus, Wagn.) is extremely active, and chiefly inhabits the borders of forests, bushy land amongst fields and forest glades with advance-growth, rather than dense forest. It gnaws larches, black pines, aspen, and other trees and shrubs, and eats and carries off the pine-buds.

The common field-vole (Arvicola agrestis, Blas.) is the greatest scourge of the agriculturist, and comes from the fields into light forests, where it does enormons damage. In the winters of $1822-23,1830-31,1840-41,1856-57,1861-62$, $1863-64,1870-71,1871-72,1872-73,1878-79$, this species was chief among the swarms of mice which destroyed the crops on thousands of acres in Germany. The destruction is greatest when it collects in swarms and wanders from place to place.

A description of the damage done in 1814 by this species and the long-tailed field-mouse is given in Nicholls' $*$ account of the Forest of Dean. They destroyed all the young oak-saplings in the forest except four or five per acre, eating through the roots just below the surface of the gromnd. The long-tailed species was chiefly found on wet ground, and the vole everywhere. To exterminate these pests, trenches 2 feet deep were dug 20 yards apart, and 100,000 tails were brought in for reward. Polecats, hawks, kites and owls increased enormously, and the mice ate one another in the trenches. Much damage was also done by voles in the Lowlands of Scotland in 1891-92. 'This species prefers hornbeam, beech, ash, hazel and sallow, but it also attacks all broad-leaved species as well as pines and larch. It is specially fond of white-thorn. Young plants two to five years old are gnawed through at the surface of the soil, or peeled of bark, or bitten through above ground, or stripped of their side-shoots. Older plants and even poles up to 10 inches in girth are stripped of their bark up to a foot from the ground and killed. Voles strip the scales from the fir-cones and eat the seeds, they

* Published by John Murray Albemarle Street, London, 1858. 
also eat grass with its rhizomes, thus destroying extensive pastures.

The southern field-vole living on the confines of forests in well-watered situations gnaws the roots and bark of beech and other trees in hard winters.

The only use of roles is that they eat larvæ, snails and slugs.

\section{Protective Rules.}

(a) In years when mice are abundant, autumn-sowings, especially on a large scale, should be abandoned; in any case, plenty of seed must be sown, and covered deeper than usual, but it is better to sow late in the spring or to use transplants.

(b) Forest nurseries should not be made near fields, and broadcast-sowing in seed-beds is preferable to sowing in drills. Small pieces of furze may be placed between acorns or other seeds in the mursery-beds.

(c) For sowings in the forest, the following precantions are recommended :- Soaling the seeds for half an hour in a 2 per cent. solution of carbolic acid in water ; 10 per cent. of the acid will kill the seeds. Acorns may also be soaked in a decoction of quassia. The seed-beds may be covered with a layer, 2 inches thick, of old tan or spruce branches, or strewn with calcium chloride, which is also a protection against certain insects.

(d) Felling-areas with grass-mndergrowth should be pastured down in summer and autumn by cattle or sheep. The grass protects the mice from observation, and renders the bark of plants in it soft and fresh, which the mice like. The cattle disturb and trample down many mice.

(c) Beech seeding-fellings should be dark in order to keep down the grass.

( $f$ ) Pigs may be admitted into the forest as long as the soil is loose, especially near nurseries. 'They root-up the ground, disturb the mice, destroy their young, fill-up their burrows, and also trample-down and eat many mice.

(g) Remoral of low undergrowth, which shelters the mice.

(h) Branches of soft-woods or hornbeam may be spread about in young beech-woods, to attract the mice from the beech. They must however be frequently replaced, as dry branches are no 
longer gnawed, and then the remedy does more harm than good, the branches having attracted mice into the wood. This is a good precaution against the southern field-vole.

\section{(i) Protection of Enemies.}

Here we must restrict ourselves to the protection of micedestroyers which may not do so much injury in another direction as to outweigh their usefulness in killing mice and voles. The following animals are useful in this way:-

\section{Mammals.}

The pole-cat (Putorius fotidus, Gray), the stoat (P.ermineus, Ow.), the weasel (P.vulgaris, Rich.), the badger (Meles taxus, Pall.), the mole (Talpa europea, L.), and the hedgehog (Erinaceus europeus, L.), also the shrews, especially Sorex vulgaris, L.

The first three beasts also plunder nests and eat eggs, young

FIG. 47 .

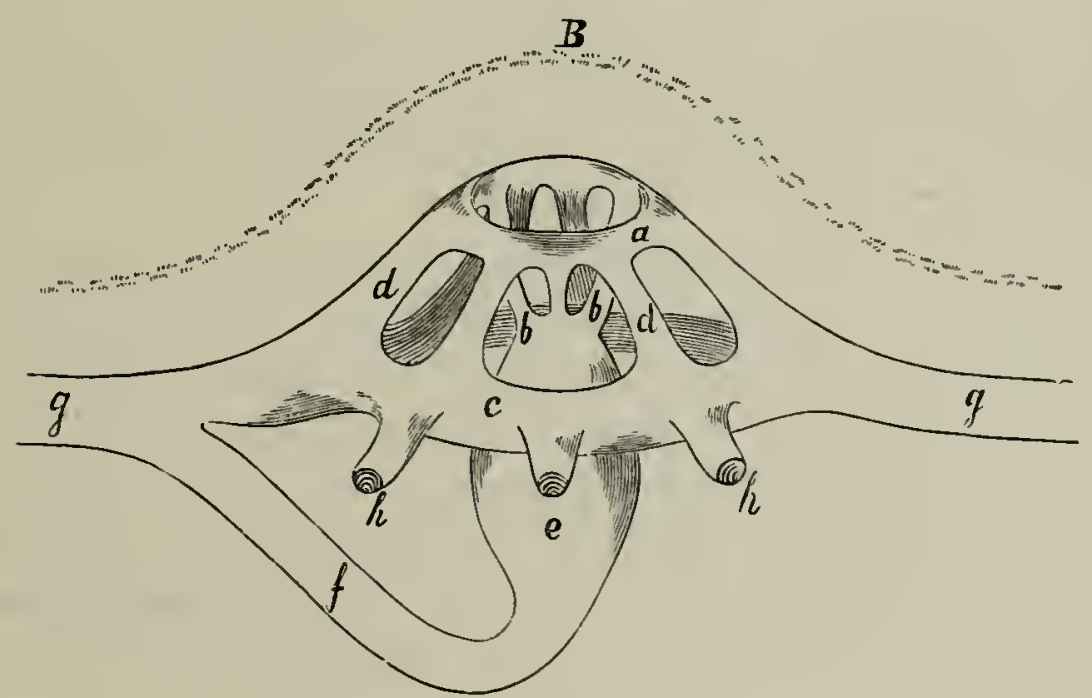

Diagram of mole-heap.
(B) Surface of ground.
(a) Upper gallery.
(b) Descending passages.
(c) Lower gallery.
(d) Ascending passages.

(e) Central chamber.

(f) Passage to chamber.

(f) Moles' run.

(h) Diverging runs from lower gallery.

birds and leverets. The badger eats fruits, mast and pheasants' eggs. The mole is hurtful to forest murseries from its habit 
of burrowing and throwing-up small heaps of soil. The hedgehog attacks nests. All these animals, howerer, are much more useful than hurtful. The well-known and much abused mole hunts for mice, crickets, snails, slugs and grubs, and is always at hand where these creatures abound, and extremely useful in destroying them. It increases rapidly, has $3-5$ young at a birth, and two broods in the year, in May and August, and is very roracious. Its ingenious nest (fig. 47) affords means of escape when pursued by a rat, or other enemy.

A limited protection may also be afforded when mice are swarming, to the fox (Camis vulpes, L.), the pine-marten (Mustcla martes, L.) the beech-marten (Mustela foina, Briss.) and the wild cat (Felis catus, L.), in spite of the damage they may do to game.

\section{Birds.**}

The following birds are extremely useful in destroying mice:- The kestrel (Falco tinnunculus, L.) ; the buzzards, especially the common buzzard (Buteo vulgaris, Leach); owls, especially the long-eared and short-eared owls (Otus rulgaris, Flein., and O. Urachyotus, Cur.); also, the tawny owl (Syrnium Aluco, Boie), the little owl (Carine noctua, Scopoli), and the barn owl (Strix flammea, L.).

The rook (Corrus frugilegus, I.) kills mice, especially in the autumn, so do the black crow ( $C$. corone, Lam.) and the hooded crow (C.comix, L.), which are sometimes said to be varieties of the same species and to interbreed freely. The above three species of Corrus occasionally attack acorn-sowings, and break off the leading shoots of conifers, and the crow does much damage by eating the eggs of partridges and other birds, but on the whole their utility is greater than their destructiveness.

Kites (Milrus sp.) are said by Hess to destroy mice, but Yarrell states that their food is chiefly offal, moles and unfledged birds. The stork (Ciconia alba, L.) occasionally feeds on mice, and so does the black-headed gull (Larus ridibundus, L.).

* The scientific names for birds follow Yarrell, British Birds, 4tl edition. Revised by A. Newton, F.R.S., and H. Saunders, is74-S5. 
Most of the other flesh-eating birds do too much damage to useful birds to deserve protection.

\section{Remedial Measures.}

Remedial measures against mice may be with or without poison. The chief rule is to adopt measures every year which suit the locality, so as to prevent as far as possible any extraordinary increase in the number of mice and voles. According to trustworthy observation, there are far more females than males in the spring, and mice should therefore be destroyed as much as possible in February and March. Private enterprise, especially in forests where it is difficult to get at the mice, is not sufficient for this purpose, but the State must direct matters and induce private persons to assist in the energetic destruction of mice both in fields and in forest, which will be to the public advantage.

\section{(a) Pitfalls.}

Trenches must be dug in the ground, and visited daily to keep them clear from leaves, etc., and to remove and kill the captives. They should be 4 inches wide, and 16 inches deep, with vertical smooth walls. The base of the pitfall must be beaten hard, and glazed earthenware vessels, or drain-pipes, one every 3 or 4 yards, buried level with the bottom of the pitfall. A few grains of wheat act as lures for the mice, and those which are found in the pitfall are killed with a pointed piece of coarse iron wire. Such trenches* are to be recommended against field-mice along the borders of fields and forests, and around forest nurseries and seed-granaries.

\section{(b) Traps.}

Traps are useful, especially against water-rats and bank-voles, and various kinds of devices may be used to trap mice according to species and local circumstances.

Traps resembling sugar-tongs are advocated by E. Heyer

* In autumn of 1872 to the end of October, 10,800 mice were caught in Mecklenburg in a trench between two fields. 
against the water-rat, as shom in the figs. 50 and 51. They must be so placed that the rat, in running into its hole strikes

FIG. 48

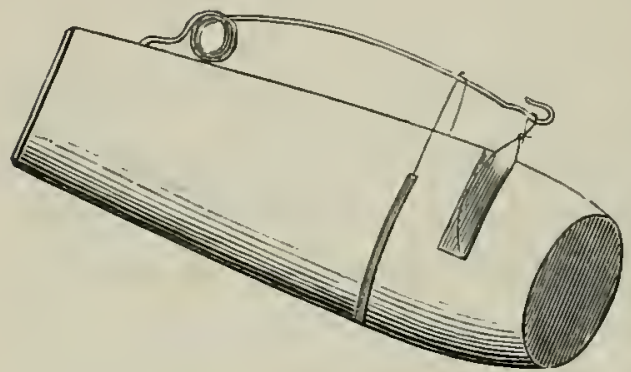

Fur. 49.

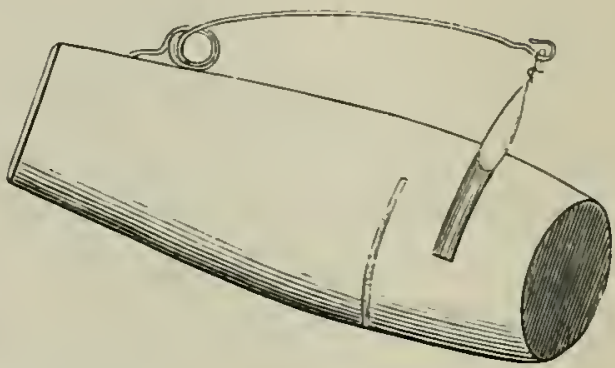

Tube-traps from Hohenheiu.

( $\frac{1}{3}$ nat. size.)

the plate $(a)$ with its head, and is then caught round the body by the pinchers $(b)$. It is better to place two such traps back

FI

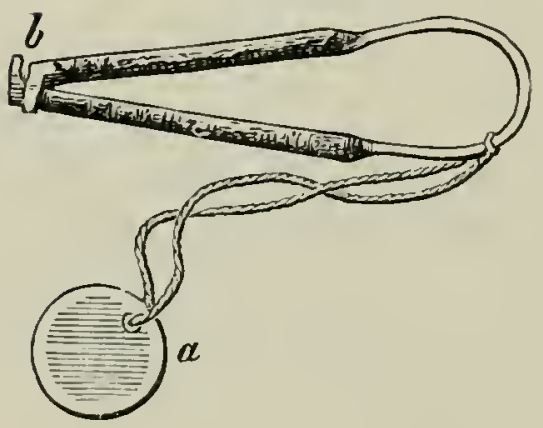

Fic. 51.

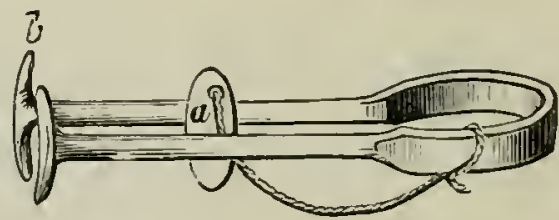

to back in a hole. For the smaller species the tube-traps from Hohenheim are very effective, figs. 48 and 49 .

FIG. 52.

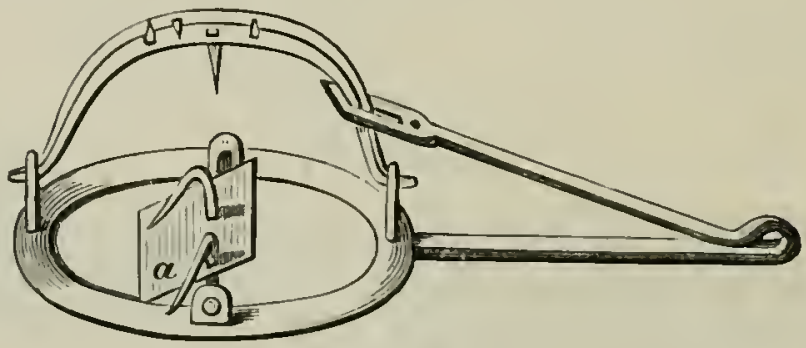

(1) ret. size.)

Ordinary spring-traps (figs. 52 and 53) are more useful in closed rooms, such as seed-stores, but when concealed by foliage, 
etc., they may also be used in forest nurseries, carrots or beetroot forming a good bait.

For seed-stores, a good trap for mice may be formed by a vessel full of water, over the edge of which a piece of wood or platform on which the bait is fastened is balanced. The mice

FIG. 53,

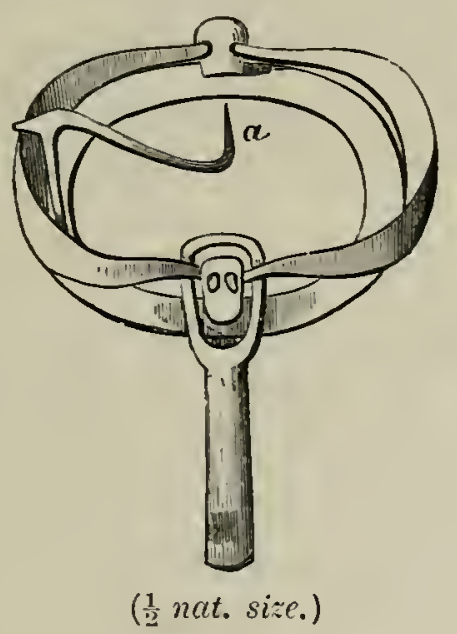

climb up a slanting piece of wood on to this platform, and going to the end of it to get at the bait, upset tine balance of the platform and fall into the water.

\section{(c) Smoling-out.}

Smoking-out mice is not possible in forests, owing to the nature of their holes amongst grass and dead leaves, and also on account of the danger of firing the forest.

\section{(d) Poisoning.}

In poisoning mice in forests, there is great danger of killing useful animals, such as weasels, foxes or owls. Such a method can therefore be employed only after every precantion has been taken against danger to useful animals, and in cases where the mice have increased enormously in numbers.

Poisoning may be done by means of phosphorus, arsenic, strychnine, corrosive sublimate, or carbonate of baryta. Of these, strychnine is the most effective. Wheat, oats or barley grains, celery or radishes may be used with the poison, the grains being first stceped in water, and then placed in the 
poisonous solution; or a meal prepared and the poison mixed up with it. It is then strewn about in pieces as big as a pea.

In order as far as possible to prevent the poisoning of useful animals, the poisoned baits must not be placed on the bare ground, but in little cylinders of wood or of grass sods, or in glazed vessels or drain-pipes about $1 \frac{1}{2}$ inches in diameter, sufficient to allow passage to a mouse. The cylinders may be placed on the ground, or in the mouse-holes, and must be inspected regularly in order to observe their effects.

Glazed ressels are better than drain-pipes, as the latter let in moisture.

Phosphorus, owing to oxidation, soon becomes ineffectual in damp or rainy weather. Arsenic is more effective, but less rapid in its action. If either of these poisons is used, the dead mice are generally found lying on the surface of the gromnd, as they run in search of air and water when feeling the pains of the poisoning. Strychnine and carbonate of baryta lill the mice in their holes after severe convulsions; it is better to change the bait and the poison from time to time.

A pest of mice rarely lasts more than 2 or 3 year's, as heavy rain, frosts, inundations and disease soon kill them by thousands. It would not however be right to wait patiently for such an event to occur, for by timely energetic action the damage may be greatly reduced.

Attempts were made (as proposed by Loeffler) in 1890, to destroy the mice which were infesting the fields in Thessaly, by subjecting them to a parasitic fungoid disease termed mousetyphus; this was communicated to the mice by pieces of bread which had previously been soaked in water containing spores of the fungus, but the results in this case were not commensurate with the expenditure, and a Commission sent to Thessaly by the British Government did not recommend its adoption to stop the plague of mice in Scotland.

\section{Treatment of Injured Plants.}

Broad-leared poles and saplings which have been badly gnawed by mice should be cut-back in the spring close to the ground, below the injured place, sharp instruments being used for the purpose, so that they may send up new shoots. If the 
plants have been girdled too deeply towards the roots, such procedure would not save them, but of course the dead poles should be removed. The workmen should work in lines so as not to leave out any injured plants, and should be properly supervised.

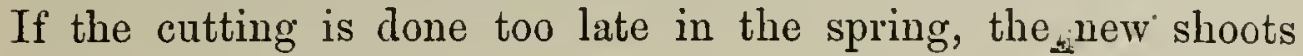
will be very weak, as much reserve material then passes into the injured stems and is consequently wasted when the stems are cut down.

Where conifers have been injured, new plants mustibe substituted for those killed by mice. 


\section{CHAPTER III.}

\section{PROTECTION AGAINST BIRDS.*}

Section I.-General Account.

The birds directly hurtful to forests belong to the order's Galline or game-birds, Columbide or pigeons, and Passeriformce or perching birds.

\section{List of Hurtful Birds.}

Grouse ('T'etraonide).

Capercaillie ('T'etrao urogallus, L.).

Black game (Tetruo tetrix, L.).

Hazel-grouse (Bonasia silvestris, Brehm.).

Pigeons (Columbide).

Ring-dove or Wood Pigeon (Columba palumbus, L.).

Stack-dove (C. anas, L.).

Turtle-dove ('Turtur communis, L.).

(Corvide.)

Jay (Gamulus glandarius, Vieill.).

Nutcracker (Nucifiaga caryocatactes, Briss.).

Einches (Fringillide).

Hawfinch (Coccothraustes vulgaris, Briss.).

Greenfinch (C. chloris, Briss.).

Chaffinch (Fringilla caelebs, L.).

Brambling ( $F$. montifringilla, L.).

Siskin ( $F$. spimus, L.).

Crossbill (Loxia curvirostra, Gm.).

Parrot Crossbill (L. pityopsittacus, Bchst.).

\footnotetext{
* The scientific names are from Yarrell's British Birds, 4th ed., 1882.
} 
A few other species of small singing birds are liurtful by eating seeds and biting-off buds, such as :-

Bullfinch (Pyrrhula europea, Vieill.).

Mealy Red-poll (Linota linaria, L.).

Red-breast (Erythacus rubecula, L.).

Even titmice (Parida) do some harm, and woodpeckers (P'ici) make holes in trees; these families, however, do more good than harm. Birds which do indirect injury by killing other useful birds will be described further on under the heading Insects.

\section{Damage done.}

Destructive species of birds eat-up seeds and fruits, bite-off buds, young shoots, and tender seedlings, but are generally useful by destroying insects, and the damage done by birds in forests is in general much less than that by the rodents and deer already referred to.

\section{Protectire Rules.}

Delay sowing until the birds have paired, and cover the seeds well. The birds, after pairing, no longer fly about in large numbers, and they kill more insects than before pairing, both for themselves and for their young.

The seeds may be steeped in red-lead mixed with water, or in distilled water, lime-water, or very dilute acids, so as to hasten the germination, and the period of dauger from seedeating birds may thus be reduced to as short a space as possible.

Sowings may be covered with moss, or branches; in nurseries, with wire-netting over hoops of hazel, willow, se.

Scarecrows may be used, or paper feathers on string, or stuffed birds of prey.

Watch the sowings till the young plants are large enough to be out of danger.

Fire off blank cartridges, or shoot the birds.

Section II.-The Capercalluie and other Grouse.

\section{Damage done.}

The capercaillie, which frequents extensive tracts of mountain forests, injures nurseries and cultivations of conifers in winter 
and spring by biting-off buds and young shoots; in nurseries, when the buds of the plants just appear above the snow, they are frequently cut-off in great numbers by these birds, the cock being more injurious than the hen. Birch-buds and small green pine-cones are also eaten. The capercaillie in winter frequents old woods with advance-growth, and feeds chiefly on the needles and buds of old spruce trees, but is very fond of the buds of neighbouring young spruce. In the spring it scratches the soil in seaich of iusects and worms.

The black grouse lives in mossy heather-land, and does much less harm to forests than the capercaillie. It eats the buds and inflorescence of birch and other broad-leaved species, and attacks buds of conifer's and young needles of the larch, but chiefly nourishes itself with berries and small shrubs (bilberry, heather, \&c.), and keeps itself alive in winter by eating needles of old spruce trees. It goes higher in the mountains than the capercaillie.

The hazel-grouse is chiefly found in broad-leaved woods, in the Austrian Alps and the Russian Baltic Provinces; it feeds during winter on birch and alder buds and hazel-catkins. In summer it chiefly eats berries, but does less har'm than black game.

Pheasants scratch-up sowings in the forest, and nursery seedbeds.

2. Protective liules.

Fence-in nurseries with tall thorny bushes, as the capercaillie is very shy, and avoids places so protected.

Branches of spruce, \&c., may be laid over sowings to impede the movements of the birds, and mursery seed-beds may be protected with wire-netting. Buy transplants.

\section{Section III.-Pigeons and Dores.}

\section{Damage done.}

Wood-pigeons and doves eat up forest seeds, especially of spruce and Scotch pine, also buds, catlins, \&c. The woodpigeon and the stock-dove in autumn also eat acorus, beechmast and beecli cotyledons. Turtle-doves eat-up seedlings, 
doing most damage in March, aud from April to October, when they often alight in flocks on sowings.

The wood-pigeon, the largest kind, prefers coniferous forest (spruce); the stock-dove, beech and mixed forest of broad-leaved and coniferous species; the turtle-dove, the smallest kind, lives near water in small woods among fields and meadows.

\section{Protective Rules.}

Those already given under the general heading apply here. Scarecrows are only useful at first, as the birds soon get used to them. Strewing seed-beds with spruce-needles instead of moss protects against turtle-doves. Shooting is best done at the breeding season with decoys, or over salt. Small vessels containing salted clay, anise, hempseed or wheat are placed here and there orer the endangered sowings, and the pigeons flying down to them are shot.

\section{Section IV.-Jais and Nutcrackers.}

\section{Damage done.}

The Jay is extremely destructive, eating acorus, beech-nuts, walnuts, hazel-nuts, cherries and other fruit, digging-up germinating beech-nuts and young oaks to eat their cotyledons. It also destroys the young and eggs of other birds, and even attacks new-born hares. Once it has discovered a sowing of acorns, it will completely strip the bed.

At the same time, by placing acorns and beech-nuts singly in holes in the ground, which it afterwards forgets, it assists in the spread of the oak and beech. Of more value is its power of attacking mice and insects, but the good done is less than the harm effected in other ways.

The Nutcracker, though not uncommon in the spruce forests of the Schwarzwald, the Bavarian Alps, the Tyrol and Switzerland, is rare in Central and Nortin Germany, and in the British Isles. Its food consists of hazel-nuts, acorns, and beech-mast, and especially the seeds of the Cembran pine, of which it is so fond as to pick them out of sowings and seedbeds in the very presence of the workmen who are sowing the seed. It also 
destroys the eggs and young of useful birds. This extremely restless bird also sows seeds, and in this respect is more useful than the jay, as the localities it prefers in the high mountain regious are those where planting is extremely costly, and any assistance to man's action in reboisement is of great value.

\section{Protective Rules.}

Cover up endangered sowings with branches of thorn-bushes, immediately after sowing.

Shoot in autumn, when jays keep flying from one oak to another. Several hundred jays are thus shot every year in Epping Forest.

Section V.-Finches and other Shalia Birds.

\section{Damage done.}

The Hanfinch, rare in the British Isles, is very fond of fruits and seeds, especially those of the hornbeam, cherry, maples, oaks, beech, alder, elm and conifers. The traces of its activity are seen in the remains of the fruit lying under the trees. It also bites-off buds. In general, however, the damage done by this bird is greater in gardens and orchards than in forests.

The Greenfinch feeds its young on soft seeds, and by thus destroying countless weeds it is of great service to the gardener and agriculturist. Later on in the year, however, it unites in large flocks with the chaffinch and other finches and small birds, and they may do much damage to sowings in the forest.

The Chaffinch is extremely fond of coniferous seeds, those of the pine, spruce, and larch, and bites off young cotyledons of conifers as long as they are covered by the testa. It also eats beech-nuts, and the cotyledons of beech-seedlings.

The Brambling appears in the late antumn and winter in large flights like clouds, and attacks beech-nuts and coniferous seeds. De Montbeliard states that in 1765 , after a good beechmast year, for several nights 600 dozens were lilled near the Rhine, and de la Fontaine computes a flight of bramblings in Luxemburg in February, 1865, at 60 millions. Stevenson in March, 1865, saw a flock of bramblings near Slough which 
passed him without intermission for 35 minutes. Both this species and the chaffinch are extremely destructive to coniferous and beech sowings, and to natural reproduction of beech, which it is extremely difficult to guard against them.

The Sistin also appears in great numbers, and prefer's the seeds of the alder, but also attacks sowings of birch, spruce, silver-fir, larch, and other conifers. Something may be said in favour of the finches on account of their destruction of insects; the hawfinch frequently catches cockchafer's even wher they are on the wing, and then, perching on a twig, picks them to pieces, letting the hard elytra and legs fall to the ground.

Crossbills are extremely ravenous, and appear in swarms when there are good seed-years of spruce and Scotch pine. They live on the seeds and berries of trees of sereral species. They bite-off cones by the base, and open-out their scales with their beaks and pull out the seeds. The common crossbill can only open spruce-cones, but the Parrot Crossbill also attacks pine-cones. They eat mountain-ash berries when cones are scarce, and even Fig. 54.

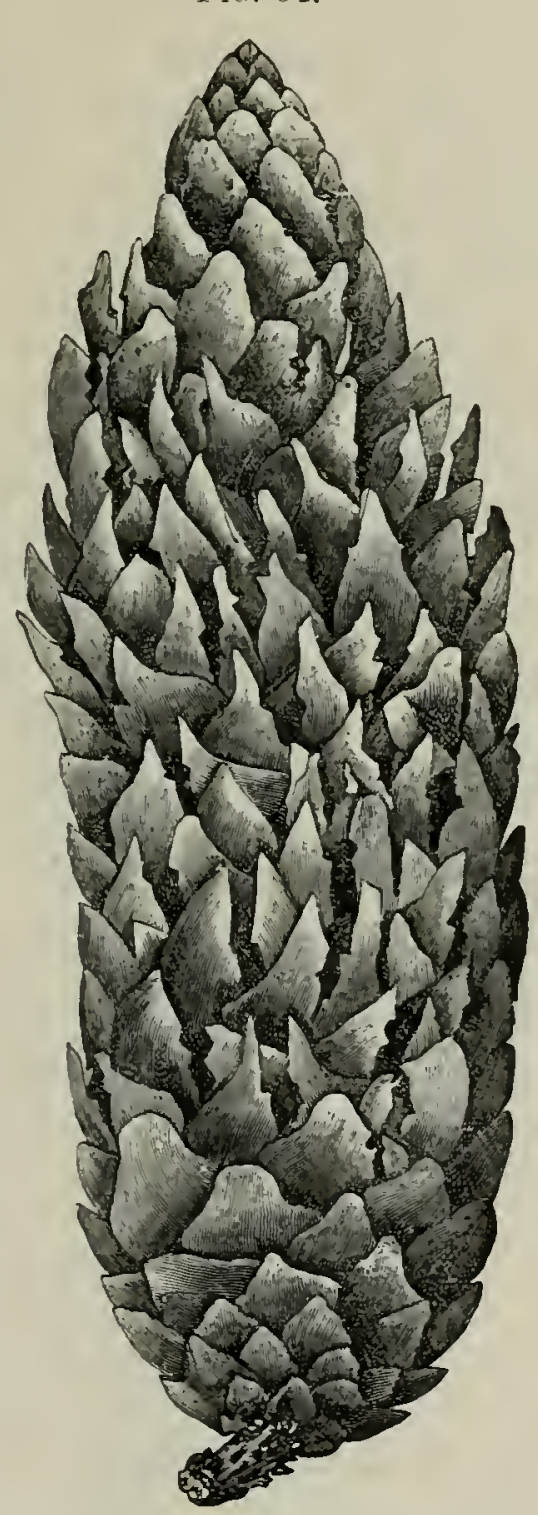

Spruce-cone attacked by Crossbill. thistle- and dock-seed, and have been seen to eat beech-cotyledons. They do some compensation by eating plant-lice.

\section{Protective Rules.}

Blue strings may be placed crosswise orer sowings.

Red-lead can be applied to the seeds in the following manner: 
In a wide ressel, water and $1 \mathrm{lb}$. of red-lead are stirred together, and 7 to $8 \mathrm{lbs}$. of spruce-seeds mixed up with it, about $1 \mathrm{lb}$. at a time, the water in the vessel being constantly stirred until the seeds will take up no more of the lead. The seeds can be sown at once without drying. This costs $5 d$. per lb. of seeds for labour and material. Dilute carbolic acid may also be applied to seeds, as already mentioned. Scarecrows are of very little use against finches.

The seed-beds may be watched during the dangerous time, and blank cartridges fired.

A good plan is to shoot some of the birds, and hang the bodies to stakes near the seed-bed.

Cones bitten-off and dropped by crossbills may be utilized to secure the seeds remaining in them.

\section{SECTION VI.-WOODPECKERS.}

The question whether woodpeckers are useful or hurtful to forests has been a subject of dispute, and will be here discussed.

\section{List of Woodpecliers.}

In Central Europe the following species of roodpeckers are found :-

Black woodpecker (Picus martius, L.).

Greater spotted woodpecker (Dendrocopus major, Koch). Intermediate spotted woodpecker (I). medius, Koch).

Lesser spotted woodpecker (D. minor, Koch).

White-backed woodpecker (D. leuconatus, Bchst.).

Three-toed woodpecker (Apternus triductylus, Gould).

Grey woodpectser (Picus camus, Gmel.).

Green woodpecker (Picus riridis, L.).

The two last species are termed ground-woodpeckers. Of these the green woodpecker is the commonest in Britain, and D. major and minor also occur. Nos. 2, 3, and 7 are said to be commonest near Giessen, where Hess resides.

\section{Opinions of rorious Authors.}

Opinions regarding the utility or otherwise of woodpeckers from a forestry point of view hare varied from time to time. 
Towards the end of the eighteenth century they were considered hurtful by pecking holes into trees which were sometimes sound ones.

In Beckmann's Handbuch der Jagdwissenschaft, published at Nuremberg in 1802, this opinion was adopted, and in consequence

Fig. 55.

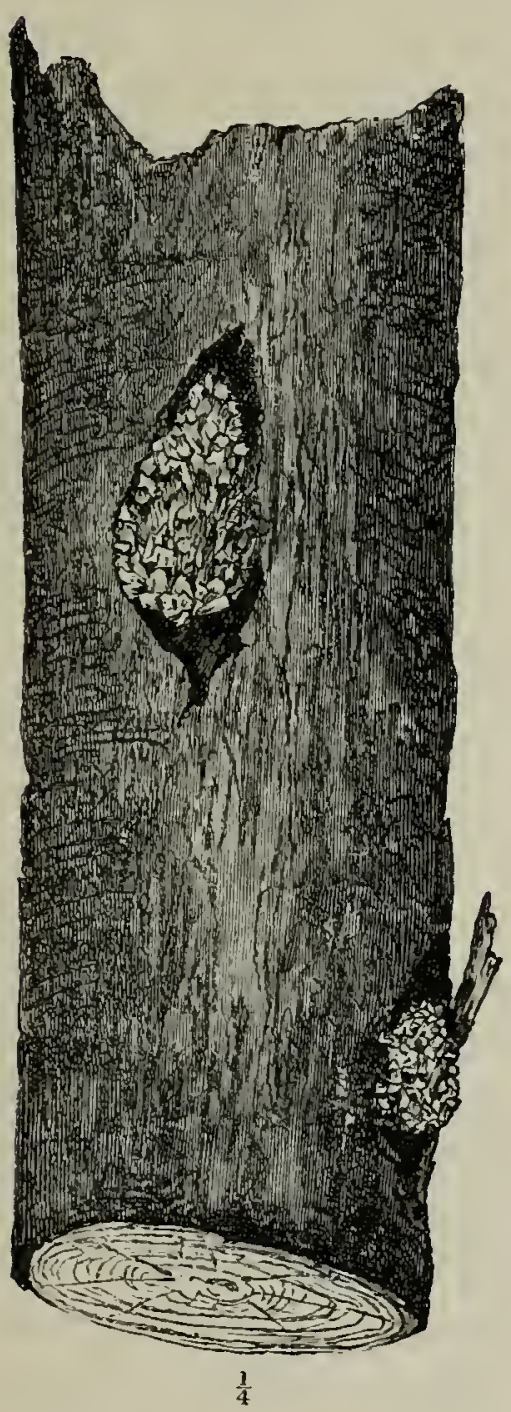

Scotch pine-cones fixed into a tree by woodpecker.
FIG. 56.

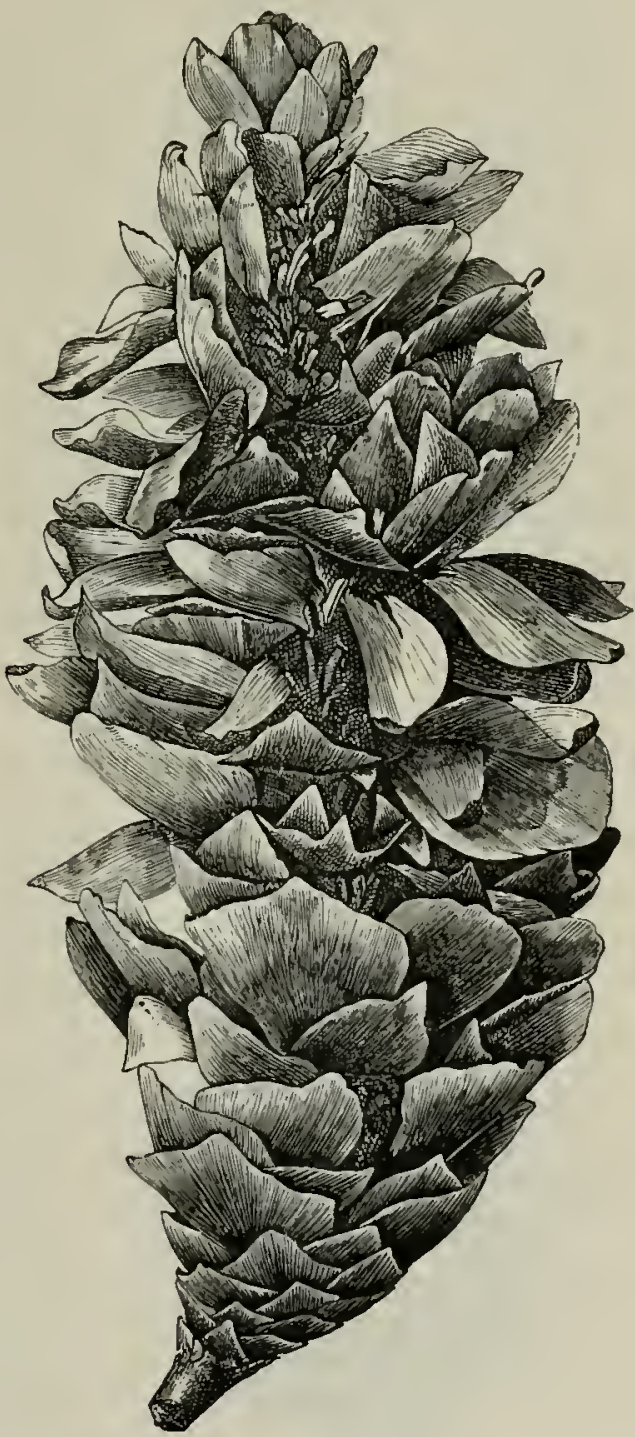

Spruce cone attacked by woodpecker.

a reward of $2 d$. per head was offered in Germany for their destruction. Bechstein was the first, in 1802, to consider them useful, and Walther in 1803 ; also Gloger about 1860. Foresters then went to the other extreme, considering woodpecker's as extremely active in destroying insects, and ignoring their 
propensity for making holes in trees. Altum in his Forstzoologie reverted to the former opinion, stating that woodpeckers were practically useless against dangerous bark-beetles, but attacked the larger and less important longicorn-beetles, and that they themselves did considerable damage to trees.

Altum wished, however, to protect woodpeckers on resthetic grounds, because they enliven the forest and please the eye. Judeich follows Altum's views to a certain extent. König, Döbner, Vogt, the brothers Müller, Taschenberg, Borggreve, Nördlinger and others consider that the utility of woodpeckers outweighs the harm they may do, and Hess expresses himself as of the same opinion, from the most recent observations on the subject.

\section{Damage done by Woodpeckers.}

Woodpeckers eat forest-seeds, peck wounds in saplings, and holes in sound poles and trees; they girdle sound trees and destroy telegraph-poles and wooden roof-shingles.

(a) Destruction of Seeds.

I)endrocopus major alone of the woodpeckers eats large

FIG. 57.

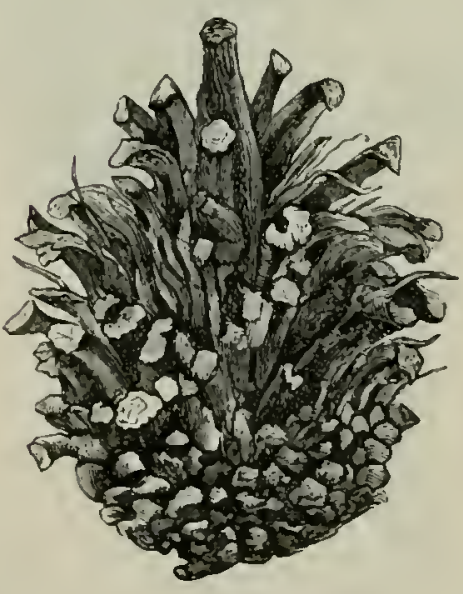

Cone of Scotch pine attacked by woodpecker. quantities of coniferous seeds. It wedges the cones which it has plucked from trees in a cleft in the bark, or in an angle between a stem and a branch, and opens them out and removes the seeds with its bill. One can distinguish between the action of the woodpecker and crossbill in this respect. Frequently the ground under a tree is covered with opened-out cones. Also walnuts, hazel-nuts, acorns, and other fruits are eaten by the great woodpecker. The damage done is not, however, very serious, as woodpeckers are solitary birds.

(b) Pecking Holes in sound Trees.

The black and the great roodpecker do most of this damage, 
and attack isolated trees and saplings. The woodpecker also attacks freshly planted saplings of oak, beech, acacia, exotics, ic., and the reason for its doing so is not very clear; in coniferous woods it may thus free the beal from resin derived from the cones it has been attacking.

Older trees are also attacked, such as avenue-trees (poplars, limes), oaks occurring in coniferous forests, boundary trees, \&c. Most of this damage is done during spring and early summer, but it is too rare to be of any practical importance.

\section{(c) Girdling Trees.}

The same two woodpeckers, while hanging to the trunk by their feet with the support of their tail feathers, encircle trees with rings of holes arranged horizontally. A callus forms at each hole, but is pecked at again and again until quite a ledge has been made round the tree. Trees may sometimes be seen with several such ledges, one above the other, resembling the rings on bamboos. The reason for these attacks on sound trees has not yet been discovered.

\section{(d) Destruction of Telegraph-Posts.}

The great roodpecker as well as the black and green woocpeckers share in this damage. Attacks have been observed both on coniferous or oaken posts, whether lyanised or not, and generally commence at an oli screw-hole. In 1881, the Director of Post-Offices for the German Empire issued a circular order that all holes in telegraph-posts should be filled with wooden plugs, and that holes freshly made by woodpeckers should be at once smeared with tar. Injuries done by woodpeckers to the wooden shingle roofs of forest lodges and other deserted honses have been noticed, but are rare and unimportant.

\section{Ctility of Woodpeckers.}

\section{(a) Destruction of Insects.}

The injurious insects which woodpeckers devour live either in or on the surface of the soil, or in the wood or bark of trees, and the latter kinds are preferred.

Woodpeckers chiefly seek animal food from April till late

YOL. IY. 
summer. They capture cockchafers, pick grubs from fruit, and eat the pupe of moths and sarflies; ther dig into ant-hills, consuming numbers of ants, which are said by Yarrell to be the chief summer food of the green roodpecker, and they peck holes into the ground in search of cockchafer grubs, wire-worms, \&c. For the most part, however, they lunt on trees for weevils, barkbeetles, longicorn-beetles and their grubs, suwfly larvæ, gallinsects, spider's, \&c.

Their tougue, owing to its construction, is extremely useful in

FIG. 5S.

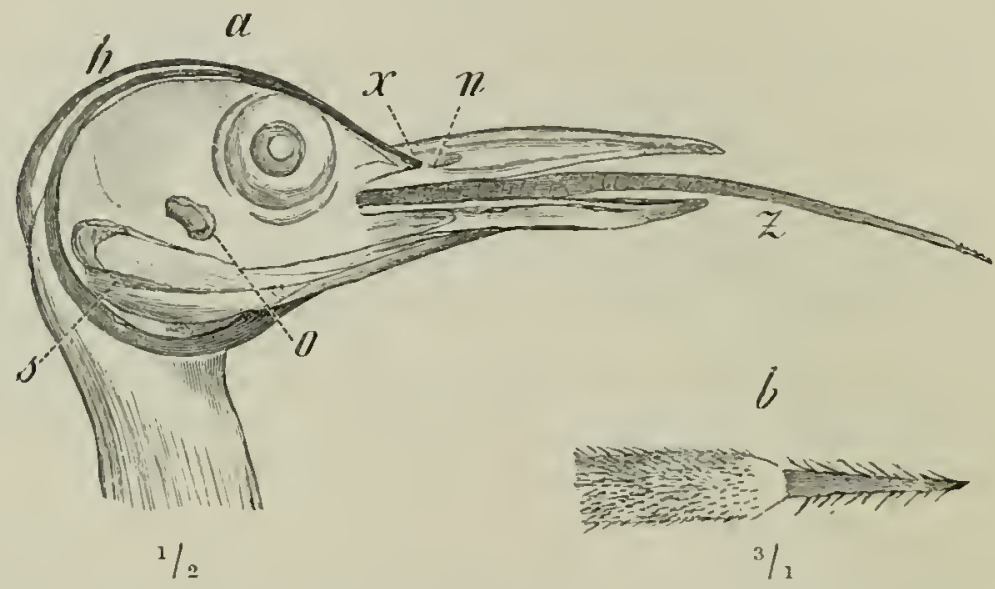

a Head of woodpecker (Picus cunus, Gmel). \& Tip of tongue with barbed hairs.

$h$ Cornua of the hyoid bone. $\quad x$ Opening in the maxilla for
$n$ Nostril.
$o$ Ear:
$s$ Salivary gland.

the search for insects; it is very long and thin, and is furnished near the tip with a few stiff barbs pointing backwards. The cornua of the hyoid bones, which support it, curve round the back of the head to its upper surface, terminating in a carity in the bones of the beak, and their mobility and great length allow the tongue to be freely extended. The wood-pecker darts its tongue into cracks in the bark, using the barbs for detaching the insects, which are captured by adhesion to the slimy surface. The spotted and ground woodpeckers hunt in this manner more or less throughout the year, the former chiefly on trees, and the latter more on the surfuce of the ground.

Woodpeckers detect insects by the senses of sight, smell and sound; it is not yet decided which of these is predominant. It camnot be denied that they prefer the large but less harmful 
larve of Cerambycide, Cossus and Sirex, to the minnte larve of weevils and bark-beetles, but repeated observation shows that they are also keen hunters of the latter. Amongst the most hurtful species which they destroy may be mentioned P'issodes pini, L., P. notatus, Fabr., Hylurous piniperdu, L., and Hylastes palliutus, Gyll. The damage done by the black and ground woodpeckers to ant-hills may indeed be classed as injury to the forests, to which ants are useful, but living larvæ of parasitic beetles are, when present, often destroyed in greater numbers than the ants themselves.

\section{(b) Nidification in Trees.}

Woodpeckers cannot make nest-holes in trees without injuring them, but this is chiefly done in the case of soft-rooded species, the aspen, lime, sc., or in rotten old hard-woods. The damage done is not great, and the holes are subsequently used for breeding by several useful birds, starlings, titmice and flycatchers, the former frequently driving the woodpecliers from a new hole they have just made, in order to build their own nest there. The holes may however be utilized by the stock-dove.

\section{Summary.}

The result of investigations into the utility of woodpeckers tends to show that these birds by their activity in the destruction of insects play a most useful part in Nature, and should therefore be protected by foresters. Hess holds the same views as Borggreve, that all useful birds tend to prevent an undue preponderance of insects, keeping their numbers more or less normal in ordinary year's. In case of a great insect calamity, however, the action of birds is inadequate to protect the forests; fungoid diseases and ichneumon-flies eventually put a stop to the plague. 


\section{CHAP'IER IV.}

FOREST INSECTS. GENELAL ACCOLNT.

\section{Section I.-Cíassification.}

INSECTs belong to the division of the animal lingdom termed Arthropoda, which includes all animals the bodies of which are bilaterally symmetrical and composed of segments, that is, of successive transverse divisions which present a more or less complete recurrence of structural features, and which have articulated appendages. The body and its appendages possess a hardened exterior, formed of a substance termed chitin, similar in character to, but not identical with, horn, and the muscles are internal, and attached to the extermal skeleton. The symmetry of the successive segments is not complete from end to end of the body, and is more evident in the body-walls and their appendages, than in the viscera. The segments are aggregated into definite groups, the components of which are more nearly related to each other, particularly in the strncture of their appendages than to the segments of the other groups. This form of segmentation is termed hetronomous. The nervous system consists of a double chain of ganglia placed along the ventral surfice of the body, connected with each other longitudinally and transversely by nerre-commissures. and traversed anteriorly by the digestive system; the vascular system is dorsal. Respiration is effected in rarious mays.

The four great Classes of Arthropoda are :-

1. Crustacea : respiring by branchire or gills, or by the general surface of the body; with two pairs of antenuix and more than eight locomotive appendages, the latter forked or biramous. Crabs, lobsters, shrimps, woodlice, \&c.

2. Arachnidı: respiring in varions ways, usually air-breath- 
ing; head and thorax united; with two pairs of jaws and four pairs of legs; abdomen destitute of limbs; no antenna. Scorpions, spiders and mites.

3. Myriapoda: respiring by tracher, or involutions of the integ"ument; head distinct, remainder of the body formed of nearly similar segments; one pair of antennæ; three pairs of jaws and numerous legs. Centipedes, millepedes.

4. Insecta: respiring by trachex; head, thorax and abdomen distinct; one pair of antemnæ; three pairs of legs on the thorax; abdomen without well-developed limbs; generally with two pairs of wings on the thorax. Insects.

A knowledge of the general anatomy of insects, and of the terms used in the present book in describing the different species, is presupposed.

Insects as a general rule before attaining maturity pass through a series of changes termed metamorphoses.

The different stages of their life consist of the egg, larea, pupa, and imago or perfect insect. Some insects, such as parasitic lice, do not appear to undergo any metamorphosis, the young on hatching-out resembling their parents in all respects except in size, although they may moult, or shed their skins frequently; they are known as cmetabolic insects.

The larval stage is essentially the stage of growth and of active feeding. The larva undergoes several moults or ecdyses, never' possesses wings and is incapable of reproduction.

The larve of insects may be destitute of legs, as in the case of fly maggots, or they may hare three pairs of true legs, on the first three segments after the head, as in the cockchafer grub, or in addition to these, two, five, six or seven pairs of clasping feet, or prolegs attached to the abdominal segments, of which the pair on the last segment are known as the anal prolegs or claspers. The larve of Lepidoptera are termed caterpillars.

The pupa of insects is usually inactive, and is protected by its dried and hardened skin; frequently, as in spinning Lepidoptera, it is surrounded by a protective case termed a cocoon, and constructed by the larra.

In the case of certain insects, as grasshoppers, the pupa only differs from the larva in having rudiments of wings; it is still active and feeds, and is termed a nymph. Such a pupa is con- 
verted into the imago by the liberation of its wings at the last moult.

The insects which undergo metamorphosis are consequently divided into metabolic insects, or insects with complete metamorphosis, in which the pupa is quiescent and does not feed, and in which the greatest weight and bulk is attained at the end of the larral stage; and into hemi-metubolic insects, in which there is an active nymph and the imago is the bulkiest and heaviest form. Metabolic insects form 95 per cent. of the whole class.

Insects may be grouped either according to the structure of their bodies, or their mode of life, and Entomology uses the former of these characters in their classification, but in Forest Protection it is of greater convenience to study the latter.

Much difference of opinion has existed regarding the classification of insects. The simplest method, based on the systems of Linnæus and Fabricius recognizes seven Orders. The former naturalist relied principally on the structure of wings in distinguishing the different orders of insects, and the latter on the parts forming the insect's mouth. The Orders may also be arranged, according to the degree of completeness of their metamorphoses, in two groups containing the metubolic and ametubolic insects respectively. Though the degree of metamorphosis is of the first importance as a guide to the systematic position of an insect, it is not, when taken alone, of the highest value in classification, as it camnot be decided by mere observation of any particular insect, without study of its life-history.

Certain writers who have attached great weight to structural differences, particularly of the wings, have increased the number of Order's to thirteen (Westwood) or sixteen (Packard). The groups which have been raised to the rank of additional Orders are of minor importance, and contain as a rule a small number of aberrant forms. In the present work, the broadest and most generally-received classification will be followed, in which the Insects are divided into seven Orders, characterised as follows :-

1. Orthoptera: with biting mouth-parts, a free prothorax, and incomplete metamorphosis. Cockroaches, crickets, locusts, termites or white ants, and dragon-flies, are examples of this order, the two latter belonging to a sub-order termed (sithopitera 
psculo-ncuroptera. In this sub-order the head is horizontal and the wings membranous in texture; in the true Orthoptera (O. genuina) the head is rertical and the wings are stronger and of a more leathery consistency.

2. Nenroptera: with biting mouth-parts, a free prothorax, two pairs of membranous richly-veined wings, and complete metamorphosis. Lace-winged flies (Chrysopa and Hemerobius) are examples.

3. Colcoptera: with biting mouth-parts, free and stronglydeveloped prothorax; two pairs of wings, of which the upper are horny, protective and not used for flight, being known as wing-cases or elytra, and the lower membranous; complete metamorphosis. It includes all beetles, of which the common cockchafer may be taken as a type.

4. Hymenoptera: with biting, or biting and partly suctorial mouth-parts; the prothorax fused at least dorsally with the mesothorax; two pairs of membranons wings with comparatively few veins, sometimes apterous; with complete metamorphosis. Examples: bees, wasps, ants and sawflies.

5. Lepidoptera: with suctorial mouth-parts, the prothorax annular and fused with the mesothorax, two pairs of membranous wings covered completely or partially with scales; complete metamorphosis. The butterflies and moths belong to this order.

6. Diptera: with sucking mouth-parts, an annular prothorax fused with the mesothorax, one pair of well-developed membranous fore-wings, the hind-wings rudimentary and rednced to small stalked knobs, forming the so-called poisers. Complete metamorphosis. This order includes all flies.

7. Hemiptera: with sucking mouth-parts, a free prothorax, and incomplete metamorphosis. Bugs, aphides and scale insects belong to this order.

The vast importance to forester's of forest insects, the enormous amount of damage which these small but mighty members of Nature's household can effect, combined with the fact that, owing to their small size and obscure mode of life, they escape observation much more readily than injurious vertebrates, render it necessary to spend more time on their study.

A full account of the anatomy of insects will not be attempted 
here, and the works of Altum, Ratzeburg, \&c., may be referred to, the most recent work on forest insects being the revision of the Sth edition of Ratzeburg's book by Judeich and Nitsche.*

The following works also merit attention: 5th Report of the United States Entomological Commission, "Forest Insects," by Dr. A. S. Packard, Washington, 1890; "Manual of Injurious Insects," by Miss Ormerod, London, Messrs. Simplin, Marshall \& Co., 1890; and "Indian Forest Zoology" by E. C. Cotes, Calcutta, 1893.

\section{Section II.-Distribution of Insects.}

As regards the geographical distribution of insects, the wandering nature of many species precludes the possibility of defining zones similar to those laid down for plants; but it may be stated roughly that there are, in Central Europe, less species in the north and east than in the sonth and west. Beetles, however, form an exception to this rule, being more abundant in the north and east. The character of the insect fauma is, however, gemerally similar over the whole of the Paliearctic region, which includes Europe, the northern coasts of Africa, and Asia north of the great mountain chains which cross it from east to west. The number of species extending over the whole of this region is comparatively small, and there are no zones in it in which the character of the insect inhabitants is abruptly changed. As compared with continental regions under similar climatic conditions, the insect fauna of the British Isles is poor. As regards altitude, the distribution of insects depends on that of the trees and shrubs on which they feed, and also on locality and climate. Most insects prefer the warmer plains and hilly districts, especially with a sandy soil, where beetles thrive. Soils naturally poor and those imporerished by remoral of litter, sunny aspects, frost-hollows, and stunted regetation are natural breeding-grounds for insects, and require the most careful superrision on the part of the forester. The number of species and of individuals alike diminishes with increasing

* Lehrbuch der Mittelemopüischen Forstinsektenkunde (als achte Auflage ron Ratzeburg's Die Waldverderber und ihre Feinde) heransgegeben von D). J. F. Judeich แ. Dr. H. Nitsche. Vienna : Eduard Hölzel, 1859-95. 
altitude, but beetles are found at a considerable elevation in mountains. Certain species of weerils and bark-beetles may be considered as mountain insects, such as Otiorrhyuchus niger, Fabr., Tomieus cembre, Heer, Hylastes glabratus, Zett. Eren species of Chermes are found at elevations of between 3,000 to 3,600 feet.

Insects, especially beetles, can support severe winters. Their horny elytra or wing-coverings protect them, and instinct impels them to creep under roots and into cracks in the bark of trees, or under moss or dead leaves for protection against the weather, or to burrow underground. Moreorer, as their enemies, moles and insectirorous birds, cannot tonch them when snow or frost covers the ground, and are themselves killed in very severe winters, such weather is really favourable to insect life. A warm winter, which is usually accompanied with much moisture, is rery destructive to hybernating insects, especially hairy larve, which suffer from fungoid diseases.

Hairless larve are most sensitive, especially at moulting periods. Cold damp weather and cutting winds will then kill them off in myriads. Uniformly warm dry years therefore tend to produce great swarms of insects.

\section{SeCtion III.--Life.History.}

\section{Generutive Periods.}

Insects, in distinction to more highly organised creatures, have generally a definite limitation to their duration of life. The time which elapses between the egg and the fresh production of eggs is termed a generation. These may be single or anmual, multiple, biennial or pluremial.

A single generation occurs when an insect goes through all Its stages within trelve months, and is by far the commonest. Thus nearly all Lepidoptera have one generation in the year. A few have more than one brood in the year, and, still more rarely, the life of a species may extend through two years, as Retinia resinclla, L., or even longer.

In the case of a multiple generation, several broods are produced during twelve months, so that the respective stages, eggs or larre, of the same species may be found in different months. 
A donble generation is here commonest, as, for instance, in the case of many bark-beetles and sawflies. Many plant-lice produce five or more generations in a single summer, and the Bengal multivoltine silkworm completes a generation every month, except during the period from November to February. Three broods are sometimes produced within two years, for instance, by Tomicus bidentatus, Hbst., but such cases are rare. A plurennial generation denotes that the insect takes more than one year for its full development, for example, two years in the case of longicorn beetles and Sirex, and three or four years for the cockchafer.

Of the several stages of the insect, that in which it hibemates lasts the longest, and is generally the larval stage. The egg and pupal stages usually last for about two to four weeks unless they happen to be the hibernating stage, and eggs laid after Midsummer do not generally hatch out till the succeeding year. As a rule, the imago stage is the least long-lived; but with beetles this is not the case, as the imagos very frequently hibernate. Many Hymenopterc are long-lived insects; bees, for example, live fonr or five years.

Many families of insects, for instance, bark-beetles, have irregular broods; the state of the weather, and the quantity and quality of their food may cause the development of one, two, or eren three broods in a year. On the other hand, certain circumstances, such as unfavourable weather, want of opportunity for pairing or for laying eggs, may not unfrequently canse delay in a brood. Thus, for instance, a brood of the pine sawfly (Lophyrus pini, L.) has been known to extend over $1 \frac{1}{2}$ to 2 years, instead of there being one or two broods in the same year.

\section{Halitat.}

The habitat of insects varies according to their state of development and the season of the year. They are sometimes found on or under the surface of the ground, or on woody or herbaceous plants. They generally hibernate under the soilcovering, or inside the bark of trees. As a rule, all insects live near the material on which they feed, but many wander far, sometimes against their will, as when they are blown into 
the sea by storms of wind. They generally endeavour to return to their former abode, as in the case of bees and ants.

\section{Mobility.}

The mode and degree of rapidity with which insects move may be usually inferred from the structure of their organs of locomotion. Some insects have iegs for rumning, as groundbcetles; for jumping, as fleas; for digging, as crickets; for swimming, as water-beetles.

The imagos run or fly; their course being rapid (Carabus), or' slow (Cerambycidce); their flight is either fast (Bombus), slow (Melolontha), irresolute (Papilio), or hovering (Syrphus); extended (Lipuris monacha, L.), or short (Gryllus). The flight of the o $^{*}$ is heavier than that of the $\delta$, especially when she is laden with eggs. The mobility of the larve depends largely on the number of their legs $(6,8,10,16,18,22)$, all but six of which are soft and fleshy prolegs. Many lepidopterous caterpillars assist their movements by spiming threads, such as those of many Bombyces, Geometer's and Tortrices (e.g. T'ortrix viridana, L.).

\section{Food.}

Metabolic insects feed only as larvie and imagos, and chiefly in the former state. Thus, the food of butterflies and moths is limited to the nectar of flowers. Some beetles, however, are destructive as imagos only (Hylobius abietis, L., etc.). Ametabolic insects also feed in the pupal stage. The appetite of larve in both groups is enormons, and there are larre which eat daily more than their own weight of food.

Insects may be termed carnivorm, or phytophargous, according as their diet is animal or vegetable. Most insects useful to the forester belong to the former category, whilst plant-feeders are all more or less injurious.

In accordance with their choice of nutriment, insects may be classed as mono-, poly-or puntophuegous. Monophagous insects only attack certain plants or at most a group of plants, such is

* The symbol of denotes the female, of the male, and $b$ the worker, or inperfect female. 
broad-leaved, or coniferous trees. Polyphagous insects attack trees of both linds, whilst pantophagous attack herbage as well, and are least numerous of all.*

Even amongst carnivorous insects, monophagous and polypluagous species are to be found. Many parasitic insects, for instance, only attack a single species of moth, and in one stage only of its growth, in the egg, larval, or pupal state.

Conifer's suffer much more from insect-attacks than broad-leaved species. They afford nourishment to a greater number of injurious linds, and do not recover from damage so readily, as they cannot replace injured members as easily as broad-leaved trees. The Scotch pine and the spruce are attacked by the greatest number of species of insects, and pure roods of these trees suffer most severely. Oak, beech, poplars and willows suffer most amongst broad-leaved trees, the birch and alder less, and less still hornbeam, maple, ash. Least of all robinia, mulberry, walnut, plane, sweet and horse-chestrut.

Suppressed, weakly, and injured or diseased trees generally suffer more from insects than healthy trees; at any rate this holds good for mature trees with thick bark.

Species of insects which live on dying, dead or rotten wood are of no importance to the forester; such are Lucanus cervus, L. and many species of Anobiide and Cerambycidce.

Many insects confine their attacks to fully-grown or old trees; others only attack young plants (Hylobius alietis, L.); other's attack trees of all ages (Hylurgus piniperda, L.).

The attack may be on the roots (Gryllotalpa vulgaris, L., Melolontha vulgaris, Fabr., in the larval state); or on the bark (most species of Tomicus and Hylesinus); or on the rood itself ('Trypodendron lineatum, Gyll., species of Sirex and Cerambyx); or on the leaves or needles (Phytophaga and most lepidopterous larræ); on buds (Curculionida, Retinia buoliana, Schiff.); or on the blossom (Anthonomus pomorum, L.); or on firuits (Balanims nucum, L., Carpocapsa pomonclla, L.) ; or on other parts of trees, for instance the pith (Hylurgus piniperela, L.).

* This definition is that of Hess. As a rule, entomologists would hardly call a species that feeds indifferently on Picea, Pinus, and Laris monophagons, bnt would reserve the term for those insects whose diet is limited to a single sprecies or grellus. 
Many insects by biting and sucking produce malformations termed galls on leares, shoots, fruits, etc. (Cynips, Aphis, Cecidomyia, Chermes and Coccide, etc.) ; such damage is easily discernible, but is of subordinate importance.

\section{Section IV.-Number.}

The number of indiriduals of a particular insect that may coexist is in many species limited, but in others may attain vast proportions, especially under farourable circumstances. Thus in 1SSt,* 200 square miles of Sál Forest (Shored robusta) in Assam, morth of the Bramaputra river, were ravaged by the caterpillars of I asychira Thuatesi, the trees exhibiting complete or partial defoliation.

Fortunately, the most prolific of insects, plant-lice, are not the most destructive to forests; these creatures, according to Réaumur, may produce 5,000 millions from one female in th course of five generations, and in one summer ten such generations may occux. Warm, dry weather and plenty of food, and breeding-places, such as diseased wood, or branches broken by snow, are very favourable to prolific multiplication. Under such circumstances, insects which are generally of limited numbers may appear locally in destructive swarms. Such an abnormal increase is frequently met with in the case of the Grey-tussock moth (Dasychira pudibundu, L.), allied to that species which ravages the Indian Sál forests.

Most insects are solitary, but many, such as bees, ants, certain linds of wasps, and termites, are social and have a wonderful organization, framed on the principle of subdirision of labour. The larra of some moths are also gregarious.

\section{- Section V.-Useful Forest Insects.}

Carnirorous insects attack other species in rarious ways, and have been subdivided by Ratzeburg as follows:-

Predatory insects follow and kill other insects in every stage. Ground-and tiger-beetles belong to this group. 
Preduccous parasitic insects, like the former class, seize other insects, but carry them to their nests, where their own larve feed on them. Such are the fossorial wasps (Sphegida or (mabronide); they first sting their prey, but without lilling them, and thus render them inert.

Finally, parasitic insects wound the larra, pupe, or even the eggs of other insects with their fine ovipositors to lay eggs in them. The larve hatching from these eggs feed on the juices of their hosts. Ichneumon-wasps and some flies (Tachinc) are examples of this group.

A classification of these insects according to their utility is scarcely possible; of predatory insects, the largest are generally the most useful, especially species of Curubus and Calosoma. Ichneumon-wasps and parasitic flies increase in unmbers in proportion to the abundance of their hosts, which bringr about an insect calamity; they are thus able to suppress it, whilst other animals, incapable of rapid multiplication, can only keep down the numbers of injurious insects in ordinary times.

\section{Section VI.-Injurious Forest Insects.}

\section{Damage done.}

The grouping of insects which are injurious to forests may follow either the degree of damage done, or the kind of damage, or nature of the attack.

\section{(a) Degree of Damage.}

In accordance with the amount of damage they do, we may distinguish forest insects as highly injurious, moderately, or. slightly injurious. The part of the tree attacked and the severity of the attack, as well as the abundance of the insect in question, decide the degree of injuriousness for any case. It is, however, impossible to assign any strict limits to the sereral groups.

An insect is considered highly injurious when by the nature and duration of its attacks, whole woods, otherwise healthy, may be killed over more or less extensive areas. 
Moderately injurious insects destroy certain organs only of trees, such as the shoots, leaves, inflorescence or fruits.

Slightly injurious insects hardly deserve notice from a forest point of view, as they only canse trifling damage; they either attack dead stems, or the damage done is very shortly repaired.

In a time of exceptional multiplication, a moderatcly injurious insect may become highly injurious. A single species of insect may also be injurious in a different degree to different species of trees; it may prefer one to another, or one tree may recover more easily than another from its attacks.

\section{(b) Kind of Damage.}

Insects may be classed according to the kind of damage they do, as commercially or physiologically injurious. The former class render useless, or greatly reduce the commercial value of the part of the tree they attack, as wood which has been bored by Sirex.

Physiological injury on the contrary is that which interferes with the ritality of plants, checling the growth, or even lilling: them ontright, as when the cambium of a tree is eaten by Tomicus tijpographus, L., or the needles of a pine by Lophyrus pini, L.

Insects coming under this category are therefore more hurtful than those which merely destroy wood, although the burrows of the latter are sufficiently conspicuous. Moreover, most woodborers live in dead wood. It is, however, possible to pay too little attention to commercially injurious insects.

The degree of physiological injury depends on the species and age of the tree, the season of attack, and on other local circumstances. Mention has been already made of the greater susceptibility of conifers; the spruce suffering most of all, then the Scotch pine, silver-fir and larch, the latter bridging the way towards broad-leared trees. Young trees suffer more than old ones, and injury in the spring is more harmful than that done in summer or autumn.

(c) Character of the Attacl.

The attack may be either primary or secondary in character. In the former case healthy trees are injured by species attacking 
the leaves, buds or seeds, by many shoot-borers, root-gnawers, and insects which attack young plants or saplings. The attack of other insects is only secondary, that is, it is made exclusively or by preference on plants already weakened by other causes (wild animals, fungi, drought, frost, etc.). This is specially true of bark and wood insects, which abound in old coniferous trees. The rich flow of turpentine from sound trees would kill the young larre. Certain species, such as the bark-beetles of broad-leaved trees, according to circumstances, may make at one time primary and at another secondary attacks.

This distinction is of practical importance, as nothing can be done in cases of primary attack except to remove the parts of the trees which have already been attacked, together with the insects concerned; species which make secondary attacks can alone be canght by tree-traps.

Species of insects which occur in forests, but confine their ravages to grasses and herbage, are of no economic importance, unless these products are of exceptional value.

The forester must, however, learn to distinguish harmless species from other injurious kinds which they may resemble.

\section{Prerentive Rules.}

\section{(a) Sylvicultural.}

Since injurions forest-insects prefer to attack sickly, stunted or weakly forest-plants, and may spread from these to their healthy neighbours, the safest method for preventing insect attacks is to follow the rules which experience has laid dom in sylviculture and forest utilization for the formation, tending and harvesting of woods. In general, the following rules shonld be observed:-

(i) Choice of suitable species of trees and proper systems of planting. The species must be those which are appropriate to the locality, and the system must correspond to the nature of the species grown. It is specially important to select strong healthy plants for plantations, and to plant-ont most carefully.

(ii) Avoidance of extensire clearings with subsequent stocking of large areas with one species of tree, especially in coniferous 
forest. It is better to hare mixed roods, and to mix broadleaved species with conifers.

(iii) Careful and frequent examination of the roods for injurious insects. This precaution is most important in coniferous woods on poor, dry soil, in warm localities and especially during the spring.

It is most important to keep a careful watch round places where swarms of insects exist, and from which damage generally extends in all directions. The subordinate Forest Staff must be instructed to recognize and attend to the signs of an impending attack of this kind. Such signs are: umusual numbers of roodpeckers or cuckoos in a compartment; bittenoff leaves or needles lying on the ground; spun threads hanging from the twigs; withering of foliage; excrement, or boring refuse, or bore-holes in the stems; exudation of resin; discoloration or peeling off of bark, etc.

(iv) Early and frequent thimnings, without interruption of the leaf canopy, are desirable. Such thinnings should remore all forest grorrth in a suppressed, sickly, or even suspicious condition. I forester who merely removes dead rood does nothing to prevent insect attacks, for in it only unimportant species breed. Dying stems are the favourite resort of bark-beetles.

(v) Every attention should be paid to the rules for maintaining and improving the quality of the soil. This is best accomplished by careful preservation of the soil-corering, by draining away any superfluity of moisture, and by timely under-planting roods of light-demanding trees, such as oak, larch or Scotch pine.

(vi) Suitable preventive measures must be taken against damage by wind, frost, snow, ice, fire or insects. Broken wood must be rrorked up and remored from the forest as soon as possible, or at least barked.

(rii) Stools of felled trees should be extracted or carefully earthed over, especially in coniferous forests, as many highly injurious species of insects (Hylobius abietis, and sereral species of Hylastes) lay their eggs in stumps and roots.

(viii) Summer-felling in coniferous forests, together with careful remoral of the bark. Wherever winter-felling is adrisible for other reasons, some of the stems should be left lying as roL. IY. 
traps and barked about June, after the bark-beetles have laid their eggs in them. If these beetles do not find wood with the bark on lying in the forest they will lay their eggs in the bark of standing trees.

(ix) The forests must be liept clean, the fellings rapidly and thoroughly cleared, and material from thimnings carted away without unnecessary delay.

Further preventive measures against many species of insects are: turning-in swine for "pannage," the employment of caterpillar-trenches, wood-traps, grease rings, etc. As, however, these measures are protective, as well as preventive, they will be discussed further on.

\section{(b) Protection of Insectirorous Animals.}

The following are the principal insectirorous rertebrates:-

\section{Mammals.}

All bats, ${ }^{*}$ especially Vesperugo noctula, Schreb., $V$. discolor, Natt., $Y$. pipistrellus, Schreb. The mole, shrers, especially Sorex rulgaris, the hedgehog, pole-cat, stoat, weasel and badger. These beasts, some of which have been already referred to as mice-destroyer's, shonld be unconditionally protected.

The fox also derours numerous insects, particularly large beetles.

Birds.

The following birds deserve unconditional protection :-

The common cuckoo (Cuculus canorus, L.); woodpeckers, the wryneck (Junx torquilla, L.) ; the night-jar (Caprimulgus curopeus, L.) ; the swift (Cypselus apus, L.) ; the tree-creeper (Certhia familiaris, L.); the nut-hatch (Sitta caesia, Wolf); all swallows (Hirundo, L.); wagtails (Motacilla, L.); pipits (Anthus, Bechst.); hedge-sparrow (Accentor, Bechst.) ; goldencrested wren (Regulus cristatus, Koch); wren (Troglodytes parvulus, Koch); redstart (R. phonicurus, L.); stonechat (Saxicola mibicola, L.); wheatear (S. ananthe, L.); flycatcher (Muscicapa, L.) ; titmice (Parus, L.); starling (Sturnus vulgaris, L.).

* Except the fruit-bats called flying foxes in India. 
Among Raptores, all owls except the eagle owl (Bubo ignarus, Foster). Gulls; the blackheaded gull (Larus vidibundus, L.) This latter frequently follows the plough, and destroys cockchafer grubs and wire-worms. The cuckoo is exceptional among the above birds for its power of eating hairy caterpillars, which other birds reject. Altum found the remains of 97 young Cnethocampa larvæ inside a cuckoo. The golden-crested wren is extremely useful in coniferous forests, spending the whole year in destroying insects' eggs, larve and pupæ, as well as plant-lice, even from the highest shoots. Titmice are also extremely useful, and although the starling may steal cherries from gardens, yet its powers of destroying cockchafers and other injurious insects are very great.

Of owls, the long-eared owl (Asio otus, i.) and the tawny owl (Symium alnco, Boie), are the most useful.

The following birds merit conditional protection :-

Passeres: finches (Fringillide); larks (Aluudide); thrushes (Turdide); the jackdaw (Corrus mouchlula, L.); the common and hooded crows $(C$. corone, Lath., and $C$. comix, L.); the rook (C. frugilegus, L.).

Raptores: the honey buzzard (Pernis apirorus, Gray); common buzzard (Buteo vulgaris, Leach); the kestrel (Falco timnunculus, L.).

Limicolce: woodcock (Scolopax rusticola, L.) ; snipe (Gallinago); golden plover (Charadrius plurialis, L.); lapwing (Vunellus vulgaris, Bechst.).

The passerine birds above mentioned do damage in various ways, chiefly as grain-eaters, but are also useful in destroying insects. Where the damage predominates, they must be kept down. Thrushes and blackbirds hunt in the forest for insect larve and pupæ, and distribute the seeds of useful shrubs and trees.

The following birds do indirect damage, by killing useful birds or eating their eggos:-

Passeres: shrikes (Lanius, L.); jay (Garrulus glandarius, L.) ; magpie (Pica rustica, Scop.) ; raven (Corrus corax, L.).

Raptores: All species except those already mentioned.

It should be noted that shrikes kill mice and insects as well as small birds. 
The mere protection of birds useful to forests is not sufficient; means for promoting their multiplication should also be undertaken. The following points should be attended to :-

(i) Preservation of a few hollow trees in forests, as such trees harbour useful birds and bats.

(ii) The provision of boxes or vessels for nest-building on trees. These may be made of earthenware, of wood, of plaited straw, or tarred basket-worls. Even dried hollow bottle-gourds may be used for titmice. The earthenware vessels should be of the

FIr: 60.

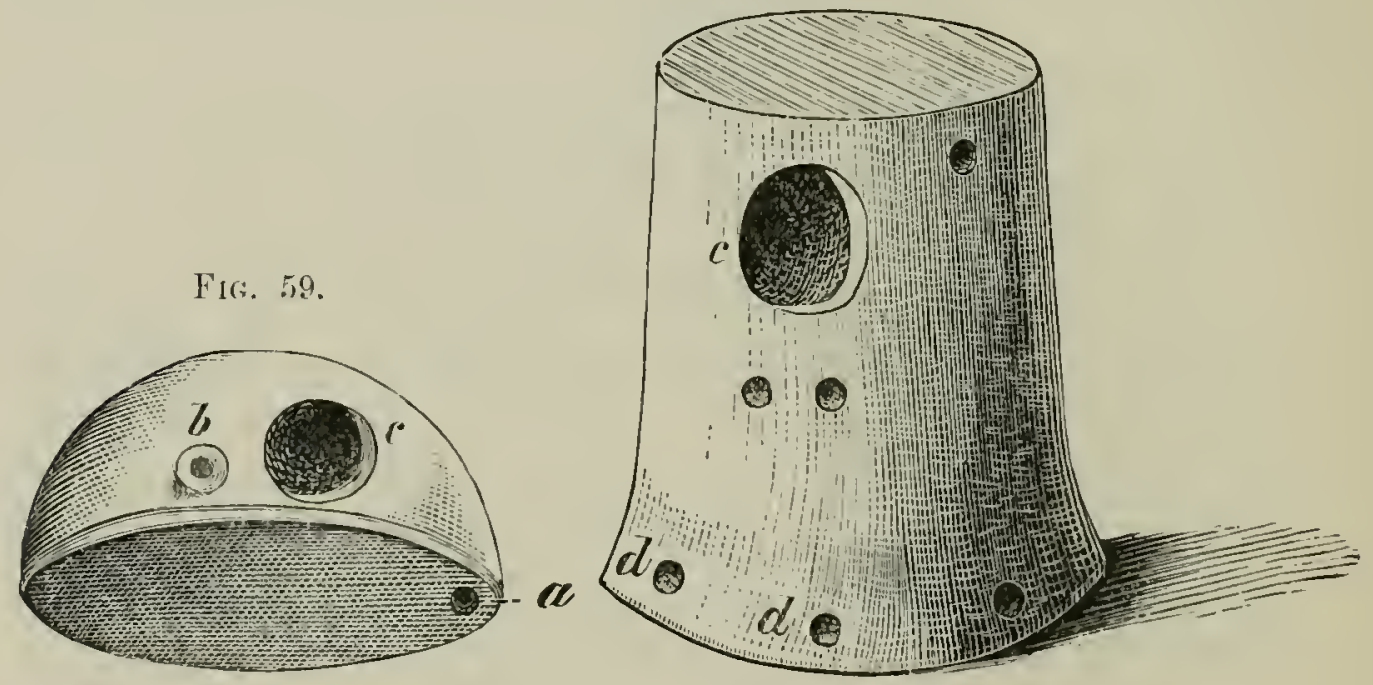

Earthenware nesting-pots.

$a$, Nail-hole for attachment to the tree. $b$, Hole for insertion of a wooden peg to assist the bird in entering. $c$, Flight-hole. $d$, Holes for the passage of a wire, to attach the bottom of the pot to a piece of wood.

shape given in the figure, and have a wooden base, and before hanging up should be tarred and covered with moss.

The wooden nesting-boxes invented by Gloger in 1853 are made out of half-inch boards, and tarred. There are six kinds, including those shown in the figures, and suitable for starlings, flycatchers, and titmice. Some are used for the birds to sleep in as well as for nests. The horizontal partition shown in the figures excludes cats, pole-cats, and other enemies, and also keeps the nest warm. It is essential to keep to the dimensions indicated by the reduced figures, or the nesting-box will be used by other species for which it was not intended. 
FiG. 61.

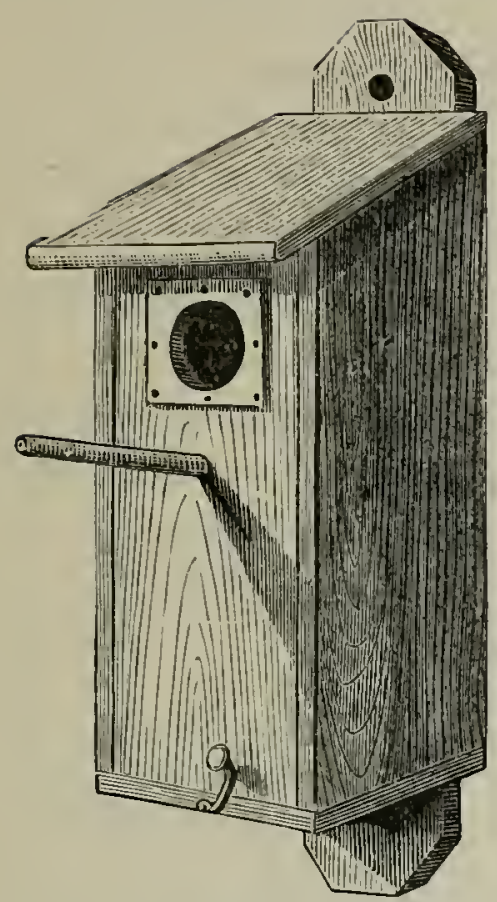

Ontside.
Nesting-BuXes of wOOD.

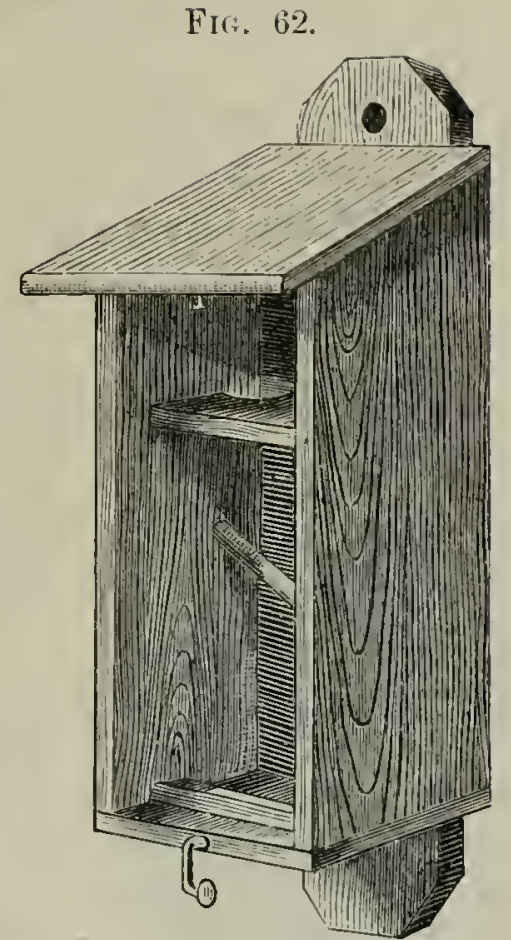

Inside.

Nesting-box for Starlings, Wagtails, Wrynecks.

FIG. 63.

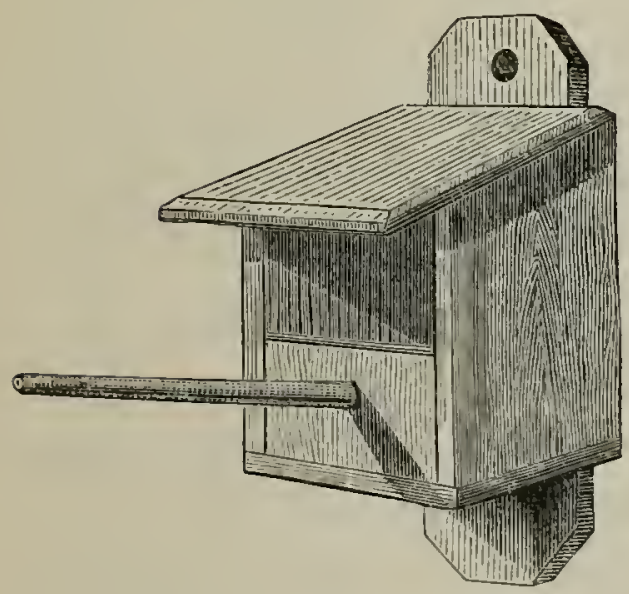

Nesting-box for the Flycatcher.
FIr. 64.

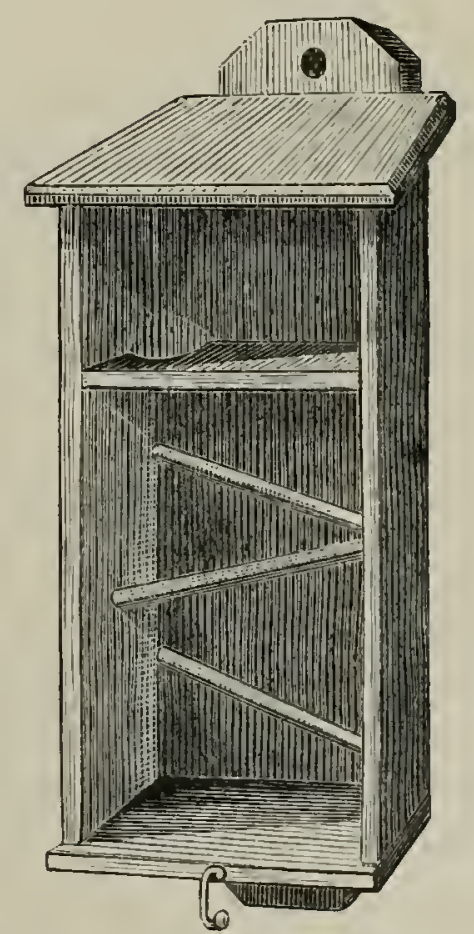

Tmner view of a box with severa compartments for a number of 'Titmice or similar birds.

The figures reduced to $\frac{2}{1 \overline{3}}$ of the natural sise. 
The following rules apply to the manner of hanging up the nest-boxes:-

The boxes should only be hung facing towards the east or sonth: nerer towards the west.

As starlings are sociable birds, several boxes for them may

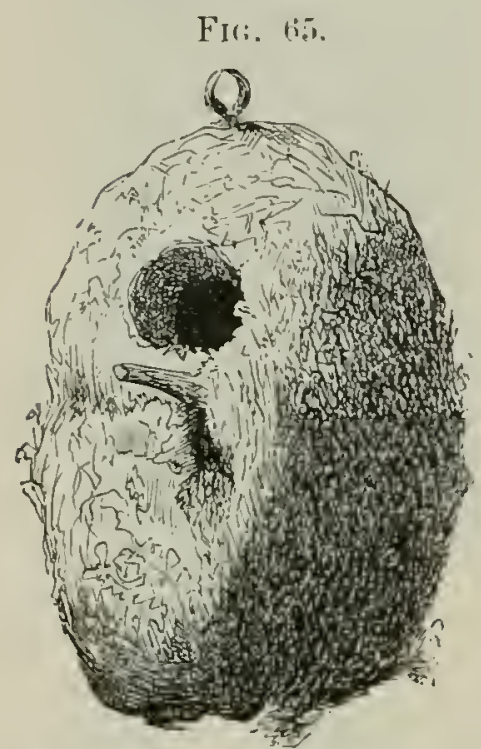

Nesting-box for the Starling, of tarred straw. be hung on the same tree, but for other species ouly one box should be hung on a tree.

Boxes for titmice should be hmig in a dark place, best of all in coniferous forest, on spruce trees.

Boxes for redstarts and flycatchers, on the contrary, slould be hung under light groups of trees, and on the border's of thin places and clearings.

(iii) Shrubs shonld be planted in sheltered places, along a brook, or by a spring, as water is a necessity for birds. Suitable bushes are priret, honeysuckle, viburnum, elder, whiteand black-thoru, roses; as an orergrowth, pollard-willows and mountain-ash. Undergrowth should also be carefully preserved in high forest, unless it must be cut for sylvicultural reasons.

(iv) The birds should be fed when deep snow is on the ground. Bread or boiled pulse should not be given, as these substances become acid and nuwholesome after weiting. For insectivorous birds pieces of suet or chopped meat are suitable. 'Thorns should be placed over the food, so that crows, doves, and sparrow-hawks may be kept oft. The following places are most suitable as feeding grounds:-high ground for titmice, tree-creepers, woodpeckers and finches; roads for yellow-ammers and hedge and tree-sparrows; fields and gardens for robins, linnets, finches, and migratory birds from the north; for fieldfares, thrushes and blackbirds, the food should be placed under a shady conifer at the edge of the forest; the places which wrens frequent should be ascertained, and the birds fed there.

(v) Forest-litter should not be remored from March till July, 
as many useful birds nidify on the ground, or close to it, and would be disturbed.

(vi) Birdsnesting and the trapping or killing of useful birds should not be allowed.

Legal enactments to protect useful birds are necessirily made by the State, and should be properly enforced. In continental forests, enormous numbers of thrushes, fieldfares and similar birds are caught every year in the antumn and winter by means of horse-hair nooses attached to the trees. Wherever such bird-catching is allowed, the open season should be limited to the period between the 1st of October and the 1st of February.

\section{Reptiles and Amphibia.}

Toads, frogs, and lizards are very useful as insect and slug destroyers, especially in gardens and forest nurseries, but they are not nearly so numerous as useful birds and mammals, Snakes and slow-worms are also useful, but the poisonous adder (Pelias berus, L.) will naturally not be protected.

\section{Insects.}

A detailed account of the chief useful insects follows in Chapter T. Their number, especially that of ground-beetles, ichnemmon-wasps and Tachince, increases steadily with that of the destructive insects; this fact is all the more important as the activity of mammals and birds altogether fails to combat such calamities successfully.

\section{Spiders.}

Spiders (Arachinida) include two distinct families of insectdestroyers, Araneina and Phalangiina. The common gardenspider (Epeira diadema, Cl.) may be taken as an example of the former class, and the common harvest-man (Phalangium parictinum, Hbst.) of the other. The former catches many small beetles and other insects in its large vertical nets expanded in the underwood of forests, and the harvest-men become very active in the evening, moving about rapidly with their long stilt-like legs, and preying on small insects, plant-lice, \&c.

The web-making spiders may do some slight injury to plants 
by their webs, which interfere with the full development of blossoms and foliage.

\section{Myriapolle.}

Centipedes, of which Lithobius forficatus, L., is an example, and millepedes, for instance, Inlus terrestris, L., live under bark, stones and moss, and kill number's of insects, also slugs and snails. Species of Iulus also attack fleshy roots in gardens and fields, as well as wheat, and fruit such as strawberries; they also appear to cut off seedlings at the collar in a manner similar to wireworms.

\section{Remedial Measures.}

In considering the measures to be taken in attacking insects, we must select the proper season, and adopt means which do not entail a greater expenditure of time, trouble, and money than the results will justify.

In general, the following rules may be adopted:--

(a) Collection and destruction of eggrs, lave, pupe or perfert

FIf. 66.

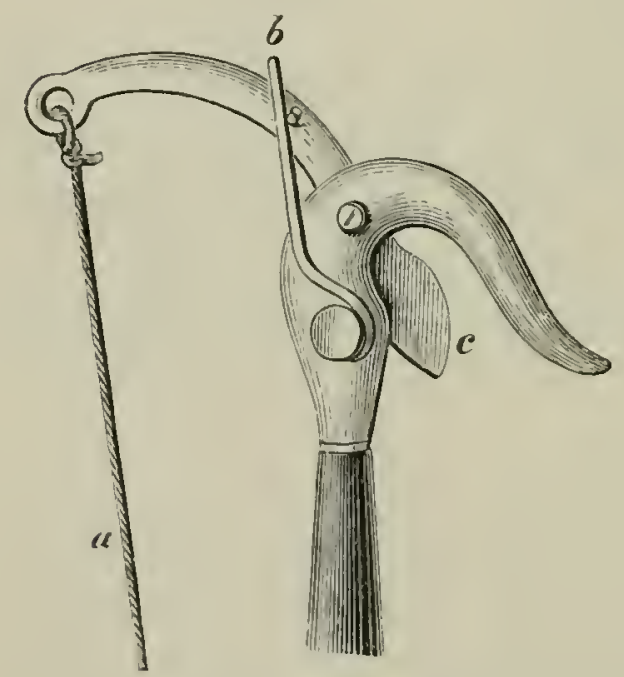

Caterpillar shears (veduced).

Front.
FIG. 67.

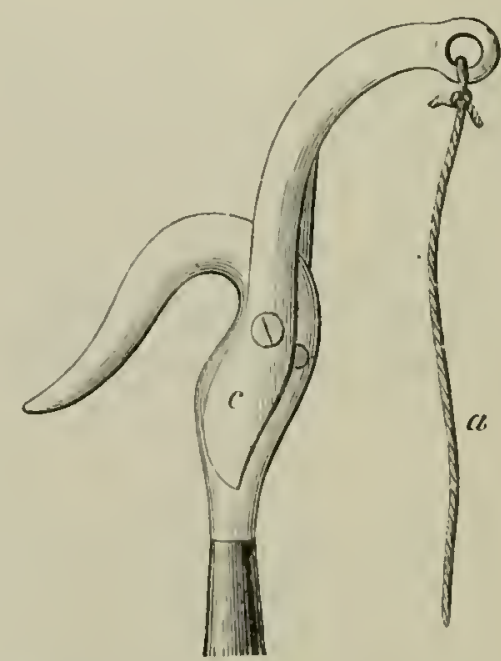

Back.

a. Cord. b. Spring. c. Mloveable blade.

insects. A linowledge of the life-history of any particular insect will inform the forester of the stage in which it is best attacked.

Collections of insect-eggs can only be made when they are laid in clusters, as those of mole-crickets, the lackey-moth, and 
the black-arches moth. The simplest method of destroying the latter is to crush them on the tree. The larve of lepidoptera and sawflies may be collected by shaking the attacked poles or saplings, or by beating with a mallet or the butt-end of an axe at the base of the branches of trees, so that the larve fall on to a cloth spread on the ground. Care must be taken to protect the hands of collectors by gloves against hairy caterpillars, which, when handled, cause inflammation. When in groups on the trees, larve may be crushed, and branches bearing the spun web-like nests of certain gregarious kinds may be cut-off with pruning-shears, or they may be burned on the trees by holding torches under them.

Larve fall most rearlily from trees in the early morning and evening or during moist, cool weather. The larva of but a few species of beetles can be profitably collected, for instance, cockchafer grubs.

The collection of pupæ is best effected when they lie in clusters in the moss and dead leaves of the soil-covering, such as the pupre of Panotis piniperda, Panz, or hang low down the stems in bark cracks, or on undergrowth.

Perfect insects may be collected by simply picking them by hand from the ground, by shaking them, like larrie, from the plants on which they settle, or by means of traps made of strips of bark, laid on the ground flat or rolled-up, into which the insects crawl; this is a common method of catching great numbers of Hylobius abietis, Fabr. The bark should be fresh and laid with the underside downwards. Other materials used as traps are faggots, $\log ^{\circ}$ and brush-wood.

In collecting the imagos of insects, it is necessary to capture the female alone, and that before she has laid her eggs. This can only be done practically in the case of those Lepidoptera, in which the $q$ can be readily distinguished by her size and by the nature of her antenuie from the $\delta$.

Larve, pupæe and imagos may be killed by pounding them in trenches, or by pouring boiling water over them, or by quicklime, etc.

(b) Preparation of Insect 'T'renches. These are useful against larve which wander on the ground, and certain beetles, for instance, the pine-weevil, Hylobius abietis, I. They should be 
made 10 inches broad, and 12 to 16 inches deep, with rertical walls, and with holes 4 to 5 inches deep every $1 \frac{1}{2}$ to 2 yards along their floor. The trenches must be inspected every morning, and the insects which have been caught should be killed.

(c) Grease rings, made of various substances such as Stockholm tar, glne and grease, may be painted on trees so as to cut off larve from their food or from the ground when they wish to descend and pupate.

(d) Suine may be driven into woods which are attacked, and they lill numbers of larve and pupx which are in the soilcovering.

(e) P'ulling-up' plants and burning shoots which have been attacked; or buds attacked may be prumed off. Infested branches should be cut off.

Stems full of insects, or their eggs, etc., may be cut down and barked, and the bark burned or exposed to the sun. This should be done before the perfect insects emerge, usually in May and June. Great care must be taken as to the proper season for barking such trees, which form so many tree-traps. If it be done too soon, before the bark-beetles have finished breeding, there is danger of other standing trees being attacked, and if it be done too late, after the perfect insects have forced their way out and flown away, then the very institution of treetraps will have multiplied instead of diminishing the numbers of the insects. It is therefore better to bark the traps before the larvæ have pupated.

(f) Preparation of tree-traps. Trees may be specially girdled to serve as traps before the eggs are laid. For such purposes stunted or siclily trees should be selected as for thinning purposes. After the insects have visited them they should be treated like trees attacked in the natural course.

(g) Clearance of infested areas. The whole wood may be cleared and the soil thoroughly cultivated after burning all the branches, etc., which are infested with larve. This, of course, is a last resort.

(h) Sproying. Trees and plants in orchards or in forest nurseries may be sprayed with certain substances to keep off insects, such as lime-water, whitewash, potassium sulphiclesolution, decoction of tobacco, etc. A good recipe appears 
to be one pound of pure unslaked lime, mixed with about 70 gallons of water. The lime is slaked and then mixed with the water and stirred up to form a milky fluid, which is allowed to stand till the lime is deposited; the water is then used on the trees. The lime can be used again for five or six times the quantity of water. The application is useful as long as the insects are still in the larval or pupal stage.

The sulphur solution is made by dissolving 1 part of potassium sulphide in 500 parts of water, and the foliage is sprayed with this solution. This drives all the caterpillars at once from the tree, and sprinkled Jeaves escape further damage; 5 men in two days, with $38 \mathrm{lbs}$. of potassium sulphide, and the necessary water, can sprinlile 250 trees, at a total cost of 50 shillings, or five trees for 1 shilling.

The most valuable mixtures for tree-spraying are arsenical washes or lierosene-emulsion. The former are made by stirring about $1 \mathrm{lb}$. of Paris-green or London-purple into 200 gallons of water, with the addition of a little flour or dextrin, and keeping it constantly stirred during the operation of spraying. As this mixture is poisonous it cannot be used where there is risk of injury to game. If it scorches the foliage it must be further diluted.

Kerosene-emulsion is made by emulsifying 1 gallon of kerosene oil with half a gallon of boiling water in which a pound of soft-soap has been dissolved. It should be constantly churned for ten or more minutes, and is diluted for use by gradually stirring in 11 or more gallons of water. It is especially suitable for suctorial insects; whereas arsenical preparations chiefly serve for biting insects.

(i) Concluding Remarlis. - A fuller account of all these methods will be given further on, under the heading of each species. Nature itself can relieve the forest best from insect attacks, for ichneumon-wasps, fungoid diseases, and damp, cold weather kill off myriads of insects and eventually put an end to any abnormal swarms of a destructive species which may occur.

As a rule, such a swarm lasts three years, but there may be a partial swarm one year before and after this period.

In Prussia, very large sums of money have been spent on 
the destruction of forest insects; according to the following table :-

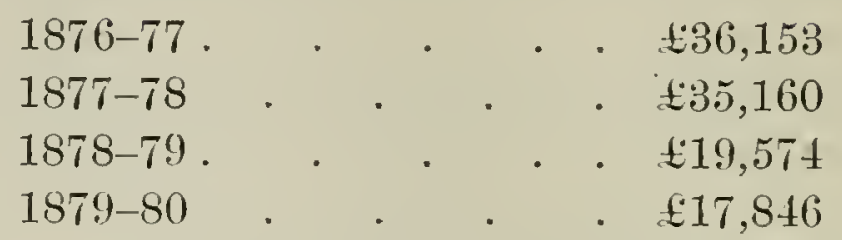

This shows a large progressive diminution, from which it may be inferred that insects are diminishing in the Prussian forests.

\section{t. Treatment of Injured Woods.}

Woods injured by insects should only be felled when there are signs that they have been fatally injured. Such signs are: drying-up or wilting of buds, shoots or twigs over the greater part of the crowns of the trees; development of small leaves or needles, the latter frequently in rosettes; exudation of watery turpentine from the bark; loosening and subsequent separation of the bark; appearance of brown or bluish-spots on the bast or sapwood; abundance of insects such as species of Ceramlycicle and Anobium, which live only on dead wood. In deciding on the importance of such signs, we must consider the special circumstances of each case, the insect, the species of tree attacked, its age, the locality, etc. Beetles kill trees sooner than caterpillars. Coniferous wood is more easily killed than broad-leaved trees, and whole spruce and pine woods are readily destroyed when badly attacked; silver-fir and larch make a better resistance. Birch, elm and ash die more readily than oak and beech. Young trees succumb more quickly to beetle attacks thian older trees. On a good soil a recovery is more hopeful than on a poor one; clearance of the wood should be less readily undertalien in the former case.

The best time for clearing is in the winter after the attack.

The large trees should first be felled, barked and removed as soon as possible from the forest. Fire-wood billets should be got ready as sonn as possible, and at least the larger pieces barked.

Before stacking, the split wood must be thoroughly dried, the stackis must be raised from the ground on transverse pieces, and placed apart in well-rentilated places. The remorial of all split wood must be expedited. 
Cultivations which have been attacked and killed must be replanted. Injured poles require the greatest care; if they are so young that transplants can be brought in, this should be done, if necessary, after widening the blanks. The beech and hornbeam are very suitable for planting in such cases. If, however, the poles are too tall, and still too dense to be underplanted, either a clearing must be made of the whole crop, and the area restocked by sowing or planting, or the wood should be heavily thinned and underplanted with a shade-bearer, such as silver-fir, spruce, beech or hornbeam, etc. 


\section{CHAPTER $V$.}

\section{INSECTS USEFLL TO FORESTS.}

IT is most essential that in combating the attacks of injurious forest insects, the forester should be able to distinguish insect friends from foes, and unimportant species from hurtful ones.

The following is therefore a short account of the most useful families of insects, which are found chiefly in the orders of Coleoptera and Hymenoptera, but also in the remaining orders, except those of Lepidoptera and Orthoptera.

\section{Order I.-Colloptera.}

\section{Cicindelide (Tiger-Bectles).}

l'erfect insects of moderate size, slender; mandibles powerful, with three teeth; antennæ filiform, with 11 joints. Legs long and slender, with five tarsal joints. Abdomen of six segments, the three first fused. Larre long, somewhat flattened and humped in the middle, with a broad head and 6 feet.

The lare dig vertical holes as thick as a quill in the sand, and remain at the entrance with projecting head, in wait for any passing insects ol worms, which they seize and suck dry. The beetles prefer sandy and sumny localities, especially wide sandy roads, are very active, alternately rumning and flying over short distances, and greedily devour other insects.

One genus, Cicindela, with a few British species; of these, C. campestris, L., is the only one with an extended distribution in suitable woodland localities.

\section{Carabide (Ground-Beetles).}

Perfect insects variable in size, but often large; mandibles smooth or with only one tooth; antenuæ filiform, with 11 joints. 
Few of the larger species hare functional wings. Legs thin and long, for running, with five tarsal joints. Abdomen of six to eight segments, the three first fused.

Larce long and cylindrical, with six legs.

The beetles live through the winter under moss, stones and pieces of bark, in old rotting stumps, etc., pair in the spring, and lay their eggs in the ground. The larva live either in or on the ground, and eventually pupate in the soil.

Both the larræ and perfect insects destroy other insects in all their stages; the larvie in particular are very voracious, and mostly prey at night. The family is rich in genera and species.

The following large species are most useful in forests where they occur: Carabus catenulatus, Scop.; C. gramulatus, L., C. cancellatus, Ill., Calosoma inquisitor, L., etc.

Other species are found on the continent, such as Procrustes coriaceus, L., Carabus auratus, L., C. auronitens, Fabr., C. sylvestris, Panz., Calosoma sycophanta, I..; the latter, which appear's in great numbers when there is a plague of insects, and seeks its prey in the crowns of trees, destroying the larvæ of destructive Lepidoptera, is especially valuable.

Certain species of Harpalus and Pterostichus devour coniferous seeds when covered with moss, and Zabrus gibbus, Fabr. is destructive to young wheat.

\section{Staphylinide (Rore Bectles).}

Perfect insects usually of small size, long-bodied, and characterised by very short elytra, which leave the greater part of the abdomen exposed. Antennæ generally threadlike, with 10 to 11 joints. Tarsi mostly 5-jointed, but occasionally with three or four joints.

The abdomen, consisting of 6 to 7 free segments, is turned up at the approach of any possible enemy.

The larve are long, with six legs. 'The pupal stage occurs mostly in autumn, and the beetles live over the winter.

The mode of life of these very active beetles resembles that of the ground-beetles. Both larvæ and imagos of the larger species feed on other insects, but from a forest point of view they are of less importance than the ground-beetles. The larræ are 
found especially under moss, but the beetles chiefly in decomposing substances, such as fungi, dead leaves, dung, carrion, etc. There are nearly 800 British species. The largest species are: Ocypus olens, Müll. (the "Devil's coach-horse") Staplyylinus ecrsareus, Cederh., Creophilus maxillosus, L., etc.

\section{Silplicle.}

Beetles flattened oblong or oblong-oval, usually with 11-jointed clubbed antennæ; thorax with a flattened side-margin; anterior coxæ conical; tarsi 5-jointed. Usually dull, black and often rugose or ribbed.

Both the larvæ, which have 6 legs, and the beetles live in carrion and decomposing substances. Some genera, such as Silpha, Fabr., attack insects. Silpha quadripunctata, L. lives in summer on oak trees, and feeds on caterpillars, \&c. It has the margins of the thorax and the elytra ochre-yellow, the latter with two black spots on each.

\section{Nitidulide.}

Bectles small, oval or oblong, with straight clubbed, 11-jointed antemne inserted under the frontal margin. Tarsi short, usually with 5 joints. Abdomen with $5-6$ segments.

Larre long, with projecting horny head and 6 legs. The flattened genera, Rhizophagus, Hbst. and Pityophagus, Shuck., which live under the bark of trees of bath broad-leaved and coniferons species, are regarded as enemies to bark-beetles.

\section{Colydiidle.}

Bectles small, thin and long, with 8-11-jointed clubbed antennæ. Tarsi 4-jointed. Abdomen of 5, rarely of 6 segments, of which the first three or four are fused. Larve long, and sometimes with horny plates below ; 6-legged.

The species of this family live in decaying wood, in fungi, or under the bark of trees, and are predaceous.

Colydium elongatum, Fabr. locates itself in old oak trees, and destroys the larve of bark-beetles, snch as Iyleborus dryogruphus, Er., lic.

'The Colydiidce and the closely-allied Cucujide, many of which 
have similar habits, are as a rule very rare in Great Britain and therefore of little economic value.

\section{Coccincllidie,}

or Ladybirls, are smali, smooth, hemispherical beetles, with red or yellow elytra, spotted with black. Antennæ very short, clubbed, 10-11-jointed. Tarsi 3-jointed. Abdomen of 5 free segments.

The larre are long and pointed behind, therefore somewhat lizard-like in shape; they possess six legs, and are covered with warty tubercles, pits or spines. Those of the commonest species are slaty-grey, with four or six yellow spots. The beetles fly in the spring, and lay their yellow egges in clusters on plants. The larre pupate in July and Angust, hanging from the leares; in 14 days the beetles appear, and they pass the winter under dead leaves, bark, \&c. Both in the larval and perfect states, and especially in the former, they eagerly hunt and lill numbers of plant-lice or aphides, and mites, which do much mischief to fruit and forest trees.

Ladybirds are migratory when abundant, and sometimes appear in certain localities in enormons numbers. The commonest species are: C. septempunctutr, L., the 7-spotted ladybird, and A.lipunctata, L., the 2-spotted ladybird. Certain species are only found in forests, as Halyzia ocellata, L., chiefly on pines, H. octodecimguttuta, L., on spruce. Seymmus, Kugel., lives chiefly in coniferons woods.

\section{S. Malacodermata.}

This group of families is characterised as follows:-Beetles generally long, with soft flexible elytra. Antennæ slender, 10-12-jointed. Tarsi 5-jointed. Abdomen of 6-7 free segments. The females sometimes resemble larvæ. Larre long, flat and generally bairy, with 6 legs.

The predaceous families included in this group are: the Telephoricle; black, brown, or yellowish beetles, abont half an inch long, of which Telephorus fuscus is a common brown species. They usually feed on other insects, but that species and $T$. obscurus, L. have been observed sucking $\check{o}-15$. 
year-old shoots of oals and Scotch pine, which then turn black and die.

Their lare are also carnivorous, feeding on earth-worms and ground insects; they pass the winter in the earth, or under stones, and during thaws sometimes come out on the snow. They pupate in the spring.

The Cleride are small, eylindrical, hairy beetles, with very short serrate antennæ, somewhat thickened at the ends. Tarsi with $4-5$ joints. Abdomen of 6 segments. Larce long, and generally rose-coloured, with horny head, 6-legged. The beetles pair in the spring, and the eggs are laid in the bark of trees, under which the larve live. New beetles appear in the autumn.

The larræ and bectles hunt the grubs of bark-beetles in their borings, and also eat dead animal substances.

Clens formicarins, L. is the best known species, and its larva are frequently found in the borings of Hylurgus piniperda, L., and the beetle may be frequently seen in the forest rumning about over heaps of firewood and felled trunks. It is gaily coloured, black, with the greater part of the thorax and the base of the elytra red, the latter also crossed by two white bands. The species is locally common in conifer-woods in Great Britain, and is the most important insect-enemy to Scolytidle we possess.

\section{Order II.-H HuLNoptera.}

\section{Ichnenmonidre*}

Certain allied families, such as the Braconide, Chalcidide and Pteromalide, are included in this description. In this book these insects are termed ichneumon-wasps to aroid confusion with certain parasitic flies ('T'achince) of similar habits belonging to the order of Iniptera.

Imagos of various sizes, long and slender. Head with three occlli. Antemme generally slender, rarely clubbed, and with many joints. The veins of the wings, when a submarginal vein exists, form distinctly closed cells, but it may be absent and the system reduced to one or two veins.

* For a complete account of German ichueumons, vide Taschenbers (Die Hymenopteren Deutschlands), Leipzig, 1886. 
Trochanters two-ringed, tarsi generally 5-jointed.

Abdomen frequently stalked, and in the female provided with a long ovipositor, formed of a slender borer and two lateral sheaths.

Larre soft and tapering at both ends, generally white, and without hair or legs.

Pupe with the limbs free, soft and white.

The season for the flight of these extremely useful insects falls between May and August. The o lay their eggs either on or in other insects (Lepidoptera, beetles and Hymenoptera), which they pierce with their ovipositors, generally attacking the larvæ, less commonly the pupæ, and seldom the perfect insects. Certain minute species attack the eggs. Only the larger larræ are attacked as a rule. An ichneumon will rarely attack an insect which has already been pierced.

The larve appear soon after the eggs have been laid, and may pass the winter in the pupe of the host.

They pupate in cocoons, sometimes outside the host, sometimes enclosed in its own pupal skin; the species of Pteromalus alone form exceptions to this rule. The ichneumon-wasps cut out a round piece from the cocoon to emerge, passing the winter under moss, in stumps, \&c.

The whole series of transformations generally requires $3-6$ weeks, and the generation is usually single, but sometimes double.

Ichneumon-wasps are shy, and run and fly rapidly; they do not, however, go far from their birthplace; they may appear in great numbers, and are constantly quivering their wings.

Most of the larve are parasitic within their hosts, whose juices they suck, but some remain outside them (many species of Pteromalide and Chalcidid(e). Infested larvæ continue living, and eat ravenously in order to supply their parasitic guests as well as themselves; they do not, however, reach maturity but die either as larre or pupre.

It was formerly believed that most insects which did not attain full development were killed by insect parasites, and breeding cages corered with coarse network were maintained in which all larva infected by ichneumon-wasps or flies were placed and fed. The network allowed the latter when fully developed to escape. 
These cages,* however, have only proved useful in allowing the life-history of the parasites to be studied.

It is now well known that insects are destroyed in large numbers by bacteria and by fungi, the spores of which find entrance into their bodies either through their skin, or amongst their food. The infected caterpillars may be easily recognized by discoloured spots on their bodies, and by their reduced activity, and they die when the mycelium of the fungus has spread inside them. Thus muscardine is a well known disease of the silliworm, due to Botrytis bassiana, and this fungus attacks P'anolis piniperda, L., Gastropacha pini, L., and other caterpillars. Wet years, being favourable to the fructification of the fungi, cause these diseases to spread amongst caterpillars. $t$

The question whether ichneumons or parasitic plants are of more importance from a forest point of view is still open. It was believed by Ratzeburg that ichneumons attack only insects already diseased owing to infection by parasitic plants, or the weather, and the importance of ichneumons is due in his opinion not to their sccomlary activity in attacking insects, but to the fact that the approaching end of an insect calamity may be predicted from the increase in their numbers. He asserts that when 50 per cent. of the caterpillars are attacked by ichneumons, it is not worth while spending any more money on measures for destroying the caterpillars, as the calamity will then die out speedily.

Taschenberg $\ddagger$ and Judeich, $\S$ however, contest this opinion, and consider that perfectly healthy caterpillars are attacked by ichneumons; their riew is now generally and properly held. It is impossible to imagine that an ichneumon, such as Pimpla, which inserts its long oripositor through the eracks of bark to

* In Bengal, where a Taehinirl fly attaeks silkwolms, these aje sometimes fed inside a frame-work eovered with ganze to exclude the flies. The most usual plan, howerer, is to rear the Bengal multivoltine silkworm for silk in alternate months only (it has seven or eight generations in the year); during the other months a linited number of worms are earefully kept to produce eggs for the next brood. The flies, which have also a generation every month, not finding sufticient silkworms to lay their eggs in, are thus greatly rednced in numbers, whereas, if the silkworms are bred in the open every month, whole broods wonld be destroyed by the parasites.

$\dagger$ For an account of fungi attacking inseets, vinle Cooke's "Vecretable Wrasps and Plant Worms," London, 1893.

¥ Forstwirthsehaftliche Insectenkunde, p. 271 .

$\$$ Waldrerderber, Ttl edition, p. 14. 
reach a concealed larve, can have any accurate perception of the state of health of its host; and the experiences of those who breed larre in captivity show conclusively that this is a matter of indifference to the Ichnemmonide.

The families referred to are very rich in species, of which many are parasitic on destructive forest insects. Ichneumonwasps are in general monophagous, to such a degree that they only attack a particular species in a certain stage of development, either as larve or pupæ, \&c. The greatest number of species (in all 39) attack the Pine moth-Grastropacha pini, L. Many are found in the Black-arches, the Pine noctua, the Pine sawfly, \&c.

On eggs: Teleas iciusculus, Ratz. (G. pini) and T. terebrans, Ratz. are parasitic.

On larre: Microgaster globatus, Nees. (G. pini), Banclus compressus, Fabr. (Panolis piniperda, Esp.).

On pupa: Eulophus xanthopus, Nees. (G. pini), E. lophyrorum, Hrt. (Lophyrus pini).

On lave and pupe: Anomalon circumflexum, L. (G. pini), Pimpla instigator, Panz. (Liparis monacha, L. dispar, Porthesia chrysorrhaca, (ic.).**

\section{Sulhegide (Fossorial Hasps).}

Imagos with a large head and 3 ocelli. Antennæ slender and moderately long. Fore wings flat and without folds, with 1--4 cubital cells. Legs with smooth femora and simple trochanters. Tibire and tarsi fossorial, and furnished with strong hairs and spines.

Abdomen stalked, generally with 7 free segments, and always terminating in the of with a sting.

The larre and pupce somewhat resemble the perfect insects, but have no legs.

These insects appear in summer, living in pairs and building their nests in sandy earth, in rotten wood, cracks in walls, \&c. They attack plant-lice, larvæ, beetles, grasshopper's and spiders, wound them with their stings and convey the disabled insects to their nests in order to lay their eggs on them. Some species close up the cells in their nests, and the larre

* The names within brackets are those of the hosts in which the parasites live. 
on emerging from the eggs feed upon the captives. Other Spheride feed their young with fresh material. Whilst these insects are hunting their prey, they carefully close their nests with particles of sand or splinters of wood.

The following are common:-Ammophila sabulosa, L. and Pompilus viaticus, Latr.; both species live in sunny places in sandy localities.

FIs. 68.

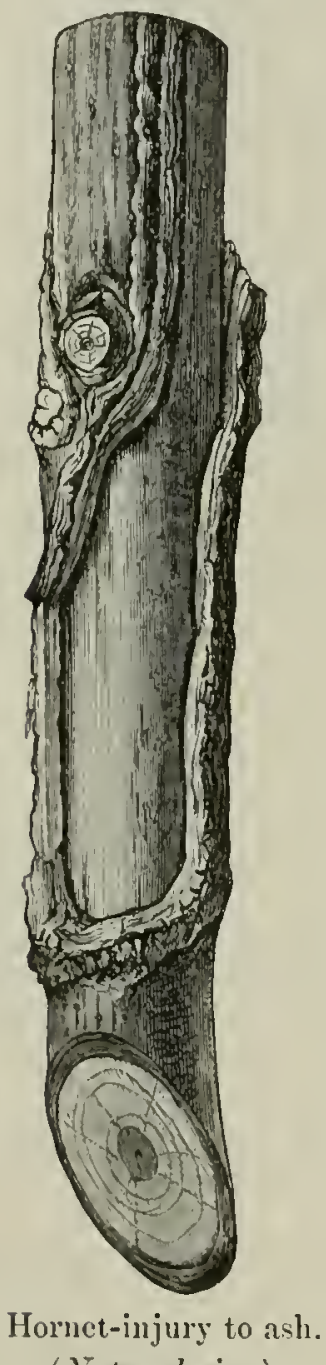

FIG. 69.

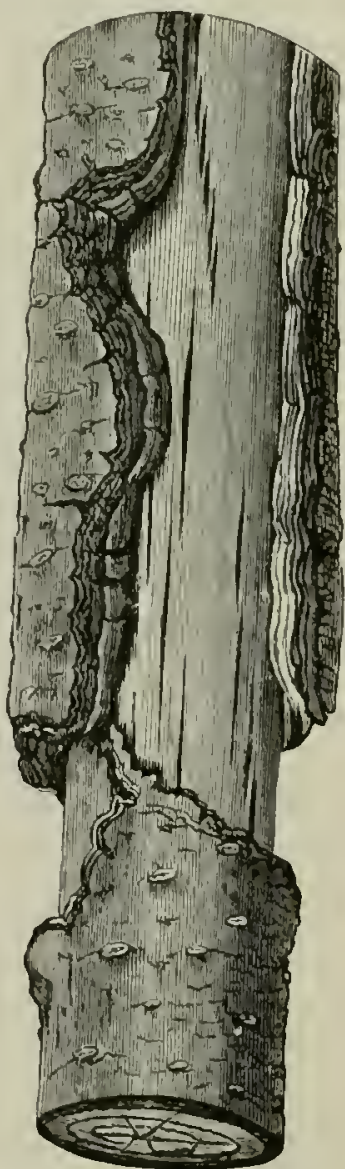

Hornet-injury to alder.

(Naturul size.)

3. Vespide (Wasps).

Imagos moderately slender, almost free from hairs, black or brown with yellowish zones; with ocelli.

Antenne approximate at the base, elbowed and with 12-13 joints, thickened at the apex. 
Fore wings folded longitudinally when at rest, with a radial cell reaching to the end of the wing, and 2-3 cubital cells.

Legis simple, without prominent hairs or spur's.

Abdomen stalked, furnished with a sting in the $q$.

The larre are white or yellowish, with brown heads, soft and legless.

The species which form this family live either socially, or are solitary.

Those which are most useful, from a forest point of view, are social wasps, consisting of three classes:- $\delta$ (drones), 우, and $h_{2}$, workers which are infertile females. The eggs are not laid by the female immediately after fertilisation; she hibernates and commences the construction of a nest for a new colony about April. From the spring until late in the summer she lays her eggs in the regularly hexagonal, prismatic, horizontal cells of the nest. She is gradually joined in her labours by her progeny, of which first $\eta$, then $q$, and lastly the stingless of are produced. 'The latter die soon after' pairing. If by any accident the mother wasp should die before any perfect

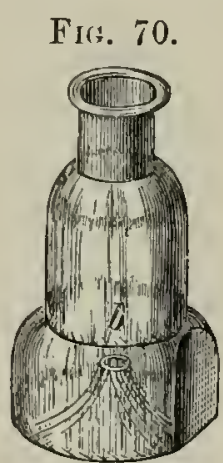

Wasp-bottle. females are produced, the whole colony would become extinct. The duties of the $\zeta$ are to continue building the nest, to feed the helpless larvæe, and to defend the colony against enemies. The nests are covered with a paper-like material, and are constructed on trees, in a hollow trunk or suspended from a branch, or in buildings or a hole in the ground. Just before pupating, the larva spin covers to their cells. The $h_{2}$ become torpid in the autumn, and their last office is to massacre the undeveloped brood, which would otherwise die of hunger, as their food-providers themselves are speedily killed by the increasing cold. The fertile females alone leave the nest and survive the winter in a dormant condition, reviving in the spring to provide fresh broods for the future.

Wasps seize insects, especially moths and flies, partly for their own nourishment and partly to use their juices as food for their offspring, or even to feed them with the living insects. They do a certain amount of damage by eating sweet fruits, plums, grapes, \&c., and especially the hornet (Vespa crabro, L.), 
by girdling 2 to 4 -year-old shoots of beech, birch, hornbeam, \&.e., and by barking ash, white alder, dre; they prepare the bark by chewing and mixing with a sticky secretion, and use it for the fabrication of their nests. Barking of trees also causes a flow of sap which serves as food.

Where much damage is done, hornets' and wasps' nests may be smoked out, or tar, lierosene, or a solution of cyanicle of potassium poured into the entrance-holes. Glasses containing beer, sc., for catching them, as shewn in fig. 70, may be hung up on fruit-trees.

\section{t. Formicide (Ants).}

Ants also have three classes-males, females, and workers. The head is triangular and very large in the $T_{i}$. There are 3 ocelli, at least in the $\delta$ and $q$. The antemna have 10-14 joints. The wings are long and with few veins. The abdomen is stallied and often spherical, with a sting at its extremity, or a gland which exudes formic acid. The o are generally much smaller than the $q$; both these sexes have a well-developed globular thorax, wider than the head, and a large abdomen. In the $I_{s}$ the thorax is very narrow, much narrower than the head, which is nearly as large as the abdomen; they are wingless.

'I'he larke are thickset, somewhat curred, white and apodal. The pupe are soft and white, with the limbs separately invested, usually enveloped in thick white cocoons, when they are known as ants' e!!!!s.

The ants fly in July and August in still warm weather, often in clourl-like swarms. 'The o, who loses' her wings after pairing, either lays her egrgs the following spring in the old nest or she forms a new colony in the ground or in a hollow tree. The larve live in thousands in the ant-hills, and are fed and carried about by the uumerous $h_{2}$, of which there may be 5000 and more in one ant-heap. In case the ant-hill should be disturbed, the Is endearour to curry the pupar to a place of safety.

The perfect insects come ont at the end of May, or the begimning of Tune, after the $t_{2}$ lave opened the cocoons. First appear the $q$, then the $\delta$, and last the ${ }_{c}$. 'The $\delta$ die soon after copulation; as the cold increases many of the $q$ also die, the $?_{s}$ live orer the winter. Ants are endowed with a re- 
markable sense of locality; if their nest be injured, they eject formic acid, which slightly burns the skin.

For a long time past the usefulness of these little animals has been recognised. They attack and kill numerous insects and larve, especially small caterpillars, and clean the forest of many dead insects. In utilising other insects they show extraordinary ability for creatures so low in the animal lingdom. Some ants, living in hollow trees, carry the larve of a beetle, Cetonia curata, L., into their nests, as these larra chew up the wood into small pieces for them: in the same way Clariger foveolatus, Preyssl., lives in the nests of the yellow ants.

Plant-lice are also kept in ants' nests, as the ants use the honey-dew which exudes from them to feed their young, milling them like cows.

Trees at the foot of which there are ant-heaps remain uninjured during wide-spread devastation by caterpillars, like oases in the desert, and the fruit-cultivators in the province of Mantua place in the spring of erery year a colony of ants at the foot of their fruit trees to secure them against insect attaclis.

It is therefore necessary to protect ants in erery possible way; though unfortunately their increase is greatly prejudiced by the search for the so-called ants' cggs for the purpose of feeding young pheasants, \&c. This also deprives useful forest birds of a portion of their nutriment. Henschel ${ }^{*}$ states that in the Austrian Alps the sale of dried ants' eggs of Formica rufi, L., amounts anmually to 50-70 hectolitres, which means from 96 to $134^{\circ} 5$ million ants, for 1 hectolitre contains about $1,920,000$ pupæ.

In Russia also the business is carried on vigorously, the right of collecting pupæ being leased on certain areas.

The damage which ants occasion by constructing their galleries and nests in sickly trees, or by eating sweet fruits, or by burrowing into planting-mounds is trifling in comparison to the good they effect.

As representatives of the family the following may be mentioned :-

Formica rufa, L., the common wood-ant, makes great heaps of needles in coniferous forests, chiefly in those of Scotch pine.

* Centralbl. fuir das ges. Forstw. 1876, p. 160. 
Lusius fulifinosus, Latr., in old trees and stumps of oaks, poplars, willows, etc.

Myrmica rubra, L., very common in forests under stones, sods, bark, etc.

\section{Apide (Becs).}

The imugos are thickset and generally hairy, with ocelli, and with a special suctorial labium. Antenne approximate at their base, elbowed, the basal portion 2-jointed. Fore-wings not folded, with one radial and two to three cubital cells. Legs hairy, the first joint of the hinder tarsi very large, compressed and forming a triangular or quadrangular plate.

Abdomen stalked, with a poisonous sting in the $q$ and $h$, which breaks off after use. The larve and pupe resemble those of wasps.

Bees are either solitary, as the mason and carpenter bees, or are social, as in the case of humble or honey bees. The former have no $h$, which are the most numerous inhabitunts of a hive of honey bees.

Social bees breed underground in mole runs, etc., humble-bees, in hollow trees, in the pith of sound trees and shrubs, as ash, walnut, rose and raspberry, or in artificial hives.

The imagos live on houey taken from plants and on pollen, and effect the fertilisation of many flowers by brushing off the pollen with their large hind legs, and carrying it to another flower. This labit is a good eximple of the direct utility of insects to plants.

Species.-Curpenter bees (Xylocopa riolacea, Fibr.) live in old dry wood, especially in the case of leguminous trees. This species is not British, but many others are common in warm countries, and slightly injurious to timber. They are large and conspicuous blue-black insects.

The mason bee (Chalicodoma murara, Fabr.) constructs its cells of grains of sand on walls, rocks, ete.

Humble-bees (Bombus terrestris, I.) live in the ground in societies of fifty to sixty members.

The honey bee (Apis mellifica, L.) is widely sprend orer the earth. A hive may contain $1 \%, 600$ to $800 \delta$, and 15,000 to $30,000 \mathrm{~h}$. The $q$ (queen) lives for five years, the $\delta$ only for a few weeks, and the $r$ for about six months. 
Order III.-Diptera.

\section{Asilide.}

Imagos long and generally slender, the face tufted with hairs. Eyes very prominent, 3 ocelli, the suctorial organs forming a pointed piercing tube. Antennæ short, 3-jointed, the third joint elongate, not annulate, terminated by a short bristle.

Wings when at rest lying flat on the body. Legs stout, with sharp curved claws. Abdomen with 8 segments.

Larre long and cylindrical, with very clearly marlied segments, white.

The eggs are laid in the ground, by choice in sandy soil. The generation is anmual. The perfect msects are bold maranders, they attack other insects of all orders and snck their juices.

Species.-A silus crabroniformis, L., common in Germany and England.

\section{Syrphide.}

Imagos with oral bodies, very large eyes, and 3 ocelli. Antemnæ 3-jointed, the last joint generally flattened, sometimes very long, with a bristle-like appendage. Wings much intersected with veins. Abdomen variable in form, with 5 to 6 evident segments.

Larra leech-shaped, of varied colours.

Pupa coarctate, pear-shaped.

They fly in July and August in bright sumshine. Their flight is of a hovering nature; they remain poised orer a blossom, darting away when disturbed, and resume their hovering at the end of their course, and they emit a buzzing noise.

The small white oval eggs are laid on leaves and twigs. The generation is double, or multiple. The larre which live on plants destroy plant-lice by sucking ont their juices.

Common species.-Syrphlus purastri, L., frequently found on fruit trees and on Scotch pine. S'. bulteatus, De Geer.

\section{Muscide (Flies).}

Imagos generally short and stout. Eyes, as a rule, densely covered with hairs; ocelli present. Proboscis fleshy. Antennæ 
short, 3-jointed, the terminal joint the largest, not ringed, furnished with a bristle on its dorsal surface. Wings of moderate size, with few longitudinal veins. Legs strong and moderately long. Abdomens, with 4-7 apparent segments, generally scantily hairy, sometimes with an ovipositor in the $q$.

Lard withont legs or distinct head, soft, and generally whitish.

Pupu coarctate, round or elliptic, brown or blackish.

Flies lay their eggs sometimes in decomposing substances, sometimes on living auimals.

In forest economy, only the parasitic flies are of importance, of which the chief are the Tachinina.

Many species of these flies are parasitic in or on the larva and pupse of other insects, as moths and sawflies. Their importance is somewhat less than that of the ichneumon-wasps, but they, nevertheless, destroy great numbers of insects. They pupate generally ontside the host, on or under the gromd. The larve not only suck the juices of their hosts, but unlike those of the ichneumon-wasps, devonr their viscera.

species.-Echinomyin fera, L. frequent on larva of Liparis moncerche and P'anolis piniperde.

The snb-family Anthomyine contains a few species which are injurions to forest trees, for example, Authomyia inficeps, Meig. According to Theodor Hartig the larva of this species which lives in the ground, especially in burned sods, eats the seeds and roots of coniferons seedlings.

\section{Order IV.-Neuroptera.}

\section{Penorpide (Stompion Irlies:).}

Imugrs of moderate size, head prolonged into a beak bearing the mouth at its extremity. Antemne many-jointed, setiform. Both pairs of wings of equal size, with few intersecting veins, and only partially covering the abdomen, sometimes imperfectly developed.

Larre with horny head and 22 legs.

The egrgs are laid in moist soil, and the lanvie pupate in oval, hollowed-ont lumps of earth. 
The larve and imagos devour insects.

The common Panorpu communis, L. flies about around low bushes and hedge-rows, and destroys the pupæ of Liparis salicis, L., \&c.

\section{Sinlide.}

Imagos of moderate size, with broad head, long neck and fairly broad abdomen; with 3 ocelli, sometimes absent. Mouthparts free, fully developed. Antennæ short, usually setiform, and many-jointed. Wings many-celled, colourless, with bristles on the reins, sloping like a roof when at rest.

Larva with 6 short and stont legs. P'pa elongate, with the limbs free.

Example.-Rhaphliclia, L. The perfect insects fly in May and Tune, and lay their eggs in or under the bark of Scotch pine or spruce. 'The snake-like brown larve live through the winter, and pupate in the spring, without any cocoon; about 2 to 3 weeks later the imagos emerge. Ir. wotuta, Schum., is very useful; its larve greedily destroy the eggs and larræo of other insects which they find on and under the bark; common in coniferous woods.

\section{Hemerobiide (Lace-winged Flies).}

Imayos long and delicate. Head small, with large hemispherical eyes; no ocelli. Mouth-parts free. Antennæ long, setiform, many-jointed.

Wings similar in size, transparent and multicellular, sloping like a roof when at rest. Legs slender.

Larra elongate, and narrowed towards the ends, with two slender curved mandibles perforated for sucking, and 6 legs.

The flight-period is in the early summer, and again in autumn. 'The stalked white or greenish eggs are laid in groups on leaves.

The larvie feed greedily on plant-lice which they suck dry, and can generally be found wherever the latter are numerous.

They grow rapidly, and pupate in firm, almost spherical cocoons, suspended by a few threads between leaves, from which the imagos emerge in 2 to 3 weeks. Generation double.

The commonest species is Chrysopa perla, L. 


\section{Order V.-Orthoptera (Pseudoneuroptera).}

\section{Libellulide (Dragon-fies).}

Imagos long, usually very slender and brightly coloured. Head large, almost entirely covered with the large many-celled eyes; 3 ocelli. Mouth-parts strongly ieveloped. Antennæ short, fine, bristle-like, and generally 7 -jointed. Wings of equal size, many-celled, and membranous. Legs short, strong; the tarsi 3-jointed. Abdomen formed of 11 segments, with a short pair of forceps on the last.

The 6-legged larre, and nymplls are characterised by an extraordinarily large labium, which can be extended forwards from beneath the head and serves for seizing prey.

The perfect insects fly in an extremely active manner in June and July, laying their eggs either on the surface of the water or on water-plants. The generation is anmual, and dragon-flies appear sometimes in incredible numbers.

The larre and pupæ live in the water, and prefer small, quiet ponds full of reeds.

In all three stages, especially as imagos, they lill other insects -even moths.

Species.-Blue and green dragon-fly-Asschna jurcea, L., A. grandis, L. common especially in mountainous countries. Libellulu quadrimaculatr, L., migrates, and therefore appear's sometimes in large swarms.

L. clepressa, L., very common.

\section{Order VI.-HexipterA.}

The tribe Geocores (loud-bugs) alone includes insects useful to the forester, and they may be characterised as follows:-

Head small and flat, generally with 2 ocelli. Antemne large, always longer than the head, 4 to 5 -jointed. Body flat. Forewings horny at the base and membranous at the extremities. All the legs generally similar. Tarsi 2 to 3 -jointed. Abdomen consisting of 7 to 8 segments.

Noticeable for their disagreeable odour. 
The species which live in forests are useful by destroying lirve and plant-lice, but a few species are injurious, sucking young shoots, or the bast of older trees. The imagos come out late in the summer, and pass the winter among dead leaves or under bark. Pairing takes place in the following spring and the eggs are laid on leaves, shoots, and in cracks in the bark.

\section{Pentatomida.}

Imagos somewhat long, with 2 ocelli. Antennæ long, filiform or club-shaped, and generally 5 -jointed. Scutellum large, and reaching at least to the middle of the abdomen. Tarsi generally 3 -jointed, with two little lappets (pulcilli) between the claws.

Species.-Pentatoma rufipes, L., common in pine-forests.

Pyrrhocoris apterus, L., often collects by hundreds at the base of large lime and other trees.

\section{Reduriide.}

Imagos large, and longer than those of the preceding family, with projecting head and long beak. Ocelli generally present. Antennæ long, filiform, thin, 4 -jointed. Scutellum small. Forelegs somewhat thickened, and adapted for seizing prey. Tarsi short, 3-jointed, pulvilli absent.

All the species are predatory and able to inflict a poisonous wound with the beak. The most important as regards forests is :-

Ploiaria ragabunda, L., which lives in the leaf-galls produced by certain aphides on elms. 


\section{CHAPTER VI.}

INJURIOUS FOREST INSECTS (SPECIAI ACCOUNT OF COLEOPTERA)。*

The greatest number and the most harmful species of injurious forest insects belong to the orders Coleoptera and Lepidoptera. Next in importance to these come the members of the orders Hymenoptera and Orthoptera. The orders Diptera and Hemiptera, except for the few useful families already mentioned, only include species which are moderately or slightly injurious, and the Neuroptera in Central Europe include no injurious species, although in the sonth of Europe, and in India and other hot countries, the family of Termites, or white ants, belonging to this order, is probably more destructive to vegetable substances, though chiefly when no longer living, than any other insectfamily.

In the following pages the more destructive families of insects will be enumerated and described. The life-history of the most important species, and their relations to forest trees, and the best known ways of meeting their attacks, will also be dealt with, but many less important species which occur in Dr. Hess's book have been omitted. Hess has also separated the injurious forest insects damaging conifers, from those which damage broadleaved trees. Owing to the smaller number of insects here dealt with, this distinction has been abandoned.

\section{Family I.-SCarabieide.}

\section{Description of Family.}

Imagos generally of considerable size and robust build.

* For a complete systematic deseription of Pritish beetles, vide Fowler, The Colcoptera of the British Isles, 5 vols., London, 1586-1891. 
Antemnie short, elbored, 10- or 11-jointed, the first joint elongate, the last 3 or more joints produced inwards into plate-like lamellie which can be separated like the leaves of a book.

The forelegs are formed for digging, and the tarsi are 5-jointed.

The abdomen consists of 5 or 6 segments. A generation lasts for several years in the case of the larger species, but only one year in the smaller ones.

The laree are thick, cylindrical grubs, curved ventrally, with the last abdominal segment large and baggy; often covered thinly with short hairs, which may be bristly on the dorsal surfice; head well-developed, horny, with distinct antemne; legs 6 , strong. They generally live underground.

Pupe almost hairless, generally with 2 horuy processes on the last abdominal segment.

In the perfect state these insects, some of which are very destructive, attack the leaves, needles and inflorescence of forest trees, whilst their larvie eat the roots of young woody plants. The larre of other species live in rotten wood, dung and in dead bodies.

1. Melolontha vulguris, Fabr. (Common Cochchufer).

(a) Description.

The beetle is 25 to $29 \mathrm{~mm}$. long; prothorax black, less often reddish-brown; elytra and legs red-brown, the former with 5 elevated longitudinal ridges, the depressions between them covered with fine down. Abdomen black, with 5 white triangular marks on each side, produced at the apex into an elongate tapering tail. Antennæ 10-jointed; the club 7 -jointed in the $\delta$, in the + smaller and only 6 -jointed. Tarsal claws with a broad tooth at the base.

(b) Life-History.

The beetles appear at the end of April and in May for about 3 or 4 weeks. About 24 hours after fertilization, the female burrows into the ground, selecting a bare spot and, where possible, a light sandy soil. In it, at a depth of 5 to $10 \mathrm{~cm}$. (2 to \pm inches), she lays about 70 dirty white subspherical eggs in 
little heaps containing from 12 to 30 cach. She then returns to the surface to die. The curved larre appear from 4 to 6 weeks afterwards, in June or July, feed in the first year on humus in the neighbourhood of their birth-place, and erentually disperse in the second summer in all directions in the ground, in order to feed on the roots of plants. In the autumn they burrow deeper into the ground, returning near to the surface in April. The larre also go deeper down when about to pupate; this change takes place in July or September of the 4th

FIG. 71.
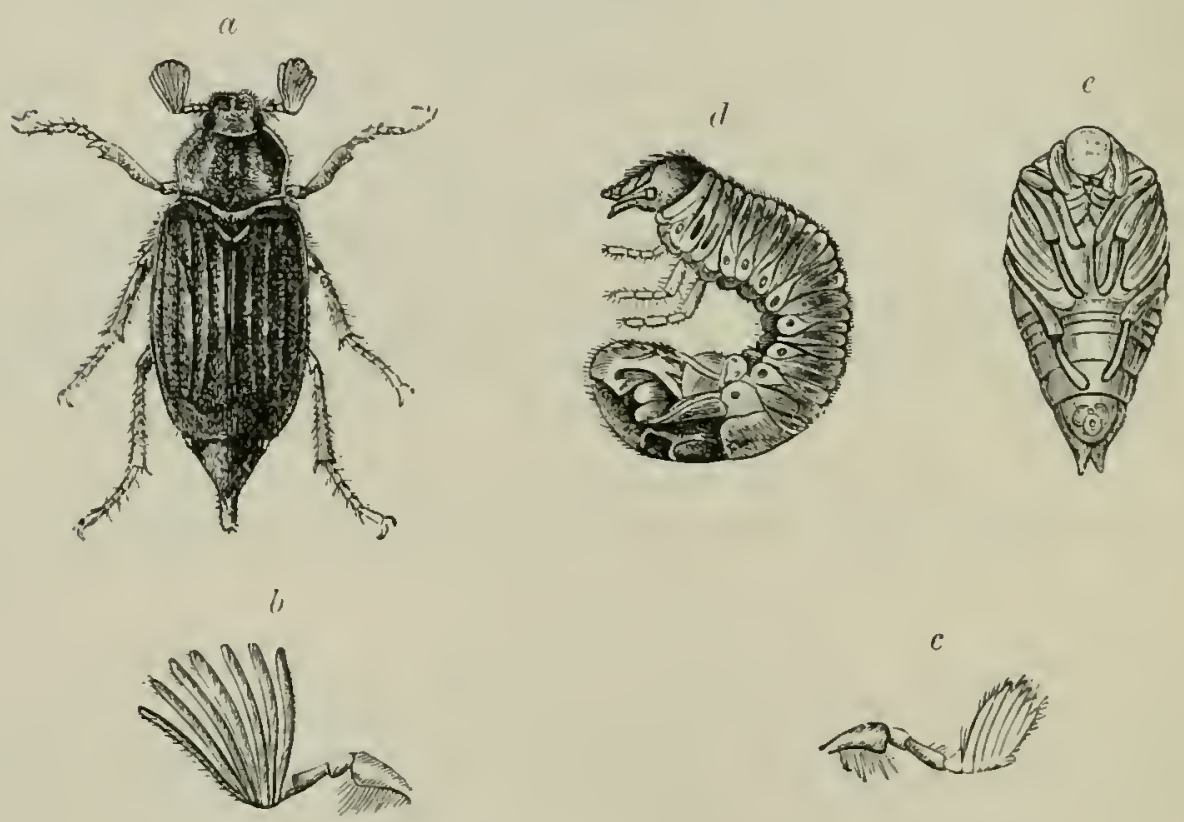

Mclolontha rulgaris, Fabr.

a Inago (O) . T) Antenna of male with 7 lamellae. $c$ Autenna of female with (i) limella!. / Girub. o Puja (ventral surface).

(iarely the 3rd) year of larral life in an oral hole in the ground, the walls of which are internally smooth and water-tight. In certain isolated cases, pupation is deferred until the following spring. The imagos generaily emerge from the pupa from four to eight weelis later, but pass the winter in the ground, a few occasionally appearing on the surface. From the month of February in the 5th (sometimes the 4th) year, the cockchafers come up from below and take flight, learing holes in the ground as if made by a stick. The farourite flight-time is on a fine evening 
in May, especially after a shower of warm rain. In mountainous countries, the cockchafer appears somewhat later than in the milder plains.

The generation differs in duration according to latitude and climate, as a rule lasting 4 years in Great Britain and Europe north of the river Main. This forms an approximate boundary, south of which the generation is triennial. In East Prussia, swarms of cockchafers have been observed at intervals of 5 years. It follows therefore that the time of derelopment of the cockchafer is not the same everywhere, but depends, within certain limits, on the latitude and longitude of a place, and on its corresponding climate. If there is an musually large swarm in any given year the same thing will occur at stated intervals every few years according to the locality. These critical years are known as swarm-years; in the intermediate years at least a few cockchafers appear, either descended from stragglers, which have since continued to produce regular generations, or from irregular individuals in an existing generation.

These smarm-years hare been little noticed in Great Britain and appear to be less marked than on the Continent, the number of chafers appearing each year being more uniform.

The flight of the cockchafer is somewhat heary, it flaps its wings up and down many times before ascending from the ground, in order to drive air into its trachere. It can endure unfavourable weather tolerably well, and is found in North Germany up to an elevation of $2,400 \mathrm{ft}$.

\section{(c) Relations to the Forest.}

The cockchafer is injurious, both in the larval and perfect condition. The attacks of the larræ are less visible, but are more harmful, especially in coniferous woods, as they affect the roots and last for two or three summers. They are worst in the two last summers. Scotch pine and spruce up to 10 years old are most endangered, then the larch, but the silver-fir does not escape. Broad-leared trees do not suffer from the larve quite so much as conifers, but nearly every species is attacked, those with tender roots, such as beech and ash, being preferred to species like the oak, which speedily develops strong roots. The 
bitten surface is rough and fibrous, and not smooth as when gnawed by a mouse, the work of which can be readily distinguished by the characteristic paired tooth-marks.

The larva is extremely destructive in forest- and orchardnurseries and in broadcast sowings; whole rows of young seedlings or prieked-out plants may be seen with drooping and dying heads, and reddish foliage or needles. If they are pulled up, it will be fonnd that the ends of the roots have been eaten,

FIG. 72.

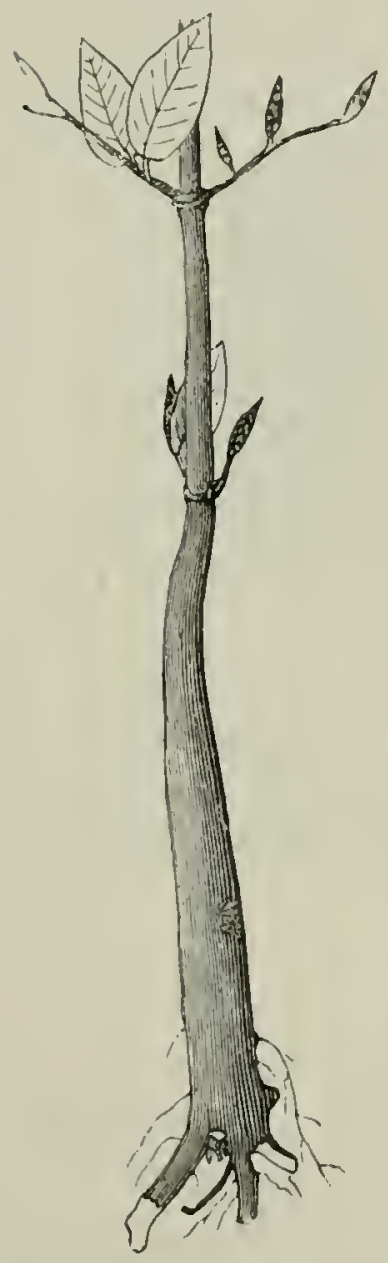

Threc-year-old beech gnawed by chafer-grubs, with loss of roots.

(Natural size.) and occasionally the larra itself may be found in sitn at the base of the injured root. The annexed figure shows a 3 year-old beech seedling which has been attacked.

The imago attacks the foliage of broadleared species from Mray till July, probably sparing the robinia and pear only. The oak is most subject to this attack; then follow maple, ehestnut and horse-ehestnut, popiars, plum, and cherry-trees. The beech, hornbeam, willows, apple. birch, plane-tree, and many shrmbs, \&c.. are also attacked, the order in which the different species are selected depending on the degree of development they have attained when the flight-time takes place.

Trees standing in the open, and border trees are preferred, as the flight of the insect to them is less impeded than it is to trees in the midst of a wood. Lofty trees are also preferred to low growtl. Conifers are less to their taste than broadleaved species, but the imagos in May and June will feed on young shoots and needles of lareh, and the male catkins of Seoteh pine and spruce, occasionally on the spring shoots of isolated silver-firs. In 1878, in the Austrian coast districts, Quevcus pubcsens suffered greatly, and even the walnut was attacked, a rare erent. The oak trees were completely stripped of leaves, and became green again by means 
of Lammas shoots. The insects prefer sandy soil in sunny places, bare, or with a scanty covering of grass, and large forest cultivations after a clear cutting. Extensive cultivations of Scotch pine bordering on agrieultural land suffer most of all.

\section{(d) Protective Rules.}

i. Clear cuttings, especially on a large scale, should be avoided in a swarm-year, and in the previous one. Strip-fellings with a few Scotch pine standards, or a shelter-wood system, are preferable. The ground being thus sheltered and kept cool is less suitable both for oviposition and for the larval life.

ii. In case sowing is advisable, broadcast sowing should be adopted in Scotch pine woods, together with antumn sowings of corn, or of birch seed.

When only partial sowing is carried out, the seedlings come up closer together than in the case of broadcast sowing, and there is more danger of the whole crop being destroyed; the cockchafers avoid cereal crops and prefer not to lay their eggs in places corered with growing coln.

iii. Planting, and especially ball-planting with strong plants is to be preferred to sowing.

In the Eberswald, planting in pits the surface of which after planting is nearly a hand's breadth below the ground-level, was tried with success; the larve which feed very near the ground-level in summer crawl from the surrounding earth on to the top of the pits, instead of getting to the roots of the plants.

iv. Pasturing herds of swine in all forest-glades. In the swarm-years this should be done in spring; and whilst the larve are in the ground, during the whole summer.

v. Protection of all enemies of the cockchafers. The badger, mole, shrew, hedgehog, rooks and crows, starlings, \&e. attack the larve; bats, owls, goatsuckers, shrikes and even finches destroy the cockchafers.

A starling will often carry off 5 or 6 larve at once; these useful birds only eat the soft abdomens of the chafers. Boxes for starlings to nest in should be always set up around forest nurseries. 
vi. When laying-ont nurseries, the neighbourhood of oak woods should be aroided, and the area should be isolated by ditclies. Beds are sometimes made with walls and bottoms of stones, and filled in with sifted soil.

vii. Oviposition may be prevented by covering the beds with dead leaves or twigs, or by sprinkling them with flour of sulphur.

\section{(e) Remedial Measures.}

i. The areas to be stocked, in swarm-years, should be completely broken up with the plongh, in order to destroy the larvie. This ean only be done on fairly level ground.

ii. Collection of the larra which are turned up in eultivating the ground, in sacks, from October till April. This is best undertaken during the summer before a swarm-year, as the larva are then nearest to the surface of the ground.

iii. Collection of the larræ by digging round plants which are attacked in the eultivations, which can be done throughout the summer.

iv. The construction of traps for larva as follows:-

a. Sods of grass or heather in square pieces measuring 8 to $10 \mathrm{in.}$ in breadth are placed with the grass downwards on the cultivations. In the forest of Allstadt, Weimal, in the antumn of 1870 , on $7 \frac{1}{2}$ acres of ground covered with grass and heather, square grass sods $s$ to 10 inches broad and 6 to 8 inches thick. were laid on the surface of the gromnd with the grass downwards, and from 3 to 11 larve were found under each sod in July, 1871. Thus in a short time 16,000 larve were collected.

b. Rolls of bark filled with loose soil, and placed in the ground.

c. Heaps of turf, weeds, humus, burned sods, and dung, Sc.

Such heaps afford looseness, dryness, warmth, and nourishment for the larval development, and Heyer greatly recommends their use in nurseries. The females also readily lay eggs in heaps of dung alternating with layers of carth, and enormous numbers of larve may be reared in them and subsequently destroyed. 
d. Traps of sticks or bark.

In a swarm-year and the year after it, at the beginning of the marm meather, fresh pieces of bark or thin-barked, sappy branches 20 to 40 inches loug are placed horizontally, balf covered with soil, in ground infested with larvie.

This may be done between the rows of plants in murseries, and aspen, sallow, ash, oak and coniferous wood can be used. These traps attract the larve. This plan was tried on a large scale in 150 forest ranges in Prussia in 1883 and 1884, but gave only poor results. In all the cases ( $a$ to $d$ ), the larre must from time to time be collected and destroyed, and the traps occasionally renewed.

v. Collection of the cockchafers is probably the best remedial method to be followed.

The chief points to be noted are:-The work should be commenced early in the season before too many cockchafers have emerged; then only is it practicable to catcli the $q$ before they have laid their eggs. Iri order to ensure economy; children and women should be employed, and the collection made only in the morning or on cool days, when the insects are sluggish in their movements. The workers are provided with narrownecked glazed vessels, or sacks in the opening of which the broken neck of a beer bottle has been fastened, to serve as a funnel through which the beetles may be dropped; the trees should be shaken over cloths, and payment should be by quantity.

The larræ and beetles may be killed by :-

Crushing on hard ground.

Scalding with hot water, which gives rise to an extremely unpleasant odour.

Immersion in casks containing a mixture of water and petroleum, or 2 per cent. of naphthalin. Both larve and beetles live for some time in water alone.

Burial in layers in a trench with unslaked lime, or powdered calcium chloride.

Subjecting the insects to fumes of bisulplide of carbon. This is the best method of destroying them, and wis first discovered by Dr. A Mayer.

When done on a large scale, a clean empty petroleum cylinder 
Qr similar vessel may be used, in which the carbon bisulphide is poured on the insects.

In order that the gas may have its full effect, the tin should be covered with a sack, or woollen cloth, to keep out the air. Lights and fire must be kept at a distance during the operation. A bushel of cockchafers may be killed by less than an ounce of carbon bisulphide, and the insects die in 5 to 10 minutes.

Where cockehafers are extremely abundant and injurious, as in Germany and France, the work of collecting them is so serious an expense that it is lightened as much as possible by the utilisation of the captured beetles.

This is done in three ways: They are used as food for swine, fowls or geese, being mixed with three or four times their weight of potatoes or starchy material; for the extraction of a coarse oil suitable for eart grease; or for manure, being mixed with earth, bone dust or stable-manure.

Their value as a food-stuff is about $1 \mathrm{~s}$. per $10 \mathrm{lbs}$; as a manure, about $9 d$. per $10 \mathrm{lbs}$.

vi. A plague of cockehafer's, like a plague of mice, being felt by agriculturists and fruit-producers, as well as foresters, must be met by energetic common action of all municipalities and village anthorities, and in case the interested parties cannot agree as to any common course of action, the State should intervene to compel unanimity.

vii. Nothing can be done to save conifers injured by the larra if, beside the talp-root, all side-roots have been bitten off. Should, however, some side-roots remain, lareh at least may recover if severely pruned almost to the ground and earthed-up round the roots. The proning limits the transpiration, and the earth romnd the roots prevents the drying-up of the existing roots and furthers the formation of new ones. These measures must be mdertalien as soon as the injured plants begin to droop.

\section{Melolontha hippocastani, Fabr.}

The betle greatly resembles the common cockchafer, but is smaller, being only 20 to $25 \mathrm{~mm}$. long. Prothorax generally red, rarely black. Antemne and legs dark brown or black. Tail 
shorter, more abruptly tapering, and somewhat clubbed at its extremity.

Life-History and Economy.-Similar to those of the common cockchafer with which it swarms, but in smaller numbers. It does not merely attack the horse-chestnut as its name implies, but nearly all forest trees. Season for swarming somewhat earlier (April). A more northern insect than the common cockchafer; in Great Britain confined to Scotland and the extreme north of England.

Protcetire Mectsures.- Same as for the common cockchafer.

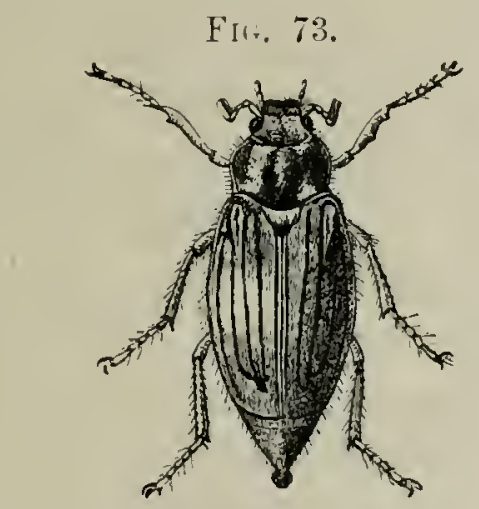

Melolonther hippocestoni, Fabr.
FIG, 74.

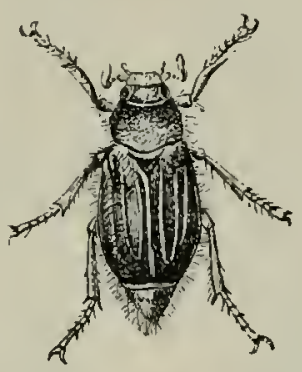

lihizotrogus solstiticlis, L.

3. Rhizotrogus solstitialis, L. (.June.chafer).

(a) Description.

Bectle 15 to $17 \mathrm{~mm}$. long, similar to the two former, but with the abdomen not produced into a tail. Brownish-yellow, with 4 raised carina on each elytron; the prothorax, scutellum and underside covered with long hair. Antenne 9-jointed, the club 3-jointed. Claws with a small tooth at their base.

\section{(b) Life-History, de.}

Similar to the common cockchafer. Flight-time somewhat later, in June and July. The beetle attacks young Scotch pine shoots, but prefers the beech, hornbeam, poplars, willows, \&c. The larve derour the roots of small plants, chiefly of grasses and grain crops. The insect is found in sandy soil, but is less frequent in forests than the two preceding species. It is locally common in many parts of Great Britain. 
Protective rules and remedial measures as for the common cockchafer.

\section{Family II.-Buprestid.e.}

\section{Description of F'amily.}

Imayos long and slender, generally with hard elytra which taper posteriorly, as a rule brightly coloured, with a metallic lustre. Antenne short, generally serrate and 11-jointed. Posterior angles of the thorax rounded. Front and middle pairs of coxie globose, the hind pair flattened. Legs short and weak; tarsi 5-jointed. Abdomen of 5 segments, of which the two anterior are fused. The active flight of these insects generally takes place in June and July in lot sunshine. A generation usually lasts two yeirs.

Larve cylindrical or flat, white, and without legs; the first

FIf. 75.

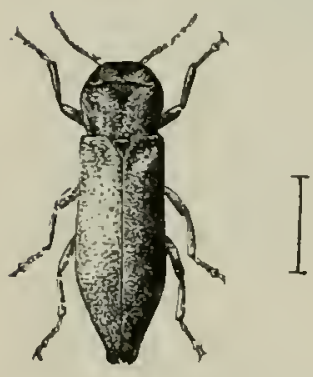

Alyilus viridtis, I. prothoracic segment is broad. They live partly between the bast and sapwood of young trees, partly in the stumps, or in old decaying trees. They pupate in situ in a cocoon made of fragments of wood. Flightholes of the imagos transverse oval, nearly half-elliptic.

The most injurious species are found on broad-leaved trees, but in Germany a few species attack coniferous woods. In Great Britain all the species of Buprestide are scarce, local and therefore unimportant. The following species, though very rare in this comtry, will serve to illustrate their life-history and ecollomy :-

1. Agrilus viridis, L.

(a) Deseription.

Bcetle 6 to $8 \mathrm{~mm}$. long, very variable in colour, being sometimes olive-green, bluish-green, blue, earth-coloured, ic.; under surface black. Thorax broader than long; the last abdominal scgment rounded at the extremity; apices of the elytra diverging slightly from one another, and finely dentate. 


\section{(b) Life-Iistory.}

Flight in June and July, in brilliant sunshine.

Eggs laid either singly or by twos and threes on the bark of smooth saplings, especially at the base of stems exposed to the sun.

The larre appear in Angust, and live over two winters before pupation, which takes place in April or May of the third summer in a pupal chambermade in the sapwood or bast.

The imagos emerge in June or July, leaving a hole oval below and straight above, thus: -

Generation lasting two years; the insects seldom appear in large numbers.

\section{(c) Relations to the Forest.}

The beetle prefers young beech plants, but also attacks alder, birch, oak and aspen, especially weakly saplings, generally standing in the open, or along the edge of the forest. It is, however, only the larva which are really destructive. They burrow through the bark down to the sapwood, and excavate in it a shallow, well-defined winding passage, sometimes extending deeper into the wood; it increases

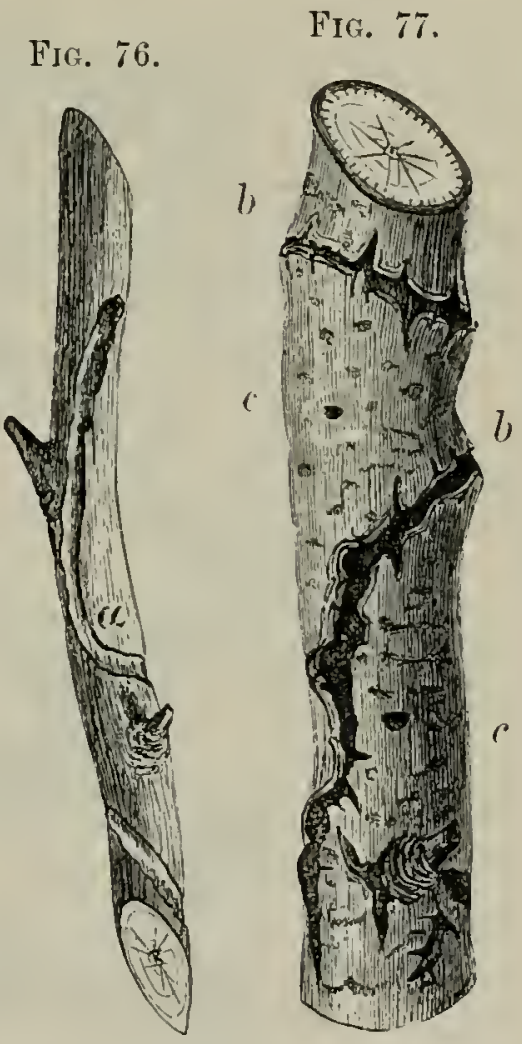

Injury eaused to beech-saplings by $A$. virielis, L. (Netural size.)

a Larval gallery, exposed by removal of the bark.

b Old larval galleries exposed by rupture of the bark.

c: Transverse oval flight-holes of the imaigo. in breadth with the age of the larve.

If the plant be girdled, the upper part of the stem dies, at least in dry localities. The bark projects somewhat all along the sides of the passage. In the case of saplings which recover, the bark splits, owing to the pressure of the callus forming over the wound. 


\section{(d) Protective Rules.}

i. Care in planting out saplings, and choice of strong healthy plants.

ii. Smearing the saplings with a mixture of 2 parts of clay, 1 of lime, and 1 of cordung, shortly before the flight of the beetles.

$$
\text { Fir. 78. }
$$

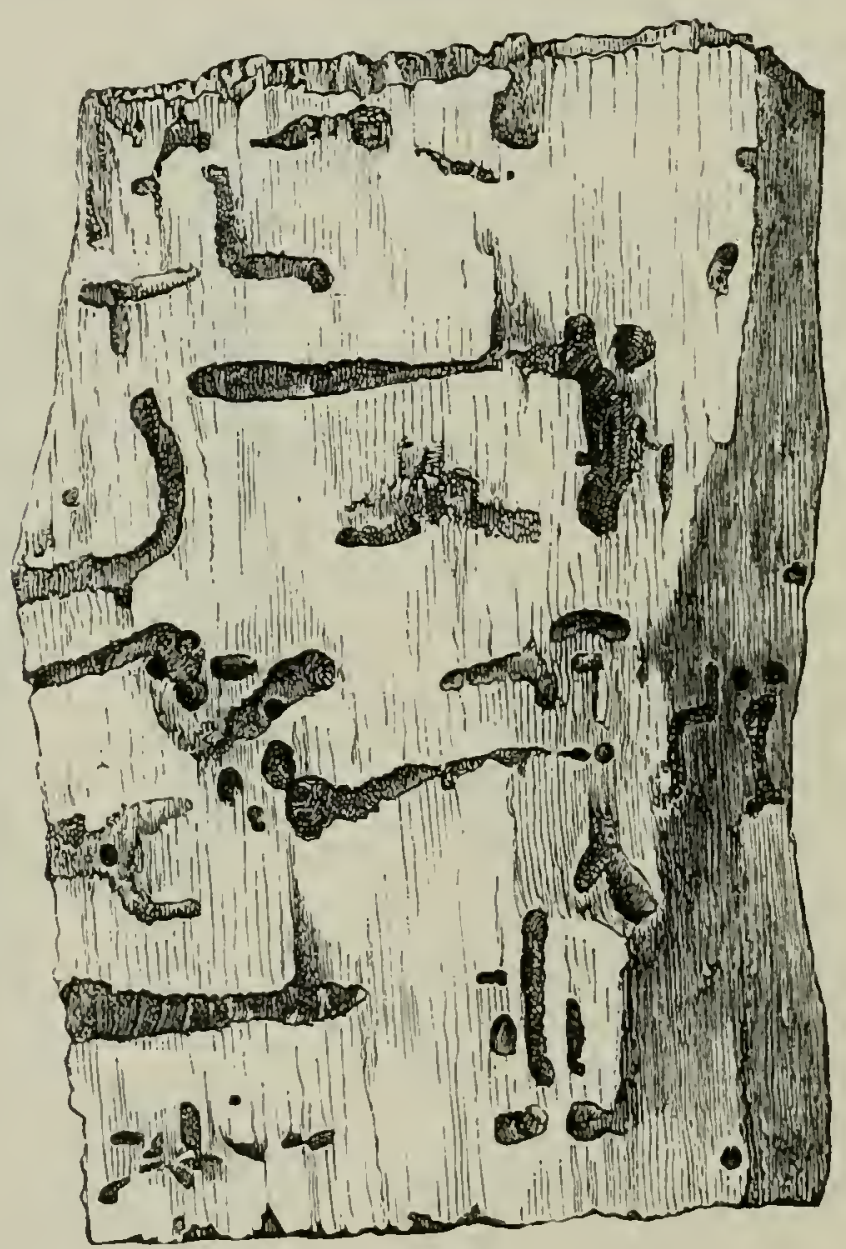

Poplat-wood bored by Ayrilus sex-guttutus, Herlst. (Nuturul sise.)

\section{(e) Tiemediul Measures.}

Pulling-up and burning all infected saplings in May and the besimning of June.

\section{Other Species.}

Other species of Amrilus, such as A. angmstulus, Ill., attack 
oak, laazel, birch and other saplings, and should be treated in the same manner as A. riridis. A. sex-yuttutus, Herbst, is common in France where it riddles the wood of old poplars.

\section{Faimly III.-Elateride (Chick-Beetles).}

\section{Description of Family.}

Imagos long and slender, hard, resembling those of the former family in general appearance, but usually without metallic Instre. Antemne filiform, generally serrate or pectinate ( $\delta$ ), 11-jointel. Prothorax broad posteriorly, its hind-angles produced and acute. Fore and middle coxic spheroidal, legs short and rather weak, tarsi 5 -jointed. Abdomen of 5 segments. When laid on their backs they are able to spring up in the air with a clicking noise, alighting on their legs.

Generation, 3-4 years; length of time in larval stage probably dependent on supply of food, and lasting only three years when they are well nourished.

Larce long and slender brownish-yellow grubs, termed wireuorms, with horny, flat, dark heads. They are lighter coloured below, and have $6 \operatorname{legs}$ and a stump-like tubercle serving as an additional leg on the last segment; they generally lire underground, or in old rotten stumps. They are omnirorous, devouring roots, rhizomes, seeds, fungi, decomposing regetable and animal matter, and even other insects. They abound in newly broken-up pasture, or clover land, and are most destructive to agricultural crops, and in forestry to sowings in nurseries and in the forest of acorns, beech-mast, maple or hormbeam, and many coniferous seeds, and to the roots and bases of the stem of young coniferous and broad-leaved plants.

Pupation underground in July. The beetles emerge a few weeks later, and may be found on flowers, or under bark or stones.

The larve of Dolopius marginatus, L., gnaw the roots of young spruce and Scotch pine, and thus do much injury in nurseries and plantations. Agriotes lineatus, L, and A. obscurus, Gyll, devour acorns, and also coniferous seeds; Athous hemorrhoidalis, Fabr. beech-mast, acorns, hazel-nuts, and seeds 
of hornbeam. Some species also attack the roung shoots of trees, in order to extract the sap. Lacon murinus, L. has been known to injure the oak in a similar way to Telephorus obscurus, L., and certain species of Corymlites do similar damage, so that the shoots beeome black, dry and break off.

Protective rules.-The conspicuous brown larve should be collected and destroyed when the nursery beds are dug up, and turf in which they are noticed may be burned. It is impracticable to collect the beetles."

\section{Famin IV.-Lruexilonid.}

\section{Description of Family.}

Imagos cylindrieal, long and slender. Elytra not eurved downwards and slightly gaping at the apex. Antemne threadlike, somewhat thiekened in the middle, or serrate, 11-jointed. Fore and middle coxie eylindrieal or spheroidal. Tarsi 5 jointed. Abdomen of $5-6$ segments.

Generation annual.

Larre long, cylindrical, soft-skinned, white. free from hair, and 6-legged. They are generally found in logs of timber in dêpots and dockyards, or in stems of trees. The beetles fly round the trees and timber in June and .July, and lay their eggs in eracks in the bark. Chiefly dangerous to broad-leaved trees.

\section{Lymexylon narale, $\mathrm{L}$.}

(a) Description. - o 8 to $10 \mathrm{~mm}$. long, black; elytra, abdomen, and legs yellowish-brown. o $12-15 \mathrm{~mm}$. long, ochreous. The head, side-margins and apex of the elytra are blackish: the latter do not quite eover the abdomen.

Larra white, with a fleshy hump on the last segment.

(b) Lifc-history. - The beetle flies on warm days from the beginning to the middle of July. The eggs are laid on large broken tree-stumps, or on large barked oak logs, but never on sound standing trees. The larrie eat galleries into the wood of

\footnotetext{
* For an areount of protective treatment agninst wire-rorms, vide Miss Ormerod, op. cit., erl. ii., ll. 111 to 118.
} 
about $1 \mathrm{~mm}$. in diameter and deflected at right angles every few inches. The vertical burrows are somewhat crooked, but the horizontal ones are quite straight. 'This insect is chiefly injurious in timber depots and dockyards.

In 1746, Limneus found the damage done to oak-timber in the Gothenburg harbour so great that he exclaimed how wonderful it was that so small a worm could do yearly so many thousands of dollars' worth of injury. His advice to the King of Sweden, at whose command he investigated the injury, was to sink the affected timber under water before the flight-time of the insects.

Lymexylon is scarce and local in Great Britain, but is liable to be imported in contincntal oak-timber.

(c) Protective rules.-Smearing felled timber with tar, when attacks are feared.

A similar species, Iylecoetus dermestoides, L., lives chiefly in the stumps of felled trees; it is locally common in Great Britain, chiefly in Sherwood Forest, but has never proved so destructive as Lymexylon to timber of commercial value.

\section{Fanili V.-AnobIide.}

\section{Description of Family.}

Imagos small, cylindrical, similar to bark-beetles, with a cowled prothorax which conceals the upper part of the head. Antennæ slender, pectinate or clubbed, more rarely serrate, 8 to 11-jointed, folded under the prothorax when the insect is at rest. Fore and middle coxie cylindrical or spheroidal; tarsi mostly 5-jointed, but 4-jointed in the case of many species. Abdomen with 5 rentral segments. Generation often lasting several years. The beetles when disturbed lie motionless as if dead.

Larve strongly curved, somewhat square in transrerse section, whitish, hairy and 6-legged. The beetles appear in the spring or early summer.

The beetles and larrie live chiefly in rotten wood, partly in standing trees, where they eat out galleries which cross one mother; also in shoots, in the pith and in spruce cones, as for instance, Ernobius abietis, Fabr. They also live in fungi, in the 
woodwork of houses, and in furniture, for instance, Aunbium domesticum, Fourc., a small brown beetle 2 lines long, known on account of the ticking noise it makes as the "death-watch."

\section{Xestolinm tesselatum, Fabr.}

Imago 5 to $6 \mathrm{~mm}$. long, convex, subcylindrical, dark-brorrn, very finely and closely punctured, and dappled with patches of short greyish-yellow hairs.

The imago and larva bore into and riddle the wood of old standing trees (oak, beech, sycamore, \&c.) and also the timberwork of churches and old houses. Locally common in England.

The attack of Anoliide on trees generally begins at an old wound, particularly on the stump of a branch.

Treatment.-The removal of attacked stems. Careful and timely dressing of exposed wounds and branch-stumps with tar.

\section{Family VI.-Curculionide (Teevils).}

\section{Description of Family.}

Imagos small or of medium size, with the head produced into a straight or bent rostrum or snout, at the end of which are the small mouth-parts. Antemne nearly always elbowed, 8 to 12 jointed, with a club of very variable structure ; their basal joint is capable of being folded into a groove or scrobe in the snont. Elytra broader than the thorax. Fore coxie spheroidal or conical, hinder coxie small and transverse. Legs stont, the thighs sometimes adapted for leaping. Tarsi 4-jointed, the list joint but one being generally heart-shaped, or bilobed. Abdomen of 5 segments, of which the two first are generally larger and united. Many species have no wings. Generation usmally ammal, but it may last for two years, or two broods may occur in one year.

Larce thick-set, cylindrical, curved ventrully, the licad horny, the body soft-skinned, wrinkled and thinly hairy, whitish and without feet.

Pupce recognizable by the conspicuous suout and antemne, generally with two posterior pointed processes. The larve and 
beetles eat the roots, bark, bast, wood, leares, blossoms, fruits or seeds of forest trees.

There are no galleries made by the parent beetles for oviposition, but the eggs are placed in situ by means of the suout. Some species are very destructive.

\section{Apoderus coryli, L.}

(a) Description.

The bectle is 6 to $8 \mathrm{~mm}$. long, bright red, with the head, antennx, a median spot on the prothorax, and the underside black. The elytra are rather short and much wider than the narrow prothorax, with rows of strong punctures.

\section{(b) Life-History, dic.}

The $q$ in May cuts the leaves of various broad-leaved trees by a transverse incision made towards the base and reaching the mid-rib. She then rolls the terminal part into a thick cylindrical roll, in which a single yellow egg is laid. The larva feeds on the interior of the roll, which subsequently becomes detached, and when mature it pupates in the ground.

The beetle is locally common, though never abundant, chiefly on hazel, also on alder, oak, beech and hornbeam; it frequents young shrubs and undergrowth, and in the perfect state feeds by gnawing holes in the leaves.

When injurious it may be collected by

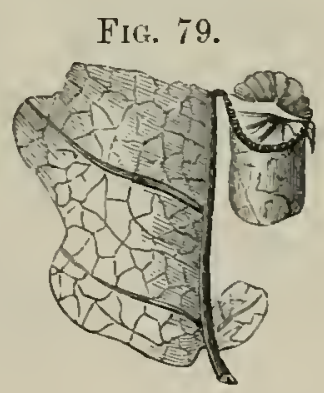

Oak-leaf, rolled up by $A$. cureulionoides, L. (Natural size.) shaking, and the rolls may be picked off.

Attelabus curculionoides, L., a very similar insect with almost smooth elytra, is locally common on oak and sweet-chestnut, chiefly on undergrowth.

\section{Rhynchites betule, L.}

(a) Description.

This beetle is 4 to $5 \mathrm{~mm}$. long, black and slightly hairy; rostrum hardly longer than the head; elytra broad with deep 
coarsely punctured striæ; posterior femora strongly dilated in the $\delta$.

\section{(b) Life-History, cle.}

The $q$ in May cuts the leaves of birch and other trees on both sides down to the mid-rib in a curved line, beginning near the

Fig. 80.

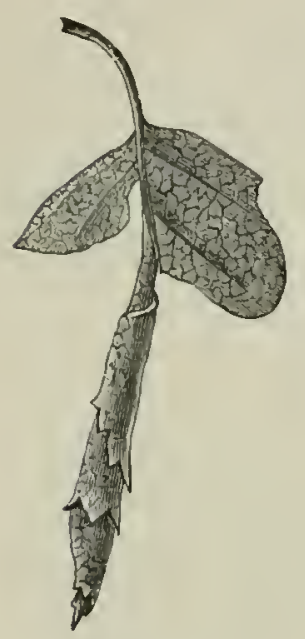

Birch-leaf, rolled up by $R$. betula, L.

(Natural size.) base of the leaf; she lays an egg on the edge of the leaf in a little pocket made in the leaf by removal of a bit of its epidermis, and then rolls up the two sides over one another, so that the egg lies in the middle of the roll, which is open at both ends.

The larva feeds on the roll, and in the autumn falls to the ground with it, and pupates in the soil.

The beetle prefer's the birch, on which species thousands of these rolls may be found; but it also attacks beech, poplars, alder, hazel, etc. It is common, and widely distributed in Britain.

(c) Protective Rules.

The rolls may be collected and destroyed.

R. betuleti is very destructive to vines, and also attacks many broad-leaved trees, as birch and hazel; and $R$. populi, L. attacks poplars and aspens. Both are local in Great Britain.

\section{Strophosomus coryli, Fabr.}

(a) Description.

The beetle is 4 to $6 \mathrm{~mm}$. in length, short and thick, with the elytra convex and subspherical; covered with close-lying mottled brownish-grey scales, except over the base of the suture, which is black and bare; prothorax with a fine median furrow; antennæ and legs ferruginous.

\section{(b) Life-History, die.}

Pairing takes place in June, and oviposition follows on small roots near the surface of the soil. The larra lie under the 
surface-covering, especially in dry places, pupating in July and the beginning of August. The perfect insects are disclosed in August and September. They are wingless, and ascend trees by climbing, beginning in early spring to feed on the needles and bark of young pines and spruce (by preference about two years old). This insect, which is abundant both in coniferwoods and in those of broad-leaved trees, is oceasionally very injurious.

\section{(c) Protective Rules.}

Thorough grubbing-up of stumps and root-stocks; employment in cultivations of well-grown and not too young plants; trapditches; the collection of the beetles in August and September under pieces of bark on the ground, which are kept down with stones and visited daily. Collection of the perfect insects from the plants by shaking, which should be done in the spring; the beetles drop readily.

S. obesus, Marsh., and S. limbatus, Schönh., are allied species of similar appearance and habits.

Various other species, as Sitones lineatus, L., and the Phyllobii, weevils covered with bright or dull green scales, also eat buds and shoots, chiefly of broad-leaved trees. The usual treatment is the collection, by shaking, of the insects at the time of the injury.

4. Balaninus nucum, L. (Nut Weeril).

(a) Description.

Beetle 6 to $8 \mathrm{~mm}$. long, oval; black and covered with yellowish-grey hairy scales. Rostrum very long, thin and curved, reddish-brown. Legs dark rust-brown, with greyishyellow hairs.

\section{(b) Life-History, die.}

The beetle pierces hazel and other nuts with its proboscis, whilst the shell is still green, from May to July, making in each nut a single hole as if pierced by a needle, in which an egg is laid. The larva (maggot) eats about half the kernel of the nut, and falling to the ground with the ripe fruit in 
autumn, gnaws its way out of the shell, and pupates in the earth till next spring. The perfect insect emerges in the summer. Worm-eaten nuts may be distinguished by either of the holes in them.

The species is common and may diminish the seed yield. An allied species, B. glendium, Marsh., chiefly attacks acorns.

\section{(c) Protective Rules.}

Hazel-nut, borel by B. nucum, L. (Natural size.)

" Hole made by the parent beetle. b) Exit-hole of larra.
Collection and destruction of the nuts which fall earliest (those infested with larræ). Collection of the beetles by shaking. Titmice attack the green nuts to reach the larræ.

\section{Orchestes fari, Gyll.}

(a) Description.

'The Beech Leaf-miner beetle is 2.5 to $3 \mathrm{~mm}$. long; black, with fine grey hairs. Elytra with striæ of conspicuous, coarse punctures; rostrum depressed under the body; antennæe and legs bright brown. Hind-legs adapted for leaping, their femora thickened and furnished with a small tooth before the apex.

\section{(b) Life-History, dic.}

The of lays her eggs one by one on the under surface of undereloped beech leares, etc., biting holes for the purpose under the epidermis, near the mid-rib. The larva hatches in the month of May and bores in the leaf-parenchyma either towards the terminal point of the leaf, or sideways, forming a winding tumnel which continually increases in size till it becomes a large patch. The parts which have been eaten, at first whitish, become finally brown. Pupation takes place near the border of the leaf, between the upper and lower epidermis of the area which has been eaten by the larra.

In June the beetle emerges, and passes the winter under the dead leaves on the ground. 
When the larvæ of this insect are abundant, the foliage of the beech trees appears reddish-brown, just as if it had been frozen by a late frost.

The beetle shortly after emergence has been known to feed on various substances; for instance, fruit (cherries, raspberries, gooseberries), cauliflowers; it also pierces the capsules of beech nuts, causing them to open before the seed is ripe. In the early summer it riddles the beech leaves with small holes, and gnaws the female flower-buds.

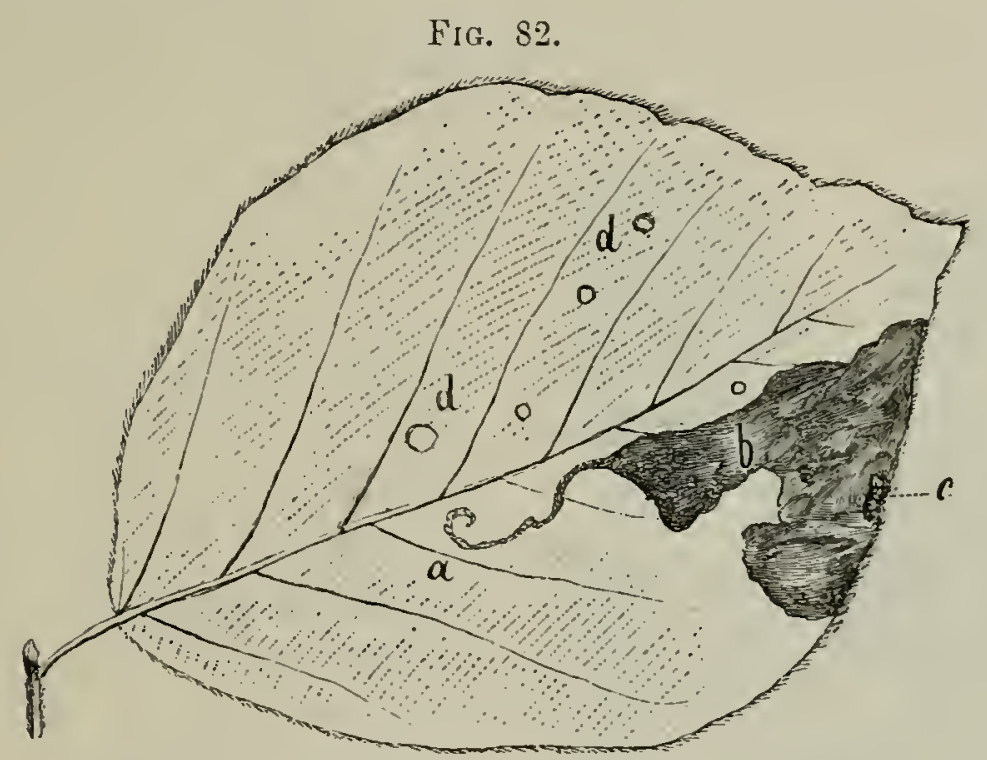

Beech-leaf attacked by 0. fagi, Gyll. (Naturcl size).

a Commencement of larval mine by a gallery, which widens at $b$ into an irregular: space. $c$ Pupa in a bladder-like cocoon. $d$ Holes of various sizes gnawed by the beetles.

The insect attacks woods of all ages, but prefers old to young growth, and especially trees bordering the wood, or isolated trees, as shelter trees in a regeneration felling. It appeared in the Palatinate in 1869 in such numbers that in many beech woods scarcely a leaf was left uninjured. It is common in Great Britain. No protective measures other than the encouragement of insectivorous birds are practicable.

\section{Orchestes quercus, L.}

Beetle reddish-yellow, covered with grey hair, and with black eyes and breast, hinder thighs with serrate teeth. It attacks the oak just as the preceding beetle attacks the beech. It is 
commonest on suppressed oak undergrowth, under Scotch pines, etc.

7. Cryptorrhynchus lapathi, L.

(a) Description.

Bectle 7 to $8 \mathrm{~mm}$. long, and very characteristically coloured; thorax and the basal two-thirds of the elytra dark brown or black, with patches of erect black scales; flanks of the thorax, the anterior part of the under surface, the apex of the elytra and the femora thickly covered with white scales. The rostrum can be folded into a furrow under the thorax.

\section{(b) Life-History.}

The beetle flies at the end of April and in May. The eggs F1G. 83 .

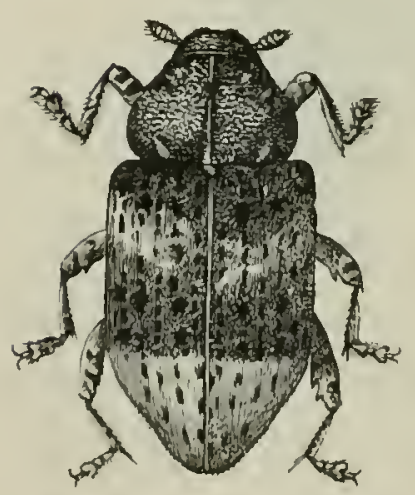
are laid in May, in small holes gnawed in the bark of the stem, or of the branches of alders, etc.

The larve appear 14 days later, in May or June, and pupate as a rule in autumn in their galleries. The beetle T emerges in antumn, and passes the winter in these galleries or under moss; but occasionally its emergence is deferred till the spring. Generation Cryptorrhynchus lapathi, L. annual, sometimes lasting 2 years.

\section{(c) Relations to the Forest.}

The black and white alder are preferred by it, then willows; but poplars and birch are also attacked. If attacking alder it selects young stems (2 to 4 years old), but older trees in the culse of willows. It is therefore more dangerous to the alder, and especially the black alder. Willow-cuttings are also attacked withont respect to species, and careless coppicing giving rise to gnarled stools increases the danger of infestation.

The insect is injurious both as a larra and imago.

The beetle eats the bark of young annual shoots down to the sip-wood. The larva then gnaws under the bark, and bores 
obliquely upwards or downwards into the wood and often to the pith, thus ruining the young stems, which die or break off (Figs. 84 and 85$)$; in the latter figure the galleries of the larvæ have been exposed.

The attack is indicated by discoloration and swelling-up of the bark, and later on by its depression over the points of injury, and by the brown wood-dust which is ejected from the burrows, or has fallen to the ground.

The beetle attacks and kills isolated stems along the banks of streams where the localities are not too dry, and since 1830 it has been common near Tharand in Saxony. In Britain it is somewhat local, though not uncommon where it occurs.

(d) Protective Rules.

Infested plants and coppiceshoots should be cut down by the end of July and burned.

The beetles should be knocked off the trees on to cloths. This should be done carefully, as the slightest shaking of the trees induces the beetles to fall and lie as if dead on the ground, where they may escape observation.

8. Hylobins (Curculio) abietis, Fabr. (Pine-Weeril).*

\section{(a) Description.}

Beetle 8 to $13 \mathrm{~mm}$. long, of

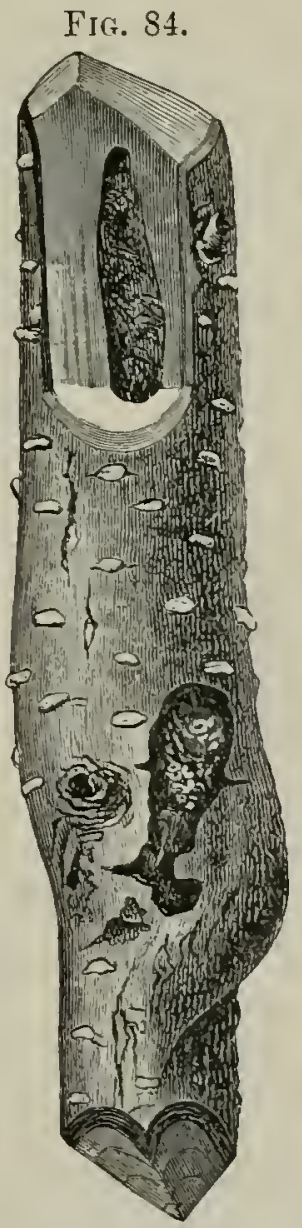

FIG. 85.

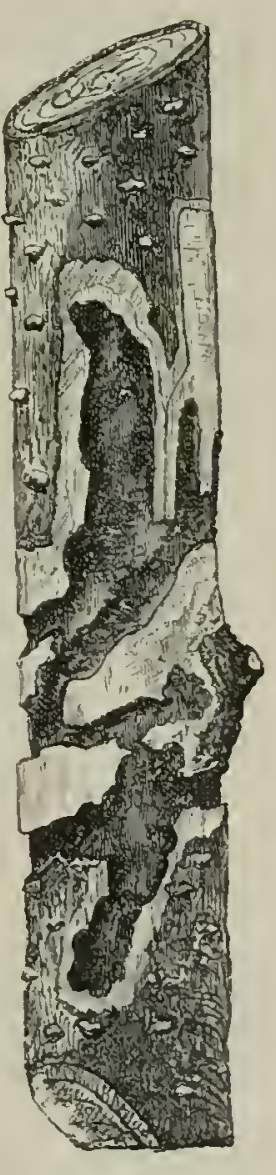

Larval burrows of $C$. lapathi, L., in Alder stems. (Natural size.) strong build, pitchy-brown, with 2 or 3 golden (rarely pale vellow) irregular stripes across the elytra, and a few spots of

* The most raluable account of this very destructive forest insect is by Obertörster ron Oppen, Untersuchungen uher die Generationsverhältnisse dés Hyl. abietis. Zeitschr. fr. Frst. n. Jgdw. 1855, pl. 81 and 141. 
the same colour near their apex. Head with a strong, somewhat curved rostrum, thorax gradually narrowed from the middle to the apex, with coarse confluent punctuation and a slightly elevated median ridge, clothed with patches of thick hair ; elytra thlice as broad as the base of the thorax, and somewhat elerated at the shoulders. Legs brown, the femora toothed below (by which it may be distinguished from Pissodes pini, L., which otherwise greatly resembles it), and generally darker than the tibir.

\section{(b) Life-History.}

The chief swarming period of this beetle, which lives from 1 to 2 years, is in the spring or early summer (May or June); but pairing and reproduction go on throughout the whole of the warmer season up to September, so that no real period for swarming exists. Copulation generally takes place on the ground.

The eggs are laid from May to September on stumps and roots of the Scotch pine and spruce, preferably on those of trees felled

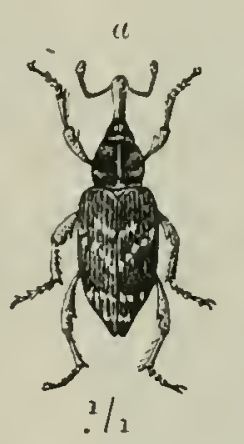

Fig. S6.

Irylobius abietis, Fabr.
“ Imago. $\quad$ Larva. $\quad$ Pupa.

about 18 months before. The under-surface of those roots which project out of the ground are especially preferred.

The larve appear after 2 to 3 weeks, and eat galleries in the bark of the stumps and roots down to the sapwood; the burrows curve at first upwards and then downwards, continually increasing in breadth, and are filled with wood-dust.

The grubs, at least those which have been hatched in the autumn, pass the winter at the end of these galleries. They do no injury of any economic importance, their sources of food being confined to valueless wood. 
In the following spring, after having been dormant for about 9 months, the larve pupate in the stump or roots in a cocoon constructed of wood-fibres and boring-dust. The pupa-state lasts abont 2 to 3 weeks. The perfect insects emerge from May till September of the second year. The period of disclosure thus extends over four months, corresponding to the season of pairing. Those beetles which emerge during the autumn do but little injury, as they do not appear in such numbers as in the spring; except for a few belated individuals, they proceed at once to copulate. Nearly the whole summer through both larve and imagos may be found. The latter pass the winter under moss, dead leaves, in the ground, in hollow stumps, under stacks of wood, etc. Von Oppen found that they prefer to winter in dense thickets of 10 to 15 -year-old plants rather than in older woods.

The generation lasts generally only one year, but may extend to 15 months; only under very favourable climatic circumstances can it be less than a year.

The beetle frequently appears in extraordinary numbers on felling-areas, where it is bred, and in plantations which it destroys. It is very common in most pine-woods throughout Great Britain.

It rarely if ever flies, moves slowly along the ground, and in times of great heat or cold conceals itself in grass, refuse of felled trees, earth, etc.

\section{(c) Relations to the Forest.}

This species is important in the perfect state alone, by the injuries it inflicts on young coniferous plants; weakly Scotch pine and spruce of 3 to 6 years old are preferred, but younger plants, even yearlings, are attacked, and exceptionally other conifers (black and Weymouth pines, Douglas and silver-fir, larch). Even broad-leaved trees are attacked, chiefly oals and other species planted in old coniferous woods, or employed as a shelter-wood for Scotch pine. The insect is therefore clearly polyphagous.

The damage is done from May to September, the bark of the young plants being gnawed all along the stem, down to the rootstock. The bast or sapwood is exposed in patches, which may be as large as a bean, and resin exudes from the torn 
walis of the points of attack. More of the outer bark is always removed than of the bast, so that the injuries appear as irregular and shelving erosions of the surface.

Frequently in this way the young trees are girdled, and very small plants are completely peeled, up to their crown. In the case of the Scotch pine the attacks of the beetle cause the development of numerous shoots from dormant buds; the spruce is sooner killed than the pine.
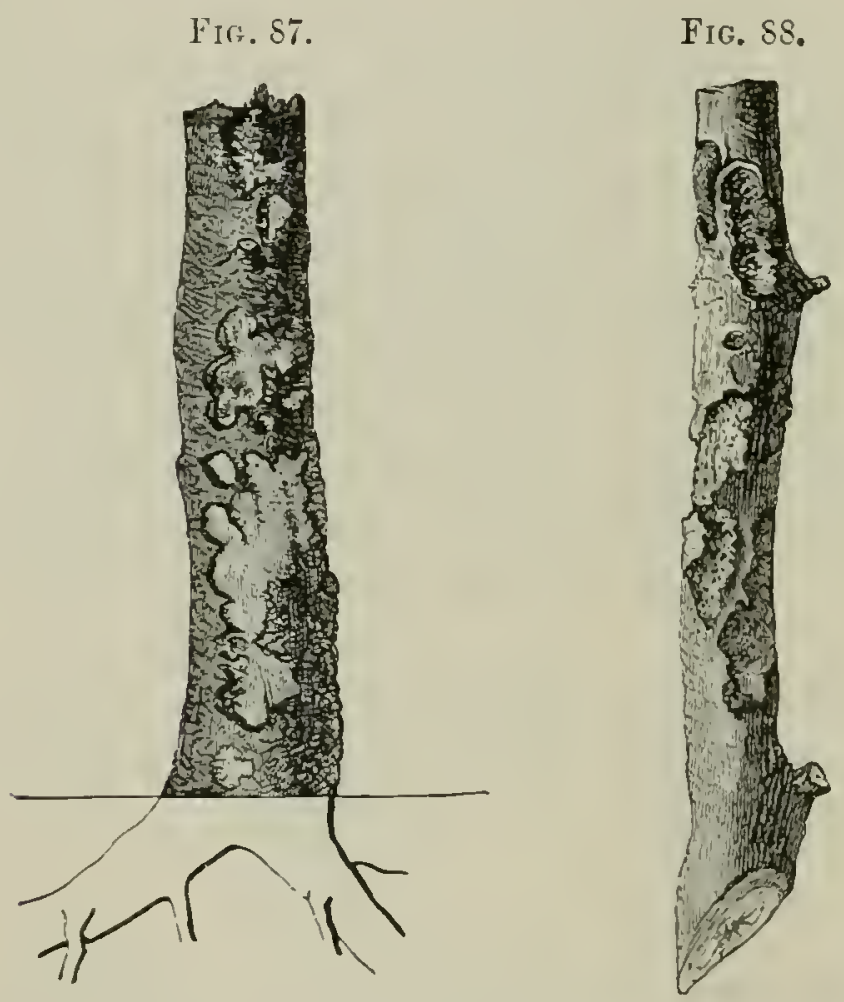

FIG. 89.

Young spruce plants gnawed by $H$. abictis, Fabr. (Natural size.) In Fig. 89, $a$ indicates the gnawed parts, $b$ those still covered with bark.

On plants over six years old, only those parts from 1 to 5 years old are attacked, as the six-years-old bark is too hard for the insect.

The damage done is much greater in the spring than late in the summer or in the autumn.

Freshly planted, extensire, sunny clearings near old woods are preferred by the beetle; especially those in which the stumps have been left in the ground, or not thoroughly extracted. The beetle does not appear at altitudes orer 3000 to 3300 feet. 
(d) Protective Rules.

The best means of prerention consist in supplying this destructive insect with as little opportunity as possible for breeding, in order to prevent its swarming in certain localities in the spring. The following are recommended :-

i. Establishment of small felling-areas, as if these are extensive the reproduction of the beetle is greatly facilitated.

Care must, however, be taken not to go too far in subdividing the felling-areas, as each area is a breeding place for weevils.

ii. Interruption in the order of successive fellings, so that when a felling has been made no adjoining area shall be felled till after the lapse of 3 to 5 years. In this way fresh breeding material is not afforded close to that of the previous year.

iii. Timely and complete extraction of stumps and roots from felling-areas in coniferous forests, in order to reduce as much as possible the number of breeding places for the $q$. This is the most effective measure of all. The extraction of the stumps must begin with the felling and be finished by the commencement of the next winter. It is better to grub up the trees with the roots attached than to fell the trees first and then extract the stumps and roots, and the former method has been followed for many years in Hesse and Nassau with very good results as regards the diminution of the numbers of weevils.

ir. The felling-areas should be rapidly cleared of all refuse, and all sickly and dominated undergrowth should be removed before the area is planted up, as such growth affords very farourable shelter for the weevils.

r. It has been proposed by Heyer and other authorities that planting should not be attempted until one or two years after the felling. By this time it is hoped the remains of the roots will have dried up and become unsuitable for breeding places. Dr. Hess considers that this involves too great a sacrifice of time and interest on capital, eren if it aroids the necessity for replacing 50 per cent. of the plants, and also that the consequent deterioration of the soil entails more expense than the cost of replanting the failures. He estimates that an interval of at least 3 years instead of 1 or 2 years is requisite to cause the roots to dry up and become incapable of serring any longer as breeding places. 
vi. Strong transplants should be used, together with 1 to 2 years' temporary field crops. Ball and mound planting are recommended, and Nördlinger prefers autumn planting, as the plants are less liable than those put in in the spring to attacks by the weevils. Temporary field-crops involve a thorough working of the soil, and this requires complete eradication of the roots of the former crop of trees.

In Saxony sowing in patches is preferred to planting where there is danger of an attack of weevils.

vii. Broad-leaved trees may be mixed with the conifers.

viii. Sheep may be fed orer the felling-area, as their droppings are obnoxious to the beetles.

ix. Protection of insect-enemies : the fox, rook, crow, jay, starling, etc.

\section{(e) Remedial Measures.}

i. Trenches to trap the beetle should be dug. These may be utilised either for isolating the plantations, or merely for catching the beetles. The isolating trenches are dug round the felling-areas in order to separate them from neighbouring cultivations, and to collect the beetles which may appear within their radius. The other class of trenches for trapping the insects is dug within the felling-areas. If this plan is followed, all cultivations are isolated. The trenches must be kept in order, and repaired after rainy weather; all beetles which are found in them should be crushed.

Unfortunately these very effective measures are not always possible, for instance in stony or very loose ground, or on steep slopes. The dimensions for the trenches are given on p. 154 .

ii. Artificial breeding-material may be supplied in June, in the form of smooth-barlied pine or spruce poles 3 to 5 feet long and 2 to 4 in. thick, cut when in full sap and buried in the ground at intervals of 30 paces apart, obliquely, so that one end is $10 \mathrm{in}$. deep in the ground, and the other about 1 or 2 in. above the surface. In order that the bark may be preserved intact, the holes must be dug beforehand and the pieces of wood placed in them and covered with earth and sods, which should be slightly trodden down. 
These traps should be placed in the felling-areas, but are useless in cultivations; they should be carefully pulled out in September and October and burned, so as to destroy the larvæ they contain, and in order that none of them may be overlooked, they should be placed regularly, or a small stick should be stuck in the ground by each of them.

iii. Traps made of pieces of bark may be distributed about the felling-areas and cultivations between the months of April and September, and must be renewed two or three times during this period as they become dry and cease to attract.

The best size is from 12 to $16 \mathrm{in}$. long $\times 6$ to $8 \mathrm{in}$. wide. They are placed with the bast downwards and sometimes several one over the other, and pressed down with clods or stones to keep them moist. They must be searched daily for the beetles. From 25 to 50 are required per acre, according to the abundance of the insects. Conifer-bark and, by preference, that of the Scotch pine should be used.

Children collect the beetles better and at a cheaper rate than adults. It is a good thing to place fresh pine twigs from the youngest shoots, under the bark to attract the beetles, which will be found eating these twigs when the bark is lifted up.

iv. Cultivations may be searched over for beetles by children or labourers engaged in plantation work just before the midday or evening rest, with good results, and at a very slight expense.

The above remedial measures, if steadily pursued, will render the attacks of these insects of no importance. The beetles should be killed by crushing on a hard surface or by scalding.

In Germany Hylobius pinastri, Gyll, a smaller species of weevil, does similar damage to that caused by $H$. abietis, and should be dealt with in the same manner. H. pineti, Fabr. attacks young larch in like manner. Neither is British.

\section{Pissodes notatus, Fabr.}

(a) Description.

Beetle 7 to $8 \mathrm{~mm}$. long, of a reddish brown colour, and irregularly sprinkled with bright-coloured squamous hairs; prothorax with about 8 yellowish-white spots, its hind-angles acute; elytra with impressed lines of punctures and two broad ferru- 
ginous or whitish bands, the anterior one interrupted at the suture.

\section{(b) Life-History.}

Period of flight: April and May. The eggs are laid in these two montlss, generally on the stems of young coniferous plants and preferably on the lowest internodes, but also on the trunk or roots of older plants, on felled trees and stacks of firewood, and on cones.

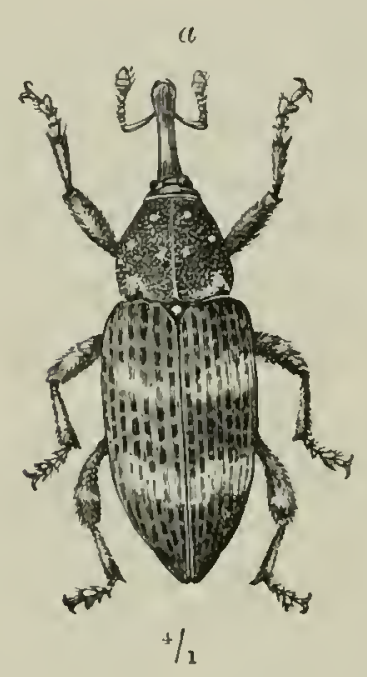

Fir. 90.
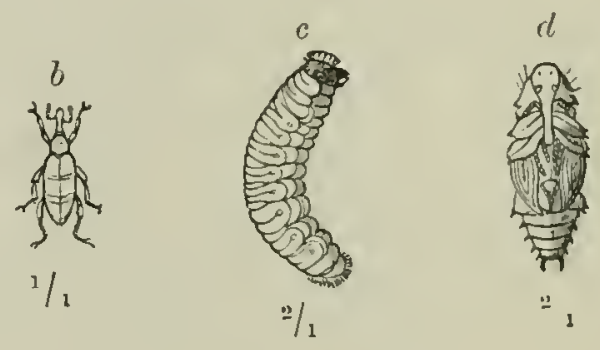

$a$ and $b$, Imago. $c$ Larva. $d$ Pupa.

The larve appear 3 or 4 weeks afterwards, in June and July, and live between the bark and wood, pupating in their burrows at the beginning of August.

The beetles emerge from the middle of August to the end of September, and hibernate at the roots, between cracks in the bark, uncter moss, litter, or in the ground.

Larve and pupie of this insect may also be met with dning the winter, and the beetles from these appear in the spring. Generation single. The insect is widely spread, but less common than Hylobius. This is decidedly the case in Britain, where $P$. notatus is almost confined to the conifer woods of Scotland.

(c) Relations to the Forest.

The beetle in May pierces the bark of Scotch and black pines, more rarely that of the Weymouth pine, spruce or larch, near 
the rootstock down to the bark and sapwood, partly to feed on the sap, and partly to lay its eggs there. It prefers 4 to 8-year-old plants, but also attacks poles up to 30 years of age. The perforations resemble fine needle holes, and are very numerous.

The larvæ eat their way between the wood and bark in descending, slightly winding, and constantly broadening passages, which become filled with wood-dust; at the extremity of the burrows they construct oval cocoons made of wood-fibres, out of which the beetle bores its way.

The insect is most destructive in the larval stage. Plants which are attacked may be recognized in July by small drops of turpentine on the bark, and by the reddening and eventual death of the needles. If it has not been girdled, a few green twigs may still be noticed on the wilting plant.

The larvæ also live in the young cones, often two or three together. Later on these cones become yellowish-grey, and may be recognized by the circular exit hole of the beetle, which is about the size of No. 6 or No. 7 shot.

\section{(d) Protective Rules.}

i. All sickly plants and dominated stems should be removed.

ii. All rootstocks should be grubbed up, and all felling areas rapidly cleared.

iii. Woodpecker's should be preserved.

\section{(e) Remedial Measures.}

i. Young plants containing larvæ should be pulled up and burned in June and July.

ii. All poles which have been attacked should be felled and barked.

iii. Billets of unbarked fir-wood should be

\section{FiG. 91}

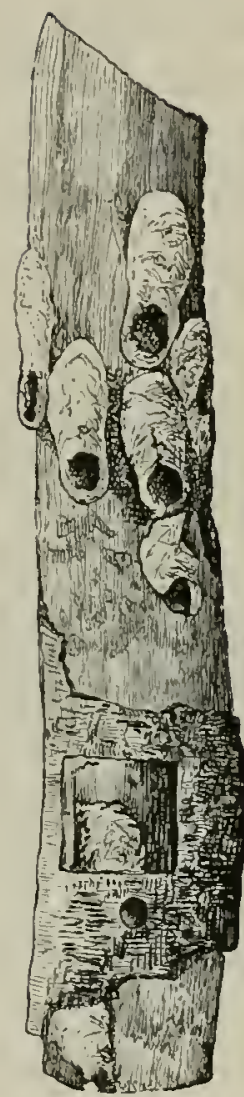

Cocoons of $P$. notatus, Fabr., on the stem of a young pine. In the portion covered with bark a square aperture has been cut, under which is a flight-hole.

(Natural size.)

\section{Fig. 92.}

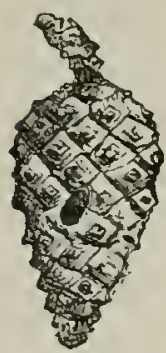

Pine-cone from which $P$. notatus, Fabr., has been bred. (Natural size.) 
laid about, as for Ir. abietis, in order to attract the beetles for egg-laying. They should be removed from the middle of June to the middle of July and burned.

iv. Cones attacked by the insects, and recognizable by the exuding turpentine, should be collected and burned.

\section{Other Species of Pissodes.}

Another species, Pissodes pini, L., attacks almost every species of pine and also young spruce in a similar manner to $P$. notatus. In Great Britain it is confined to Scotland, where it is locally common. It is a rather larger insect, with the anterior fascia on the elytra reduced to a few pale spots and the posterior fascia much narrower. Other species of Pissodes destructive to conifers in Germany are $P$. piniphilus, Hbst., on Scotch pine; P. hercynice, Hbst., on spruce, which has been very destructive in the Harz and other forest districts in Germany; and $P$. picere, Ill. on the silver fir.

\section{Fanilly VII.—SCOLYTidæ (Bark-BeETles).**}

\section{Description of Family.}

Beetles small and cylindrical, resembling the Anobiidce in their general form. Head globose, rarely produced into a short muzzle, and inserted deeply into the convex thorax; antennie short, more or less elbowed, and terminated by a large club, their funiculus composed of 2 to 7 joints. Legs short, the tibire spined or toothed on their outer border, the tarsi with four evident joints, the third sometimes bilobed. Abdomen of 5 segments, the two first of which are generally fused.

Generation: usually annual, sometimes biennial, or extending over a year and a half. Larce cylindrical, curved, with tubercles bearing strong hairs, apodal, and closely resembling the larve of weevils.

Pupe short and thick, with a few spines and hairs.

The larve and beetles live almost exclusively in the bark, bast

* Eiehlıoff, Wr. Die Emropäischen Borkenkäfer, Berlin, 18S1. The best monograph on the Bark-beetles. 
or wood, more rarely in the pith of our forest trees. They attack roots, stems, branches, twigs and young shoots, and young or old wood, preferring the latter. The lind of tree which they attack, and the arrangement of their borings is usually characteristic of each species. The beetles penetrate into the trees by boring a small entrance-hole, like a shotwound, through the bark. This is usually accomplished by the $q$, but in some polygamous species the $\delta$ enters the tree and excavates in the bark a small pairing-chamber. From this chamber, or from the entrance-hole, proceeds the gallery, which is made by the $q$, and in the outer surface of which a few air-holes may be perforated. The galleries may be divided into those constructed in the bark or alburnum, parallel to the exterior surface of the tree, and those which rum more or less vertically into the rood; the former may be subdivided into longitudinal or transverse simple galleries, forked galleries, or stellate galleries, the latter being formed by several $q$ boring radially outwards from the circumference of a pairing-chamber. The form of the gallery is in the main constant for each species, but may be modified by the size of the stem which is attacked, by the presence of kuots, \&c., or by the over-abundance of insects boring in the same trunk. The of lays her eggs as a rule in small hollows bitten out alternately on each side of the gallery she is gradually excavating, packing them in with wooddust. The larve, after hatching-ont, eat galleries which radiate from the breeding gallery, becoming gradually wider with the growth of the larræ, and filled with wood-powder; they pupate in a chamber formed at the end of the gallery either in the bark, bast or sapwood. Finally the beetles eat their way out through round holes-flight-holes - of the diameter of their own bodies.

This is the general mode of life of the bark-beetles. The larrie of those few species of Scolytidie which eat wood do not make regular galleries, but merely enlarge the egg chambers in the rood of the tree, and the mature insects escape through the bark by the original boring made by the mother.

Bark-beetles are specially addicted to conifers, and most of these species are monophagous. An occasional departure which they may make from this rule is to be looked upon as an exception due to local circumstances. There are also numerous 
species of these insects which feed solely on coniferous trees or on broad-leaved trees, but without attaching themselves exclusirely to a particular lind of tree. Even the few polyphagous species show an individual preference for either coniferous or broad-leared trees. There are no pantophagous bark-beetles, which eat herbaceous as well as woody plants, whilst those which only attack herbaceous plants are very few in number and without interest to the forester.

This family of the Coleoptera is generally regarded as the most important which the forester has to guard against, owing to the large number of very injurious species which it contains. Fortunately, many of these are mnknown in Britain, or are so rare as never to have been classed among our destructive insects.

\section{A. Subfamili Touicini.}

\section{Description of Subfamily.}

Head generally round, hidden beneath the thorax, and scarcely visible from above. Antennal funiculus 2 to 5 jointed. Thorax not contracted in front, convex or subspherical, its surface covered in front with small asperate or tubercular projections, behind usually punctate or smooth. Tarsal joints simple, never bilobed, the first much shorter than the other three together. Elytra sloping downwards at the apex, the sloping portion, termed the apical declivity, sometimes impressed or excavate and often toothed. Under-surface of the abdomen flat. There are 11 genera and 29 species recorded from Britain.

They generally live between the bast and sapwood, some entirely in the wood, and a few in the outer bark, and are very common in coniferous forests.

\section{Tomicus typographus, L.}

(a) Description.

Beetle 4.5 to $5.5 \mathrm{~mm}$. long, stoutly built, dark brown or blackish, shining, hairy, with testaceous antennæe and legs. Head with a small tubercle immediately over the mandibles. Thorax as broad as long, its dorsal surface with rather fine sparse 
punctuation orer the posterior half. Elytra with deeply impressed strix, somewhat finer posteriorly, the intervals flat, not punctured except at the sides and apex; apical excavation dull and irregularly punctate, with four teeth on either side, of which the third is the largest.

(b) Life-History.

Flight-time at the end of April or in May, at higher altitudes at the beginning of June. Under farourable circumstances a second brood may appear in July or August. The beetles are

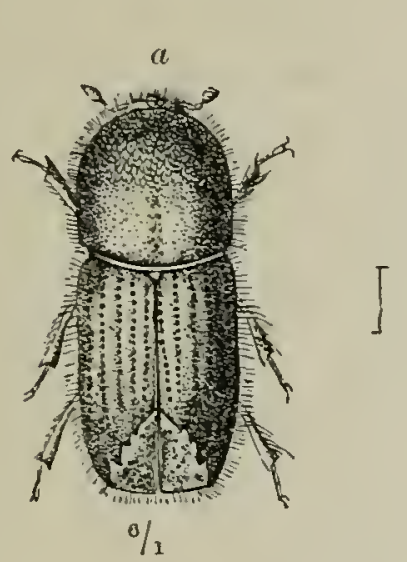

FIG. 93.

$$
\begin{aligned}
& \text { Tomicus typograplus, L. } \\
& \text { a Imago. } 6 \text { Larra. } \quad \text { Pupa. }
\end{aligned}
$$

found in pairs boring into the trunks of large spruce trees under the crown, especially on the sunny side; when they reach the bast, they prepare a breeding chamber; after pairing the of excarates one or more galleries running in the long axis of the trunk, which besides the original bore-hole, may contain 2 to 5 air-holes. On the right and left of the mother-gallery she bites out little recesses of the size of a poppy seed, and lays in each an egg, generally to the number of 30 to 50 , but sometimes as many as 120 , which she covers with fine wood-dust.

After 14 days the first larre appear in May and June, before the egg-laying is quite completed, and eat out slightly winding galleries in the bast, somewhat at right angles to the direction of the mother gallery, pupating at their ends in a chamber in the bast.

The newly disclosed beetles leave the trees through round 
looles in the bark in July or the beginning of August, and hibernate in stumps, cracks in bark, under bark, and more rarely in moss. When they come out early, before the end of Jume and under other favourable circumstances, they at once commence to lay eggr for a new brood, from which beetles may appear during September at the latest.

The entire development lasts on an average for 10 weeks, which is thus distributed over the various stages: egg, 1늘 to 2

FI $1 \dot{x}, 94$.

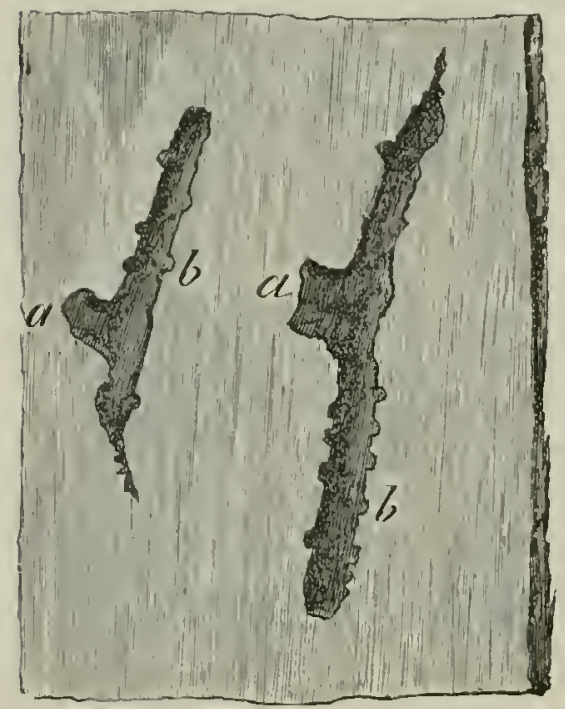

Burrows of T. iyporyrapleus, L., in spruce-bark. (Natural si:e.)

Commencement of mother-galleries with pairing-chamber $(a)$ and eggrecesses $(b)$. weeks; larva, 2 weeks; pupa, 3 weeks; and imago, $3 \frac{1}{2}$ to 4 weeks. When circumstances are rery favourable they can reach matulity in 6 or 8 weeks, but under unfavourable circumstances, damp cold weather, or in shady places, 12 to 13 weeks are required.

The generation is therefore either single or double, but in mountainous regions, such as the Thuringian forest and the Erzgebirge, a double generation is much rarer than in the plains.

In rare cases where there is abundance of food and a very large* swarm of beetles a threefold generation has been observed.

This dangerous pest has fortmnately been very rarely observed in Britain, and has never yet been recorded as a destructive insect. Observations on the duration of its generation in this climate are therefore wanting, but it is probably an annual one. As other insects, such as Xyleborns dispar, Hellw., which are normally rare in Britain, may occur unexpectedly in some numbers and prove destructive, it is desirable that the forester should be acquainted with the economy of such species as the present, so as to be prepared to meet a contingent outbreak, which is by no means impossible. T. typornrophus, L. may be

* Von Knjawa often found in pieces of bark $10 \mathrm{~cm}$. long and broad, as many as 40 to 50 beetles, and 1,000 pairs of beetles attacking one tree in the spring are capalie of produciug as many as 800,000 by the autumn. 
imported from time to time in the bark of unseasoned sprucetimber.

Bark-beetles are generally slow and lazy insects, which only in very warm weather will Hy to the top of trees. A flight of them to remote places is therefore a rare occurrence, due to over rapid multiplication and want of food.

(c) Relations to the Forest.

The beetle, both as a larva and as a perfect insect, does physiological damage to conifers.

It chiefly attacks old spruce trees, generally those between 80 to 100 years old, and very seldom when under 50 year's. It is said to have been found quite exceptionally on larch and Scotch pine and on the Cembran pine. Even if, in these cases, it has not been confused with the extremely similar species $T$. amitinus, Eichh., on the larch, and T. cembre, Heer, it must be admitted that $T$. typoF19. 95.

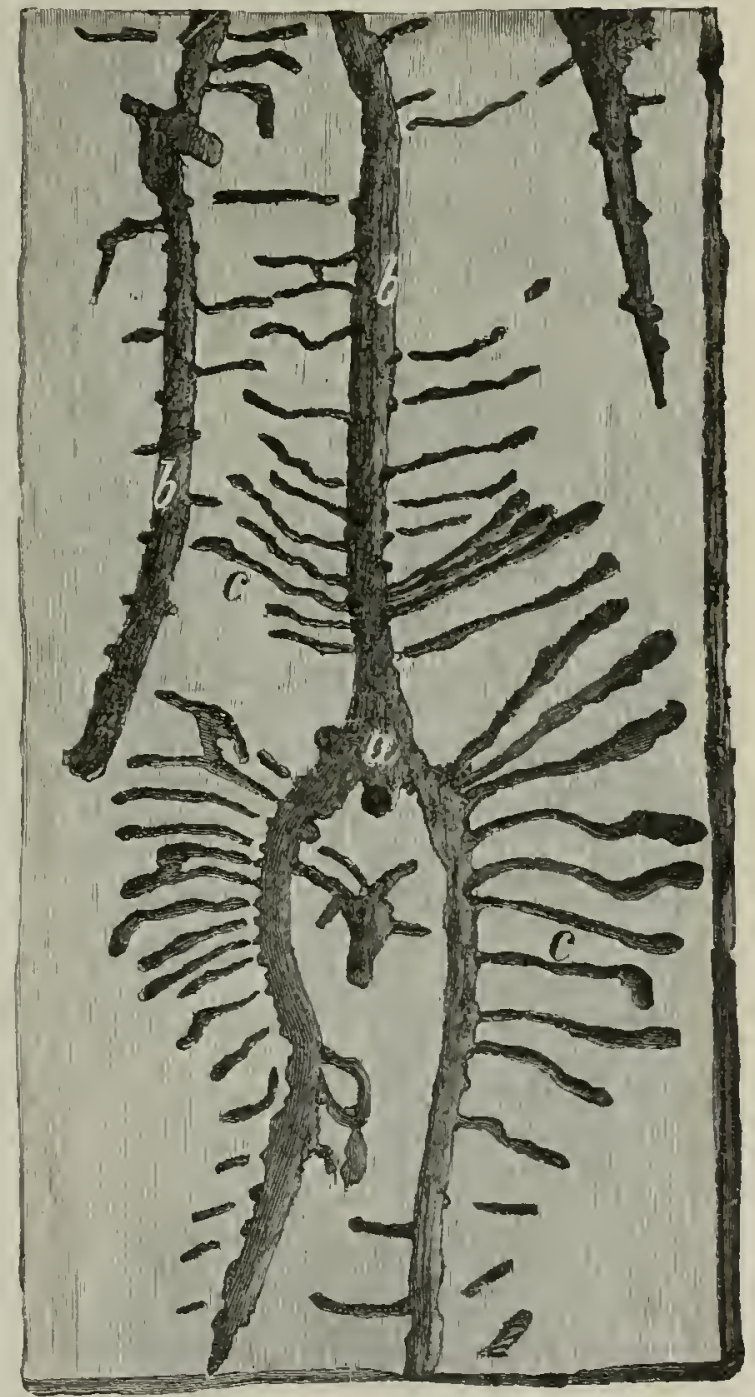

Burrows of T. typographus, L., in sprucebark. (Nutural size.)

(c) Pairing-chamber (with entrance-hole).

8 Mother-galleries (vertical and forked).

c Larral-galleries (widening outwards).

graphus only appears in swarms in spruce roods, and only attacks trees with thick bark.

The injuries are confined to the bast-layer, and are fatal to the trees which are attacked.

The resulting disease is called spruce-canker. Sy'mptoms of the attack are-yellow or red discoloration of the needles, grey- 
Fir: 96.

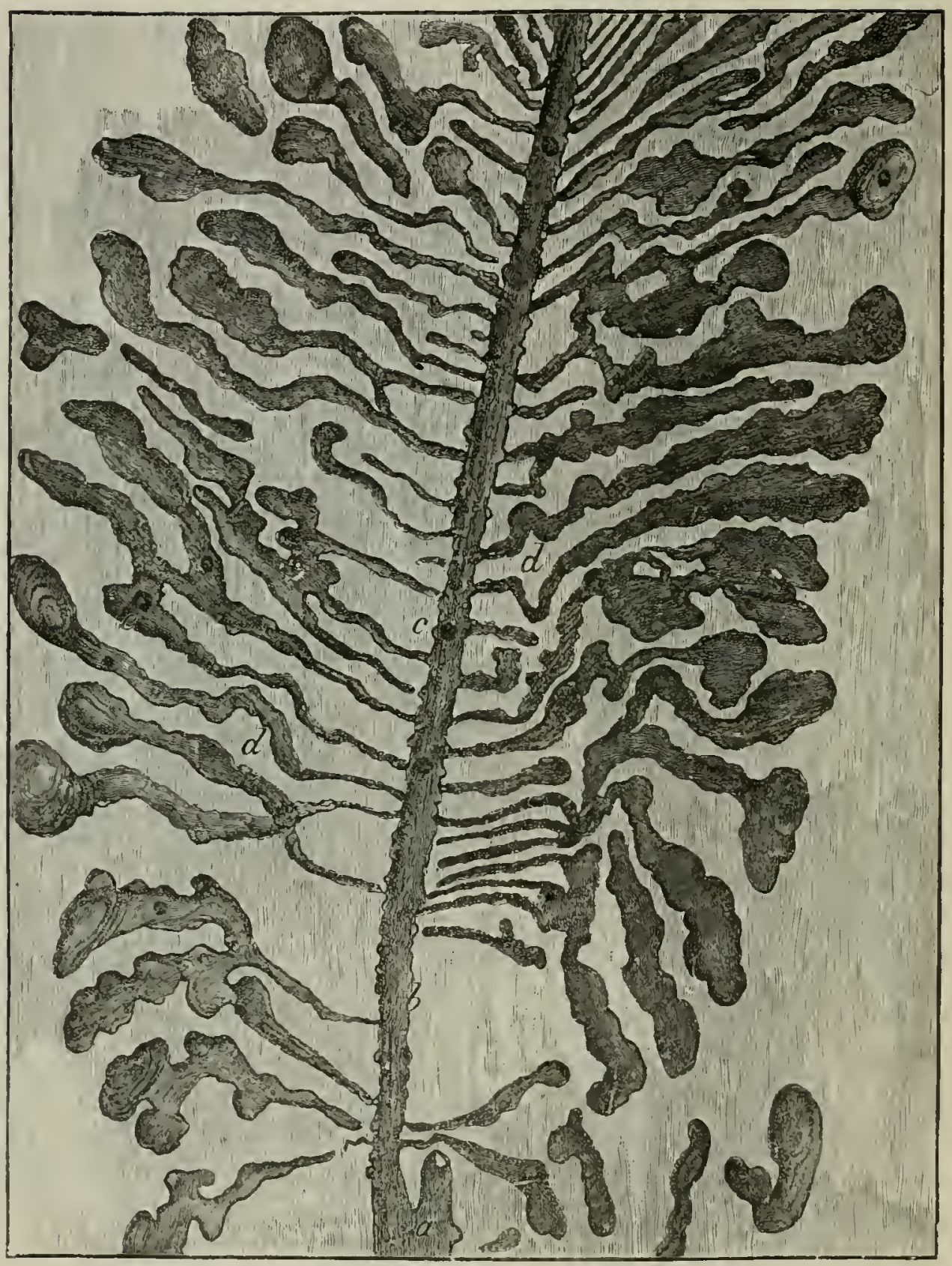

burrows of T. typographus, L., in spruce-bark. (Naturul size.)

"Pairing-chamber. $c$ Air-hole. e Flight-hole.

$b$ Mother-gallery. d Larval-galleries.

ness, loosening or falling off of the bark, numerous bore-holes through its substance, and the presence on the trunk of boringpowder ejected from"the burrows.

Trees infested in the spring appear differently affected to those injured in the summer. The needles change colour rapidly in 
the former case, whilst in the latter the needles remain green, even whilst the bark has already partially fallen off. This depends on the difference in the movement and composition of the sap at the different seasons of the year. In the spring, the ascent of water from the ground is cut off from the crowns of the trees by the destruction of the bast, and the foliage at once begins to change colour. In the summer the descent of the supply of nutritive material prepared by the leaves is cut off, while the crowns still get the nutriment, hence the needles remain green while the bast is killed. Nevertheless trees attacked in summer eventually die.

This species of Tomicus is therefore extraordinarily destructive to spruce forests, and may be considered the most destructive of all European forest insects. The beetle prefers trees freshly felled during the season of growth and also sickly standing trees, but when it appears in large numbers, even perfectly sound trees are attacked. It avoids barked logs, and rarely attacks stools; it only utilises the upper layers of firewood-stacks for oviposition. Its favourite resorts are thinly stocked woods, and the borders of felling-areas, generally in sheltered, dry warm places with a southerly aspect. Its distribution extends far north and high on the mountains, which it prefers to the plains; it is hardy and but little affected by unfarourable weather.

The worst attacks of this insect recorded in the present century were in East Prussia between 1857-1862, and in the Bohemian and Bavarian forests in 1873-1876.

Professor Lindemant Moscow thinks that this beetle nerer attacks perfectly sound wood. As the Russian forests are generally full of dead and dying wood, it is no wonder that the beetle should have no reason there to attack sound trees.

\section{(d) Protective Rules.}

i. Spruce-trees should only be grown in suitable localities. They should be mixed with silver-fir, and there should be early and frequent thimnings.

ii. The woods should be inspected every May, and all sickly trees should be removed.

iii. All rules applicable to tlre locality for protection against 
windfall, snow-break, etc., should be observed, as all broken wood affords good breeding material for bark beetles.

ir. All broken wood should be speedily barked and worked up, including semi-erect trees the roots of which have been loosened by the wind. In this operation standing trees should be injured as little as possible.

v. Damage by game, especially peeling, should be guarded against.

vi. Extensive clear-cutting areas should be aroided, and the felling areas should be cleared as soon as possible. Above all the woods should be kept clean.

Small felling-areas should be adopted as are usual in the Thuringian forests, in contra-distinction to the large fellingareas in the Harz, where the insect has been notoriously injurious.

vii. All $\operatorname{logs}$ intended to remain for any prolonged time in the forest should be barked.

It is imperative that this shall be done to all larger logs, but this work need not be carried out till May, in order that the larve which may have developed in the logs may be destroyed. Barking in May is also cheaper than in winter, as the work is easier and the days longer. All large fuel logs sbould be split so that their bark may be limited to narrow strips. They should be stacked with the bark downwards. Stools remaining in the ground should also be barked.

viii. Trap-trees should be prepared for felling (see $e$, i.).

ix. All enemies of bark-beetles should be preserved. Tomtits, golden-crested wrens and woodpeckers are most important in this respect. When a swarm of bark-beetles is approaching extinction, ichneumon-wasps appear in great numbers.

\section{(e) Remedial Measures.}

i. 'Trap-trees should be felled from March till September, and should be barked and the bark burned as soon as the larve are full-grown. Old or somewhat dominated spruce-trees with small crowns should be chosen, especially when the root-stock has been somewhat loosened from the soil by the wind, as such trees are more readily attacked by the beetles. In the spring, whilst 
the weather is still damp, it is sufficient to fell new trap-trees at intervals of from 5 to 6 weeks, but in summer this should be done at least once a month. The local flight-periods should be followed in this respect, and from 8 to 14 days before trap-trees are barked fresh ones should be felled.

In order to facilitate control the trap-trees should be numbered, and a register kept up to record the development of the beetles. Cogho reckons 5 trap-trees for 100 paces along the boundaries of the felling areas.

Ratzeburg recommends that the trap-trees should not be deprived of their branches, and that they should be placed on stumps or stones, so that the beetles may bore in from below as well as from above. Most anthors agree with this adrice, but Fischbach recommends the lopping off of the branches, as then the trees dry up the sooner, and he also maintains that the barkbeetles only attack lopped trees, which is contrary to experience. Hess recommends that the branches be left, both on account of the cost of lopping, and becanse numbers of bark-beetles of other species are attracted to them. The trap-trees should be barked at latest as soon as pupation of the larva has occurred, and all the bark must be burned.

If the barking be longer deferred, some of the beetles will escape, and if it be done too early too many trap-trees will be required, or the beetles will oviposit in standing trees.

The removal of the bark must be carefully done over cloths, and should be done on cool moist mornings, as the beetles are then most inert.

It is not sufficient to expose the bark to the effects of the sun; this may lill larve which are really exposed, but in the case of thick bark many would escape, and pupre from which beetles are just ready to emerge would not be killed.

It is best to burn the bark during cool weather in natural hollows, or in trenches, and to surround them with a wall of glowing embers, so as to kill any beetles which might happen to creep out. The smaller branches and twigs should also be burned, as they generally contain many other smaller but dangerous bark-beetles, such as $T$. chalcographus, L. $T$. typographus, L., may also swarm in the branches.

It is 110 use burying the bark at a less depth than 16 to 
18 in., as the beetles can find their way out from shallower pits.

ii. All standing spruce which show signs of having been attacked should be felled and barked in Jume, and the bark burned.

iii. In the case of a large swarm of these beetles, all trees attacked must be felled, the larger baulks barked and the remainder made into firewood or charcoal. All recently attacked trees should be felled first, as the beetles have probably left the trees which have been long attacked.

Some details may be given of the latest plagues of bark-beetles in the Bavarian and Bohemian forest.* In the former about $24,700,000$ c. feet of wood was killed in six forest-ranges. The beetles were occasionally so numerous as to obscure the sun. Accompanying $T$. typographus, L., were 'T' chalcographus, L., Hyl. palliatus, Gyll, \&c. In the Finsterau range 1,000 woodmen were engaged to fell and bark the trees, and, as local labour was insufficient, Bohemians and Italians were recruited for the work.

In the Bohemian forest, the damage done was even on a larger scale: between 1872 and 1874, on 9,012 hectares (22,530 acres), $3,632,050 \mathrm{~cm}$. $(127,964,000 \mathrm{c}$. feet) of wood, or about $450 \mathrm{c}$. feet per acre, were felled. Thus altogether in Bohemia and Bavaria 152,600,000 c. feet of wood was killed by these insects.

\section{2. 'Tomicus amitinus, Eichl.}

(a) Description.

Imago 4 to $4.5 \mathrm{~mm}$. long. It greatly resembles the foregoing species, from which it can be distinguished as follows:lead without frontal tubercle; interstices between the elytral striie punctured throughout; apical excavation with a silky lustre, with regular rows of punctures.

\section{(b) Life-History, dec.}

Similar to the foregoing species, but besides spruce the beetle attacks Scotch pine and larch more frequently than ' $T$ '. typographus, L. Its mother-galleries are bifurcating and frequently

* Der Borkenkiaferfinss in Bihmerwalde. Allg. Frst. u. Jgdztg., 1874, p. 349 
stellate; the larval galleries start at an oblique angle to the former, and run in a zigzag direction, and both galleries are more in the sapwood, whilst those of $T$. typographus, L., are confined to the bast. The insect, which is more active than 'T.t.ppographus, L., is often commoner on the Continent. It is at present unknown in Britain, but is, perhaps, as likely to occur in injurious numbers as its congener, and is certainly a worse enemy to the Scotch pine.

\section{(c) Protective Rules.}

As in the former case, but in mixed coniferous forests, besides spruce, Scotch pine and larch trap-trees should be felled.

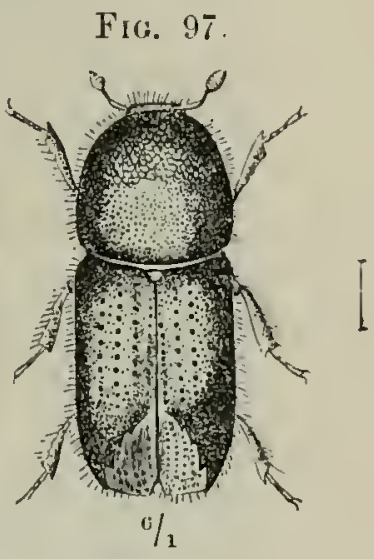

Tonicus amitinus, Eichb.

\section{3. 'Tomicus (Pityogenes) chalcographus, L. (S'mall 6-tootherd} Spruce Barli-beetle).

(a) Description.

Beetle 2 mm. long. Very shining, almost glabrous, either entirely bright reddish brown, or with the thorax and the base of the elytra dark brown. Prothorax contracted towards the apex, its posterior half scantily punctured, with a smooth median line. Elytra with fine punctured striæ, their interstices mostly smooth and impunctate, apical excavation narrow and deeply impressed, its elevated sides armed with 3 teeth on each elytron, which are larger in the $\delta$ than in the $q$.

\section{(b) Life-History.}

Season of flight: April and May. The eggs are laid in spruce-bark. The larve appear in May and June; pupation follows in June and July, and the newly hatched beetles bore their way out generally in July. The insect may hibernate in the larval, pupal or imago stage; the generation is usually annual, sometimes twice in the year.

$T$. chalcographus is much less rare in Great Britain than T. typograplus. It is, however, local and not usually common, 
Fir. 0 .

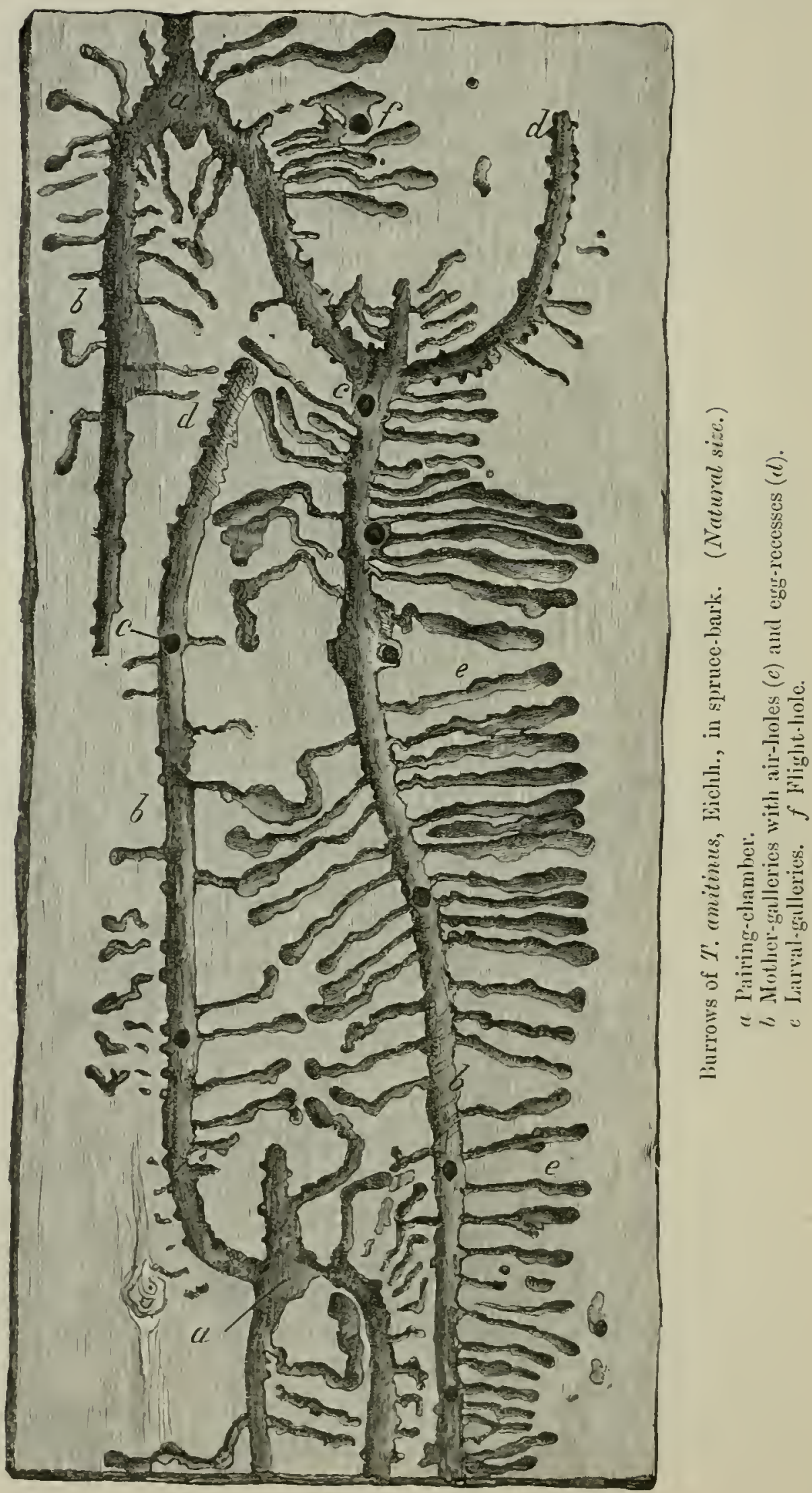


resembling in this respect many other insects that feed on the spruce, which is not an indigeuous tree. On the Continent it generally accompanies the two preceding species.

\section{(c) Relations to the Forest.}

This bark-beetle ordinarily attacks only the spruce. It has, however, occasionally been found in silver-fir, larch and Scotch pine, and also on Weymonth and mountain pines.

It is very fond of interrupted pole-moods about 40 years old: in the case of old trees it attacks only the branches and cromn,

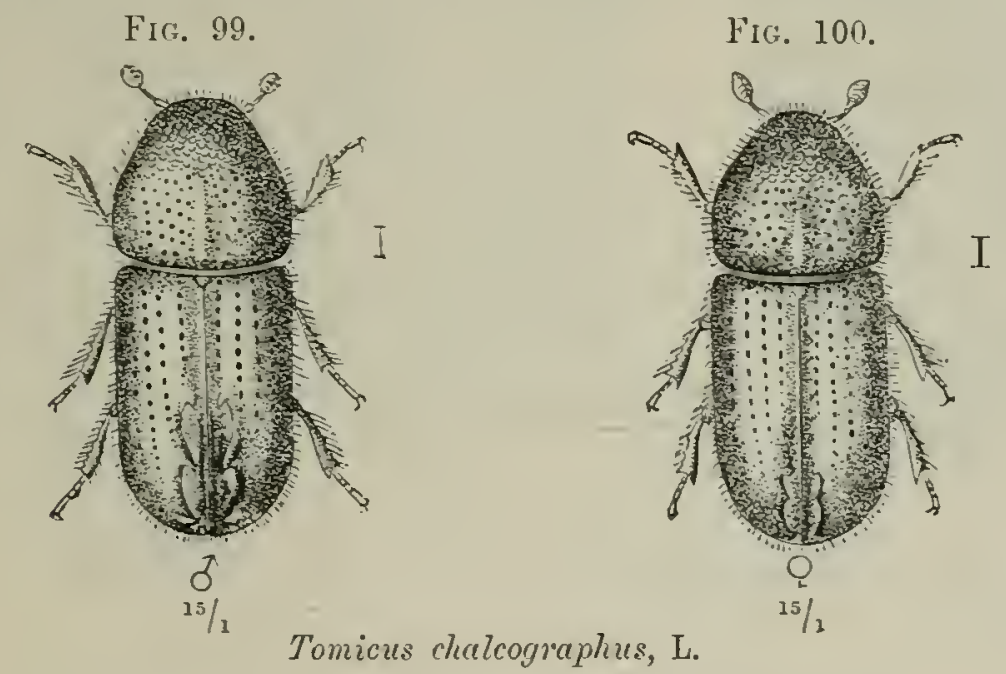

leaving the destruction of the bast of the stem to the larger species. Exceptionally it may be found in 8 to 12 -years-old spruce thickets which have been attacked by fungi (Ácidium abietinum, de Bary).

The breeding-galleries are of characteristic stellate form, consisting of 4 to 7 slightly curved arms, which run transversely rather than longitudinally, groove the sapwood and spring from a pairing-chamber excavated in the outer part of the bark. From each side of these extend the larval galleries which rum principally in the bast, marking the saptrood less deeply.

The protective rules are the same as for T. typographus, L.

\section{Tomicus sexdentatus, Boern.}

(a) Description.

Bectle 6 to $8 \mathrm{~mm}$. long. The largest species of Tomicus. Elongate, cylindrical, shining, with long pubesceuce, brown, 
with yellowish-brown antemne and legs. Prothorax longer than broad, sparsely and moderately deeply punctured behind the middle, with a wide smooth median line. Elytra with strong punctured striæ, apical excaration deep, its elevated margins furnished with 6 teeth on each elytron, of which the 3 upper ones are small, and the th is the largest.

FIG. 101.

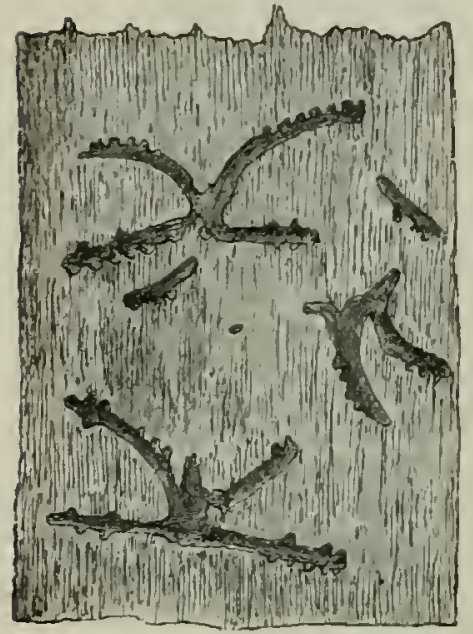

Stellate galleries of $T$. chalcographus, L., with egg-recesses, in spruce-bark.

(Natural size.)
FIG, 102.

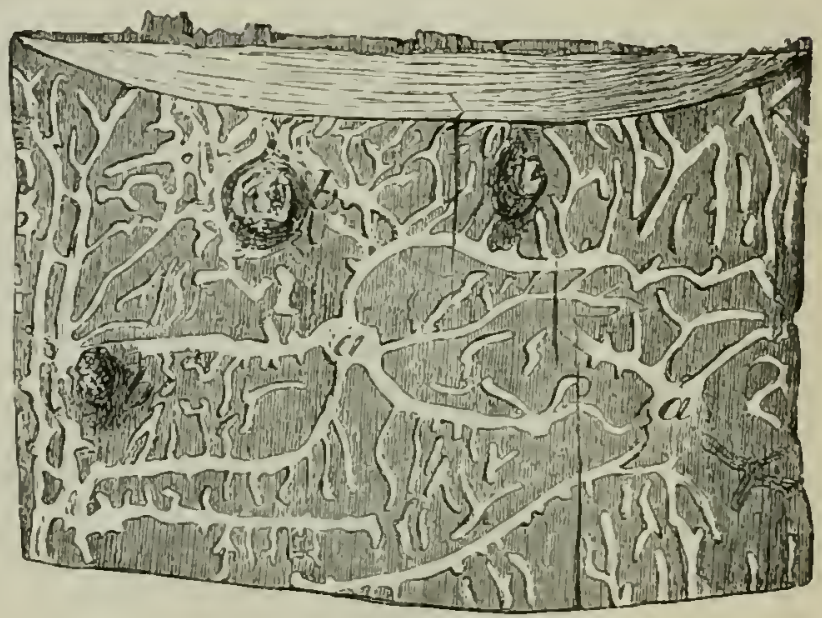

Stellate galleries of $T$. chalcographus, L, on spruce sapwood, radiating from the pairing-chambers $(a)$. l. Knots.

(Natural size.)

\section{(b) Life-History.}

Season of flight: usually somewhat later than for 'T'. typorraphus. It is found in May and again in August and September.

It selects for oviposition large Scotch pines with thick bark, and generally fallen or freshly-felled trees, windfalls and stacks of firewood; rarely standing trees. The derelopment resembles that of ' $T$ '. typographlus.

The larve are found in June and July; the pupæ in July and August; the newly emerged beetles in Angust and September. The latter forthwith pair, and a new brood commences. The insect hibernates under bark as an imago of the first or second brood.

Generation either ammual or twice in the year.

\section{(c) Relations to the Forest.}

The beetle attacks the Scotch pine, and prefers old trees with 
thick bark. It has also been observed on black and cluster pines, and very rarely on spruce. In the absence of old woods it has here and there attacked poles 20 to 30 years old. The attack is on the bast, and resembles that of ' $T$. typographus, but is less regular, and the breeding galleries are long and wide. Sometimes the numerous larval galleries coalesce, in which case the brood live together and completely undermine the bark. This beetle is more frequent in the plains than in the mountains, and may be considered rare. In Britain it has been found about as often as $T$. typographus, L. The protective measures are the same as for that insect.
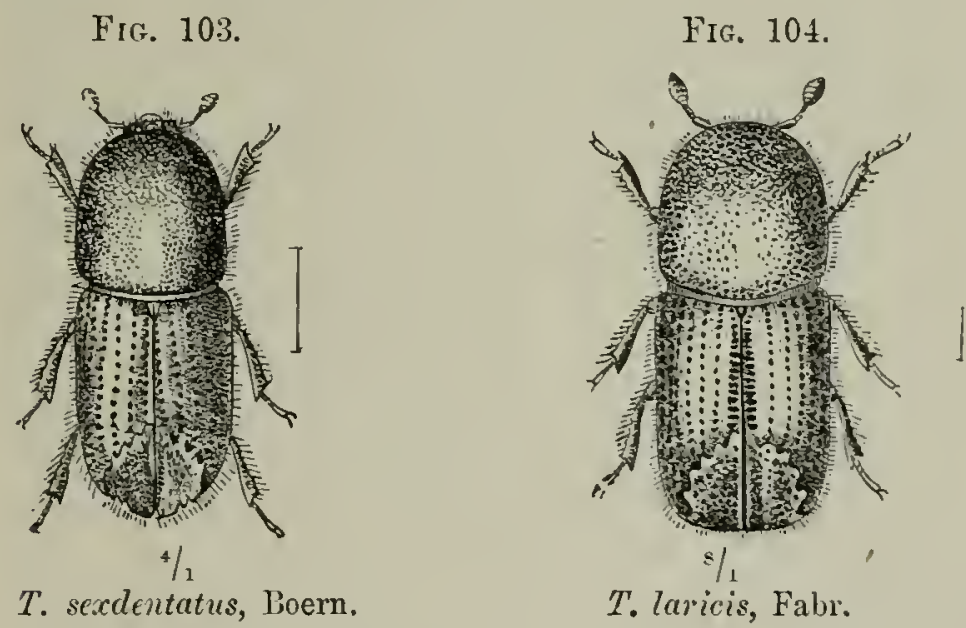

5. Tomieus larieis, Fabr.

(a) Deseription.

Beetle 3.5 to $4 \mathrm{~mm}$. long, of cylindrical shape, dark brown, shining, thinly haired, with antennx and legs ferruginous. Thorax scarcely longer than broad, its posterior half sparsely punctured, with a less distinct median impunctate line. Elytra with regular punctured striæ, the interstices with single rows of fine points, apical excavation almost circular, deep, its elevated margin with from 3 to 6 short blunt teeth, and an accessory tooth on the inner side of the 2 nd and 3rd teeth.

(b) Life-History.

Season for flight: April and May; a second brood appears in July and August. 
FIG. 105.

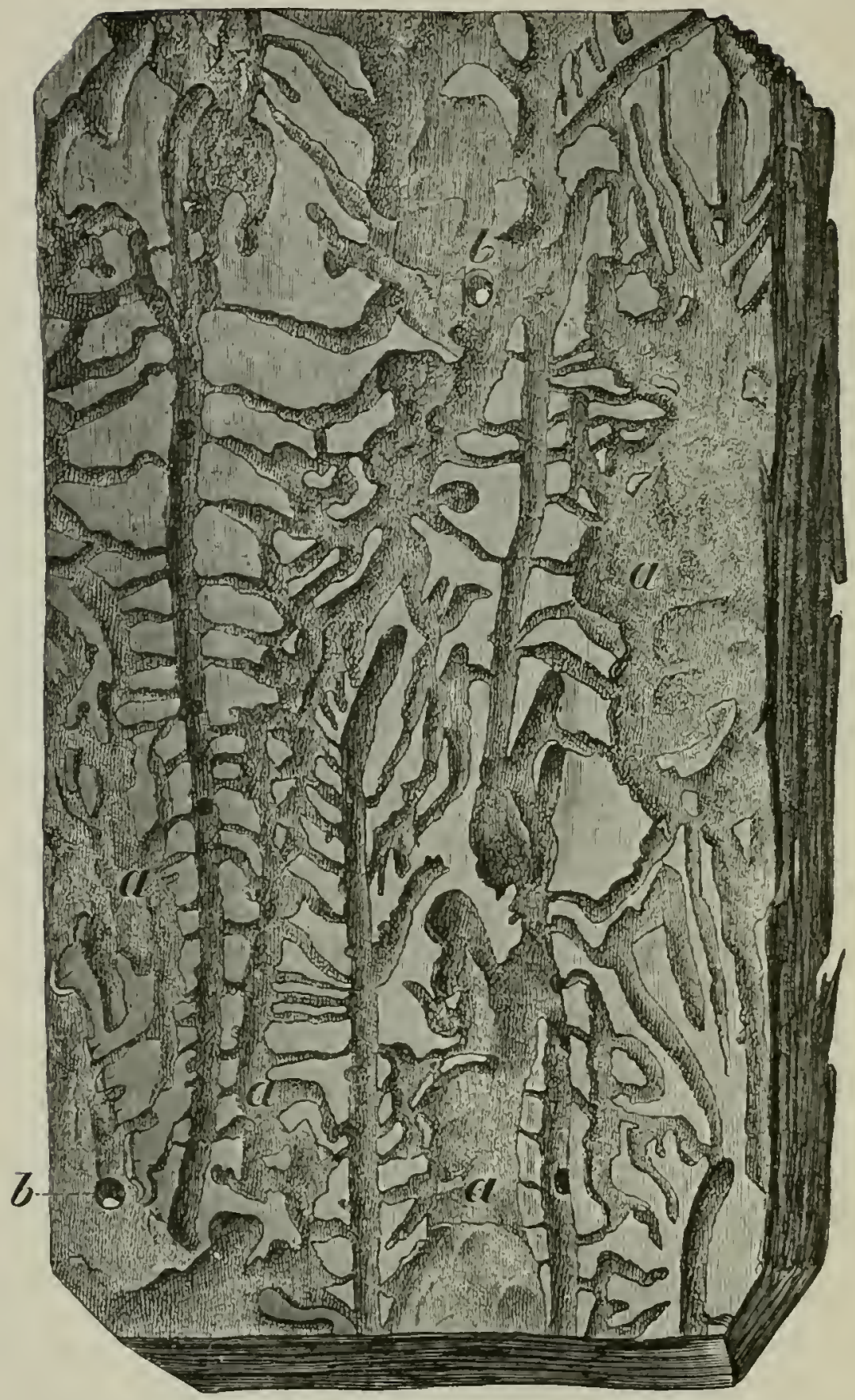

Burrows of T. laricis, Fabr. in larch-bark. (Natural sizc.) a Conjoinecł larval-burrows. $b$ Flight-holes.

The eggs are laid in the bark of various conifer's. Stems injured by a forest fire, or felled trees, are selected in preference for egg-laying.

Larve appear in June, and those of the second brood in 
August or September. Pupation takes place in the bast in June, July, and again in September and October.

The first brood reaches maturity in July, and the second brood in October. The beetles hibernate under the bark.

The generation is therefore donble, and may be threefold in southern France. The beetle is found almost throughout Europe, and is conmon in most places. In Britain it is, perhaps, the least rare species of the genus, if Tomicus bidentatus, Hbst. be excepted.

\section{(c) Relutions to the Forest.}

The beetle does not by preference attack the larch, but is found on all conifers, particularly on the Scotch pine, and then on the spruce. It attacks poles and mature trees, and exceptionally young growth.

The mother and larval galleries are in the bast. The former are generally vertical, slightly curved or bent at an angle at either end, with 2 to 4 air-holes (Fig. 105); the latter are horizontal for a short distance, but gradually bend up or down, and often rum into one another, forming a common chamber (Fig. 105, a).

The beetle is said to gnaw young plants (Scotch pine), near the collum, but this statement requires confirmation.

\section{(d) Protective Rules.}

(a) Precention.

Keeping the forest clean, and rapid clearing of felling-areas.

(b) Remedial Measures.

i. Trap-trees as for 'T. typogruphus, L.

ii. Poles or logs used for traps stuck and placed into the ground in March. These should be examined in June, and those containing larve should be burned.

iii. All young plants which may be attacked and which may be recognized by the reddening of the needles, should be pulled up in June and burned. 


\section{T'omicus (Pityogenes) bidentutus, Herbst.}

\section{(a) Description.}

Bectle 2 to $3 \mathrm{~mm}$. long; pitchy-black, somewhat shining, with fine hairs; antenna and legs ferruginous. Thorax constricted in front, and rather deeply punctate behind, with a smootl median elevated line. Elytra with rows of punctures, impressed towards the sides only, apical excavation somewhat deep in the $\delta$, with a single strong hooked tooth on each side; in the of the declivity is impressed on either side of the suture, and the teeth are reduced to inconspicnous tubercles.

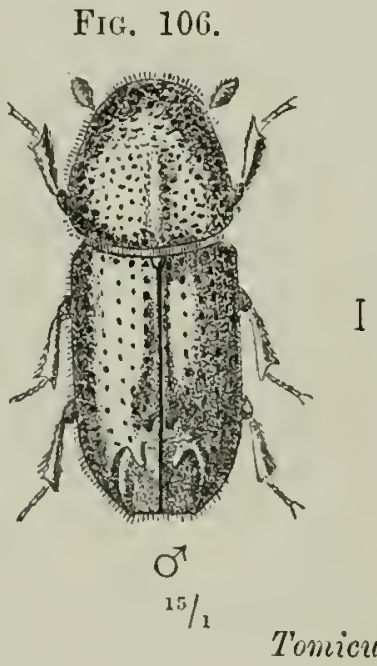

T'omicus bidentatus, Hbst.

FIs. $10 \%$.

(b) Life-History.

The of lays her eggs in May and June in Scotch pine woods, on young plants, poles, branches, and on refuse on felling areas. The pairing chamber is often furnished with short prolongations which are breeding galleries commenced but abandoned, and penetrates deeply into the sapwood. Portions of the stems covered by thick bark arc aroided.

The larve appear in June and July; the second brood in August and September.

Pupation: in July and August, in the bast or sapwood; the second brood, which hibernate as larve, pupate in the following May.

Flight-period: in August. The second brood is mature by 
June of the following year, and is followed by a third brood in the autumn which winter in the beetle stage.

The generation thus extends over $1 \frac{1}{2}$ years. The beetle frequently appears in company with $T$. laricis, Fabr., and is widely distributed. It is common in conifer forests in Britain.

\section{(c) Relations to the Forest.}

The common Scotch pine is the chief tree attacked by this barkbeetle. It has, however, also been found in the Weymouth, cluster and mountain pines, and R. Hartig has noticed it on the spruce. It prefers the plants of 6 to 12-years-old cultivations, and only attacks the branches and twigs of older trees, where the bark is thin. As, however, it attacks trees which are thoronghly sound, the crowns of trees are considerably thinned out by this beetle.

The bast and sapwood are both attacked. The irregularly stellate mother-galleries are generally 4 to 7 -armed, rarely 3 -armed. The branches of these galleries run longitudinally rather than horizontally, and have a knotted appearance, as the egg chambers are large and comparatively far apart. The larval

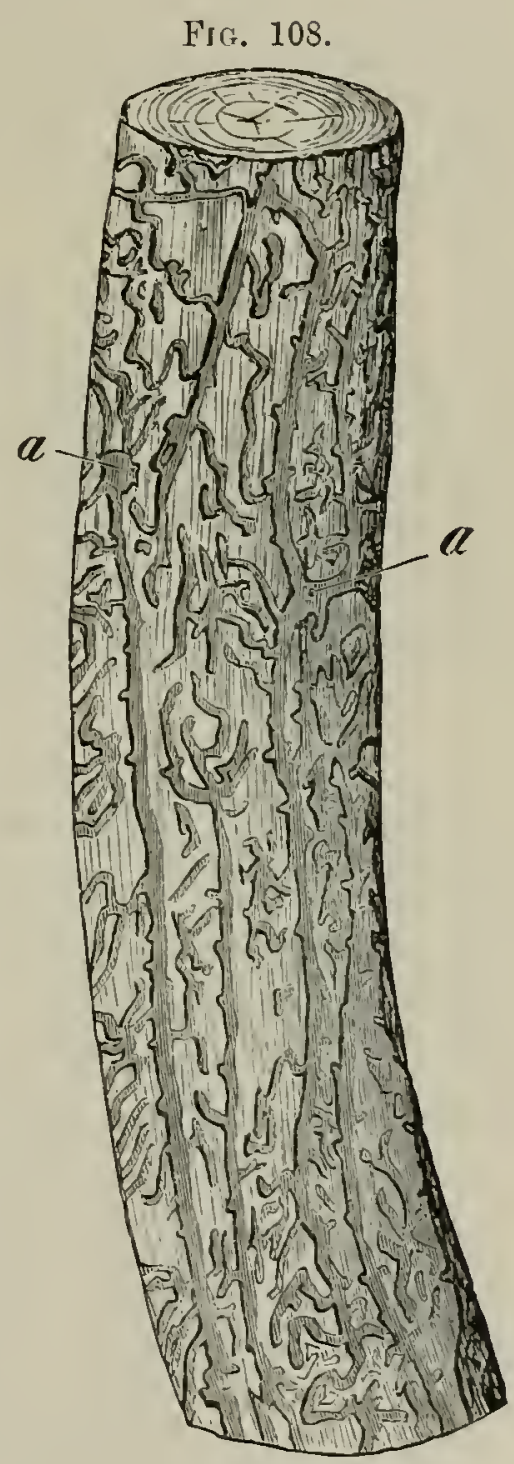

Burrows of T. bidentatus, Hbst. on pine sapwood.

(Natural size.)

a Pairing-chambers. galleries are somewhat winding and sparsely distributed; botl linds of galleries may be clearly seen on the sapwood, though those made by the larva are more marked in the bast.

This beetle readily attacks woods which have suffered from fire. Trees which have been severely attacked may be recoguised by the yellowish colour of their crowns. 


\section{(d) Protective Riules.}

As for $T$. laricis, L.; but trap-trees are useless. Instead of these, branches may be used as traps, which should be burned as soon as they are stocked with larve, and replaced by fresh ones every 4 to 5 weeks until the autumn. Poles seen to be attacked by larvæ should be immediately felled and barked, and the bark burned.

\section{Tomicus acuminatus, Gyll.}

Beetle 3 to $4 \mathrm{~mm}$. long; brown, with yellow-grey pubescence. Elytra regularly punctate-striate, the excavation circular, acuminate at the apex of the suture, its elevated margin with 3 t,eeth on either side, the first a small tubercle, the last the largest, and situate about the middle of the margin.

\section{Life-History, de.}

This species chiefly infests the crown of full-grown or old Scotch pines. The mother-galleries consist of 3 to 5 branches, radiating from a spacious pairing-chamber and grooving the sapwood rather deeply when excavated in thin bark. The larval galleries are twisted, frequently coming into contact or even crossing, but as a rule scarcely marking the sapwood.

The species, though not very commou in Europe, is not rare in Scotland and the north of England, and must be considered as one of our injurious species. Its attacks must be treated on the same lines as those of other species of Tomicus.

\section{Trypodendron lineatum, Gyll.}

(a) I)escription.

Bectle 3 to $4 \mathrm{~mm}$. long, short and cylindrical, black, the hinder part of the thorax and the elytra yellowish brown. The latter with three black bands each, along the suture, in the middle and along the outer margin, of which the middle band is not always complete; they are marked with rows of large punctures; apical declivity not impressed nor toothed. Antenval club flattened oval, blunt at apex, without trace of sutures. 


\section{(b) Life-History.}

'The season for flight is in March and April, and again in June and July.

The o prefers felled trees, provided they are still sufficiently moist, also windfalls, and sometimes stems still in the ground, high stumps or broken trunks. A good deal of care is shown in the selection of breeding places, and the material must be neither too fresh nor too dry. The beetle rarely bores into cleanly barked stems, and is only rarely found in standing healthy trees. The o bores vertically into the tree for an inch or more, constructing one or more brood galleries at the end of her tumnel, usually at right-angles to the entrance burrow, and always transversely to the long axis; in the floor and roof of these galleries she guaws small cylindrical holes vertically into the wood for the reception of the eggs, and after oviposition, she blocks these holes with wood-dust, forming partitions between the secondary and primary galleries. There are generally from 30 to 50 eggs.

The larve appear in May, and those of the second brood in July and August.

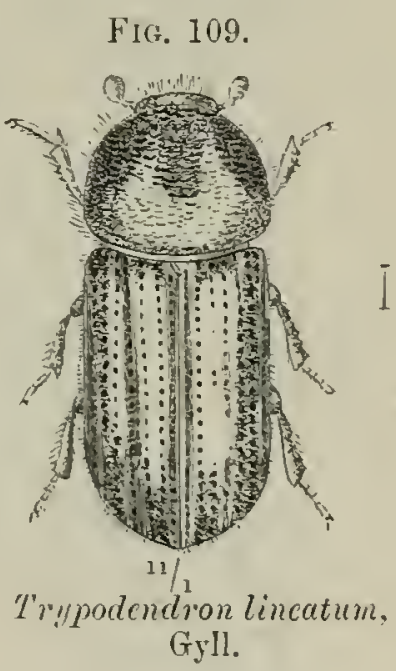
They pupate in a cocoon of particles of wood in July, and again in August and September.

The imagos appear about the middle of July, and leave their birthplace through the old mother-gallery, after breaking through the partition, which remains intact up to that time. They at once set to work to produce a fresh brood. The species is wideiy distributed throughout Europe, but is confined in Great Britain to a few localities in the Tay and Dee districts of Scotland, where it has not as yet proved injurious.

\section{(c) Relations to the Forest.}

The beetle attacks all conifers, but chiefly the silver-fir and spruce, and only large trees. The round-bored gallery penetrates at right angles to the axis of the tree. It consists of 
an entrance passage and breeding gallery. The latter is either' merely a prolongation of the former, or is usually composed of two branches, which generally follow the annual zone of the wood in the same plane. It is rare that several amnual zones are traversed by it. The entrance gallery is generally confined to the sapwood. The larra on emergence feed on the sap of the wood, and by gnawing extend their egg chambers to short

FI: 110 .

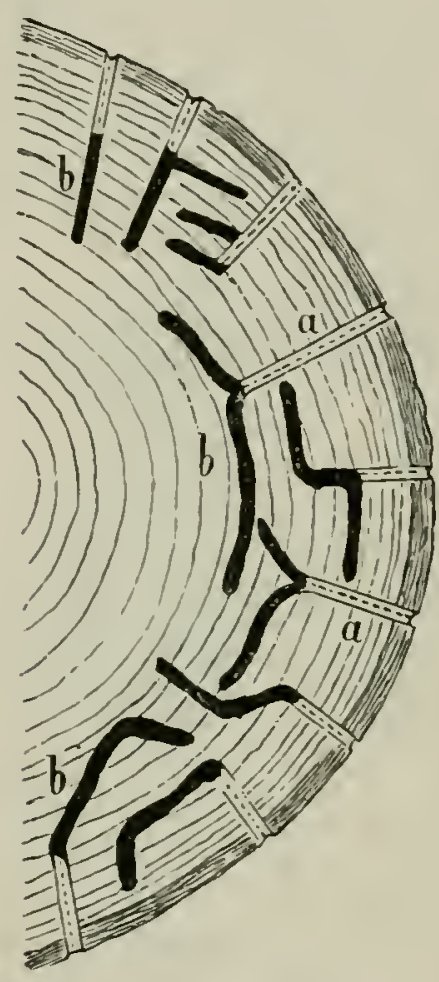

Transverse section of it spruce stem (reduced) with burrows of $T$. lineatum, (ivill. (Natural size.)

a Entrance-galleries.

$\checkmark$ Breeding-galleries.
Fic. 111.

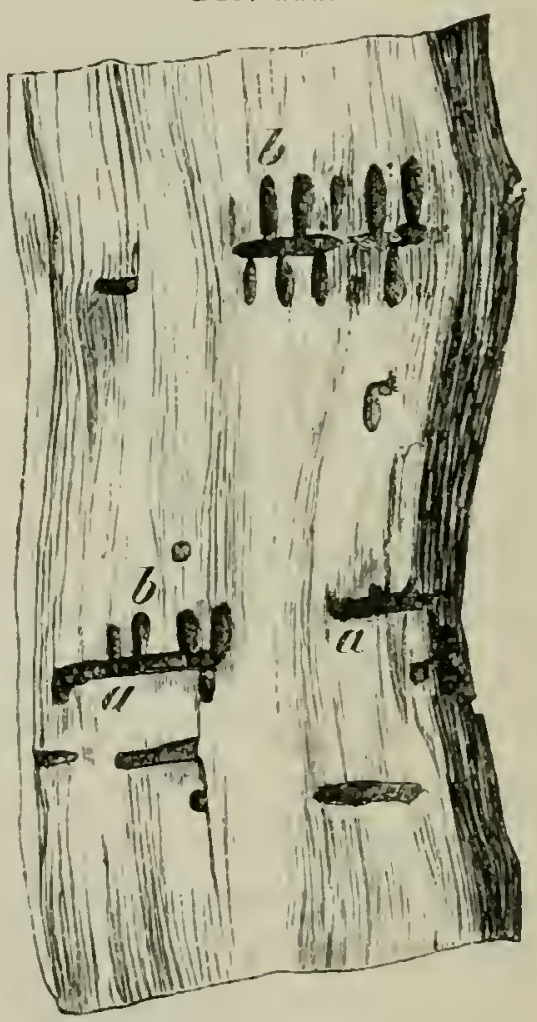

Raclial burrows of $T$. lincotum. Gyll., in spruce-wool. (Natural size.)

a Itother galleries.

b Larval galleries and l'unal cliambers.

cylindrical tumnels in which they pupate. In the secondary galleries, and on the partitions, white fungus mycelia (Monilin candida) appear, which are also devoured, not as was formerly supposed because they are the chief food of the larre, but to clear the way for the larva.

Later on the walls of the galleries and the adjoining rood become black owing to fungoid growth.

The beetles damage the commercial value of the wood, the 
finest stems being frequently bored like a sieve, and rendered useless for most purposes. The insect is most frequently found in forests where much wood is broken by wind or snow, and where there are winter-fellings.

\section{(d) Protective Rules.}

i. Immediate removal of all sickly coniferous trees and of broken wood and stumps from the forest. The latter should at least be barked, if their timely removal is not advisable.

ii. Felling in the growing season, and immediate removal of the bark.

It may happen, when the beetle is in great numbers, that barked trees may be attacked. If winter-felling cannot be avoided, and barking is impossible, the wood should be removed before March.

\section{(e) Renedial Measures.}

i. Tree-traps may be felled in July and August to attract the beetles about to lay. These trees must be barkeả and split open to destroy the larve, and fresh tree-traps provided continually till October.

ii. Fire-wood may be used as traps, but must be removed from the forest before the beetles come out.

\section{Trypodendron domesticum, L.}

(a) Description.

Beetle 3 to $4 \mathrm{~mm}$. long. Similar to the preceding species but more elongate, with the prothorax entirely black; the elytra livid yellow, regularly punctate-striate, and impressed at the apex on either side of the suture. Antennal club as in the preceding species, but produced into a blunt angle on the inner side of the apex.

\section{(b) Life-History, die.}

Similar to that of ' $T$. lineutum; but less important on account of its breeding chiefly in stumps and windfalls. It attacks not conifers but broad-leaved trees, chiefly beech, oak and hirch, also lime.

The mother-galleries do not branch as a rule but run vertically 
into the wood for two or more inches. This insect is not uncommon in large woodlands in Britain. If it injures

FIG. 112.

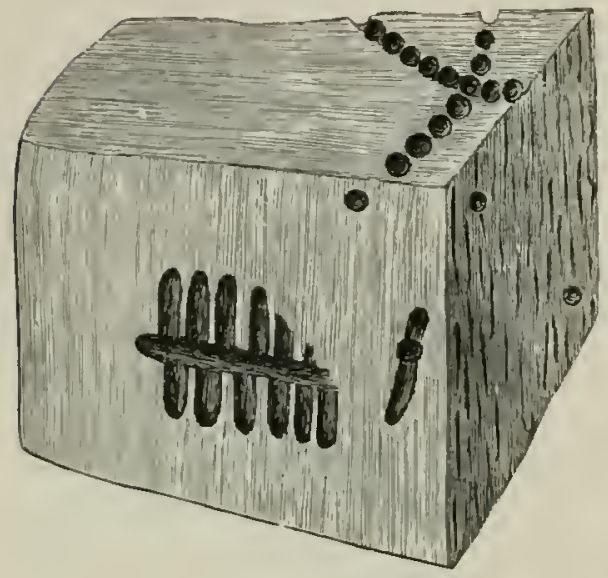

Rarlial galleries of $T$. domesticum, L.. in beech-wood.

(Natural size.) commercially raluable timber, the forest should be cleared of material containing the insects; spring felling is desirable.

'T. quercus, Eichh., is still more like T'. lineatum, Gyll, in appearance, but is distinguished by having the antennal club angulate at the apex, as in ' $T$ '. domesticm. In habits it resembles the latter species, but is much less common in Britain, being almost entirely confined to

the neighbourhood of Sherwood Forest.

10. Xyleborus dispar, Hellw.

(a) Description.

Bectle of $2 \mathrm{~mm}$. - o $3 \mathrm{~mm}$. long. Pitch-black, the antenne and legs testaceous-red. o short, conrex, ovoid and very hairy, with the thorax granular in front, punctured torards the base, with a smooth median line. The of cylindrical, its thorax in front strongly asperate. Elytra strongly arched at the declivity, with rows of deep punctures, and raised tuberculate interstices between them.

\section{(b) Life-History.}

The secuson for flight is in May. 'The of bores into several kinds of broad-leaved trees to lay her eggs, in preference below a branch, but never near the ground, attacking felled wood and young standing trees.

The larve appear in June, pupate in July in the secondary galleries, and the beetles emerge in August. They hibernate in the galleries, and there is only one generation. This beetle is not everywhere common on the Continent, and till recently was 
regarded as one of the rarest British insects. But since 1891 it has been destructive in certain Gloncestershire fruit-orchards.

\section{(c) Relations to the Forest.}

Oals and fruit-trees, especially apple and pear, are chiefly attacked; also beech, hornbeam, birch, maple, ash, alder, horse chestnut and plane.

The $q$ bores a vertical entrance-gallery into the tree, like other species which enter the wood deeply, from which she excavates one or more transverse secondary galleries along the line of one of the annual rings ; from these again are constructed

F 1 (., 113.

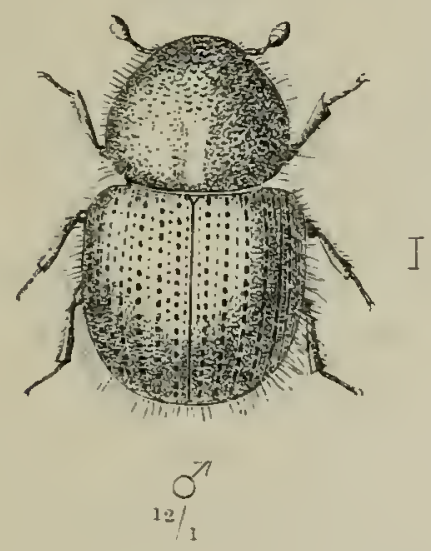

FIG. 114.

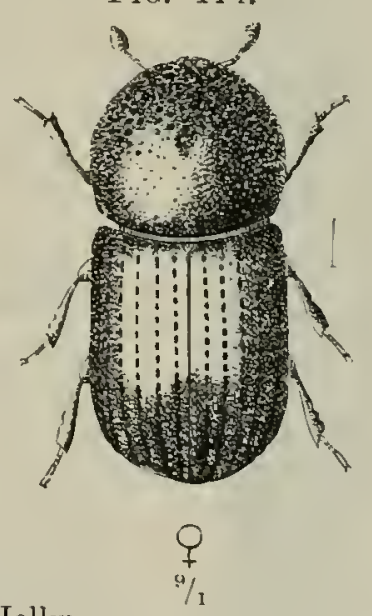

Nyleborus dispar, Hellw.

tertiary brood-galleries which run longitudinally upwards or downwards. In the brood-galleries the eggs are laid in clumps: the larræ live in them, and do not bore but feed on the exudations of sap and on the fungi which overgrow the burrows. The galleries are bored at the height of the growing season in the onter zones of the wood of perfectly healthy saplings, which become diseased and die. The presence of the beetles may be detected by the borings, and the whitish bore-dust heaped up at the foot of the plant.

The beetle is rery destructive in orchards, and sometimes to young oak-saplings.

(d) Protective Rules.

Unbarked orchard-props should not be used, as it frequently 
happens that the beetle finds its way from such props into the fruit-trees.

FIเ: 115.

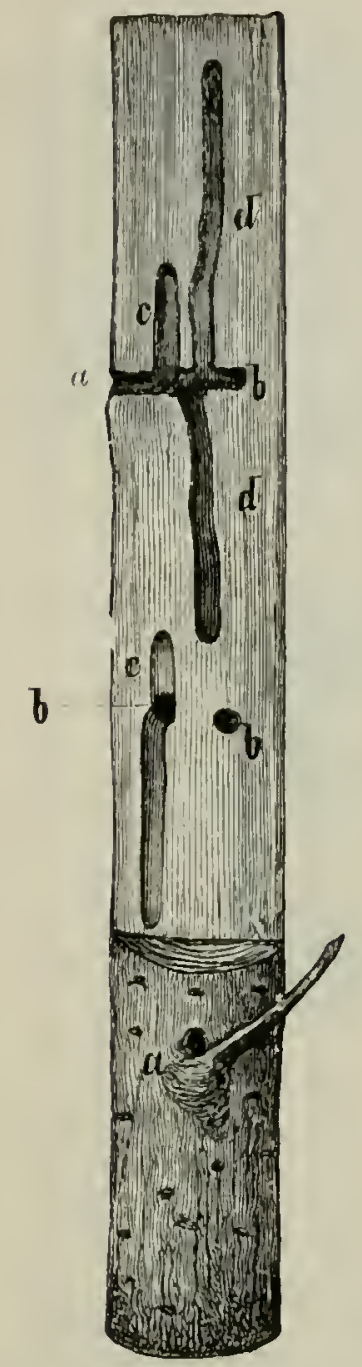

linrows of $X$, dispar, Hellw., in an oak-sitpling. (Naturol sive.)

¿ Eintrance - hole, usually under a twig.

b) Mlozher - galleries.

c Commencement of lateral galleries.

(l Completed lateral galleries in whieh the larve lie. (e) Remedial Measures.

i. The entrance-holes to the burrows should be smeared with tar.

ii. All plants which have becn attacked should be removed and burned.

iii. The beetles may be killed inside the galleries with wire, and the bores blocked up by wooden pegs. 'This method of treatment is generally impracticable, but has been adopted with success in orchirds.

\section{B. Stbfailiy Hylesinint.}

\section{Description of Sulffamily.}

Head prominent and not concealed by the prothorax, with a short and broad rostrum; antennie with a funiculus of 5 to 7 joints; thorax narrowed in front, uniformly punctate on the back; first tarsal joint much shorter than the other three togrether, the third bilobed or heart-shaped (except in the case of Polygraphus pubescens, Er.); apical declivity convex and without teeth; undersurface of the abdomen not abruptly flexed upwards.

Most species breed in the bast and especially frequent conifers; a few make pupal chambers in the sap-rood.

1. Iylastes palliatus, Gyll.

(a) Description.

Bectle 3 to $4 \mathrm{~mm}$. long, of stout build; thorax and elytra reddish-brown and covered with fine grey hairs; the former broader than long, strongly constricted in front, densely and 
coarsely punctured with a narrow median ridge. Elytra with rather fine punctured striæ, the interstices rugose, tuberculate, and with a series of short hairs.

\section{(b) Life-History.}

The flight-season is at the end of March and April.

Coniferous wood in logs, or stacks of fuel, chiefly when damp and lying in shady places, are selected to receire the eggs.

The newly disclosed beetles appear from April or May until July; they at once pair and produce a new brood, and in July new breeding galleries are found amongst the larve and pupre of the old brood.

The second brood of beetles appears from the beginning of October, and hibernates in cracks of the bark, moss, sc. There are two generations, and the species is common and widely distributed both in Britain and on the Continent.

(c) Relutions to the Forest, dic.

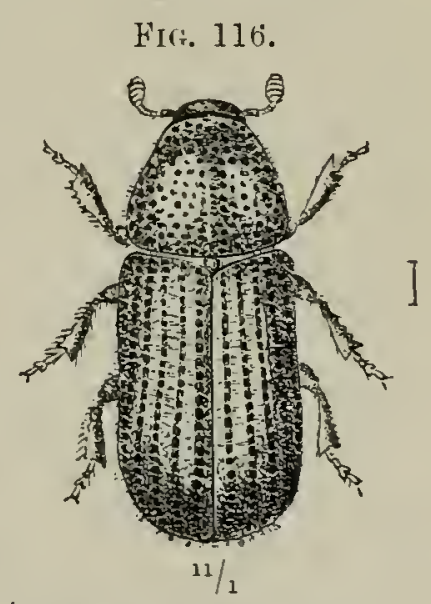

The beetle attacks all conifers, but Hylastes palliutus, Gyll. especially spruce and Scotch pine, and only middle-aged and old wood; they also bath as larvæe and beetles damage the bark and bast.

The primary galleries are short and vertical, with a bootshaped bend at one end. They are sometimes forked. The secondary galleries are conspicuously long and irregular, often crossing one another and extending down to the sap-wood.

Authorities differ as to the destructiveness of this beetleRatzeburg, König and Kelluer consider it very destructive; Stein thinks its destructiveness over-rated, and Eichhoff that it only does secondary damage.

More information as to its habits is therefore called for. The economic treatment of this species is the same as that of T. typographus, L. 
2. Hylastes ater, Payk.

(a) Iescription.

Bectle 4 to $5 \mathrm{~mm}$. long, of slender build; deep black, with brownish-red antenn:e and tarsi. Thorax much longer than broad, parallel-sided, closely and deeply punctured, with a smooth median ridge. Elytra deeply punctate-striate, with wrinliled and somewhat tubereulate interstices.

\section{(b) Life-Histor\%.}

This species, and $H$. opacus, Er., hare a similar biological history, which is as follows:-They fly in March, April and May. Eggs are laid in stumps and roots of the Scotch pine, in preference in those of trees felled in the previous year; but in the ease of 11 . ater, eggs are sometimes laid in young pine transplants.

The larre appear in April, and the mother and larral galleries then form a confused pattern.

The newly hatched beetles may first be seen in June, and according to Eiclihoff they may produce a fresh brood, which comes out in October or November. The imagos hibernate in stumps or in plants which they have injured.

The generation is ammual or double, or it may be biennial according to various observers; it requires further elucidation.

\section{(c) Relations to the Fionest.}

'This beetle is only hurtful in the imago stage; before the middle of June they begin to wander from their breeding places to the neighbonring plantations and eat the bark of 2 to 6 -yearold Scotch and Austrian pine, and of other species of pine, especially at the collum and on the roots. The needles of the plants which have been attacked turn yellow and fall off; the plants die, or become so loose in the soil that they can be easily pulled up. $I$. ater is common in Britain, and its aliy H. opacus, Er. is nearly as frequent. The latter species is also recorded from elm and ash. 
(d) Protective Rules.

i. Timely and thorough removal of stumps and roots, burning of the bark, or thickly smearing all exposed wood with tar.

ii. Thorough cleaning of the felling area.

iii. Careful planting, and avoidance of all deep planting.

\section{(e) Reniedial Measures.}

i. Burying trap-logs, or laying out bark-traps as against Hylobius abietis, Fabr., p. 205.

ii. Digging up all attacked plants with a spade, and burning them in kilns with the roots inwards.

Fir: 11\%.
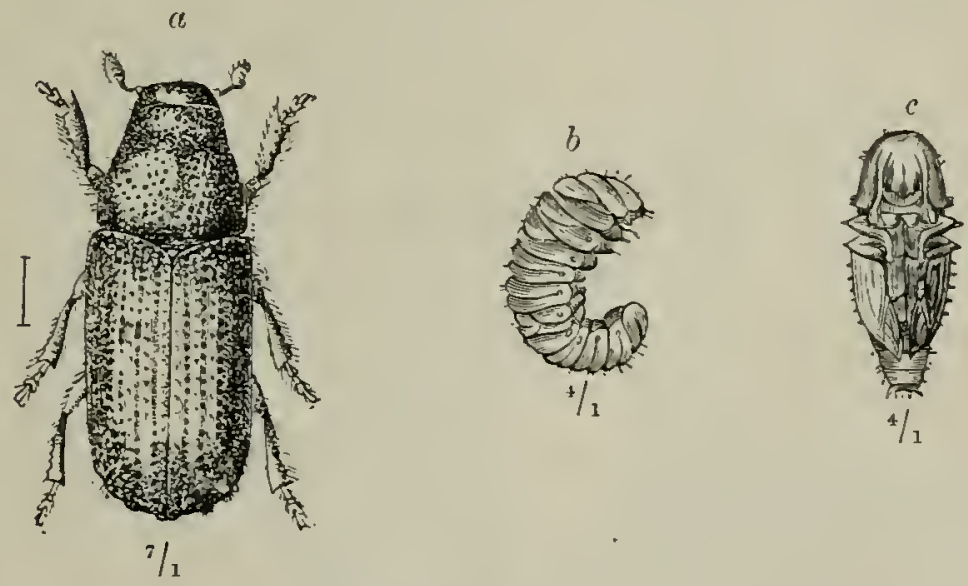

3. Mylurgus (Myelophilus) piniperda, L. (The Pine Bectle).

(a) Description.

Beetle 4 to $5 \mathrm{~mm}$. long; head and thorax black, elytra blackish or dark brown; antenna and tarsi rusty red. Thorax not longer than its width at the base and tapering in front, shining, with scattered deep punctures, obsolete towards the middle. Elytra with fine punctured striæ; the interstices somewhat granulate, each with a row of bristle-bearing tubercles, absent on the apical portion of the second interstice (counting from the suture), which is shightly impressed. 


\section{(b) Lịfe-History.}

The flight is at the end of March, April, and also in May; under farourable cireumstances, again in June and July. The eggs, to the number of 100 and orer, are laid similarly to those of $T$. typographus, L. on large Scoteh pines, \&c., and in preference on the south-west side of the trees. There is, however, no breeding chamber, as copulation takes place outside on the trees. The o prefers dying or felled timber with rough bark, windfalls, stumps and broken trees. On standing trees the lowrer coarsebarked portion of the stem is selected, as the brood-galleries are entirely limited to the bark. If no old wood is to be found, the beetle attacks young poles.

The larre hatch in April or May, in about 12 to 20 days after the eggs have been laid; they pupate in June or the beginning of July.

The beetles appear at the end of June and in July. Some later ones may emerge in August. The beetles which develop early, in .Tune in mild localities, produce a second brood, which is ready by the end of August, and attaclis the terminal shoots of the tree and branches; those which come out later do not pair but at once commence their destructive work in the crowns of the trees. Thus the whole development of the beetle may last from 60 days under very farourable circumstances, to 80 days. In order to hibernate, the beetle bores into the rootstock or roots of standing trees, sometimes into stumps, often into the thick bark at the lower part of the trunk.

The generation is either single or double. The insect is rery numerous, and widely distributed; it is common in almost every pine-wood throughout Britain.

\section{(c) Relations to the Forest.}

The beetle generally attacks the Scotch pine, but also the Weymouth and cluster pines and other species of pines. It has also been frequently observed on the spruce; rarely on lareh.

It attacks old and young trees, but prefers the former, and is rery rarely found in woods less than ten years old. Woods between thirty-five to forty years old are chiefly attaclied. The insect does three linds of damage. 
First of all the beetles and larre attack the bark and bast. The beetle makes longitudinal galleries, with one to three air-holes, which may be straight, but generally

FIG. 118.

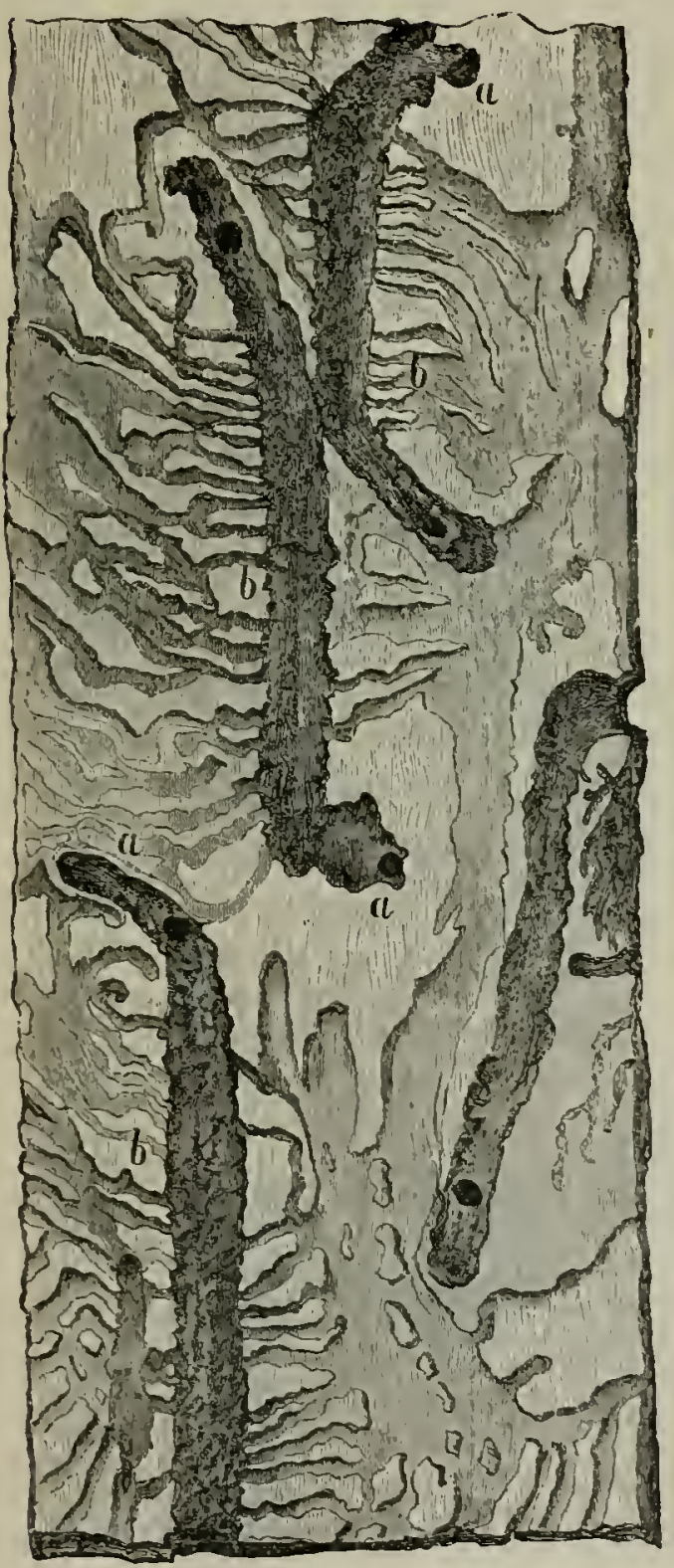

Burrows of $H$. piniperda, L., in pine-bark. (Natural size.)

" Characteristic angle near the beginning of the mother-gallery. commence with a characteristic hook-like hend. The entrance-hole is usually under a bark-scale, and may be marked by ejected woodpowder or by a drop of turpentine. The larræ eat out secondary galleries in the bast, which branch out at right angles to the primary gallery, soon becoming wide, irregular and confluent. They only graze the sapwood. The pupre and immature beetles are embedded in the bark, near. its onter surface.

FIG. 119.

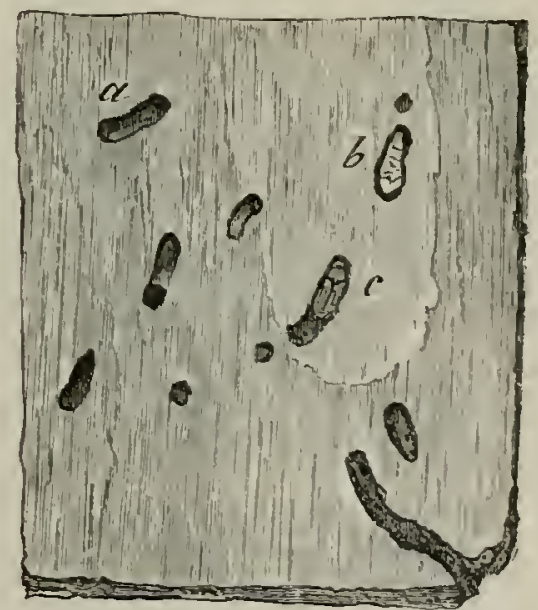

Pine-bark with chambers $(a)$. pupre $(b)$ and imagos $(c)$ of $H$. piniperda, L.

(Natural size.)

The second and most serious form of damage is done to the young shoots. The nerly-disclosed beetles of the first or second broods, in August and September, bore into the pith of young 
pine-shoots at a distance of 1 to $3 \mathrm{in}$. from their extremities, choosing especially those of sickly or old trees, in preference on sumny borders of woods; they eat out a burrow about an inch long, working upwards to the buds. The entrance-holes into these shoots are surrounded by a whitish ring of resin. The beetle leares the hollowed-out shoot either by the original bore-hole or by a fresh hole made at the end of the burrow,

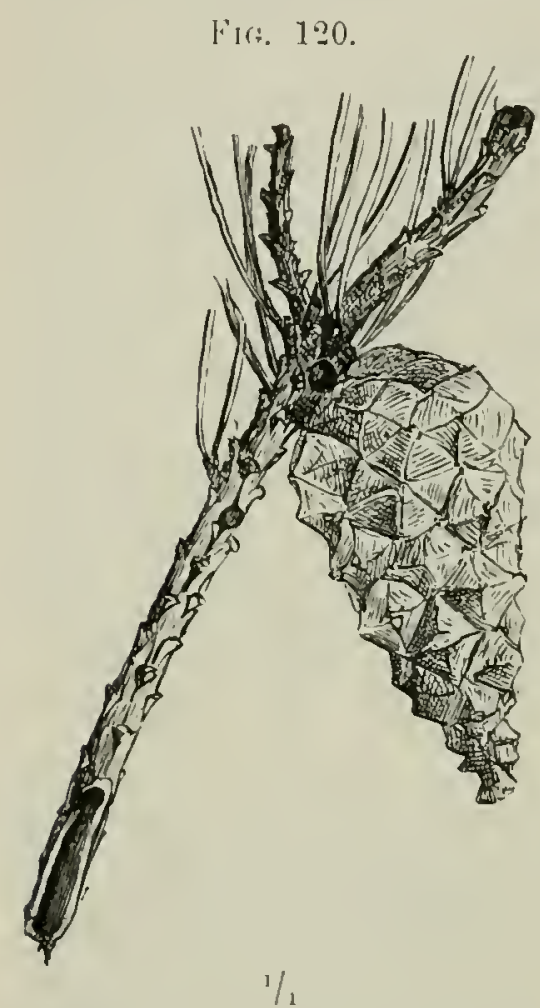

Pine-shoot, hollowed out by $/ I$. piniperde, L., with two beetleholes. and recommences his destructive work in another shoot. In these galleries excrement is never found, and thus the action of $H$. piniperda, L. may be distinguished from that of Retinia buoliana, Schiff., the caterpillar of which also bores out Scotch pine shoots, but always leaves excrement in the borings. Weak side-shoots which have been bored break off generally at the bore-hole, and fall to the ground. Stronger shoots from the cromn derelop the suppressed buds between the pairs of needles, which with favourable spring-weather grow into short needles, and give the shoots a bushy appearance. The height, growth and development of the crown are thus seriously affected; and the production of cones being materially reduced greatly impairs the success of natural regeneration of Scotch pine forests. Fig. 120 shows a hollowedout twig bearing a cone. Such twigs may be found lying on the ground in thousands after an antumnal storm. Sometimes tro beetles are found in the same twig, and some beetles hibernate in them, but this is probably a rare occurrence. Owing to the loss of these bored twigs, the crowns of trees, if repeatedly attacked by the pine-beetle, acquire a characteristic appearance which may be recognized from a distance. They acquire the form of the cypress instead of possessing the usual dome-like shape, and here and there a few side-branches which have been 
spared mar project outwards from the tree (fig. 121). This curious aspect of the trees has given to the insect the appellation of Hortulanus naturce ("Waldgärtner" or Pruner).

Besides the direct damage (loss of increment, diminution of the seed-harvest) inflicted on attacked trees by the reduction of their assimilating organs, indirect damage is also done by reduction

FIG, 121.

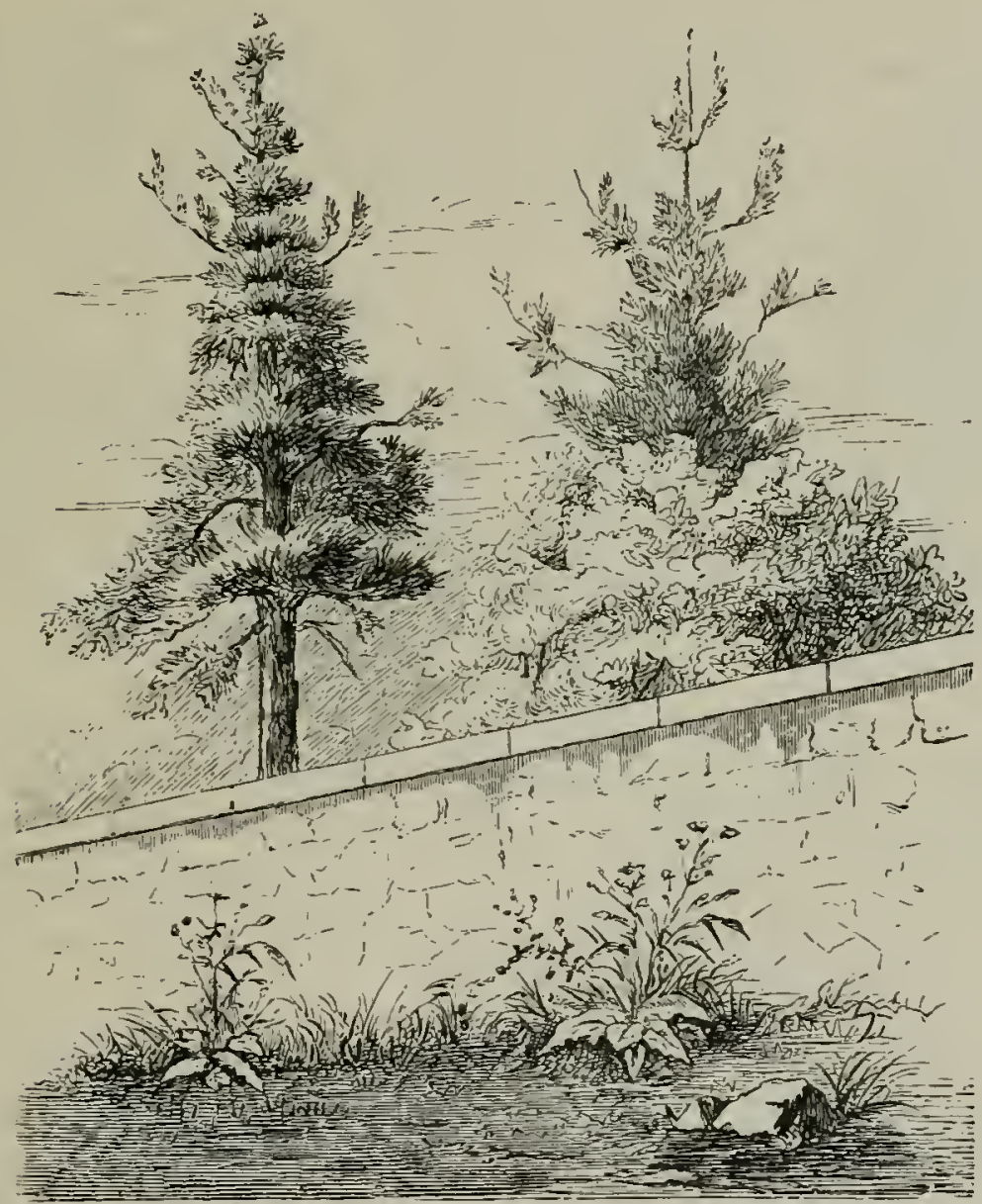

Weymonth pines injured by the Pine-beetle in the cemetery at Wieseck (near Giessen).

of the cover, and consequent exposure of the soil. As the cover of Scotch pine woods is apt to open out even under favourable conditions, this form of injury is very serious.

Exceptionally, the beetles in summer eat out irregular longitudinal galleries in the first 5 to 6 year's' growth of shoots on vigorous 12 to 15 -years-old Scotch pines, but without laying any eggs. Altum* states that these galleries, which run partly

* Ein neuer Sommeraufenthalt von Hyl. piniperia. Zeitschr. fr. Frst. u. Jgdw. 1879 , page 264.

VOL. IV. 
in the bast, partly in the sapwood, are only used to harbour the beetles.

Lastly the beetle does damage by boring down for 2 or more inches to the sapwood of the rootstock of sound standing trees in order to hibernate. If this should happen on a large scale, the trees might die, or at any rate would become sickly and attract more beetles in the ensuing spring.

The pine-beetle prefers forests in flat or undulating country, isolated trees, trees along the borders of woods, and those which have suffered from fire; it is also common near timber-depôts. Like all bark-beetles it prefers windfalls or trees partly uprooted by the wind, and sickly trees, but does not exclusively attack such trees.

In a pine-forest on the peninsula of Darss on the Pomeranian coast, which had been flooded with salt water on the 12th and 13th November, 1872, and the trees thus rendered sickly, the beetle appeared in such enormous numbers as to completely destroy 2,500 acres of the forest.

\section{(d) Protective Rules.}

i. Timely and frequent thinnings of pine-roods, and quick removal of all sickly trees.

ii. Clearance of the felling-areas, at the latest by the middle of April; removal from the wood of all raluable timber with thick bark before the beetles emerge.

iii. Uprooting of stumps and broken trees. If for any reason this is not practicable, they must at any rate be barked.

iv. Pine-woods injured by fire must be felled.

v. All insect-eating mammals and birds must be protected, especially those referred to under T. typographus, L. (page 216).

\section{(e) Remedial Measures.}

i. Trap-trees should be felled from February till September so as to lieep up a supply of trees which are not too dry for the beetles to breed in. Thick-barked trees injured by storm, snow, caterpillars or fire should be selected; some of them should be barked in the middle of May and others at intervals of 4 to 6 weeks, and the bark burned in pits. 
ii. All standing trees containing larvæ or pupæ should be felled and barked and the bark burned.

\section{Mylurgus (Myelophilus) minor, Hart.}

(a) Description.

Beetle 3.8 to $4 \mathrm{~mm}$. long; closely resembling the preceding species in appearance, but with the bristle-bearing tubercles continued on the 2 nd interstice of the elytra up to its apex, as on the other interstices.

\section{(b) Life-History.}

Season for fliglut. April and May, about 8 to 10 days later than the preceding species.

Standing Scotch pines are selected for breeding, but as a rule the thickly barked lower part of the stems is avoided, and the upper portion where the bark is thinner is chosen. The young brood

FIG. 122.

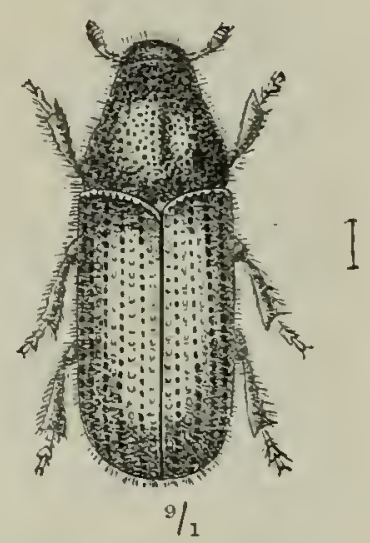

Hyluryus minor, Hart. requires for its development somewhat fresher material than in the case of $H$. piniperda.

The larræ hatch in June, and pupate in July in a chamber made in the sapwood.

The beetles emerge in July and August, and generally pair in the following year. Those, however, which appear early, usually produce another brood within the year, as in the case of the preceding species.

Generation single or double. The beetle is found in company with the former species, but is rarer, or at any rate more localized. In the British Isles it has only been found, and that very rarely, in the Dee district of Scotland, but it is so like the much commoner $H$. piniperda, L., that it is probably overlooked.

\section{(c) Relations to the Forest.}

H. minor, Hart. chiefly attacks the Scotch pine, but has also been found on the spruce. It prefers poles, but may attack 50 to 
70-years-old trees. The mother-galleries are large, regular, double-armed, and horizontal, with a rather long entranceburrow, and groove the sapwood deeply (fig. 123). The injury which its breeding causes is therefore greater than that of $H$. piniperda, as the circulation of the sap is more endangered by

Fic. 123.

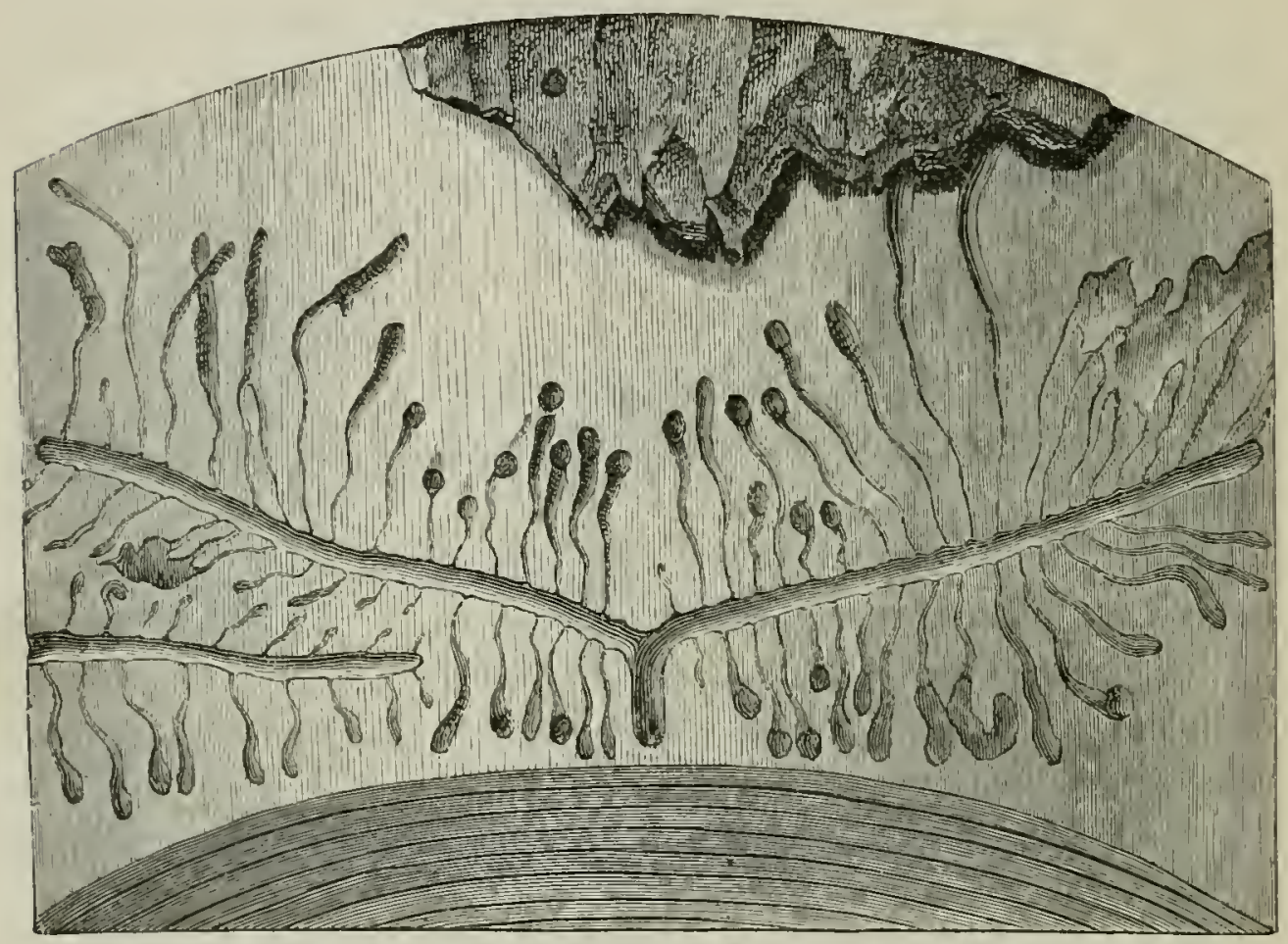

Burrows of $I I$. minor, Hart., on pine sapwood. (Natural size.)

these horizontal galleries. It is not therefore surprising that quite sound trees are lilled by it, or at any rate become stagheaded.

The larval galleries are short, not rery numerous, and terminate in a deeply-cut pupal chamber. This beetle, unlike the preceding species, is said not to confine itself to the border's of a pine-wood, but to be found deeper in its interior.

II. minor also bores into the pith of young pine shoots in the same way as $H$. piniperde.

\section{(d) Protective Rulles.}

As for $H$. piniperla, but the trap-trees must have thin, smooth bark. 
5. Hylesinus fraxini, Fabr. (the Ash Bark-Beetle).

(a) Description.

Beetle 2 to $3 \mathrm{~mm}$. long, short and thickset; pitchy-brown or reddish, variegated with short close-lying ashy and fuscous scales, forming a series of irregular transverse bands on the elytra. Prothorax transverse, finely granulate; elytra with fine but distinct punctured striæ; legs piceous with the tarsi reddish, antennæe ferruginous.

(b) Life-History.

Flight period at the end of April and beginning of May.

The eggs are laid on the branches and stems of healthy ash trees, as well as on

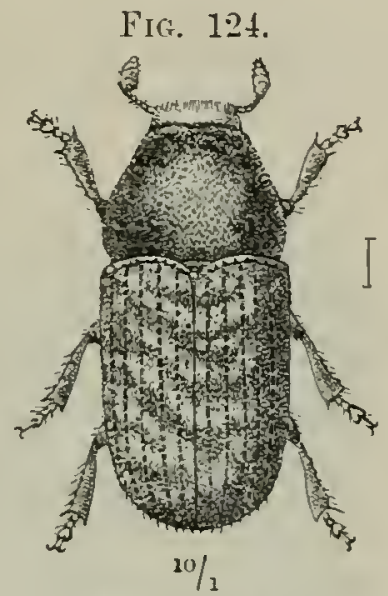

Hylesinus fraxini, Fabr. dead and felled trees. The larve hatch in May, and develop in July to the perfect insects, which pass the winter in irregular borings in the bark.

Generation single. Common and generally distributed throughout the British Isles.

\section{(c) Relations to the Forest.}

The beetle bores into the bast of ash-poles and trees, constructing extremely regular, double-armed, horizontal galleries, with a short entrance-burrow (fig. 125, a). The larval galleries are short but close together, cutting deeply into the wood, and are always rery regular (fig. 125, b). The pupal chambers are in the wood (fig. 125, c). The beetles eat their way out in August, making numerous perforations, so that the bark is riddled, as if by shot. Once a tree has been attacked, numerous galleries are excarated in it one over the other.

The beetle prefers quite sound trees, according to Hess, and kills them, but Miss Ormerod says that the damage is chiefly done to decayed or sickly trees. This insect also attacks large ash-trees standing in the open, boring down to the bast in order 
to hibernate there, and such winter-quarters are generally occupied again in the succeeding autumm by more numerous beetles, so that rough, scabrous, rosette-like prominences are erentually formed on the bark. It has occasionally been observed to attack the robinia and apple-trees, but its galleries are then rertical rather than horizontal. It may be laid down as a general rule that the smaller the branches which are attacked, the more do galleries which are normally horizontal tend to become vertical.

FIG. 125.

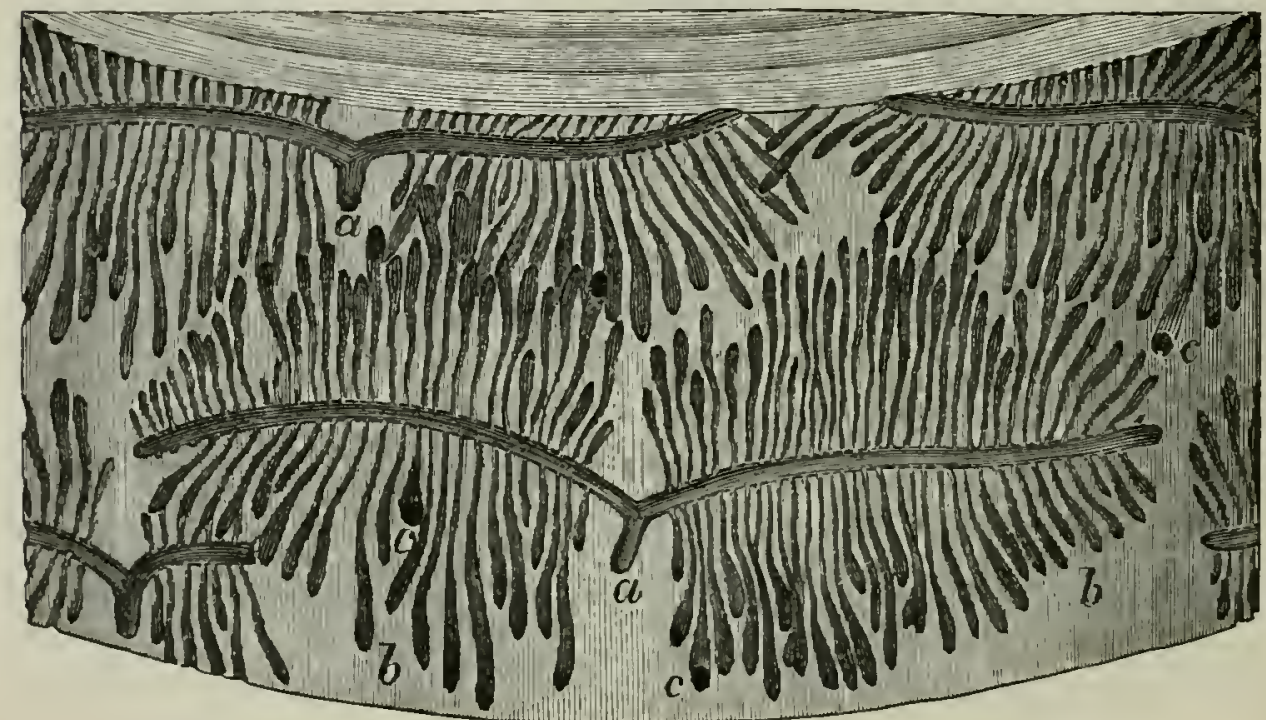

Burrows of $I I$. fraxini, Fabr., on ash sapwood. (Natural size.) a Mother-galleries. 6 Larval galleries. e Pupal chambers.

\section{(d) Economic Rules.}

i. Selection of suitable localities for planting ash-trees, and attention to such rules of management as will keep the trees healthy.

ii. Ali infested trees should be barked in June and July, and their bark and branches burned.

iii. Trees attacked may be tarred.

6. Hylesimus vittatus, Fabr.

Beetle similar to $H$. fraxini, Fabr., but only $1 \frac{1}{2}$ to $2 \mathrm{~mm}$. long; with a white stripe on each elytron extending from the 
shoulder to the middle of the suture and enclosing a common oval dark patch; it makes double-armed horizontal galleries in the elm.

7. Hylesinus crenatus, Fabr.

\section{(a) Deseription.}

Beetle 5 to $6 \mathrm{~mm}$. long; ovate, blackish-brown or black, its under surface hairy.

Thorax tapering in front, distinctly broader than long, thickly and coarsely punctured; elytra broadest at the middle, obliquely and not strongly declivous behind, with coarse punctured strix, the interstices granulate and furnished

FIC, 126.

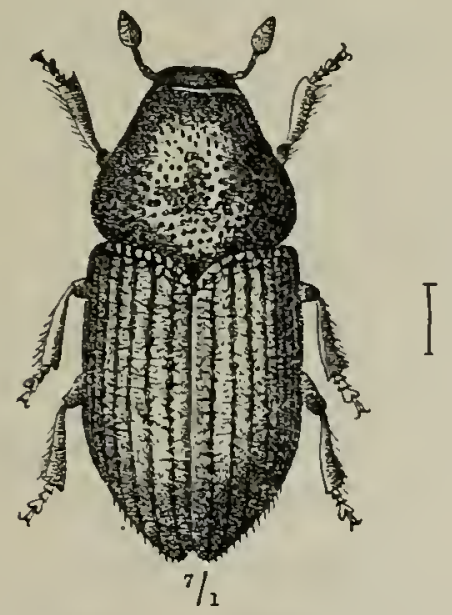

Hylesinus crcnatus, Fabr.
FIr. 127.

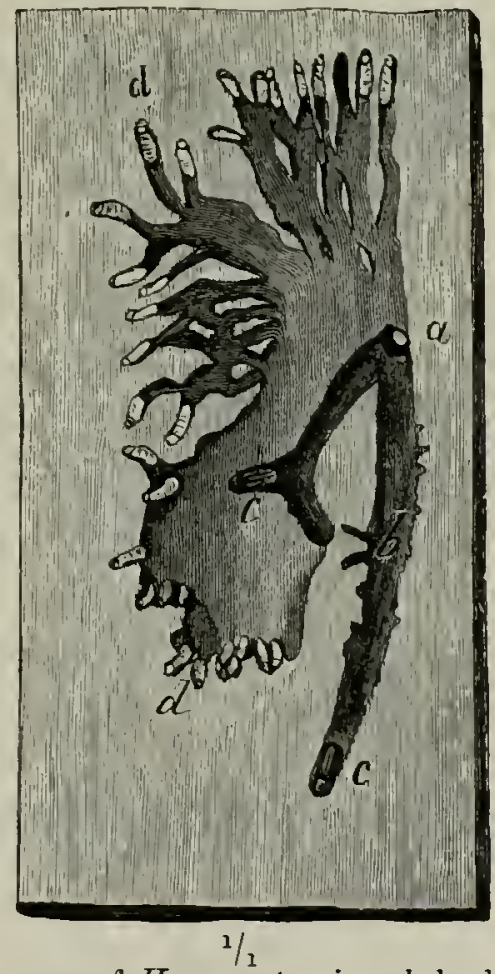

Burrows of $I I$. crenctus, in ash-bark.

a Entrance-hole.

$b$ Mother-galleries.

$c$ Beetles excavating galleries. d Boring larve.

with short black hairs; abdomen curved upwards towards the apex.

(b) Life-History.

Similar to that of $H$. fraxini; but the generation is said to be double. The flight-period is at the beginning of April, and again in October. When pairing takes place late in the spring (May and June) the generation is only single. 


\section{(c) Relations to the Forest.}

This beetle attaclis the ash almost exclusively, and prefers large trees with fissured bark. The female makes short, slightly bent, generally two-armed galleries. The two arms are generally of unequal length and inclined at an acute angle; sometimes only one is present. The larval burrows run at first upwards or downwards, that is, at right angles to the mother-galleries, gradually curving and becoming horizontal; they are of great length, and are often abruptly bent on themselves once or trice in their course. Fig. 127 shows the appearance of a gallery, in which boring beetles as well as larve may be distinguished; the latter so closely packed that their galleries have coalesced. It is, however, hardly typical of the species. If the of do not lay, they bore simple tumnels, frequently just under the outermost bark, which then generally splits and flakes off orer the point of attack. Exceptionally the beetle has been found attacking old oak-trees in the Russian Chersonese; the galleries in this case may be three-armed.

The attacks of this insect may be treated as for H. fiaxini.

\section{Subfamily Scolytini. \\ Description of Sulfamily.}

This sub-family contains a single genus, Scolytus, the species of which possess a projecting head with a short broad rostrum. Antennal funiculus 7 -jointed. First tarsal joint much shorter than the succeeding joints together, the third bilobed. Elytra scarcely declivous behind. Under surface of abdomen flexed upwards from the base of the second segment.

They breed exclusively between the wood and bark of broadleaved trees, and sometimes make very regular galleries, which generally cut deeply into the sapwood. Pupal chambers in the outer layers of the sapwood.

1. Scolytus destructor, Oliv. (Elm Bark-Bectle).

(a) Description.

This beetle is 4 to $5 \mathrm{~mm}$. long, black, with the elytra brown; antenmæ and legs reddish brown. Front of head and rostrum 
without any carina. Thorax broader than long, punctured, the punctures becoming weaker towards the middle of its upper surface. Suture of the elytra depressed from the base to its middle; their interstices broad, with two or three rows of punctures. Third and fourth abdominal segments in both sexes with a small tubercle.

\section{(b) Life-History.}

Flight at the end of May and June, and sometimes again in August.

The eggs are laid in the bark of elms, by preference in sickly trees.

The larræ appear in July and the beetles

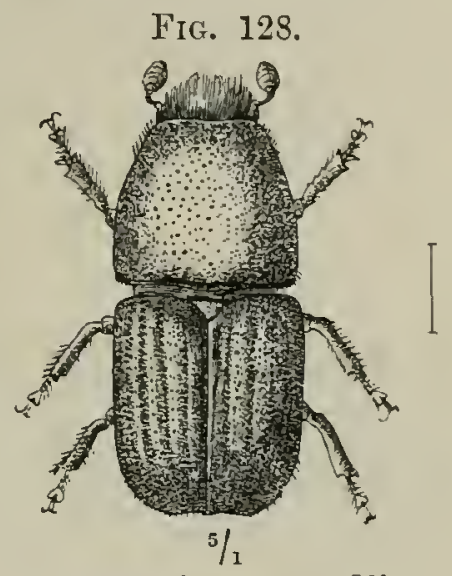

Scolytus destructor, Oliv. fly in August, and at once proceed to pair. The larve of the second broad hibernate in their borings, and pupate in the following spring, generally in the bark or less frequently in the sapwood.

The beetles of this brood come out at the end of May. The holes of exit are about the size of No. 5 shot.

The generation is usually double on the Continent, and apparently so in England in warm seasons. But in Britain, where the insect is common soutl of Scotland, a single generation is more usual, the larvæ which hatch in May or June becoming full-fed at the end of July and remaining in the tree throughout the winter.

\section{(c) Relations to the Forest.}

The beetle attacks old and young elm-trees, and sometimes also the ash.

The mother-gallery is broad, slort, ascending and vertical, about $2.5 \mathrm{~mm}$. broad, and with 1 to 2 air holes. The secondary galleries ramify from it at right angles in a fairly regular manner, lie close together, are long, sometimes extending for more than 4 in., gracefully curved, and somewhat broader at their ends than the primary gallery. The pupal chambers when the bark is thin are excavated partly in the sapwood.

This beetle especially attacks elms in the neighbourhood of large towns; thus in 1842, elms in Regent's Park were infested, and in 1870, many elm-trees were killed in Berlin. 


\section{(d) Protective Rules.}

As a preventive measure, elms in arenues, parks, etc., may be smeared with Leinweber's* composition.

All stems attacked by the beetle should be felled, beginning in July, and the bark burned. Trees that have been felled may be used as traps, and treated accordingly.

\section{Scolytus intricatus, Ratz.}

\section{(a) Description.}

Beelle, 3-4 $\mathrm{mm}$. long; black, with the elytra, antennæ aud legs, pitchy-red, or brown; the former with close rows of punctures, the interstices narrow, closely wrinkled, the suture depressed round the scutellum; abdomen unarmed.

(b) Life-History, ace.

It lays its eggs on oaks, but otherwise resembles the elm beetle in its mode of life. It has, how-

FIG. 129.

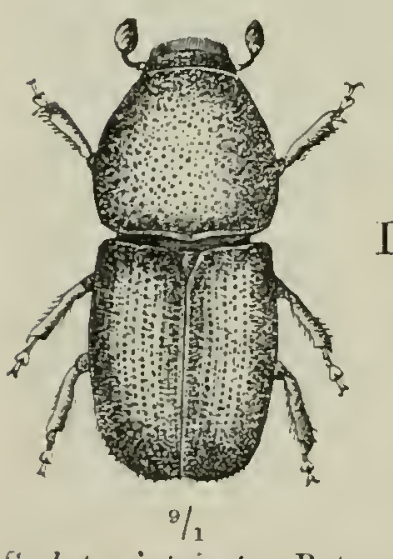

Scolytus intricatus: Rat\%. ever, only one generation in the year.

It attacks several species of oak and more rarely the beech, and it prefers young stems and branches to older parts of trees.

The beetle bores a simple gallery; the larval galleries, 30 to 40 , run partly upwards and partly dormwards, and are long and narrow. The pupal chambers groove the sapwood superficially. The beetles attack perfectly healthyoak saplings and kill them.

In the Bois de Vincennes, several year's ago, about 50,000 30-years-old oaks were lilled by this beetle, which breeds freely in oak-posts which lave not been barked, and are used for fences.

Care in the management of plantations of saplings, and avoidance of unbarked wood in palings, are the chief protective measures arailable.

* 5 lbs. tobacco, mixed with $\frac{1}{2}$ pailful of hot water, are kept hot for 24 hours ; the water is then squeczed ont of the tobacco and nuixed with $\frac{1}{2}$ pailful of bullock's blood, I part of slaked lime and 16 parts of cow-dung. This is kept in an open tub and stirred once a day, and used after fermentation has set in. The rough bark, moss, \&c., is trimmed off the tree, and the latter painted with the mixture for three successive days, until a crust is formed which the rain will not wash ofl. 
Two other species of Scolytus, S. pruni, Ratz. and S. rugulosus, the latter a very small species, are especially attached to fruit-trees, plum and apple. Both are locally common in England, and sometimes injurious, but they are not important to the forester.

\section{Family VIII.-Ceranibycide (Longicorn Beetles).}

\section{Description of Family.}

Longicorn beetles are elongate, and generally of large or moderate size, with a cylindrical thorax, often spined at the sides; elytra somewhat depressed, wider at the shoulders than the thorax, and tapering behind.

Antennæe filiform or setaceous, rarely serrate, and always becoming thinner at the ends, usually very long, with 11 or more joints, the second joint always the shortest.

Legs slender and long. Tarsi four-jointed, the three basal joints flattened and spongy beneath, the third bilobed.

Abdomen with 5 segments. Generation usually bieunial.

Larve soft, white or yellow, usually cylindrical, rarely somewhat flattened, with projecting broad thoracic segments, of which the first at least is furnished above with a horny plate. Their feet consist of six minute tubercles, or are entirely absent.

Pupre fusiform, and recognizable by the long horns bent down in a curve from the head.

Flight-holes transversely oval.

The larve generally live under bark and in wood, but usually only in broken trees or in stumps; a few species are found in beams of houses. Their attack is of a secondary nature, as they bore into trees lilled by bark-beetles and other insects, but on account of the large size of their galleries, and the quantity of boring dust which exudes, it easily attracts attention.

On sumny days the beetles may be found on flowers, shrubs, and felled trees; the females do not make mother-galleries.

Longicorn beetles are rare as a rule in the British Isles, and most of the species found are small and of little or no economic importance. In tropical countries they play an important part in the destruction of fallen and decaying timber. 
1. Saperda carcharias, L. (The Large Poplar Longicorn.)

\section{(a) Description.}

Bectle 26 to $30 \mathrm{~mm}$. long, grey or brownish yellow, dotted with many shining black points. Thorax short and "cylindrical. Elytra with the shoulders prominent, narrowed posteriorly and bluntly spined at the apex. Larva extending up to $35 \mathrm{~mm}$. in length, without legs, cylindrical, yellowish white, with the man-

\section{FIG. 130 .}

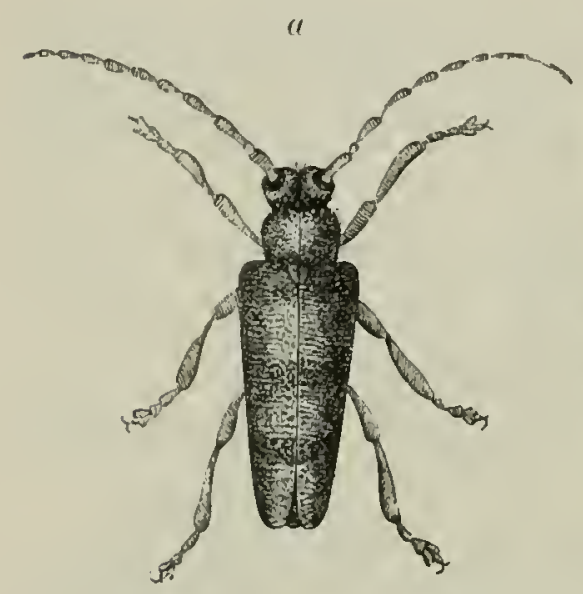

Saperda carcharias, L. a Inago. $b$ Larva. dibles and segmental shields brown, the latter on the dor'sal surface of segments $3-10$, and the ventral surface of segments $2-10$.

\section{(b) Life-History.}

Season for flight: Jume and July.

The eggs are laid in Jume in crevices in the bark of poplars, especially near the ground.

The larve emerge in July and August, and live and hibernate in the wood, pupating in May of the 3rd year.

The pupæ lie head downwards in a chamber blocked with a plug of wood-dust.

The imagos emerge in June.

Generation biennial. The insect is rather common in a few parts of Great Britain, chiefly in the Eastern Counties.

\section{(c) Relations to the Forest.}

The larve bore into young, healthy poplars, and also into willows; aspen and black poplar up to 20 year's old are specially attacked. Seedling-trees are liable as a rule to be attacked from their 5th year, and suckers from the 3rd year.

The larvæ make vertical galleries, which reach the centre of the tree: these become gradually filled with wood-dust, which is forced out of the tree by the grubs, through a bore-hole, and 
becomes heaped up at the base of the plants. The stem is attacked near the ground and reacts by developing a large irregular swelling, the bark of which is fissured. Such perforated saplings are easily broken by the wind. This insect is chiefly of importance where poplars are grown in long avenues as in France and Germany. Tt is sometimes associated with Sesic apiformis, Fabr., and Cossus ligniperda, Fabr.

\section{(d) Protective Rules.}

i. Poplar-nurseries should not be established near older poplars.

ii. Poplar-saplings liable to attack may be smeared in June up to 5 feet in height from the ground, with a mixture of clay and corv-dung, or Leinweber's composition (p. 250). This treatment is to be recommended for nurseries.

\section{(e) Remedial Measures.}

i. Collection of the beetles by shaking the saplings in June and July.

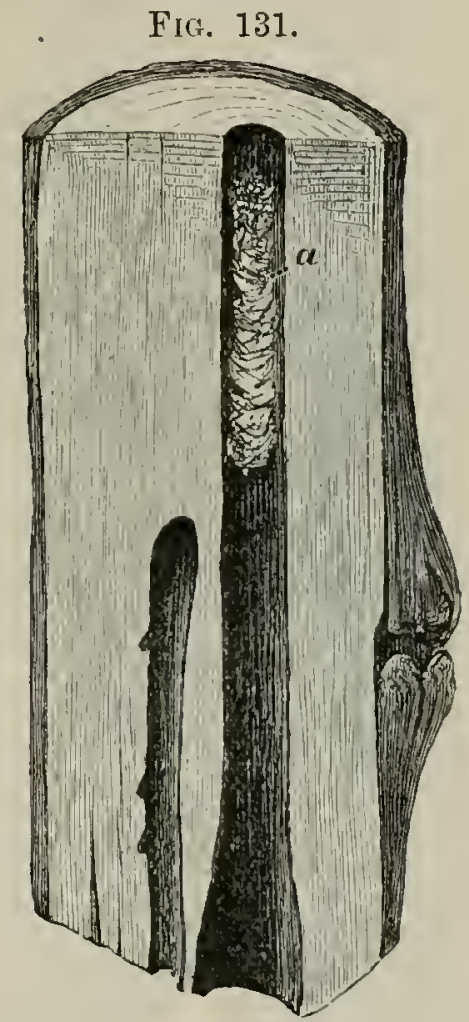

Larval burrows of $S$. c(t)charias, L., in the stem of it young poplar.

(Natural size.)

a Plug of boring clust.

ii. Felling and removal of all attacked saplings before the beetles emerge.

2. Saperda populnea, L. (Small Poplar Longicorn).

(a) Description.

Bectle 10-12 mm. long, black, covered with yellow-grey pubescence; thorax with 3 lines of pubescence; elytra with the median line, and a broad lateral stripe, and three or four spots on each side pubescent. Antemnæ ringed with white.

\section{(b) Life-History.}

The female deposits her eggs in May and June in cracks on the bark of young aspens, less commonly on other species of 
poplar, sometimes on willows. Seedlings of 2 to 6 years old and suckers are preferred.

Generation biennial. The larva hatches in July, bores throngh

Fic. 132. Fig. 133. the bark and eats a circular gallery

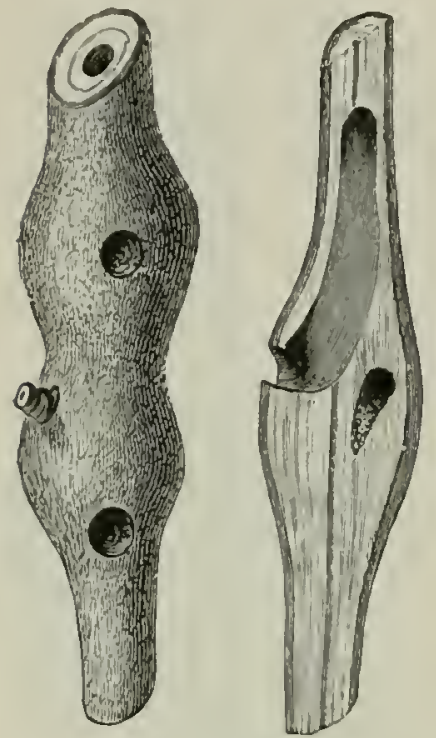

Burlows of S. populnea, L., in an aspen twig.

External view with two flight holes. View of interior with the larval burrow exposed. round the sapwood. The stem, usually one of the smaller branches, reacts by forming a gall-like swelling, which however is not found on willows.

In the second summer the larva changes its course, boring upwards along the middle of the stem for about an inch. The flight-hole is circular and situated on the swollen portion.

This insect is usually found in open sunny places, and is not uncommon in the Midlands and south of England. It seldom liills the trees, but cripples the branches and prevents growth. Where it is abundant, hardly a branch can be found free from its galls.

\section{(c) Remedial Measures.}

Collection of the beetles in June by shaking; cutting and burning the attacked branches during the winter.

\section{Fanilly IX.-Chrisonelide (Leaf-Beetles).}

\section{Description of Family.}

Leaf-beetles are small or of moderate size, conver and short, of an oral or hemispherical shape.

Antennx filiform, bead-like, or slightly thickened at the ends, 11-jointed. Legs usually short, strong, sometimes framed for jumping; tarsi 4-jointed, spongy below, the 3rd joint bilobed. Abdomen with 5 segments. Generation simple.

The larvæ are short, flattened, usually either parti-coloured or black, with 6 legs, the last segment usually with a retractile process. Pupæ thickset, sometimes hanging upside down from 
leaves. Some species are very injurious, both the imago and larva eating the leaves of broad-leaved trees.

1. Melasoma populi, L. (Red Poplar-leaf Bectle).

(a) Deseription.

Beetle 10 to $12 \mathrm{~mm}$. long, of an obovate shape, blackish-blue, the elytra brick-red, their extreme tip black; thorax narrower than the elytra, its sides rounded, broadly raised and coarsely punctured; antemnæ short, compressed, thickened towards the ends.

Larra 6-legged, of a dirty white colonr, with many black

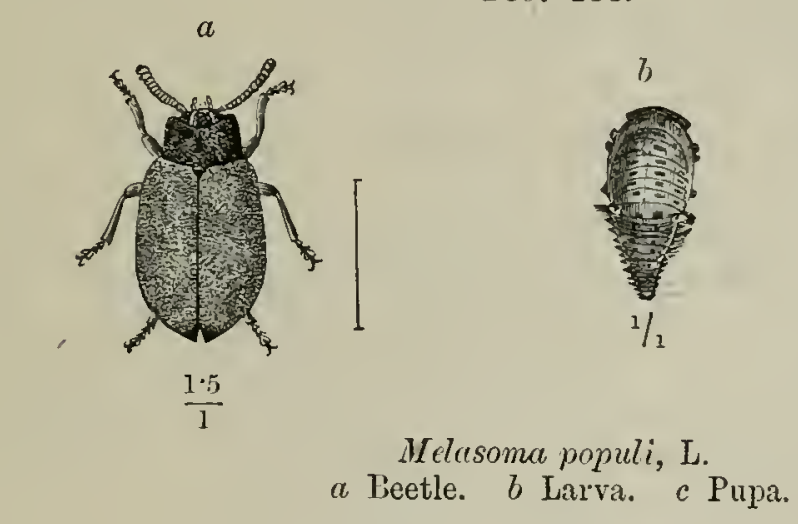
Fig. 134.

spots, and two white lateral projections on the 2nd and 3rd segments.

Pupa sharply narrọved towards the posterior extremity, brownish yellow, with regularly distributed black spots and stripes.

\section{(b) Life-History.}

The season for flight is in May and June.

The of lays her yellowish-white eggs in clusters of 10 to 12 , in all 100 to 150 , on the leaves of young poplars.

The larvæ emerge in June or July, feed openly on the leaves, and if disturbed exude a milky-white fluid, with an odour of bitter almonds.

Pupation takes place in July and August; the pupæ hang reversed from the leaves by their pointed end.

The beetles emerge by the end of August, and after October 
hibernate under leaves or moss, reappearing in the open in April.

Generation generally annual. Locally common in many parts of the British Isles, chiefly in South England.

\section{(c) Relations to the Forest.}

The insect, both in the larval and beetle stages, attacks young poplars and sometimes aspen shoots. Occasionally they are found in osier-beds, especially on Salix purpurea, L, and S. pentandra, L. and to a less extent on S. rubra, L., etc. The larve attack the leaves, which are completely skeletonised, the parenchyma being eaten and the reins left intact. The imago eats holes out of the leares.

The attacks last from June to August.

\section{(d) Protective Rules.}

Collection of the beetles on to cloths by beating the trees in May and June, and again in August to September.

M. tremule, Fabr., is somewhat smaller than, and greatly resembles the above species, but has no black tips to its elytra. It is the more destructive of the two, sometimes completely destroying the foliage and shoots of young aspen.

2. Phratora vitellince, L. (Wrillow Beetle).*

(a) Description..

Bcetle 4 to $5 \mathrm{~mm}$. long, oblong-oval, of a bronze or green tint, sometimes coppery. Elytra regularly punctate-striate.

\section{(b) Life-History, dic.}

The beetles come out in the spring from their sheltering places, and lay their eggs on the under-surface of leaves of willows-Salix riminalis, L., S. purpurea, rubra, etc., and also on poplars. The imagos and larve attack the young shoots and leaves, commencing with the under-surface, and eating their way through the leaf, or up to its epidermis. 
Pupation takes place in the soil. The beetle lives through the winter, hibernating in various localities; it is found some-

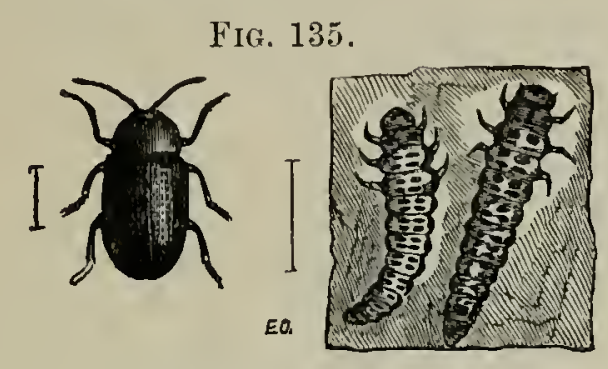

Willow beetle and larve.
FIG. 136.

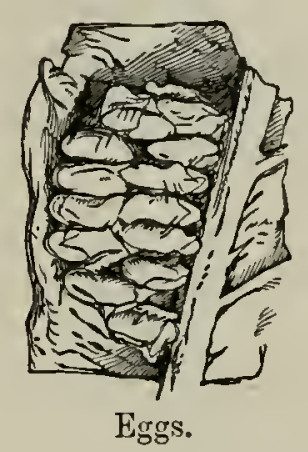

times high up on willows in sheltered places, un ter the rough bark of old pollards, in hollow stems of herbaceous plants, among the terminal shoots of neighbouring young pine trees, or on the soil amongst fallen leaves and old stumps of osiers. They will also hibernate in the heaped-up peel of osier's, which should not therefore be left lying about.

Generation generally single, rarely double. This beetle is extremely common and decidedly injurious. In 1884, according to Miss Ormerod, in osier beds in the Lymm district, near the borders of Lancashire and Cheshire, it was estimated that the whole crop of osiers on 50 acres would have been destroyed if protective measures had not been taken.

\section{(c) Protective Rules.}

i. Dragging across the osier-beds a rope weighted in the middle. This operation, which should be repeated several times, knocks off the beetles, which will lay their eggs on the ground, Injured willowwhere they die.

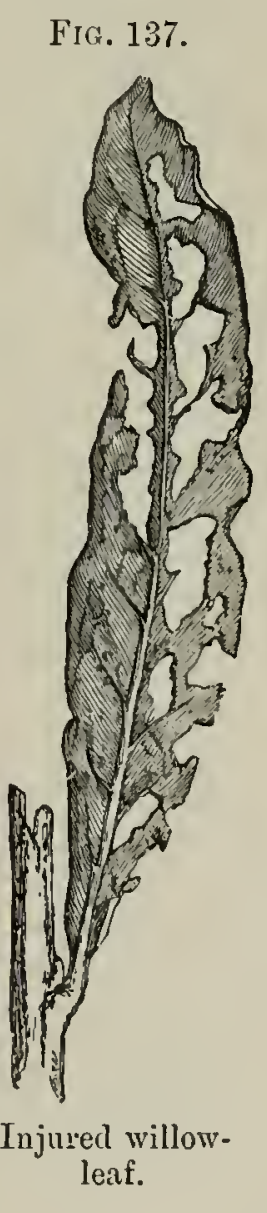

ii. Sprinkling the osier-shoots with a strong solution of wood ashes, or with Paris green (arsenite of copper, see p. 155).

iii. Knocking the beetles off the osiers into square tin VOL. IV. 
vessels containing ashes, but this procedure must be done repeatedly.

iv. Collection of the beetles in their winter quarters.

Traps of birch-bark, planks, etc., may be put above the flood-level ; under these the beetles collect in myriads for shelter, and may then be destroyed. 


\section{CHAPTER VII.}

\section{LEPIDOPTERA-BUTTERFLIES AND HOTHS.**}

This order is subdivided into Rhopalocerc or butterflies, and Heterocera, or moths. The former are distinguished from the latter by the possession of somewhat rigid slender antennæ, which are clubbed or knobbed at the tip; and by the absence of a frenulum or bristle attached to the base of the hind-wings and passing through a loop or retinaculum at the base of the forewings. In the moths the antennæ are usually flexible, seldom rigid, and are at most thickened towards the apex with no welldefined club; they usually possess a frenulum.

Butterflies are of slender build, they fly by day and are often gaily coloured.

They are of no importance in Europe from a forest point of view, although the larva of Pieris crategi, L. does much damage on the Continent to the foliage and infloreseence-buds of orchard trees, as well as species of Sorbus and Cratcegus.

\section{Heterocera. Moths.}

$$
\text { FAMILY I.-SESIIDE. }
$$

\section{Description of Family.}

Diurnal moths which fly rapidly in hot sunshine. Antennæe fusiform; 2 ocelli. Proboscis sometimes rudimentary. Wings narrow, more or less hyaline, and resembling those of Hymenoptera; frenulum present. Body stont.

Generation, 1 to 2 years.

Caterpillars cylindrical, Jellowish white, with fine scattered

* The most comprehensive work on the British species of Lepidoptera is "The Lepicloptera of the British Isles" by C. G. Barrett, London, 1892-(in progress). 
hairs; 5 pairs of prolegs; head and prothoracic shield horny, and usually dark coloured.

Pupe slender, armed with circles of spines on the abdominal segments, in a cocoon spun out of chips of rood.

The larve live in wood, chiefly of broad-leared trees, and bore galleries in the stems, twigs or roots.

Fir: 138.

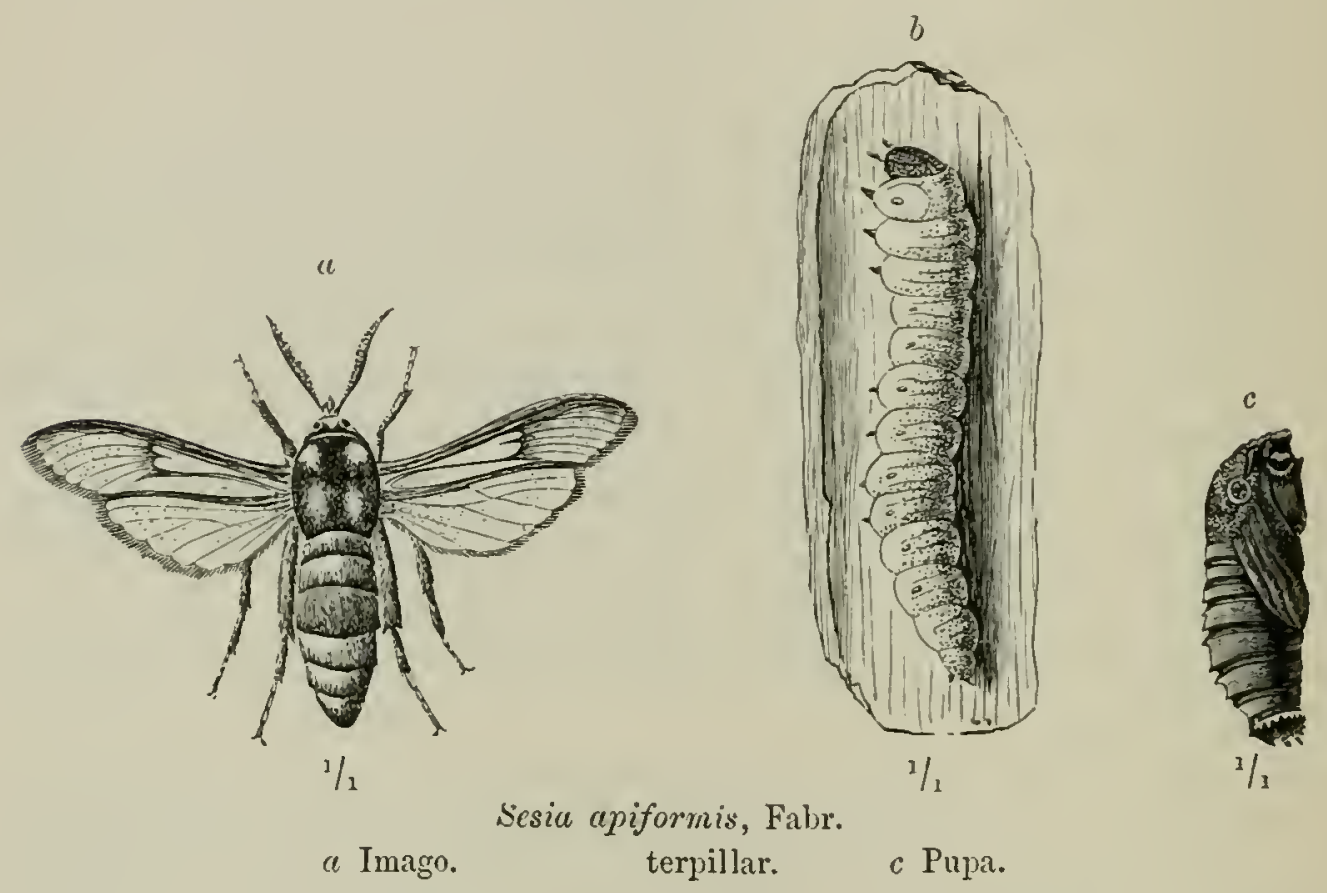

1. Sesia apiformis, Fabr. (Hornet Clearuing Moth).

(a) Description.

Moth with a spread of wing of 35 to $45 \mathrm{~mm}$.; body dark brown, with 3 pairs of bright yellow spots, behind the eyes, on the front and on the hinder part of the thorax ; and with the last segments, and the 5th segment of the abdomen, counting from the tail, bright yellow. Wings transparent, with rust-red borders and veins. Caterpillar with $16 \mathrm{legs}$, of a dirty white colour, with a reddish brown head and a dark line along the back. Pupa brown, with spines on the back of the segments and apex of the abdomen.

(b) Life-Histor!.

The moth flies in June and July.

The brown eggs are laid in July in cracks in the bark of 
poplars towards the lower part of the stem. The caterpillars appear in July and August, pass two winters in their galleries, and pupate in May of the third year, in a cocoon of wood-dust constructed inside their borings, near to the ground ; exceptionally in the ground when tine larva has bored low down towards the roots of the plant.

The imagos emerge in June, when the empty pupa cases may be seen projecting from the stems.

The generation lasts 2 years. The moth is widely distributed and often common among poplars; the injury caused by the caterpillars often accompanies that of Saperda carcharias, L.

\section{(c) Relations to the Forest.}

The larva bores cylindrical galleries in the wood of poplars, especially of the black poplar and aspen. As a rule it prefers trees less than 20 year's old, but is sometimes found in older trees. It generally bores low down in the tree, and its attack can be recognized by the wood-dust which collects on the ground or blocks up the holes by which the moth will emerge, and through which the pupa can push itself by means of its spines. The injured saplings are frequently broken by the wind. The cater. pillar is chiefly injurious in nurseries and avenues.

\section{(d) Protectice Rules.}

Saplings may be smeared as for protection against the poplar longicom. 'The moths should be caught on the tree-trunks and destroyed at the end of June. Saplings infested with larvæ should be cut down.

\section{FaMILY II.-Cosid te.}

\section{Description of Family.}

Imagos of this family of wood-borers with setaceous or bipectinate antennæ; without ocelli; the mouth-parts rudimentary. Body stout, and covered with close short hairs. Flight nocturnal, the wings strong, and roof-shaped when at rest. Generation extending over 2 or more years. Caterpillar's smooth or cylindrical, and with a few scattered hairs. Pupe long, with 
rings of spines on the abdomen, in a cocoon spun up of chips of wood.

The caterpillars live in the wood of broad-leared trees.

1. Cossus ligniperda, Fabr. (the Goat Moth).

(a) Description.

1. Woth with a spread of wing of 65 to $70 \mathrm{~mm}$. (ठ) - -80 to 85 $\mathrm{mm}$. ( + ). Body stout; head and neck corered with yellowishgrey hair ; fore-wings marbled with greyish-brown and light grey, with numerous dark brown transverse lines; hind-wings ashy grey, or greyish brown. Abdomen long and thick, of the sane colour as the wings, with whitish marginal rings to the segments.

Caterpillar 90 to $95 \mathrm{~mm}$. long, with 16 legs, at first reddishyellow, and later cherry-red, darker above, with a brown head, and brown shield on the prothoracic segment; it possesses a rery offensive smell. Pupa stout, reddish-brown, with rings of sharp spines on the abdominal segments.

\section{(b) Life-History.}

The moth emerges in June and July.

The o lays her eggs up to 25 in number in a cluster deep in cracks in the bark of willows and other broad-leaved trees.

The caterpillar hatches in July, and bores into the wood, in which, or sometimes in the ground, it pupates in May of the third or fourth year in a large stiff cocoon with a smooth interior made of particles of wood roughly spun together. The moth :lppears 3 to 4 weeks later.

Generation, 2 or 3 years. Found throughout Great Britain and generally common, at least in the south.

\section{(c) Re? ations to the Forest.}

The caterpillars chiefly attack willows, but also poplars, alder, elm, oak, birch, lime, fiuit-trees, even the wahnut, preferring the lower part of the trunk. The mode of attack resembles that of Sesia, but many caterpillars may always be found in the same stem, sometimes 200 or more; they attack not only sickly 
Fig. 139.
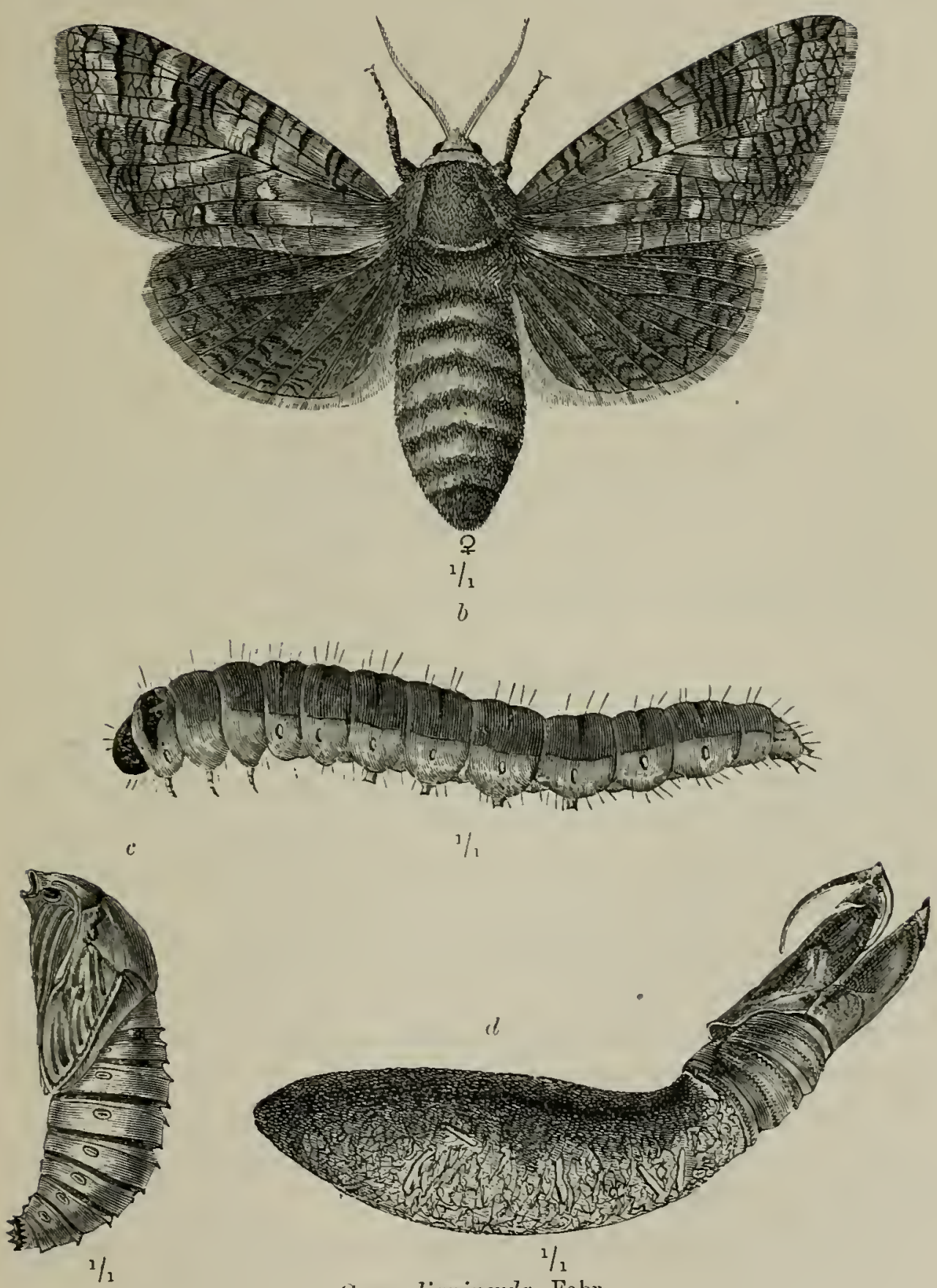

Cossus ligniperda, Fabr.

a Imago (q). b Caterpillar, not fully grown. \& Pupa. d Cocoon and pupal exuviæ (after emergence of the moth).

trees, but thoroughly sound wood, and prefer solitary trees in hedge rows, along forest borders, \&c. They are rery roracious, and the wood which has been attacked is useless as timber. Infested trees may be easily recognized by the bad odour due to 
the caterpillars, and by the wood-chips thrown ont from their borings, which are of various sizes up to the thickness of a man's. finger.

\section{(d) Protective Rules.}

As for Sesia. Bats, owls, and goat-suckers attack the moths. Saplings which have been attacked should be felled, split, and burned with the caterpillars they contain.

2. Zenzera resculi, L. (Wood-leopard Moth).

(a) Description.

Moth with a spread of wings of $45-50 \mathrm{~mm}$. (ठ) , $55-65$ mm. ( $q$ ); white with numerous round steel-blue spots on the wings and six on the thorax; abdomen long, deep blue witl white rings. Larra naked, yellow with black warts and dorsal shield, 16-legged. Pupa with rings of spines.

(b) Life-History, ice.

The eggs are laid singly on saplings or branches of broadleaved trees. The larva emerges in August, bores into the sapwood in the first year, passes the winter in the stem, and in the second summer excavates a gallery ruming upwards along the middle of the rood. In this it passes the second winter, eventually pupating under the bark. Generation biennial. It attacks many species of trees, maple, ash, lime, apple, birch, beech, oak, horse-rhestnut, elm, poplars and willows, and has even been found in mistletoe.

It is widely distributed, though rarely very abundant; sometimes it is rather common and injurious in the neighbourhood of large torms such as London.

Treatment consists in the cutting and burning of the infested stems and branches.

\section{Fanili III.—Bonbycinæ.}

\section{Description of F'amily.}

Antennie short, pectinate in both sexes (simply pectinate in $q$, doubly in $\delta$ ); ocelli usually absent. Proboscis small and 
usually functionless. Wings ample, sometimes small in proportion to the size of the body, roof-shaped at rest. Body stout and long, generally densely hairy, usually larger in the $q$. Flight as a rule nocturnal. Eggs frequently laid in clusters, and covered with hairs from the tail of the $q$. Caterpillars usually hairy, seldom naked, with 16 legs. Pupe stout and short, in a cocoon spun out of silk, often with the larval hairs interwoven.

The caterpillars feed on needles, leaves, \&c., and are usually very voracious. Some of the most destructive species of insects in European coniferous forests belong to this family.

\section{Gastropacha pini, L. (Pine Moth).*}

(a) Description.

Moth with a spread of wings of $60 \mathrm{~mm}$. (o) to $80 \mathrm{~mm}$. $q$. Body thick and stout; fore-wings whitish or brownish grey, in the $\delta$ with dark reddish-brown transverse bands, and with a long unicolorous patch, in which is a white lunate spot; in the $q$ the bands and patch are reddish brown; the hindwings in both sexes are rusty brown. The colouring and markings of the wings vary much in individual examples.

The catcrpillar attains a length of $80 \mathrm{~mm}$., has 16 legs, and varies in colour from ash-grey to reddish brown, or dark brown; there is a dark dorsal stripe, and sometimes a series of lateral white patches. It is hairy with clusters of greyish bristles, and possesses on the 2nd and 3rd segments from the head two steel-blue bare stripes, which become apparent at the second moulting, and are very characteristic.

Pupa somewhat cylindrical, dark brown, enclosed in au elliptic, whitish grey cocoon, which is pointed at both ends, and of looser texture near the head of the pupa to facilitate the exit of the moth.

\section{(b) Life-History.}

The moth emerges from the cocoon from July till the end of

* This destructive pest is fortunately not a native of Great Britain. It plays, however, so important a part in the literature of Emopean forestry, and has often proved so serionsly destructive, that it has been thought desirable not to exclude it entirely from the present translation, but to present an abridgment of Hess's account. 
August. It lays in the second half of July about 100 to 200 bluish-grey eggs, as large as hempseed, in clusters of about 25 to 50 in number, in the bark-crevices of standing Scotch

Fis. 140.
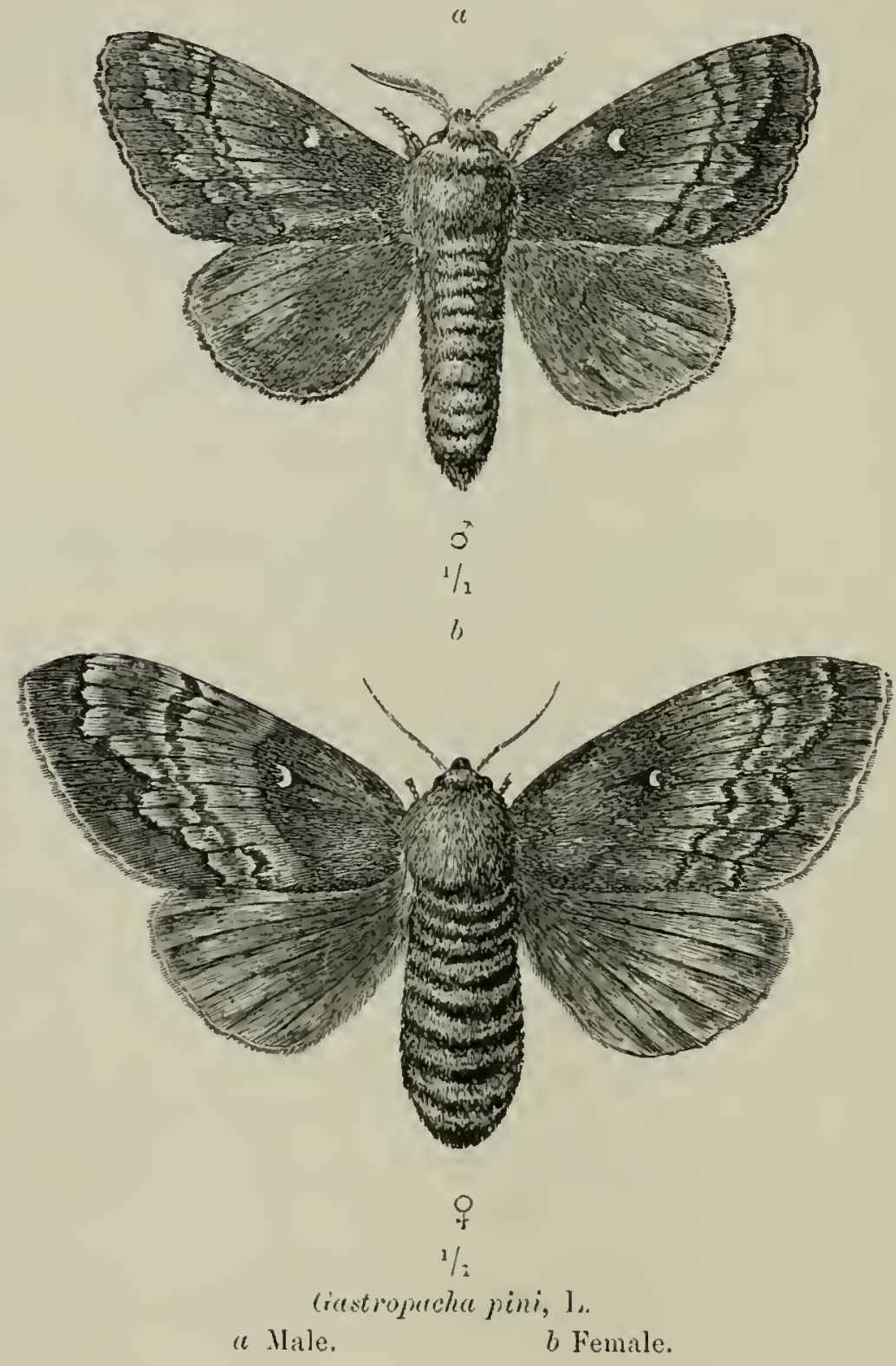

pines, usnally at about the height of a man, or on the needles and shoots of young pines.

The caterpillars hatch after 20 to 25 days, about the mildle of Angust. They at once devour their egg-shells, and then scatter themselves among the twigs, where they begin to feed. When about half grown, they descend the trees (in October and 
November) to hibernate in moss, dead leaves, $\mathbb{E}$., at the foot of the trunks, and remain there till the next spring (March or

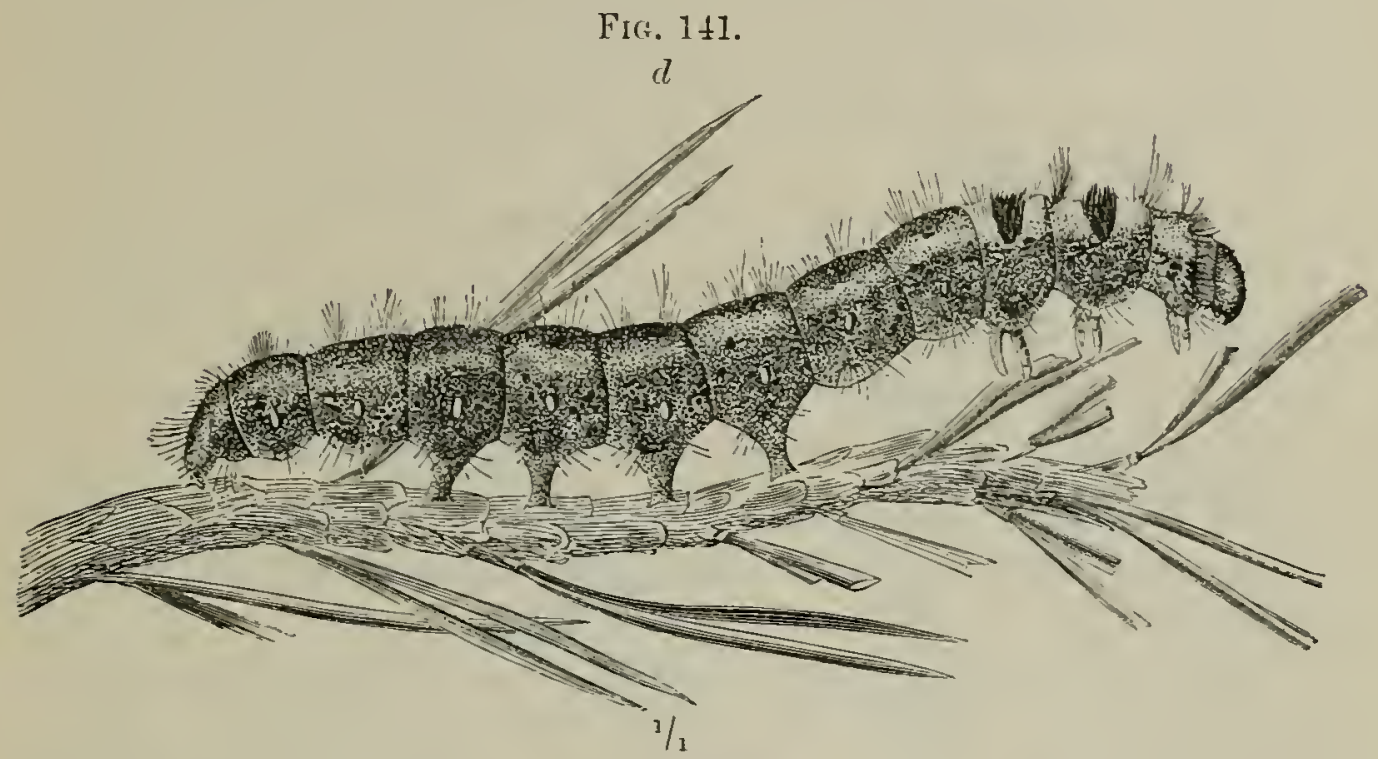

April), when they climb again up the trees. Exceptionally they may hibernate in the bark-crerices. The time of reascension depends on the degree of warmth of the season and on the quarter from which the wind is blowing.

Pupation takes place at the end of Jume or beginuing of July, either on the needles and twigs of the crown of the tree, or in the larger bark crevices.

The moth emerges in July, about 20 day's after pupation.
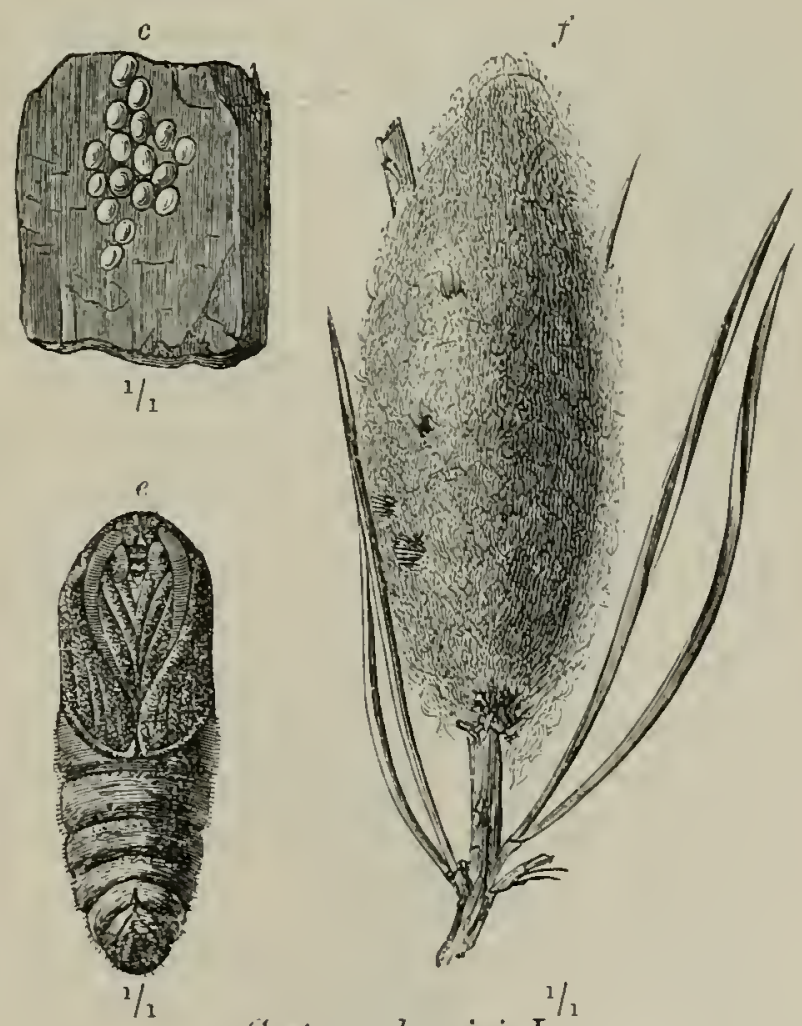

Gustropache pini, L.

c Eggs on pine-bark. d Mature citerpillar, feeding on the needles of a pine-shoot. ¿ Pupa. $f$ Cocoon.

Generation annual; but sometimes irregular when the insect occurs in great numbers. Very common in Germany. 


\section{(c) Relations to the Forest.}

This is the most destructive of all insects to Scotch pine forests in Middle Europe, as it may appear in large swarms throughout the summer for several consecutive years, and is enormously voracious. The caterpillar also attacks the Austrian and mountain pines, and in case of scarcity of food, both the spruce and larch. It prefers 60 - to 80 -years-old trees, but when abundant it will attack younger trees, and thickets of young growth and plantations.

The attack is on the needles. When the caterpillars are very young they gnaw the sides only of the needles, but fully-grown caterpillars eat them down to the sheath, usually leaving the latter, and in this manner completely strip the twigs.

Even the terminal buds may be eaten. The older caterpillar's prefer needles of the previous year. A single caterpillar will eat a needle in 5 minutes, and may destroy in all 1000 needles. After complete destruction of the needles and buds the tree must perish, and as a premonitor of death a few clusters of stunted needles, termed rosettes by Ratzeburg, may appear.

The trees may recover if, for a pole, 200 needles, and for an old tree 400 needles, still remain green. An attack commencing in April and lasting till June is the worst, as this affects the formation of wood. An attack generally lasts for 3, occasionally for 4 years, and is at its maximum during the 3rd year. Irregularity in the development of the insects, and degeneration of the caterpillar's, which are largest in the first year and become successively smaller and weaker, rapidly ensue. At the same time, insect-parasites and bacterial diseases become more and more active, until the caterpillars die from these causes in immense numbers.

This pest is most dangerous in pure Scotch pine forests, on sandy soils, in dry districts, and in the plains and hills of North and North-eastern Germany, less so in the south and west; it is rare in mountainous districts.

A succession of warm summers favours its multiplication to an extraordinary degree. 


\section{(d) Protective Rules.}

1. Avoidance, as much as possible, of pure Scotch pine forests in localities exposed to the attacks of this insect.

2. Careful search for caterpillars, chiefly in November, when they are libernating. The soil-covering round large trees is raked up and searched, and if 6 to 8 caterpillars are found around a tree, measures should be taken at once to destroy the caterpillars.

3. Careful management of thinnings. This removes sickly trees, admits the wind, which the moths dislike, and facilitates collection of the caterpillars.

4. Protection of enemies: bats, badgers, cuckoos, owls, goat-suckers, etc. 'Titmice, goldencrested wrens, and tree-creepers destroy the moths' eggs. A number of ichneumon-wasps

FIG. 142.

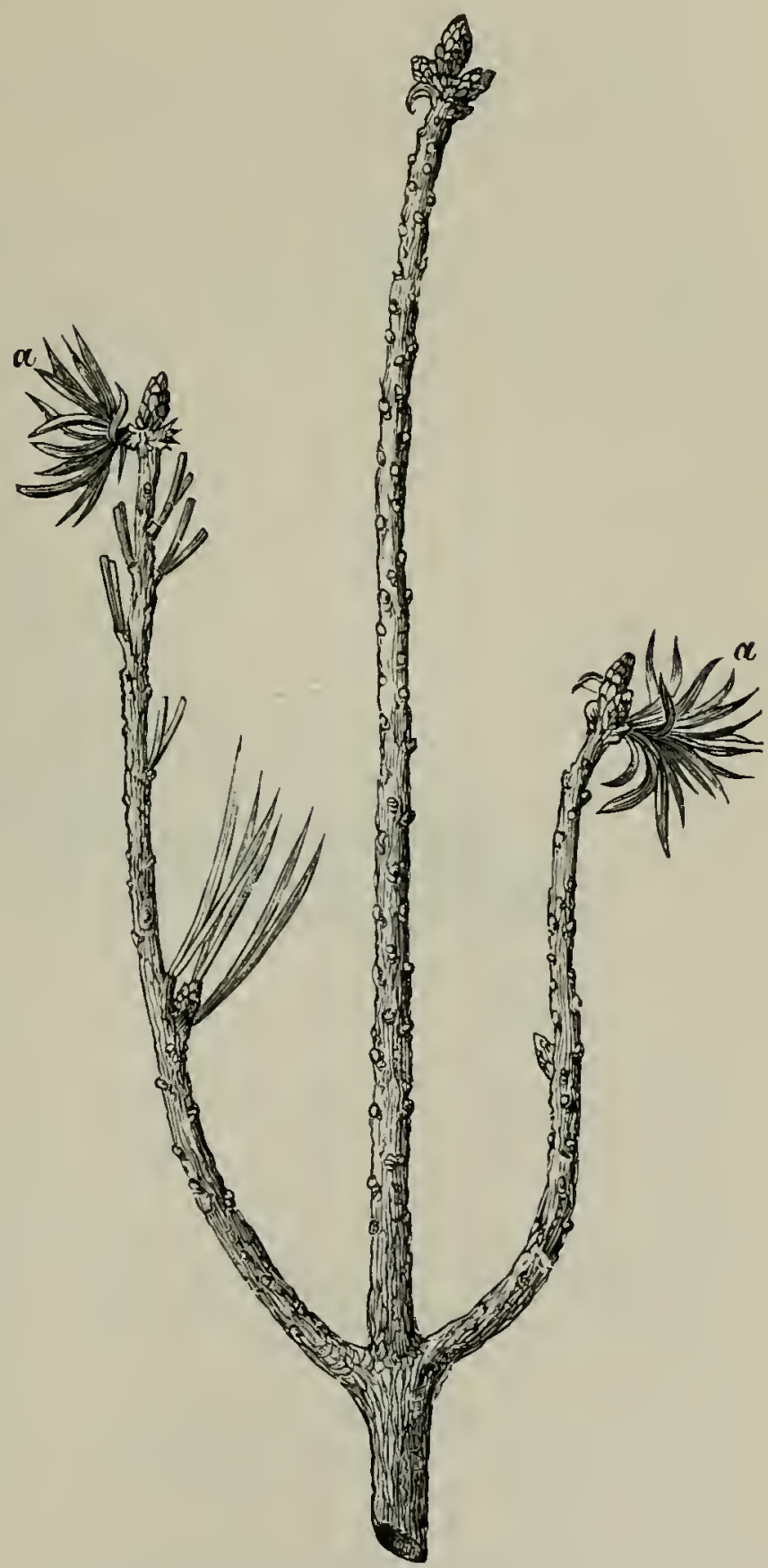

Rosette-needles $(a)$ on Scotch pine, following defoliation by G. pini, L. (Natural size.) and parasitic diptera attack the larvæ. Fig. 143 shows a caterpillar covered by the pupæ of Microgaster globatus, L. 


\section{(e) Remedial Measures.}

These are briefly: The excavation of trenches in the ground to catch the caterpillars. Trenches are made for the purpose of either isolating attacked areas, or to catch caterpillars within the infested wood.

Collection of eggs, by scraping them from the trees; but this method also destroys many ichneumons.

Collection of caterpillars. - This is undertaken either after November, or by shaking the trees in August.

This method is less efficacious than smearing girdles of tar on the trees, as at least half the caterpillars escape.

FIG. 143 .

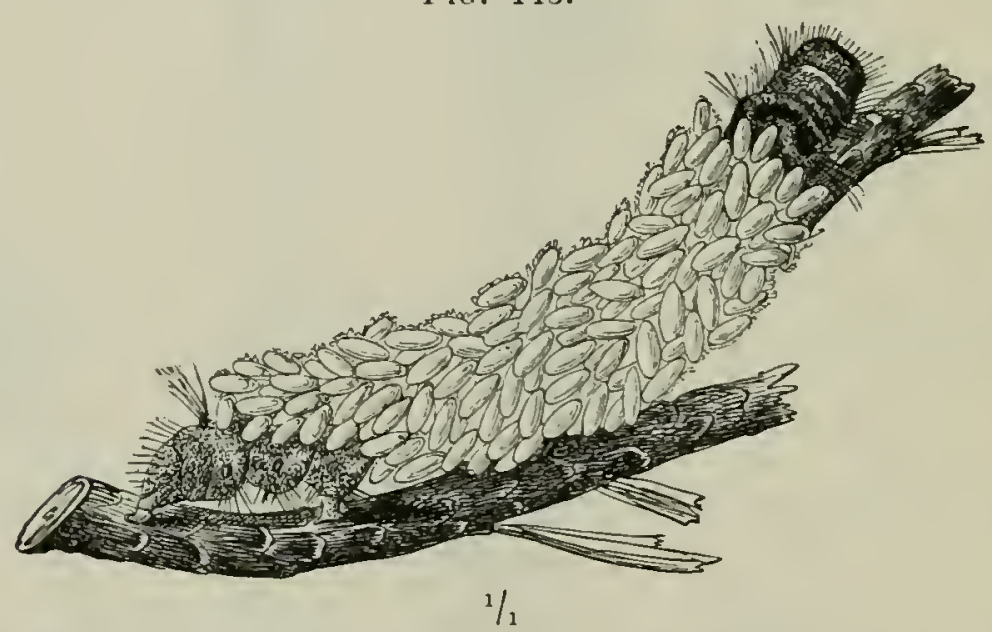

Caterpillar of the Pine Moth covered with Microyustcr cocoons.

Collection of pupe.-In June and July.

Collection of the o moths. - This is carried out in July in the morning and on cold wet days before the eggs are laid.

By this means ichneumons are not destroyed.

Girdling the trees uith grease-bands. This is the best and safest method to adopt when the insects have appeared in large numbers. It was first employed in Silesia in 1829 against L. monacha, L., and only in 1866-7 at Glïcksburg, against the present insect.

The details necessary to ensure success by this measure are carried out as follows :-

The woods which have been attacked are thinned, in order that tar may not be wasted on suppressed stems; all under- 
growth which might serre as bridges for the caterpillars is cleared away.

The coarse bark is remored from the pines in rings 10 to $15 \mathrm{c} . \mathrm{m}$. broad, in order to present a smooth surface for the tar. Care is taken not to injure the bast.

The smooth places are covered with a horizontal band of tar or grease 6 to $8 \mathrm{~cm}$. broad in February or the beginning of March, and this operation is repeated at intervals of 6 to $S$ days, or again in April, when the former application has become too dry to catch the insects.

Ratzeburg has distinguished experimental tarring from general tarring. The former is used on lines of trees here and there throughout a wood, where a severe attack is feared, and if 5 or 6 caterpillars are canght on each tarred tree, then a general tarring of all the trees is undertaken. There is howerer a danger that the general tarring may come too late, and it is recommended to try the experimental tarring in the autumn, and if a general tarring is shewn to be necessary, to take all preliminary measures for it during the winter. The best tar is made from pine roots and stumps; it should be of a cherry-brown colour and possess a proper consistency, be neither too thick nor too thin, and must be put on cold. Coal-tar must not be used for this purpose.

Certain compositions are also used which are superior to tar, such as tar mixed with 9 to 15 per cent. of resin, or 9 to 11 per cent. of acetic acid. For similar purposes in England, greasebands are made of "cart-grease" or mixtures of Stockholm tar, nnboiled linseed-oil, \&c., \&c.

In order that a composition may be really useful for this purpose, it must combine cheapness with prolonged stickiness. A thick coating should always be used, or else the substance is absorbed by the bark.

The quantity of tar used and the cost of painting the rings varies with the age of the roods, and in Prussia averages 40 to $50 \mathrm{lbs}$. per acre for old wood, and 50 to $60 \mathrm{lbs}$. per acre for young rood, the arerage cost in either case being 6s. and $9 s .6 d$. per acre for tar.

In 1878 in Plietnitz in W. Prussia, 45 millions of caterpillars were destroyed by means of tar rings, at a cost of $7 s$. per 10,000 
caterpillars. In woods under 60 years old the hibernating cuterpillars were collected at a cost of 20 s. per 10,000. The value of the annual increment of wood sared was 8s. per acre, as against $7 \mathrm{~s}$, the cost of the tar rings.

The efficacy of the tar rings is less interfered with by frost than by great heat, as the latter easily melts it and causes it to run down the tree. Most of the caterpillars which attempt to cross the rings adhere to the lower part of them; but about 3 per cent. of them, chiefly the larger ones, manage to cross the ring, although of these about 59 per cent. soon die from the effects of the tar, so that only 1.2 per cent. of the whole number really survive and pass the rings.

The caterpillars whose way to the tree-crowns is thus cut off, return to the ground and try to find their way to other trees; they are therefore prevented from so doing, by isolating, by means of trenches, the wood containing the tarred trees from other woods which have not been so protected.

Caterpillars infested by ichneumous, or fungoid diseases, may be introduced amongst those which are healthy.

In cases where the attack is very bad, but only localised over a small wood, the soil-covering is burned whilst the caterpillars are hibernating, or even the whole wood is burned, measures being taken in both cases to protect the adjoining woods from the spread of the fire.

Robert Hartig, in 1871, experimented near Eberswald on the effects of the different methods of protecting the Scotch pine from these caterpillars, with the following results :-

The collection of hibernating caterpillars, as long as the moss and dead-leaf' covering is replaced in position, has no influence on the growth of the tree.

The jarring of young trees in order to knock off the caterpillars involves local decay in the bast, and consequent reduction of increment.

Tarring does not hurt the trees in the slightest degree.

2. Bombyx neustria, L. (Lacley-1Noth).

(a) Deseription.

Moth with spread of wings of 30 to $40 \mathrm{~mm}$. Body and fore- 
wings ochreous-yellow or red-brown, the latter traversed across their middle by a darker band which is bordered by pale stripes; hind-wings somewhat lighter, crossed by a rague darker stripe.

Caterpillar extending to $45 \mathrm{~mm}$. in length, with $16 \mathrm{legs,}$ marked with alternate stripes of blue, reddish-brown and white, thinly corered with long hairs, head blue with two black spots.

Pupa bluish-black, covered with short hairs, in a yellowishwhite thick cocoon.

FIG. 144.
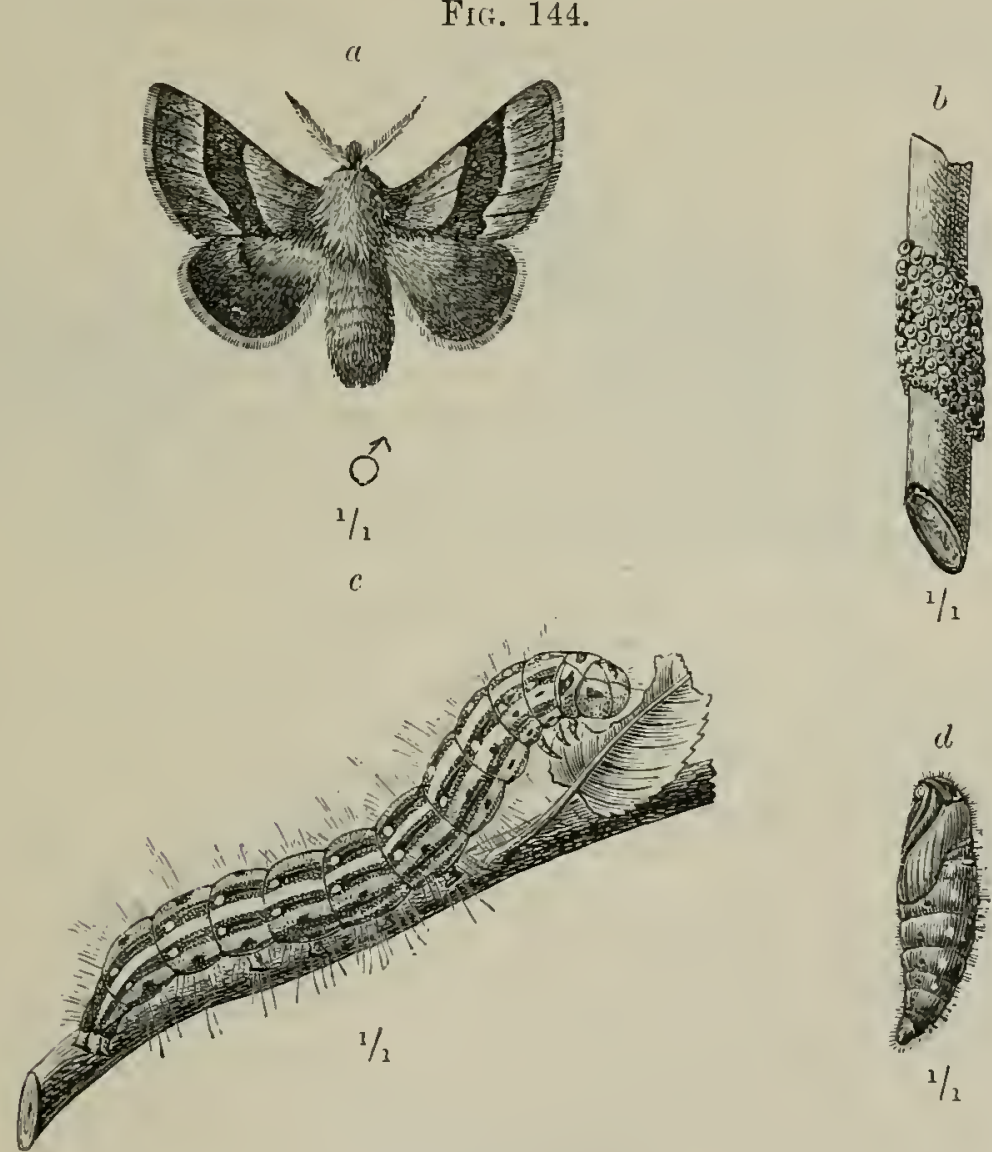

Bombyx neustrin, L.

a Imago (Ô). $b$ Egg-ring on a twig. $\quad c$ Larva. $d$ Pupa.

(b) Life-History.

The moth appears in July and August, flying in the evening and resting during the day in sheltered places.

The $q$, about 8 days after pairing, lays from 300 to 400 brownish-grey eggs in a close spiral, forming a cylinder round a young shoot.

The caterpillars hatch in April or the beginning of May, and live socially in companies of 50 to 100 , until they are full grown. 
in web-nests spun by their joint labours, and increasing in size as they grow up. They leare these nests to feed on leares, returning to them in wet weather or by night. In fine weather they are fond of sunning themselves. When disturbed, they let themselves down to the ground by threads, or after hanging some time in the air, draw themselves up again.

When full grown, in June, they disperse, and spin cocoons among the leaves, or in bark-cracks.

Generation annual; the insect is very common over the greater part of Europe and in England.

(c) Relations to the Forest.

The caterpillar is found on many trees, especially on apple and other orchard trees, and on oak; also on elm, hornbeam, poplars, willows, thorns, briars, \&c. Its attack commences on the blossom and leaf-buds, then extending to the foliage, and lasts from the end of April till the beginning of June. It is chiefly important in orehards, to which it does immense dimage.

\section{(d) Protectire Rules, ife.}

i. Protection of enemies, notably titmice, the golden-crested wren, the cuckoo, finches, \&c.

ii. Pruning and burning twigs bearing the egg-rings during the winter.

iii. Destruction of the young eaterpillars in their webs by erushing with gloves, or short brooms, or by cutting off the webs and letting them drop into a pail containing paraffin. These remedies can be economically applied in orchards and tree nurseries only.

3. Dasychiva pudibunda, L. (Pale Tussock Moth).

(a) Description.

Moth with a spread of wings of $45 \mathrm{~mm}$. (ठ), 50 to $60 \mathrm{~mm}$. (q). Fore wings whitish-grey, sprinkled with darker spots and with 2 to 3 narrow grey-brown transverse waved lines; abdomen and hind-wings somewhat lighter, the latter with a faint greyish band ; of darker and more spotted than the $q$.

Cuterpillar, when mature, about $40 \mathrm{~mm}$. long, with 16 legs, 
at first greenish yellow, later becoming reddish or brownish, hairy, with four truncated tufts of yellow or brownish-grey bristles on the 4 th to the 7 th segments, separated by black velvety bands, and with a rose-red pencil of hair on the last segment.

Pupa thick-set, dark brown, covered with short grey hair, in a yellowish-grey cocoon spun np with the larval hairs.

(b) Life-History.

The moth appears at the end of May or beginning of June. Fig. 145 .
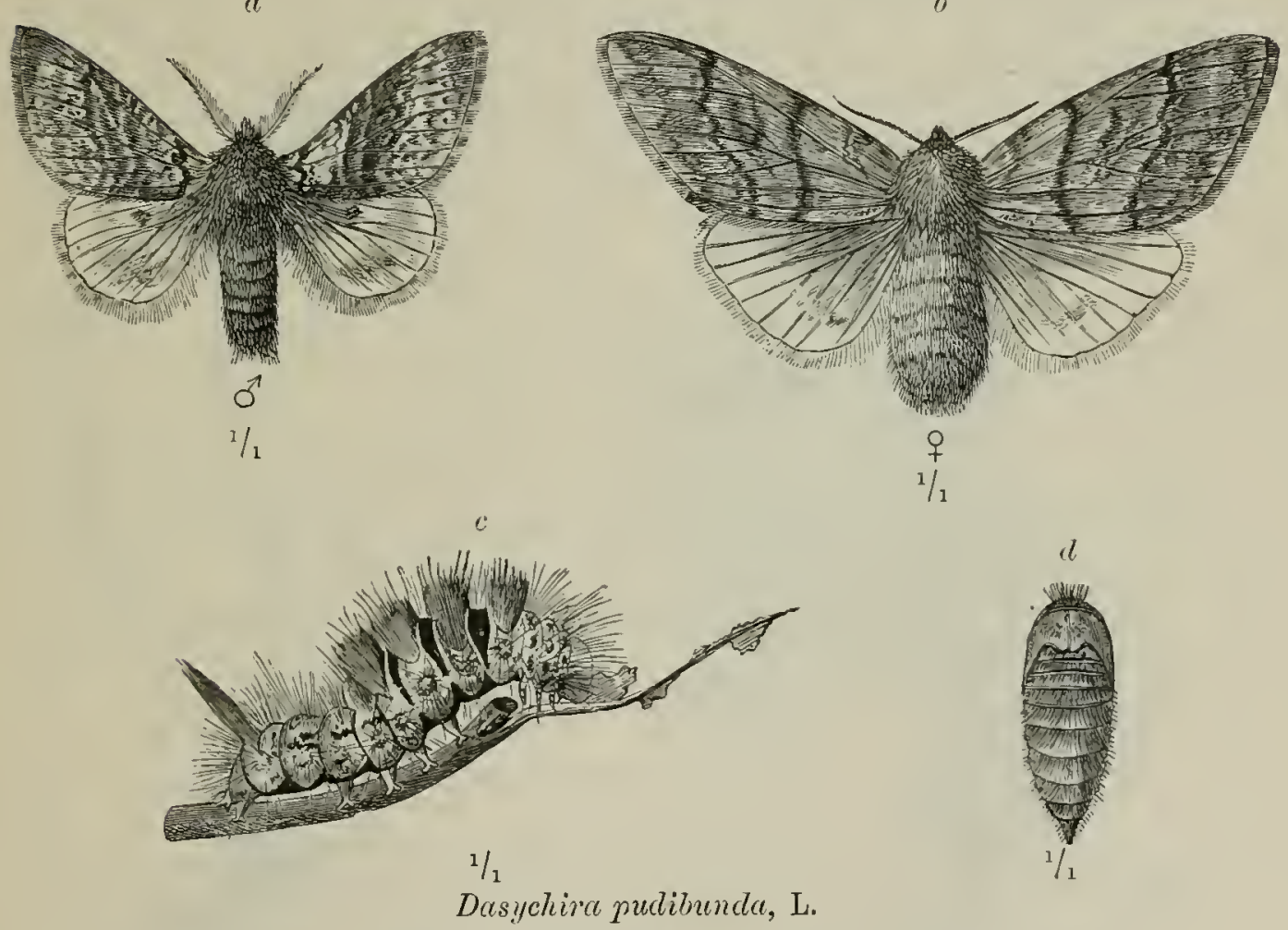

Dasychira pudibunda, L.

a Male. $b$ Female. $c$ Caterpillar. d Pupa (dorsal surface).

In June the female lays about 100 to 150 bluish-grey eggs in a cluster on the bark, generally low down, at about 1 yard from the ground, but often a few yards up, sometimes on twigs or dead wood on the ground, or even on grass or herbage.

The caterpillars hatch after 3 weeks, in June or July, make their first meal off their egg-shells, and remain a short time in clusters, with their heads usually turned inwards; about the middle of July they separate and wander towards the crowns of the trees, coming down to pupate in September. 
Pupation occurs at the end of September, or in October, usually under dead leaves, dead fallen wood, \&c., on the ground, in the bark-cracks of oaks, Scotch pines, \&c., or among herbage on the ground.

The generation is annual.

The caterpillar is very hardy, and withstands snow and cold well.

(c) Relations to the Forest.

The caterpillar lires singly on almost all forest trees, eren conifers, but has only been observed in abundance on the beech,

FIG. 146.

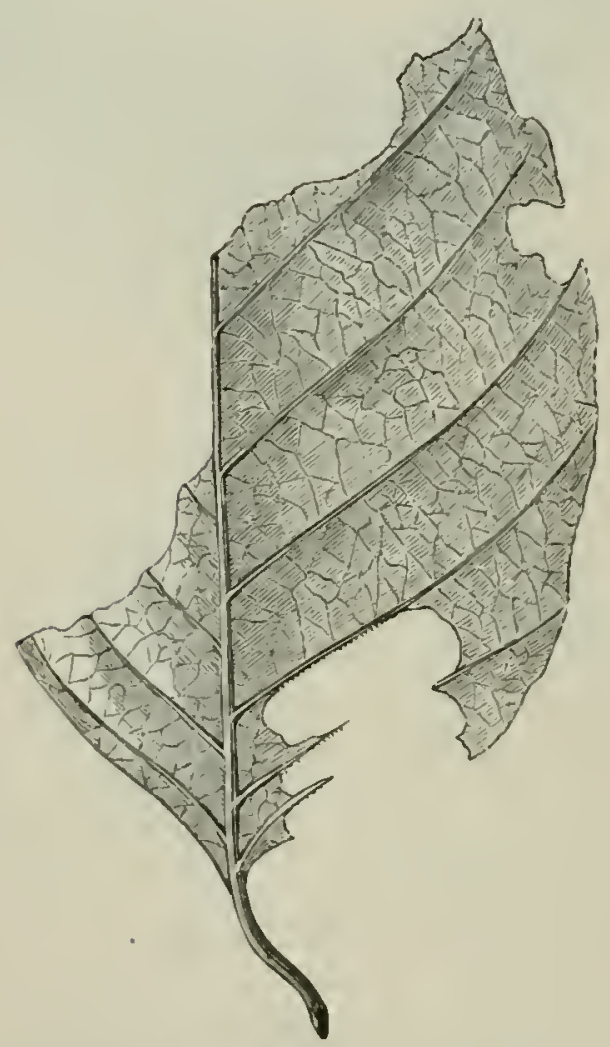

Beech-leaf, eaten by the larva of $D$. pudibundr, L. (Naturell size.)
FI(i. 147.

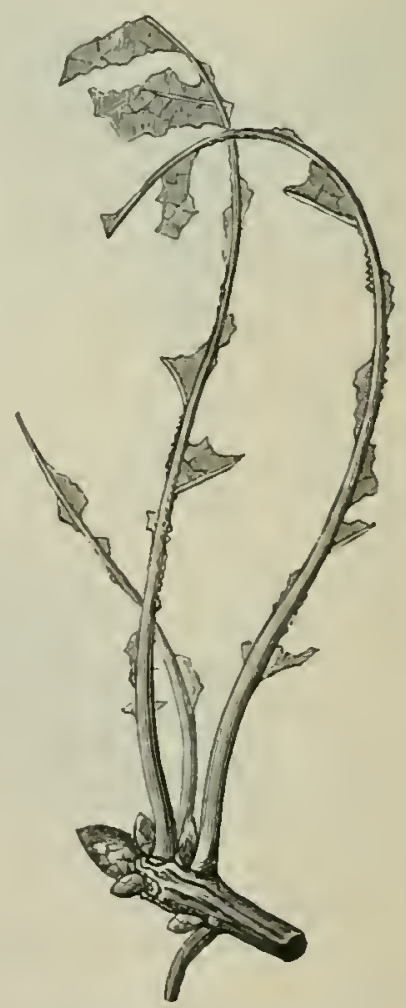

Oak-leaf, stripped by the larva of 1 . pudibunda, I.

(Aritural size.)

and occasionally on the horubeam, oak or alder. It prefers dry sunny elerated places, and avoids valleys. It has often been noticed that an attack commences simultaneously at several points of high elevation, from which it spreads in all directions.

It prefer's 40 to 80 -year-old woods. The foliage is at first only skeletonised, but after August the leaves are almost entirely 
eaten and fall to the ground in thousands after the caterpillars have bitten through the petioles.

In the case of the oak, the petioles and mid-ribs remain.

The damage done consists in loss of increment, and reduction in the production of seed, as fewer flower-buds are developed; the quantity of beech-mast is much diminished, and the nuts are often empty.

This is highly prejudicial to beech forests under natural reproduction.

The insect prefers southerly or south-westerly aspects; it is very common in North Germany, France and Belgium (Ardennes), being found at altitudes up to 1,300 feet abore sealevel. It is tolerably common in Great Britain, but is seldom destructive, except in hop-gardens.

\section{(d) Protective Rules.}

i. Beech may be grown in mixed woods of conifers, oak, maple, dc.

ii. Protection of enemies-crows, jackdaws, cuckoos, thrushes, finches, titmice, \&c. Ground-beetles and ichneumon-wasps are rery efficacious, and a spider (Epeira, sp.) has been observed to be extremely destructive to the insect. A fungoid disease due to Isaria farinosa, Fries, is also common.

\section{(e) Remedial Measures.}

i. Collection or destruction of caterpillars (end of September -beginning of October), as they come domn the trees to pupate. ii. Collection of pupæ in the winter.

iii. Girdling the trees with grease-bands at a height of 1 to 3 yards. This method has given fairly good results in the Eberswald. On 3 acres about 500 caterpillars per tree were caught at an expense of $11 s$. per acre. Unfortunately most of the eggs had been laid above the bands, and the eventual destruction of all the foliage of the trees was only delayed.*

* Dasychira thuccitesi, MLore, is rery destructive to foliage of the sal (Shrrec robusta) in Assam, and occm's in enormons numbers orer rery extensive areas. It also attacks the leaves of tea shrubs. Indian II useum Notes, vol. I, 1. 29. 
4. I'orthesia chrysorrhoea, L. (Brourn-tail Moth).

(a) Description.

Moth, with a spread of wing of 30 to $40 \mathrm{~mm}$. White; the inner margins of the wings fringed with long hairs; fore-wings in the of usually marked with small black spots about the middle and towards the anal angle. Abdomen brown towards the tip, which is furnished in the $\delta$ with a tuft of dark-brown down, thicker and red-brown in the $q$.

FIs. 148 .
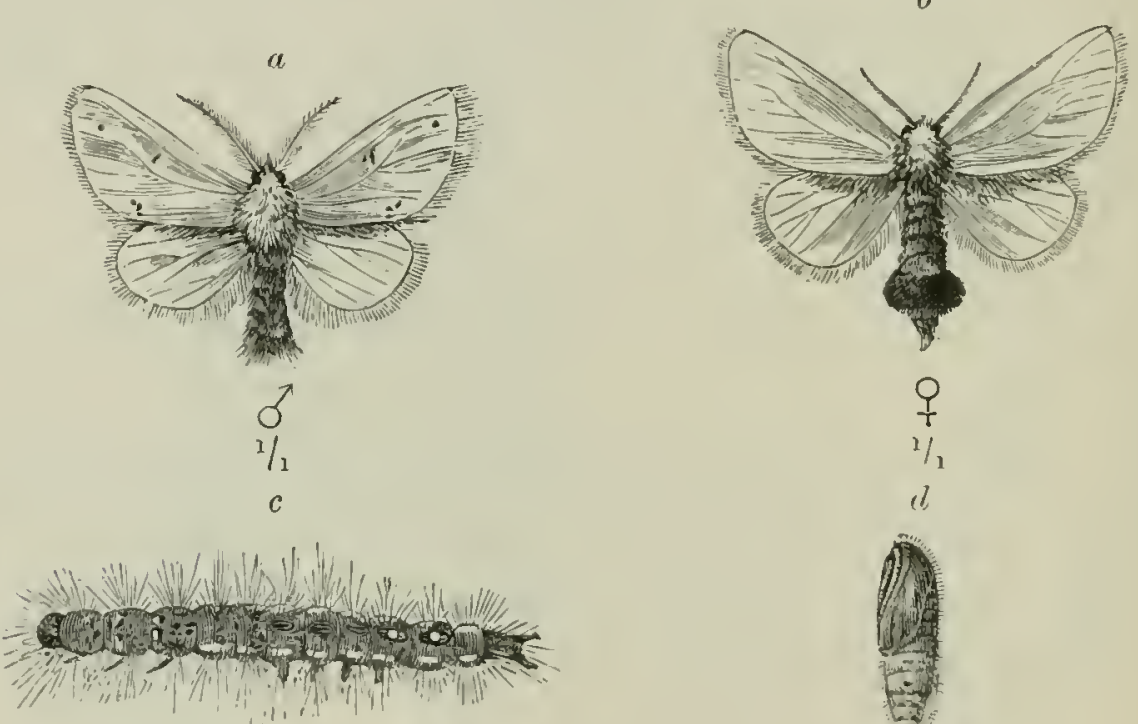

$1 / 1$

Porthesia chrysorrheen, L.

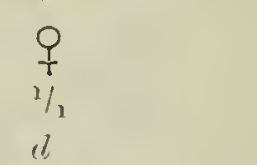

a Male. b Female. c Caterpillar. d Pupa.

Caterpillar $35 \mathrm{~mm}$. long, 16-legged, with radiating tufts of long yellowish-brown hairs, brownish-grey above, with 2 red, slightly zigzag lines along the back from the 6th segment towards the tail, and 2 vermilion warts on the 9 th and 10 th segment, grey beneath. with yellow spots and streaks.

P'upa dark brown, hairy, with pointed tail, in a brownish-grey cocoon.

\section{(b) Life-History.}

The moth appears at the end of June and in July.

The of lays 200 to 300 brownish-yellow eggs on the lower 
surface of leaves of many broad-leaved trees, and covers them with the dense fluff from her tail.

The caterpillars appear 2 to 3 weeks later, usually in August and at once spin web-nests among the neighbouring leaves. In the autumn they spin large caterpillar-nests, as big as the fist, in which they hibernate, binding together many leaves with their threads, and thus forming chambers which they line with silk and fasten firmly to the twigs.

Pupation takes place in June in a thin greyish-brown cocoon between leares.

Generation annual. This insect is common, but rarely appears in great numbers. In the Berlin Zoological Garden they destroy the foliage almost every year. It is less common in Britain than the closely allied $P$. similis, Füss. (auriflua, Fabr.); an insect of similar appearance, but with the abdominal tuft of down golden-yellow. It resembles $P$. chrysomhoca in habits, and especially attacks hedgerows and orchard trees.

\section{(c) Relations to the Forest.}

This insect is polyphagons; the caterpillars are found on pear and plum trees, on oak, white-thorn, and also on beech, elm, maple, hornbeam, willows, poplars, roses; even on robinia when nothing else offers.

The caterpillars, enclosed in their common web-nest, first gnaw the upper side of the leaves. Next spring, after renewing their nests, they feed on the buds and young leaves, and later, on the blossoms and fully developed leaves, except the petiole. In this way, the fruit is considerably reduced in quantity, if not entirely destroyed. Up to the middle of May, in bad weather and also during the night, they retire to their nests. After the third moulting, at the middle or end of May, they abandon their nests, and wander among the trees to feed.

The crowns of the trees which are attacked begin about the end of August to look as if they had been singed by fire; later, the woods become more or less completely defoliated. If defoliation takes places before Midsummer a second foliage may appear. 
(d) Protective Rules.

Protection of enemies. Titmice and the cuckoo are very useful.

Cutting off the caterpillar nests with shears, and burning them.

Collecting and killing the caterpillars in May, and the pupse in June. Care must be taken to protect the hands against the hairs, which canse inflammation. The above measures should be adopted for orchard and avenue trees.

Liparis monacha, L. (Black Arches, or Nun Moth).

(a) Description.

The moth has a spread of wings of $40 \mathrm{~mm}$. ( $\left.\delta^{7}\right)$, up to $50 \mathrm{~mm}$. (q). Fore-wings white, with many black zigzag transrerse lines and patches, hind-wings light grey; abdomen with broad, rosered bands, separated by black bands, which are very well marked in the $q$.

The catcrpillar is 40 to $50 \mathrm{~mm}$. long, with 16 legs, hairy, tapering slightly towards the tail, reddish-grey above and greenish-grey below; with 6 bluish warts bearing tufts of long hairs on each segment, and on the 6 th a velvety-black lieartshaped spot.

The pupa is at first greenish, later dark brown, with a bronze lustre, and covered with shaggy hairs.

\section{(b) Life-History.}

The moth appears in July and at the beginning of August, and may exceptionally be found till the end of September.

In the month of Angust the $q$ lays about 150 eggs of a reddish-bronze colour in groups of from 5 to 50 in bark-cracks, or among the moss and lichen of large poles and tree stems, preferring Scotch pine, usually at a man's height from the ground. Later the eggs become of a pearly grey colour, and hibernate without any protective covering.

The caterpillars hatch at the end of April, or the beginning of May. They remain for a few days (2 to 6) in small groups near their hatching place, and then ascend to the crowns of the 
trees. Until they are half-grown, they are able to let themselves up and down by threads should they be disturbed. They become full grown by the end of Jume, or the begimning of July. When roung, they are rather sensitive to changes of weather, and are easily blown down by the wind, and may then fall on to young forest growth.

FrG. 149 .

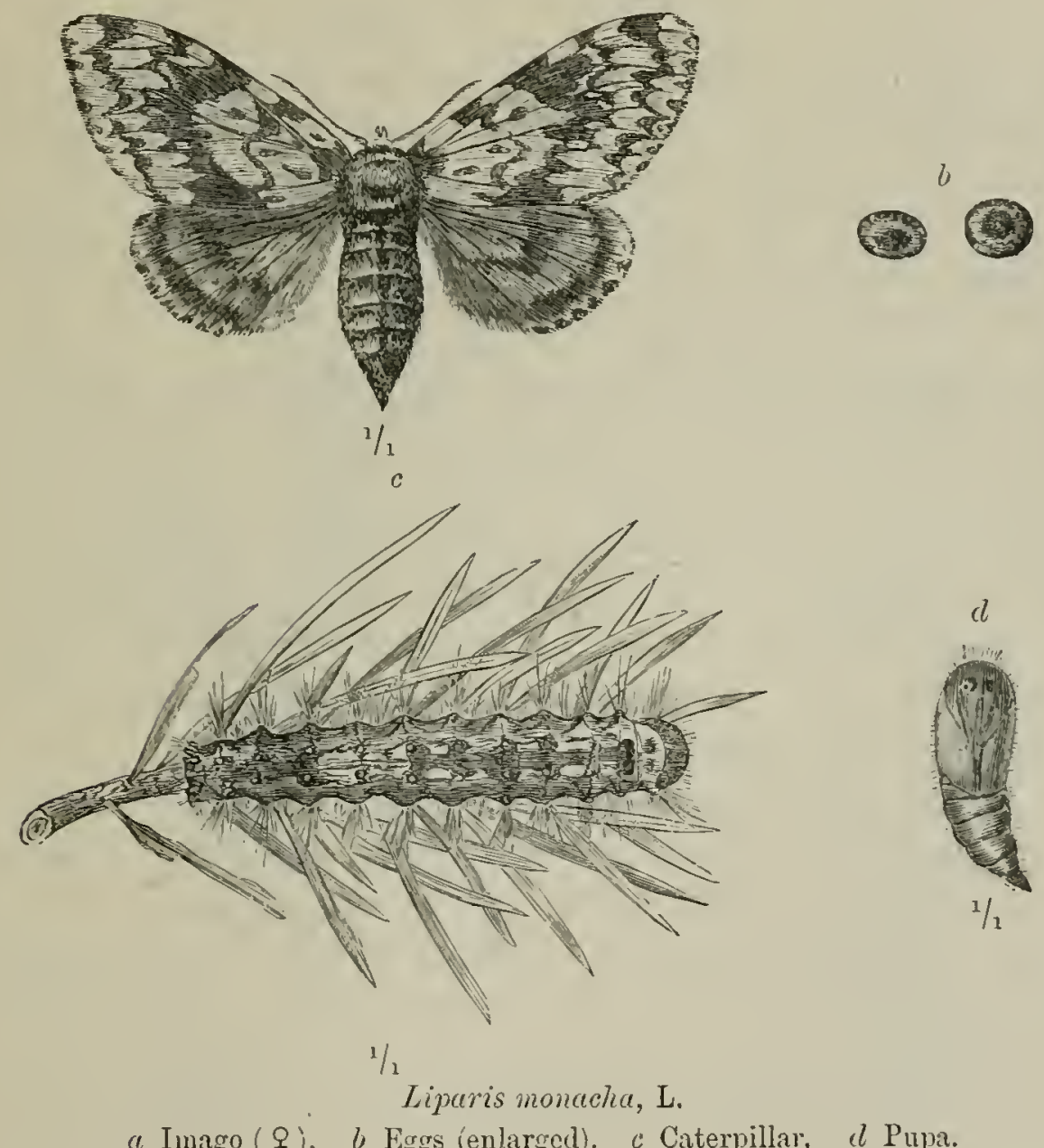

Pupation takes place at the end of June or the begimning of July, and the pupæ may be found fixed by a few threads in barkcracks low down on the stems, also on needles of low branches, and even on undergrowth.

The moth emerges in 15 to 20 days after pupation, the actire $\delta$ appearing a few days before the $q$.

Generation annual. The insect appears sometimes in truly formidable numbers. The moths are very active, and may fly to -ong distances in swarms, but usually remain localised. 
L. monacha is tolerably common in many localities in Britain, chiefly in the S. of England, but is not generally regarded as an abundant insect. It is rare in conifer-woods and, consequently, seldom if ever dostructive; its usual foor-plant appears to be the oak. Indeed most British lepidopterists seem to be unaware that it is a conifer feeder.

(c) Relations to the Forest.

This species attacks all conifers, but prefers the Scotch pine and spruce, and tall poles and old trees of these species to younger ones; it also, however, attacks young growth and also broad-leared trees, such as beech, hornbeam, birch, oak, orchard trees, least of all the ash and alder. In cases of scarcity of other food, it will not disdain low shrubs.

The caterpillars derour the needles and buds. When young they bore into the tender shoots, causing them to wilt; the older larve attack the fully formed needles, and in the case of spruce, eat them from the apex dowmards. They feed on Scotch pine in a most wasteful manner, biting off the tops of the needles and letting them fall to the ground, and only eating their lower portions. The quantities of half-eaten needles lying on the ground then betray the presence of the enemy.

In ligh coniferous wood the older needles are preferred to the rounger, and the attack spreads downwards and outwards from the summits of the trees. Among young growth, on the contrary, the young shoots are eaten first. If the attack is extensive, and towards its end, the caterpillars return in swarms to the summit of the trees and eat off all the younger shoots. Repeated observation has proved that these caterpillars are all sickly and erentually die, and inside them a great rariety of parasites is found.

The attack lasts from May till July, and is repeated for about 3 years. In the 2 nd or 3rd year it culminates, and complete defoliation may kill the whole wood. The spruce is more sensitive to the attack than the Scotch pine. The latter may recorer the loss of half its foliage.

The process of recovery in the spruce is shown in Figs. 150, 151, which represent portions of trees attacked in silesia during 1855 and 1856. The length of the internodes was least in 
1858, the normal growtl not being resumed till 1861, and a characteristic growth of stunted "bristle-needles" appeared, a feature which not unfrequently occurs in the case of Scotch pine.

The insect is found both in the plains and in hilly country. The most serere attack by the "Nun" during the present century

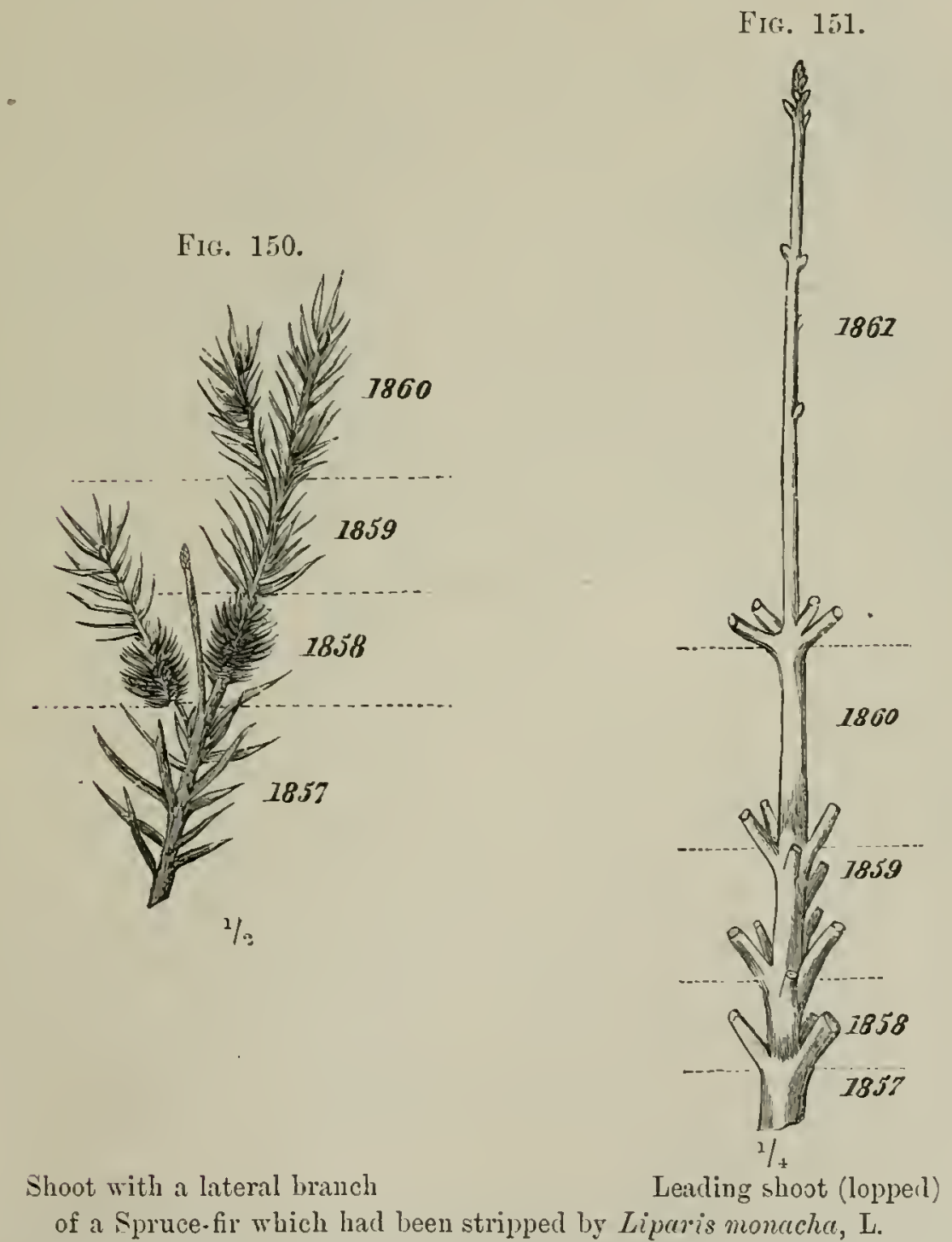

Date of injury, 1856 ; production of short growth, 1857; of bristle-needles, 1858 ; of short growth, 1859; of nearly normal growth, 1860; of normal growth with lateral dormant bucls, 1861 .

was during $1853-1858$ in East Prussia, Lithuania, and Poland; in 1858 a bark-beetle attack followed, and the calamity only stopped in 1860. From the 29th July, 1853, to the 27th June, 1855, in the Rothebude Forest, where the attack commenced, 6,375 acres of forest were completely stripped of needies, 
and about half as much more nearly stripped. The larral droppings corered the ground to a depth of 5 to $8 \mathrm{~cm}$., in many places to $15 \mathrm{~cm}$, and kept falling to the ground with a sound like heary rain. Up to the 1st October, 1862, 31,360,000 cb. feet of wood were lislled, of which $30,823,000 \mathrm{cb}$. feet by the Nun, and $437,000 \mathrm{cb}$. feet by barls-beetles. The raraged area exceeded 21,000 acres, and in East Prussia, between 1853 and 1863 , over $467,000,000$ cubic feet of wood had to be felled,

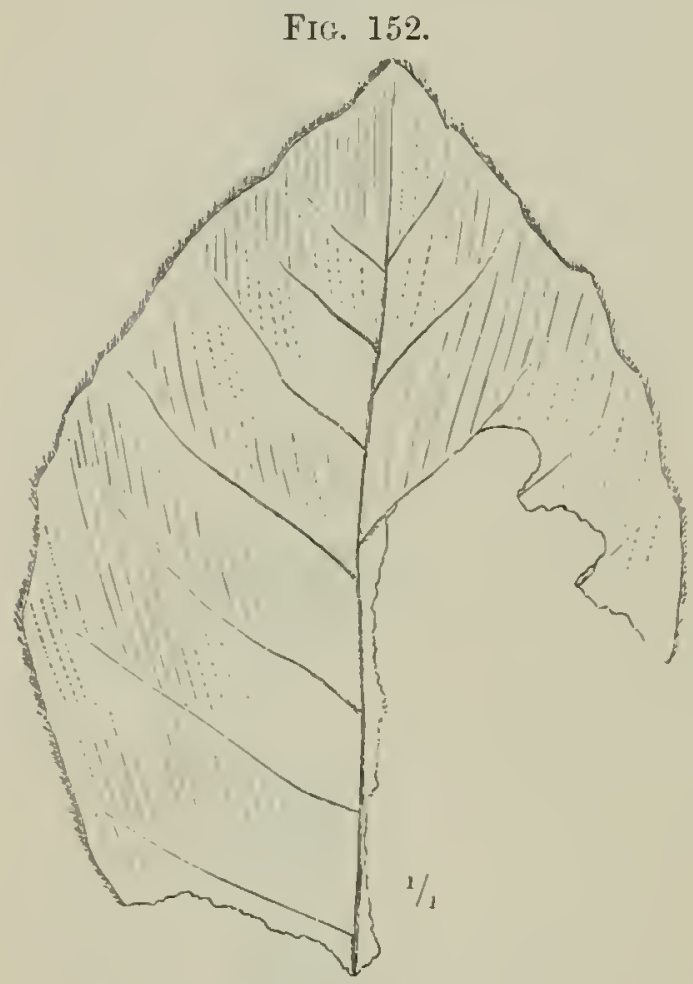

Jeech leaf eaten by a caterpillar of L. monacha, L. whilst 267,000 acres were derastated.

The damage done in the neighbouring Russian province was still greater, and it has been computed that by the Num and bark-beetles 6,400 geographical sq. miles of forest in Russia, and in Prussia $600 \mathrm{sq}$. miles, altogether $7,000 \mathrm{sq}$. miles of forest, were destroyed, and at least $6,42 \bar{\jmath}, 500,000 \mathrm{cb}$. feet of timber killed. It was noted as a curiosity that the manuring of the forest soil by the dung of the caterpillars, and the opening-out of the roods, produced such a heary growth of grass that the stags, owing to the greater abundance of provender, bore antler's of unusual size.

In 1889 and 1890 this insect proved rery destructive in Bavaria, south of the Danube, the expeuses of the campaign against it amounting to as much as $\$ 100,000$.

In attacking broad-leared trees, the caterpillars frequently eat the base of the leares, letting the remaining portion fall to the ground: this is the case with birch and aspen (Fig. 153), whilst with beech and oak only a portion of the leaf is eaten, the leaf-stalk being usually untouched (Fig. 152).

The attack is never fatal to broad-leaved trees. 


\section{(d) Protective Rules.}

i. Avoidance of pure spruce or Scotch pine woods and introduction of suitable species in intermixture with such woods.

ii. 'Thinning.-By careful thinning future remedial measures are facilitated, and a better control over the collectors of eggrs, larrie or pupie is maintained.

iii. Protection of enemies: bats, cuckoos, moodpecker's, crows, starlings, titmice, golden-crested wren, \&c. The two latter are extremely useful in destroying the eggs throughout the winter. The groundbeetles, Carabus glabratus, L., and Calosoma sycophanta, L., are also very useful

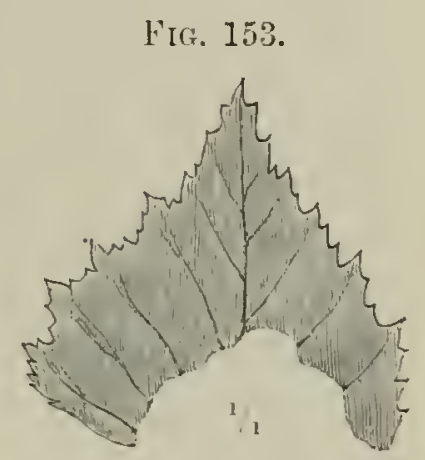

Birch leaf eaten by the caterpillar of $L$. monacha, L.

on the Continent, the larve of the latter attacking the moths" eggs, and the beetles the caterpillars. Many ichneumon-wasps and Tachince attack the caterpillars, for instance, Tachina monache, Ratz., 'T. phalcenarum, L., \&c.

\section{(e) Remedial Measures.}

i. Collection and destruction of the eggs by fire from autumn till the middle of April. The piece of bark on which the eggs are laid is remored, and the eggs scraped off with a knife into a bag furnished with a rooden fummel-shaped mouth. The stems are cleared up to 16 feet high, preferably by day-labourers, at first on foot and then with a ladder, and the woods in which many moths have been observed should be first treated. This treatment is easier in smooth-barked pole-woods of spruce than in older woods with rough bark.

One gramme-weight of eggs contains about 1200, and the cost of collection is about $3 d$. to $1 s$. for 15 grms. In the winter of 1839-40, in the Biesenthal forests near Eberswald, 10 tons of eggs were collected. The eggs should be burned in small lots, as otherwise they explode like gunpowder.

ii. Killing the clusters of newly-hatched caterpillars in April and May by means of cloths, brushes, or by rubbing them with moss, sods, \&c. Great care must be taken to seize the proper moment for this operation, and a delay of only a few 
days may prevent its being done. The cloths, \&e., used may be soaked in tar to render their action more efficacious. This operation is also best done by daily labour, but under careful supervision, one overseer being appointed for every 20 to 30 workmen. One man should be able to work orer 6 to 8 acres per diem, and the most suitable place to work in is among young poles, where the caterpillars can be readily seen, and are not too high up the stems.

iii. Collection of caterpillars and pupe, commencing in June. Small caterpillar's are usually collected in young growth, on to which they have been blown; later on, when they have ceased spinning, they are shaken down from the poles. It is preferable to collect the pupæ.

iv. Collection of $q$ mothes from the beginning of July. This should be done as soon as they emerge, and in the earliest hours of the morning; it gives the best results during cool weather. A cloth may be covered with adhesive matter, and used to daub the insects.

It is not yet fully decided whether this measure is very effective or not, some authorities, such as Altum, ranling it as the best to be adopted, and others, as Ratzeburg, considering it as almost useless.

In the forests near Ebersdorf in Reuss-Greiz, between the 26th June and the 12th August, 1868, 600,000 o were destroyed at a cost of $£ 270$.

v. Trenches are usually of little use. Smearing the stems in winter from the ground up to the large branches with a mixture

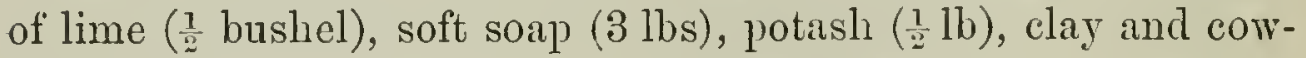
dung destroys the eggs. This method can only be used for orchard trees.

vi. The application of grease-bands about 2 in. wide at a height of 16 to $20 \mathrm{ft}$. from the ground, above the places where eggs are laid. This should be done at the end of March or April, and the bark here is sufficiently smooth, and requires no preliminary scraping. The rings are smeared by means of a broad brush fastened at right angles to a long pole. This has in many cases proved an excellent remedy. T'he little caterpillars remain sitting in thousands below the rings, which cut off their way to the crowns of the trees. The composition used 
should retain its fluidity for some time, but need not be rery sticky, as the caterpillar's to be caught are so small.

Of all the remedial measures discussed here, this, and killing the caterpillars before they ascend the trees, are the most effective. Large fires lighted at night in the forest to attract and burn the moths have failed to do any good. In 1890, in the Bavarian forests the moths were attracted by electric lights to the mouth of a large funnel into which they were sucked by an exhaust current of air produced by steam power. Large numbers were collected by this method, and killed, but it cannot be stated whether the utility of this proceeding is commensurate with its expense.

\section{Fanilu IV.-Noctuide (Night Moths).}

\section{Description of Family.}

Moths with long, setaceous antennæ, usually covered with fine hairs, and sometimes pectinate in $\delta$; ocelli present; proboscis long; wings narrow, during repose roof-like or level; fremulum present. The markings of the fore-wings are usually characteristic and take the form of three or four transverse lines of which the second from the outer margin is elbowed, and of three spots; two are situated near the anterior margin, the outer being kidney-shaped (reniform stigma), the inner circular (orbicular stigma); the third is elongate, and is beneath the orbicular spot (clariform stigma). These markings are constant in position, but some or all of them may be absent. The body is thick, and usually covered with down; the head surrounded by a collar. Flight nocturnal or during twilight, hardly erer by day.

Caterpillar's usually bare, rarely hairy, commonly with 10 prolegs, sometimes with 8 or 6 .

Pupation of the bare caterpillars generally takes place in the ground, in a cocoon made of grains of sand bound together by a few threads. The hairy caterpillars spin a cocoon above ground. Pupe usually slim, spindle-shaped and dark coloured. Many of the caterpillars live on woody plants, eating needles and leaves, but the majority of them feed on grasses and low plants. A few species are highly injurious to forests. 
1. I'anolis pininerda, Panz. (Pine Beauty, or Pine Noctua).

\section{(a) Description.}

Moth with a wing-expanse of $35 \mathrm{~mm}$.; fore-wings russet-red marbled with grey; orbicular and reniform stignata yellowishwhite, conjoined, the latter large, oblique and produced towards the tip of the wing; hind-wings and abdomen greyish-brown.

C'aterpillar $40 \mathrm{~mm}$. long, with 16 legs, almost hairless, of a yellowish-green, with 3 or 5 whitish-coloured stripes and a light-brown head.

l'upa somewhat elongate, of a bright brown colour, with two spines on its tail.

FIr:. 154.

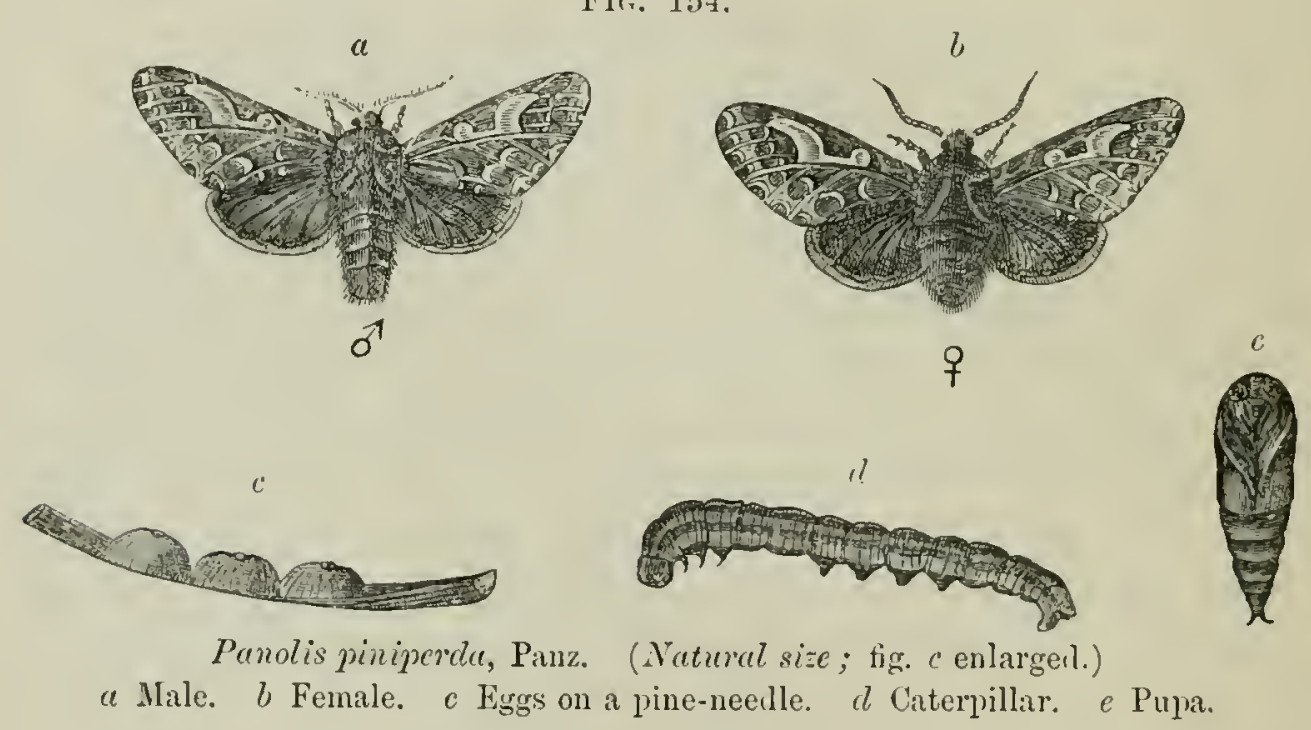

(b) Life-History.

The moth appears from the end of March to the begimning of May.

The $q$ lays 30 to 70 round, dull-green eggs on the needles of old Scotch pines.

The caterpillars hatch out in May, spin freely when young, and are fully grown by the middle of July.

Pupation takes place at the end of July or beginning of Angust, under moss, dead leaves, on or in loose earth, usually under the cover of the tree on which the insect feeds. The pupre are sometimes found in colonies, in the holes whence stumps, ete., have been extracted. 
Generation annual. The caterpillar sometimes appears in enormons numbers, but is susceptible to changes of the weather. It is tolerably common in pine-roods throughout Great Britain.

\section{(c) Relations to the Frovest.}

The caterpillars attack chiefly the Scotch pine, especially when 20 to 40 years old, but in case of necessity it may feed on older trees and other conifers, such as spruce, Weymouth pine and juniper.

When young the caterpillar, ascording to Ratzeburg, bores into the bud-sheaths of the spring shoots, which thus become brown, wilt and die. Later on the needles are attacked, begimning with their edges, and finally they are entirely devoured, usually on the lower branches, but also high up in the crown. The attack lasts from May till July, but is not so destructive as that of Gastropacha pini, L., as the Scotch pines, eren if extensively stripped by it, usually form new buds and recover. One should therefore await results before felling woods that have been completely stripped of needles. Only when the fatal rosettes of needles (fig. 142) appear is the deatl of the trees imminent. The insect imhabits lilly regions, and is most common in forests where the soil has become impoverished by removal of litter.

\section{(d) Protectirc Rules.}

Protection of cncmies : fox, badger, hedgehor, shrew, cuckoo, crow, starling, thrush, titmice, golden-crested wren, etc. Calosoma sycophanta, L., is very useful on the Continent, and many parasitic insects and fungi attack the larve.

Fungi (Empusa sp.) killed nearly all the caterpillars in the Tuchler Haide in 1867, their bodies being covered with yellowish-grey sporangia which after rain became dark brown. The infected caterpillars were brittle like the pith of elder, and filled internally with a yellowish substance.

\section{(e) Remedial Measures.}

i. Pigs may be admitted to the woods from July till hard frost sets in. In the forest district of Cloppenburg in Olden-

VOL. IV. 
burg in 1845, 58 pigs in 29 days (November and December) are estimated to have destroyed 16,000,000 pupæ.

ii. Caterpillars may be collected from the middle of May onwards by beating the stems, or in July by picking them from lower growth, or at the foot of the stripped trees, where they often collect in numbers.

iii. Pupæ may be collected during the winter, under moss, etc.; the holes whence stumps have been extracted should be specially examined.

iv. Moths may be collected by striking the trees in cloudy weather or by "sugaring."

Trenches are not of much use, as the caterpillars are little given to wandering about.

\section{Agrrotis vestigialis, ${ }^{*} \mathrm{Hufn}$.}

(a) Deseription.

Moth with an expanse of wing of 30 to $35 \mathrm{~mm}$. Fore-wings ashy grey, mingled with brown, variable in depth of colour, with fine black veins, the three stigmata conspicuous, darker than the ground, the orbicular and reniform with light borders, the former sometimes reduced to a point. Hind-wings light grey with darker borders.

Caterpillar $35 \mathrm{~mm}$. long, with 16 legs, of a dull brownish grey; head with a triangular frontal spot, and another on the vertex, meeting at their apex, their borders forming a $\times$.

Pupa brown, terminated by two very short points.

\section{(b) Life-History.}

The moth appears from the middle of Angust till the middle of September.

The eggs are laid on the ground amongst the grass and herbage.

The caterpillars hatch in September, and hibernate in the soil when half-grown; as they are earth-coloured it requires an accustomed eye to detect them.

* Larve of the different species of Agrotis usually live in the ground; they gnaw through plants above the roots and are appropriately termed cut-rcorms in Ameriea. 
Pupation takes place from the end of June till August, either in the ground, in a cocoon, or exceptionally among the needles of young Scotch pine.

Generation annual.

The caterpillar dislikes the light, and during the day remains in the ground or concealed under the leares of the plants on which it feeds.

\section{(c) Relations to the Forest.}

The caterpillars of species of Agrotis are termed "surface caterpillars," and that of the present species chiefly feeds on agricultural crops, young shoots of grasses, potatoes, turnips,

FIf. 155.
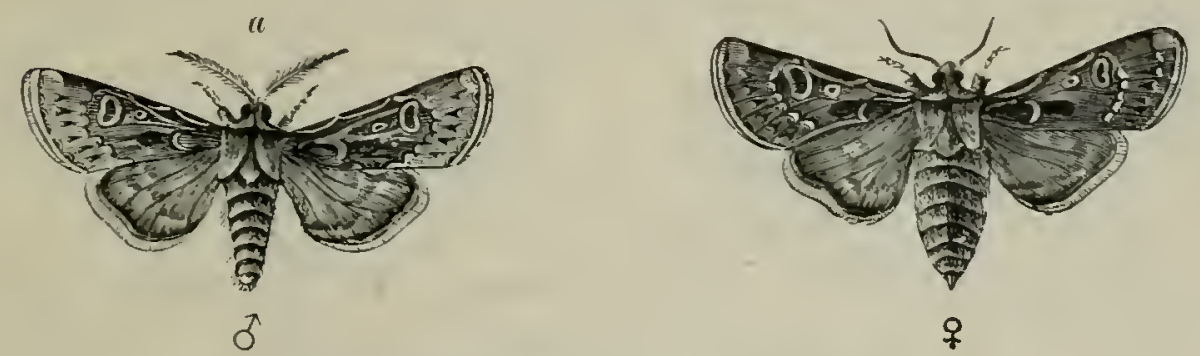

Agrotis restigialis, Hufn. (Nutural size.)

etc., towards harrest time. It also attacks the Scotch pine and the larch as seedlings in their first and second years, and exceptionally the seedlings of broad-leaved trees. The little one-year-old seedlings are usually bitten off by it in April and May close to the collum, never deeper than 1 in. under ground. The larva then feeds on the root, the lower part of the stem, and lastly on the needles. In June, when the plants are somewhat older, they are bitten off at about the middle of their height, and the stem and roots gnawed.

Two-years-old seedlings usually have their weaker side shoots bitten off', more rarely the leading shoot as well, and some of the needles are eaten; the bark may also be gnawed, but such plants commonly recover from the injury they have received.

The damage is usually done at night, when the caterpillars crawl along the surface of the ground from one plant to another; during the day-time they proceed under ground. 
Poor sandy soil in plain districts is most frequented by this pest.

'This insect has recently become very injurious in North and North-east Germany. It is tolerably common on the coasts of the British Isles, but is rarely met with inland, and has attracted little or no attention as an injurious species.

\section{(d) Protectice Riules.}

i. Areas both in murseries and in the forest which are to be sown up should be thoroughly weeded in the previous year, as the $f$ will not lay her eggs except among grass and herbage.

ii. For planting-out, not seedlings of the first year, but 2 to 3-years-old plants with balls of earth should be employed, as the caterpillars find it difficult to bore through the firm earth of the balls.

iii. Protection of enemies.

\section{(e) Riemedial Measures.}

Pigs may be driven into places where this pest has appeared.

The ground may be ploughed up or trenched with hoe or spade, and the caterpillars collected and destroyed. In quite loose sand the plants may be lifted by hand, and those uninjured or slightly injured replanted.

The caterpillars may be poisoned by laying baits of cabbage or lettuce-leaves sprinkled with arsenic along the beds.

The moths may be caught by "sugaring," and destroyed.

\section{Agrotis segetum, W.V. (T'urnip Dart-Moth).}

\section{(a) Description.}

Moth with a wing-expanse of $40 \mathrm{~mm}$. ; fore-wings yellowishgrey or yellowish-brown, with darker marks, stigmata of the same ground-colour as the wings, the reniform and orbicular margined with black; hind-wings mills-white, with no lunate spot.

Catcrpillar $50 \mathrm{~mm}$. long, with 16 legs, coloured like that of the former species, but with the triangular spots of the forehead and vertex separated at their apices by a space, $x$.

Pupa light brown, with two long anal points. 
(b) Life-History.

The moth appear's from the end of May till the middle of June. The $q$ flies a few days later than the $\delta$. The larval life is passed in the ground, the caterpillars hatching out in June and July, and pupating in April and May.

Generation annual. Very common everywhere in Germany and in the British Isles.*

\section{(c) Relations to the Forest.}

The caterpillar chiefly attacks the roots of grasses, cereals and root-crops, also seedling and one-year-old spruce plants. In some

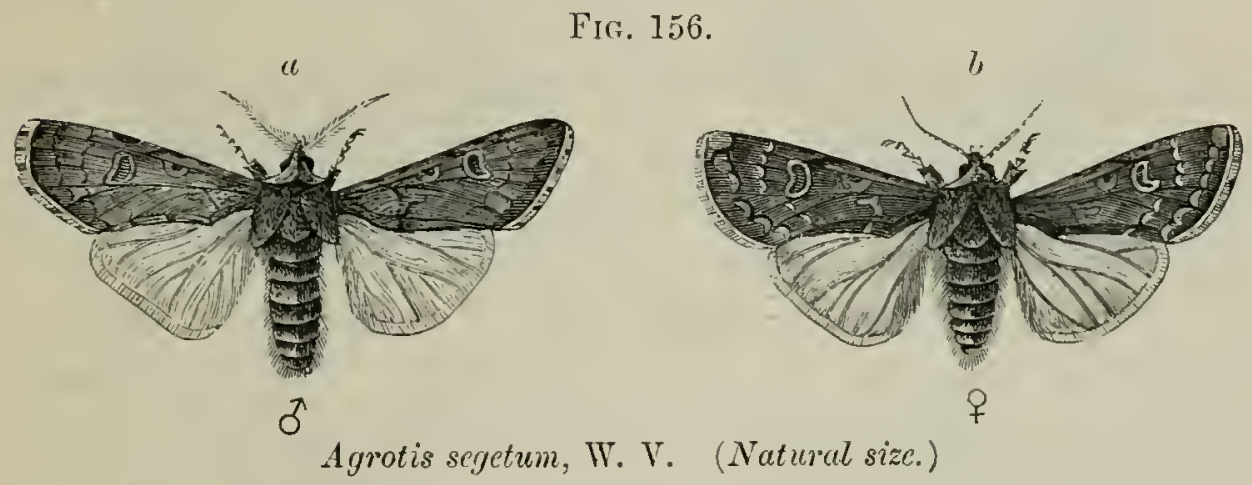

Prussian forest districts it has also been observed attacking oneyear-old plants of Scotch pine and beech. Except during hard weather in the winter its attack lasts from August to April. Seedlings are bitten off below the cotyledons, and one-year-old plants gnawed about the collum, so that they frequently die. In 1864 this insect proved very destructive in Silesia. The protective measures are the same as for the previous species.

\section{Family V.-Geometride (Loopers).}

Descripition of Family.

Antenne of the imago either filiform or setaceous, with a thickened basal joint, not unfrequently pectinate in $\delta$; ocelli absent; proboscis short; wings large, broad and delicate, usually lying more or less level in repose, sometimes sloping; frenulum always present. Bodies slim, resembling those of 
butterflies. Flight usually at dusk, or by night; a few species fly in sunshine. Caterpillars bare, or only slightly hairy, with 10 (rarely 12) feet; they move about by looping, owing to the absence of the first 3 or 2 pairs of sucker feet; hence their name, loopers or span-worms.

Pupe long, with a short pointed tail, bright brown, lying usually without cocoon under grass, moss, or in the soil.

The caterpillars feed on needles, leaves, buds, \&c., and a few species are injurious to forests.

1. Bupalus piniarius, L. (Bordered-uhite or Pine Looper-Moth).

(a) Description.

Moth with a wing-expanse of $35 \mathrm{~mm}$. $\delta$ bright yellow, with a sharply-defined area at the tip of the fore-wings and the margins of both pairs black-brown, hind-wings with two transverse dark bands; antenne bipectinate. of reddish-brown, the tip of the fore-wings, borders, and 1 or 2 transverse bands on both wings dark brown; antennie setaceous. In both sexes the under-side of the wings is brownish, with dark lines and numerous spots, and a broad light-yellow band across the middle of the hinder pair.

Caterpillar $35 \mathrm{~mm}$. long, with 4 prolegs, smooth, yellowish green, with 3 white dorsal stripes, of which the middle one is broadest, and two broad yellow stripes along the spiracles.

Prupa at first green, later bright brown, with sharply-pointed tail.

\section{(b) Life-History.}

The moth flies in May and June. The $\delta$ is fond of flying about on sunny sultry days; its flight is unsteady. The $q$ is also very active.

The smooth somewhat flattener green eggs are laid in a row (2-12) on Scotch pine needles in the crowns of the trees. The caterpillars hatch out at the end of June or the beginning of July, and are fully grown by October, when they let themselres down from the trees by threads. If the weather be mild, caterpillars may even be found in December. Pupation occurs in October and November under moss or other soil-covering, or 
in the soil, usually under the cover of the trees on which they hare been feeding.

The moth emerges in May or Jume.

Generation annual. Very common, and widely distributed in pine-woods.

(c) Relations to the Forest.

The caterpillar attacks the common Scotch pine, rarely other pines, the spruce or silver nir, and prefers 20 to 40 -year-old trees, but will even attack trees up to 60 years of age.

\section{FIC. 157.}
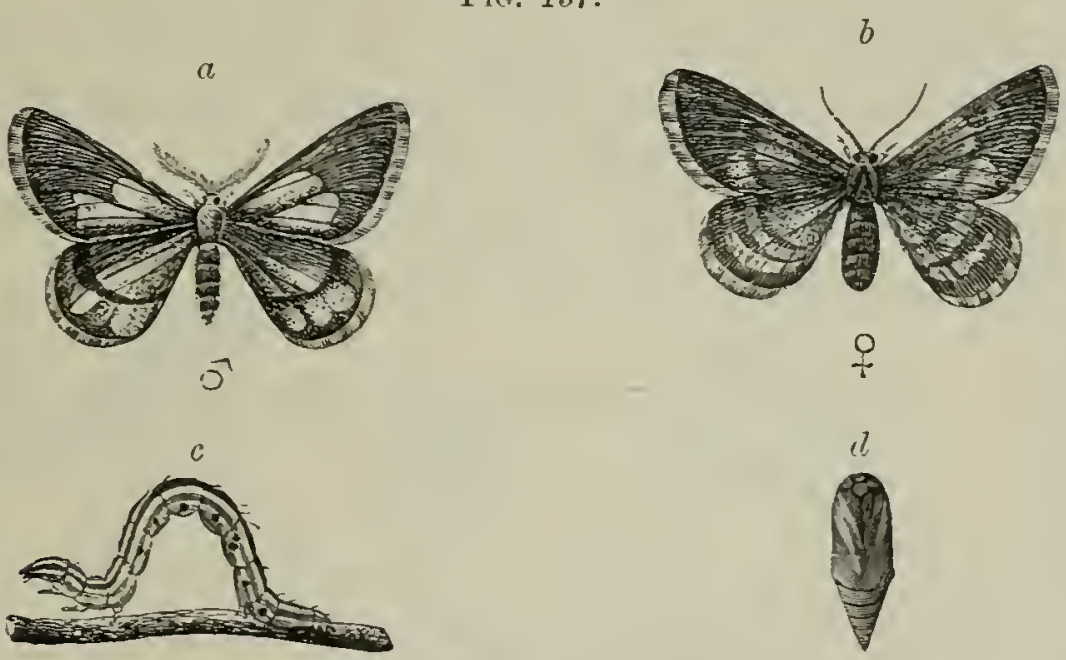

Bupalus piniarius, L. (Natural size.)

a Male. $b$ Female. c Caterpillar. $d$ Pupa.

The needles are eaten from the beginning of July to the end of October, but not the buds. At first the shoots of the current year are spared, but later on they are also attacked. The young caterpillars gnaw the sides of the needles; as they get larger they eat down to and beyond the mid rib. The fullgrown larræ cut off the points of the needles, but eat the remainder completely. Complete defoliation seldom results in the death of the trees, as the buds produce fresh foliage, and the attack commences late in the season. It is therefore $\mathrm{mn}$ necessary to commence immediate felling of defoliated woods, as after an attack of $P$. piniperda, L. Dense roods in sumy aspects of rarm hill districts are preferred by this moth, and windy borders of the woods are avoided. 


\section{(d) Protective and Remedial Rules.}

Protection of enemies, as for Trachea piniperda.

Admission of pigs from October to April (50 pigs to 500 acres).

Collection of pupr in winter.

Collection of caterpillars in August by shaking the poles.

Painting rings of grease or lime-whiting 12 to $15 \mathrm{~cm}$. broad on the trees at $1 \mathrm{~m}$. from the ground. This costs $7 \mathrm{~s}$. to $8 \mathrm{~s}$. per acre for tar, and $4 s$. to $6 \mathrm{~s}$. for lime, and has proved effective.

Raking up into heaps, and burning the soil-covering. This method gave excellent results orer about 190 acres in Pomerania in 1881-83; about $\frac{1}{2}$ to $\frac{3}{4}$ of the pupæ were burned with the litter, and most of the remaining ones being exposed by the remoral of the soil-covering were eaten by birds. There the soil-covering had been left intact, the moths appeared in the following spring in large numbers.

\section{Cheimatobia brumata, L. (Winter Moth).}

(a) Description.

Male with a wing-expanse of 25 to $30 \mathrm{~mm}$.; fore-rings ample, grey-bromn, with several darker transverse wary lines; hind-wings lighter, with a faint dark waved stripe in the middle. Female $8 \mathrm{~mm}$. long, of a brownish-grey, wings short and aborted, with two dark bands across them, antenne and legs long, the latter strongly developed.

Caterpillar $16 \mathrm{~mm}$. long, with 4 prolegs, hairless, at first grey, later yellowish-green, with a dark dorsal line, and 3 bright longitudinal lines on either side.

Pupa $11 \mathrm{~mm}$. long, thickset, yellowish-brown, with two small outwardly-pointed hooks on its tail, in a loose cocoon.

\section{(b) Life-History.}

The moth appears from October to December, and the $\delta$ flies especially at erening-time.

The eggs are first greenish, and later on reddish; in all 200 to 300 are laid, either separately or in cluster's of 3 or more, on buds, veins of leaves, and points of twigs of almost all broad- 
leaved trees. The $q$ ascend the trees usually by the east and north-east sides, which are protected from rain.

The caterpillars hatch at the end of April or in May, are full grown by the middle of June, and in July let themselves down by threads from the crowns of the trees in order to pupate; this takes place at the bottom of the trees in a smooth hole 2 to $3 \mathrm{in}$. deep in the ground.

Generation annual. Very widely distributed and common, a well-known orchard pest* throughout England.

\section{(c) Relations to the Forest.}

The caterpillar attacks several broad-leaved trees, especially the oak, hornbeam, lime and orchard trees; to the latter, especially

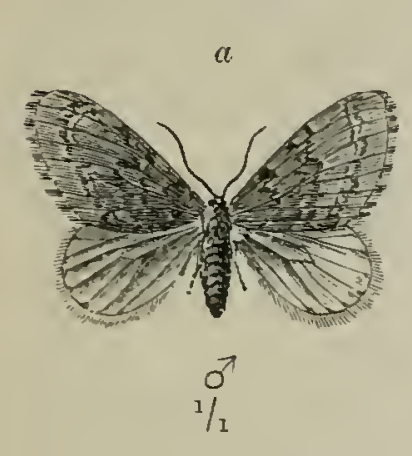

Fir. 1.5S.
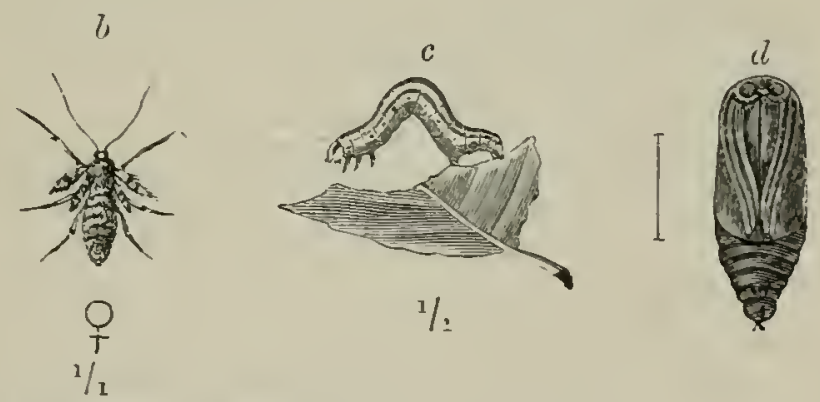

a Male. $l$ Female. c Caterpillar. d Pupa.

to apple and pear trees, it is most destructive. When young, the caterpillar bores into buds through the side, and later attacks blossoms and leaves, as well as the green shoots and young fruits. It continues to spin during these attacks, and when disturbed will let itself down and climb back again to the tree by a thread. After destroying the foliage of standards over coppice, it will attack the underwood, and great damage is thus done at times.

\section{(d) Protectire Rules.}

Grease-bands should be applied to the trees in the middle of October in order to catch the of moths on their way up the trunks. The trees are usually encircled with paper strips $t$ in. 
broad, bound to the tree by string above and below, and the tar or composition is painted on to the paper, the lower part of which being bent upwards to prevent the composition from trickling down.* These bands catch many other insects which are destructive to orchard trees, such as the apple-blossom weevil, Anthonomus pomorum, L., and the codlin moth, Carpocapsa. pomonclla, L. The caterpillars of the last species creep under the paper to pupate.

The practice of spraying with arsenical washes before flowering or after the blossom is set is a valuable method of treatment.

Other species of Geometride, which emerge in the winter months, and the females of which are apterous, such as Hibernia defoliaria, L., \&c., may be dealt with when injurious in the same manner.

The pupe may be destroyed in orchards from July to September by spreading earth over the soil at the foot of the trees, and stamping it firm.

Fanily VI.-Tortricide (Leaf-roller Moths).

Description of Fimily).

Moths with somewhat short, filiform, or bristle-like antennæ with a thick basal joint; 2 ocelli. Wings rhomboidal, the anterior pair usually bright-coloured, roof-shaped in repose; fremulum present.

Generation usually amnual.

Caterpillars with a few short hairs on little warts; with 10 prolegs; usually with a horny shield on the prothoracic segment and a horny anal flap. Very active, and strong spimmers.

Pupation in a cocoon either abore or in the ground. Pupe with rows of spines on their backs. The caterpillars attack the buds or shoots, the fruits and seeds, or the needles or leares of broad-leaved or coniferous trees. The characteristic rollingup of leaves is only practised on broad-leared species. Many insects injurious to forests are included in this family.

For a gool acconnt of these grease-hands and nature of the grease to be used, see Miss Ormerod, op. cit., P. 34 . 


\section{Earias chlorana, L. (Green Willou Leaf-Roller).}

\section{(a) Description.}

Moth with wing-expansion of $20 \mathrm{~mm}$. ; fore-wings and thorax light green, the former with a whitish anterior border; head, hind-wings and abdomen white, the latter sprinliled with greenish-grey scales.

Caterpillar $15 \mathrm{~mm}$. long, with 16 legs, of a dirty flesh-colour, with a dark dorsal stripe, and a few bristles. Pupa light brown, with rounded head and smooth hinder extremity.

\section{(b) Life-History, de.}

The eggs are laid in July on the terminal buds of young willows, especially on Salix riminalis, L. The caterpillar hinders the development of these buds in May, spinning up the terminal leaves into a bundle which is bent towards one side of the shoot in which it lives; it feeds from June till August, not only on the leares, but on the tender young shoots of the osiers. The lengthening of the osiers is thus rendered almost impossible, and a straggling production of side-shoots results. In July the larvæ pupate in white boat-shaped cocoons. The moth appears 14 days after pupation.

(c) Protectire Rules.

Cut off the shoots containing the caterpillars, from June till the beginning of August. Each bundle contains only one larva, which should be killed.

\section{Tortrix riridana, L. (Oak-leaf Roller').}

\section{(a) Description.}

Moth with wing-expausion of 18 to $22 \mathrm{~mm}$.; fore-wing formly light green, and hind-rings light grey; whitish fringes to all the wings.

Caterpillar $15 \mathrm{~mm}$. long, with 10 prolegs, at fisst greenish grey, afterwards dull green, with head and anal flap black, with warts on the back. Pupa $11 \mathrm{~mm}$. long, slender, and black. 


\section{(b) Life-History.}

The moth flies during daytime at the end of June and the beginning of July. The eggs are laid singly or in little clusters on the already bitten buds of the oak, and pass the winter there. The caterpillars appear in April and May, and, as pupation approaches, spin threads by which they let themselves up and down from the branches; they pupate usually at the beginning of June, on the twigs of the trees which have been attacked,

Fig. 159.
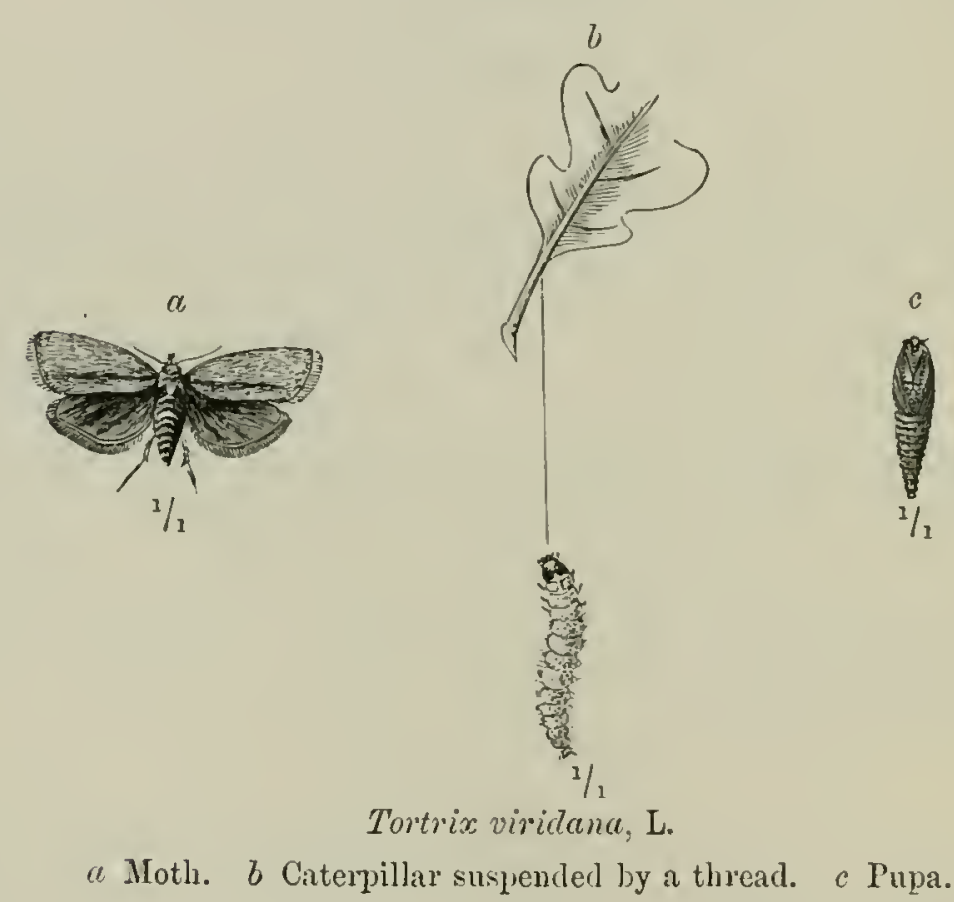

generally in the upper leaves, which they roll together, and also in bark-cracks.

Generation annual. Everywhere tolerably common, and sometimes present in enormous numbers. Very destructive in oak-forests in the south of England.

\section{(c) Relations to the Forest.}

The oak-leaf roller-moth only infests oaks, and chiefly tall poles and mature trees. The attacks of the caterpillar involve the buds, leaves and inflorescence, and spread from the summit of the crown downwards. The formation of foliage, 
blossoms and acorns for the year is seriously compromised, and sometimes the former is completely destroyed, and may then be restored by Lammas shoots.

In coppice-with-standards only the oak standards and underwood are attacked. The attacks of this moth are very persistent, having lasted for 4 years, in the Steigerwald from 1869-72, and in Windsor Forest from 1890-94.

\section{(d) Protective Measures.}

Protection of enemies: starlings, rooks, jackdaws, \&c. Hardly any remedial measures can be tried in forests. The caterpillars of the Dunbar moth, Cosmia trapezina, which are carnivorous, are useful in clearing off their attack, as well as that of the winter moth. This Noctuid moth has a spread of wing of about $30 \mathrm{~mm}$; the forewings are variously marked with pale grey, rust-colonr, or brown, with transverse dark and pale lines, the hinder wings greyish-brown. The of lays her eggs chiefly on oak. The caterpillars are pale dull-green, apple-green beneath, and have 5 pale whitish or yellowish longitudinal stripes, and numerous small black warts, each surrounded by a white ring, eight to a segment, arranged transversely on the first three segments behind the head, and in a square of four, with two below on each side on the succeeding segments.

FIG. 160.

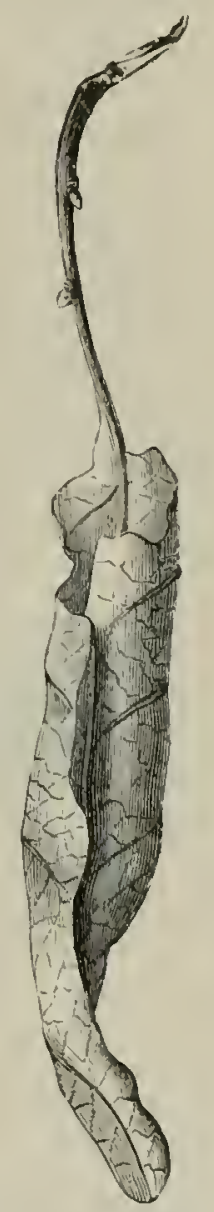

Oak - leaf rolled up by the caterpillar of the Oak-tortrix. (Natural size.)

3. Retinia buoliana, W. V. (Pine-shoot Tortrix.)*

(a) Description.

Moth with wing-expansion of 19 to $22 \mathrm{~mm}$.; fore-wings narrow, reddish-yellow, traversed by $6-7$ broad, wavy $\gamma$-shaped silvery marks, hind-wings dark grey; both pairs with light grey fringes. Thorax orange, abdomen grey. 
Caterpillur $14 \mathrm{~mm}$. long, with 10 prolegs, bright brown and smooth, the head and first segment black.

I'upa yellowish-brown, with a row of fine prickles on the back of the abdomen.

\section{(b) Life-History.}

The moth appears from the end of June till the end of July. During the day it sits somewhat concealed amongst the pine needles, its colour assimilating with the withered pine shoots, but it becomes active with the approach of twilight. The eggs are laid among the terminal buds of young Scotch pine plants. The caterpillars hatch out at the end of August, and in Sep-

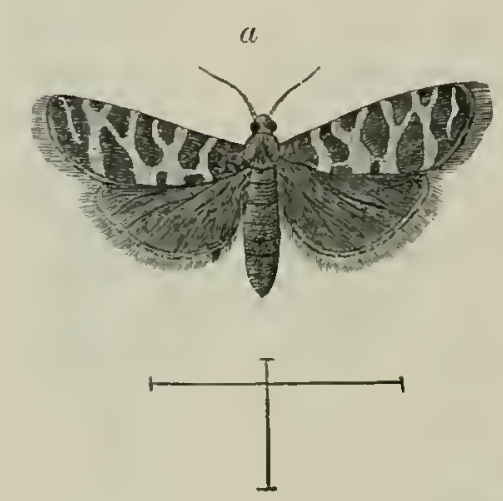

FI:. 161.

$$
\begin{aligned}
& \text { Retinia buoliana, W. V. } \\
& \text { a Inago. b Larva. c Pupa. }
\end{aligned}
$$

tember hibernate in the buds, becoming full grown in the following May.

Pupation takes place at the end of May or June, at the base of the injured shoot. The pupa is exposed, and the empty pupal case may be seen for some time on the shoot.

The moth emerges 4 weeks later.

Generation annual. The insect is common and widely distributed wherever Scotch pine trees are grown in Europe.

\section{(c) Relations to the Forest.}

The Scotch pine and occasionally the Weymouth, black and cluster pines are attacked.

The insect exclusively attacks young growth, and prefers weakly 6 to 12 -year-old plants on poor soil and in sumny situatious. 
The attack is made by the larva boring into buds and shoots. Late in the summer the buds, particularly the terminal buds, are slightly gnawed at their base, so that turpentine exudes. In the following spring, as soon as the plant begins to shoot up, the caterpillar bores right through the pith of the young shoots. Shoots eaten on one side become curved as in the figure, and if

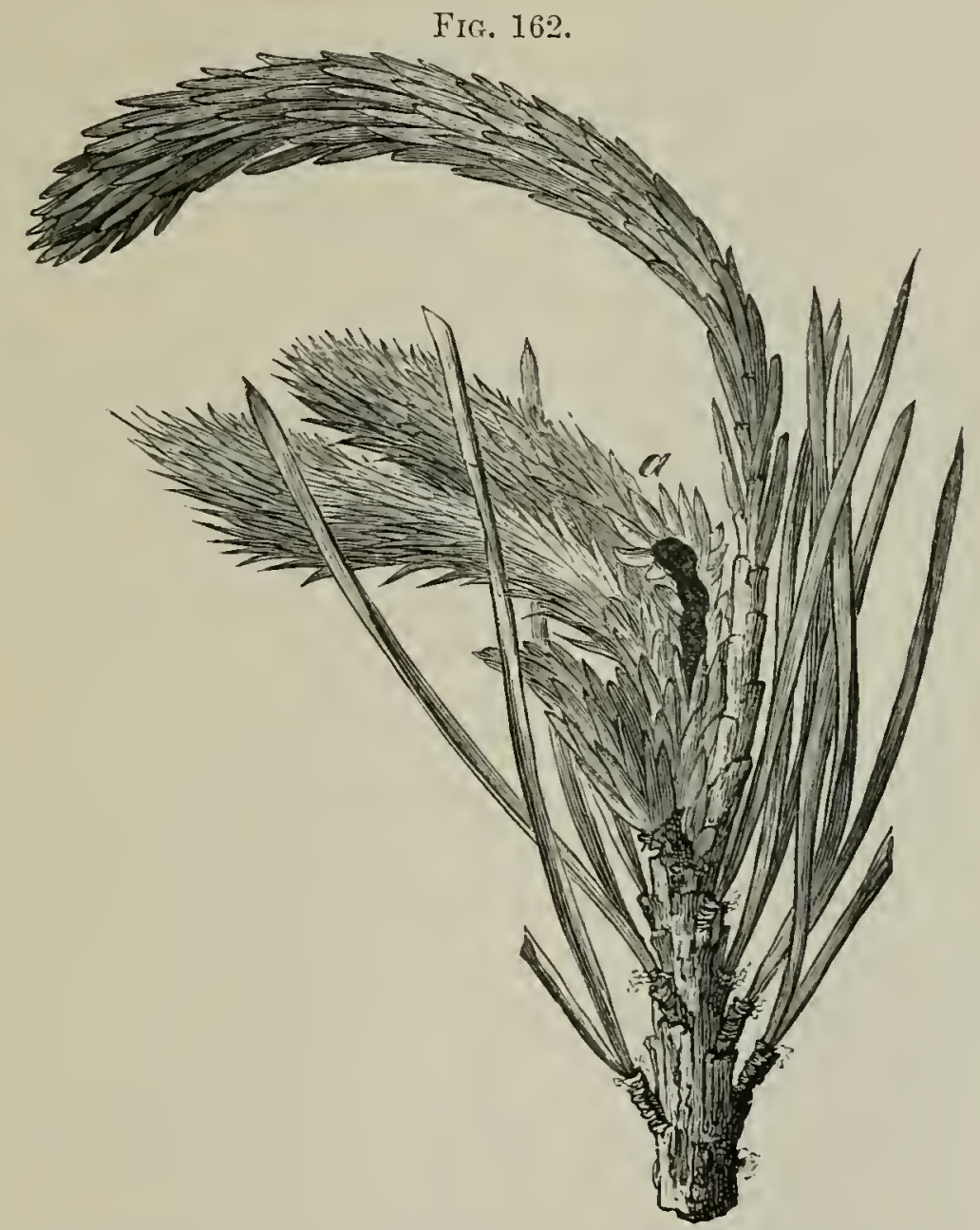

Pine-branch, showing distortion after antecedent injury by $R$. buotiana, $T$. $T$. A larral gallery is exposed in the broken shoot, $a$. (Natural size.)

no further injury is done, will recover their vertical position, but the perforated shoots dry up, turn brown and fall off. After destroying the terminal shoot, the larva directs its attention to the side shoots; it sometimes spins several together, and passes from one to another. The attack can be distinguished from that of the pine beetle by the crumbling excrement.

The injury causes the pine to send out brush-like shoots, and 
the resulting loss of increment is considerable, as frequently the pest recurs year after year.

\section{(d) Protectire Rules.}

Careful planting and rearing of plantations of vigorous pines, without undue crowding.

The shoots which are attacked may be broken off and burned.

Remoral of all misshapen stems at the first thinning, till which time they are spared to help to cover the ground.

\section{Retinia turionana, $\mathrm{Hb}$.}

(a) Description.

Moth with a wing-expanse of $16-18 \mathrm{~mm}$. ; fore-wings browngrey, ochreous towards the tip, with leaden-grey transverse wavy lines; hind-wings whitish, the tip greyish ( $\delta$ ) or ochreous ( $q$ ). Head and thorax ochreous; abdomen grey.

Larva $10 \mathrm{~mm}$. long, with 16 legs; light brown, with black head and thoracic shield.

(b) Life-History, cie.

The eggs are laid in May or. June singly on the middle buds of the whorls of the stem of young Scotch pines (usually 5-15 years old). The caterpillar bores as a rule into the middle bud, and hollows out the pith-canal in the course of the summer. The shoot is checked from the commencement of its growth and takes on a blackish-grey colour; eventually it dies and the lateral buds, which are seldom attacked, become abnormally large.

Pupation takes place in the following year (at the end of April or in Nay) in the hollowed bud, which is spun over with a thin web, and the moth emerges at the end of May or the beginning of June.

Other species of pine, such as the Weymouth pine and Pinus ponderosa, Dougl., are liable to attack. The insect is less common than the preceding.

\section{(c) Remedial Measures.}

The injured buds, which can be recognised by their small size and dark colour, should be cut off towards the end of April. 


\section{Retinia resinella, L.}

\section{(a) Description.}

Moth with a wing-expanse of 16 to $18 \mathrm{~mm}$.; fore-wings slatygrey with numerous shining leaden-grey transverse lines forked on the fore-margin ; lindwings grey-brown; the fringes pale. Body slaty-grey.

Caterpillar $11 \mathrm{~mm}$. or more in length, with 16 legs, orangebrown, with brownish-red head and thoracic shield.

\section{(b) Life-History.}

The eggs are laid in May just under the whorl of buds of the recently-grown shoots of young pines, usually on the lateral shoots. The caterpillar bores into the pith and thus causes the growth of a hollow gall-like resinous mass, as large as a pea, in which it passes the winter. In the spring it continues feeding, causing the gall to increase to the size of a cherry or of a small walnut and form a swelling on the under-side of the shoot which almost completely encircles it. On section the gall is seen to be divided into two compartments by a strong vertical partition. In

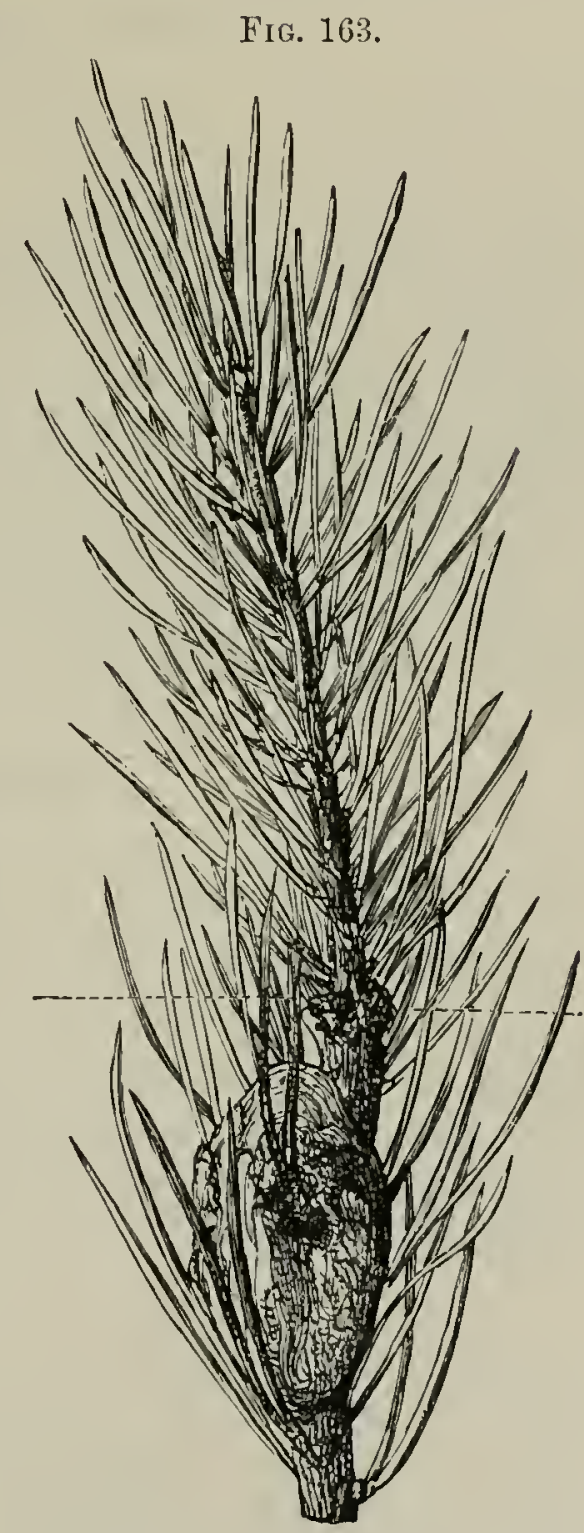

Resin-gall of $R$. resinella, L., on a pine shoot. (Natural size.)

the larger one the larva lives and pupates (in April or May of the 3rd year); the smaller one contains its excrement.

The moth flies about May; the generation extending over two years. As a rule the pine recovers its injuries; but in an unfavourable situation or after bad weather the attaclied shoots

VOL. IV. 
perish. The species is tolerably common in a few localities in Scotland.

The treatment consists in the destruction of the galls during the second winter.

\section{Pedisca rufimitrana, H.-S.}

\section{(a) Description.}

Moth with wing-expansion of $15 \mathrm{~mm}$.; fore-wings dark greyish-brown, with lead-coloured wavy lines at their base, a rusty yellow median band with a lead-coloured border, and a round dark spot on a rusty yellow patch near the corner of the wings; hind-wings brownish grey, with grey fringes; thorax rusty yellow near the head, abdomen brownish-grey.

Caterpillar $10 \mathrm{~mm}$. long, with 10 prolegs, of a dull yellowishgreen above and yellow below, with reddish-brown head. Pupa 6 num. long, bright brown.

\section{(b) Life-History.}

The moth flies from June till the end of July, sometimes also in May. The eggs are laid on silver-fir needles, where they remain during the winter.

The caterpillars hatch in the succeeding spring, and when fully grown at the end of June, let themselves down by threads, and pupate in the soil-covering in a cocoon made of silk and bits of earth. The moth appears 2 to 3 weeks later. Generation annual.

\section{(c) Relations to the Forest.}

The caterpillar, commencing operations as the young shoots appear in May or the beginning of June, eats the needles and youngest shoots of the silver fir. It devours the young needles, bites off the older ones at their base and gnaws the epidermis of the young shoots, spinning a thin web over the parts attacked. The insect prefers woods of 60 to 100 years old, but when the moth appears in swarms, younger wood is also attacked. The edges of the crowns of the trees become reddish, and after attacks repeated for several years the trees become stag-headed, the topmost branches being as bare as 
brooms, and die. There have been several severe attacks in Germany on silver fir by this moth since 1876, and in 1879 , 1,800 acres of forest were ravaged in Nagoldthal, and the attack spread to the surrounding districts.

\section{(d) Protective Rules.}

Mixture of other species with the silver fir, and clean woodcraft.

Protection of enemies : titmice, the wren, \&c.

\section{(e) Remedial Measures.}

Smoking out the caterpillars by burning green branches in damp weather. This is done in May with branches from trees and poles felled in thin rings, which are burned in heaps.

Admission of pigs to the forest as soon as the cocoons are in the soil covering, during the first half of June.

Raking-up and removing the soil-covering whilst the pupæ are there.

Felling trees which are badly attacked.

7. Pedisca occultana, Dougl. (pinicolana, Zll.).

(a) Description.

Moth with wing-expansion of 18 to $20 \mathrm{~mm}$. ; fore-wings long, with strongly sinuate inner border, bright ashy-grey, with numerous dark brown wavy stripes; hind-wings somewhat broad, of a uniform brown or ashy grey colour; both pairs with brownish-white fringes.

Caterpillar $10 \mathrm{~mm}$. long, with 10 prolegs, dark green, darker on the back, with two brighter green stripes along the sides; head and prothoracic shield shining black.

(b) Life-History.

The moth appears in August and the beginning of September.

The eggs are laid at the base of young larch shoots, and remain over winter. The caterpillars appear in May or June, and pupate at the end of July or in August in a silken cocoon amongst the needles, on twigs or, when the insect is very numerous, in bark cracks. Generation annual. 
(c) Relations to the Forest.

The caterpillars usually attack only old larch, and chiefly sickly trees, but when very numerous they also attack healthy trees, and underrood of spruce or P. Cembra growing below the larch. They eat the needles, at first those of the lower shoots, subsequently climbing to the summit of the trees. The insect

FIG. 164 .
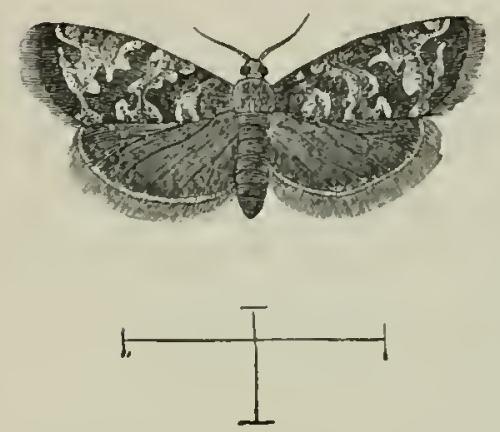

Peclisca occultana, Dougl. sometimes appears in such numbers as to completely strip the trees of needles, and entire woods may then appear with a brown canopy, as if the needles had been burned. As a rule fresh needles appear during an attack, but if it should last for 2 to 3 years, even the healthiest trees will succumb. Badly stocked woods on shallow soil and with a southerly aspect suffer most of all.

This insect is common in Switzerland, and has been observed over fairly large tracts of forest in 1855-56-57, 1864-65, 1878-79 in the Ober Engadin, Wallis and Graubundt. In 1879 in the Ober Engadin, where larch is the dominant species, over 15,000 acres of forest were attacked by it. It is not uncommon among larches in Britain.

(d) Protective Rules.

Protection of birds.

Smoling out as described for the preceding species.

\section{Fanily VII.-Tineide.}

\section{Description of Family.}

Imagos with long filiform or setaceous antennæ, seldom pectinate; ocelli usually present; wings long and narrow, usually pointed, and, especially the hind-wings, characterised by long fringes, during repose either roof-shaped or folded orer the body; frenulum present; legs stoutly spurred. Generation annual.

Caterpillars slightly hairy, usually with 10 prolegs. A few 
species have only 6 to 8 prolegs, and those reduced in size (leafminer's).

Pupation usually in a cocoon. Pupe with a thin hairless skin, rarely with spines on the abdominal segments, but characterised by the elongate wing-cases which reach almost to the apex of the abdomen.

The caterpillars generally live in rolled-up leaves, or in shoots, flowers, fruits, seeds, \&c. Many species are leaf-miners, living on the parenchyma of leaves, between the upper and lower epidermis. Other's bore into the pith, wood, bark or buds. Few of them, however, are important enemies of the forest.

1. Hyponomeuta padella, L. (variabilis, Zell.).

(a) Description.

Moth with wing-expanse of 18 to $20 \mathrm{~mm}$.; fore-wings white, clouded with brownish-grey on the anterior border, with 3 irregular longitudinal rows of black spots, and a group of smaller spots along the outer margin; hind-wings brown-grey; fringes pale-grey or whitish.

Caterpillar $14 \mathrm{~mm}$. long, with 16 legs, yellowish-grey, marked with round black spots, with black head and thoracic shield. Pupa light brown.

(b) Life-History, dc.

The eggs are laid at the end of June and in July on buds, usually of underwood. The larve do not hatch till the spring, when they attack buds, leaves and blossoms under the protection of a conspicuous gauzy web, which they spin in common over the ends of the branches.

The chief food-plants are the plum and apple trees, the mountain-ash and especially the hawthorn. This caterpillar has also committed great ravages among willows in Hungary. It is very common in the British Isles, and often completely defoliates hawthorn trees and hedge-rows in the open spaces of London. Pupation takes place on the branches or trunk in June or July in a white cocoon. 


\section{(c) Remedial Measures.}

Cutting-off and destruction of the caterpillar-webs at the beginning of June. Destruction of the moths (July), which often sit in conspicuous groups at a moderate height on the trunks.

Where defoliation is an eyesore, as in public parks, the trees may be carefully sprayed with a weak arsenical misture or syringed with a stronger jet of plain water or soap-mixture.

Other species of Hyponomenta-e.g. H. euonymella, Zell. on the spindle-tree, are closely allied in appearance and habits.

2. Prays curtisellus, Don. (Ash-twig Moth).

\section{(a) Description.}

Moth with a wing-expanse of $16 \mathrm{~mm}$.; fore-wings, head and thorax white; the former with a large triangular dark-grey blotch on the anterior margin and with the base and outer margin clouded with blackish marks; hind-wings and abdomen grey-brown, the latter lighter beneath; fringes grey-brown.

Caterpillar 7 to $10 \mathrm{~mm}$. long, with 16 legs, bright honeyyellow with brown head and dorsal shield. (According to Stainton the larva is greenish, marbled with reddish-brown.)

Pupa yellow-brown, glossy, in a neat cocoon, pointed at each end and of a silken lustre, constructed away from the larval feeding-place.

\section{(b) Life-History.}

The moth flies in May and June and lays its eggs on the leaves of ash, which are mined by the newly-hatched larva. In the autumn, when the leaves turn yellow and fall, the caterpillar, which is still very small, bores into the sheathing scales of the terminal buds; here it moults and excavates a hole in which to hibernate. Its presence is indicated by the fine powder visible in the entrance-burrow. As soon as the buds begin to swell in the ensuing spring, the caterpillar begins to feed again and reaches maturity about May. The injured bud is incapable of development and is outstripped in growth by the next uninjured shoot, causing the ends of the branches to become forked. 
The species is tolerably common wherever ash is grown.

(c) Remedial Measures.

Cutting off the injured buds in autumu, together with the adjacent lateral buds. This is only practicable in nurseries and on saplings.

3. Coleophora laricella, Hbn. (Larch-miner Moth).

\section{(a) Description.}

Moth with wing-expansion of 9 to $11 \mathrm{~mm}$.; wings very narrow, shining ashy-grey, with very long fringes, especially to the hind-wings.

Caterpillar 4 to $5 \mathrm{~mm}$. long, with 10 prolegs, dark reddish-

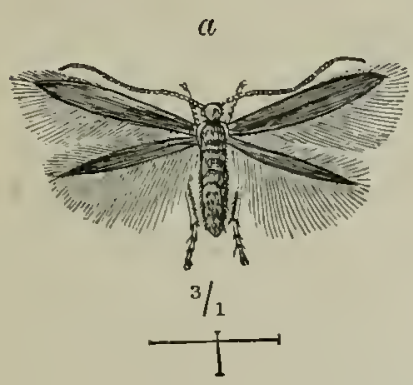

FIG. 165.

Coleophora laricella, Hbn.

$a$ Moth. $b$ Caterpillar. $c$ Larval case. $d$ Pupa.

brown. Pupa 4 to $5 \mathrm{~mm}$. long, narrow, dark brown, with fine bristles.

\section{(b) Life-History.}

The moth flies in the daytime in May and June.

The $q$ lays its little roundish yellow eggs on healthy larch needles, usually only one egg on a needle. After 6 to 8 days the eggs become grey.

The caterpillar's hatch in June, and continue to grow till September. The pupal stage is passed from the middle of April till May in a case on the needles. The moth emerges in the latter half of May.

Generation annual. Very common. The caterpillar is very susceptible to late frosts, wet and cold rainy weather and hail. 


\section{(c) Relations to the Forest.}

This insect is a most dangerous enemy of the larch, and prefers 10- to 40-year-old trees, but may also attack woods which are older or younger than these.

The little caterpillar, as soon as it has emerged from the egg,

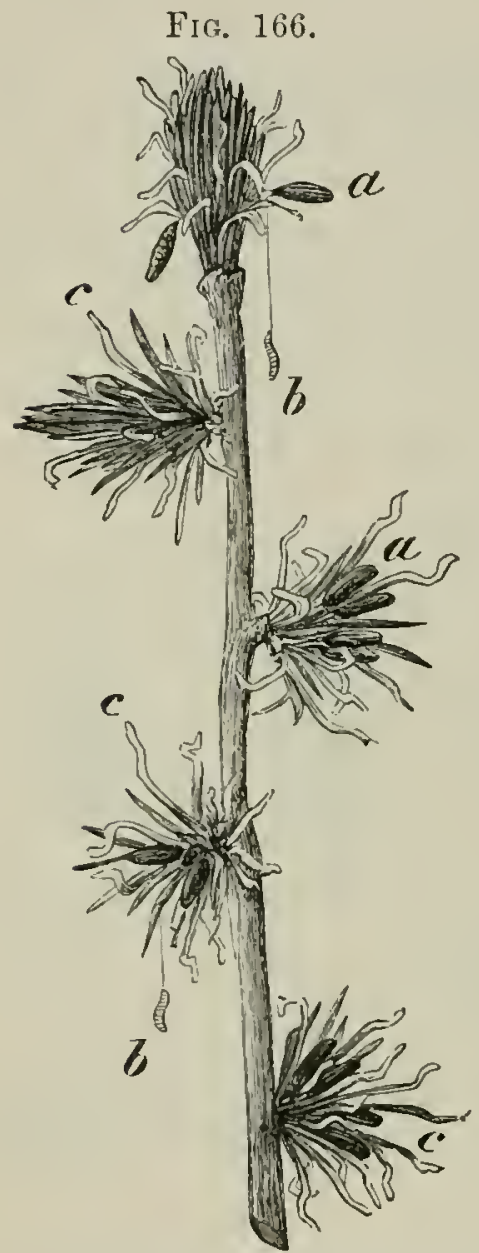

Larch-needles injured by $C$. laricella, Hbn. (N'utural size.)

a Larval-cases. 6 Spinning caterpillars. $c$ Hollowed and twisted needles. bores into the young larch-needles to about half their length, so that their upper ends shrivel up and turn yellow, as if injured by frost. The appearance of a plant which bears a large number of infested needles is very conspicuous and characteristic.

In September the fully grown caterpillar prepares a little case out of the dry part of the needle, which it cuts off for the purpose, and in this it libermates on the twigs, usually at their tips, or in bark-cracks, or among lichens on the stems.

In the spring the caterpillar, carrying its case with it, bores again about half-way into a larch needle, and about the middle of April finding its old case too small, it fastens it along the freshly hollowed-out needle, like two fingers of a glove. It then cuts out the adjacent walls of its old case and of the needle, thus preparing a new case twice as wide as the former. When the insect is ready for pupation it spins the new case firmly to a needle.

The loss of increment is considerable, owing to the repeated destruction of the larch needles in the spring.

The little insect likes sunny warm localities, sheltered from the north and east, and prefers the westerly borders of woods, avoiding isolated trees, probably on account of their exposed position. It has been observed up to an altitude of 2,000 feet, and in Germany and Britain it constantly accompanies the larch, 
though it is rare in the Tyrol and Switzerland, where the larch is indigenous.

Independently of its large numbers and wide dissemination, its great hurtfulness results from its eating the needles twice during the same year, and appearing year after year in the same localities. As the larch disease almost always accompanies this insect, the latter probably renders the tree susceptible to this highly destructive fungus.

\section{(d) Protective Fiules.}

Choice of suitable localities for larch, and planting it widely apart.

Mixture of larch with beech, spruce, silver fir, sc.

Early thinning, and removal of the thinned material, at the latest, by the end of March.

Protection of titmice and other small birds.

\section{(e) Remedial Measures.}

Pruning the lower branches of larch trees, on which the insect usually appears.

Removal of badly attacked and weakened trees from the middle of June till the end of August. The caterpillars in the needles of these trees will not then become fully developed.

The little cases may be picked off the trees, and destroyed during the winter and spring, but this plan can be followed in forest nurseries only. 


\section{CHAP'TER VIII.}

DESTRUCTIVE insects (concluded).

\section{A. Hymenoptera. \\ Family I.-Tenthredinid (Sawflies). \\ Description of Family.}

SA WFLIES have straight, usually filiform or setaceous antennæ, rarely club-shaped, occasionally serrate, or in $\delta$ doubly pectinate, and with 3 to 30 joints ; 3 ocelli; prothorax usually rery short; wings with full complement of veins, the fore-wings with 1 or 2 radial and 3 or 4 cubital cells.

Legs with a double trochanter; the anterior tibiæ with two apical spines; tarsal joints often furnished below with membranous expansions, sometimes cup-shaped.

Abdomen sessile, of 8 segments; in $q$ with protrusible serrate ovipositor.

Generation usually double, sometimes treble, but in the cocoon-spinning sawflies it may be plurennial.

Larte usually bright-coloured, with 8 or 18 to 22 legs, resembling caterpillars but distinguishable usually by the greater number of legs and by a conspicuous simple eye on each side of the head; they are social, and after 5 to 6 moultings spin a firm cocoon which is of oval or oblong-oval form and often parchmentlike in consistency.

Pupation takes place in the cocoon about 2 weeks before the sawfly emerges. The pupæ are soft.

The larræ feed on needles and leaves; they are often social when young, and when disturbed assume a characteristic S-like attitude. The perfect insects usually feed on honey. Some 
species (Cimbex) girdle young beech-shoots in order to get the sap. A few species are very destructive.

\section{Lophyrus pini, L. (Pine Saufly).}

\section{(a) Description.}

Male with a wing-expansion of $15 \mathrm{~mm}$.; body black, abdomen reddish at apex, spotted with white on the underside of the first segment; antennæ doubly pectinate; hind-wings with a dark border.

Female with a wing-expansion of nearly $20 \mathrm{~mm}$. ; body dullyellow, with the head, 3 spots on the thorax, and the middle of the broad abdomen alone blackish; wings yellowish, slightly infuscate along the outer margins.

Legs yellow in both sexes.

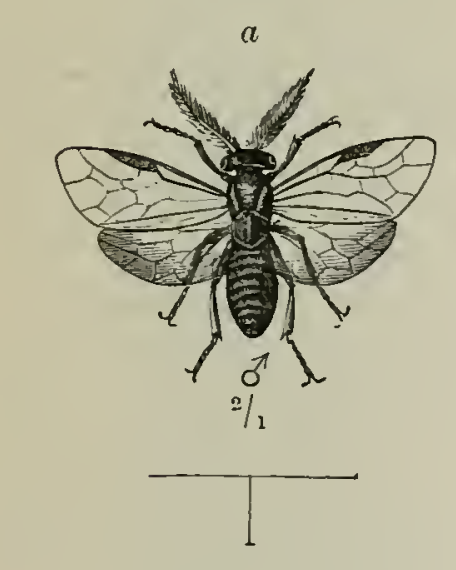

FIG. 167.

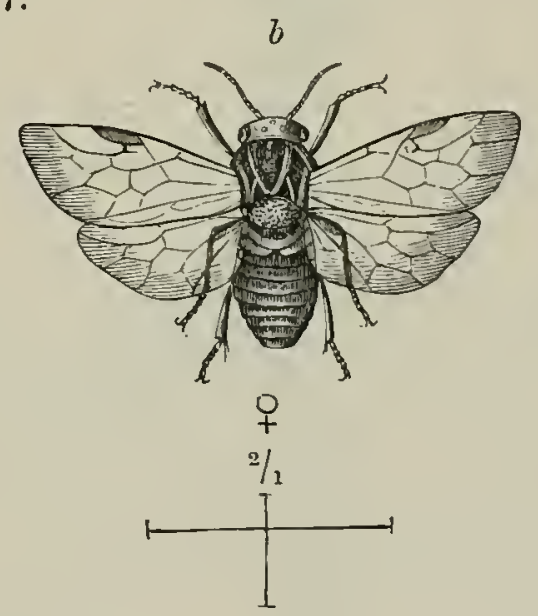

Lophyrus pini, L.

$a$ Male. $\quad b$ Female.

Larva $25 \mathrm{~mm}$. long, with 22 legs, changing colour as it becomes older, finally of a dull green with a round brown head, and black semicolon-shaped marks above the prolegs.

\section{(b) Life-Ifistory.}

The sawfly appears in April and May, and again at the end of July and in August. Only the $\delta$ appears to fly. The $q$ creeps lazily along the twigs and needles. The $q$ cuts slits into Scotch pine-needles with her saw-like ovipositor, and lays 
a sausage-shaped egg in each slit, depositing 10 to 20 in each needle, and 80 to 120 altogether; she seals up the wounds with a frothy secretion.

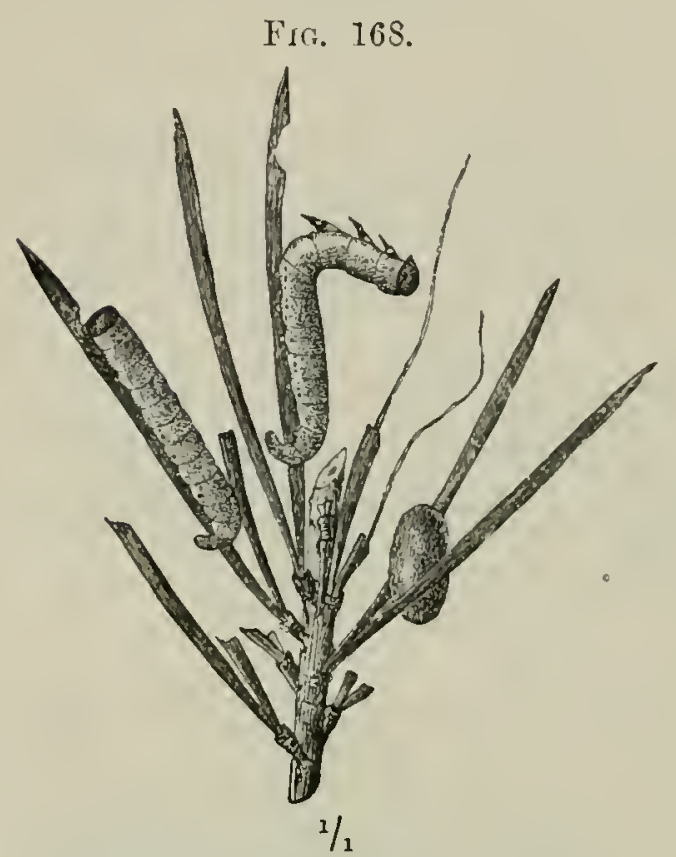

Pine-needles, with larvæ and cocoon of L. pini, L.

The larre hatch 2 to 3 weeks later, in May and June, and those of the second brood in August and September. The latter hibernate in cocoons under moss, or on stems or twigs. There is not, however, always a second brood, and the larve of the first brood may then hibernate.

Pupation takes place at the beginning of July* in a compact brown cocoon, among the needles, or in bark cracks on the stems of the pine. The second brood pupate in March or April in cocoons under moss at the foot of the tree they have attacked.

The sauflies of the first brood appear at the end of April, about 2 to 3 weeks after pupation. The insect when ready for flight cuts a circular lid off the cocoon. If an ichnemmon fly should emerge instead of the sawfly, a little hole appears at the end of the cocoon ( $\odot$ ) instead of the lid. The second brood emerge in April.

Generation double, but frequently lasting over a year. In rare cases it has lasted for 2 to 3 years. The insect is very common on the continent of Europe and in the British Isles.

The naked larre are susceptible to cold and wet weather.

\section{(c) Relations to Forest.}

The larve attack the Scotch pine, and prefer sickly poles where the leaf-canopy has been interrupted, 20 to 30 years old,

* Theodor Hartig states that cocoons spun mnler moss are dill brown, and those on the tree silky ash-grey, dirty white, or yellowish. Even clean white and rusty red cocoons may occur. 
on poor soils and with a sumny aspect. Border trees especially suffer.

The larvæ till half-grown eat the needles in dense companies of 60 to 80 and more. When young they merely gnaw the edges of the needles; later on they eat them in short strips parallel to the mid-rib, which they leave intact. An attack by the pine sawfly may be at once recognised by the remaining yellowish, thread-like mid-ribs.

\section{FIG. 169.}

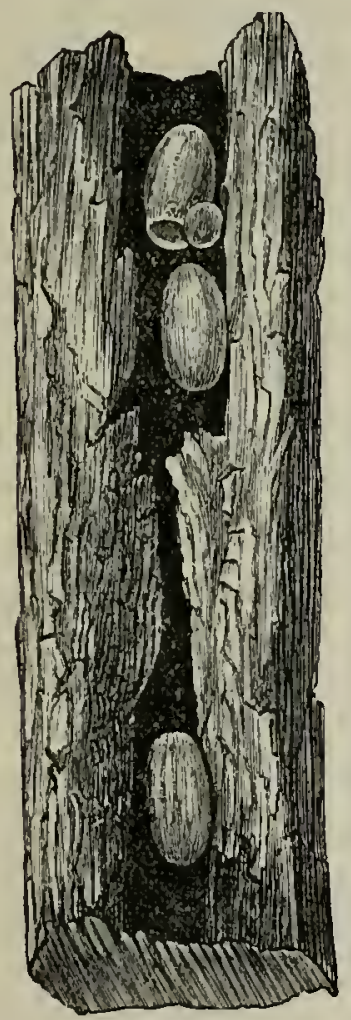

3 cocoons of the Pinesawfly on pine bark.

(Natural size.)

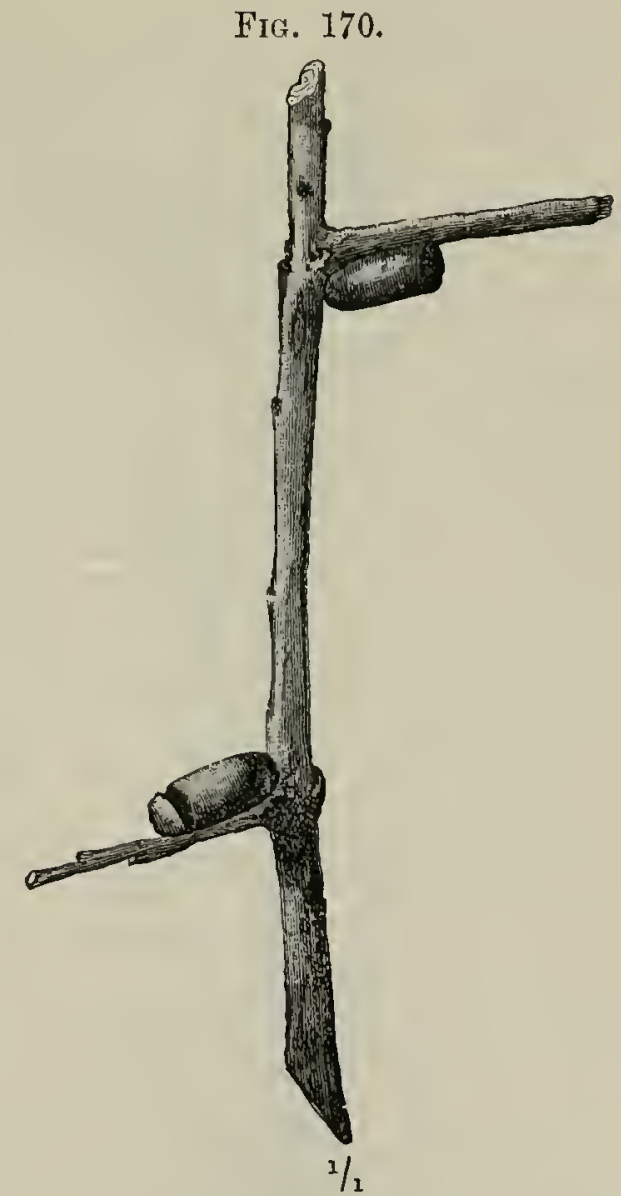

2 empty cocoons of the Pine-sawfly on an oak-twig. The upper one has lost the lid.

The older caterpillars only leave short stumps to the needles. The first brood chiefly devour 1-year-old needles, and the second brood those of the current year. The larvæ also gnaw the soft young bark in patches, often down to the wood. After the crowns of larger poles are stripped, smaller Scotch pine poles, underwood, and young plantations are attacked.

This and all other species of Lophyrus have the habit, when 
disturbed, of bending the front part of their bodies in the figure $S$ (vide fig. 168).

(d) Protective Rules.

i. Maintenance of healthy well-stocked Scotch pine woods, so that the soil may not be impoverished.

FIG. 171.

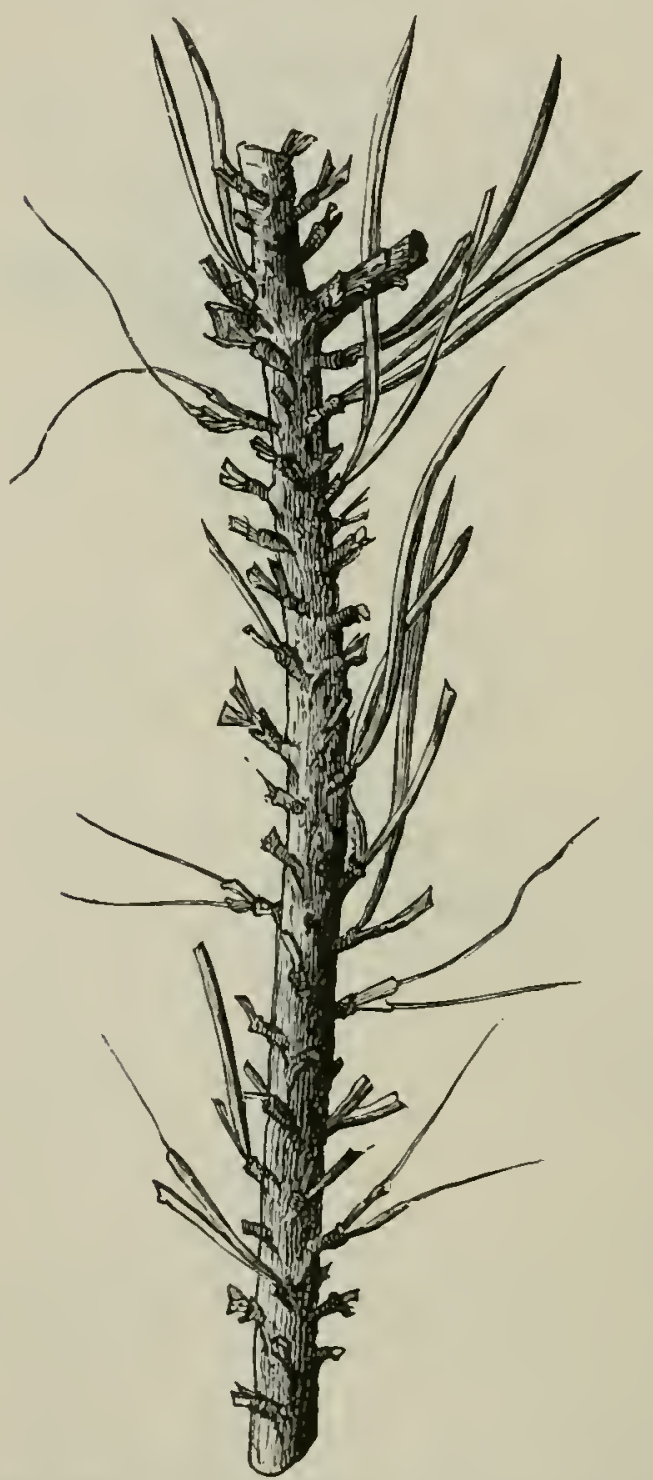

Pine-shoot with needles eaten by $L$. pini, L. (Natural size.) ii. Protection of enemies: cuckoo, starling, crow, goatsucker, swallows, \&c. Mice and squirrels open the cocoons during the winter, and devour many larvæ.

Many* parasitic ichneumon wasps and Dipter a attack the larva.

(e) Remedial Measures.

i. Collection of larvæ by stripping or shaking them from the trees on to cloths spread on the ground, in May and June, and again in September and October. One man shaking the trees, with two boys to collect the larve, can clear 15 25-year-old trees before 9 a.m., and such work is most efficacious in the morning when the larvæ are slightly torpid.

ii. Collection of cocoons under the moss in winter. They may generally be found near the base of the attacked

trees, and sometimes in masses as large as the fist.

iii. Admission of pigs in September and October, when the larve

* For a list of these, vide Taschenberg, op. cit., p. 230. 
come down to hibernate. The pigs will not eat the cocoons, which are too tough for their taste, but crush them in numbers.

iv. Planks smeared with tar may be put up to catch the sawflies, the tarred sides being turned towards the sun, and the tar renewed from time to time.

v. The ground under trees which have been attacked may be ploughed up deeply, in order to bury the cocoons.

vi. If no other remedy should be found effective, the damaged wood must be cut down, and the roots grubbed up late in the summer or winter; branches may be spread on the soil and burned before grubbing up the roots, and one or two field-crops harrested before the land be restocked with pines.

Several other species of Lophyrus of generally similar habits also attack Scotch pine. Miss Ormerod* states that much injury was done in 1890 to three or four thousand acres of young Scotch pine in Argyleshire by L. rufus Klug, the larræ of which are dull greenish-grey, with black heads. The flies appear in August only, and the $q$ are reddish and the $\delta$ black; both sexes have red legs.

Plants 2 to 6 feet high were more subject to attack than older ones. In Germany this species is said to attack trees of all ages, but to prefer those 10 to 15 years old, and one-year-old needles. It attacks the Austrian as well as the Scotch pine, and appears to have a single generation. It is not so common as L. pini, and should be treated similarly.

\section{Faniluy II.-Urocerid (Wood-Wasps).}

\section{Description of Family.}

Wood-wasps have straight filiform or setaceous antennæ, always shorter than the body, and with 11 to 24 joints; 3 large ocelli; body long and cylindrical; wings elongate with complete renation. Legs with double trochanter, anterior tibiæ with a single apical spine. Abdomen sessile, with 9 segments; ovipositor elongate, projecting beyond the end of the abdomen, and consisting of two lateral sheaths and a strongly serrate median borer.

Generation lasting at least two years. Lavice cylindrical, * Op. cit., p. 255 . 
soft, and whitish, with 6 legs, and a spine at the rounded posterior extremity. Pupce soft and white.

The larve live chiefly in coniferous wood, in which the perfect insects lay eggs with their long ovipositors. Pupation also

FII. 172.

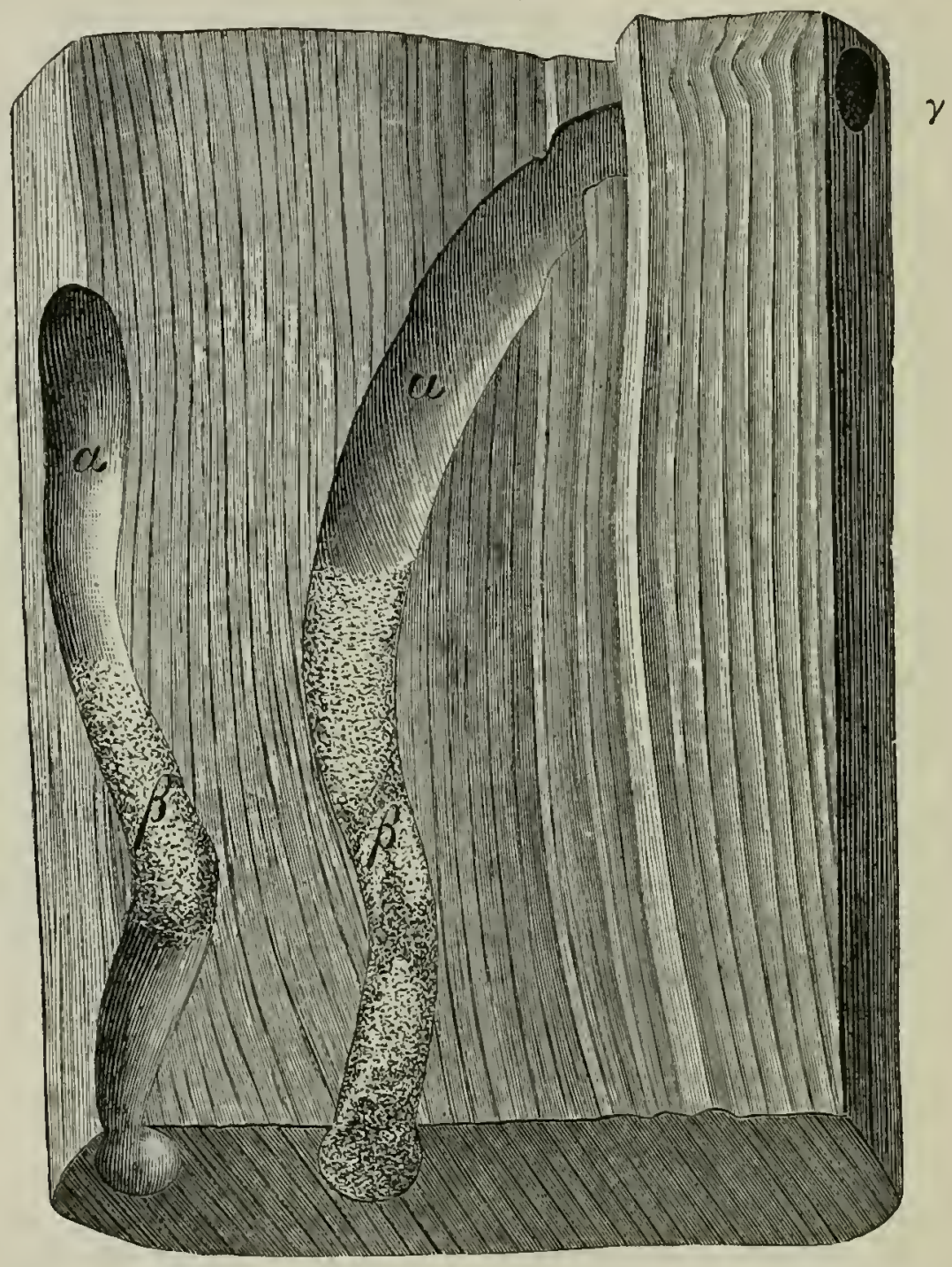

Pine-wood bored by the larva of Sirex juvencus, L. (Natural size.) a Larval burrows partly filled with boring-dust $\beta . \gamma$ circular flight-hole.

takes place in the wood, and the wood-wasp emerges by a circular hole.

1. Sirex juvencus, L. (Steel-blue Wood-wasp).

(a) Description.

The insect attains a length of $16 \mathrm{~mm}$. (o) and $30 \mathrm{~mm}$. ( $q$ ); thorax and abdomen steel-blue, the latter in the $\delta$ with the 4 th 
to the 7th segment inclusive, yellowish red; in $q$ the steel-blue ground-colour of the abdomen is iridescent, with a coppery sheen. Wings yellowish, with brown margins. Ovipositor shorter than the abdomen. Lava $30 \mathrm{~mm}$. long, with 6 very small feet, white.

\section{(b) Life-History, dic.}

The $q$ in July bores the bark of the Scotch pine, usually of trees in pole-woods, down to the sapwood, and lays an egg in each hole. The larva eats out in the wood a curved burrow of circular section; at first it lives in the softer layers of the sapwood, but after the first hibernation it bores deeper into the tree, living on the resinous and starchy matters in the burrow, the dust of which it packis behind it.

After a second hibernation, in the early summer of the $3 \mathrm{rd}$

FiG. 178.

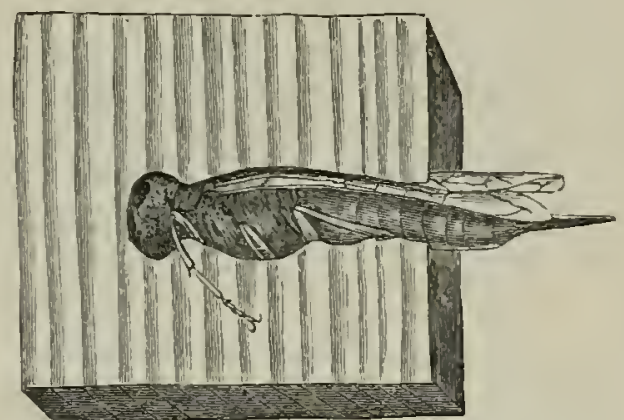

Wood-wasp in the act of boring, exposed by splitting the wood. year, it constructs a pupal chamber at the end of the burrow, lining it with a glazed coating. The cood-uasp emerges in July, by a larval-gallery, or by boring for itself a short way through the wood. The flight-hole is circular, and about the fourth of an inch in diameter. The generation lasts at least two year's, and sometimes longer, the wasps appearing from wood which has been worked up for some time.

In Germany, it sometimes attacks spruce as well as Scotch pine, and in the British Isles, ${ }^{*}$ it has been observed in larch, silver-fir, and other conifers. All wood-wasps prefer weakly trees, which have been injured by deer, lightning, or wind, and especially trees felled in the growing season and stripped of bark. They never attack actually rotten wood, or perfectly sound standing trees. Miss Ormerod relates an instance where, at Workington, Cumberland, in $1889,1,700$ c. feet of silver-fir ralued at $£ 30$ were irretrievably ruined. 
(c) Protective Rules.

Removal of all high stumps and broken wood. Felling of all weakly or damaged poles and trees at the thinnings, and rapid removal of coniferous timber from the forest.

2. Sirex gigas, L. (Yellow wood-uasp).

(a) Description.

Imago $15 \mathrm{~mm}$. (ठ) to $35 \mathrm{~mm}$. ( q ) in length; black, head with a large yellow spot behind the eyes; abdomen ( $\delta$ ) reddishyellow, with the first and last segments black, (q) black with the 2 anterior and 3 posterior segments yellow; legs black, with the knees yellow; ovipositor nearly as long as the body.

Laria, like that of the preceding species.

$$
\text { (b) Life-History, cle. }
$$

This species is particularly attached to the spruce, but is sometimes found in silver-fir. Its habits are the same as those of $S$. juvencus, L.

It is tolerably frequent in Britain, and prefers large trunlss.

The treatment of its attacks is similar to that adopted for $S$. jurencus, L.

\section{Fanily III.—Cynipidæ (GaLL-Wasps).*}

\section{Description of Family.}

Imagos with straight, filiform antennæ, with 13 to 16 joints; ocelli far back on the crown of the head. Forewings with only 6 to 8 cells, with no stigma, and with 1 radial and 2 to 3 cubital cells. Some species have no wings, or only abortire ones. Abdomen pedunculate, laterally compressed and truncate at apex, much shorter than the wings. of usually very small. Larece usually thick and fleshy, curved, smooth, white, and apodal. Pupe thick-set, smooth, and white. They are divided into 3 groups: True Gall-wasps, Secondary Gall-wasps, and Parasites.

* As the family of Diptera, known as Cccidomyiidle, contains many species of gall-flies, it is preferable to term the Cynipidce gall-wasps. 


\section{True Gall-uasps.}

The true gall-wasps bore with their ovipositor into leares, buds, shoots, fruits and other parts of woody plants, and they insert one or more eggs in the wound. The egg hatches in due time and the larva lives in a chamber formed in a growth or gall, often of hard or moody consistency, formed by the proliferation of the surrounding plant-cells. The growth of this gall is not due to the irritation caused by the mother, but to the stimulus caused by the internally-feeding larva. Galls may be on roots, bark, buds, leaves, blossoms or fruits. They may also contain one larval chamber, or many, the former being most usual.

The oak is attacked by numerous species of gall-wasp, and galls are chiefly found on badly-growing underwood in coppice or high forest. The consequent damage is not serious; and some species are useful as producing the galls used in commerce on account of the tannic or gallic acid they contain.

Probably the most harmful species is the common marble gallwasp (Cynips kollari, Hart.), which sometimes occurs in large numbers on young oak plants. The galls * may be cut off with a knife while they are still young and soft, and if thrown away they dry and shrivel, and the maggots within perish. Titmice are very useful in oak nurseries, as they pick the maggots out of the galls.

It is interesting to know that in many species of gallflies, a wingless, hibernating, parthenogenetic generation always alternates with a winged generation of both sexes. As an example, the wingless agamic female form, Cynips aptera, is hatched from galls on the roots of the oak, and hibernates in the soil, laying in the spring, on the terminal buds of the oak, a number of unfertilised eggs. These cause galls on the terminal shoots from which the winged forms of both sexes, $C$. terminalis, develop. The fertilised $q$ of this insect lays her eggs on the roots of the oak, and from them $C$. aptera is hatched out, and so forth.

\section{Secondary Gall-ucasps.}

These are also termed Inquilines, or fellow-lodgers, as their

* Miss Ormerod, op. cit., p. 237. 
\& lay egges in galls made by the true gall-flies, and their larre are either parasitic on the larve of the latter, or else merely live with them in the same gall.

\section{Parasitic Gall-uasps.}

The of lay their eggs in other insects in which their larre are parasitic, and thus form a connecting link with the Ichneumonide.

\section{B. Diptera.}

\section{Fanily I.-Cecidonimide (Gall-gNats).}

Flies with long thread-like or moniliform antenne, with 10 to 36 joints, usually with whorls of hairs; body delicate; wings moderately large with rounded anterior border, constricted at the base, often iridescent, with 3 to 5 longitudinal veins; abdomen cylindrical, consisting of 8 segments, in $q$ pointed and often furnished with a projecting tubular ovipositor; legs slender, the tibire unarmed at apex.

Larve long fusiform legless maggots, slightly flattened, without chitinous month-armature, but with a chitinous fork or "anchor-piece" embedded in the skin of the rentral surface; usually pale yellowish or reddish.

The imagos lay their eggs in needles, leaves or bark, in which the young larve feed by sucking, and thereby cause gall-like swellings.

Several species are common on willows.

1. Cecidomyia saliciperda, Duf. (Trillow Gall-ynat).

(a) Description.

Fly 2 to $3 \mathrm{~mm}$. long; black-brown, the wings milly-white with whitish hairs; antennx shorter than the body.

Larva yellowish red.

\section{(b) Life-History, ire.}

The eggs are laid during May in rows on the bark of young willow-shoots and branches (Salix alba, viminalis, \&e.). The maggot bores horizontally through the bark, in which from July 
to the following April it excavates short irregular vertical galleries. This causes the appearance of spindle-shaped swellings of the bark and underlying wood, at least in the larger stems, which eventually become rough owing to the irregular detachment of the bark. Pupation takes place in the same spots, and the emergence of the flies riddles the bark with small holes.

This species is sometimes decidedly common and injurious in osier-beds. The only satisfactory treatment is the timely cutting-off and burning of the infested shoots before emergence of the gnats.

The family of Cecidomyiide also contains the Hessian-fly, $C$. destructor, Say, one of the greatest of pests to cereal crops, and various species attacking conifers, of which $C$. kellneri, Husch., gives rise to galls on the buds of larch.

Little can be done to prevent or cure these attacks except to cut off and burn the infected branches.

\section{Hemiptera.}

\section{Faniluy I.-Aphidid Fe (Plan't-lice).}

\section{Deseription of Family.}

Insects with long, usually filiform or setose antemnæ, of 5 to 7 joints; ocelli either absent or 3 in number; rostrum usually well developed. Wings membranous, often absent, especially in ․ Legs usually long and thin; tarsi of 2 joints.

\section{Chermes abietis, L. (Spruce-gall Aphis).}

The species of Chermes comprise those Aphides which are of most importance as being injurious to forest-trees, especially to coniferæ.

\section{(a) Description.}

Imago, o $2 \mathrm{~mm}$. long; yellowish-green, ochreous or light brown with a whitish bloom; antemnæ and legs pale. Wings white (when present). Male smaller, slenderer and paler.

(b) Life-History.

The female passes the winter under bark-scales or at the foot of the buds on young spruce. In the spring she inserts her 
rostrum into the base of the bud, which reacts by forming a swelling resembling a fir-cone, eventually attaining the size of a small walnut. She oviposits in the spot where she feeds, and the young, on hatching, cluster at the base of the bud needles, and by their sucking cause the gall to rapidly increase in size. As

FIG. 174.

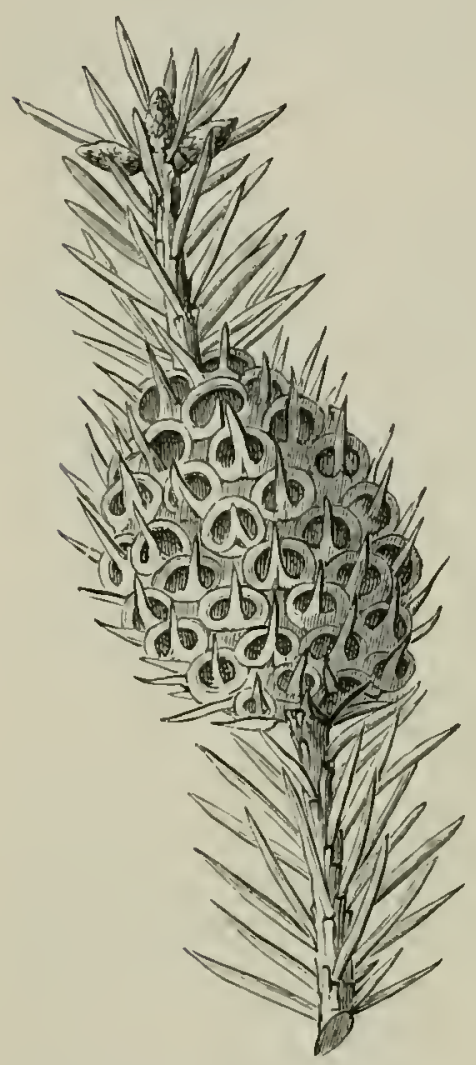

Gall of Chermes abictis, L., on a spruce-twig. (Natural size.) it grows they are enclosed in chambers caused by the swelling of the lower part of the needles. By August they are fully grown and have acquired wings. The needles forming the chambers of the gall shrink and allow them to emerge. These winged females disperse over the tree and over adjacent trees (a certain number of them migrating to the larch), feed as before and lay their eggs, which are covered with a cottony deposit.

The males (which have only lately been discovered) appear in the autumn only and pair with the females. From the sexually-produced eggs arises the wingless female form (stem-mother) who lives through the winter and starts the growth of the gall in the following year. The other generations are agamic.

(c) Relations to the Forest.

The galls which result from their injury are at first soft and green, becoming later purplish-red in places and finally, when hard and dry, brown. They contain a quantity of tannin. Their size is characteristic, as is the fact that they are topped with a sprig of needles, one or more times longer than the gall. This is the stunted young shoot. The injured shoots take on a characteristic curvature towards the side on which the gall is growing. The loss of growth may be considerable.

This Chermes is common both in plain and hilly country, and especially attacks young spruces in nurseries and those which 
have been injured by frost or animals. It is also common on the border-trees of 10 - to 20 -year-old plantations. Fortunately the attack is usually confined to the side-shoots, and the leading shoot escapes.

\section{(d) Remedial Measures.}

Protection of the smaller insectivorous birds: tits, the nuthatch and golden-crested wren. A spider (Theridion) is an active destroyer of this insect, spinning its web over the galls and preventing the escape of its inmates. Direct treatment is troublesome; the galls if on seedlings may be snipped off, and the experiment may be tried of spraying the young trees in April with kerosene-emulsion. (See the following species.)

2. Chermes laricis, Hart. (The Larch Apliis).

\section{(a) Description.}

Imago o , rather smaller than the preceding, blackish-brown, covered with a white woolly down; the winged form dirty green, or with the head and thorax reddish-brown. No male is known.

\section{(b) Life-History.}

The wingless females pass the win-

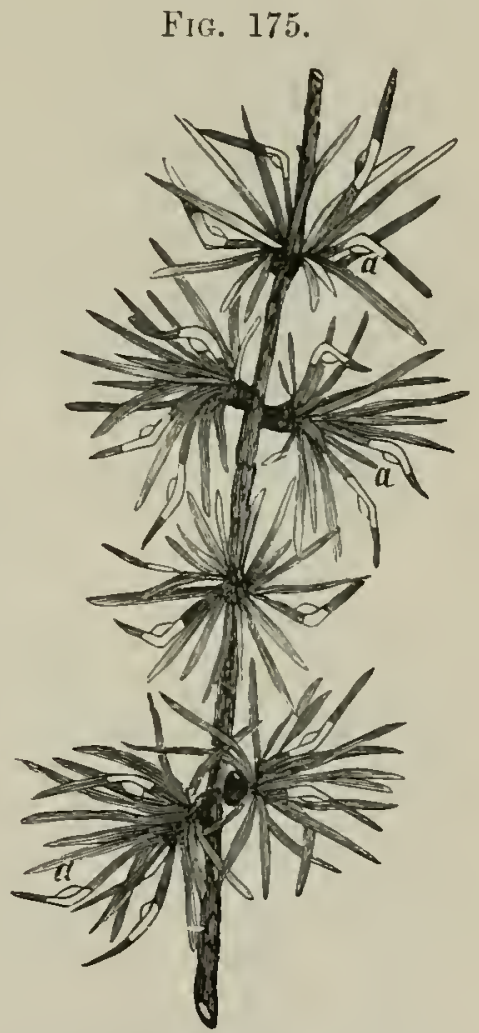

Larch-shoot attacked by Chermes laricis, Hart.

(Natural size.)

a Insects feeding on the needles, which show a characteristic angular bend.

ter on the larch, like those of $C$.abictis, L. They lay their eggs and from April to August the aphides sit and feed on the needles, which become discoloured and acquire a peculiar elbowed shape. No gall is formed. They acquire wings in Angust and disperse to other larches or to the spruce. When they are abundant, the larches look as if they had been sprinkled with snow. 


\section{(c) Treatment.}

Spraying with kerosene-emulsions, soft-soap, lime-water or weak solutions of corrosive sublimate.

Recent researches have shown that the above species of Chermes are almost certainly alternating forms of one and the same species. The sexual generation occurs at most once a year, and always on the spruce, while it is separated from its successor by a series of agamic generations consisting entirely of female forms, which may remain on the spruce or may migrate to the larch. The forms on the larch are therefore all agamic.

If these discoveries are accurate, it follows that the common mixture of spruce and larch favours the insect by providing both its host-plants in association. At the same time it is possible, though rigid proof is wanting, that the species can continue on the same species of tree from year to year without migration.**

\section{Fainily II.-Coccide（Scale-Insects）.}

\section{Description of Family.}

Insects with moniliform antennæ, of 6 to 25 joints; rostrum rudimentary in the $\delta$. $\delta$ with 2 or 4 membranous wings without cells; $q$ apterous, swollen, more or less shield-shaped; one tarsal joint. The $q$ in May and June lay numerous eggs on plants, and die on the eggs. The larve pupate in autumn or spring. Single generation.

The imagos and larve, under the protection of shields or puparia, partly composed of fibrous secretion, partly of the castoff exuviæ, suck the young shoots, leaves, bark, \&c. of perfectly sound plants, and cause blistering and disease in the orgaus which they have attacked. In this way spruce, oak, robinia, and other plants may be attacked by different species; the most effective treatment known for nursery plants so attacked is to wash them with lime-water in the spring, or cut off and burn infected twigs. The plants may also be treated, when practicable, with kerosene emulsion or washes made by forming a soap with boiling water, resin and potash. The scales may also be scraped

* For an account of recent investigations on this question, vide Blandford, Journ. R. Hort. Soc. X1V., 169-176. 
off with a blunt linife, or rough brush, and the plants smeared with soft-soap and water.**

Lecanium racemosum, Ratz, causes a black, paste-like coating on branches and twigs of 5-to 15-years-old spruce, which causes them to languish for several years. This insect is attacked by a parasitic weevil (Braclytarsus rarius, Fabr.). It has done much damage to spruce plantations in Saxony, and near' Tharand was found on mature spruce, which had been injured by locomotive smoke.

\section{Orthoptera.}

Fanily I.-Grillide (Crickets).

\section{Description of Family.}

The insects of this family possess a thick, free head, with long bristly antennæ of many joints, and 2 or 3 ocelli; hind-wings folded longitudinally, and projecting beyond the wing-cases, but often aborted, or absent, not roofshaped in repose. Body cylindrical; fore legs formed for burrowing; tarsi

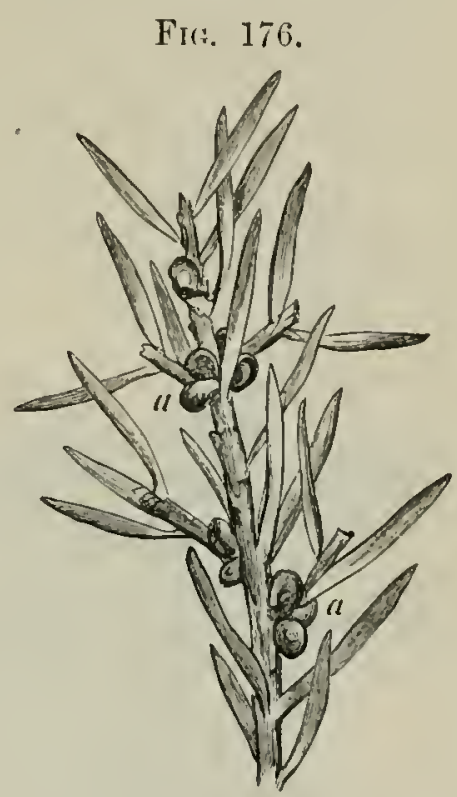

Spruce-shoot attacked by Lecunium racemosim, Ratz.

(Natural size.)

a Feeding scale-insects. 3-jointed. Ovipositor long, sometimes absent. The species produce a chirping noise by rubbing the wing-cases together.

They dig holes in the ground, and live partly on larvæ and worms, partly on the roots, seeds and fruit of forest plants, or on grass and herbage.

\section{Gryllotalpa vulgaris, Latr. (Common Mole-cricliet).}

\section{(a) Description.}

Imago 35 to $45 \mathrm{~mm}$. long, reddish-brown or dark brown, and lighter beneath; the wing-cases short with black veins, not covering the wings; abdomen with two caudal processes. Fore-legs sturdy, resembling hands, used for burrowing, like those of the

* For apple-scale Miss Ormerod recommends 2 lbs. soft soap, 1 lb. flour of sulphur, 14 gallons of water. 
mole. The laria and nymph greatly resemble the perfect insect in form and colour, but have the wings undeveloped.

\section{(b) Life-History.}

Pairing takes place underground from the beginning of June till the middle of July.

The $q$ during the month of June lays 150 to 250 pale yel-

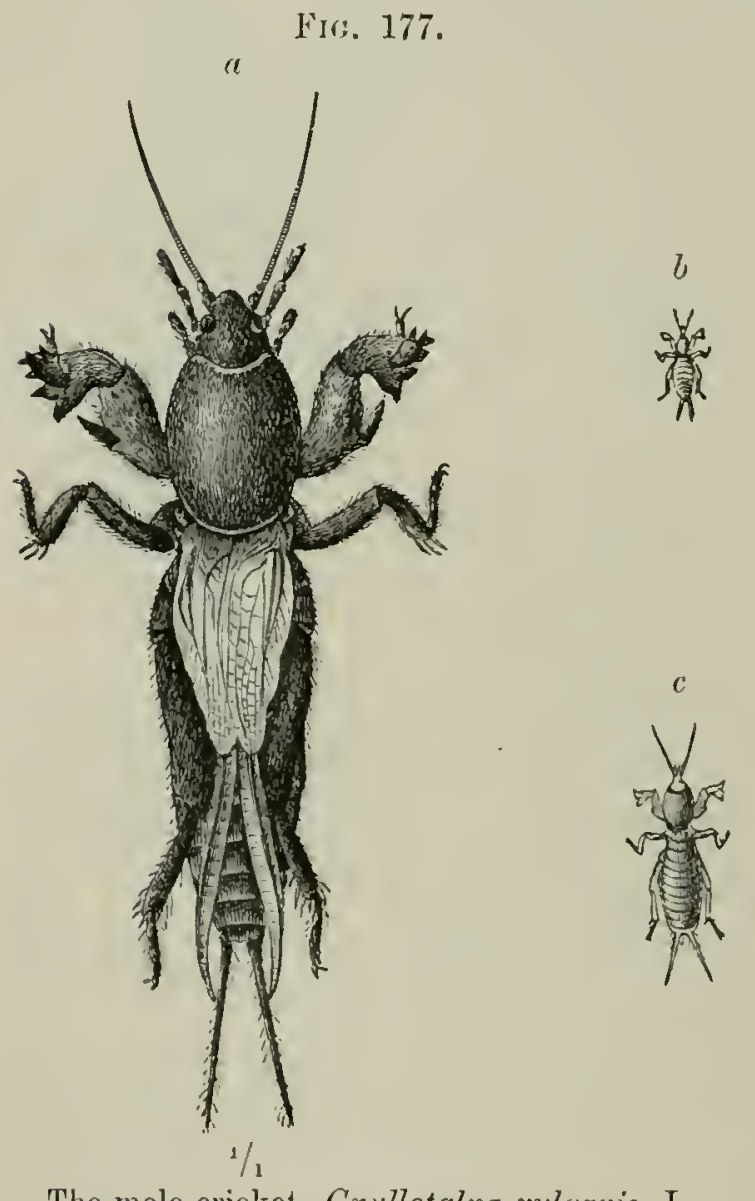

The mole-cricket, Gryllotalpa vulgaris, L.

a Perfect insect. $b$ and $c$ Larve in early stages.

The nymph-stage takes place at the end of May or beginning of June with the fourth moulting, the nymph being active and feeding, and shortly, with the last moult, instead of the little lappets which represent the wings in the nymph, 4 true wings appear, and the form of the perfect insect is assumed.

Generation annual, but occasionally the larvæ may remain over another year. lowish eggs, as large as hempseed, in a hole of the size of a hen's egg, and about 10 to $12 \mathrm{~cm}$. below the surface of the ground, with which it communicates by a tumne or shaft, with a circular section.

The earth above and around the hole is rendered more compact by the saliva of the $q$. The o watches the nest carefully, and when disturbed returns to it by the tunnel.

The young hatch after 2 to 3 weeks, and remain 3 to 4 weeks in the nest; they then begin to burrow in the ground, moult 3 times before October or November, and then hibernate in the ground. 


\section{(c) Relations to the Forest.}

The insect, in all its stages, damages forest plants, by biting through the roots of young conifers, especially of spruce and Scotch pine, when 1 and 2 years old, in the process of making its burrows, which are about a finger's width. It also uplifts young plants, which fall over and die. The mole-cricket also bites off the germinating shoots of oak and beech before they reach the surface of the ground, and the roots of young broadleaved seedlings, tearing the latter with its fore legs.

On the other haud the mole-cricket is useful by destroying

FIG. 178 .

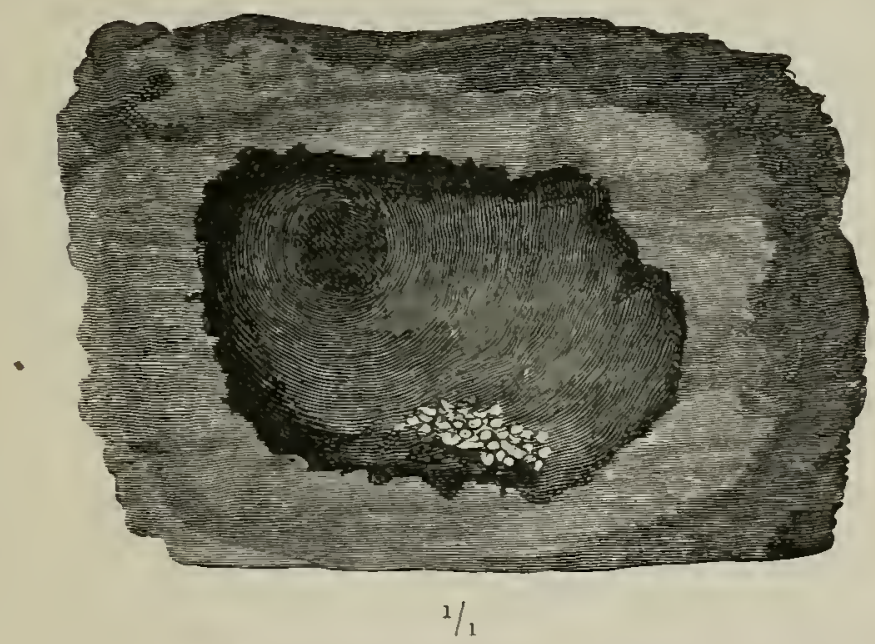

Nest and eggs of the mole-cricket.

numbers of underground grubs. The $q$ has been observed to eat some of her own brood.

Farourite localities for this insect are loose level sandy soils, free from regetation, but it is also found on clay lands. Thinly stocked beds of seedlings are preferred to densely stocked beds, and patches of seedlings to strips.

The mole-cricket also cuts through the roots of agricultural crops. It is not yet decided whether it damages plants for its own nourishment, or to clear the way for its burrows.

The mole-cricket is local in England, and does not occur in the N. It is perhaps commoner than is generally supposed, as owing to its underground habits it is seldom seen. 


\section{(d) Protective Rules.}

i. Isolation of seed beds by trenches 25 to $30 \mathrm{~cm}$. deep and wide; if flower-pots or ressels with smooth sides be placed with their tops lerel with the bases of these traps, many crickets will be caught and may be destroyed.

ii. Protection of enemies. Mole, shrew-mice, crow, starling, \&c. The larre of ground and rore-beetles also attack molecrickets.

\section{(e) Remedial Measures.}

i. Destruction of nests in Jume and July. They may be discorered from the circular orifice in the ground which leads down to them, and by the wilting plants which may be near them. They are dug out, and trampling, pouring hot water orer them, or exposure to the sun will kill the brood.

ii. Destruction of the full-grom crickets in June. Great caution must be exercised, as the creatures are rery shy. Just after dusk, the worker, who should be barefooted, approaches cantiously the places whence the chirping arises, and exposes the concealed cricket by a stroke of the spade. When seized the insect emits a thick black excrement.

\section{Fanily II.-ACRIDIID (Locusts). \\ Description of Family.}

Insects with rertical head, the antemm shorter than the body, with not more than 25 joints; wings roof-shaped in repose, the fore-wings narrow; body laterally compressed; tarsi with 3 joints, usually with a lappet between the claws; abdomen with an anditory organ on each side of the first segment, oripositor short.

Locusts are plant-eaters, and chiefly feed on the produce of fields and meadows, but also on the foliage of broad-leared trees and shrubs, especially when they come in swarms, and they can then be extremely hurtful.

The commonest European species is Pachytylus migratorins, L., and its area of sub-permanent distribution is from lat. $40^{\circ} \mathrm{N}$. in Portugal to $48^{\circ}$ in France and Switzerland, and rising eastwards to $56^{\circ}$ in Russia, Siberia, N. Japan. Its area of occa- 
sional distribution is wider, and it has visited England and Scandinavil. It is also found in S. latitudes in New Zealand and Anstralia, and in Mauritius and Africa. Only an occasional visitor to India.

Acrydium peregrinum is permanent in Africa and tropical Asia, especially India, and occasionally visits the South of Europe, and in 1869 was found over a large part of England.

\section{Pachytylus migratorius, L. (Migratory Locust).}

(a) Description.

Imago 35 to $48 \mathrm{~mm}$. long ( greenish, or brownish; pronotum produced into a blunt point in front; wings yellowish, or pale brown, almost transparent, slightly darker at the tips; chest with white hairs; hind femora bluish on their imer side, with a black ring in front of the joint; hind tibire yellow.

Larra with broad brown bands on the front part of the back, and wingless until it has moulted four times.

(b) Lite-History.

The eggs are laid in the ground 3 to $4 \mathrm{~cm}$. deep, in.groups of 70 to 80 , and as the $q$ die immediately after laying, their dead bodies lying on the ground show where eggs have been laid.

\section{(c) Relations to the Forest.}

Locusts chiefly devour agricultural produce, sometimes appearing in such countless swarms as to leave nothing green over many square miles of country. South Russia, with its extended grain-producing plains, is specially liable to this scourge, and also Hungary. Its permanent home appears to be the barren steppes of Central Asia. It occasionally spreads westwards over Germany as far as Belgium, and eren into the British Isles. While, however, chiefly devouring agricultural crops, the locust does not spare the young leaves and terminal buds of broad-leaved trees, though it only rarely strips off all the foliage of a forest. In 1880, in Istria, oak and ash were chiefly 
attacked by it, other broad-leaved trees being spared. Vineyards were also attacked.

(d) Protective Rules.

i. Destruction of eggs. Very difficult to carry out on a large scale.

ii. Destruction of larvæ, which is the best method.

They have been exterminated in Cyprus by an organised system of digging trenches, into which the larræ are driven; strips of cloth on stakes lead up to the trenches, and the locusts are crushed by thousands when the trenches are nearly full, and then fresh trenches are dug.

iii. Destruction of the full-gromn locusts may be effected during wet weather, when they fly with difficulty.

\section{LIST OF DESTRUCTIVE INSECTS.}

A list is here given of all the destructive insects dealt with in this book, arranged according to the species of tree attacked and the different organs of it which suffer.

The following details are given in the list :-

Organs of tree attacked: root, bark, cambium, wood, buds, young shoots, needles, leaves, blossoms, fruits and seeds.

Stage of the insect at the time when it is injurious: larva, imago ; or, sometimes, in the case of Orthoptera, or Hemiptera, all stages, including the nymph or pupa.

Grade of injuriousness of insect.

Age of woods attacked: seedlings, young plants, poles, or trees.

Characteristics of attack, which serve to indicate the offender.

The following abbreriations are used :-
I. Imago.
L. Larva.
A. All stages.
(V.G.) Vertical gallery.
(F.G.) Forked ,
(H.G.) Horizontal ,
(L.G.) Ladder ,, ; the charac- teristic form of Trypodendron.
(S.G.) Stellate gallery,

S. Seedling.
(Y.P.) Young plants.

P. Poles.

T. Trees.

* Highly injurious.

Slightly

Insects not marked with either of the above sigus are moderately injurious. Those, with the mark + placed after them, rarely oceur in the case referred to. 


\section{THE SPRUCE.}

Roots.

* Nelolontha vulgaris. L. 2 to 3

PAGE summers. (Y.P.) ........... 177

* M. hippocastani. Id. ........... 185

Dolopius marginatus. L. (Y.P.). 189 Agrotis segetum. L. S. ........ 292

${ }^{*}$ Grylletalpa vulgaris. A. S. ... 329

BarK.

Strophosomus coryli. I. (Y.P.). 194

S. obesus. Id. ................. 195

*Hylobizes abictis. I. (Y.P) ..... 199

${ }^{*}$ H. pinastiri. Id. ................. 205

Pissodes notatus. Id.†.......... 205

, pini. I. (Y.P.\& P.)... $20 \mathrm{~s}$

, hercymiac. I. T. ..... 208

\section{Cambium.}

Pissodes notatus. L. (Y.P. \& P.) +205

P. pini. Id. ..................... 20s

P. hereynice. L. T. ............ 208

* Tomicus typographus. I. \& L.

(V.G.) T. .................... 210

*T. amitinus. I. \& L. (F.G.) \&

(S.G.) T...................... 218

* T. chalcographus. I. \& L. (S.G.)

P. \& T. ....................... 219

T. sexdentatus. I. \& L. (L.G.) $† 221$

T. laricis. I. \& L. (V.G.)

P.\& T. .................... 223

OT. bidentatus. (Y. P. \& P.)

(S. G. $)+\ldots \ldots \ldots \ldots \ldots \ldots \ldots . \ldots 226$

Hylastes palliatus. I. \& L.

(V.G.) (P. \& T.) ............ 234

Hylurgus piniperda. I. \& L.

(V.G.) T.t

237

H. minor. I. \& L. (H.G.) (P.

E T. $)$

WOOD.

PAGF

Hylecoctus dermestoides. I. \& L.T. 191

*Trypodendron lincatum. I. \& L.

(L.G.) (P. \& T. ) ................ 228

Sirex juecncus. L. T. t ........ 3z0

S. gigas. L. (P. \& T.).......... 322

\section{Buos.}

*Liparis monacha. L. (P. \& T.) 280

Yousg Shoots.

*Hylobius abictis. L. (I.P.) ... 199

Chermes alietis. A. (F. \& T.)

Large galls..................... 325

Lecanium racemosum. A. (Y. P.

$\&$ P.) $\ldots \ldots \ldots \ldots \ldots \ldots \ldots \ldots \ldots \ldots \ldots$

\section{Nefoles.}

ONelolonthe spp. I. (P. \& T.) ... 177

Strophosomus coryli. I. (Y.P.) 194

S. obesus. Id. ................... 195

Sitones lincetus. Id. ........... 195

*Liparis monacha. L. Trees of all ages ........................ 280

Panolis piniperda. L. (P.\& T. $) \dagger 288$

Bupalus piniarius. Id. ......... 294

Lccanium racemosum. A. (Y. P.

\& P.) .......................... 329

\section{INFLORESCENCE.}

Melolontha vulyaris. I.(P.\&T.) 177

\section{Cones.}

Ernobius alictis. L. 191

\section{Germinatiag Seeds.}

Agriotes spp. L. .............. 189

\section{SILVER FIR.}

\section{Roots.}

*1Celolontha spp. L. (Y.P.) 2 to 3 summers ................... 177

*Gryllotalpa vulgaris. A. S. ... 329

BARK.

OStrophosomus obcsus. I. (Y. P.) +195

${ }^{*}$ Hylobius abictis. I. (I. P.) † ... 199
Pissodes picece. I. P. 208

OAphis spp. A. (P. \& T.).. ..... 325 OCoccus spr. A. (Y. P. \& P.) ... 328

\section{Cambioar.}

Pissodes picece. L. (P. \& T.) ... 208 Tomicus chalcographus. I. \& L.

(S.G.) (P. \& 'T.) † 219 
T. larieis, I. \& L. (H.G.) (P. \& T. $)$ t.

Hylastes palliatus. I. \& L.

(V.G.) (P. \& T.)

WOOD.

OHylecoctus dermestoides. I. \& L.

$\mathrm{T}$.

* Trypodendron lineatum. I. \& L.

(L. G. ) T.

Sirex spl]. I. (P. \& T.) 228 320

BuDs.

Pedisea mefinitrane.

L. T, .. 306
Yousg SHoots.

PAGF.

Stromkosomus obesus. I. (Y.P.) 195

Pedisca rufimitrence. I. T. ... 306

OCoceres spl. A. (P. \& 'T.) ..... 328

\section{NEEDLES.}

OMelolonthe spp. I. (P. \& T.)... 177 OStrophosomus obesus. I. (Y.P.) 195

*Liparis monacha. L. T. + ..... 280

* Predisea rufimitrana. L. T. ... 306

\section{Germinatixg Seeds.}

OAgriotes spp. L 189

\section{SCOTCH PINE.}

\section{Roor's.}

* Hclolontlea splp. L. (Y.P.) "2 to

3 summers $17 \%$

ODolopize marginatus. I.(Y.P.) 189

*Agrotis vestigialis. L. S. .... 290

*A. segetuem. Id. ................ 292

* Gryllotelpa vulgaris. A. S. ... 329

BAIR.

Stropleosomus coryli. I. (Y.P.) 194 S. obesus. Id. ................... 195 *Hylotrus abietis. I. (T.P.) .. 199

${ }^{*} H$. pinestri. Id. . ............ 205

* Pissoder notatus. I. (Y. P.\& P.) 205

*P. pini. Id. ................... 208

*P. piniphitus. I. (P. \& T.).... 208

Lophigpres pini. I. (Y.P. \& P.) 315 L. rufus. Irl. ................ 319

\section{Cambiem.}

*Pissodes notatus. L. (Y.P. \& P.) 205

P. pini. Irl. .................. 208

${ }^{*} P$. piniphitus. L. (P. \& T.) ... 208

OTomieus typogreptuss. I. \& L. (Y.G.) T.† ................... 210

OT. amitinus. I. \& L. (F.G.) \& (S.G.) T.十 ...................... 218

OT. eheleogrophus. I. \& L. (S.G.)

(P. \& T.) t .................. 219

*T. sexdentetus. I. \& I. (V.G.)

T........................... 221

* T. laricis. I. \& L. (V.G.)

(P. \& T.)
*T. bidentatus. I. \& L. (S.G.)

Trees of all ages............... 226

T. acuminatus. I. \& I. (S.G.)

T........................... 228

Hylastes palliatus. I. \& L.

(V.G.) T..................... 234

*H. ater. I. (Y.P.) Near the collum ...................... 2:36

H. opeeus. Id.... ... ....... 236

*Hylurgues piminerete. I. \& L.

(V.G.) Trees of all ages ..... 23i

*H. minor. I. \& L. (H.G.).

Trees of all ages............... 243

WoOD.

Tryportendron tinertum. I. \& L.

(L.G.) (P. \& T. )† .............. 228

Sirex jurencus. L. (P. \& T.)

2 summers ................... 320

S. gigas. Id..................... 322

BuDs.

* Gastropecha pini. L. (P. \& T.) 265

Lipar is monache. Id. .......... 280

* Retinia buotiana. L. (Y. P. \& P.) 301

I. turionane. Id. .............. 304

Young SHoots.

Hylobius abictis. I. (Y.P. \& P.) 199

II. pinastri. I I. ............... 205

* IIylurgus piniperta. I. I'ith of trees of all ages ............. 23t

* H. minor. IH. ................. 243

* Iictinia brotiana. L. Pitl of trees of all ages ............... 301 
PAGE

1i. turionane. L. (Y. P. \& P.) 304 OR. resinclla. L. 2 year's. ( $\mathrm{T}$.

P. \& P.). Resin-galls ....... 305

Coccits spl). A.................. 328

Needues.

Olihirotrogus solstitialis. 1. (P.

\& T. ) ..................... 185

Strophosomus coryli. I. (Y.P.) 194

S. obesus. Id. .................. 195

S. Timbatus. Id. ................ 195

${ }^{*}$ Gastropacha pini. L. (P. \& T.) 265

*Liparis monache. L. (Y.P.)

(P. \& T.) 280

* Panolis piniperda. I. (P.\&'T.) 288 Agrotis restigialis. L. (Y.P.)... 290

*Bupalus piniurines. L. (P. \& T.) 294
${ }^{*}$ Lophyyrus pizi. L. (I.P. \& P.)

Social.

I"AGE

*L. vufus. Id. 319

\section{INFLORESCENCE.}

OAcloluntha vulyaris. I. (P. \& T.) $17 T$

OEnobius alietis. L. ........... 191

\section{Germinating Seinds.}

O Agriotes spp. L. 189

The above-mentioned insects also attack other species of pines, such as $P$. Strobus, Laricio, Cembra, montance; but none suffers so much as $P$. sylvestris.

\section{IARCH.}

Roots.

*Nelolontha spp., L. (Y. P.). 2 to

3 summer's 177

Agrotis vestigialis, I. S. 290

* Gryllotalpa vulgaris, A. S. 329

BARL.

Hylobius abictis, I. (Y. P.)† ... 199 H. pincti, I. (Y.P.) ............. 205 Pissodes notatus, I. (Y.P. \& P.) +205 Chomes laricis, A. Trees of all agres 327

\section{Cambiun.}

Pissodes notatus, L. (I.P.\& P. ) 205 *Tomicus typographus, I. \& L. (V.G.), T.†............... 210 * T. amitinus, I. \& L. (F. or S. G.) T. ................... 218 T. chalcographens, I. \& L. (S.G.) (P. \& T. )................... 219 T. laricis, I. \& L. (V.G.), P. \& T. 223
WOOD.

Trypodendron lincatum, I. \& L. (L. G.) T.† 228 Sircx gigas, L. T. 322

Buds.

Cecidomyia kellncri, L. Trees of all ages 325

\section{Needues.}

O.Mclolontlea spp., I. (P. \& T.) ... 177 Lipreris monacha, L. (P. \& T. ).. 280 Agrotis vestigialis. L. (Y.P.) ... 290 Pedisece accultana, L. 'T. ........ 307 * Colcophora lavicella, L. (Y. P.

\& P.) ......................... 311 OChcrmes lavicis, A. (T.I'. \& P.) $32 \pi$

\section{Geinunativg Seens.}

Algriotes spp. 189

\section{BEECH.}

\section{Roots.}

*Nclolontha sp]., L. (T.P.) 175 Gryllotalpa vulgaris, A. S. 329 VOL. IY.

BATK.

Hylobires abictis, I. (Y.P.)†..... 199

Vespa crabro, I. (Y.I. \& P.) ... 16 


\section{C.hกLitid.}

*Agivilus vivilis, L. (Y.1.). $2^{\text {l'AGE }}$ summer's

A. angustulus, Id. † .............. Iss OScolytus intricatus, I. \& L.

(H.G.). l'. and branchest ... 250

\section{1)1\%.}

Ollylccoctus dermestuieles; L. T.... 191 Yestobium tesselutum, I. \&. L. T. 192 Trypodendion domesticum, I. \&

L. (L.G.) T. 231

Xylchorus dispur, I. \& L. (F.G.)

(Y.P.) 232

Zcnscrec cisculi, I. (Y.P.) 2 summer's 264

BuDS AXD LEATES.

Melolontha spp., I. (P. \& T.) ... 17 T ORhieotrogus solstitialis, I. (P. \& T.) 185 CApoelcrus coryli, I. \& L. (Y.P.). Leaf-rolling .................. 193

Clibyuchites spe. I. \& L. (Y.P.).

Leaf-rolling ................ 193

Strophosomus coryli, I. (Y.P.)... 194

s. obesus, II. ..................... 195

Phyllolius spp., [1. ... ........ 195

Orehestes fugi, I. \& I. (Miner).

Trees of all ages.............. 196

*Dasychire pudibunda, L. (P.

\& T.)

Porthesia chrysorvhcea, Id. ...... 27s

OPorthesie similis, L. (P. \& T.)... 279

*Liparis monache. Id............ 280

CHibernia defoliavia, L. (P. \& T.) $29 \mathrm{~s}$

Frits.

Athous hemorthoidalis, L. .... 159 Orchestes fagi. I. Lnripe fruits 196

\section{OAK.}

livots.

*.1Yctolonther splp., L. (Y.P.), esp. S........................... 178

OCynips slpr., I. \& L., Galls...... 32:3 Gryllotelpe valyaris. A. S. ... 329

\section{B.ARK.}

OIIylobius ubirtis, I. (Y.P.) +..... 199 OCynips spp., I. \& L. Galls. ... 323

Vespa crabro, 1. (1.P. \& P.) ... 167 OCoccus spl., A. (Y.P. \& P.) ... 328

CAMBILA.

Agrilus viridis, I. (Y.l.) $\dagger$ ? summers...................... 186

${ }^{*} A$. angustulus, lil. ............. 188

Hylesinus cicuatus, I. it L. (H.G.), 'T. 247

Scolytus intricatus, I. \& L.

(H.G.). 1'. and branches ... 250

\section{WOOD.}

Lymexylon navale, L. T. ........ 190 OHylecutus dermestoides, I. 'T. ... 191 OXestobium teswelatum, I. \& L. T. 19?

*Xylchorus dispar, I. \& L. (F.G.), (Y.P.) ....................... 23.2

Cossus lignipurale, I. T. 2 slunmer's. $26^{\circ} \cdot 2$
CZcnzere cesculi, L. (Y.P.). 2 summers........................ $20 \frac{1}{2}$

Buds AXD LEAVES.

Strophosomus spp., I. (Y.P.) ... 194 CPhyllobius spr., I. (Y.P.) ..... 194

${ }^{*}$ Boinlyyx ncustrice, L. P. \& T. ... 27.2

Porthesia spp., L. (1. \& T.)..... 27S

"Chcimatobia brumata, Il. ...... 296

Hibcrita clefoliceriu, L. (P. \& T.) 298

* Tortrix viridena. Id........... 299

Oc'ynips spp., I. \& L. Galls. ... 323

LEAYE.

*Hclolontha sp., I. (P. \& T.) ... 17T C.Apoulcrus coryli, I. \& L. (Y.P.).

Leat-rolls $19: 3$

C.Attclubus rureulionoilles. Id.... 193 Corchestes quercus. I. \& L.

Suplressed growth .......... 197

Dasychira pudibunde. L. (P.

\& 'T.) ..................... 274

Liparis monacha. L. (l'. \& D.) 280

(See preceding section.)

Youx: ShooTs.

Telephorus obscurus. I. (Y.P.) 161

Lacon murinus. Id. ........... 190

Corymbites spl'!., Id............. 190 


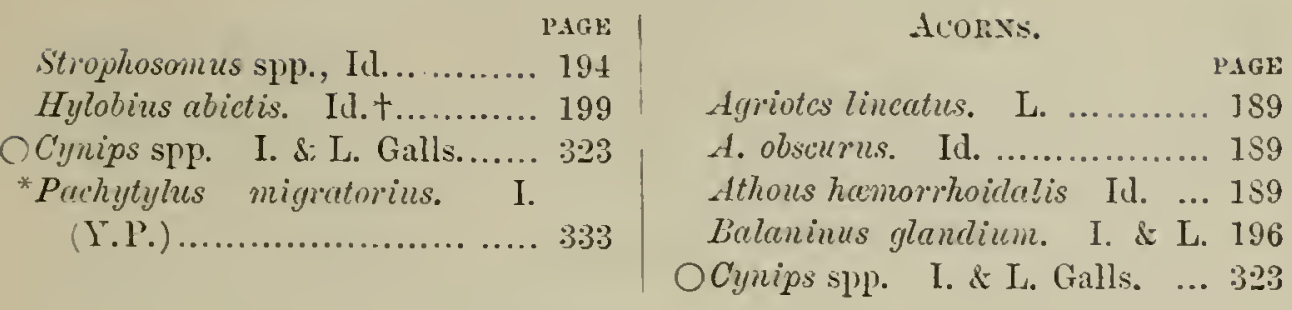

\section{HORNBEAM.}

Roors.
*.ICloloithe spp. L. (Y.P.) .... 177

\section{Woon.}

CXcstobium tesselutum. I. \& L. T. 192

Tylebonus dispai. I. \& L. (F.G.), (Y.P.\& P.) 232

Buds aNd Leaves.

*Eombyre neustria. L. (P. \& T.) 272 Porthesia similis. Id............ 279

*Cheimatobia brumate. Id...... 296 Hibcrinia defoliuriu. Ir.

\section{LE.AVES.}

Mclolontha spp. I. Trees of all ages ............................ 177 ORhizotrorjus solstitialis. Ict. ... 155 Dasychira purtibunda. L. (P.

\& T. ) ........................... 274

*Porthesia chrysorihoea. Id. ... 27s

Liparis monacha. Id............ 280 (See preceding section.)

Flivits.

Athous hwmornoidalis. L. ... 199

\section{ELM.}

Roots.
*.Yclolontha spp. L. (Y.P.)..... 177
Gryllotalpa valgaris. A. S. ... 329

\section{Cambivar.}

CHylesinus vittatus. I. \& L. T. 246 Scolytus destruetor. I. \& L. (L. G.)

(P. \& T.) 248
Woov.

C'ossus ligniperda. L. (P.\& T.)

2 summerst 262

Zcnvera resculi. L. (P. \& T.)... 264

\section{Buds AND LEAVES.}

Bombyx neustria. L. (P. \& T.) 272 Porthesia chrysorrhoe. Id. ... 27s

P. similis. Id................... 279

Hiberia defoliaria. Id......... 293

\section{9. $\mathrm{ASH}$.}

\section{Roots.}

-Mclolontha spp. L. (Y.P.)......

B.trk.

Vespa cralio. I. (Y.P. \& P.). On young shoots.

\section{C.meium.}

*Hylesinus fraxini. I. \& I. (H.G.) (P. \& T.). Bark rosettes ....................... 245 H. ercnatus, I. \& L. (H.G.) T. 247
Scoiytus destructor. I. \& L. (L.G.) (P. \& T.) t ............. 2 48

Wood.

Fylcborus dispar. I. \& L. (F.G.) (Y.P. \& P.) …...... 232 Cossus ligniperda. L. (P. \& T.). 2 summers 202 Zeñcra ceseuli. I. (Y.1.). ¿2 summers 264

Buds.

Prays curtisellus. L. (I.T. \& l'.) 310 


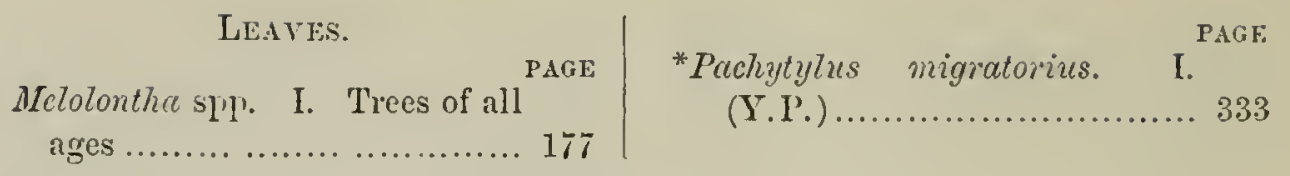

\section{MAPLE.}

\begin{tabular}{|c|c|}
\hline Roors. & Cossus ligmiperda. L. (T.\& T.) \\
\hline Melolontha spp. L. (Y.P.)..... I & 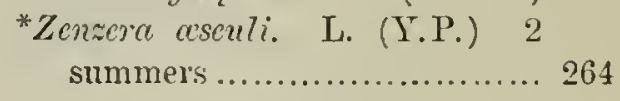 \\
\hline us dermestoides. & 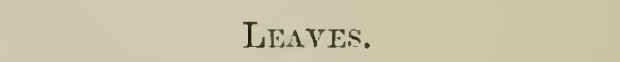 \\
\hline 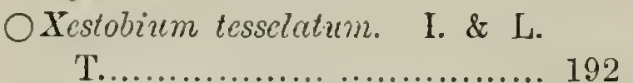 & 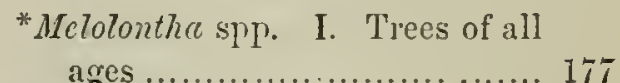 \\
\hline $\begin{array}{l}\text { Trypodendron domesticum. I. } \\
\text { \& L. (L.G.) T. .............. } 231\end{array}$ & 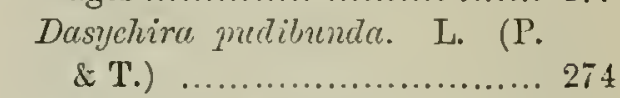 \\
\hline 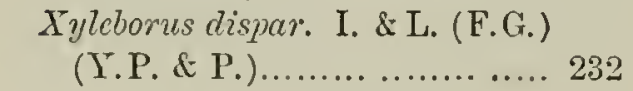 & $\begin{array}{l}\text { Porthesia clerysorrhasa. Id } \\
\text { Liparis monacha. Id....... }\end{array}$ \\
\hline
\end{tabular}

\section{ALDER.}

\author{
Roots. \\ *Melolontha spp. L. (I.P.)..... 17t \\ Bark. \\ Cryptorrhynchus lapathi. I. (I. \\ P.)

Vespa crabro. I. (Y.P. \& P.)... 167

Canbium.

Acprilus viridis. L. (Y.P.) 2

summers 156

\section{Woop.}

OXestobium tesselatum. I. \& L. T. 192 *Cryptornhynehus Trepathi. L.

(I.P. E P.). 198
Xyleborus dispar. I. E L. (F.G.) (Y.P. \& P.) …............. 232 OCossus ligniperela. L. T. 2 summers ....................... 262 OZenzera asculi. L. (Y.P.) 2 summers. 264

\section{LEAYES.}

OApoderuscoryli. I. \& L. (I.P.). Leaf-rollingt ................... 193

Rilymelites spp. Id............. 193

Dasychira mulibunda. L. (Y.

P. \& Y.) ..................... 274

Liparis monache. H............ 280

12. POPLAR.

Roots.

*ALclolonthe spp. L. (I.P.) ... 177

BAIK.

Cryptorrhynehus Tapathi. I. (T. P.) 198

\section{Campiem.}

Agritus viridis. L. (T.1'.) 2 summers. (Aspen.).......... 186 OA. scxguttatus. L. T. 2 summers
Wood.

Cryptorihynchus lapathi. L. (I. P.) ........................... $19 \mathrm{~s}$

* Saperda carcharias. L. (Y.P.

\& P.) 2 summers............. 252

S. poputnece. Id. Branches .....253 Sesic apiformis. Id. .......... 260 Cossus lignipesda. I. P. \& T.

2 summers ..................... 262 Zenzera ceseuti. L. (Y.P.)t 2 stmmers 264 
BuDs.

OBombyx neustric. I. (P. \& T.) 272

LEaVEs.

Jelolontha spp. I. (P. \& T.)... 177

Rhizotrognes solstitialis. I(l. ... 185

Rhynuchites spp., I. \& L. (Y.P.).

Leaf-rolling 193

Melcesome populi. I. \& L. (I.

P.) (stool shoots) ............ 255

1I. tremule. Id. ................ 256

Phratora vitclline. I. \& L.

(Y.P.)† ..................... 256

Bombyxir neustria. L. (P. \& T.) 272

OPorthesia chrysorrhea. Il. ... 278

OLipuris moncecha. Id. $+\ldots . . . . .280$

\section{WILLO W.}

Roots.

*Helolonthce spp. L. (Y.P.)..... 177

\section{BARK.}

C'yptorhynechus lapathi. I. (Y.

P. \& P.) 198

Vespa crabro. I. (Y.P.) ........ 167

\section{Wuod.}

Cryptorrhynchus Tapathi. L. (Y.

P. \& P.) 198

Saperda carcharias. L. (Y.P.

\& P.) 2 summers............. 252

S. populnca. Id. ................ 253

* Cossus ligniperda. L. (P. \& T.)

2 summers ...................... 262

Zenserce cesculi. L. (Y.P.)

Osiers. 2 sunmers ........... 264

Cceidomyia saliciperla. $\mathrm{L}$.

Gall-like swelliugs .......... 324
Buds.

Bombyx nenstria. L. (P. \& T.) + 27:2 OPorthesia elu'ysorrhoa. L. P. \&

T........................... 278

P. similis. Idl.................. 279

Yous: SHoots.

Earias chlorente. L. (Y.P.)

Osiers 299

\section{LEAVES.}

OMclolonthe spp. I. ........... 177

+Rhizotiogues solstiticalis. I...... 185

Mclasoma populi. I. \& L. (Y.P.) 255

M. tremulce. Id. ............... 256

* Phratora vitcllina. Id. ..... 256

OBombyx neastria. L. $\dagger$........ 272

Porthesia chrysorrhaa. L. ..... 278

Lipuris monache. L. Sallow 280

Earias chlorance. L. (Y.P.)

Terminal leaves bound to-

gether ....................... 299

\section{BIRCH.}

\section{Roors.}

*.Uclolontha spp. L. (Y.P.) ..... 177 Gryllotalpa valgaris. A. S. ... 329

Batis.

Vespacrabro. I. (I.P. \& P.).. 167

Cambium.

Agrilus rividis. L. (Y.P.) 2 summers 186

WOOD.

OHylcentus icrmestoides. L. T. 191 Xyleborus dispor: I. \& L. (F.G.) (Y.P. \& P.) ............. 232

Tryprodendron donesticum. I. \& L. (L.G.) T. 231
OCossus ligniperda. L. (P. \& T.)

2 summers .................... 262

Zcinzerce cesculi. L. (Y.P.). 2

summers 264

LEAVES.

Wclulontha vulgaris. I. Trees of all ages .................. 177

Strophosomus spp. I. (T.P.)... 194 ORhynchites betulce. I. \& L. 'YY.

P.). Leaf-rolling ............. 193

Oli. betulcti. Id. ................ 194

Dasychira pudibanda. L. (P.

$\& \mathrm{~T}.) \quad \ldots \ldots \ldots \ldots \ldots \ldots \ldots \ldots . . . \ldots \ldots . . .274$

Porthesic simitis. L. (P. \& ' 'I.) 279

Liparis monacha. Il............ 280

Hibernia defoliariu. Id.......... 298 


\section{IIIME.}

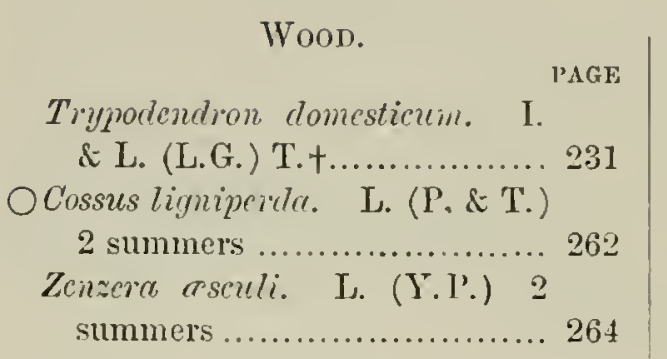

BUN AND LEAYES.

I'AGE

OPorthesia simitis. L. (i'. \&. T.) 279 Cheimatolia brumate. L. (I'.

\& T.) $\ldots \ldots \ldots \ldots \ldots \ldots \ldots \ldots . \ldots \ldots$

Hibcrnia refolistia. Id......... 298

LEAVES.

O. monache. L. (P. \& T.) ...... 280

\section{ROBINIA.}

Roots.

Mclolontha spl. I 177 | Elateride spp. 188

\section{HAZEL.}

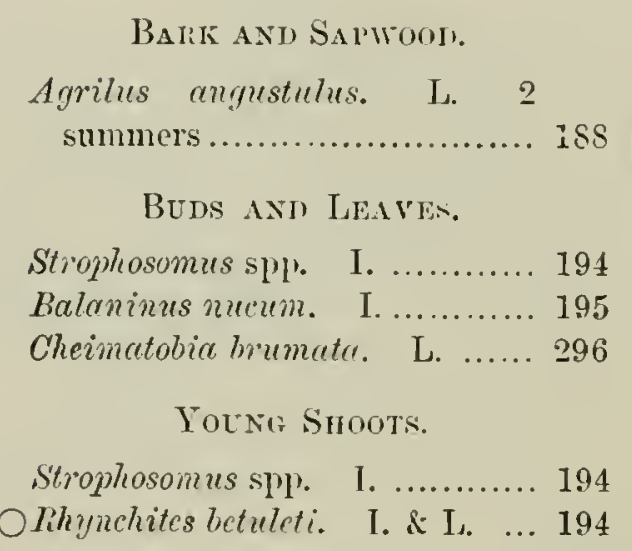

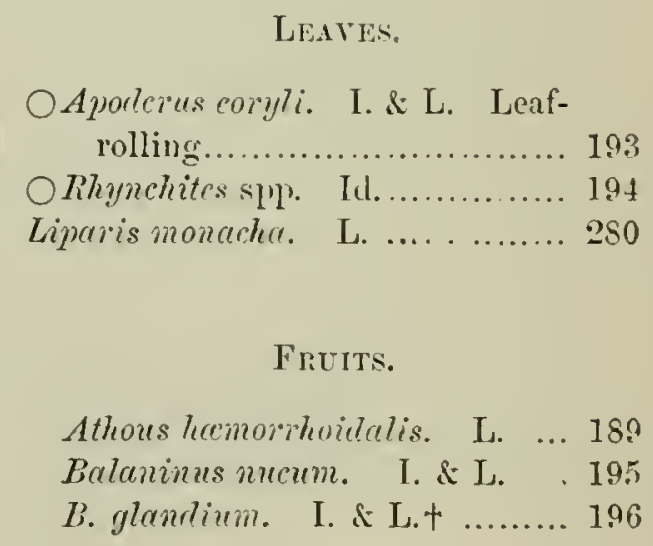

In concluding this Chapter, it is desirable to impress strongly on the forester the necessity for a careful study of forest insects. Inattention to these little creatures has already in many cases been severely punished by the sacrifice of the labour of years. It must not be imagined that insects always attack in a secondary mamner, that is, after a plant has been weakened by previous injury or disease, nor must the danger arising from them be under-estimated, and this is especially important as regards coniferous forests.

The most effective means for combating insect attacks consist in careful and cleanly forest management, and in repressing an attack at its very commencement; once it has 
attained large dimensions man's efforts against it are almost powerless. In order that his attempts at repression may be successful, the forester must know the life-history and relations to the forest of injurious insects; for this purpose mere book-learning will not suftice, but must be supplemented by careful and continuous observation in the forest. 


\section{PART III.}

PROTECTION AGAINST PIANTS.

Plants injurious to forests are either weeds which cover the soil, or climbers and parasitic phanerogams or fungi, which, attack trees and forest plants. The following sections will contain an account of these dangerous enemies of the forest.

\section{CHAP'TER I.}

PROTECTION AGAINST FOREST WEEDS.

Section I.-Gexerdl Account.

1. Definition of the term Frorest ITeed.

The ter'm forest weed usually comprises plants which by their vigorous growth in masses more or less retard the development of young forest plants. By extending the meaning of the term, shrubs, and even many otherwise useful trees, may be included, which injure the growth of the principal local forest species. When for instance sallows or aspens spring up in large numbers in beech woods, or birches among conifers, or even the hardy and fruitful horubeam competes too freely with beech, it becomes necessary to remove these inferior species in cleanings. More detail on this point is given in sylviculture; it may, howerer, be noted here that the most numerous and dangerous forest weeds are woody plants of more or less rapid height-growth, the most bushy ones, and those producing root-suckers being the worst. In Burmese teak forests, bamboos which grow to heights of fifty feet and more within a few weeks, may render teak reproduction impossible, until the bamboos seed gregariously and die, or are lilled by fires. 


\section{Clussification of Forest Weeds.}

In classifying forest weeds, the forester should be guided by the following points:-

(a) Structure of the stem.

(b) Duration of life of the weed.

(c) Local occurrence.

(d) Preference for any particular soil.

(e) Amount of mineral matter in its ash.

$(f)$ Demands as regard light and shade.

(q) Kind of injury done.

(h) Relative amount of injury.

It is highly interesting to note the changes which take place in the constituents of the soil-covering in a forest according to the species of tree grown, and the degree of density of the cover.

(a) Strueture of Stem.

Weeds may be either uoody or herbaceous. To the former class belong brooms, white-thorn, black-thorn, brambles, elder, Sc. ; to the latter willow-herbs, groundsell, belladomna, fox-glove, grasses (except bamboos), sedges, reeds and rushes.

\section{(b) Durution of Life.}

Weeds may be either annuals, biemnials, or peremuials.

Most herbaceous plants, except some grasses, are annuals; belladomma and foxglove are biemmials, but this class is rare among forest weeds, and all woody plants are perennials.

\section{(c) Local Occurrence.}

Forest weeds may be classed as belonging to the plains, to swamps, hills, or mountains. Of these, the flora of swamps and of high mountains are most specialised.

\section{(d) Nature of Soil.}

Plants may be particular, or indifferent as to soils.

The former class is divided into plants special to sand, clay, loam, calcareous soil, or to dry and sour soils. It should, how- 
ever, be remembered that the plants produced in any locality are affected by the subsoil and surrounding conditious as well as by the surface-soil, so that we must not be surprised if a sandy soil, for instance, occasionally produces plants peculiar to other soils.

Most forest weeds are indifferent as to soil, and appear on soils differing from one another both physically and chemically.

On sand!y soils we chiefly find ling (C'ulluna vulgaris, Sal.) and heather (Erica), broom (Cytisus sroparius, Link.), lymegrass (Elymus arenarius, L.), marram-grass (Ammoplyyllu armudinacea, Host.), sand-sedge (Carex arenaria, L.) ; Festuca glauca, Schrad.; I'cnicum glabrum, Gand.; thrift (Armeriu vmlgaris, Wild.), \&c.

On clay soils: coltsfoot (T'ussilago Farfara, L.), wound-wort (Stuchys palustris, I.), marestail (Équisetum), cotton-grass (Eriophorum), rushes (Juncus).

On loam, on account of its favourable nature, very numerous weeds abound, such as all good meadow-grasses, bind-weed (Comrolvulus), Teronica, sc.

Calcareons weeds are Stachys germanica, L.; Rubus saxatilis, L.; many P'apilionacece, and of grasses, Melica and Seslevia.

On rich humus soil: raspberry (Imbus Idaens, L.), balsam (Impatiens Noli-me-tangere, L.), hemp nettle (Galeopsis 'T'etrahit, L.), black night-shade (Solanum nigrnm, L.), \&c.

On peats: we find mint (Mentha paliestris, L., \&c.), Vaccinium uliginosum, L.; Carex, Eriophorum, Juncus, Scirpus, lousewort (I'edicularis), dock (Linmex), loose strife (Lythrum Salicaria, L.), peat-moss (Spharmum, sp.), \&c.

On salt soils: sea mill-wort (Glanx maritima, L., Plantayo maritima, L.), marsh-samphire (Śalicornia herbacea, L.), saltwort (Salsola liali, L.), \&c.

\section{(e) Mineral Substances in Ashes of IVects.}

The mineral character of the soil on which plants will thrive camnot be decided by the quantity of any substance such as silica, calcium carbonate, or sodium chloride, which may be found in their ashes. The physical nature of the soil, i.c., its degree of 
moisture, capacity for being heated, porosity, \&c., has more influence on the growth of plants than its chemical composition, thongh the latter has an indirect influence on its physical nature.

In the strife between weeds and cultivated plants, the former gain grom by the easy dissemination of their seed by wind, water, or birds, as well as by their superiority in the struggle for light and for space for their roots. If cultivation of the fields were to cease in Europe, it is probable that in 100 years, only grass-land, forest, or swamp would be found, according to the degree of humidity of the soil.

\section{(f) Demands as to Light.}

Plants are termed light-demanding or shadebearing according to their demands in the matter of light, or capacity for bearing shade.

Heather is a light-demanding plant, bilberry (Vaccinium Myrtillus, L.), a half shadebearer: the holly and Daphne are shadebearing plants, as they flourish in dense woods.

\section{(g) Kind of Injury done.}

Weeds may overtop young trees and deprive them of light and dew; they may constrict them, as in the case of the woodbine, or completely stifle them by growing all orer them, like the bindweed; they may smother and bend them down when pressed on them by snow, as dead bracken; or cause swamps like the peat-moss, siphagnum.

\section{(h) Degree of Injury done.}

Weeds may be classed as very injurious, injurious, or only slightly injurious. Many forest weeds are either technically or indirectly useful, as will be explained in the next paragraph.

\section{Utility of Certain IVeeds.}

Many weeds, such as grasses, are directly useful for fodder, thatch, or litter, or may be used by manufacturers, or for medicine. A full account of such plants is given under Forest 
Utilization. Other weeds are indirectly useful as evidence of certain physical or chemical qualities of soils.

Weeds may also be useful in the following ways:-by binding the soil together on steep slopes or on shifting sands, by maintaining moisture in the soil and enriching it with their detritus, when the weeds are tall and not too bushy; by affording shelter to tender forest plants in exposed places against frost, dry winds, or insolation; weeds of an erect habit such as the broom are most useful in this respect. Thorny bushes protect all kinds of forest plants against grazing animals or deer, and afford shelter to useful birds.

On these grounds forest weeds should not always be extirpated, but only when they do more harm than good.

\section{Damage done by Forest Weeds.}

(a) General Nature of-.

The damage done by forest weeds is either direct or indirect, many weeds being liurtful in both ways.

Poisonous plants, such as Daplne Mererium, L., nightshade, or belladonna, are hurtful to animals grazing in the forests. A dense growth of black-thorn, roses, brambles, \&c., is also a great hindrance to fellings, and may therefore be considered directly hurtful.

The indirect hurtfulness of weeds is due to the following causes :-

(i) The matted roots of many weeds increase the difficulty of reproduction of the forest, as in the case of heather, bilberry and conch-ginss.

(ii) The remoral of raluable mineral matter from the soil, which thus becomes imporerished, for instance, of potassium phosphate in grass-seeds.

(iii) Mechanical injury to young forest plants by aspen, sallow, grasses, fc., owing to deprivation of light, heat, air, dew, or rain.

(iv) Injuries by smothering or constricting plants, as by honey-suckle, clematis, convolvulus, wild hops, \&c.

(v) Retention of excessive moisture in the surface-soil during wet weather, and formation of swamps; consequent increase of 
damage by frosts: all peat plants, and especially Spharmum increase the swampiness of the soil.

(vi) A dense growth of grass or weeds may prevent dew or light rains, which merely dry off the surface of the weeds, from penetrating the soil, and is thus very hurtful to plantations and sowings during droughts. This may be easily proved by digging up a sod and examining the soil beneath it. Besides excluding moisture from the soil, the grasses, \&c, draw up the soilmoisture from below and transpire it into the air, so that the denser the growth of grass, the drier the soil becomes.

(vii) Certain plants produce a sour or dry humus which is unsuitable for most forest trees: this is the case with heather, reeds, and other sour grasses and half grasses.

(riii) Shelter is afforded by grass and herbage to mice and insects.

(ix) Weeds increase danger from forest fires.

(x) Some weeds serve as hosts to injurious fungi, which may afterwards spread to forest trees or to agricultural crops. Many parasitic fungi are either most frequently found on weeds, or attack agricultural crops ouly after passing one stage of their existence on a weed.

Thus certain grasses-e.g. Arhenatherum and Avena-spread certain kinds of rusts on to cereal crops, such as Tilletia caries, Tul., and Ustilago carbo, Tul. Puccinia graminis on wheat comes from Aecidium Berleridis on the barberry; and oat-rust ( $P$. coronata, Corda) from buck-thorn. Foresters should always look with suspicion on any fungus appearing on wild plants.

The amount of damage done to forests by weeds depends on their wide dissemination and on the vigour and special nature of their growth. These are determined by the locality, the prevailing system of forest management, and the state of the weather during the growing season. Weeds are chiefly disseminated by winds which carry light seeds and fruits by millions, as for instance, the fruits of Composite ; many birds, especially thrushes and blackbirds, disseminate seerls either by pecking at the ripe fruit-heads and causing the wind to disperse the seeds, or by eating the fruits and voiding the indigestible seeds. This is especially the case with white-thorn. Other birds, such as finches, eat the seeds of many weeds and are so far serriceable. 
Hares, deer, and other animals also carry seeds about in their fur. The seeds of miny water-side plants are carried down by streams and inundations.

\section{(b) Damage according to sipecies of 'Tree.}

Slow-growing species are more easily injured by the growth of weeds than fast-growing ones, and of these, light-demanding species suffer most.

The following scale shows the degree in which the different trees suffer.

Suffer much from ueeds:-Osier-willows, oak, ash, elm, chestnut, silver-fir and spruce.

Sinfer less:-Beech, lime, sycamore, alder.

Suffer still less:-Hornbeam, tree-willows, larch, Scotch and black pines.

Suffer least:-Robinia, species of Sorbus, P'yrus, Prunus, birch, aspen and other poplars, sallow.

This scale, of course, will vary for different localities which suit certain trees better than others.

\section{(c) S'ystems of Management.}

In high forests with natural regeneration, or artificially planted moler cover, the soil is not nearly so liable to become covered with weeds as in the clcar-cutting system, which favours the spread of weeds in the highest degree.

On fresh, and especially damp, rich soils, after a clearcutting, a dense growth of grass and weeds springs up in a surprisingly short time. Thus foxgloves and groundsel on the porpliyry of the Thüringerwald; balsams and willow-herbs on the basalt of the Vogelberg; brooms and genista on sandy soils - spring up in masses after a felling. 'This can only be explained by a supposition that the seeds of these weeds remain dormant in the soil, and only germinate when the removal of the trees allows enongh heat to reach them. Jhuming, or the thorough burning of branch-wood on the soil, after a clear-felling, may destroy sceds of weeds in the upper layers of the soil, and thus keep it free from weeds until it has been restocked with forest growth. 


\section{(d) Lye of Wood.}

Forest trees are most endangered by weeds in the first few years of their life. Forest cultivations, therefore, suffer most of all, and of these, sowings and natural regeneration-areas more than plantings. Where weeds abound, very small transplants should not be used, and frequently four or five-year-old plants are preferable.

Some poles and coppice-shoots, and especially osier-willows, are attacked and frequently lilled by climbers and parasites.

In tropical countries trees of all ages are liable to be killed by the strong woody climbers and twiners which abound in the forests of these regions and attain sereral feet in girth, and may mount to the top of the highest trees, depriving their crowus of light and bending down and breaking poles with their weight. The twiners also constrict trees, moulding their stems into corkscrew shapes, and in the case of trees with a sapwood, the passage of sap may be so interfered with, that the trees are killed.

\section{(e) Locality.}

Fertile, fresh, and moist soils, especially on basalt, produce more weeds than soils over dry sandstone rock. Damp air also farours the growth of weeds, as can be seen from the vigorous weedy growth on mountains. Fortunately, on good soils, the growth of forest trees also cnables them to get out of the reach of the weeds sooner than in unfarourable localities.

\section{(f) Density of Forest Grouth.}

The growth of weeds which have taken possession of the soil after a felling, makes way for a corering of moss, needles or dead leares, after the forest has been reconstituted. When age again begins to open out the wood; or when, owing to bad management, or to accidents, thin places and blanks appear, weeds reappear in direct proportion to the amount of light admitted to the soil.

\section{(g) Weuther.}

Damp warm years are most favourable to a growth of weeds, and during such years tender forest species require little or no 
shelter. Hence for both these reasons weeds are then most hurtful.

(h) Inabit of the Weeds.

Peremnial weeds, and especially those which produce rootsuckers, are much worse than ammuals. Also those with dense foliage and those which are gregarious injure forest plants more than scantily foliaged and solitary growing weeds. Species such as black-thorn, aspen and forest-willows soon get the upper hand of other weeds.

Treeds which by their decomposition yield dry or acid humus are also hurtful, as they produce soil unsuitable for forest regetation. Dry humus formed of lichens, \&.c., contains little carbon dioxide, easily crumbles, decomposes with difficulty and absorbs very little water. Acid humus, on the other hand, does injury by exhaling marsh-gas, and by containing certain organic acids which are detrimental to tree life.

\section{Protective Rules.}

The following rules for keeping down forest weeds should be observed :-

(a) Maintenance of the Density of the Forest.

Great care must be taken in the shelter-rood systems, on soil liable to become weedy, that the fellings are not too open. The seeding-fellings must be dark, and the secondary fellings made gradually. All blanks should be filled in with strong transplants.

\section{(b) Moderately Long Rotations.}

Long rotations should be aroided and woods of light-demanding species (oak, Scotch pine, or larch), should be under-planted at the right time with shade-bearers (beech, silver fir, spruce, \&c.).

If a soil-protection-wood is to serve its proper purpose, it must be introduced before grasses have sprung up and helped to dry the soil.

(c) Rapid' Replanting of Cleared Areas.

Clear-cuttings should be rapidly re-stocked with strong transplants planted closely. 


\section{(d) Maintenance of Soil-Corering.}

The natural soil-covering of dead leaves, needles or moss should be maintained, by keeping up a dense cover, and by preventing the removal of litter.

\section{(e) Drainage.}

Drainage should be carried out on very damp localities, before they are re-stocked.

\section{(f) Grazing.}

A dense growth of heather may be kept down by sheep.

\section{(g) Rules for Forest Nurseries.}

Nursery-beds should be weeded before the weeds blossom, and during rainy weather. Burned sods should be used as manure, as this destroys the seeds of weeds. Manure from old manure heaps is often full of nettle-seed, and when burnt compost is not strong enough for a nursery, artificial manures should be used. Such manures are largely used in German forest nurseries.

Spaces between plants may be covered with moss, dead leaves or sawdust. This prevents the soil from caking and retains moisture near the surface, and thus replaces completely the expensive processes of working the soil, weeding and watering. In damp places, burned compost introduces liver-wort (Marchantia polymorpha, L.), but this does no harm to the plants.

\section{Remedial Measures.}

The nature of remedial measures to be adopted depends on the habit of the weeds, their degree of development, and the nature of the locality. The simplest measures will often suffice, but sometimes special measures must be taken as follows :-

(a) In order to remove too great a soil-covering of grass and herbage, cattle may be admitted, or the weeds may be pulled up or cut down, always before the blossoming period. In very bad cases the hoe or plough may be used all over the area, and the 
land made to produce a field-crop before being restocked with forest growth. The cutting of grass and herbage may be profitable, or the cost of the operation at least covered by the sale of the produce. The weeds when mixed with lime may be collected into heaps, and then yield raluable manure for forest unrseries, or they may be burned and their ashes spread over the soil.

(b) If the soil is covered with short woody plants they may be mowed down or pulled up, as in the case of heather; raspberries may be simply beaten down, and soft roods cut off at about one foot from the ground, or the woody plants may be girdled close to the ground.

Fin. 17Sa. This cutting should be done in July, at the

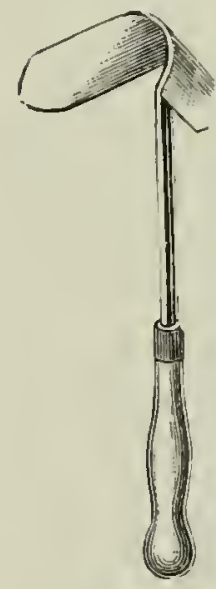

Tree-scraper. height of the growing season, when their powers of reproduction are least, as there is then least reserve-material in their roots and rhizomes. In coppice and coppice-with-standards, inferior species such as blackthorn should be cut out several year's before the underwood is felled.

(c) To remore the coating of lichens and moss from trees, which close their lenticels and deprive them of air, various instruments may be used, as shown in the figures; but this would only be done for specially valuable trees or in

FI: 179.

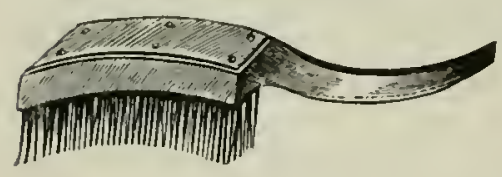

Steel-wire blush.

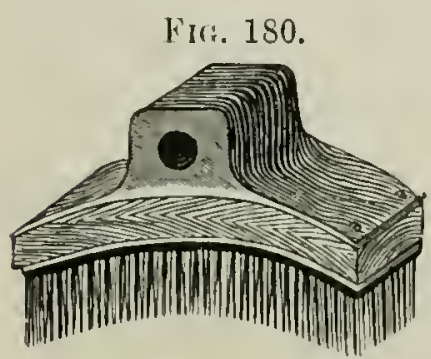

Ditto, with hole for handle. orchards. A mixture twenty parts by weight of wood-ashes with one part carbolic acid may also be used. This is boiled and smeared on the stems with a brush, and in a few days' time all the lichens will fall off. Lime-water has the same effect, and also destroys insects.

(d) In Indian forests, woody climbers are cut periodically, and especially two years before fellings, as they then rot and no longer bind trees to be felled to others intended to remain standing. 
Section II.-Special Account.

\section{List of Forest Weeds.}

THE following is a list of the weeds most hurtful in the forests of Central Europe, with an account of the special means of combating them. It is better to consider them in order of their demands on light and the amount of injury they do, and not according to their systematic botanical arrangement.

The following groups occur:-

Light-demander's, which generally spring up on blanks and clearings.

Half-shadeberer's, oceurring in the interior of woods as soon as they become too light. All shrubs and herbs belonging to this class grow all the better in the open.

Shadebearers, springing up in more or less closed woods.

IVeeds of wet or turfy soils.

Climbers.

Parasitic phanerogams.

Weeds acting as hosts to injurious fungi.

In each group, first the woody species and then herbaceous ones will be considered.

\section{Light-demanding weeds.}

These weeds injure forest plants by overtopping them and excluding light and other atmospheric influences, or by occupying the soil with their roots, or in both ways. They may also produce a humus which is unfavourable to forest growth.

\section{(a) Broom (Cytisus scoparius, Link.).}

'This evergreen shrub attains four feet and more in height, and prefers deep sandy or loamy soil; it springs up on clearings in mild localities, and is found throughout Europe. The seed may remain dormant in the soil for many years.

Broom, when not growing too densely, may be useful to young broad-leaved plants, such as oak-saplings and stoolshoots, by affording them shelter, but it is very destructive to one- and two-year-old pine and larch sowings. The best remedy is to uproot the young broom at its first appearance, or it may 
be cut off at mid-stem, when the stems dry up and do not shoot out again. Its removal may repay the cost, as it is used for litter, fuel, and for making brooms, hedges or thatch. It may be browsed down by sheep. In Italy, between the Alban aud Sabine mountains, regular crops of broom are cultivated with rotations of five or six years, and used for fuel.

(b) Genista, I.

There are several species of Genista, termed in England dyer's-weed, needle-furze, \&c., which may be treated like broom.

\section{(c) Wild Briar (Rosa).}

There are several species of wild briar, the commonest being Rosa canina, L. They spring up wherever the soil is not too wet, both in plains and hills. Their great power of sending out suckers renders them very injurious to forest growth, and the best way to get rid of them is to pull them up by the roots.

\section{(d) Common Ling and Heather.}

Ling (Calluna vulgaris, Salisb.), Scotch heather (Erica cinerea, L.), and cross-leaved heather (E. Tetralix, L.), as well as other species of Erica, cover large areas, the first chiefly in Central and Northern Europe, the second in Western Europe, from the south of Spain to Norway, and the last to the west in Southern Europe, but in the north extending eastwards as far as Sweden and Livonia. They grow in very variable soils, but prefer sandy tracts, especially when poor and dry. A luxuriant growth of heather is a sure sign of a poor sandy soil, which may have become impoverished by bad management. Heather is injurious not only by filling the ground with its roots, and excluding atmospheric influences, but also by producing as it. decays an unfavourable humus, on which only pines, birch and aspen thrive. It is lighly inflammable in the spring, and when burning in dry windy weather may cause extensive conflagrations in coniferons forests.

It reproduces itself chiefly by seed carried by the wind, and less by suckers and shoots. 
The best measures for getting rid of excessive heather-growth are as follows:-

(i) Maintain a close forest growth.

(ii) Graze the heather down by sheep, but this can only be done as long as the heather is young and tender. Old, tough heather will be eaten by sheep only as a last resource; they will prefer young forest plants.

(iii) Cut down or mow the heather, specially strong scythes being used for the purpose. This should be done either early in spring or late in summer, in order to keep the soil somewhat, protected against the heat of summer and the winter's cold. The material may be used as fuel, thatch or litter, or made into brooms.

(iv) Burn the heather in situ. This nay be done when there are no forest plants in it, the destruction of which should be avoided, or immediately after a coppice felling. Fire-traces of sufficient width should be made around the areas to be burned, and the burning should be done on dry, still days in March or April, the fire being lighted to leeward, or downhill, and closely watched.

(v) The ground may be stripped of sods containing the roots of the heather and cultivated, if advisable, before planting it up with Scotch pine. The instrument shown in Fig. 181 is used for this purpose.

\section{(e) Birch.}

The two species of birch (Betula alba, L., and $B$. pubescens, Ehrh.), the latter $\quad a b=4$ inches; $c d=10$ inches; $\leftarrow^{\varkappa}=60^{\circ}$. preferring boggy ground, are sometimes hurtful in coniferous forests, as their hard, whiplike branches break off the tender spring-shoots of conifers. Owing to their rapid growth when young they may also be prejudicial to young oak plants, but may also act as useful 
nurses to the latter against frost and drought. As birch has nsually a number of collum-buds, it should be cut below the level of the soil.

\section{(f) Other Light-demanding Weeds.}

The best remedy for the remaining light-demanding weeds is to effect natural regeneration of the wood, or to replant it, if clear-cut, as soon as possible. They are St. John's-wort (Hyperi('um); balsam (Impatiens Noli-ne-tangere, L.), which grows in damp, fertile soil, in masses often a yard high and over large areas: willow-herb (Epilolium angustifolium, L.) on similar soil, the seed of which appears to remain latent for a long time, and is carried far and wide by the wind; groundsell (Senecio), springing up in masses on sandy soils, the seed carried far by wind (these plants also act as hosts to parasitic fungi); hawkweed (Hieracium); Atropa Belladonna, L., on fertile damp soil in shady mountain forests of Europe and Asia (Himalayas), is very poisonous; foxglove (Digitalis) may grow in such masses that the hill-side appears red, both species, D. purpurea, L., and the yellow one, $D$. grandiflora, which is not indigenous in Britain, are poisonous; Verbascum, four species found on dry, stony gromnd; nettles (Urtica wens, L.), an anumal, and the perennial nettle, with strong rhizomes (U. dioica, L.), are frequently troublesome in forest nurseries; wood-rush (Luzulu), four species common in mountain forests.

Grasses deserve a separate paragraph. The most common injurious kinds are:-Species of bent-grass (Agrostis); Aira cospitosa, L., and A. flexuosa, L.; Melica ciliata, L.; sheep's fescue (Festuca orina, L.), and other species of fescue; conchor twitch-grass (Ayropyrum (T'riticum) repens, Beaur.); lymegrass (Elymus arenarius, L.); mat-grass (Nardus stricta, L.).

The damage due to a thick growth of grass is of several linds: the soil may become matted with its roots, which may prevent the seed of forest trees from reaching the ground; young growth may be choked, the soil dried up, or moisture kept in, and frost increased; damage may also be done by mice and insects which shelter in the grass. When grass grows densely it is a sign that the forest is too thin and admits too much 
light. Twitch flourishes in sandy soils, creeping in all directions through the soil and filling it with rhizomes; it may even penetrate roots of living plants, and thus interfere with their growth.

Weedy places may be treated as already stated for heather, and are best recruited by means of transplants. Twitch is got rid of by repeated ploughing, and by collecting and burning its rhizomes; three years grazing on land where it grows is very useful, as finer grasses then gradually replace it.

\section{Half-shadebearers.}

These are all woody plants, except the last two.

(a) Blackthorn (Prunus spinosa, L.) is common on moist, loamy and clay soils, and on marls, and ascends to 3,000 feet in mountains. It stands frost better than whitethorn, and replaces it for hedging in very frosty localities. It sends out roots and suckers, and has a spreading root-system, and does much harm in regeneration areas and among coppice. It is best to dig it up by the roots in clearings, or cut it back sereral years before coppice is felled.

(b) Brambles (Rulus fruticosus, L.). There are numerous subgenera of this species, termed blackberry or dewberry bushes, the latter (R. cresius, L.) growing in moister localities than the common blackberry, which prefer's well-drained soils and hedgerows.

Brambles frequently cover large areas in fresh and moist soils, sending out new suckers every year. To keep down these widespread pests of the forester seeding-fellings should be dark. Admission of cattle is also useful. In case there be a dense growth of brambles on the ground it should be trampled down round the plants which require protection, or be beaten down with a billhook. They should be cut as little as possible, as this only increases the production of suckers. Plants which they are crowding should be set upright, and their branchlets placed over the brambles. If this be done early in the summer then little will be needed in the autumn, but it may be necessary to repeat the operation the succeeding year; by the second winter the plants will probably get out of reach of the 
brambles. Cutting or digging up the brambles is expensive, and not so effectual as the above procedure. Where a reproduction area is orergrown with brambles, and there is little natural regeneration, it will be better at once to plant up the area.

(c) Rasplerry (Rubus Idous, L.). This grows chiefly on fertile but stony soils rich in humus. Its babit is straight, and it does not produce such dense growth from suckers as the bramble, but may become dangerous, and should then be treated similarly to the latter. Grazing has a very repressive effect on the growth of raspberry canes.

\section{(d) Whitethorn (Cratregus Oxyacantha, L.).}

Whitethorn is not particular about locality, and is widely spread up to altitudes of 3,000 feet. The rich shoots and extensive root-system of this slow-growing shrub, which attains a height of 20 feet, are destructive to young conifers, but in forests open to grazing it protects oak, ash, maple, and other broad-leaved trees until they have grown above it, when it forms a thorny defence around them until they are too large to be injured by cattle. It also forms capital hedges, bearing trimming well, and shelter's the nests of many nseful birds from small carnivora and other enemies. Where it is harmful to young growth, it should be dug up in cleanings and thinnings. Various thorny bushes in India similarly afford great protection to bamboos and other valuable species in grazed forests.

\section{(e) Other Shruls and Bushes.}

The wild gooseberry-bush (Ribes Grossularia, L.), elder (Sambucus), guelder rose (Viburnum Opulus, L.), wayfaring tree (V.lantana, L.), the spindle tree (Euonymus europous, L.), and privet (Ligustrum vulgare, L.) are widespread, the latter and Viburnum Lantana, L., chiefly on calcareous soils in hills. None of these plants are, however, particularly hurtful to young forest growth except the herbaceous dwarf elder (Sambucus Ebulus, L.), which grows in masses from rhizomes in damp places. Daphne Mezereum, L., is a small shrub growing in hilly and mountain woods on damp soils, and is highly poisonous. 


\section{(f) Forest Willou's.}

Sallow (Salix Caprea, L.) flourishes on fresh soils in plains and hills, but will also grow on dry soil and in mountains up to 5,500 feet, attaining at times the dimensions of a small tree; it sends out numerous stool-shoots, but has a shallow rootsystem, so that it may be easily pulled up by the hand, as well as the other willows mentioned below.

Salix cincrea, L., a variety of the sallow, is a smaller plant of a shrubby nature; it sends out suckers on damp soils and along water courses; ascends to 3,000 feet.

Salix aurita, L., resembles the sallow in its habit, but sends out suckers, ascends to 5,000 feet, on wet or dry soils.

Salix repens, L., is a small, straggling bush, growing chiefly on turfy and heather land, and also near swamps; ascends to 3,500 feet.

All these willows when hurtful to forest growth should be cut back or pulled up in cleanings and thinnings.

\section{(g) Aspen (Populus tremula, L.).}

Aspen is a tree which is disseminated throughout Europe, except in the extreme south, up to $70^{\circ} \mathrm{N}$. latitude, and 5,000 feet altitude; it is often very hurtful to valuable forest plants owing to its rapid growth and abundant production of suckers. The roots of a felled aspen, which spread far from the stump, close to the surface of the ground, remain living for years after the parent tree has been removed; they then send up numerous suckers from adventitious buds after the wood in which the aspen formerly grew has been cleared. The aspen is not particular as regards soils, but can grow on cold wet soils and is frequently found in frosty localities, as, for iustance, on the London clay in Epping forest.

Cutting down the suckers is of little avail, as is also extracting the stumps and longer roots of felled trees, but completely girdling a standing tree gradually dries it up and eventually prevents the formation of suckers.

The aspen is also a host for an injurious fungus, Melampsor Tremule, which, in the forms Cooma pinitorquum and $C$ Laricis, attacks pines and larch, and will be described further ou. 


\section{(h) Bilberry (Vaccinium Myrtillus, L.)}

This is a small shrub growing throughout Europe up to 6,000 feet altitude, in masses, on fresh, damp, and even somewhat sour soil. It may also be found on dry sandy soils, but not on calcareous ones. It prefers a slight shade, especially of pines. When it appears in masses it denotes insufficiency of stock and deterioration of the soil, and the surface-soil becomes choked with its roots. Its berries are, lowerer, valuable for making alcohol and preserves.

The cowberry (Taccinium Vitis-Idea, L.), is an evergreen plant, growing on loose, damp, sandy soils in high, cool places; it is social, and has a distribution similar to that of the bilberry. A dense growth of either of these species hinders natural regeneration and increases the difficulty of artiticial restocking. There is then no alternative but to take up these plants in sods, beat off, in situ, all the soil attached to their roots, and remore them. Planting is better than sowing where they prevail.

I. uliginosum, L., is found on swampy land and mountaintops, and the cranberry ( $V$. Oxycoccos, L.) on peaty soils.

\section{(i) F'erns.}

The commoner kinds of ferns found in forests are: (Polypodium vulgare, L.), Beech fern (P. Phegopteris, L.), Male fern (Nephrodium Filix-mas., Rich), Lady fern (Athyrium Filixfomina, Bermh.), and Bracken (Pteris aquilina, L.).

The above prefer damp and stony ground, and their appearance denotes a fertile soil, as well as a slight opening out of the leafcanopy. They spread above and below ground often to the prejudice of young forest plants, by causing excessive moisture, and depriving them of light, and by being pressed down on them in a rotting state in winter by the snow. This frequently kills light-demanders.

In the case of bracken, the best plan is to knock off the soft young shoots in early summer, which can easily be done before they have unrolled. Dried bracken is largely used in England and elsewhere for litter, and in the Forest of Dean, repeated early cutting, in Angust instead of October lias greatly weakened 
the rhizomes of the plant, so that only a short weak crop is produced, as compared with that in the Windsor and New Forests, where it is cut later in the autumn.

\section{(k) Mosses.}

Two species of hurtful mosses are common in forests: Polytrichum commune, L., and P.juniperinum, W. They form dense couvex tufts in damp places, which may be distinguished at a distance by their darker green colour from the paler and more spreading mosses, Hypnum and Hylocomium, which form a useful soil-covering in forests. They are chiefly found in high forest, and especially in spruce woods, and do harm by favouring excessive moisture in the ground and hindering the germination of seedlings. The tufts should be turned over and broken up.

\section{Shadeberting Treeds.}

These are all woody plants. Alder-buckthorn (Rlacmmu: Frangula, L.) is common throughont Europe on damp ground, and chiefly in lowlands; it produces many suckers, and is spread much by birds which eat the berries. It is used for gunpowder-charcoal.

The common buckthorn (R. cotherticus, L.), is a thorny shrub with spreading roots and many sucker's, found on similar soil to the former, and along banks of streams.

Both kinds may be dug up during cleanings.

Dog wood (Cormus sanguinea, L.), on fertile moist soils, ascends to 2,600 feet in monntains, and sends out numerous stool shoots. The wood is used for skewers and was formerly employed for arrows.

Holly (Ilex aquifolium, L.), a large evergreen prickly shrub or small tree, found chiefly on good damp loam or loamy sand; it coppices well. Where it abounds it is possible to plant only strong transplants between the holly bushes, and the latter need constantly cutting back, until they are no longer dangerous. Holly makes excellent hedges, but requires plenty of humus.

Night-shade (Solanum Dulcamara, L.), a small shrub growing in shady, damp, low lands and along banks of streams, climbing 
«p to 10 feet in height on pollard willows and osiers. This plant, as well as S. nigrum, L., which chiefly grows along roadsides, is highly poisonous.

Common juniper (Juniperus communis, L.) is a coniferous shrub wide-spread all over Europe in plains and mountains up to 9,800 feet in the Alps. It is very hardy and indifferent to soils. It spreads owing to thrushes which swallow the berries. Grows well in the open and also in dense pine woods. Should be cut down or pulled up where dangerous to young growth.

\section{Forest Weeds of Wet Peaty Soil.}

To this group belong the numerous species of the following genera.

Rushes (Juncus, L.), (Scirpus, L.), Cottongrass (Eriophorum, L.), Sedges (Carex, L.), Reeds (Culamagrostis, Adans), and Marestail (Equisetum, L.).

All these except the last may be termed half-grasses, and they all form sour herbage, and are chiefly found in low lands, or on peat, and are somewhat light-demanding. A species of Equisetum is a troublesome weed in the somewhat wet sandy loam of part of the Coopers Hill forest nursery.

Sphagnum. Several species of this peat-moss exist and grow chiefly in the open, in opposition to Polytrichum, which grows under cover. They are most dangerous mosses, producing peat and swamps, and rendering the soil unsuitable for forest growth.

The invasion of sour herbage and peat-mosses is best kept back by maintaining the leaf-canopy. If a swamp has been formed it must be drained; sometimes, however, on flat land, with a tendency to swampiness, as shewn by the presence of these weeds, after a forest crop has been cleared, ash and alder. should be planted instead of oak and beech, the swampiness disappearing after the forest growth has been reconstituted.

\section{Climbers.}

'The first two European climbers given are woody and the others herbaceous. The shoots of all climbers should be cut repeatedly below ground till no more appear. There is no necessity to unwind the twiner, unless it is a woody species, as it soon dries up after being cut from the root. 
(a) Traveller's joy (Clematis Titalla, L.) is widespread throughout Europe, chiefly on hills and mountains; it is a half-shadebearer and attains a height of 20 feet, climbing up stems, bushes, and rocks. The shoots may strike root wherever they rest on soil, and the plant sometimes grows in masses and is dangerous to young forest plants.

(b) Honeysuckle or woodbine (Lonicerc Periclymenum, L.), a twiner growing in hedgerows, edges of woods, and inside woods throughout western Europe; it is found on dimp soil and chiefly in lowlands. A half-shadebearer, twining round saplings to a considerable height, and thus producing misshapen spiral stems as in Fig. 182. If no suitable stems are available, it covers the ground and the herbaceous plants growing on it. It does much damage to raluable saplings in coppice-with-standards. I. Caprifolium, L., with connate upper leaves, is common in southern Europe, and has become wild in certain localities further north; it has similar habits to the former.

(c) Bind-meed (Coniolvulus, L.): $C$. arensis, L., chiefly found in fields and waste places; C. sepium, L., in hedges and thickets. Both species are extremely troublesome in nurseries and in osierbeds, as their rhizomes fill the ground, and their shoots twine round and bear down the young plants.

Black bind-weed (Polygonum Conrolvulus, L.) is chiefly found in fields and waste places, and has similar habits to the above.

To deal with these pests, the ground when bare should be trenched, and the soft whitish rhizomes of the bind-reed col- 
lected and burner. It is difficult to do this thoroughly, as the roots go down to 18 inches in the soil.

(d) Wild hops (Humulus Lupulus, L.). The hop is found in damp places in lowlands; it twines from right to left up woody plants and drags them down.

(e) The common ivy (Hedere Helix, I.) is ridely distributed and extends over Europe, Northern A sia, into India and Japan, and North Africa. It climbs trees, rocks and walls by means of its adhesive rootlets, which however suck no nutriment from the host on which it is growing, but merely support the ivy. The smaller forest variety is said not to flower, and sometimes covers the soil of a forest. Matthieu* considers it hurtful to forest trees by interfering with the passage of the sap, and by corering the crowns of trees with its foliage, and it certainly at times constricts oak and other saplings and poles, like the honeysuckle. The ivy, however, rarely ascends higher than the middle of the crown of a tree, and may be useful in preventing the formation of epicormic branches on standards. It dries the surface of ralls on which it is growing, and also the soil when creeping over it. Ivy sometimes attains very large dimensions, a plant at Montpellier being 450 years old and $9 \frac{3}{4}$ feet in girith.

\section{Parasitic phanerogams.}

(a) Mistletoc (Viscum album, L.).

This interesting plant lives as a semi-parasite (obtaining carbon from the air, but water, nitrogen, and mineral matter from the sap of its host) on many conifers and broad-leaved trees, and chiefly on their branches. The hosts, or trees on which it lives are, most fiequently, the apple-tree, both wild and cultivated varieties; next, the silver-fir; frequently, birches, poplars (except aspen), limes, willows, Scotch pine, mountainash, and white-thorn; occasionally, robinia, maples, horsechestnut, hornbeam and aspen.

It is very rarely found on oaks. The alder, beech and spruce appear to be always free from mistletoe, and it very rarely attacks pear-trees. 
It is commoner in Southern Europe than in the North, and is extremely abundant where cider is made. In the Himalayan districts of India, it is common on apricot trees, which are the commonest fruit-trees there.

Its white berries are eaten by birds, chiefly by the missel-thrush ('Turdus visciroins, L.), and the seeds are either rubbed by the beak against branches of trees, or roided on to them; the seeds, owing to the viscous nature of the pulp surrounding them, then become attached to the branches.

The plant sends down haustoria termed sinkers through the bark as far as

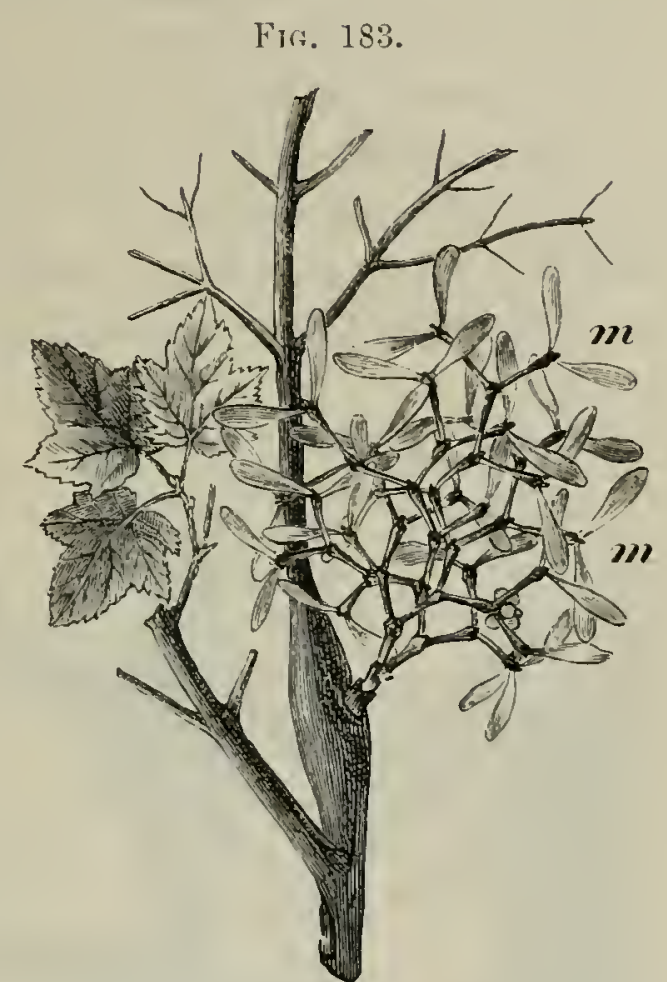

Accr rubrum, L., attacked by Mistletoe (m). (Redneed.) the wood. It also emits side shoots, or cortical roots, into the bast, chiefly in the longitudinal direction of the branch of its host, and these do not grow down into the wood. The growing point of the cortical root obtains nourishment from the bast, but does not injure the cambium ring; the cortical root sends down as far as the wood fresh sinkers which also absorb nourishment, and upward shoots through the bark into the air, and these, like the original sub-aërial shoots, ramify and become covered with foliage, and bear fruit. The haustoria elongating outwards like medullary rays become deeply imbedded in the wood of the host by the growth of the latter, and the older part of the cortical root gets gradually driven outwards by the growth of the bast until it is cut off by the formation of corky tissue within the bast, when it eventually falls off' with the older bark. The sinkers thus losing connection with the living mistletoe die inside the wood by which they are gradually surrounded. As they are formed of soft tissue, they soon decompose and eventually disappear, leaving a series of holes in the wood. 
This dying of the cortical root is quicker in the Scotch pine than in the silver-fir owing to the earlier formation of rhytidome or true bark in the former.

The portion of the host to which the mistletoe is attached generally swells owing to a supply of carbo-hydrates being absorbed by it, partly from the mistletoe. Where only a branch is attacked, the damage done to forest trees is not worth mentioning, but when this extends to the stem, the wood becomes

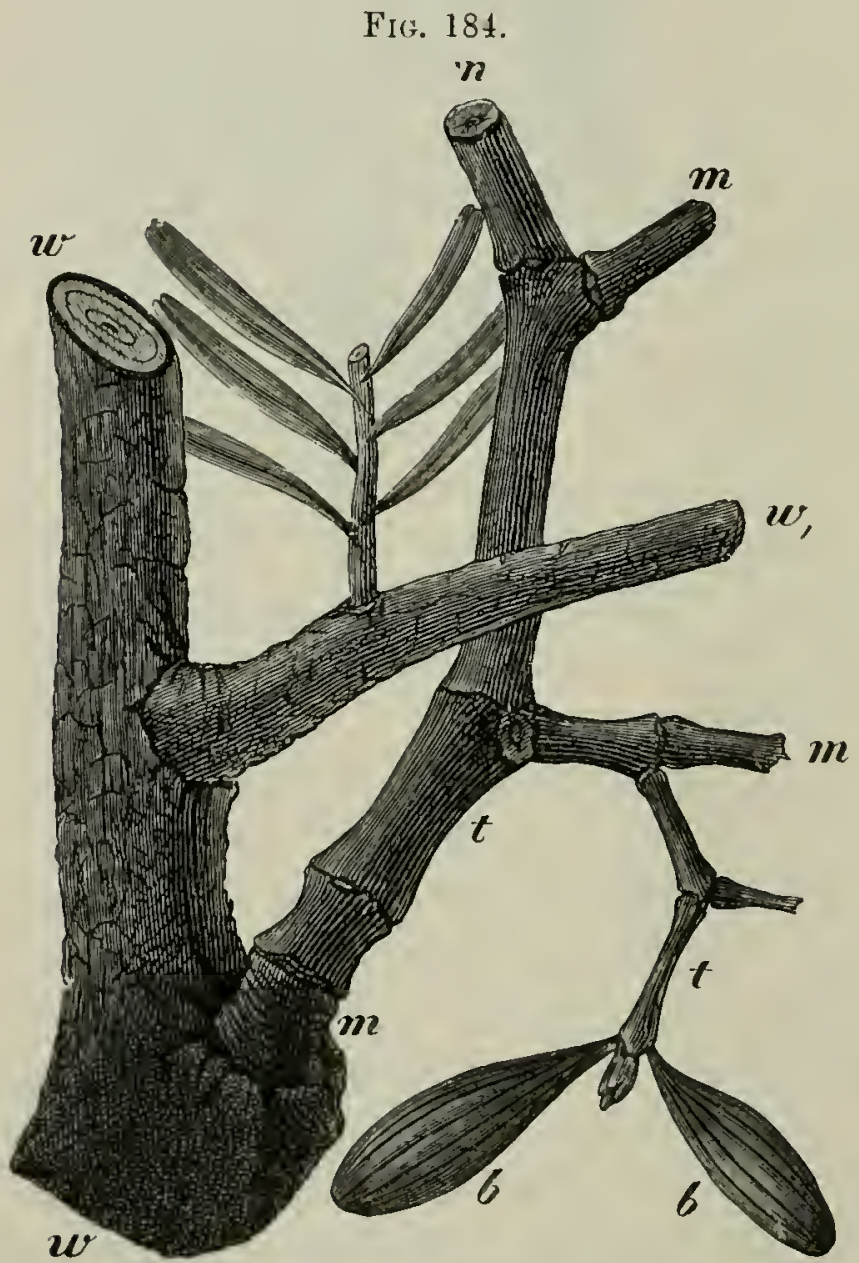

Silver-fir ( $v$ ) attacked by Mistletoe $(m) . \quad(t)$ Annual shoot (b) opposite leaves of latter. (Natural size.)
FIG. 185

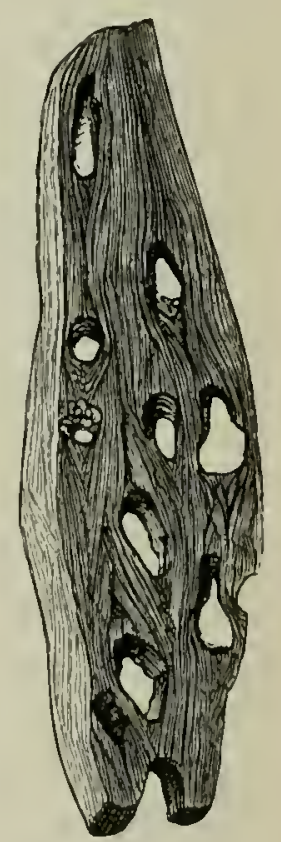

Silver-fir wood perforated by mistletoe, the haustoria of which have fallen out.

(Natural sizp.)

technically injured, being no longer suitable for timber, and is liable to be broken by the wind.

Extensive damage is thus sometimes done in old scotch pine and silver-fir forests, owing to neglect in removing infected trees in the thinnings; nearly every tree in a compartment may then be attacked by mistletoe. 
As a remedial measure, pruning off the mistletoe is no use, for the cortical root sends out new shoots, which break through the bark of the host and develop into new plants. The only radical plan is to prune off the whole infected branch and cover the wound with tar, or to cut down infected trees in the thinnings. For fruit trees, and in nurseries, the former method should be adopted.

Mistletoe makes good fodder for cattle, and for roe-deer in winter. Steamer loads of it are sent from Normandy to London for Christmas decorations.

(b) Loranthus europens, L.

This species chiefly attacks oaks, Quereus Cerris, L., Q. sessiliflora, Salisb., and less frequently $Q$. pedunculata, Ehrh., and Castanea rulgaris, Lam. It is found in Austria and Saxony, but not in the north of Europe, and chiefly on the branches of

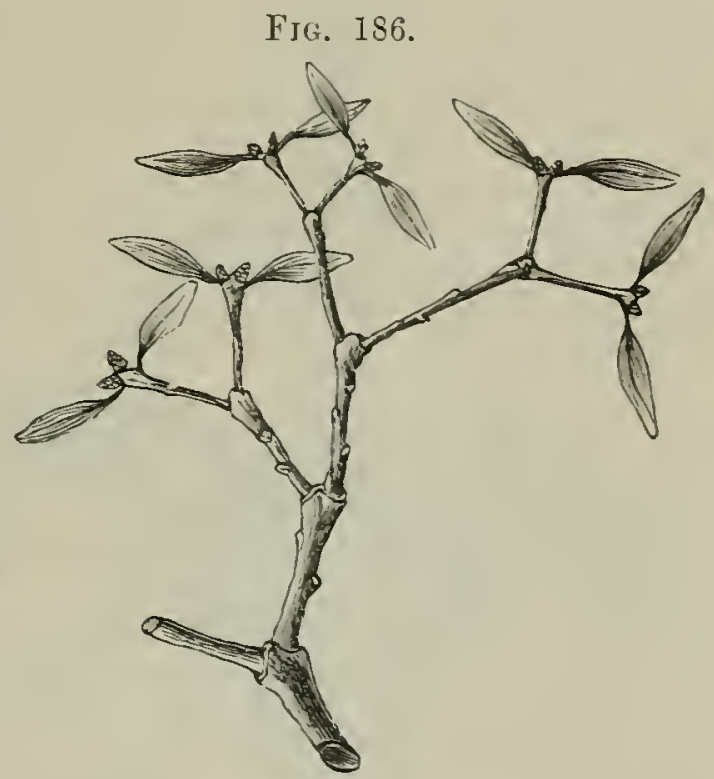

FIG. 187 .

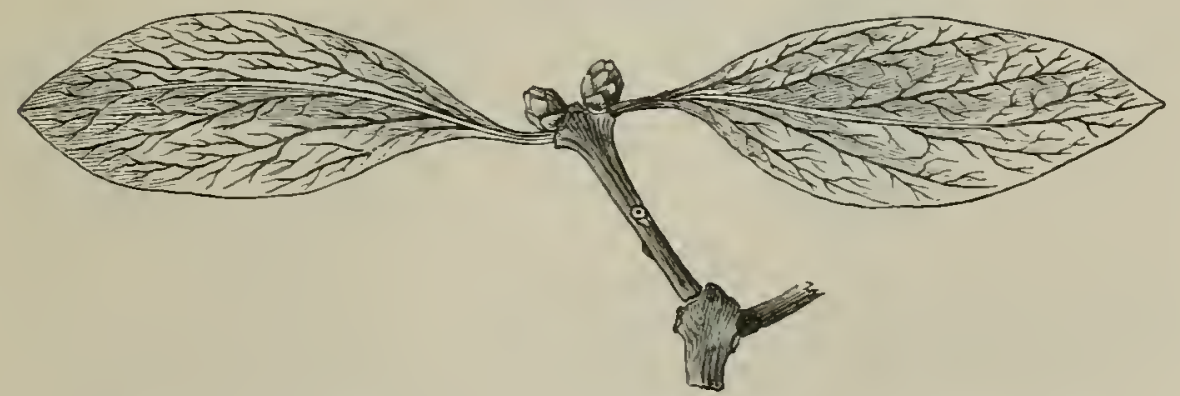

Loranthus europecus, Jacq. Fig. 186 reduced, fig. 187 natural size.

standards over coppice. The main difference between the growth of this parasite and mistletoe, besides its outrard appearance with bright yellow berries, is that the side shoots of the first hanstorium occur in the cambium and sapwood and not in the bast, and continue to grow parallel to the woody fibres of its host, sending out no sinkers. These shoots terminate in a wedge which looks as if it split the wood as it proceeds, but at the

roL. IV. 
commencement of their second season, they can no longer proceed except in the cambium, now further outward, and therefore grow from a new growing point above the old one; this occurs at the commencement of each season's growth, so that a series of wedge-shaped steps are produced in the sapwood of the host.

Places on the host where the parasite is exposed to the air

Fir(:. 188.

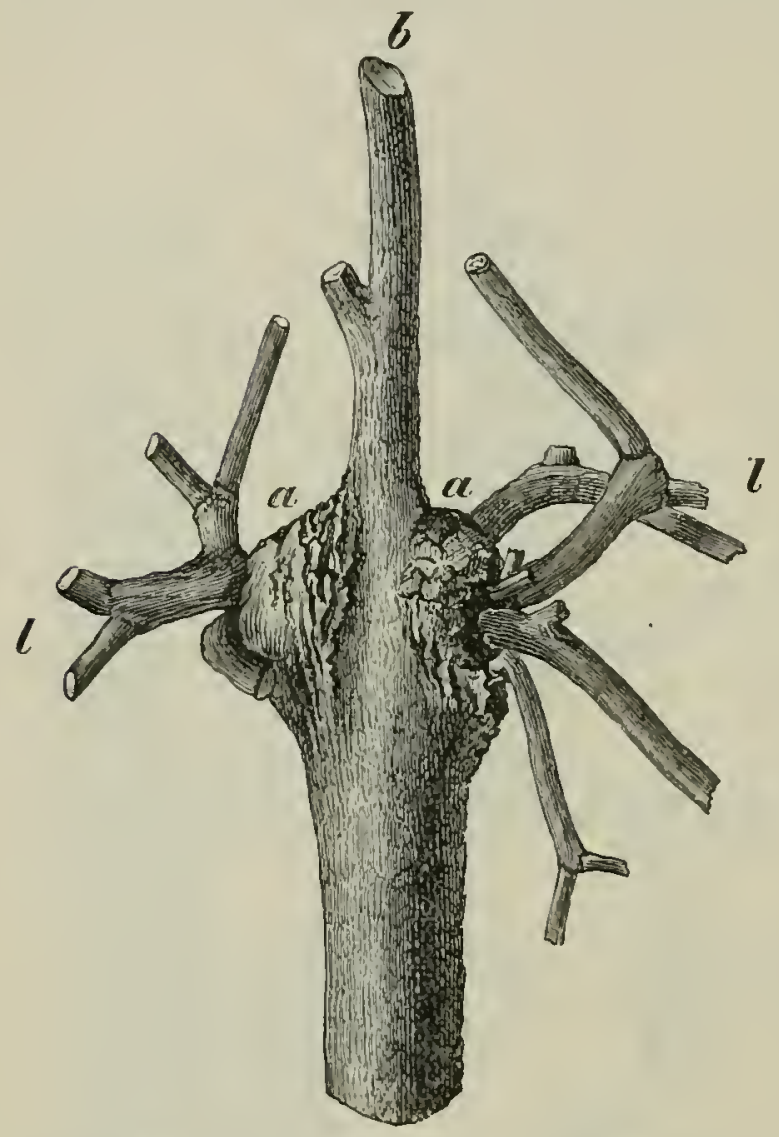

Qucreus cerris, L., with two Lorantlus parasites (l). (a) Swellings procluced by the parasites. (b) Stunted leader of the oak which will eventually die. swell up into masses as big as a man's head, whilst the branch of the host not only suffer's in growth, but frequently dies. The damage done is therefore greater than by the common mistletoe. The seeds are carried on to the trees by birds, and chiefly by the missel-thrush. The younger portions of the shoots of this parasite absorb from its host water, nitrogenous and mineral matter, while it partially nourishes the host with carbohydrates formed by its own aërial branches.

There are many species of Loranthus in

India, which grow on various species of forest trees; these they seriously injure, and infected trees should be cut ont in thinnings. Fortunately, infected trees are not generally found except along the borders of a forest.

(c) Dolder (Cuscuta, Touruef).

There are several species of Cuscuta, of which C. Epithymum, L., is the commonest in Britain, growing chiefly on furze, 
thyme, ling, \&c.; and also on clover and lucerne; whilst $C$. Epilinum, Weihe, chiefly grows on flax; and C. europea, L., on hops, nettles, vetches, \&c., and also on many trees and shrubs, such as hazel, willow, poplar and blackthorn.

The different species of dodder germinate in the ground, but speedily die unless they become attached to weeds or agricultural or forest plants, on which they climb and pierce down to their woody bundles by means of haustoria, or sucker-like roots.

The plants attacked by these parasites are killed or weakened, or bent down by the weight of the dodder, and much damage is thus done in India to young fruit- and avenue-trees.

Of European forest plants osier-willows suffer most, as an abnormal growth is produced at places where the haustoria have pierced the cortex of the host, thus rendering the osier's unfit for basket work.

In the case of agricultural crops, care should be taken to obtain seed free from dodder-seed, and where the dodder attacks osiers, the shoots with the dodder on them should be cut as deeply down as possible at the beginning of the blossoming period (end of June and beginning of July) and forthwith burned. This operation should be repeated in consecutive years, as seeds of the dodder may remain 2 and 3 years dormant in the ground. Hares spread the infection by swallowing the seeds and passing them undigested on to the ground.

As dodder spreads from forest plants and hedgerows, where it is very frequent, to crops, its destruction is urgent from motives of general utility.

\section{Forest weeds acting as Hosts for Injurious Fungi.}

The common barberry (Berberis vulgaris, L.) is a shrub widely spread over Europe, both in the lowlands and mountains generally along the edges of forests. It grows even on poor sandy soil, soon attains a height of 12 feet, and sends out its deep root-system in all directions. It is very hurtful as the host of wheat-rust (Puccinia graminis, Pers.), and should therefore never be used to form hedges.

Puccinia graminis forms yellow lines of sporangia on the B $\quad$ B 2 
blade of wheat and other grasses which afterwards become reddish-brown, and in this way the nourishment of the plants attacked is interfered with and the crop reduced. It lives alternately in the form known as Ecidium Bcrberidis, Pers., on the barberry, the spores of which falling on cereals and other grasses hibernate as $P$. graminis, the spores from which re-infect the barberry, and so on. Another form, P. coronata, which also forms a rust on cereals, and especially on oats, arises from Acidium Rhamni, forming golden yellow swellings on Rhamnus catharticus and R. Frangula, the two species of buckthorn already described.

Species of Senecio harbour Coleosporium Senecionis, Fr., which alternates in the form of Periderminm Pini acicola, Pers., a fungus attacking the needles of Scotch and other pines, and described further on. Species of Coleosporium growing on Enphrasia and Tussilago also produce pine-needle blister.

The aspen (Populus Tremula, L.) has its leaves infected with a fungus, Melampsora Tremule, so that its foliage may appear quite golden-yellow in August, and then rapidly fall. The sporophores of this fungus on aspen leaves eventually turn dark brown, hibernating on the fallen aspen leaves, and in the spring, the spores infect Scotch pine and larch with the fungi. The alternate forms, Cocoma pinitorqum, A. de Bary, and C.Laricis, R. Hrtg., will be described in the next chapter.

Vaccinium Vitis Idrea, L., acts as host to Melampsora (Calyptospora) Goeppertiana, Kühn, which, growing on the stem of this plant, develops spores infecting the needles of silver-fir with Ecidium columnare, Alb.

The forester should always look with suspicion on weeds or shrubs in his forests which may be infested with fungi, and if the injuriousness of these fungi to agricultural crops or forest or fruit-trees is proved, he should if possible eradicate the wild plants on which they first appear.

9. Classification of Forest Weeds according to their Powers of Injury to Forests.

Hess has classified forest weeds as very injurious, less, and least injurious. As the amount of harm that weeds occasion 
varies greatly with circumstances, it would appear to be sufficient to give the following list of the most injurious forest weeds.

Woody Plants.

Broom (To conifers).

Heather.

Brambles.

Mistletoe.

Loranthus.

Blackthorn.

Birch.

Forest Willows.

Honeysuckle.

Aspen.

Herbaceous Plants.

Grasses.

Bracken.

Sphagnum.

Dodder.

Bind-weed.

Epilobium.

And other tall weeds when growing in masses. 


\section{CHAPTER II.}

PROTECTION AGAINST FUNGI.

\section{Section I.-General Account.}

\section{Position of Fungi in the Tegetable World.}

Plants belonging to the lowest division of cryptogamous plants - which is termed 'Tluallophyta, and includes among other families bacteria and fungi-have at most only rudimentary differentiation into stems, leaves, and roots; and consist of cellular tissue which may, however, in certain cases become hardened.

Bacteria-termed also Schizomycetes, or fission-fungi, from their habit of constantly dividing to form new cells, are plants consisting of cells the diameter's of which are usually considerably less than $\frac{1}{30} \overline{0}$ of a millimetre. They are parasitic or saprophytic on organic substances, and under certain conditions may multiply enormously in the blood or digestive organs of men or animals, and cause highly infections diseases such as cholera, malaria, typhoid fever, \&c.

Marshall Ward has recently published some papers in the "Proceedings of the Royal Society" proving that sunlight is prejudicial to the growth of bacteria, which camnot therefore thrive on or in the young sub-aërial organs of plants; certain bacteria, however, according to Hartig, cause bulbs and potato tubers to rot, yet he states that the only disease in European trees hitherto ascertained to be dne to bacteria occurs in the case of I'inus halepensis, Mill.

By their presence in the soil, bactcria greatly assist regetation by decomposing and dissolving organic refuse, and the finct that a forest soil when exposed for some time to the action of the sun's rays becomes less fertile than when it is constantly 
sheltered by trees is in complete accordance with Ward's researches.

As already stated, bacteria, and certain fungi as well, also protect forests by killing insect pests in enormous numbers. The only thallophytes which cause serious injury to plants are therefore fungi, which are also devoid of chlorophyll, and therefore obtain their nutriment from other, dead or living organisms. In the former case they are termed saprophytes, and in the latter parasites. Another class of fungi obtaining its nourishment from humus, but becoming attached to and rendering abnormal the roots of many trees and shrubs, deserves notice. Fungi growing on the exterior of other plants may be termed epripleytic.

The number of known fungi is very great, over 5,000; here only those which affect the growth of forest plants will be considered.

2. Classification and Importance of Fungi from a Forest Point of Vieu.

(a) Saprophytic fungi.

As saprophytic fungi live on dead or dying organisms, they do not cause disease, but follow or accompany an already diseased condition of their hosts. Fortunately, the majority of known fungi belong to this class. Fungi which are saprophytic in certain cases, as Agaricus melleus on rotten stumps of beech and other broad-leaved trees, may be parasitic on other trees such as conifers.

\section{(b) Parasitic fungi.}

Parasitic fungi attack healthy plants, and either cause a sickly condition or actual death to their hosts. Some parasitic fungi subsequently become saprophytic in tissues which they have killed.

\section{(c) Epiphytic Fungi.}

Among these the family Tuberacei deserve mention as they sometimes form underground mycelia in soils rich in humus, and thus cover the roots of Cupulifere, conifers, willows, limes and other plants, to the exclusion or modification of their root- 
hairs. This altered root with its matted coating of mycelium receives the name mycortiza, and the fungus has the power of absorbing nutritive matter from the soil and conveying it to the roots of the host. These fungi * do not in any way injure the plants on which they grow, but feed them more richly than the plants can feed themselves by their own root-hairs in the absence of the fungi. Edible truffles belong to this family, and are commonly found in oak forests in the South of England and the more southern part of Europe.

The study of fungi should be followed as carefully by the forester as that of injurious insects, although the damage recognized as done to forests by insects is much greater than by fungi and the remedies against them are more effective, it being often difficult, if not impossible, to combat hurtful fungi. As, however, no remedy can be devised without studying the causes of diseases which break out among forest trees, the importance of the study of fungi injurious to our trees must be admitted. The forester should be able to say whether any fungus is the canse, or merely a consequence of a disease or injury; he must know how to observe phenomena in the forests, and should hand over the specimens he may collect to be examined by mycologists.

The treatment of the question here adopted is therefore purely from a forest point of view. The anatomy and physiology of fungi should be studied, and a knowledge of mycology is presupposed. A few remarlis on the life-history and distribution of fungi are, however, advisable, and a short account of the structure of fungi camnot be dispensed with.

\section{Mocle of Life of Fungi.}

Fungi are cellular plants without chlorophyll, and are either unicellular or formed of many branching elliptic cells, as in yeast, or of elongated cells termed hyphe with apical growth, which may remain undivided or become divided into cell-rows by septa, or transverse membranes.

They are best known and classified by the forms of their reproductive structures, which are generally sub-aërial, as in the common mushroom; but the mass of the hyphre grows and

\footnotetext{
* Sce Frank's Lehrbuch der Botanik, 1893.
} 
spreads through living or rotten wood, in humus, or other media, forming a collective growth termed a mycelium. The mycelia of fungi may consist merely of branching hyphæ, but large masses of mycelium are sometimes formed in hollows of rotten wood, as by Polyporus sulphureus, Fr.

The reproductive organs of fungi are often formed on special branches of the hyphre termed sporophores, certain cells of which produce myriads of isolated cells or spores, which on escaping into the air or soil are capable under suitable conditions of giving rise to new individual fungi. Spores may be produced either sexually, or asexually by division, the latter mode being by far the commoner, the spores thus formed being termed gonidia. For an account of the formation of sexual spores special boolss* may be consulted. Among them are certain thick-walled spores termed oospores, or resting spores, which are rich in nutriment and may remain dormant for prolonged periods, as in Phytophthora omnixora.

As a rule gonidia only remain for a few days in a condition fit to germinate and produce new individuals, but they appear in immense numbers in the air or soil, are of microscopic size, and are sometimes carried for miles by wind or water, or even by men and animals. The sexual spores are usually larger than the gonidia, better protected and richly provided with protoplasm, and in certain cases may remain alive up to 3 or 4 years. Gonidia and sexual spores germinate as soon as they meet with favourable conditions of temperature and moisture; it may be laid down as a general rule, that gonidia serve to reproduce the fungi in great numbers, while the resting spores carry on the species over winters or prolonged dry seasons. Fungi do not usually require the same amount of heat as the higher plants for their development, and their fructifying organs are usually most numerous in October. As already stated, they may be either saprophytic or parasitic, while some fungi are epiphytic, living on the epidermis of leaves or shoots, and merely piercing into it from time to time with delicate minute haustoria, or rootlike ramifications of the hyphr, which are devoid of any rootcap. The mycelia of parasitic fungi live on or in the tissues of

* Dr. K. Goebel's Ontlines of Classification of Special Morphology of Plants Translation by H. E. F. Garnsey, Oxford Clarendon Press, 1887. De Bary, Morplology and Physiology of Fungi, \&c., same translator and yublisher. 
living plants or animals, their spores gaining admission into the former through wounds, lenticels or bark-cracks, or through the stomata of leaves or young shoots, or the soft growing points of roots. There they germinate, and emit tender thin-walled, generally colourless hyphie, which, when very young are filled with protoplasm; but cell-sap or bubbles of air soon occupy part of their Immina, the protoplasm then merely lining the walls of the hyphr or dying away altogether. Oil may also be found in the hyphæ, especially when they pass through tissues of the host which are rich in reserve-material. This oil is frequently of a golden-yellow colour, as in many kinds of rusts on leaves or shoots.

The hyphi grow by their apices, and their terminal cells are always rich in protoplasm. In the case of parasitic fungi, the hyphæ may grow either in an intercellular manner between the tissue elements or in the resin-ducts and other intercellular spaces, merely sending their haustoria into the lumina of the tissue-elements, or, if the hypha are furnished at their apices with a ferment capable of decomposing the cell-walls, they themselves penetrate through the cell-walls of their host, and thus pass from one cell to another. As they proceed the younger cells of the hyphre procure protoplasm from the older cells, in which eventually nothing but air is left.

The walls of the hyphr are at first always soft and colourless, but when older they may be considerably thickened and coloured brown or greenish-blue, as in rotten spruce- or beech-wood. Sometimes the hyphre unite into compact bundles with hard walls, termed rhizomorphs, which resemble roots, and serve to carry the mycelia through ununtritious or dry media. These are very conspicnous in Agaricus melleus, L. Hyphre also sometimes unite into small tuber-like bodies termed sclerotia, which have thick cell-walls, and are richly supplied with protoplasm and oil, which, as in Rosellinia quercina, R. Hrtg., may remain for some time dormant and resist desiccation, but under farourable conditions develope new mycelia or sporophores.

In this way the mycelia of parasitic fungi live on the tissues and untritive material of their host, and interfere with its transpiration and assimilation; they also dissolve the cell-walls and their contents, often causing liypertrophy or excessive formation of cells, and chemical change in the cell-wall. In the 
latter case they cause the death of the host. Insects frequently attack trees which have become weakened by fungi. Eventually the fructifying organs, which are characteristic for each species of fungus, break out on leaves, twigs, bark or at the scars of dead branclies, sometimes through perforations made by barkbeetles, sometimes on the roots of the host, or on rhizomorphs, as in Agaricus melleus, L. Innumerable spores issue from the sporophores, some of which find suitable resting-places, and the fungus-life recommences in fresh hosts.

Most fungi are very transitory, and their life occupies only a few months or weeks. In the case of others the resting spores hibernate, and the mycelia of some fungi may live for two, three, or many years. Most of the destructive forest fungi have the latter character. The polymorphy which exists in the case of certain fungi requires an explanation here. From the spores of certain fungi the same form does not always appear, but sometimes one perfectly distinct, unlike the parent fungus and living on a different host; its spores may even produce a third form, though eventually the original fungus is reproduced. Thus many fungi, formerly considered as distinct species, are now recognised as being merely stages in the development of one species. The most highly organised of these stages, in the case of any species, is considered to be that which bears sexually fructifying organs or their equivalents. Fungi which thus grow in different forms on different hosts are termed heterccious; some, however, go through all their forms on the same host.

\section{Distribution of Fungi.}

The spread of fungi is favoured by certain conditions of the weather and locality. It depends chiefly on heat and moisture, light being prejudicial, many fungi growing in the interior of trees or in the ground. Fungi can flourish and become numerous only under suitable conditions, so that in damp years, and especially in damp sheltered localities, they thrive better than in dry years and exposed places. Thus, in a wet June, Cicoma pinitorquum is most destructive to pine trees.

Parasites attack not only weakly plants but the most flourishing individuals. The conditions which most favour their spreaddamp air and wet soil-are, however, unfavourable to many 
woody species, and injuries of any kind to trees favour fungus attacks. Wild plants, especially when growing in masses, are just as exposed to their ravages as cultivated plants. Conifer:e suffer more from fungi than broad-leaved species, because the latter recover more readily from damage.

The question, whether a fungus is the canse or consequence of a disease can be solved only by infecting a perfectly healthy plant with the spores of a fungus, and observing the results. The external circumstances which favour and hinder the development of the disease must also be noted. Such observations are troublesome and difficult, and demand great care and foresight to avoid deceptive conclusions. Much information has, however, already been obtained, and every year is adding to our knowledge of the subject.

A glance must be given over the species and modes of attack and the spread of a disease. In the case of diseases which are induced by certain conditions of soil and weather, the whole of a wood almost simultaneously shows symptoms of disease. An attack by fungi on the contrary is propagated by infection from one or a few individuals which are first attacked, and therefore starts from a centre, spreading generally in a centrifugal manner, like the fairy-lings in a meadow.

The next two sections give a list of the fungi which experience has shown to be injurious to forest trees, with a short description of their external appearance, the classes of woods and localities liable to be infected, and the distribution-areas of the fungi; also an account of the damage done and the means for combating it. For a full description of the pathology of each disease induced by fungi, reference is invited to the works of R. Hartig," on which these notes are chiefly founded.

It is best for the purpose of Forest Protection to distinguish fungi attacking coniferous from those attacking broad-leaved trees, and within each group according to the organ attacked (roots, stem, branches, needles or leares, or fruits).

\section{Section II.-Fungi attacking Conifers.}

The following is a table containing twenty-two species of fungi, the most destructive kinds being marked by an asterisk:-

* The Diseases of Forest Trees, R. Hartig. Translated by Somerville and Marshall Ward. Macmillan \& Co., London, 1894. 


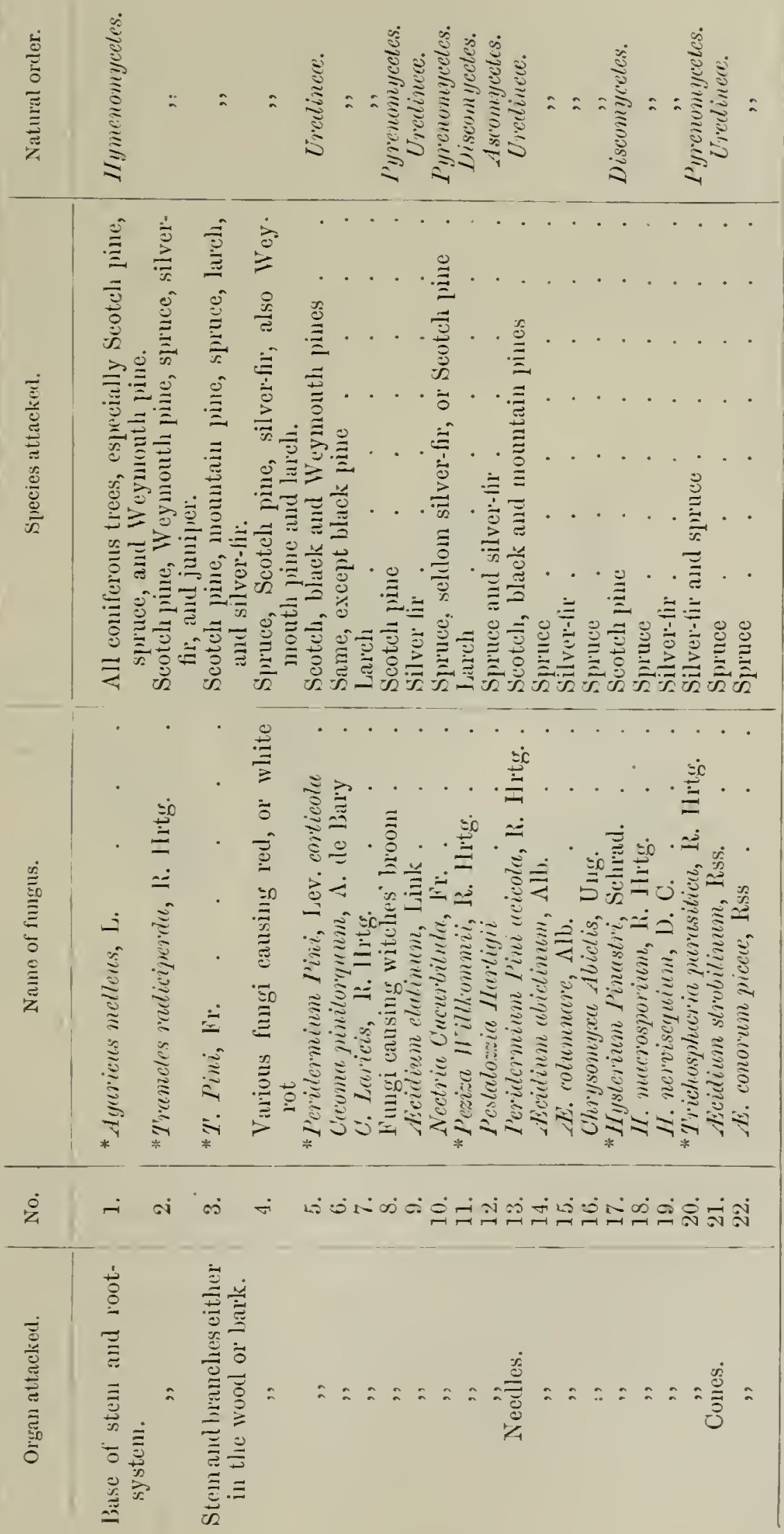


*1. Agaricus melleus, L.

(a) Description and Mode of Attacl.

The honey fungus (Agaricus melleus, L.), which is one of the commonest in the British Isles, causes a well-known disease amongst conifers. The symptoms are :- Yellow colour in the needles, which gradually dry up and fall; the shoots wilt; the base of the stem swells up and the bark peels off, whilst turpen-

FIG. 189.

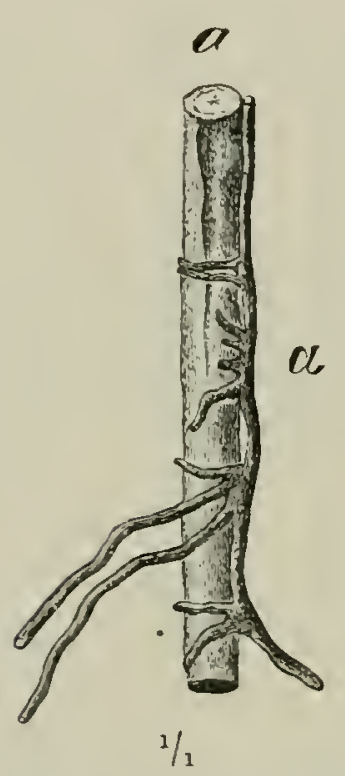

a Root of a Scotch pine killed by Ayarieus melleus, L. a Rhizomorph, external to root, which it bores at $\alpha$.
6

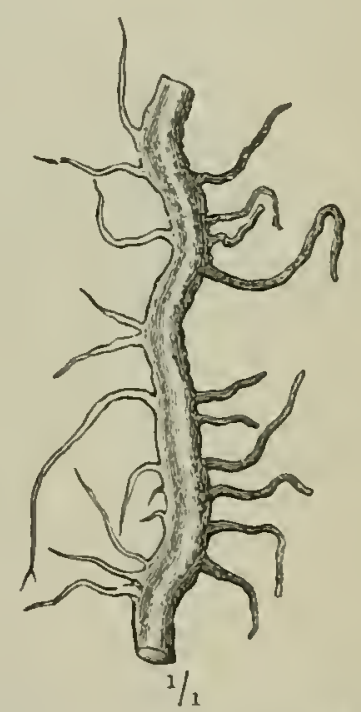

$b$ Flattened Rhizomorph passing between the dead wood and bast of a Scotch pine; its left-hand branches are white. and resemble ordinary mycelia.

tine exudes freely, clogging together the soil around the tree; the bark decays and fibrous fungoid tissues appear in the soil, seldom deeper than four inches, which are termed rhizomorphs. These latter are persistent mycelial hyphæ like sclerotic fibres, and resemble branching roots; they sometimes anastomose. White ribbon-like bands of mycelium are formed between the bast and sapwood and in hollows in the dead bark and bast, and often spread like a net; mycelial strands which pass into the soil from these white bands are round and dark-brown rhizomorphs, which may also develop between the wood and the cortex. 
Plants which have been attacked eventually die, and when young generally in the first year of the disease. If the dead plant be examined microscopically it will be found that the bast and cambium have been destroyed, the resin-ducts are full of hyphæ and enlarged and deprived of resin; fine hyphæ also proceed along medullary rays towards the centre of the tree. Starch is transformed into turpentine which flows from the tree.

The edible sporophores first come to light in great numbers during damp weather in October, at or near the base of the dead trees, and spring from the rhizomorphs.

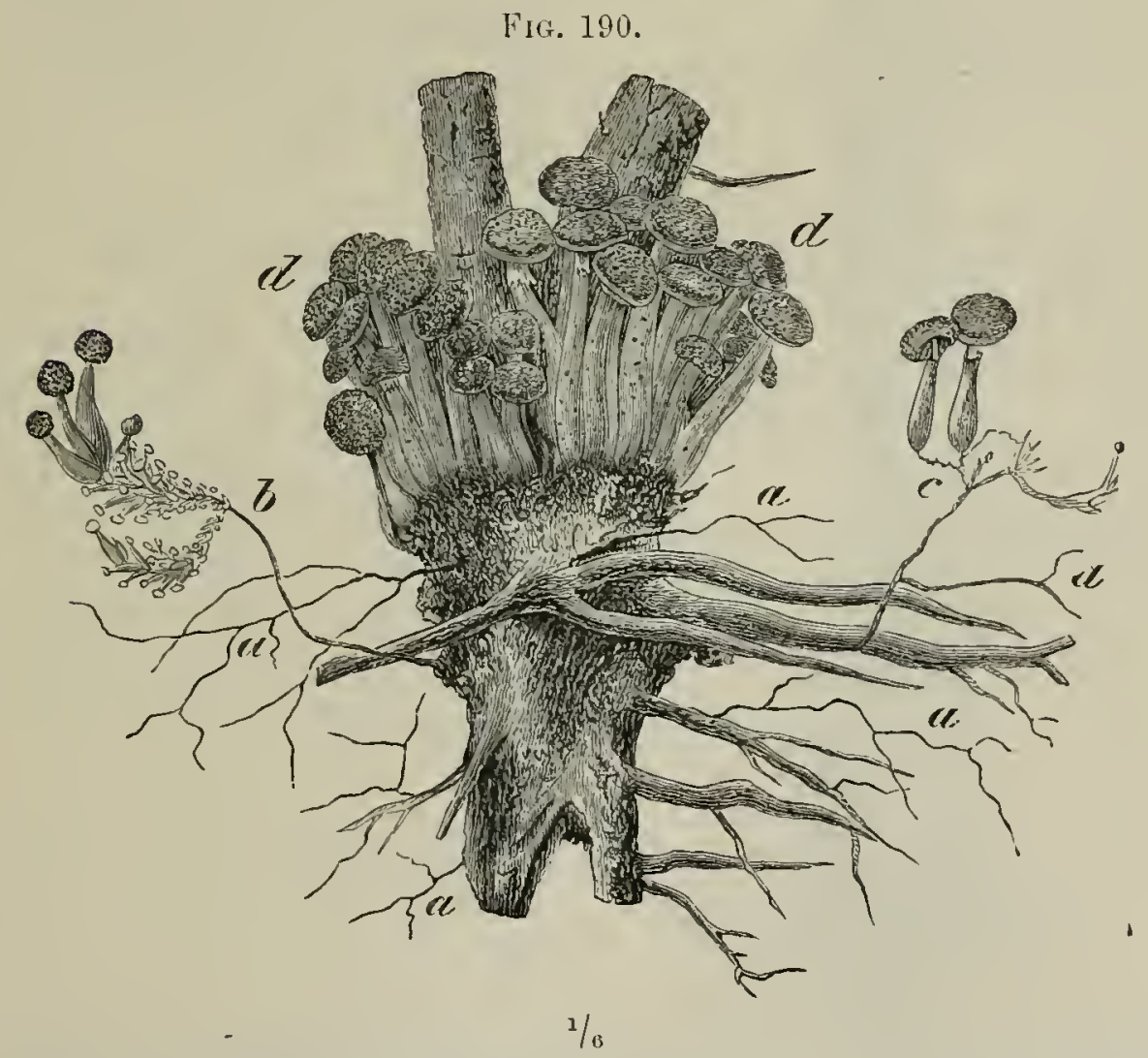

Fight-y ears-old Scotch pine killed by Agaricus melleus, L. a Sterile rhizomorphic strands. $b$ and $c$ fertile ditto; some of the sporophores are abortive. $d$ Sporophores springing from nuycelia under the bark. (Reduced.)

Fig. 191 represents a sporophore. Its cap varies in colour from that of honey to a dirty brown, with dark, hairy scales; its lamellæ are yellowish-white, and become later on speckled with reddish-brown. The cylindrical stem of the sporophore is at first dull red, and bears a flocky white ring. The sporophores emit myriads of white goniclia, which spread the infec- 
tion to other coniferous plants and to dead broad-leaved species, on which it is saprophytic.

The rhizomorphs grow in all directions through the soil, and

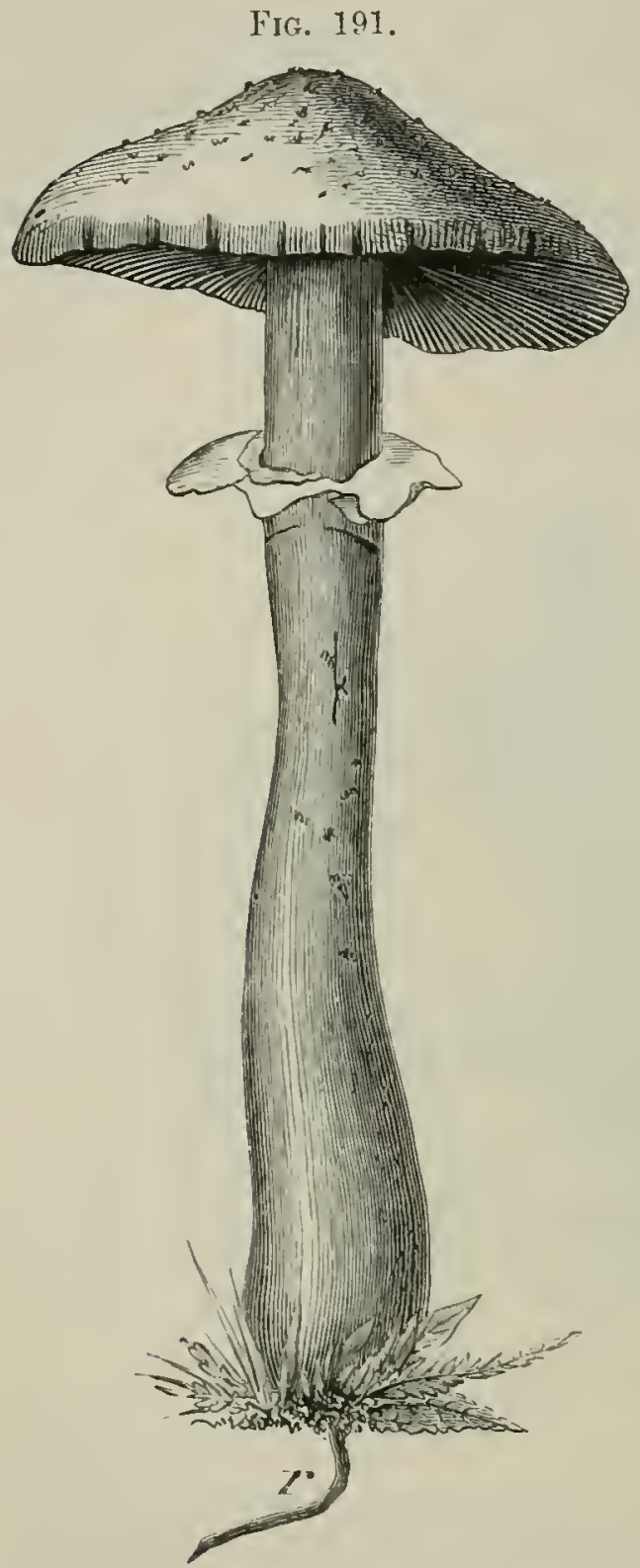

Fully-grown sporophore of Aguricus melleus. $r$ Rhizomorph. (Natural size.) by means of their soft apices bore into the roots of neighbouring plants and trees, which they eventually kill. In dense young growth, whole groups of plants may be thus killed and considerable blanks produced. In old woods, the attack is more confined to individual trees, and the disease spreads several feet up their stems.

(b) Subjects of Attacli.

The fungus attacks all indigenous or exotic conifers, especially the Scotch and Weymouth pines and the spruce; the larch not unfrequently suffers, but the black pime rarely. Plants may be attacked from four to a hundred years old, but especially between four and fifteen year's. In dense sowings and multiple plantings the disease is at its worst, especially when the wood was originally stocked with broadleaved trees on which the fungus is saprophytic, such as beech, oak, horubeam, birch, species of Pyrus and Prumus, * ic. The fungus also attacks timbers of bridges and other forest-works.

The stumps of broad-leaved trees left in the ground of a plantation form nurseries which propagate the fungus. Plants which

* A. melleus is said by Hartig to be sometimes parasitic on species of Prunus. 
are attacked generally die either between April and July, or from the middle of October to the end of November, and frequently the liealthiest and most flourishing plants succumb. It is difficult to recognise plants which are attacked until the year before ther die, when their needles turn pale and their shoots are stunted.

\section{(c) Protective Rules.}

(i) All stumps and roots of broad-leaved trees should be thoroughly extracted before plantations of conifers are established on the site of a broad-leaved rood, and where the disease has once appeared dense sowings of conifers and multiple planting should be avoided. When the disease shows itself-

(ii) All plants which are attacked must be dug up with all their roots and the rhizomorphs and burned. Should this produce a blank, the ground must be thoroughly trenched and all strands of rhizomorphs extracted before it is replanted, and then it is best to plant broad-leaved species.

(iii) Snall isolation-trenches should be dug round plants, or groups of plants which have been attacked, so as to localise the injury and prevent a further spread of the rhizomorphs. The trenches should be far enough from the attacked plants to exclude all rhizomorphs from the healthy trees.

\section{Trametes radiciperda, R. Hrtg.}

(a) Description and mode of Attack.

This parasite, which is very destructive in pine and spruce forests of North Germany, and is not uncommon in the British Isles, causes red- or root-rot in the Scotch pine, spruce and other conifers, and has been found on old stumps of birches and beech which have been injured by mice, although it is probably not parasitic on broad-leaved species. Trees attacked by it are eventually killed.

The infection usually comes from the diseased roots of a neighbouring tree, but also from gonidia. The colourless soft mycelium is more delicate than that of A. melleus, resembling VOL. IV. 
tissue paper, and is developed in the bast and rood of the root-system of trees. The walls of the bast and wood-cells are bored and disintegrated by numerous hyphre until the roots become totally rotten. The rot proceeds from an infected root upwards into the stem and from the collar downwards into the hitherto sound roots, only in the Scotch pine does the resinous root-stalk form an impediment to the ascent of the mycelium. In spruce-rood, the presence of this parasite is decidedly shown by the appearance of black spots surrounded by white colour in the spring-wood. Ontwardly the mycelium penetrates cracks in the bark, in the form of small yellowish-white tufts.

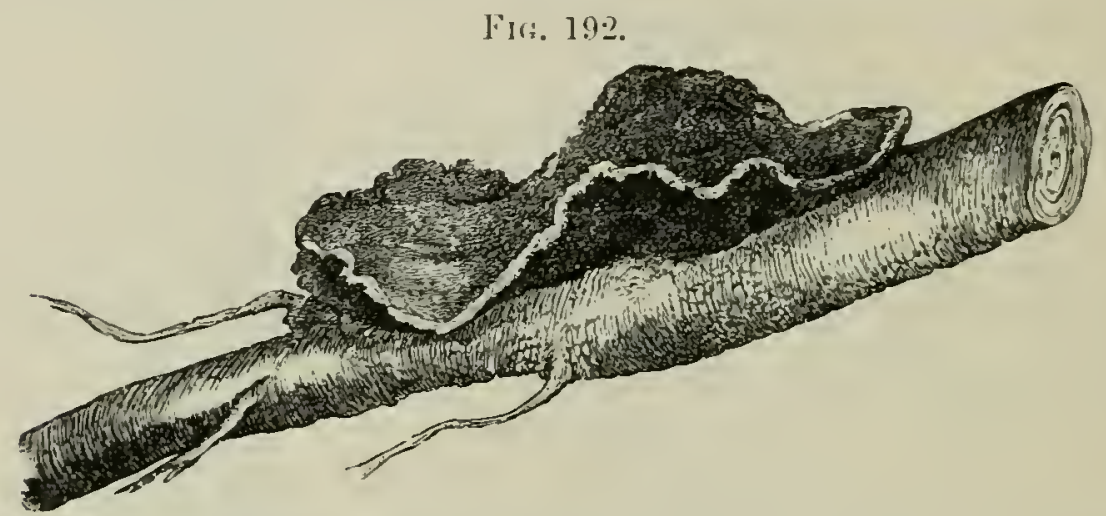

Sporophore of Trametes radiciperda, R. Hrtg., on a Scotch pine root. (Reduccel.

The sporophores are chiefly on the root-stalk, but also on the roots either in the form of incrustations or masses like yellow or snow-white grapes. Under favourable circumstances of growth they may assume the form of brackets.

The disease generally spreads ripidly, turning the rood first brown and then white and causing large hollows in it. By the artificial infection of six ten-year old Scotch pines, fire of them were lilled in a year and a half.

\section{(b) Subjects of Attacl.}

The fungus has been observed on the Scotch and Weymouth pines, the spruce, silver-fir and juniper, of all ages up to 90 year's, and on Scotch pine transplants from five years old. It may cause extensive blanks in coniferous woods, which spread centrifugally from a centre of infection. Its spread is favoured 
by mice and other animals which carry the spores in their fur. Trees which are attacked have pale needles and stunted shoots, as in the case of $A$. melleus.

\section{(c) Protective Rules.}

(i) Mixing broad-leared trees with conifers.

(ii) Remoral of all infected trees, as som as they are noticed, and filling up the gaps by broad-leared species.

(iii) Digging up and charring all roots which show traces of sporophores. Hess considers isolation-trenches of little use in this case, as they only farour the production of gonidia from the exposed hyphie. Hartig, however, considers it possible to scrape the walls of the trenches free from gonidia, though this could probably be done only in isolated cases of the disease. Isolation trenches will at any rate prevent the infection of lealthy trees by contact between their roots and those of diseased ones.

\section{*3. Trametes Pini, Fr.}

(a) Inescription and mode of Attacli.

The mycelium of this fungus develops in the heartrood of the Scotch pine and other trees. The spring-wood of the amnual zones becomes gradually reddish-brown, with numerous regularly distributed perforations coated with white, and at length disappears. The remainder of the wood, and especially the resinons autumu-rood remains intact for some time, but eventually succumbs so that the tree may become completely hollow. As the mycelium develops most rapidly length wise along the infected ring, we find zones of attacked and sound wood alternating and forming a kind of cup-shape. The rotting rood, except in the slightly resinous silver-fir and in spruce branches, is generally bordered by a zone rich in resin which prevents the outward spread of the mycelinm.

At the scars of dead branches in the case of an infected pinc or larch, or anywhere from the bark of a spruce or silver-fir, bracket-like brown sporophores eventually appear and emit spores which may germinate on fresh wounds, unclosed by resin, 
on other trees. Such wounds may be caused by wind- or snowbreakage, by mischief, or by careless pruning. The hyphre resulting from these spores pass along the branch-wood enclosed in the stem to the heart of the tree usually learing the sapwood unaffected.

This disease is commonest near villages and towns where forests are much exposed to mischief, and also in forests liable to wind-or snow-break.

FIG. 193.

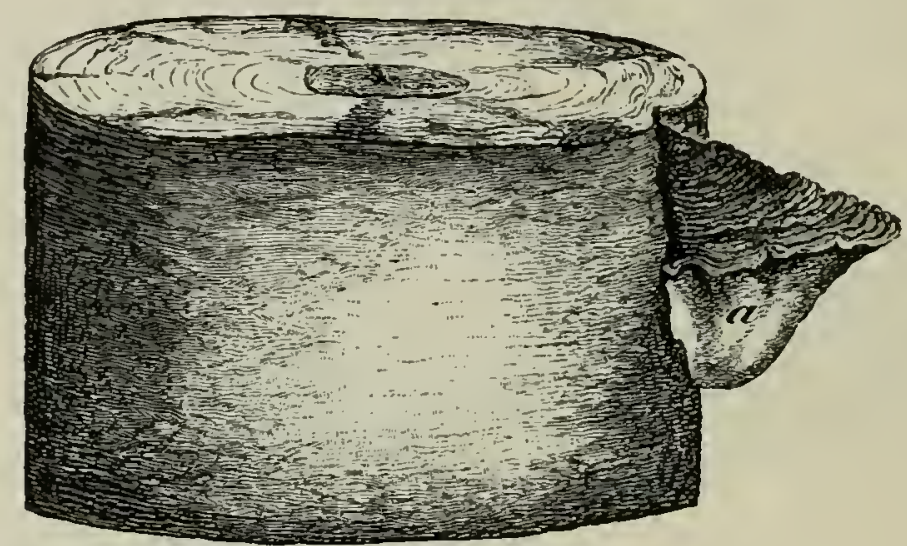

a Sporophore of Trametes pini, Fr., on the smooth cortex of a Scotsh pine.

(b) Suljects of Attack.

Trametes pini is prevalent on trees from forty years old and upwards, as it does not generally attack sapwood owing to its turpentine, and because wounds in young trees are usually soon closed with resin. It attacks the larch, spruce, and silver-fir, as well as the Scotch pine. In the silver-fir, decay spreads to the youngest woody zones which contain little turpentine.

The sporophores may become very old, up to sixty years, and attain large dimensions. The technical value of the wood is greatly impaired by the disease. The fungus is common in the Scotch pine forests of North Germany, and in the Harz and Thüringer-Wald and South Germany, chiefly on the spruce. In the Carpathians it attacks silver-fir and larch woods. It occurs in the British Isles.

(c) Protective Iilles.

(i) Pruning living branches of Scotch pines which already 
contain heartwood must be abandoned. Living branches may be pruned up to thirty years of age, as they contain no heartwood, and the infection is less liable to occur in young wood. In any case prunings should be clean cut with a saw, and, in the case of silver-fir, at once tarred over.

(ii) All infected trees should be removed during thinnings. In this way the sporophores may be destroyed and the spread of spores hindered; also wood of diseased trees may be utilized before the decay has gone too far, as it is at first frequently confined to the upper part of a tree.

\section{Fungi eausing Red- or White-Rot.}

A short account will here be given of certain fungi, which assist in causing red- $0 r^{\prime}$ white-rot in standing trees, the origin of which may however be due to certain bad conditions of the soil.

In the case of red-rot, the substance of the cell-wall is dissolved by a ferment contained in the protoplasm of the hypha of the fungi and a residual substance consisting of gum, tannin, mineral matter, \&c., remains, which owing to the oxidation of the tannin assumes a reddish-brown colour.

Recl-Rot is caused by the following fungi :-

\section{(a) Polyporus caporarius, Fr.}

On sprnce and Scotch pine and rarely on silver-fir, both roots and wounds above ground being attacked. Wood attacked by this fungus becomes dark-reddish brown and full of rectangular cracks, as in the case of Merulius lacrimans which causes dry rot in timber. When rubbed between the fingers, the rotting wood falls as a yellowish dust. Snow-white branching mycelia several yards long are formed; the sporophores form white incrustations. The spores gain entrance to the trees through wounds, and the fungus is also common on beams in buildings.

(b) Polyporus Schweinitzii, Hrtz.

This is termed P. mollis, Fr., by Hess, but Hartig has now given the correct name as above. It is found on Scotch pine, and also Weymouth pine and larch. Resembles (a), but no 
white branching mycelia occur. Sporophores reddish-brown brackets.

\section{(c) I'olyporus sulphureus, Fr.}

On the larch; it is also a very common parasite on several broad-leaved trees, and will be described further on.

White rot is produced when the ferment of the hyphre decompose the lignine of the cell-walls, leaving the white cellulose untouched, which accounts for the light colour of the decomposed wood. Some of the canses of white rot are the following :-

(d) I'olypurus borculis, Fr. On the spruce; the wood turns brownish-yellow, and characteristic radial grooves appear in the spring-rood which are filled with white mycelia, the latter having a strong tendency to spread lorizontally. The sporophores are ammal, bracket-shaped and frequently in tiers.

(e) I'olyporus ILartigii, All., named L'. fullels, Scop. by Hess, but corrected by Hartig. It produces white-rot in the silverfir and rirely in the spruce. It is frequently associated with silver-fir canker, described further on, its spores entering the wood by the cracks in the cankerous swelling. The wood becomes yellowish, and if clean-cut, appears intersected by numerous white longitndinal bands. Narrow dark lines appear at the junction between the sonnd and rotting wool. The mycelinm is yellowish, at first growing strongly but becomes later on very tine. The bracket-like sporophores are yellowishbrown above, ashy-grey below and almost smooth. $\dagger$

The best preventative of L?. Inrtigii is to fell cankered silverfir in thimings. ${ }^{+}$

\section{\%. Periderminm I'ini, Lev. rar. contirola.}

(a) Irescription and Life-histury.

Scotch pines infested with this disease, which is very common in the British Isles and called pine-blister, are termed foxy trees by English forester's.

The disease may be recognized by the compressed orangeyellow coloured little tufts of the acidia, or sporophores, which

+ For it further aceolint of red and white rot, see p. 564, et seq. 
break through the bark of branches and stems of the Scotch pine in June, and eventually burst and set free their spores. As a rule, only bark infected in the previous year produces recidia. The mycelium of the fungus grows perennially in the bark, bast and medullary rays of its host, and through the latter may penetrate into the wood to a depth of a hand.

The mycelium converts the starch in the wood-cells into turpentine which becomes infused in the tissues, and cuts off the supply of sap. Erery year it spreads chiefly longitudinally from the diseased to the sound wood, so that the canker which is covered with resin constantly increases in size. The sap being coufined to the sound portions of the rood, produces abnormally large annual zones on the side of the tree away from the canker, and when the infection has gone nearly round the tree, its crown dies above the point of attack, sometimes within a year, but in other cases a long period up to sixty or seventy years may elapse before the crown is killed.

Hot dry summers accelerate the death of the crowns of infected trees, as the wood surcharged with resin cannot pass on enough water to sup-

FIG, 194.

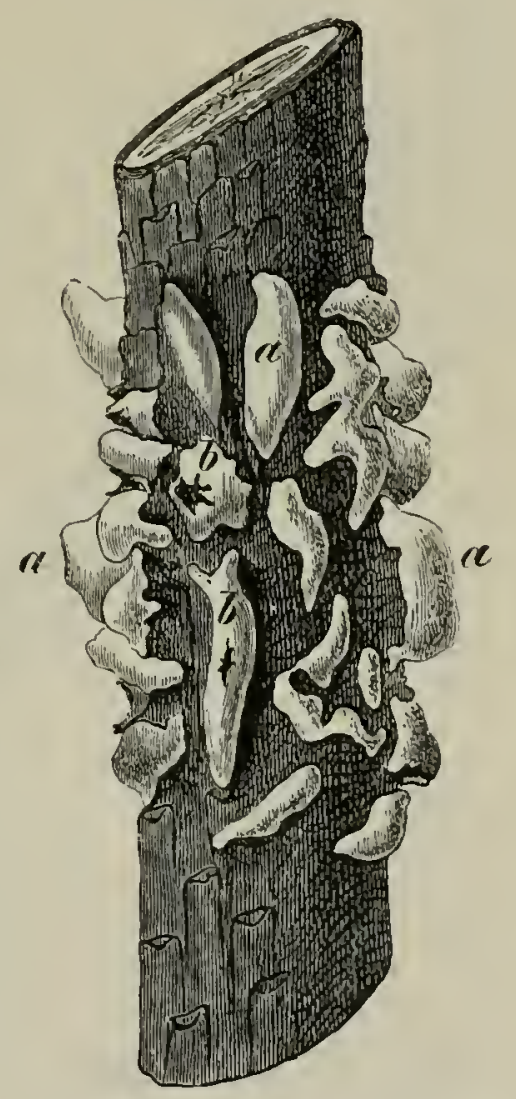

Acidium pini, Pers. (corticola), on a 5-year-old shoot of a mountain pine. The sporophores are closed (c), or have already burst (b). (Natural sisc.) ply the loss by transpiration. Although the summit of the tree is dead, the lower part of it may continue to live, provided there are enough living branches below the canker to nourish the tree.

Whether or not infection must always proceed from a wound in the cortex of the tree is as yet undetermined. Parts of the stem older than 20 to 25 years appear incapable of being infected.

The alteruate host of this fungus is not yet known, but an allied fungus, Peridrminm Commi, which causes a somewhat 
similar attack on Scotch pines, has an alternate form, Cionurtium asclepiarl'um on Asclepius rincetoxicum. I'. Stroli attacks Weymouth pine, its alternate form being Cron.mbicolum.

\section{(b) Suljigets of Attack.}

Scotch pines of all ages are attacked by pine-blister, but preferentially 15 to 20 year's old poles. It only attacks organs two or more years old, and is commonly found at verticils of branches and in the crown of the tree. It has often been observed in mixed forests of pine with beech or hornbeam, where the branches of the broad-leared species, swayed by the wind, have rubbed off the bark of the pines.

The disease is well known all over Europe west of Poland.

\section{(c) Protectice Measures.}

Fell infected pines as soon as the disease is noticed.

\section{Croma pinitorquum, A. de Bary.}

\section{(a) Description and Life-history.}

This fungus is dereloped, especially in North Germany, in the cortex of the roung shoots of the Scotch pine. Before they hare attained their full length, at the end of May or beginning of June, long rellow sporophores of the fungus appear, which eventually turn reddish-yellow, and become raised like cushions until the epidermis of the host splits and so allows the dissemination of the spores, whilst turpentine exudes from the split. As the growth of the pine-skoot is checked at the split, but goes on normally elsewhere, the infected part becomes concare, and the healthy part bends orer it. If the attack is slight the sickly place may heal orer, and the branches recover their erect position. Often, howerer, splits follow one another so frequently that the shoots become twisted in various directions. At length it may happen that the bark is attacked all round the shoot, the supply of water is then cut off, the needles turn yellow, and the shoot dies towards the end of June or in July, hanging down as if it were frozen.

The plant, by sending out sereral side-shoots at the base of 
FIG. 195.
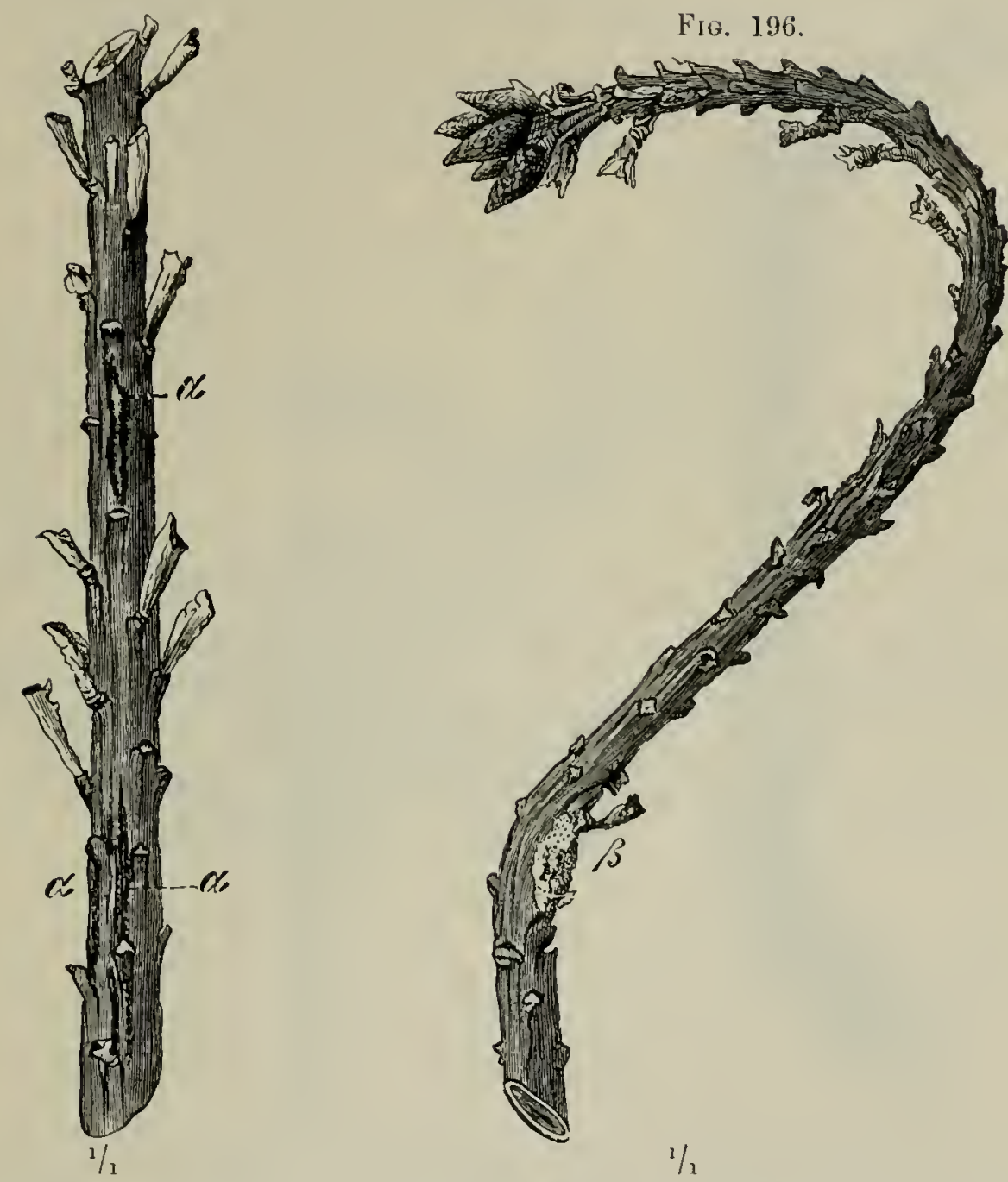

Spring shoots of Scotch pine attacked by Ceoma pinitorquum, De Bary.

Part of shoot in middle of June with sporophores $(\alpha)$.
Entire shoot $(\beta)$ exuding resin. The needles lave been pulled off.

the lost leader, endeavours to replace it; but these shoots usually become infected in succeeding years. The mycelium of the fungus grows in the green cortex and becomes perennial in a plant which is once attacked, while sporophores annually appear in the spring-shoots, except in very dry springs. The infected wood becomes brown down to its pith.

This fungus alternates as Melampsora Tremule on the leaves of the aspen, which produces resting-spores or teleutospores; these hibernate on the dead aspen leaves, and produce promycelia in the spring from which spores develop, which then infect young pines. 
Fig. 127

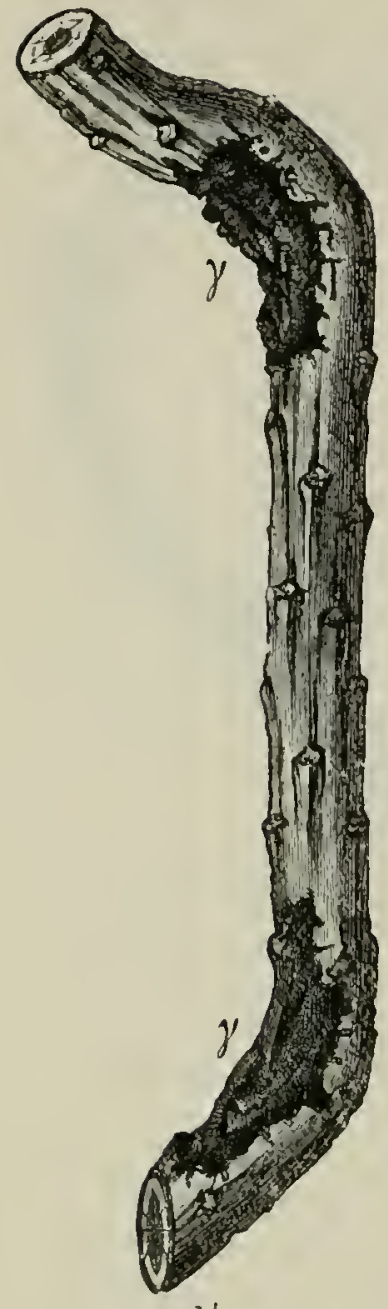

liart of it $2-$-reatr-old shoot, bent at y iwing te the wouncls cansed by Came.

Fig. 198.

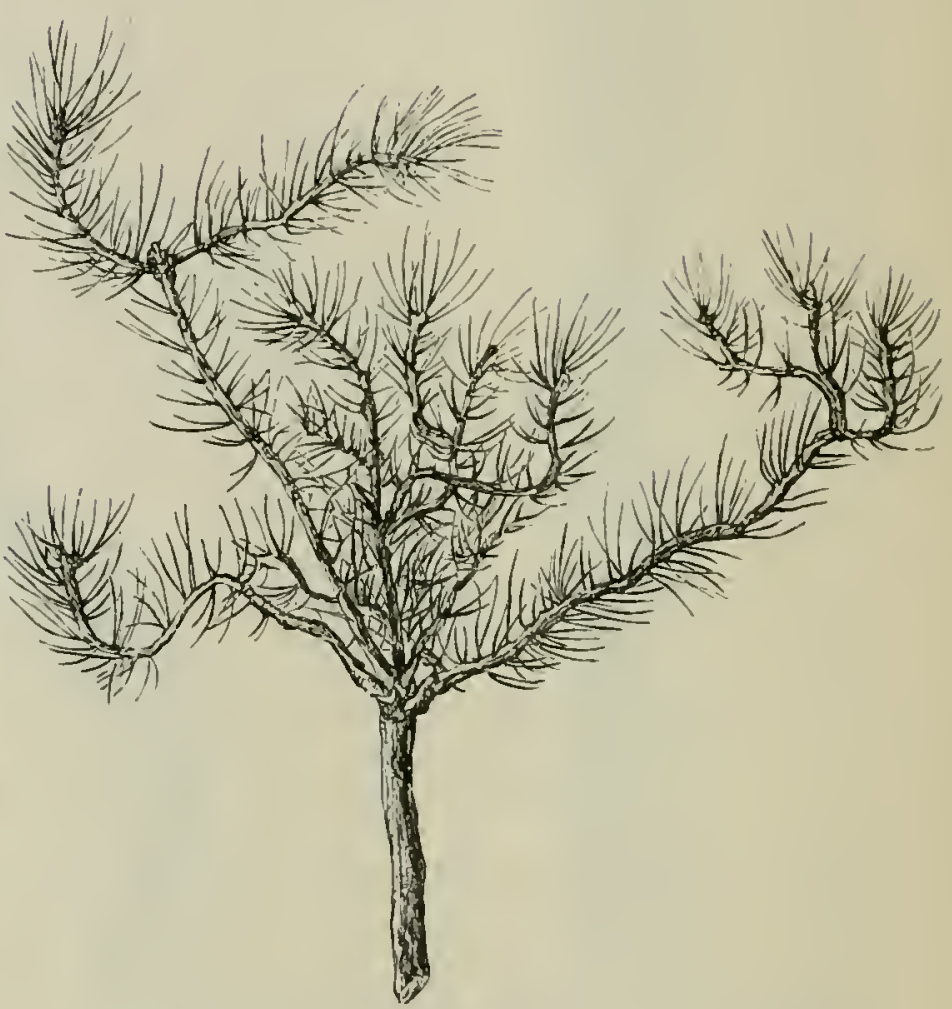

Cripuled condition of a scotch pine shoet which luas been attacked by deoma for several successive rears. (liednecel.)

(b) Subjects of Attreli, and Distribution.

This fungus chiefly attacks young - 1 to 10 rear's old-Scotch pine, also Weymouth and mountain pines, but never trees over 30 years old; it is most frequent on damp soils, and in cold. moist summers. The exemption of older pines from the attacks of this fungus is probably due to the fact that the snores proceed from dear aspen leaves lying on the ground.

One to three years-old cultivations of pines may be entirely destroyed by it, the disease spreading centrifugally from a centre of infection; and in older woods, especially after $\leadsto$ snccession of rainy years. such misshapen stems may be formed that the 
marks of the damage always remain patent; the development of the malady is however retarded by dry weather, and the disease disappears about the thirteenth year. This disease is known all over Germany, especially in the north, and did great damage between 1870 and 1873 .

\section{(c) Protertice Measures.}

Careful choice should be made of suitable localities for growing Scotch pine.

Immediate pruming and burning of infected shoots should be effected.

Remove aspen from pine woods.

\section{Creoma Laricis, R. Hrtg.}

Melampsora 'Tremule also gives rise to the larch needle-rust, which may destroy all the needles of a tree. It resembles the attack of Chermes laricis, and may thus be overlooked.

Aspens should not be allowed to grow near larch plantations.

\section{Fungi causing Witches'-broom.*}

Certain unknown fungi cause witches'-broom in the Scotch pine, witches'-broom being an abnormal hypertroplyy of twigs also appearing on spruce, silver-fir, pines, larch, beech, horn-beam, cherry, birch, dc. Most witches'-brooms appear to be caused by fungi, but perhaps they may be sometimes due to insect attacks.

The mycelia of the above develop in the cortex of branches, which swell up at the points of infection; thence they pass into all newly-developed twigs and into the needles, the latter remain abnormally short, become pale and die, and pale brown sporophores issue from their stomata and emit gonidia.

\section{Ecidium elatinum, Link.†}

(a) Description and Life-history.

This fungus causes the well-known silver-fir canker and witches'-broom. 'The latter may be distinguished from normal

* Hexenbesen der Kiefer Allg. Forst 11. Jyd. 2tg., 1871, 1. 236. 'The witches'broom on the hornbean is caused by Exoascus Carpini, Rostr., that on the cherry and almond-tree by $E$. deformans, Berk., on the birch by E. turgidus. These witches'-brooms, as well as those on the Scotch pine, do not appear to be ver'y prejudicial to their hosts, that on silver-fir is described uncler next lieading.

† Der Weisstannenkrebs, Dr. Karl N. Heck. Berlin, Springer, 1894. 
shoots of silver-fir by its erect brush-like growth, resemblingr the parasitic growth of mistletoe, on the drooping branches of the fir, and by the small yellowish-green needles growing all round the shoot, which fall off in their first autumn. There is also a slight swelling of the affected shoot, and in it the mycelium of the fungus grows in the cortex and bast of the host, passing into the younger shoots and needles till the witches'broom dies, the mycelinm still living in the cortex of the cankerous swelling, but apparently not in the wood. It does not grow down through the cortex of an infected branch into the stem, but a stem-canker is produced when the stem grows over the infected base of a branch.

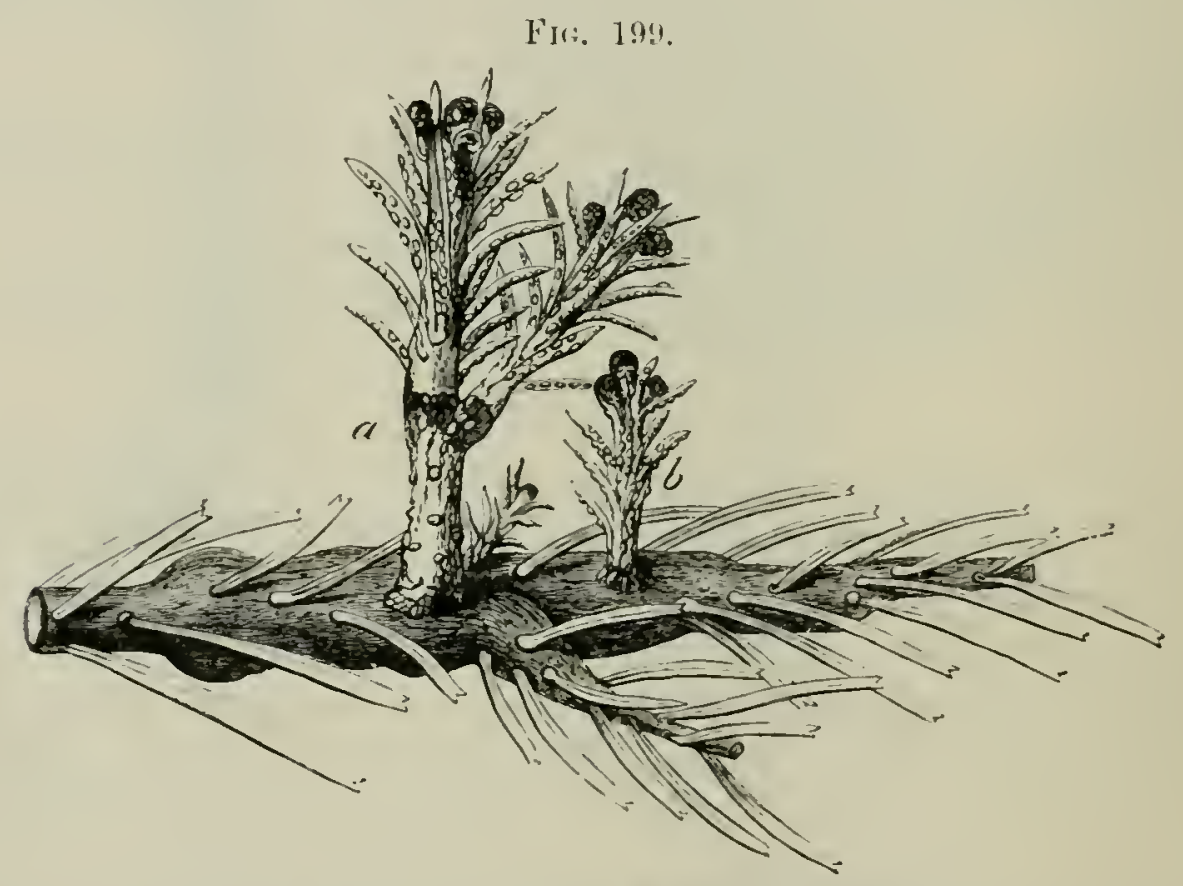

Shoot of Silver-fir attackel by . Feillum clatimm, Link.

"Cankerous swelling. I Needles unaffected by the fungus. "Teclles of the witches'-hroom. (Natural size.) After Hartig, from Proe. uf Royal Soc., Fol. 47.

The canker may be distinguished externally by a swelling either on one side of, or all round the stem, on which the bark is deeply cracked and dark brown, showing here and there a little resin; it crumbles away in parts, exposing the wook. It may be found at any height on young or old trees or their branches. and may attain a large size. The mycelinm which grows in the cortical parenchyma is the same as that which produces a witches'-broom, but the latter is formed only when the mycelium reaches a living hod. If, however, the shoots are old and have no living buds, no abnormal shoot-production takes vlace, and the canker alone is 
formed. The infection appears to spring from a wound in the shoots affected.

The old or orma-colomred recidia or sporophores are formed Fli: 200.
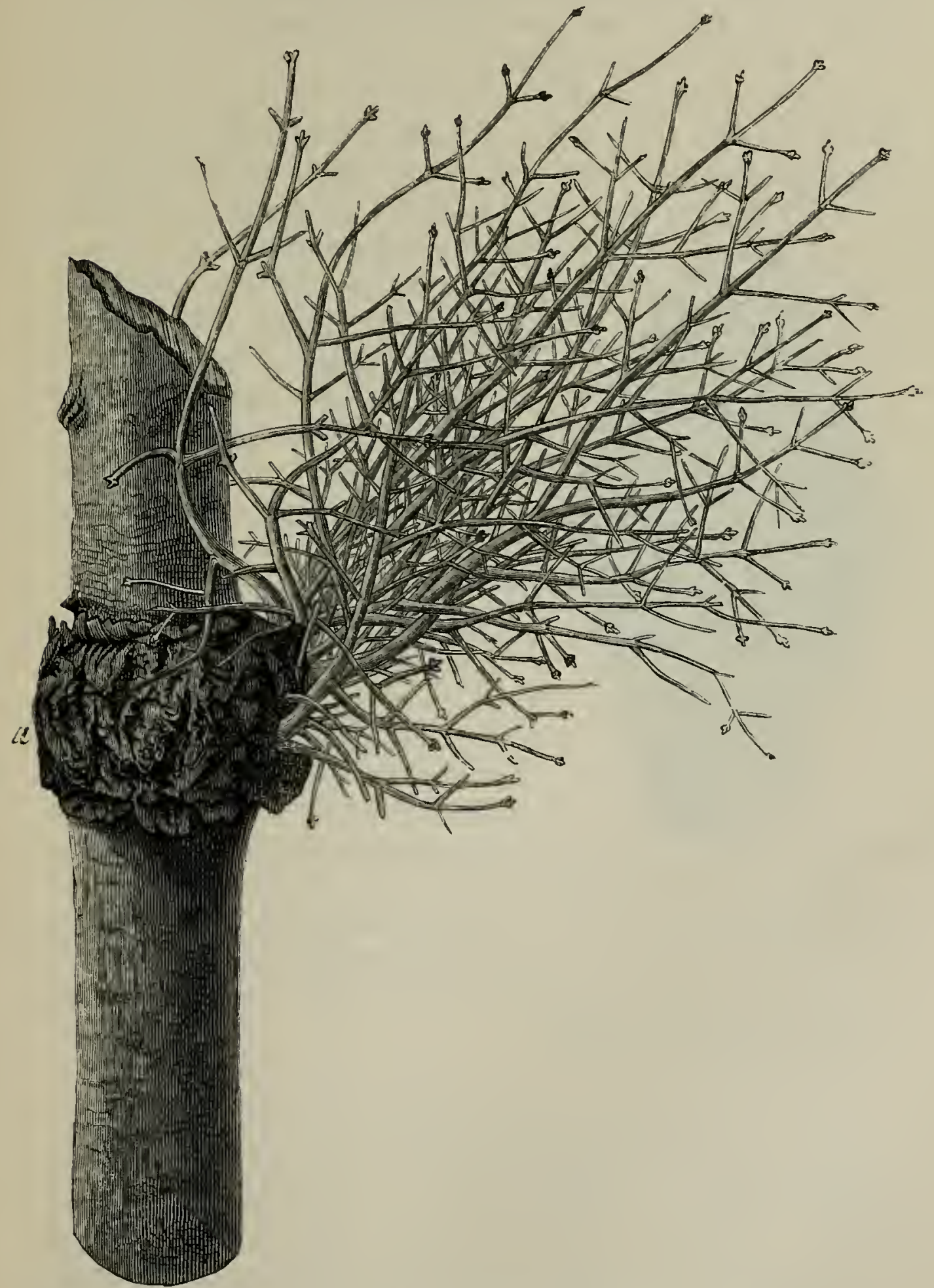

Old witches'-broom on the Silver-fir. "Cankerous swelling cansed by the mycelinm of the fungus. 
on the under surface of the diseased leaves. They appear in two rows, open-out and emit their spores in June, the needles subsequently dying. The witches'-broom continues growing for about 20 years, chiefly upwards, and branching freely resembles a mistletoe plant on the usually horizontal branches of a silverfir. It at length dies, and only the canker remains, which does not produce any sporophore. Hartig has not yet succeeded in infecting a tree artificially by the spores of this fungus, and a case of polymorplyy may be concerned here, but the alternate

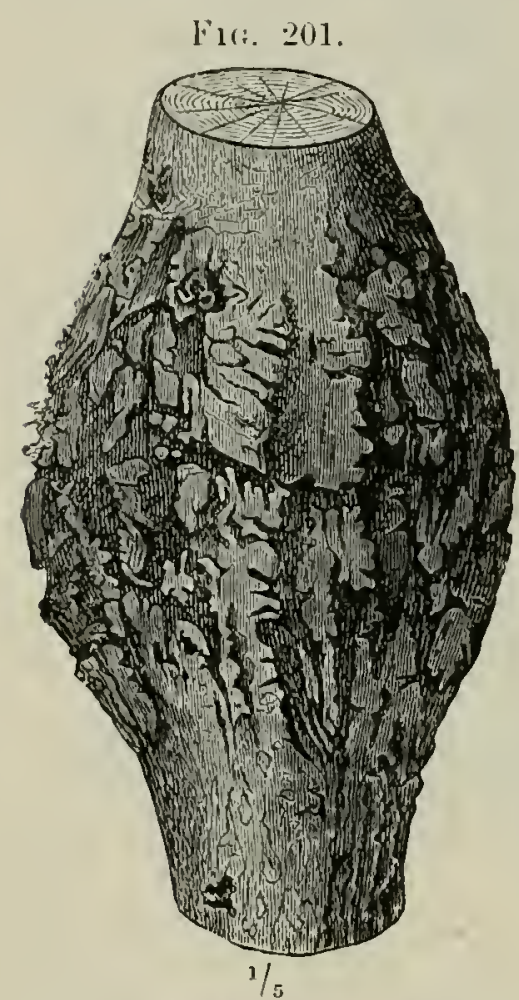

Canker on a Silver-fir ahout 45 years old caused hy Ecirlium clatinum, Link. host of the fungus, if one should exist, is not yet known.

The damage done is direct and incliret, the former consisting in loss of increment and depreciation of the quality of the wood, as cankered wood camnot, be used for constructions. The indirect damage consists in increased danger of brealiage by storms or snow, and a greater disposition to insect attacks and those of other fungi, such as Polyporns Iravtigii and Agaricus adiposus, which render the wood rery britile. A practical distinction is made between sound and diseased cankers; sound cankerous trees yield some pieces of good timber, but badly cankered trees are only fit for fuel.

Several cankers may be sometimes seen on the same tree, and cankered trees may die outright in hot summers. The canker may live for 50 years and longer.

\section{(b) Suljects of Attack: and Distribution.}

The disease is everywhere widespread in silver-fir* forests, and especially in the Black Forest. It is common in Windsor Forest. Cankerous stems are found on every soil and locality, but the disease is less prevalent on sandy soils and at high

\footnotetext{
* Also attreks Abies Pichte, A. lalsamer, Nordmamiana and Pinsapo.
} 
altitudes than on loam or in or near the plains, where the progress of the disease is more rapid.

The damage in old woods is greater than in roung ones on account of the increase in value of the trees, and in pure high forests than in mixed selection-forests.

\section{(c) I'rotectice Rules.}

Mix other species with the silver-fir.

Prune off the witches'-brooms, which chiefly appear on roung trees, by sawing off infected brauches close to the stem before the spores are dispersed, and tarring the wounds.

Remore cankerous stems in thinnings and preparatory fellings, and transport them speedily from the forest. Eren dominating cankerous trees should be remored, and dominated trees left to replace them.

Old roods full of cankerous trees should be felled before the prescribed period. 'The group-system practised in Baden allows this to be done, and it is the most effective remedr.

\section{Nertria Cucubitula, Fr.}

\section{(a) Firternal Structure and Life-history.}

This fungus produces the spruce-bark disease, and more rarely attacks the silver-fir, Scotch pine, ic. Its external symptoms are :-Pale colouring of the needles, the bark and bast turning brown and dring up, generally after insect attacks, and less frequently after rounds from hail or other canses. Numerons little red, glerlin-like sporophores appear in the bark, which may rum into one another like felt. Gonidia issue from them from late in the autumn till the spring, and infect surrounding plants through any wounds they may have, and spread the disease.

The branching mycelium grows chiefly in the sieve-tubes of the soft bast and the intercellular spaces between them. The growth of the fungus is very rapid, but appears to proceed chiefly in the season of rest of the bark-tissues, not in that of their vegetation. When the fungus has spread all round the stem the tree dies, or at least that part of it which is above the point of attack. If, lowever, the diseased tree can retain any sound bark on one side till the ensuing spring, it is saved, for it 
protects itself by producing a corky sheath between the sound and diseased part, which stops the further progress of the fungus. The dead bark is then thrown off, and the cankerous place grown over.

(b) Subjects of Attack, and Distribution.

The fungus appears chiefly on young spruce from three to

FIG. 202.

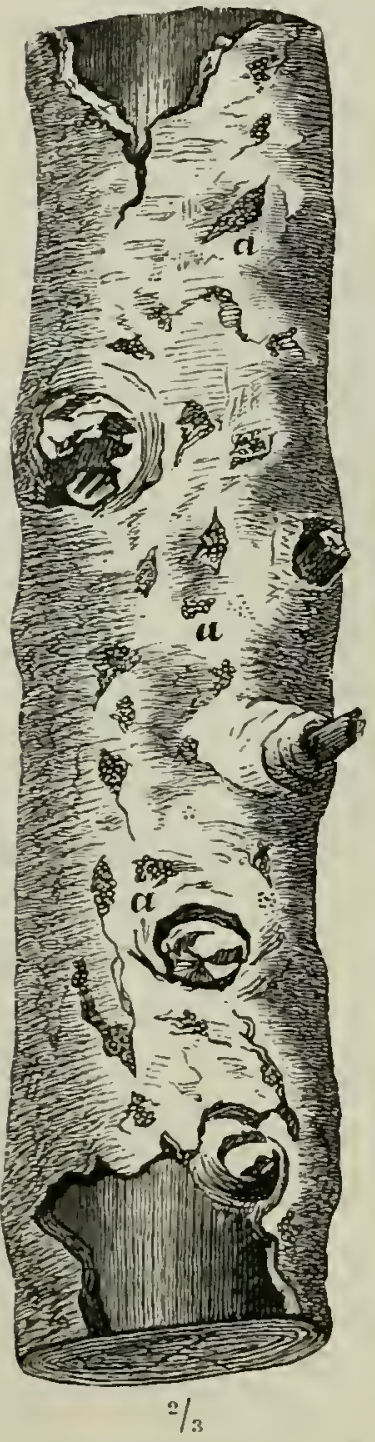

Spruee attacked l,y Nectrice cucurbitula, Hr. a Clusters of sporophores on the dead bark. thirteen feet in height, and both in pure spruce woods and in mixtures of spruce and beech. It is rery common in frosty localities. The gonidia can find admission to the tissues only through external wounds, which are therefore extremely dangerons in localities where the fungus is present. Badly-growing plants are the more subject to its attacks, as injuries by insects or hail heal up less readily than in the case of rigorous plants, and are therefore longer exposed to the attacks of the fungus.

In 1850, the moth Grapholitha pactolana, Kuhler, had raraged the spruce forests of Bohemia; damage by this insect is, howerer, generally only of a temporary nature, but in this case, it was followed by Nectria Cucurlitula, and great destruction of the spruce occurred. It has also appeared recently in the forests of Bavaria and Würtemberg, but is rare in North Germany.

\section{(c) Protectire líles.}

Cut down young stems and shoots attacked by the fungus with a pair of vineshears in autumn and early winter. This method does not cause the spores to be so scattered as when the stems are felled with a billhook.

The larger stems attacked must be felled at the same time. In both cases all the infected parts should be removed carefully, 
and burned in an out-of-the-ray place, as the spores easily spread from any pieces left lying about.

*11. Peziza Willkommii, R. Hrtg.

(a) Description and Life-history.

This fungus causes the destructive larch-blister, of which the symptoms are as follows:-appearance of little swellings on the stem and branches, chiefly below the crown; the bark splits and turpentine exudes, forming light greycoloured patches, and the split increases till the rood is exposed. Little yellowish - white sporophores of the size of a pin's head appear in the cracks. These are incapable of at once producing fertile spores, and merely wither away if exposed to dry winds. Where they are surrounded by moist air, however, they develop into cupshaped fructifications, whitish above and

FIG. 203.

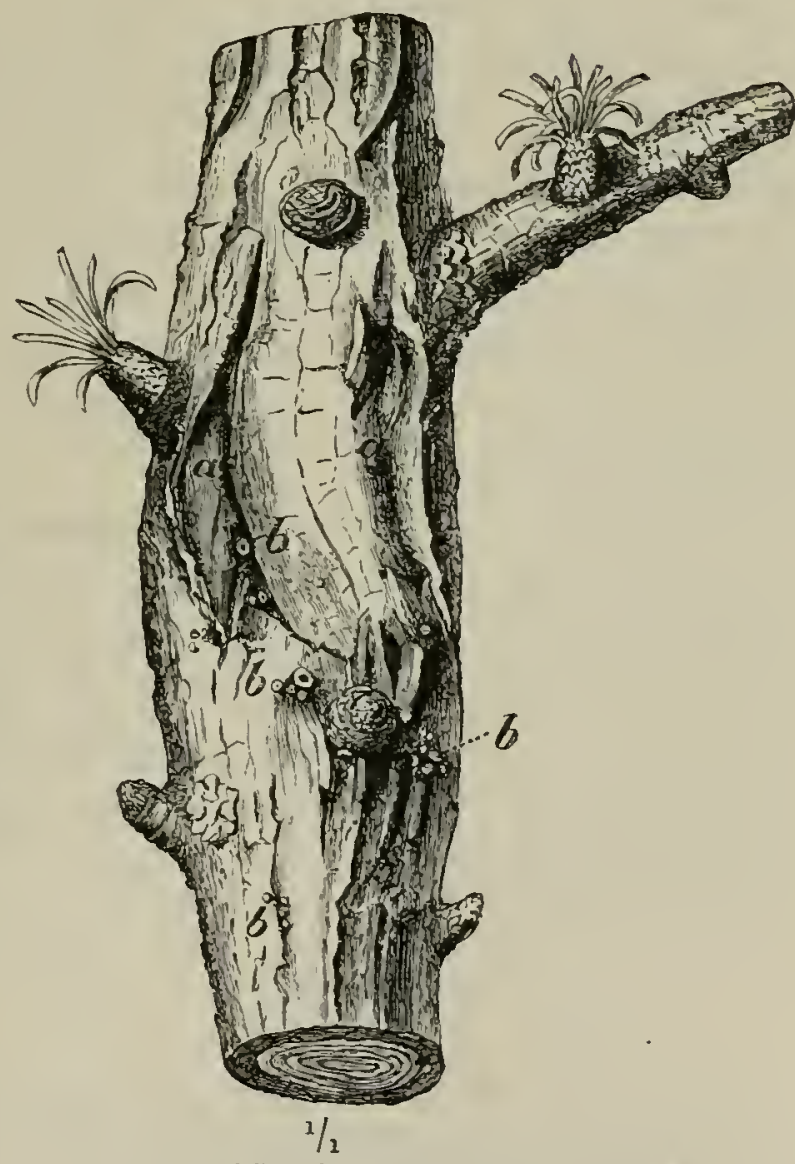

Portion of Larch-stem attacked by Pcziza Willkommii, R. Hrtg.

a Cracks with outflow of resin. $b$ Sporophores. pale red below, and these give rise to fertile spores, which infect other trees. The dead parts of the tree turn black, and owing to the swelling of the walls of the canker and the local stoppage of the growth, its centre forms a spoon-shaped depression, and the canker itself is spindle-shaped. Several cankers may appear on the same tree. 
The fungus can gain admission only through wounds, frequently of brachyblasts eaten by Coleophora laricella, Hbn., or due to suow-break, \&c. After the entrance and sprouting of the spore the richly-branching mycelium traverses the bast, but only during the spring, as its further progress is cut off by the formation of corky tissue separating the diseased place from the still healthy bast. 'The exposed wood exudes turpentine, and in the autumn the mycelium grows again from the cambium into the healthy bast and increases the size of the canker. Fresh layers of cork again cut it off, and the growth of the mycelium is repeated, a protracted contest between the tree and the fungus usually ensuing. In the Tyrol, a living larch tree has been seen affected by a canker 100 years old; if, however, the parasite grows fast and the larch is not flomishing, the canker may in a few year's surround the stem or branch, when the whole of the tree above the point of attack dies. The mycelium may also penetrate to the centre of the tree through the medullary rays.

In bad cases the tree loses its needles and spring-shoots, and whole branches dry up until the tree dies, especially in damp localities, where the sporophores, which are very sensitive to drought, develop in numbers on the bark. In such localities the cankers may be of reduced size, but the mycelium spreads throughout the wood, and the sporophores appear in all directions on the bark.

\section{(b) Suljects of Attack, and Distribution.}

'The larch-blister or canker is found in localities which differ widely from one another, but is most prevalent in damp places with moist ail and in frosty and cloudy localities. 'The disease spreads most rapidly in plains and ralleys and among low hills. Trees ten to twenty years old suffer most, but the attack is rare in the case of trees more than forty years old. Dense stocking does not suit the larch, and assists in spreading the disease; sowings therefore suffer more than plantations, and pure roods more than mixed woods. Larches growing with broad-leared trees are least liable to canker.

The disease originated in the Alps, and when during the first 
twenty years of this century extensive larch plantations were made all over Northern Europe they escaped the disease, even when on inferior soils, but spores of the fungus probably found their way down with larch-seed from the Alps, and the disease became widespread in more recent plantations. In the Alps it is usually confined to individual trees, and does not ruin whole roods as in Germany, Denmark, and Scotland.

The reason is that in the Alps there is a sudden change from winter to quite warm weather, so that the needles derelop rapidly, whilst at lower elevations the soil becomes heated at the end of March, and the larch needles then appear, but are subjected to the treacherous spring weather, and do not harden till the beginning of May. During this prolonged period of derelopment of the needles they are liable to attacks of Coleophora Laricis and of Chermes Laricis, which promote the spread of the canker. In the Alps, moreover, the fertile spores are only produced in damp places, near the lakes for instance.

It is probably everywhere in the British Isles damp enough for the fertile spores to be produced, though the disease is not yet prevalent in Ireland; but it is stated that on good fertile soil near the Scotch lakes the lareh grows so rapidly as to ontgrow the disease, even when infected.

The disease canses loss of increment, and reduces the quality of the timber, it encourages insect attacks and snow and wind break, and may lill trees outright. Wherever, therefore, larch grows badly owing to unfarourable soil or climate, it is better to give up planting it.

\section{(c) Protective Rules.}

Great care should be taken in the selection of sites for larch plantations; pure larch-woods should be avoided, and larch should be given plenty of room. It prefers exposed, breezy places on hills and mountains, fertile but not too binding soil, plenty of room for root-development, and abundance of dead leares or snow on the soil, so that the ground may not be heated and the larch forced into growth early in spring and afterwards retarded by the spring-frosts. No tree requires more light or room than the larch. All cankered larches should be 
cut out in thimnings. Plantations badly attacked by the disease should be felled and replanted with another species.

\section{Pestalozzia IIartịii, v. Tub.}

This fungus canses a disease in spruce and silver-fir seed-

FIG. 204

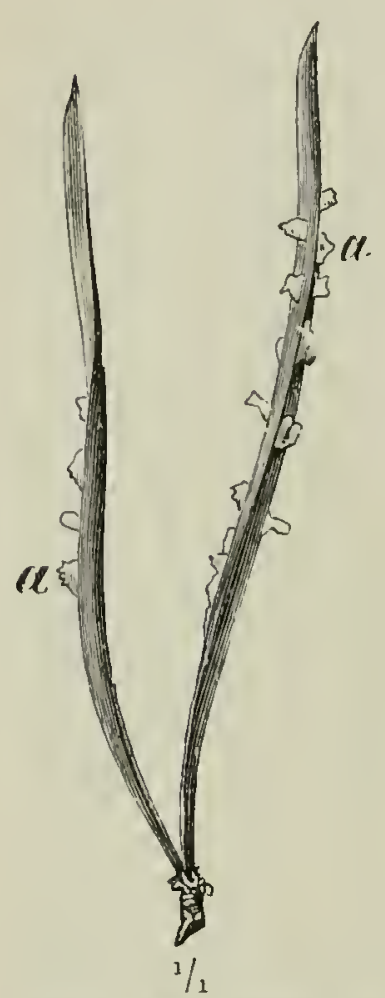

Pcridermium Pini acicola on Scotch pine needles. a Burst sporophores. beds and nursery-lines. Its first symptoms are that a number of plants turn pale and die, and when pulledup it will be noticed that their cortex close to the ground is withered, whilst above this withered portion the stem has attained its usual dimensions. The mycelium of the fungus may be found in the bark, where the contraction in the stem takes place, and sporophores spring from the point of attack.

This disease appears to attack sereral broad-leaved species as well as conifers, and all infected plants should be at once pulled-up and burned.

\section{Peridermium Pini acicola, R. Hrtg.}

During April and May, on the one-year or two-years needles of young pines of different species, orange-yellow blisters appear, about the size of mustard seed, often several of them being in a row on one or both sides of the needles. When ripe, they turn brown and split, emitting their spores and leaving on the needles blackish spots with lighter borders. The mycelinm is perennial on the needles, and without lilling them, may, during the ensuing year, develop fresh sporophores. The needles die 
and fall only when the disease is very intense. The pine-needleblister, as the disease may be termed, comes from spores of species of Colcosporium, a fungus infesting several species of Senecio, or groundsell, Euphrasia and Tussilago.

The fungus prefers plants 3 to 10 year's old, but may attack trees up to 30 years; it is widespread throughout Europe, including the British Isles, but does little harm to the trees which it attacks.

\section{Acidium abietinum, Alb. and Schw.}

This fungus causes a needle-blister which appears on the previous year's shoots of the spruce at midsummer, the needles then assume a dull reddish-yellow colour; during August, bright-red recidia of the size of a pin's head project from the needles, and at the end of August or the beginning of September they burst and emit their yellow spores in a clond of clust. The affected needles, which on lateral shoots are usually only on the upper side of the branches, die and fall before the close of the year, and the fungus may be thus distinguished from Chrysomyxa Abietis, Ung. The alternate hosts of Ecidium abietinum are several species of rhododendron in the Alps, and Ledum palustre in Finland and parts of North Germany, and these plants carry the discase through the winter. Spruce trees of all ages are affected, especially in the Alps, from an altitude of 1,000 metres to the highest limit of spruce, where whole spruce-woods sometimes assume the yellowish-red colour. The disease is also very prevalent in Russia; no practical remedy has been devised against it.

\section{Ecidium columnare, Alb. and Schw.}

Ecidia break out in July and August on both sides of the mid-rib of silver-fir needles, in the shape of long yellow blisters full of spores. This fungus alternates as Mclampsora Goeppertiana on the cowberry (Vaccinium Vitis-Idcea) which causes that plant to become abnormally tall, with a thickened spongy stem, at fir'st whitish, then rosy-red, and eventually dark brown.

The fungus kills silver-fir needles and causes them to fall, but it is not widely spread and becomes dangerous only when young thickets of silver-fir spring up among cowberry plants, when the latter should be uprooted and destroyed. 
16. Chrysomyxa Abictis, Ung.

(a) Description and Life-history.

This form of spruce-needle-rust may be recognized by dull yellow bands appearing from May to the middle of June on yearling spruce needles.

FII. 205.

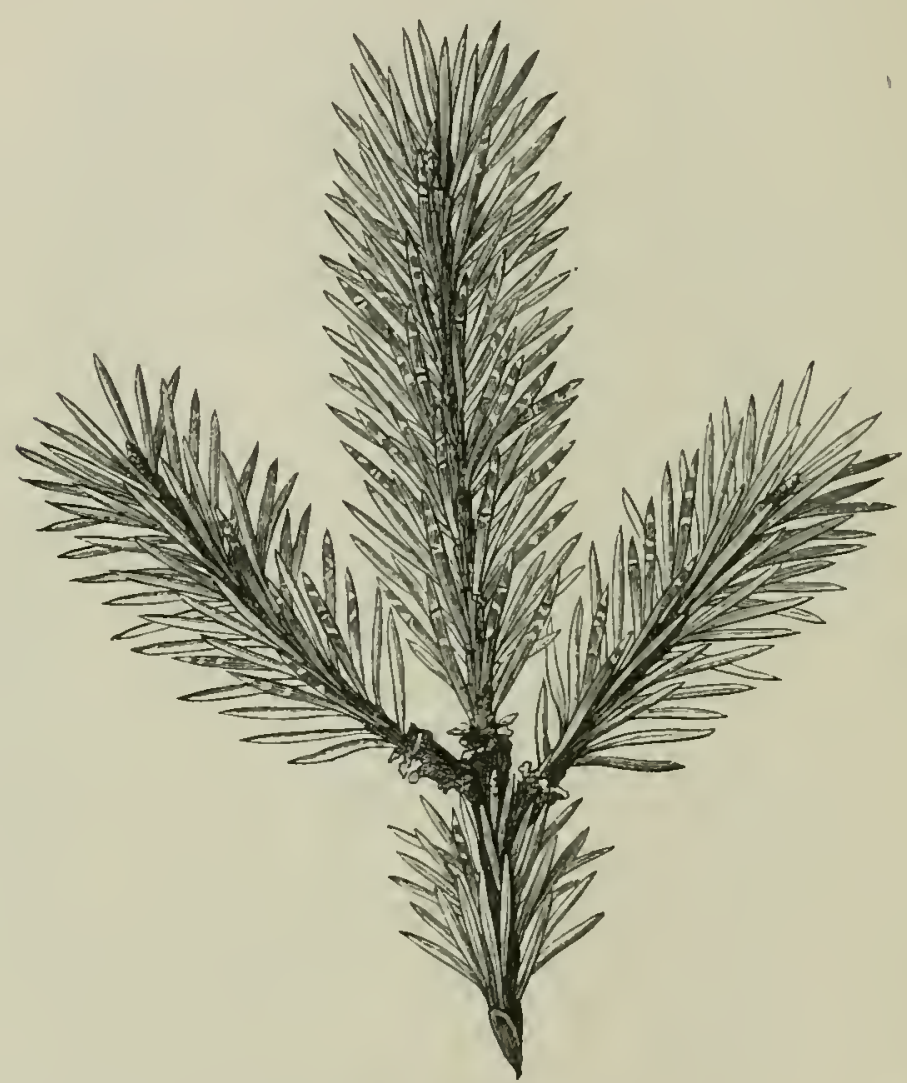

Shruce twig attacked by Chrysomyon Abietis, Ung., in antumn. (Natural size.)

They gradually become broader and assume a brighter yellow colour. Towards the end of August brownish longitudinal stripes appear on the affected needles which by November assume a golden-yellow colour, and swell up slightly on one or both sides of the mid-rib; the fungus hibernates on the tree in this condition. The swelling becomes greater at the beginning of spring, and from April to the middle of May the epidermis of the needle bursts and the spores are scattered, the affected needles wilting and falling in June and July. The spores which are disseminated in May, when the young shoots of the spruce are forming, can then infect them and continue the disease. 
(b) Suljects of Attack, and Distribution.

The fungus only attacks yearling needles, usually those on the lower branches, and never near the top of the tree.

Spruce is most subject to this disease when from 10 to 40 years old. In damp, dense, 10 to 20 yearsold thickets, the fungus is most common, but the nature of the soil does not appear to have any influence on it. It is met with up to altitudes of 1,600 metres, and is most frequent on south and south-west aspects, or in valleys exposed to the south, whilst damp

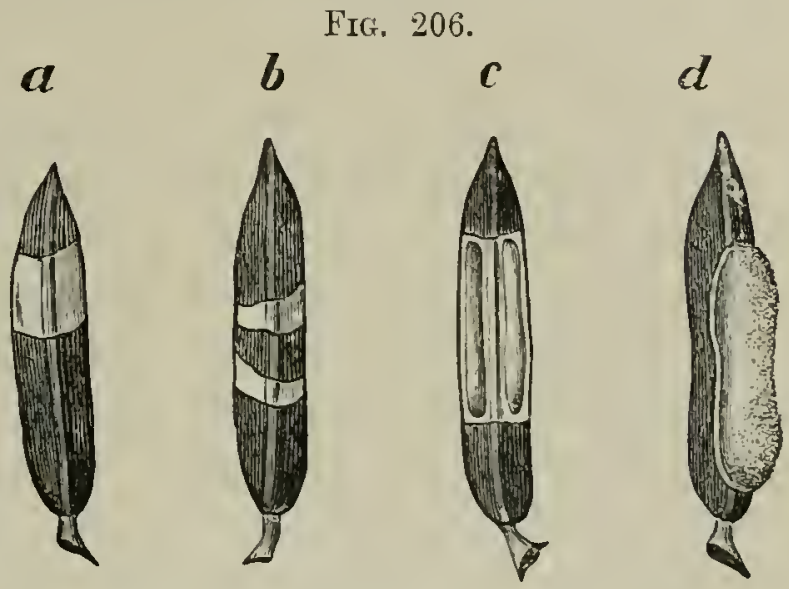

Spruce needles attacked by Chrysomyoce Abietis,

Ung. (Somewhat enlarged.)

$a \& b$ First appearance of disease in the form of pale-yellowish marks on needles.

c Needle with reudish-brown longitudinal blisters (end of March and beginning of April).

d Needle with fully formed orange-yellow cushion (May).

weather favours its spread, wherever spruce is extensively grown.

The damage done consists chiefly in loss of increment, and exposure to attacks by bark-beetles, but the trees are not often directly killed by it. Spruce trees are not usually sufficiently advanced in growth to become infected when the spores ripen, and thus frequently escape.

\section{(c) Protective Rules.}

Carry out early and strong thimnings, especially on trees affected by the disease, and promptly remove the latter from the forest.

*17. Hysterium Pinastri, Schrad.

(a) Description and Life-history.

On the needles of young Scotch pines, solitary brown spots may appear in July or later on in the year, and if the affected needles are examined microscopically, the mycelium of Hysterium Pinastri will be found in them. Black 
sporophores subsequently appear before winter, but their spores do not seem to germinate. As a rule the diseased primordial needles die in the spring, without falling from the plants, and older needles frequently turn completely brown in March and April and fall off, owing to the formation of cork at their base. This sudden shedding of pine needles is the characteristic of the disease so widely spread in Germany and termed Schiitte, or needle-cast, which may, however, be due to other causes besides the fungus, as explained on p. 576. If, owing to a mild wet winter and spring, the black sporophores should burst, which only happens when they are exposed to much moisture, the spores issue from them and infect fresh plants. This, however, frequently happens only after the needles have fallen. Dry summers and cold winters therefore impede the spread of the fungus, which is frequently only saprophytic on old dying pine needles, in crowded seed-beds. This saprophytic form of the disease is always present in the Scotch pine nursery at Coopers Hill College, but has never attacked the pine seedlings or transplants. The latter are kept two years in seed-beds and two years in nursery-lines, and about 50,000 healthy four-years-old plants hare been removed from the mursery every year since 1891.

\section{(b) Subjects of Attack, and Distribution.}

As a rule the fungus attacks only 1 to 5 years-old plants, but it has been observed on older poles and trees. Damp cloudy localities are favourable to its spread, and plains and lowlands suffer more than mountains and hills. Large regeneration-areas and dense stocking also favour its spread. Under certain unfarourable conditions of soil and climate, the cultivation of Scotch pine must be abandoned, owing to this disease, and the area stocked with Weymouth-pine,* or some other resisting species.

\section{(c) Irotective Measures.}

Mix spruce or Weymouth-pine with Scotch pine, in lines or

* According to Hartig, the Weymonth-pine sufters from a similar fungus, $I T$. brachyosporum, and the linch from $H$. laricinum, which may however be only a saprophyte. 
belts rumning from north to south, so as to interfere with the dissemination of the spores by damp westerly winds. In nurseries, the seed should not be sown thickly in drills, and the yearlings should be transplanted into nursery-lines, or at once into the forest.

New Scotch pine nurseries should be made in localities free from the disease, best among broad-leaved trees, in any case not near pine-woods, which are especially dangerous to the west of the nursery.

The spaces in nursery-beds between the rows of seedings should never be covered with pine-branches which favour the spread of the disease, but with leaves of broad-leaved trees or moss.

All diseased plants found in nurseries should be at once burned to ashes.

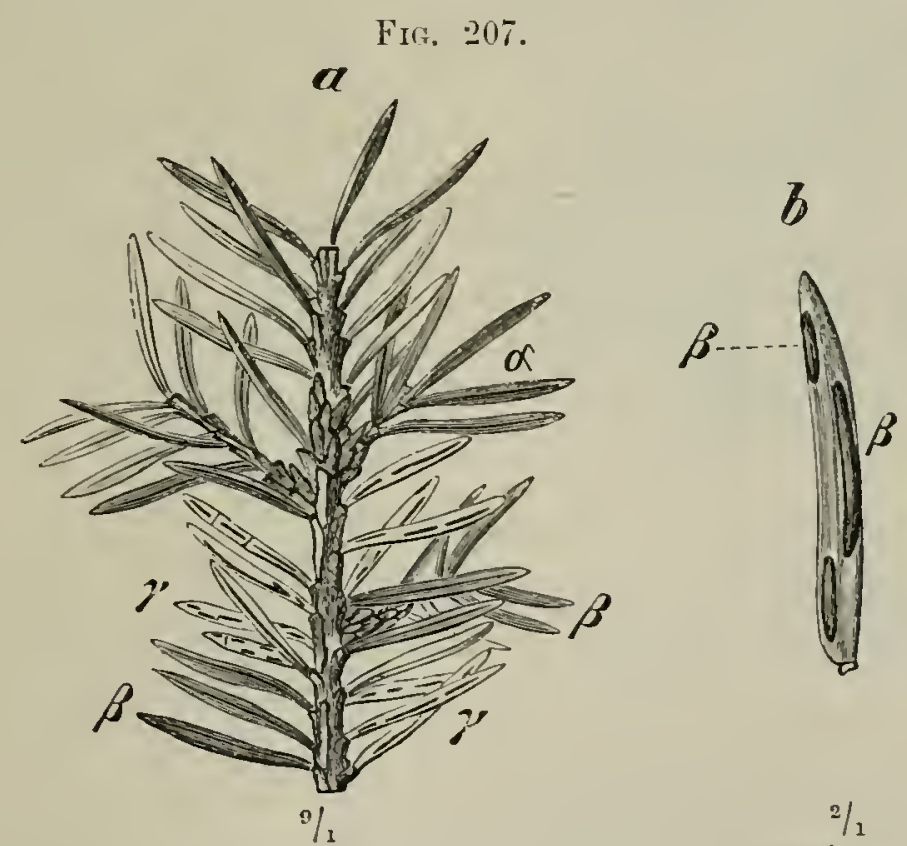

a Under surface of a spruce twig in winter, attacked by Hysterium macrosporum, R. Hrtg.

a Dead brown needles at the base of the second year's shoot.

o Freshly attacked third year's needles.

$\gamma$ Needles with black sporophores.

$b$ Brown needles with ripe sporophores $(\beta)$ not yet burst.

18. Hysterium macrosporium, R. Hrtg.

This fungus on the spruce, according to R. Hartig, causes either needle-r'ust or needle-shedding.

The former disease appears in mountainous regions at mid- 
summer as a rusty discoloration of needles on two-years old shoots, and in the plains later during autumn; finally black sporophores appear on the under surface of the infected needles, which burst longitudinally and emit their spores in the succeeding April or May. The needles with the empty sporophores remain on the tree for several years.

In the case of needle-shedding a more virulent form of the disease occurs, and the needles turn red in August and fall before

FIfi. 208.

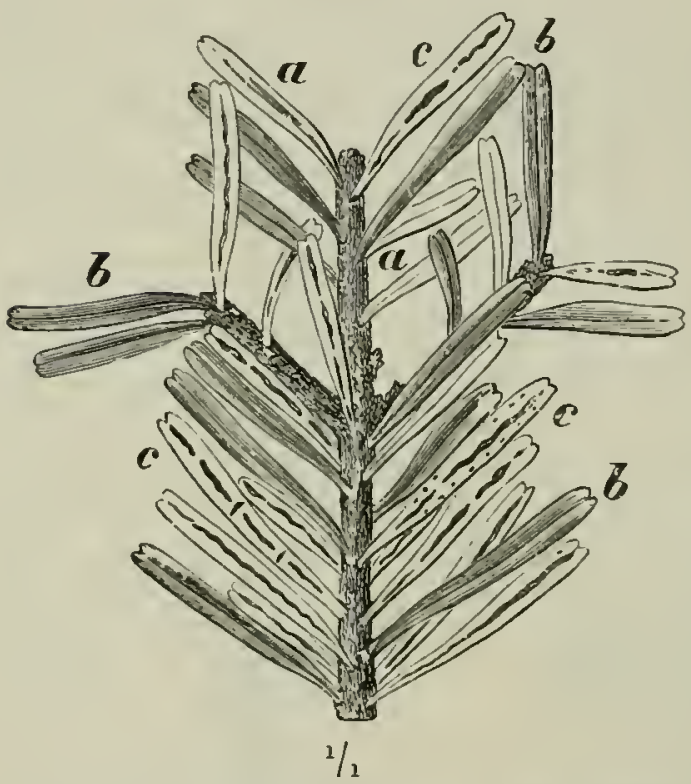

'I'wig of Silver-fir attacked by $I I$. nevvisequium.

a Unaffected needles.

¿ Attacked needles turning brown.

$c$ Needles with ripe sporophores. the winter.

The spores of all species of Hysterium gain admission through the stomata, and the wetter the weather, the sooner the spores ripen.

The disease affects 10 to 30 years-old spruce, especially in the lower part of their crowns, but is unimportant except when needleshedding takes place.

\section{9.'Hysterium nervisequium,}

D. C.

This is a very similar fungus to that described above, and affects the previous year's and older needles of silver-fir, turning them brown and eventually causing them to fall from May to July. Numerous dark brown pustules may be noticed on the upper surfice of infected needles, and long dark-brown sporophores eventually break out in the mid-rib of their lower surface.

'I'hey ripen in April of the succeeding year, on the needles in their third year, but a large number of the infected needles have generally fallen before this occurs.

This disease is wide-spread in silver-fir forests, and has proved destructive in the Erzgebirge, where the trees lose most of their needles. 
*20. Trichospharia parasitica, R. Hrtg.

The fine colourless mycelium of this fungus covers the twigs of the silver-fir down to the buds, especially on their under surface and spreads to the lower needles, whilst the shorter upper needles usually escape infection. The mycelium forms superficial white crusts on the white lines of stomata of the needles. They therefore become discoloured, and at lengtl quite brown; they do not, however, fall from the tree, but hang down, being still attached to the twig by the mycelia of the fungus. The minute dark-brown sporophores appear on the dried-up needles in November, and greyish spores issue from them, and infect new twigs of silverfir.

The mycelium hibernates on the twigs and needles and grows again on to the new springshoots, attacking the needles from the base upwards, so that needles on the older shoots which escaped during the previous year may now be attacked.

Trees once attacked by this

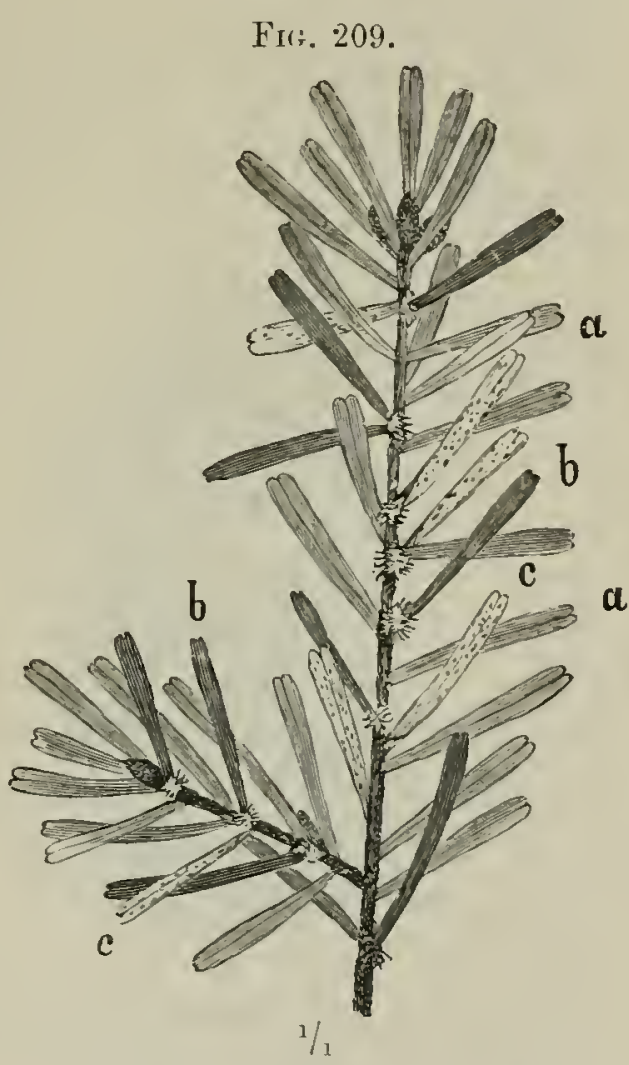

Twig of Silver-fir attacked by Trichospherice peresitice, R. Hrtg.

a Sound needies.

6 Dead brown needles fixed to the twig by mycelial strands.

c Under surface of needles with white mycelia ant dark sporophores. fungus appear never to become free from it, from which its dangerous nature is evident.

This disease is wide-spread in silver-fir forests and especially among 20 to 40 years-old woods on the lower branches and on advance-growth, and according to von Tubeuf, it also attacks the spruce. It has done much damage in the Bavarian forests, near Passau and other places.

Underwood, and diseased branches and twigs, should be removed by clearing, pruning and cutting off twigs with shears. 


\section{Ecirlium strobilinum, Rss.}

This fungus develops its mycelium in the still green scales of spruce-cones and destroys them. The hemispherical brown rcidia are crowded together on the inner surface of these scales.

The infected cones which have fallen to the ground may be easily detected by their opened-out appearance. The life-history of this fungus is not yet made out, and artificial infection by

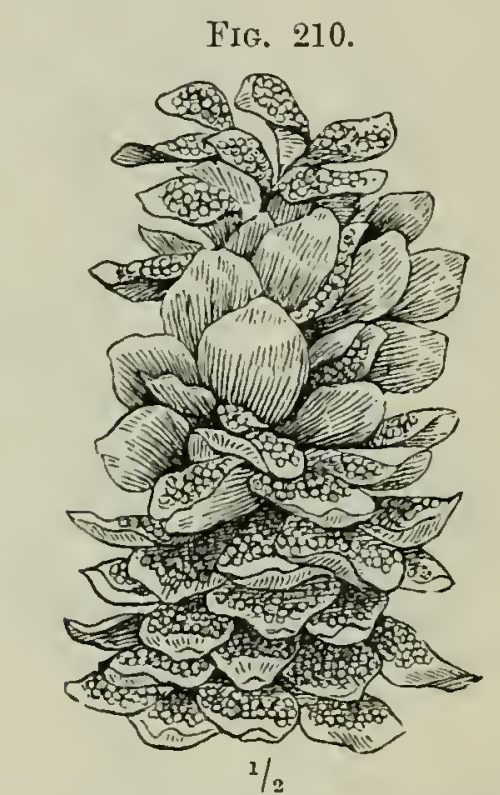

Apruce cone attacked by Ecidium strobilinum, Rss.

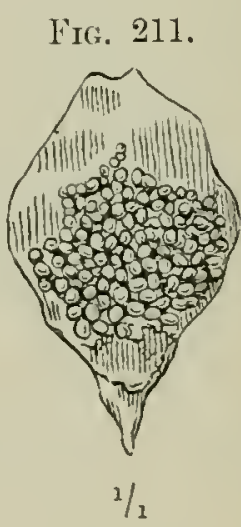

Sporophores of E. strolitimum on the under-surface of a scale of a spruce cone.

spores has failed to produce it. It is known over all North Germany and in the lower Alps.

Another fungus, Acidium Conorum Picere, Riss., also affects spruce-cones, and may be distinguished from the above by there being only two rcidia on each scale of the affected cones. After the recidia burst and disperse their spores, pale spots are left on the scales.

\section{Section III.-Fungi attacling Broad-Leaved Trees.}

The numbers of dangerous fungi attacking broad-leaved trees may be limited for description here, to seven, besides some wound-parasites. 


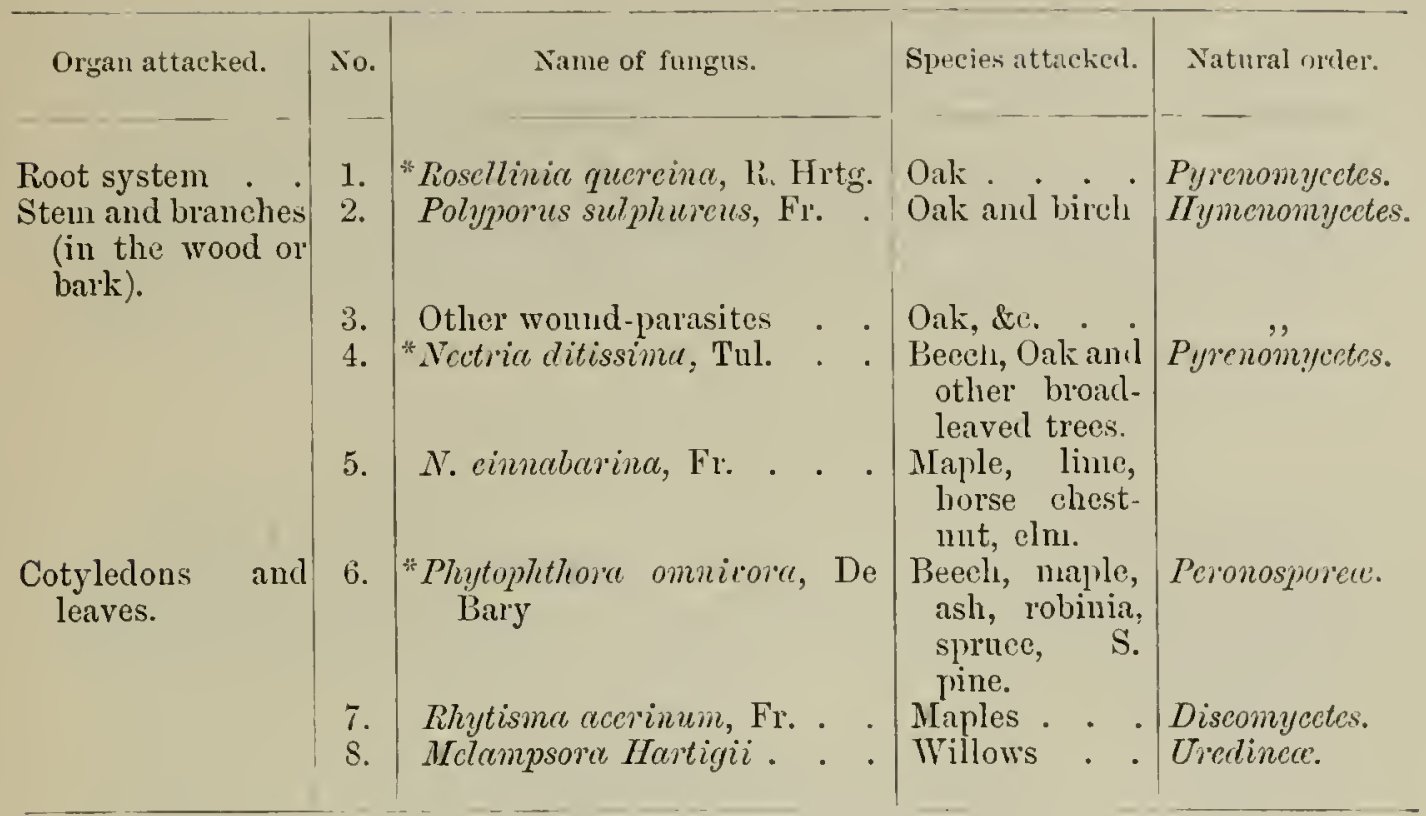

*1. Rosellinia quercina, P. Hrtg.

(a) Iescription and Life-listory.

The leaves of infected 1 to 3 years-old oak seedlings become gradually pale and at length dry up. This commences with the topmost leares and proceeds downwards. At the top of the tap-root just below the surface of the ground, the bark and wood turn brown and shrivel up, and this at length spreads to the whole tap-root and the plant dies. On pulling up the plant and examining its tap-root, black spheroidal sclerotia of the size of a pin's head are seen, which spring from numerous brown rhizomorphs, which have branched freely and surround the plant's roots, and are prolonged into the soil. These rhizomorphs readily communicate the disease to roots of neighbouring plants, as in the case of Agaricus melleus.

The method of infection is very interesting; as the tap-root is protected by cork, the shoots of the mycelium attack the side roots. At the places where these branch off from the main roots, little fleshy swellings are formed, which send out conical processes through the cork into the inner tissues of the tap-root. The fungus only grows in damp warm weather, and if the weather be dry, the infected plant can delay the progress of the fungus, by cutting it off by cork-formation from the still healthy 
tissues. By means of the sclerotia, the fungus can persist through dry periods, or hibernate, which the ordinary mycelium cannot do. The disease is also perpetuated by gonidia springing from the portions of the mycelium growing above ground, or by spores produced either from the sub-aërial portion of the oak-plant or in the ground, these as a rule only germinate in the year following that of the original infection.

\section{(b) Suljects of Attack, and Distribution.}

This fungus is very dangerous in seed-beds and dense sowings in the open, especially in wet years. It is common in NorthWest Germany.

\section{(c) Protectire Rules.}

(i) Places where the fungus has appeared should be isolated, by digging trenches one foot deep to prevent the spread of the rhizomorphs.

(ii) Plants which have been attacked must be at once removed and burned, which can always be dome in nurseries.

\section{Polyporus sulphureus, Fr.}

This widely-distributed fungus, which is very common in the British Isles, and has been already referred to as attacking the larch, destroys the wood of oaks, poplars, tree-willows and birch, and is saprophytic on fruit-trees. The infection occurs at wounds in the branches of trees; the wood, in consequence, turns reddish-brown, cracked and dry, the mycelium spreading through the cracks and forming large felted white sheets, it also fills the vessels, which on the different sections of the wood appear like white lines or points. At the scars of dead branches, or other parts of the stem, large sulphur-yellow, fairly smooth, fleshy sporophores appear annually which are somewhat reddish above and very conspicuous. All infected trees should be felled if this does not open out the wood too much, and great care should be taken during fellings to avoid wounds. Broken or forlied branches, which it is advisable to remove, should be sawn off cleanly and the section tarred. 
3. Other Wound Parasites attacking Oak Wrood.

(a) Polyporus dryadens, Fr.

White and yellow irregularly shaped longitudinal marks appear in the wood, which at length becomes cimmamon-coloured and rotten. The sporophores are large, brown and hoof-shaped, but do not last long.

(b) Polyporns igniarius, Fr.

The commonest cause of white-rot. Infected wood becomes pale yellow and gradually lighter in colour and softer. The tannin is at once attacked and decomposed by young mycelia of this fungus, so that oak-rood loses its characteristic odour, the absence of which is an excellent practical test of incipient unsoundness. This fungus also occurs on fruit-trees and other broad-leaved trees. Sporophores, hoof-shaped ( $P$. betulinus, Bull, and P. lerigatus, Fr.) cause red and white rot respectively in birch, the former having roundish sporophores and the latter incrustations.

(c) Hydnum diversidens, Fr.

Also causes white-rot. The wood, and especially its spring zomes, turus ashy-grey, at first in stripes. The sporophores are yellowish-white incrustations or brackets. Also found on beech.

(d) Thelephora perdix, R. Hrtg.

Produces the well-known partridge-wood form of rotten-wood (Rebhuhnholz), which is common in Germany, but not known as British by Marshall Ward. The dark reddish-brown rottenwood becomes honeycombed with whitish blotches surrounded by hard walls. Later on, these blotches become greyish-yellow, and are filled with mycelium. The sporophores, brownish-yellow incrustations.

\section{(e) Sterenm hirsutum, Fr.}

Snow-white or yellow longitudinal bands surrounded by brown tissue appear in the wood, which is said to be yellow- or uhitepiped. Sometimes the whole of the wood turns uniformly yellow. The sporophores, at first mere incrustations, later on assume prominent horizontal edges. Common in Britain. 
*4. Nectria ditissima, 'Tul.

(a) Description and Life-histor?.

This fungus produces the beech-canker, which may be recognised by the local destruction of the cortex and the appearance

FIG. 212.

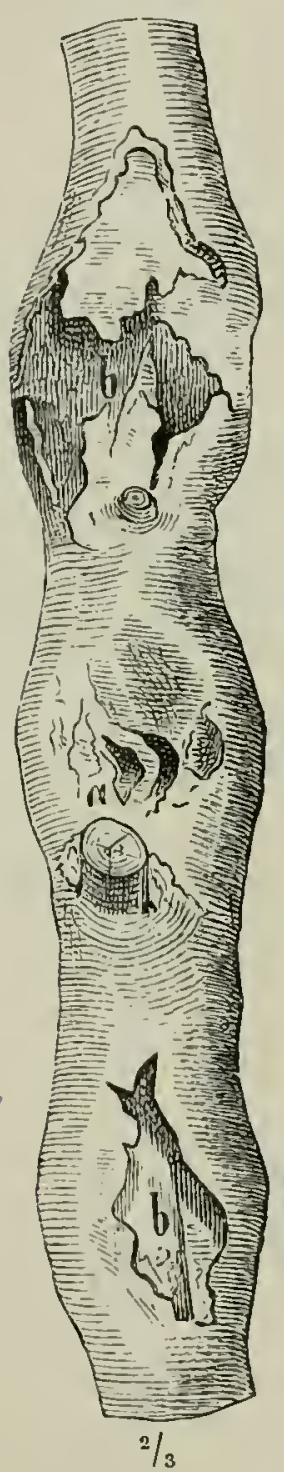

Nectria ditissima, Tul., on a Beech. a Commencernent of the disease, which las procecelerl deepcr into the wood at $b$.
Fig. 213.

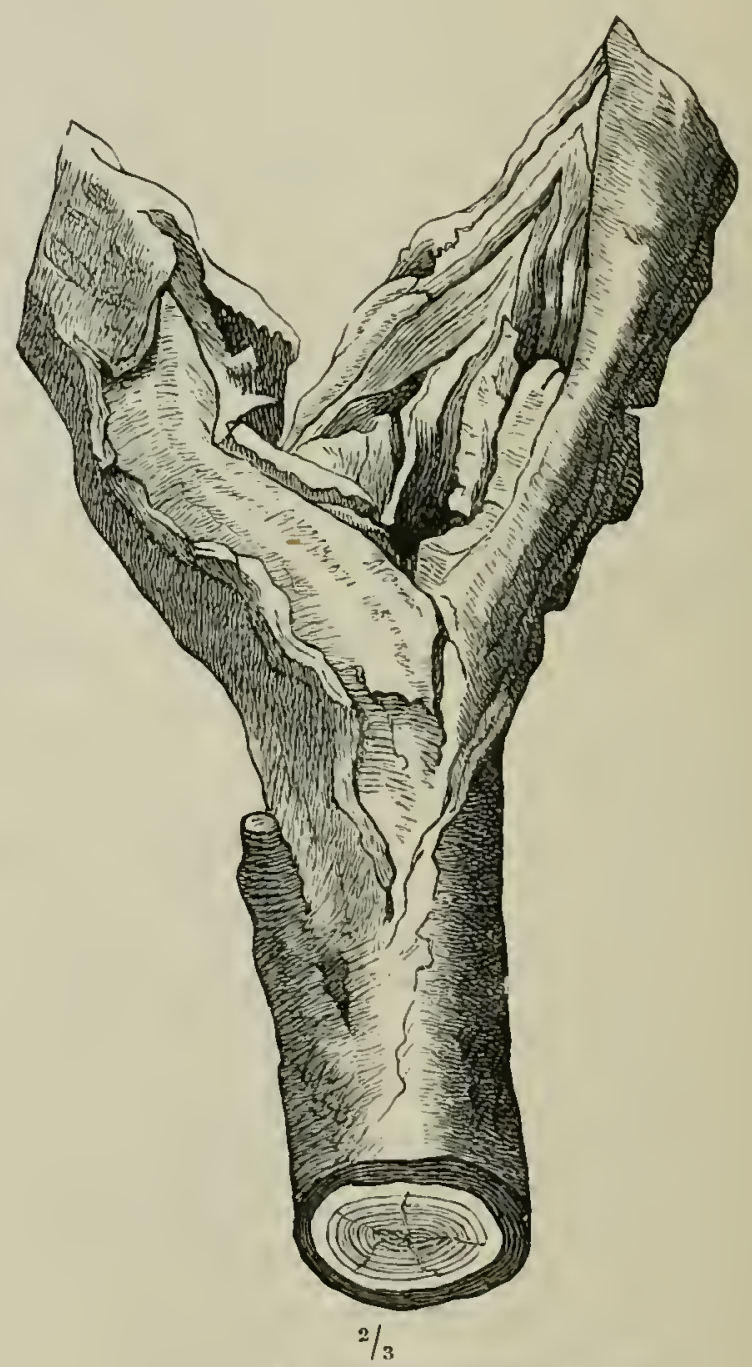

Canker on an oak caused by Nectria ditissima, 'l'uJ.

of small white tufts of gonidia; and later on by dark-red sporophores on the canker. The infection always arises at a wound caused by abrasures of bark by felled trees, hail, ic., and from the point of infection the fungus spreads more or less 
regularly in the wood, but most quickly along the stem. The wood turns brown and dies wherever it is attacked. The diseased portion of the wood appears sunk into the stem, owing to the hypertrophy of the growth of the portions of the stem round the canker.

Thus the attacked branches and stems become spindle-shaped. The canker becomes every year deeper and more open.

\section{(b) Subjects of Attack, and Distribution.}

The beech-canker chiefly attacks the beech, but oaks, ash, hornbeam, hazel, alder, lime, cherry, maple, and apple are also attacked. It is found in thickets 5 to 7 years old, but also in 100-year's-old woods, and is worst amongst healthy smooth-barked trees.

Infected branches eventually die, and infected trees in the course of time assume extraordinary shapes, and are only fit for firewood.

The disease has been known since 1865 in the Saxon Erz mountains and in the extensive beech forests in Hesse. It is common in the British Isles, especially on apple trees.

\section{(c) Protective Rules.}

Cut out all infected trees in cleanings and thinnings, provided too large gaps are not thus caused in the standing-crop.

Avoid all injuries to the bark during felling operations.

\section{Nectria cinnabarina, Fr.}

\section{(a) Description and Life-7istory.}

The presence of this parasite in living broad-leaved trees may be surmised by the sudden drying up and death of apparently healthy shoots, by the greenish or black colour of the wood and by the breaking out of the vermilion-coloured sporophores, which eventually turn brown, on the stem or branches of the tree, chiefly in the autumn, after rainy weather. The infection takes place at a wound of some kind, chiefly of branches, but also of roots. The mycelium grows rapidly in the wood, pierces the walls of the wood-fibres, decomposes the starch, and leaves 
a green substance within the infected tissues. The cambium and bark remain sound, but by the destruction of the wood, the water-supply is cut off from the crown, the leaves wither and drop off and the shoots dry up. The sporophores appear in autumn or spring on the dead bark of the infected trees, and the danger of infection is then greatest.

FIG. 214.

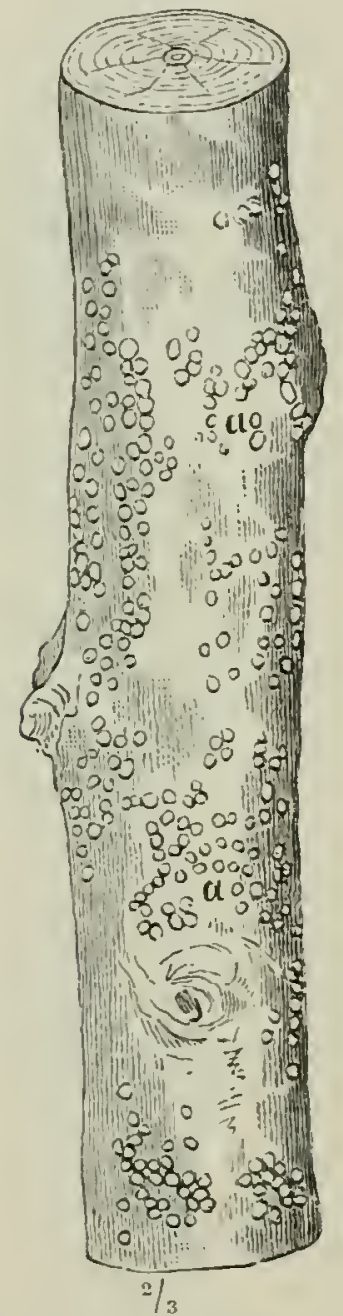

Naple stem showing the rermilion coloured sporophores (a) of Nectriacinnabarina, Fr.
Fig. 215.

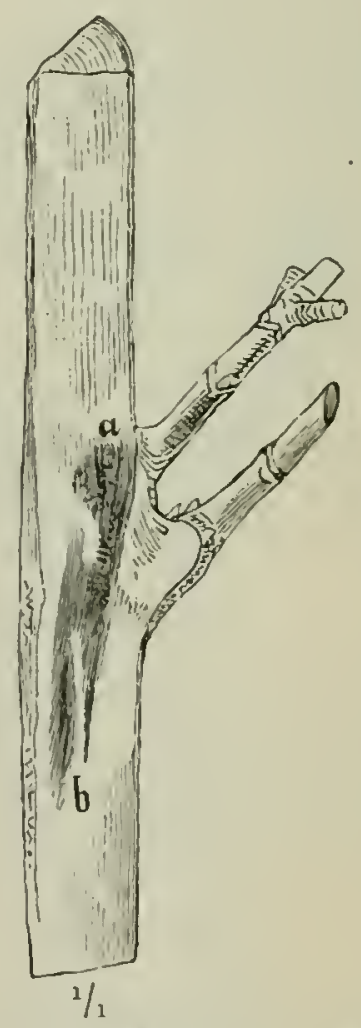

Section of Maple stem attacked by Nectria cinnabarina, Fr. Between $a$ and $b$ the wood is colonred bright green owing to the decomposition of the tissues.

(b) Subjects of Attack, and Distribution.

(i) Description and Life-history.

This fungus is saprophytic on the dead branches of various broad-leaved trees and shrubs, such as maples, cherries, birch. Marshall Ward notes that it may be often seen on pea- or beansticks, which become dotted with red points. 
As a parasite, it attacks young plants of maple, lime, horsechestnut and elm, and soon kills them. It is very widely spread throughout Europe.

\section{(c) Protective Rules.}

(i) Clean pruning of broken branches and tarring the wounds.

(ii) All twigs, branches, or stems which show sporophores of the fungus should be cut off and burned.

\section{*6. Phytophthora ommirora, De Bary.}

\section{(a) Description and Life-history.}

This fungus causes great damage among beech seedlings; these, when affected, turn black and die from below upwards, during their germination or immediately after the cotyledons have appeared. The little stem shrivels up and turns brown above and below the cotyledons, whilst they are still green, or dark specks appear on the cotyledons or on the young leaves. Within six or eight days after the first appearance of the disease, it attaciss the whole plant, especially in protracted rainy weather in the months of May and June. In dry weather the attacked plants appear as if singed by fire.

The first infection of the beech by the parasite comes from oospores which have remained in the ground since former sowing's. The mycelium, which is intercellular, spreads into the stem and cotyledons, and numerous hyphr break through the epidermis or stomata, and produce lemonshaped spores. After the bursting of these, fresh ones are formed, and the spores are spread in all directions, and in this way the disease may extend over a considerable area of young plants by attacking their cotyledons, or primordial leaves. The development of the fungus is so rapid that in rainy weather and in damp localities, in 3 or 4 days after the first appearance of the disease, sporophores are formed on the host. At the same time thick-walled oospores are produced sexually within the cotyledous; these fall to the ground in the rotting tissues, and may then remain alive for four years and more. These oospores reproduce the malady from year to year if the place be used again for sowing beech. In dense sowings on damp soil, the fungus infects the roots of the plants until whole rows of them die at once. 
The fungus has been obserred to attack maple, ash, and robinia, at the seedling stage, and several conifers, especially the spruce and Scotch pine. Hence the name "omnirora." The symptoms are similar in these other cases. If only the leaves of the seedling are affected, it may recover, but whenever the stem is attacked from below, it succumbs. Worms drag down infected seedlings into their holes, and hence gaps sometimes arise in what was formerly a flourishing nursery-bed.

(b) Suljects of Attuck, and Distribution.

This fungus causes considerable damage to all the species it attacks, and the spores are transported by wind, mice, roe-deer, and by the tread of men or horses, or even cart wheels. Damp, warm years are favourable to the spread of the fungus. It has been noticed all over Germany.

(c) Protective Rules.

(i) Pull up and burn all infected plants and leares lying on the ground as soon as the disease is noticed.

Seed-beds should be carefully watched in May and June for this malady. The workman should wear an apron, in which he places the infected plants, and should take care not to tread on the beds and bury any oospores. Any bed which has been attacked should be examined daily.

(ii) Beech and coniferous seed-beds, where the disease has appeared, should for sereral years be used only for transplants, and it is then best to change the species grown.

7. Rhytisma acerinum, Fr.

This fungus causes black spots on the leares of maples, especially of the Norway-maple and sycamore.

During damp weather in July, round yellowish spots $\frac{1}{4}$ to inch across, appear on maple-leares, which turn black in August, retaining a lighter tint on their borders. 'The leares fall earlier than is usual. On the fallen leaves during winter and the following spring numerous sporophores develop on the black spots and they open in long cracks in damp weather. The spores which issue from them in the spring germinate on the leaves and produce fresh spots as before. The parasite appears to be an annul, and is very common. 
The damage done is mostly due to reduced assimilating powers of the leaves and is relatively unimportant.

Where the dead leaves are swept up and burned, as in parlis and gardens, the disease does not spread, but in places where dead maple-leaves are allowed to lie about in ditches, \&c., it may recur annually to the detriment of the beauty and shade of the trees.

FIG. 216.

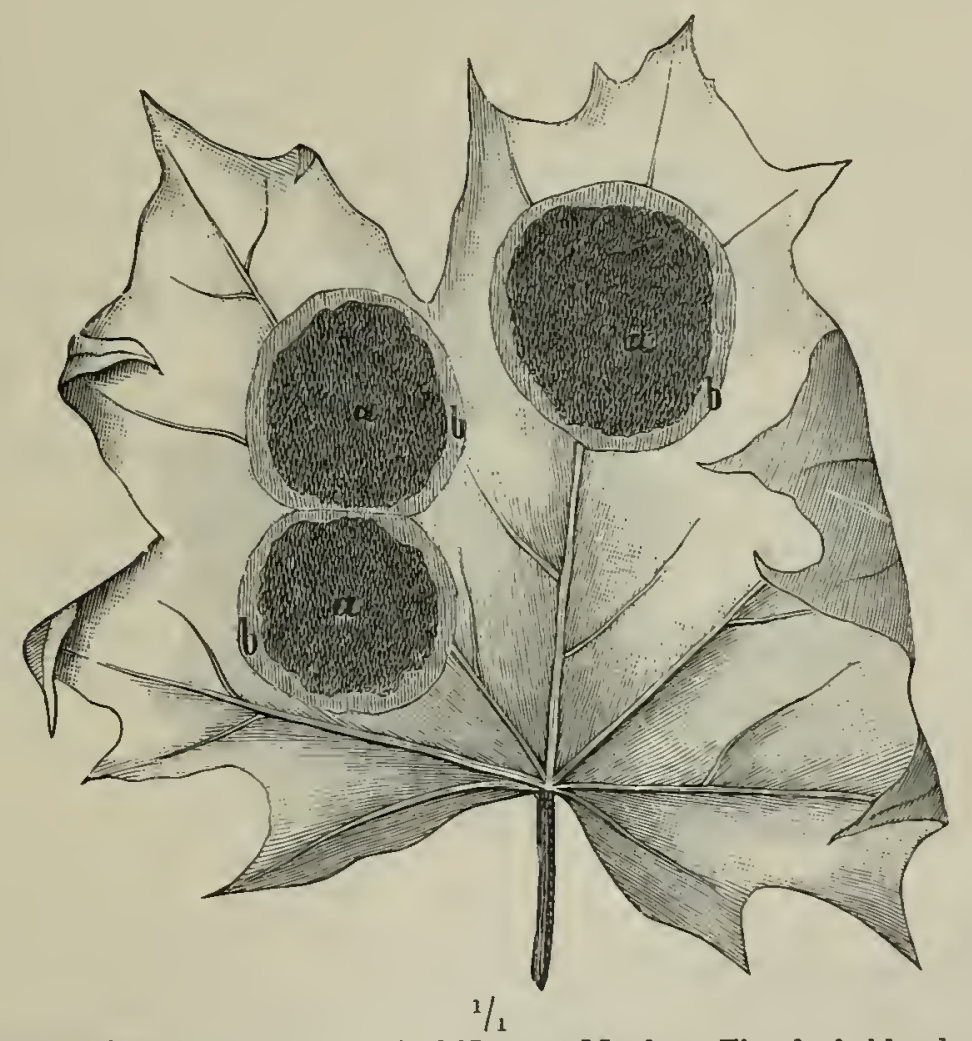

Rlyytisma acerinum, Fr., on a leaf of Norway Maple. The dark blotches $(a)$ are surrounded by a dead lighter coloured zone $(b)$.

8. Melampsora Hartigii, Thüm.

(a) Description and Life-history.

On the leaves of several species of willow, and especially on their under-surface, and the ends of their young shoots, little goldencoloured marks, subsequently tarning brown and then black, mar appear at the end of May or the beginning of June. Leaves which have been attacked soon become marked with black blotches and fall off; the badly infected shoots also die from their tips downwards. The sporophores hibernate on the dead leaves lying on the ground and emit spores in the spring which spread the malady by germinating on fresh leaves and shoots.

VOL. IV. 
The same disease infects species of Ribes (currant or gonseberry plants), as Creoma Ribesii, Link., but this intermediate

FIG. 217.

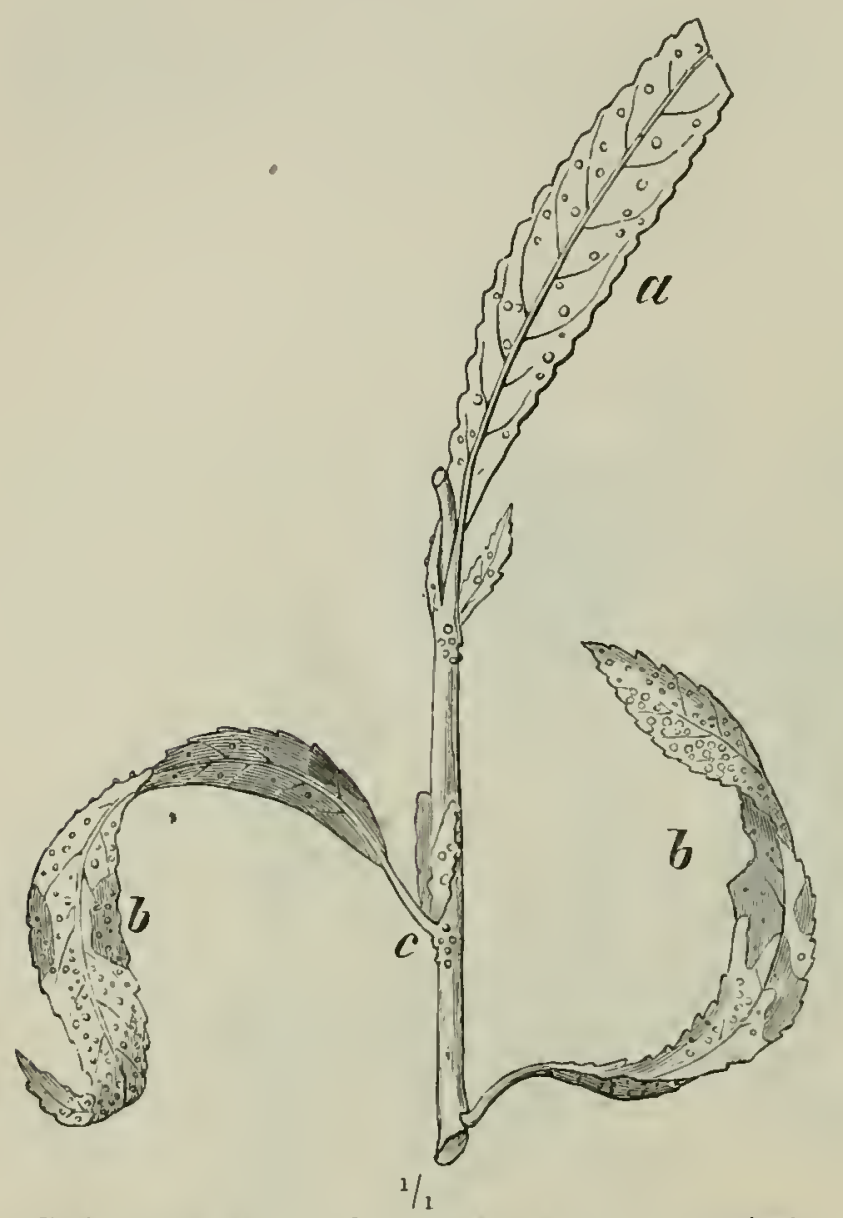

Salix acutifolia attacked by Melampsora Hartigii.

a Green leaf with orange yellow sporophores.

$b$ Leaves with black patches, withering.

c Sporophores on the epidermis of the stem. stage is unnecessary in the life of the fungus.

(b) Subjects of Attacl, and Distribution.

The fungus, which is not noted by Ward as occurring in Britain, is most destructive in its attacks on the Caspian willow (Salix acutifolia, Willd.), but also attacks $S$. daphnoides, riminalis, purpurea, \&c. Yearling shoots suffer most, and 2 to 4 years-old shoots are less liable to infection.

(c) Protective Iiules.

Cut off and burn all infected shoots, as soon as they are noticed. All infected dead leaves should be collected during the autumn or spring and burned.

Infected osier-beds may be sprinliled by means of an ordinars white-washing brush with dilute carbolic acid, one part to 500 of water. This should be repeated several times, and costs about 1s. an acre.

Cultivation of the Caspian willow may have to be abandoned when the fungus is prevalent, which is much to be regretted as this willow thrives on dry soils and has proved useful on railway embankments, sand-hills, \&c.

Melampsora Salicis-Caprea, Pers. is common on S. Caprea, aurita and cinerea, and develops recidia of Ceoma Euonymi, Gmel. on the spindle-tree. 


\section{PART IV.}

\section{PROTECTION AGAINST ATMOSPHERIC INFLUENCES.}

Fonests from the seedling stage up to maturity are subject to the influence of the weather, and may thus be injured in various ways. The chief meteorological phenomena in question are frost, heat, wind, heavy rainfall, hail, snow, rime and ice.

As a matter of course, these phenomena frequently act beneficially on vegetation; frost disintegrates the soil and prepares it for the reception of seed and the growth of forestplants; the wind disseminates the seed of many trees and shakes snow from off their crowns which might otherwise be broken by its accumulating weight; atmospheric precipitation and heat are indispensable for vegetable growth; snow is a bad conductor of heat, it keeps the soil comparatively warm in winter, and protects young plants from frost.

Forest Protection has, however, less to do with the beneficial action of these phenomena than with the damage they may inflict on forest plants, and the means which experience teaches for protecting them. The amount of damage done is conditional on several circumstances. In the first rank are the extent and intensity of the phenomenon, but the season and the state of the weatber during and after the calamity are also of importance. On the other hand, the nature of the wood and locality should be considered; of great importance are the species of tree grown, the system of management of the forest, and the age and density of the injured woods, as different species and age-classes suffer in different degrees from bad weather.

As regards locality, not only the soil and configuration of the ground, but also the nature of the soil-covering may be of importance. Since then, all these items may be combined in a 


\section{4:4 PROTECTION AGAINST ATMOSPHERIC INFI.UENCES.}

great variety of ways, the damage done must vary greatly according to circumstances.

The mode of occurrence of frost, wind, hail and snow should be studied under meteorology, the importance of a thorough knowledge of which to the forester is obvions. Every forester should keep a record of any great damage done by frost, storms, hail, snow, \&c., not only as to its extent, but reference should also be made to all those local and temporary influences which may hare faroured or limited it. 


\section{CHAPTER I.}

\section{PROTECTION AGAINST FROST.}

As regards its distribution, frost may be either widespread or local: as regards season, curly frosts occur in the antumm and late frosts in the spring. Early or late frost may be either ridespread or local. Late frosts are commoner in Europe than early frosts, and chiefly oceur in low lands, early frosts being more prevalent in mountainous regions. The extensive damage done by late frosts is due not only to their frequency, but also to the susceptibility of plants during the revival of regetation in the spring. In the North-West of India, early frosts do most damage, as the bright days and cold nights of November sometimes involve daily ranges of tempcrature of 40 and even 50 degrees Fahr., which are fatal to the sappy shoots of trees.

Winter-frosts in Europe rarely injure indigenons trees, though they may kill unprotected exotic evergreen plants such as laurels, sc. The mild winters experienced in the west of France and of the British Isles, render possible the out-door cultivation of many plants whose natural habitat is further south, and which would succumb to the severe winters of more easterly Emropean countries, as was the case with the common gorse (Sequoia scmpervirens) and many other exotics, in Surrey, in 1895.

Frost damages forest-plants in four ways :-

(i.) By freezing young woody plants or young organs of plants.

(ii.) Splitting the stems of trees.

(iii.) Causing canker in stems of trees.

(iv.) Uprooting young plants.

\section{Section I.-Frozen Plant-Organs.}

.1. External Appearance of Injured Plants.

Frozen plants, or organs of plants, become soft, flexible and bang down or wilt. Whon dead they eventually turn brown or 
black. These outer signs result from the reduced tension of the tissues injured by frost, and from their inability to fulfil their proper functions. Foliage frequently falls prematurely owing to early frosts, a film of ice forming at the base of the petiole, as in robinia and elder, which may become leafless in a few days, the fallen leaves remaining quite green and apparently maffected by the frost. In other trees, as hornbeam, beech or oak, the frozen foliage may die and turn brown, and remain on the tree until the bads swell in the spring, the normal autumnal leaf-fall being prevented by the fact that the leaf is killed before the usual layer of cork which causes defoliation has formed at the base of the petiole.

\section{Explanation of the Action of Frost.}

The death by freezing of plants, or certain parts of plants, is usually due to a rapid thaw rather than to the direct effects of the low temperature to which they have been exposed. This is because, owing to the low temperature, the liquid contents of the affected tissues becomes denser, and a change ensues in them. The cell-sap becoming more concentrated than before, sets free part of the air which it contains; this increases the permeability of the membranous lining of the cell-wall, which loses its powers of resistance to the passage through it of certain substances, and allows the cell-sap to pass into the intercellular spaces of the plant, where it freezes. The injured tissues thus become limp from loss of water.

A similar result happens in the case of frozen starch-paste, in which the water and starch become separated, and will not remite after a thaw. The air which escapes from the frozen ússues may also decompose the chlorophyll, and hence the brown and eventually black colour of the dead organs. If, however, the ice formed in the inter-cellular spaces thaws slowly, the cell-wall may recorer its normal elasticity and reabsorb the water beforc the chlorophyll has decomposed. With a rapic thaw this is impossible, as the water then remains in the inter-cellular spaces, and death ensues.

The effect of allowing the thawcd water to become reabsorbed may be well observed in a meadow after a sharp frost in May, 
when the grass has been in full growth. No bad results follow from the frost, miless men or animals tread on the frozen grass, but wherever they do, the crushed grass appears black and dead, as if singed by a red-hot iron. This is because the crushed tissues will not allow the return of the sap when the thaw sets in. The more water an organ or plant contains, the more it is subject to be frozen. The old theory that plant-cells are split by the freezing of the cell-sap, and consequent expansion of the ice, is not true; in the first place, the cell is not filled with sap, and secondly, the cell-wall is sufficiently expansible to resist an extension of $\frac{1}{10}$ th of its volume, which would be required to prevent its splitting, supposing that it were full of sap and the sap converted into ice. Hartig also states that cortex and bast containing concentrated sap do not freeze so readily as young wood and leaves, which contain a more watery sap, and which, owing to the scarcity of inter-cellular spaces in wood, turn to ice within the lumina of the cell, at the same time depriving the cell-walls of their water and cansing them to shrink.

\section{Amount of Lamage done.}

\section{(a) General Nature of Damage.}

Late and early frosts often lill young plants and destroy the foliage, shoots, blossoms or young fruit of trees. This retards their upward growth, canses a loss of increment and reduction in quantity or complete loss of the crop of fruit; thus the management may be impaired, especially when natural regeneration is desired. Early frosts hinder the complete ripening of the wood, especially in coppice-shoots; by the early fall and lilling of leares forest trees suffer a loss in potash and phosphoric acid, if these substances have not completely returned to the stem, as they do before the normal leaf-fall. Orring to the narrow ammul zones of wood which are formed in years of severe frost, they may be recognized on an inspection of a crosssection of a stem. Frost also causes certain forms of canker in broad-leaved trees.

The physiological effects of serere winter-frost consist chiefly in killing wood which is not fully ripe, and which has been 
spared by the early frosts. In this way, cither the youngest shoots, the autummal woody zone, or the whole annual ring of wood inside the cimbium-zone may suffer and cause cup-shake in wood. Where cup-shinlise is thus ciused, the concentrated sap in the cambium-zone preserves it from damage, while the zone of the saprood next to it becomes so dried by the freezing of the sap within it as to separate partially or entirely from the eambium. Mechanical injuries done by winter-frost will be lescribed further on.

The damage doue under the headings species, organ, system of management, age, locality, soil-corering, density of stock, and weather will each be considered separately.

\section{(b) Sprecies of live.}

As a rule, broad-leaved trees are more susceptible to frost than conifers, and species which prevail in the south suffer more than those from the north. As special conditions affecting the extent of the damage done by frost, the degree of development and power of recovery of the plant are important. 'Thus the oak is much less liable to injury by frost than the beech, as it shoots ont later in the spring.

As regards recovery from damage, the ouk is also more favoured than the beech, for if its leader be frozen, side buds develop new leaders, but the beech having fewer dormant buds camot do this so well. The ouk can also put out a second foliagre during the yenr if the first be frozen, but the beech cannot. Hence wood-formation is less hindered in the oak than in the beech. Similar considerations affect other species.

A classification of woody plants according to their susceptibility to frost is not impossible, but can only be of local value, as the curlier or later shooting out of a tree depends on the altitude, as vell as on the species crrown.

The following list groups trees according to their susceptibility to late frosts :-

\section{rery Frost-tender s'pecies.}

Walnut, ash, sweet chestnut, beech, oaks, ${ }^{*}$ robinia, silver-fir.

* Some North Americen oaks amd asli-trees suller less than European speeies, and pedumenlate oak less than sessile oak; Tmrkey oak is less hardy than either. 
Moderately Frost-tender Species.

Sycamore, Norway-maple, horse-chestuut, lime, spruce, larch, cluster-pine.

\section{Frost-hardy Species.}

Hornbeam, elms, aspen, poplars, willows, species of Pyrus, hazel, alders, birches; Scotch, black, Weymonth, Cembran and mountain pines.

In the case of very severe late frosts, species in the last group, such as the Scotch pine, may suffer, or be killed when quite young.

If the locality be taken into account, as sea-coast, flat, hilly, or mountainons land, some modifications must be made in the above groupings.

In general, local trees which shoot out early are more or less frost-hardy, for instance, the birch, alder, and sallow; frosttender species such as the oak and ash shoot out later in the spring, and the beech, which shoots earlier than either, owes its immunity from frost to its power of resisting cover under which spring frosts do not occur.

The larch, which shoots out early in the spring, suffers in low situations from late frost, and the sessile oak for the same reason suffers more than the pedunculate oak, and is more adapted to resist drought than late frost.

As regards extreme winter-cold the following somewhat different scale applies :-

\section{T'ery Frost-tenter species.}

Sweet chestunt, walnut, plane.

\section{Frost-tender Species.}

Elms, pedunculate and sessile oaks, silver-fir, cluster-pine.

Someithat Frost-tender Species.

Beech, Turkey-oak, Douglas-fir, spruce.

\section{Frost-hardy Species.}

Maples, horse-chestunt, lime, poplars, willows, hornbeam, birch, larch; Scotch, Weymonth, mountain and Cembran pines, juniper. 


\section{(c) Part of Tree.}

The inflorescence, opening leares and young shoots suffer most; the developed leaves and needles less, and least of all the buds. In silver-fir and spruce the damage is nearly always confined to the spring-shoots, the old needles escape, and as in the silver-fir the terminal buds open-ont later than the lateral buds, the latter are more often frozen.

\section{(d) System of Management.}

Coppice, especially with short rotations, suffers more than high-forest, as the susceptible young growtl occurs so frequently. If the cutting of coppice is delayed in the spring, the annual shoots may not be completely lignified before ther are exposed to early frosts. T'le underwood in coppice-rith-standards suffers less than simple coppice, owing to the shelter afforded by the standards. The varions shelter-wood systems constantly afford shelter to young growtl, and are therefore less liable to danger from frost, than the systems of Coppice and of Clear-cutting in High Forest.

\section{(e) Agre of Woorl.}

Woods are most exposed to danger in youth, especially during the sprouting of the seed; a single frosty night at this period may at once annihilate the results of a forester's care. The chief danger continues until the young plants have grown above the local frosty zone. As, however, this varies according to the configuration of the ground, a scale of susceptibility for each species, according to age, cannot be attempted.

Quick-growing species in breezy hilly localities are most favourably situated, while slow-growing tender plants in valleys and plains suffer most.

In the case of widely-spread frosts and exceptionally low temperatures, the leares and shoots of taller trees may suffer.

\section{(f) Locality.}

The following localities are specially liable to injuries by frost :-

(i.) Damp, low-lying places with stagnating air, for instance, narrow, closed-in ralleys, or small depressions in the ground 
termed frost-hollows. In such places, frost-hardy species such as hombeam, aspen, and birch are natmally invasive, whilst the more raluable species become stunted, and there is generally a plentiful coating of lichens on the trees; if the soil is dry, the radiation of the plants cools them, and if it is wet or moist, or there are water-courses or swamps near at land, the eraporiltion of the rater still further reduces the temperature, whilst owing to the absence of air-currents the cold air is not replaced by warmer air from the neighbourhood, and the descent of cold streams of air from above which collect like a lake ores the low ground causes sharply-defined frost-limits.

(ii.) Woods on north-easterly, easterly, sonth-easterly or southerly aspects suffer most from frost; on the two former aspects, becanse, unless sheltered by a hill, they are exposed to cold frosty winds, whilst the sudden exposure to the sun's rays after sunrise increases the danger of easterly aspects. On south-easterly and sontherly aspects, growth begins earlier in the spring than on colder aspects. Northerly and westerly aspects are least exposed to injury by frost.

(iii.) High plateanx are more heated by the sun than lowlands, where the atmosphere is denser; regetation on them is therefore more precocions, but the radiation of heat at night is greater than in lowlands and consequently there is a greater rauge of temperature, while woody plants stand sudden changes from heat to cold worse than intense cold.

As a rule, ralleys, lowlands, and plateanx suffer more from frost than hills and mountain sides.

(iv.) Wet impermeable soils such as cold clays induce low air-temperature. The richer and deeper the soil, the more quickly do plants recorer from freezing and grow ont of the reach of frost.

\section{(g) Nature of Soil-covering.}

A dense and high growth of grass increases the danger from frost, as it prevents the soil from being heated, diminishes the circulation of the air, and reduces the temperature by transpiring moisture and radiating heat. From observations made at Viemheim in Hesse, the temperature orer an area covered with grass may be $16^{\circ}$ Fahr. lower than on a plot of similar 
land bare of regetation. On the other hand a lightly shading growth of birch, sallow, thorns, broom, \&c., will reduce radiation and thus preserve from frost plants of valuable species which may be growing among the woody undergrowth.

\section{(h) Density of Stuck.}

Natural regeneration-areas as well as plantations and sowings under a shelter-wood, which reflects back the radiated heat towards the ground, whilst the croms of the shelter trees prevent rapid changes of temperature, suffer much less from frost than sowings and plantations in the open. Young plants suddenly exposed by the remoral of a shelter-wood are highly susceptible to damage by frost, and large areas of spruce 6 feet in height may be thus killed.

Damage by frost is much less in well-stocked roods than where blanks or thinly stocked places occur. Unrestricted radiation of heat and non-circulation of the air expose such places to frost; in the same way young growth surrounded by tall roods is often frozen.

\section{(i) State of the Weather.}

The clearer the sky during day-time and the brighter the night, the greater is the danger from frost, especially with an east wind. It seldom freezes with a cloudy sky, as then the heat radiated from the ground is reflected back again by the clouds. Late frosts accompanied by rime are more dangerons than black frosts, as the coldness of the air is still further increased by the evaporation of the frozen dew. In a prolonged frost, accompanied by cold dry winds, the frozen twigs may be thied up and killed. A wet autumn generally increases the subsequent bud effects of the winter's cold.

As a rule, in Central Europe, all danger from frost is over by the midule of May, but exceptions may occur, and in 1892 the grass-temperature at Coopers Hill, in Surrey, from the 13th to the 16 th Jume, raried betreen $25^{\circ}$ and $32^{\circ}$ Fahr., so that potatoshoots and bracken were frozen and killed in the neighbourhood. In mountainous regions, late frosts are to be feared till July. In the north of India, night-frosts may occur, on clear nights, from October till the end of March, and they cause considerable 
damage to Síl (Shoreu robusta) and other winter-green and evergreen trees.*

\section{t. Liegister of Serere Frosts.}

In Central Europe, luring the forty-three years from 1848 to 1890 , severe late frosts occurred, on the average, every other year ; the worst years for persistence and severity of these frosts being 1854,1866 , and 1876. Not a single month is absolutely free from frost, not eren July or August. On May 21st, 1894, the foliage of the oak standards in the lower ground of Prince's Coverts, near Esher, in Surrey, was entirely destroyed by frost, whilst much damage was also done to the ash and other underwood; the crowns of the oak trees, which were blackened by the frost, did not become completely green again till the middle of July. A similar event happened in the Forest of Dean on May 29th, 1819.†

In Central Europe, during the present century, there has been one hard winter every five or six years, the coldest year's previous to 1895 being $1823-30$ and $1879-80$, when at Giessen, on the 10th December, 1879, and in February, 1830, temperatures of $31^{\circ}$ and $25^{\circ}$ below zero, Fahr., were observed. The lowest temperatures at Coopers Hill in December, 1879 , were $16^{\circ}$ Fahr. and $10^{\circ} \cdot 1$ in February, 1895. Loughborough is the coldest place in Britain, and its minima on the 8 th, 9th and 10th February, 1895 , were $5^{\circ}, 4^{c}$ and $1^{\circ}$ below zero, Fahr. During 1895 the frost continued at Coopers Hill from January 25 th to February 18th.

\section{Protective Measures.}

Protective measures against frost may be taken during the formation and utilization of roods.

(a) During the Formution of Woods.

(i.) Drain wet places and all swamps in the forest before restocking.

(ii.) Abandon attempts to grow frost-tender species in the open. Such species as beech and silver-fir should not be grown in bad frost localities, and, in any case, should be protected by

* Jany trees in India lose their leaves in the spring after retaining them ilnoughout the winter.

+ "The Forest of Dean," by H. G. Nicholls. J. Murray, London. 1858. 
planting fast-growing hardy trees, such as Scotch pine, larch, or birch beforehand, or simultaneonsly with them as nurses.

(iii.) Natural regeneration under a shelter-wood and keeping seeding-cuttings dark should be preferred, especially on easterly or southerly aspects. Lor-branching shelter-trees should be pruned to promote air-circulation.

(ir.) Strong transplants should be used, plants with balls of earth and mound-planting being preferable for frost localities. On wet ground, ridge-planting may be adopted.

(v.) Protective belts of spruce may be established aloug the easterly boundaries of a wood.

(vi.) Where areas to be restocked are corered with a dense growth of grass or herbage, this should be remored before planting or sowing is attempted.

(vii.) Trausplants should be lifted from the mursery early in the planting season and heeled-in in shady places near the area to be planted, in order to delay their sprouting.

(riii.) Wherever frosts are to be feared in forest nurseries, the following rules should be obserred :-

They should be situated on northerly or north-resterly aspects.

Seed should not be sown too early, say before the 1st of May; it should be well covered.

In autumn, beds of seedlings may be corered with brushwood, and seed-beds with dead leaves, moss, or saw-dust. In spring, brush-wood or shelter-mats may be used. These latter may be placed on light wooden supports and can then be remored and replaced at will.

Smoliy fires may be lindled during the night, the clonds of smoke preventing radiation from the ground. This practice is extensively followed in French rineyards, coultar, or small boxes filled witl refuse resin being burned.

Plants which are corered wich rime may be watered with cold water before sumrise so as to delay their thawing.

(ix.) Tender ornamental evergreen plants may be wrapped up during winter in matting or straw, until they have grown beyond the reach of frosts. 'The so-called hardening of transplants which have been a fer years in the ground is dne to the fact that their roots get gradually deeper into the soil, and conduct 
the heat of the soil to the plants better than superficial roots. Covering the base of transplants with cinder-dirt or clead leaves also protects them from frost.

All parts of plants which in spite of these precautions have been killed by frost, should be pruned, and frozen plants, such as oak-saplings, which have collum-buds, may be cut back level with the ground. Dead conifers and plants like beech, which coppice badly, must be pulled up and the vacant spots replanted with strong transplants.

\section{(b) During the Utilization of Woods.}

(i.) In natural regeneration-fellings, the shelter-wood should be only gradually removed, the final felling being delayed till the plants have grown out of the reach of late frosts. In frosty localities, regeneration-periods will be long-from 20 to 30 years.

(ii.) In the case of clear-cuttings, only small areas should be cleared at one time.

(iii.) A protective belt should be left intact on exposed easterly and north-easterly borders of a wood, at any rate until the young growth which it protects is out of danger from eutting wind's.

(iv.) Coppice-fellings must be effected in the spring; if made in autumn, winter-frosts would injure the stools; they should also run from west to east, so as to protect the young growth from cold winds; this precaution is specially necessary for oak coppice, as frozen oak-shoots thaw rapidly when exposed to the rising sun.

\section{Section II.-Frost-Crack.}

1. External Appearance.

Frost-craclis are long splits caused in stems by winter-fiost, which start at the bark and proceed radially and more or less deeply towards the centre of the tree. 'I'hey are frequently followed by the formation of projecting longitudinal ridges on the stem of an affected tree, which are termed frost-ribs.

\section{Explanation.}

Frost-craclis are due to the contraction of the wood along its periphery owing to extreme cold. 
It has been prored by actual measurement, that the girth of a tree is lessened during rapid and serere frost. The contraction of the wood, the reasons for which have been explained in the preceding section, commences at freezing point and increases as the mereury falls, but the stem recovers its original dimensions during a thaw. For a tree to crack, howerer, there must be a rapid fall of temperature, so that the external layers of wood shrink more than the central zones, which are liept relatively warm by heat conducted from the soil by the roots. In conse-

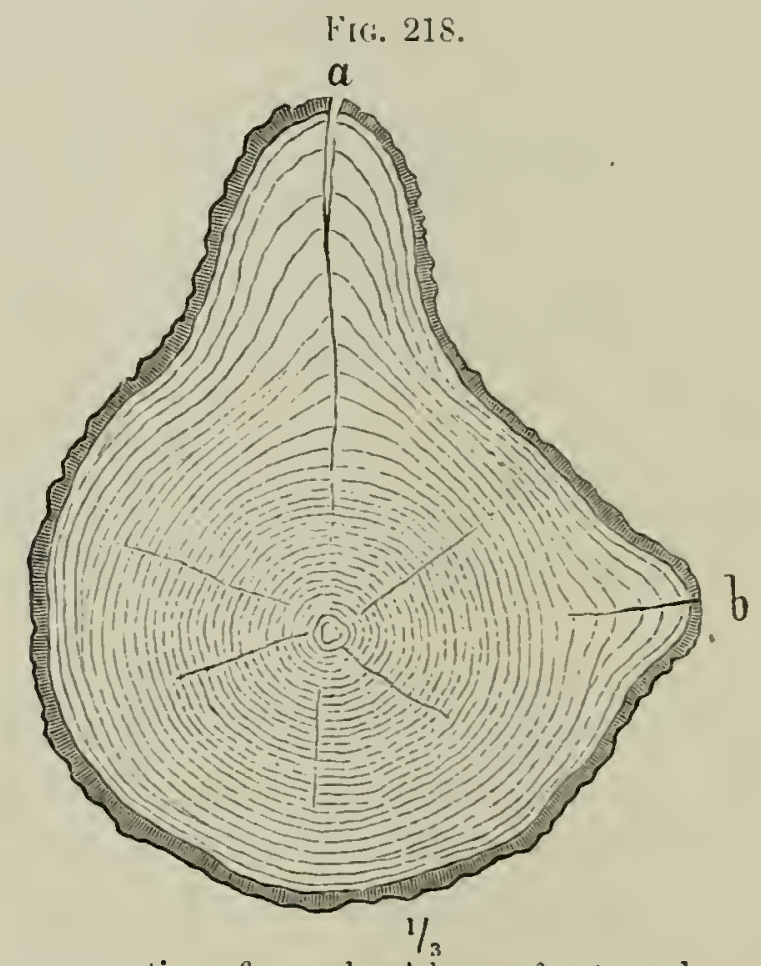

Transverse section of an oak with two frost-cracks, a and $h$.

quence of this circumferential shrinking of the onter zones of the wood, they can no longer enclose its unshrunken central portion, and the outer zones therefore split radially and longitudinally, the erick thus forned penetrating more or less deeply towards the centre of the tree.

The expansion of the sap which flows into the crack and freezes, also assists in further splitting the tree and in extending the crack to the centre. Most frost-cracks ocenr on cold nights, between milnight and 8 a.m., when the temperature is lowest and the contraction of the wood is consequently greatest; the split is accompanied by a noise like a pistol-shot. Frost-craclss may, howerer, also occur before midnight or eren 
soon after sunset, when unusually mild weather on a clear, sunnywinter's day, is followed by a cutting and extremely cold east wind.

Frost-cracks may attain lengths of from sixteen to twenty feet along a stem. They close again with the rising temperature, after the ice which has formed in the wood has thawed, and new zones of wood form over the wound ; this new wood is, howerer, so soft that the crack frequently opens again in succeding winters, year after year, when owing to the reduced tension of the tissues along the line of the crack, an abnormal annul growth of wood occurs, causing the characteristic frost-rib as shown in fig. 218.

A frost-crack may sometimes close up completely, owing to a succession of mild winters.

\section{Damage done.}

(a) In general.-The timber of trees cracked by frost is of reduced technical value, and secondary damage by insects or fungi may supervene.

(b) Species.-Hard woods with large, medullary rays are most subject to frost-crack. Deep roots also farour it, as they pass into zones of soil which are only slightly affected by the airtemperature and thus keep the stem comparatively warm. This difference of temperature between the outer and inner zones of the rood of a tree increases its liability to crack. Oak. beech, walnut, sycamore, elm, ash and chestnut are the trees most subject to frost-crack, and Turkey and sessile oaks more than pedunculate oak. The sap which pours from the wound after a thaw, turns dark brown and betrays the injury which the tree has received. Frost-cracks also occur in the case of soft woods, such as the horse-chestnut, lime, poplars and willows, and less frequently on conifers, and then chiefly on the silver-fir or spruce.

(c) Part of Tree.-Frost-cracks usually occur in the lower part of the stem of a tree, especially at places where the growth is uneven near the root-stock, at knots, or where the stem is eccentric. Splitting is furthered by local rounds, and is very common in the case of coppice-shoots which have been allowed to grow into trees, and which are always unsound at their base. Splits from the root-stock proceed upwards and from a knot 
downwards; on eccentric stems, they are always towards the largest diameter.

In the case of stems of a regular shape, the south side suffers most from frost-crack, and then the north and east sides, the westerly side suffering least of all. The south side suffer's most, because the most vigorous circumferential growth takes place there, and the tissues are consequently very sappy.

(d) Systems of Management.-Standards over coppice suffer most, as they are exposed to cold winds, whenever the underwood is felled. Standards in high forest which are exposed after growing in a dense wood are also very liable to frostcrack.

In the Kiottenforst, near Bonn, an area of 7,400 acres at an altitude of 426 feet, where the treatment is that of coppice-with-standards, and the soil clay with an impermeable substratum, over twenty per cent. of the oak standards are frost-cracked. Frost-crack is also very prevalent in the seventy to eighty-year-old oak-woods in Windsor Forest, owing to the absence of underwood, and it is also extremely common in the open parts of the Forest of Dean, where the underwood has been browsed down by sheep.

(e) Age of Tree.-Large old trees, as a rule, suffer more from frost-crack than younger trees, because the differences in temperature between their outer and inner woody zones are greater.

(f) Locality.-Fertile and moist soils favour frost-crack. It is very frequent in narrow valleys along water-courses, where the night temperature falls exceptionally low in winter.

(g) Season.-Frost-cracks generally occur late in the winter, when the sap begins to flow, prorided intense cold should set in. The sapwood then rapidly cools and contracts, while the inner zones of the rood retain a higher temperature. Long protracted and gradually falling temperatures are not so dangerous. Storms increase the dauger by blowing the frozen stems backwards and forwards; Hess even considers it probable that storms may occasion frost-cracks at the commencement of a thaw, but as the outer zones of the wood would then be expanding, whilst the inner zones remain cold, a enp-shalic, or separation of the wood along a portion of the whole of an anmual ring, would probably result. 


\section{Protective Rules.}

(i.) Thoroughly drain wet soils.

(ii.) Keep up the density of woods, and underplant all pure oak high forests with a shade-bearer, such as beech or silver-fir.

(iii.) Establish protective belts of spruce along the norther'n, eastern, and south-eastern boundaries of a wood.

(iv.) Abandon the practice of reserving oak and other standards in places where frost-crack is common.

\section{SECtion III.-Frost-Canker.}

Caukers may be caused by frost among young broad-leaved species, such as oaks, ash, maple, beech, fruit-trees, \&c., which have not yet grown above the local frost-level. Thus, at the base of a young shoot, which has been repeatedly frozen down to the main stem, the living bark separates from the dead wood. A callus forms round the wound in the growing season, but is frozen on the recurrence of severe frost, and as, in frost-hollows, this may happen annually, a canker is thus formed, and the wood may be killed down to the pith, on the side from which the branch arose. These cankers are formed near the root-stock of oaks and ash growing in depressions on stiff clay soil; they may be distinguished from others caused by fungi, as they increase in size only after severe frost.

Frost-cankers on Shorea robusta are very common in frosty depressions in Northern India, the shoots being killed down to the ground annually until an abnormally large flattened stool is formed. Coppice-shoots of a variety of sweet chestnut from the south of France are also similarly frozen down in Alsace, while the common rariety of the tree produces splendid coppice-poles.

\section{Section IV.-U Uprooting of Seedlings by Frost.}

\section{General Account.}

During February and March, when night-frosts alternate with thaws in the day-time, it is often found that young seedlings are raised with the soil, and in the subsequent thaw,

VOL. IV. 
when the soil sinks back again, their roots lose their hold on the ground, and the plants fall over and die.

Fig. 219.
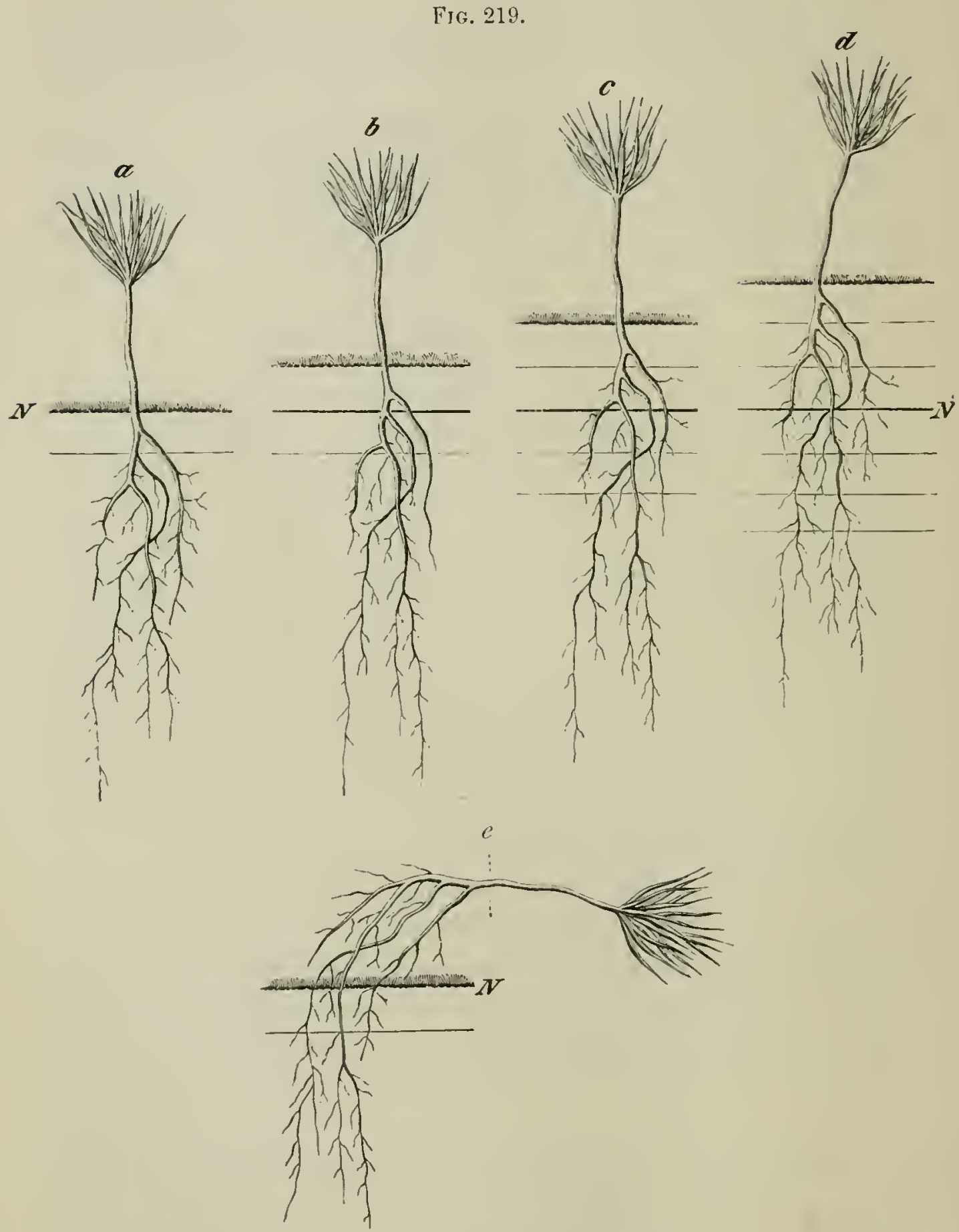

Spruce seedling $(a)$ raised $(b)(c)$ and $(d)$ and uprooted by frost $(e) . \quad\left(\lambda^{-}\right)$original ground-level.

In such cases the surface-soil is raised by the conversion of the water in it to ice-crystals, and the little seedlings are thus 
lifted above their original position. When the thaw sets in, and the soil gradually softens and returns to its original level, the plants cannot do so, as their roots are in the deeper and still frozen soil, while the surface-soil is thawing; when, therefore, the soil has completely thawed, the plants lose their root-hold and fall over, as shown in fig. 219.

\section{Damage done in Particular Cases.}

(a) Species and Age of Plant.-Nearly all woody plants may be uprooted by frost during the first two years of their life, and especially those of shallow-rooted species, such as spruce, birch, alder, beech, hornbeam, \&c. Even ash, sycamore and silver-fir are not unfrequently uprooted in this way. Sweet chestuut, hazel and oaks escape this form of injury on account of the depth to which their tap-root descends during germination. The greatest damage is done in nurseries to seed-beds and beds of transplants, and to sown areas in forests.

(b) Locality.-Certain soils and localities suffer more than others in this way. Thus, provided they are moist, light, loose soils, such as peat, sand, marls and loam, are most exposed to frost-lifting. Dry sandy soils do not suffer. As a rule, the finergrained a soil is, the more water it absorbs, and plants are therefore more easily lifted in such soils, whilst in coarse-grained, sandy soil, the water descends, and the surface is therefore not subject to lifting. Soil bare of herbage is also more easily lifted than soil which is kept down by the roots of grass and weeds.

As regards locality, deep depressions suffer most, as there is then less chance of the moisture draining away. Warm aspects, except resterly ones, suffer most, as, on them, thawing and freezing follow one another most frequently; northerly aspects hardly suffer at all from frost-lifting.

\section{Protective Rules.}

(a) For the Forest.-Drain away all superfluous moisture by open drains; drain-pipes may be used in nurseries. Planting should be preferred to soring, and ball-planting is the best security against this evil, while spring-plantings suffer less than autumn-plantings. Where sowings are adopted, oats may be mixed with the seed, which should be sown rather densely. 
(b) For Forest Nurseries.-Mix 25 to 33 per cent. of clay with fine sandy soils. Raise the seed-beds so as to secure good drainage. Sow deeply and densely, and cover the spaces between the drills or rows of plants with straw, dead leaves or sawdust, all of which are bad conductors of heat; even cinderdirt mixed with sand may be used; this delays thaws. After weeding between the rows of plants, fill-in with good soil all inequalities thus produced in the beds.

It is advisable in autumn to leave a few weeds in the beds, as their roots give coherence to the soil. Any plants which have been uprooted by frost, should be at once replaced, and fine soil placed round them. This is not an expensive operation if boys are employed, and only costs from threepence to fourpence per thousand plants. 


\section{CHAP'TER II.}

\section{PROTECTION AGAINST INSOLATION.}

Insolation may dry up seeds and young plants, or twigs and branches of trees, and may also scorch or crack the bark and wood of trees.

\section{Section I.-Drought.}

\section{Appearance and Canse of Injury.}

Woody plants and parts of them which have been dried by the sun, have much the same appearance as if they had been killed by frost; blossoms, leaves, needles and young shoots first wilt, then gradually turn brown and shrivel up; they finally fall off, although dried leaves may remain for a long time hanging on the trees.

This drying-up of leaves and shoots is the direct result of prolonged hot, dry weather, which abstracts much moisture from plants and from the soil; transpiration being thus greatly increased, plants pass off more watery vapour into the air than their roots can absorb from the soil, which becoming continually drier is less able to meet their demands.

\section{Damage done.}

(a) In Genercl.-Owing to the want of the necessary moisture in the soil usually caused by high degrees of heat, seeds may be prevented from germinating, and young seedlings killed. In the case of older plants the foliage dries up and falls prematurely, the younger shoots may be killed, and the annual wood-increment may be considerably reduced. Occasionally single stems, or groups of poles may be killed by insolation; this is frequently the case with beech-standards, which after growing in a dense wood are exposed, as mother-trees, in seeding-fellings. 
Dry years, as well as frost-years, may be chronicled on the transverse sections of stems by the formation of narrow zones of wood, and Henry* states that in 1893 the trees in Lorraine only produced $30-76 \%$ of their normal increment. Ebermayer ${ }^{\dagger}$ quotes sereral analyses of leaves taken from trees during different months of the year, which prove that an early leaf-fall, due to drought, deprives trees of much nitrogenous matter and phosphoric acid. This loss interferes with the subsequent production of seed, for which a reserve of these substances is so essential. Thus, an analysis made by R. Weber at Aschaffenburg, in 1872, gives the following:

Phosphoric Acid in ash, 品.

Young leares on 2ud May, 1872 . $\quad$. $\quad 23 \cdot 89$

Fallen autumnal leaves of same tree . . $5 \cdot 90$

Another analysis by Rissmüller, made in Munich in 1874, shows that in May, thoronghly dried beech-leares contain 28.2 per cent., and in November only 7.8 per cent. of nitrogenous compounds, whilst in July and August the per-centage is about half-way between these extremes. Similar figures hold good for the leaves of other forest trees, and it is therefore evident that nitrogenous matter and phosphoric acid pass back in the autumn from the leaves into the twigs, and that if the foliage should fall prematurely, the trees must lose a quantity of these valuable substances.

Other secondary dangers caused by drought are a greater liability of trees to insect-attaclis, and increased danger from forest fires.

(b) Species.-The relative susceptibility of trees when very young to be injured by insolation is shown in the following groups :-

\section{(i.) Very Susceptible Species.}

Beech, ash, sweet-chestnut, silver-fir, spruce.

(ii.) Susceptible Species.

Hornbeam, sycamore, alder, birch, larch, Cembran pine.

* Rerue des Laux et Forêts, 1895, p. 35.

† Ebernayer; Waldstreu. Berlin, $18 ; 6$. 


\section{(iii.) Fairly Hardy Species.}

Elms, limes, Scotch pine, Sorbus.

\section{(iv.) Hardy Species.}

Oalis, field-maple, horse-chestnut, robinia, planes, Prumus and Pyrus species, poplars, willows, black and momtain pine.

(c) Age of Tree.-Sowings and plantings in the open are most exposed to damage during the early years of their life, until they have completely corered the ground. On poor. shallow soils, and in hot places, without lateral shelter, plants aged up to twelve or fifteen years may die from drought. It has been observed that older transplants on weedy ground suffer more from drought than younger transplants on fresh clearings: as in the latter case dew and rain have more access to the soil. When once a plantation has closed-in, so as to cover the soil completely, the chief danger from drought is over; but spruce poles have been occasionally killed by prolonged drought.

(d) Locality.-In plains and hilly lands, the danger from dronght is greater than in mountains, where the most extensive forests are found, as damper air, more frequent precipitations and moister soil prevail. Small flat hills and narrow ridges suffer most of all. As regards aspect, the southern and southwestern slopes suffer most from drought, and the northerm slopes least of all. In very narrow valleys which have been cleared of trees, or are scantily wooded, the reflection of the heat from side to side greatly increases its effects, and rows of houses have the same effect on street-arenues. Woods growing on calcareons soils, and especially on stony superficial soils above calcareous rocks, suffer most from heat, then those on stift clays, whilst sandy soils are more farourable as regards drought, especially when the gruins of sand are fine; roods on sandy loams and loams stand drought best of all. This is due to the following causes: poor shallow calcareous soil is not retentive of moisture, while the porous rock beneath it drains away water rapidly from the surface; marls and clays become hard when exposed to heat and crack in all directions; coarse sands suffer more than fine sands on account of the greater capillarity of the latter, which attracts water from below; loams readily absorb rain, dew and snow-water, and retain moisture in the subsoil, 
and can, therefore, easily replace the loss of the surfacewater.

(e) Soil-covering.-Weeds, and especially a dense tall growth of grass increase the dangers of drought, filling the soil with their roots and absorbing and transpiring its moisture, which would otherwise be arailable for the woody plants growing in or above the grass. A light covering of isolated shrubs, on the contrary, may prove beneficial by shading the valuable species.

Leaves and moss on the surface of the ground shelter the roots of trees from the sun.

(f) Density of Stock.-Woods in which the trees stand somewhat far apart from one another, suffer more from drought than well-stocked woods. Isolated,

FIG. 220 .

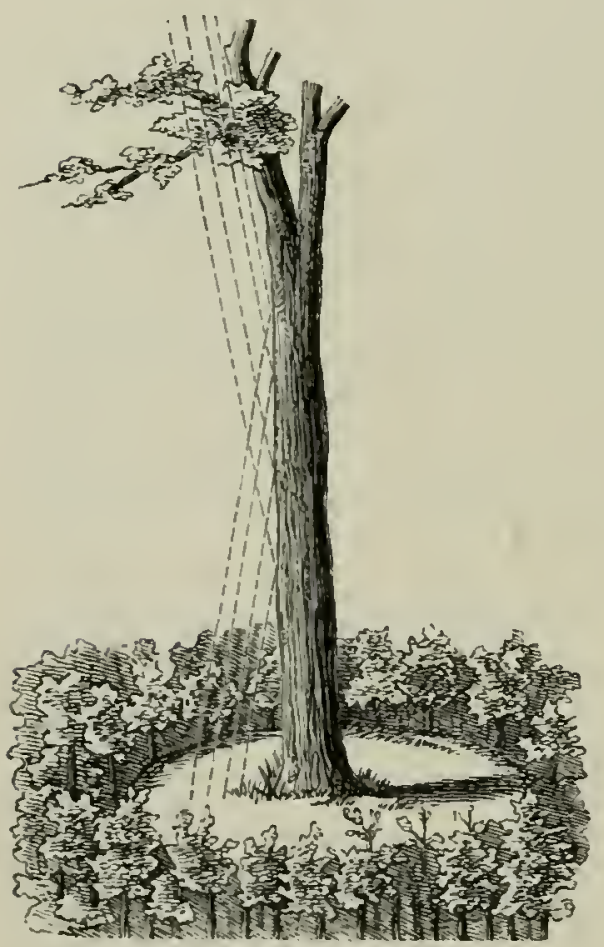

Damage to young growth by reflected heat. clean-boled standards with smooth bark, such as beech, hornbeam, birch, silver-fir, reflect the rays of the sum on to the soil, as shown in fig. 220 , and thus dry up the soil around them; young natural-regeneration may fail completely around such trees.

(g) Wreather and Seuson of the Year.-The drying-up of little plants owing to drought may be recognizable early in the summer. A dry May with a continuance of cutting east-winds soon disperses the moisture in the soil which has accumulated during winter, and if there is insufficient rain in June, many plants on areas recently sown or planted may be killed. If the dry weather should continne throughout July, more damage will be done, and it is generally from the middle of July till the middle of August that the plants die, for the maximum summer-temperature is attained at about a month after Midsummer-Day. From the beginning of September, young plantations and sowings which have hitherto escaped may be considered out of danger from drought. 
In India, the period of the dry season varies, being interrupted by about one week's winter rain in the Punjab, whilst there is scarcely any winter rain in Bengal and none in Assam, where it is dry from November till April, the spring rains in April preventing any serious drought. In the North-West Provinces and the Punjab, May and June are the hottest and driest months, the summer monsoon lasting generally from July to September and into October in Assam.

\section{Register of Dry Years.}

During the present century, the following have been years of drought in central Europe: 1800, 1807, 1811, 1812, 1822, 1834, $1842,1846,1857,1858,1859,1863,1865,1868,1874,1876$, $1881,1883,1889,1893$; or, on the average, one year in fire. To give a local example, the monthly rainfall and maximum temperature observed in 1893, at Coopers Hill College, Surrey, are here given.

\begin{tabular}{|c|c|c|c|c|c|c|c|}
\hline \multirow{2}{*}{ Moхтнs. } & \multicolumn{3}{|c|}{$\begin{array}{l}\text { RaINFald IX } \\
\text { LNChES. }\end{array}$} & \multicolumn{3}{|c|}{$\begin{array}{l}\text { Arerage Max. } \\
\text { TEMPrRature } \\
\text { IX Defrees Fahr. }\end{array}$} & \multirow{2}{*}{ REMARIis. } \\
\hline & 1593. & $\begin{array}{l}\text { Arer- } \\
\text { ages } \\
1875-92 .\end{array}$ & $\begin{array}{c}\text { Diffe- } \\
\text { rences. }\end{array}$ & $15 ! 3$. & $\begin{array}{c}\text { Aver- } \\
\text { ages } \\
1575-92 .\end{array}$ & $\begin{array}{l}\text { Difte- } \\
\text { rences. }\end{array}$ & \\
\hline January & $1 \cdot 29$ & $1 \cdot 98$ & $-\cdot 69$ & - & - & - & 3in. of the March rainfall \\
\hline Februiry.. & $3 \cdot 07$ & $1 \cdot 70$ & $+1 \cdot 37$ & - & - & - & fell on the first 5 days of \\
\hline March & -38 & $1 \cdot 52$ & $-1 \cdot 14$ & $55 \cdot 4$ & $47 \cdot 1$ & $+8 \cdot 3$ & the month, about sin. feli \\
\hline April & $\cdot 12$ & $1 \cdot 77$ & $-1 \cdot 65$ & $63 \cdot 6$ & $53 \cdot 2$ & $+10 \cdot 4$ & on the 12 th July, and $2 \cdot 5 \mathrm{in}$. \\
\hline May ............... & 76 & $1 \cdot 92$ & $-1 \cdot 16$ & $66 \cdot 4$ & $59 \cdot S$ & $+6 \cdot 6$ & on the 10th October. \\
\hline June & $\cdot 75$ & $2 \cdot 2 \cdot 2$ & $-1 \cdot 47$ & $73 \cdot 6$ & $66 \cdot 3$ & $+7 \cdot 3$ & The temperature wasabove \\
\hline July ................. & $2 \cdot 14$ & $2 \cdot 72$ & -58 & $67 \cdot 4$ & $68 \cdot \bar{T}$ & $\mid-1 \cdot 3$ & $80^{\circ} \mathrm{F}$. on the 21 st $A$ pril, on \\
\hline August $\ldots . . . . .$. & $1 \cdot 35$ & $2 \cdot 38$ & $-1 \cdot 03$ & $72 \cdot 4$ & $68 \cdot 8 *$ & $+3 \cdot 6$ & 4 days in June, 5 days in \\
\hline September ...... & $1 \cdot 01$ & $2 \cdot 26$ & $-1 \cdot 25$ & $68 \cdot 1$ & 61 & $+4 \cdot 1$ & July, S days in Allgust, \\
\hline October ........... & $6 \cdot 10$ & $* 2 \cdot 61$ & $+3 \cdot 49$ & - & - & - & and once in September, the \\
\hline November ...... & $1 \cdot 84$ & $2 \cdot 54$ & -70 & - & - & - & maximum being $1 \mathrm{~S}^{\circ}$, on \\
\hline December $\ldots$. & $3 \cdot 00$ & $2 \cdot 01$ & +99 & - & - & - & the 19th August. \\
\hline Totals ....... & $21 \cdot \$ 1$ & $25 \cdot 63$ & $-3 \cdot 8 \cdot 2$ & & & $*$ For 1 & 17 years only. \\
\hline
\end{tabular}

All farms on the shallow soil above the chalk suffered greatly from drought, and there was scarcely any hay, and corn was very short in stalk. As regards the effects on forest growth, there was an enormous crop of acorns and sweet chestnuts. All the lime blossom fell without maturing fruit, and isolated 
beech, elm and lime-trees lost most of their foliage in August. The heary fall of rain in February and the first few days of March soaked the ground so thoroughly that a plantation of twenty acres of three-year-old Scotch pine transplants $(5 \mathrm{ft} . \times 5 \mathrm{ft}$.) on the Bagshot sauds, in Wiudsor Forest, was a complete success, in spite of the drought.

\section{Protective Rules.}

(a) Inring the Formation of Woods.

(i.) Natural reproduction is preferable to artificial sowing, or if it cannot be carried out, choose deep-rooted strong transplants and cover the planting spots with sods or large stones. Nursery transplants, when planted out in the forest, stand drought better than seedlings taken directly from the seed-beds. Coniferous plants taken from the nursery with balls of earth round their roots, stand drought less well than strong wellrooted transplants; mound-planting also gives bad results in very dry years, and it may then be necessary to plant out spruce only under shelter of birch or Scotch pine nurses.

(ii.) The soil should be deeply trenched, and sowing, or planting of yearlings, should be carried out simultaneously with the growth of al crop of oats, or buckwheat, which will shelter the young plants till the autumn; the deeply trenched soil enables scotch pine seedlings to form deep roots, and soil which has been well worked parts with moisture less ireely, and is more hygroscopic than a compact soil. In years of drought and on poor dry soils, moss should be placed between the lines of sowings; this costs about $\mathfrak{t} 1$ an acre.

(iii.) In hot countries, planting should be done at the very commencement of the monsoon, and sowing is often preferable, as many plants, such as teak, form very long tap-roots immediately after germination. Planting may also be done by means of plants grown in small bamboo-baskets, which soon rot and allow the roots to spread in the soil.

(b) Rules for Nurseries.

(i.) Subdivide the area of the nursery br narrow evergreen 
hedges, or provide temporary side shelter by mats; these precantions are especially necessary for spruce.

(ii.) Trench the nursery-beds deeply in antumn, and manure with compost, or burned sods; this not only keeps the beds free from weeds, but also promotes the development of strong fibrous roots.

(iii.) Transplant yearling plants, especially of spruce, into nursery-lines.

(iv.) Nursery-beds of seedlings may be temporarily protected by sticking branches into the ground on the sonth side of the beds or all round them, or by covering them with mats, supported by a frame-work, 4 to $6 \mathrm{ft}$. high, as in protecting plants against frost. The mats may be removed during showers. and only placed over the beds at the hottest time of day, from 11 A.x. to 3 P.x. Such shelter should also be withdrawn in the antumn in order to harden the plants. Where branches are used to protect plants from the smu, Scotch or Weymouth pines are preferable, as broad-leaved branches soon have their foliage shrivelled, and spruce needles fall off', while silver-fir foliage is too dense.

(v.) Teep the beds free from weeds, as weeding prevents the soil from caking, and renders it hygroscopic; for this purpose the spaces between the plants should be hoed in hot summers, even if there are no weerls. Soft earth may be placed on either side of the rows of plants, when the beds are weeded.

(vi.) The plants may be watered, or irrigated; it is best to water in the evening, and when watering has been commenced it must be repeated from time to time till rain falls, as it encourages the formation of superficial rootlets, which would soon die should the beds become too diry. On this account the beds should be watered only when absolutely necessary. The crust of earth on the surfice of the beds, che to watering, must from time to time be broken up with the hoe. An account of nursery-irrigation is given in Schlich's Sylviculture.

\section{(c) Tiules for T'ending IVoods.}

All epicormic branches must be proned from standards

* Mamual of Forestry, vol. II., 1. 100. 
reserved in high forest, or over coppice, as they keep rain and dew from the young plants, and render the standards stagleaded. The standing-crop should be kept as dense as possible, and the natural soil-covering preserved. Trees along the boundaries of a forest, or along roads, should be kept dense, and the onter row be allowed to branch down to the ground, so as to exclude dry hot winds from the forest. A series of horizontal trenches may be dug along dry slopes, in order to retain the rain-water.

\section{(d) Rules during Utilisution of Woods.}

The seeding-cuttings on poor dry soils should be kept dark, but at the same time, after a good crop of seedlings has sprung up, the plants should be rapidly or gradually exposed according to their demands on light so that they may get the full benefit of rain and dew, and develop rapidly. All isolated smoothbarked mother-trees should be felled, and the bare patches round their stumps planted up. Small narrow felling-areas should be established, rumning from north-west to south-east, as far as this can be done withont danger firom storms, so that the young crops may get lateral shelter from the old wood to the south-west of them.

\section{Section II.-Barli-Scorching.}

\section{External Appearance.}

The name barli scorching* denotes a well-known malady of trees, which generally occurs on the western or south-western sides of stems and in directions intermediate to them, the W.S.W. side being the commonest seat of injury, while it only exceptionally happens on the southern side of a tree. This injury is first rendered visible by the drying up of the bark of affected trees, which assumes a reddish colour, and then gradually splits lengthwise and horizontally from the stem, and fills off in pieces. The injured sapwood turns brown, the brown colour fading gradually towards the still sound wood, and dry

\footnotetext{
* The term bark-scorching is used in Somerville's translation of Hartig's biseases of 'Trees, and is a better term than bark. blister, which laas already been ipplied to diseases caused by fungi.
} 
rot spreads in a wedge-shaped manner in the wood which has been exposed by the loss of its bark.

\section{Explanation.}

Bark-scorching is the result of powerful insolation. If the sun beats directly on a stem, its west and south-rest sides become considerably heated. The southern side of a tree is

FIG, 221.

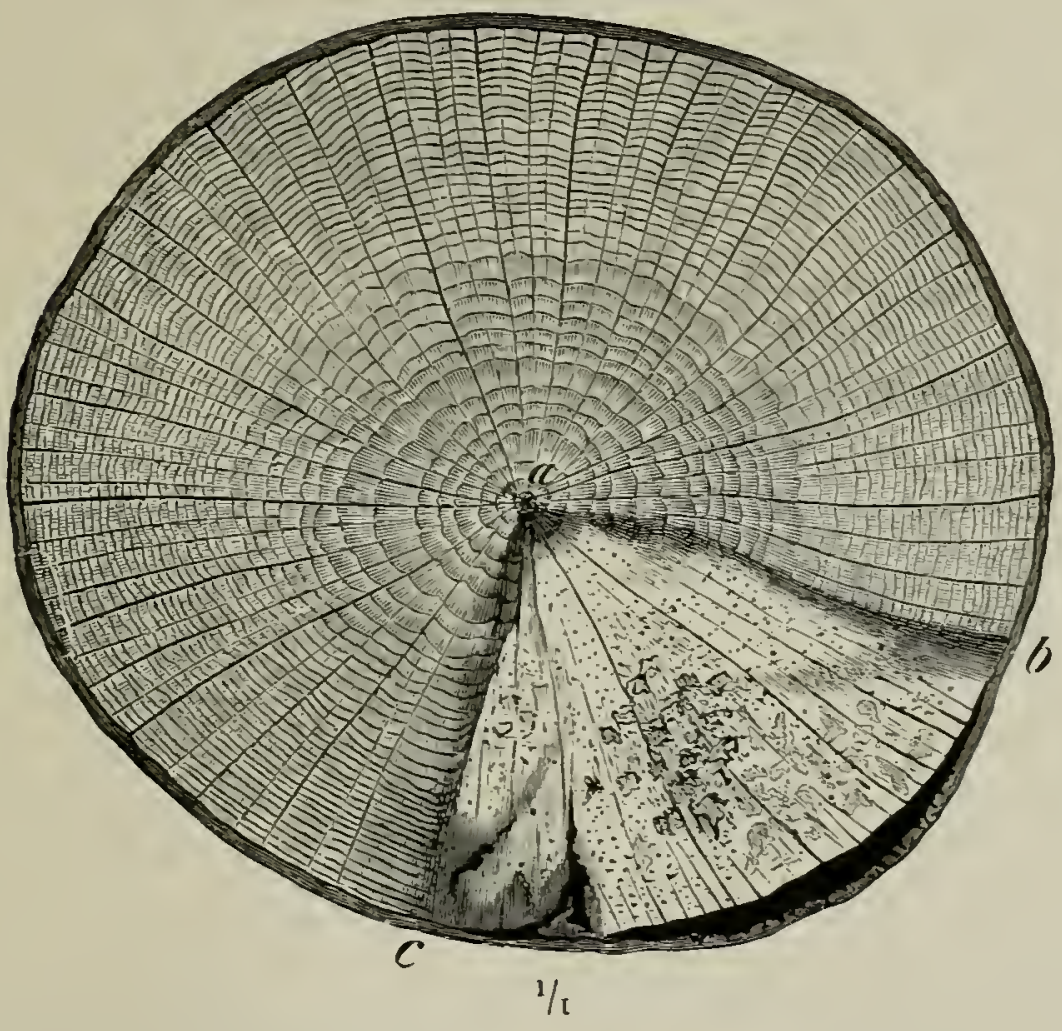

Transverse section of $a$ beech affected by bark-scorching, cut 12 feet above the ground. The damage is limited to the sector $a b c$.

less heated owing to the frequent easterly winds, which blow during hot anticyclones when the sky is clear, and skim past the southern side of trees, and reduce the temperature of their bark and saprood on that side, whilst the W.S.W. side of the tree is not affected by the east wind. This explanation is confirmed by the fact, that when the southern side of a tree is scorched, it has been found to be sheltered from easterly winds by an adjoining dense wood. The greater effects of the sun's rays on the W.S.W. side of a tree are also dne to the fact 
that the maximum daily temperature is in the afternoon, when the sun has passed the meridian, and that the lower the sun is, the more direct are its rays in the radial direction of the stem, and the more intense are their effects.

Tonhausen found that the maximum temperature on the W.S.W. side of a tree, between its bark and saprood, was $120^{\circ}$ Fahr. when the air-temperature was $91^{\circ}$ Fahr., while in Bavaria, on the 18th August, 1892, with an air-temperature of $96^{\circ} \cdot \mathrm{S}$ Fahr., Hartig observed a temperature of $131^{\circ}$ Fahr. between the bark and saprood of some isolated 80 -year-old spruce trees. Cambium cells of European trees camot withstand temperatures between $104^{\circ}-130^{\circ} \mathrm{Fahr}$. any better than leaves and herbaceous shoots, which are speedily lilled by such temperatures.

\section{Damarge done.}

(a) In general.-This malady reduces the techmical ralue of the stems and frequently kills a tree. The forest-owner thus suffers a loss of timber and increment, to which may be added langer of breakage and of insect-attacks, and exposure of young growth requiring shelter.

(b) Species.-Bark-scorching chiefly affects trees with long persistent smooth bark, which is free from cracks, such as beech, also hormbeam, ash, sycamore, lime, sweet-chestunt, cherry, mountain-ash and apple. Among conifers, Weymouth pine and spruce suffer. Coarsely fissured-barked trees, such as elms, oalis, Scotch pine and larch, never suffer in this way, nor does the parchment-like barked birch. I)ad fissured bark is a bad conductor of heat,* and does not therefore become heated like smooth bark, and affords protection to the cambium and bast against the sun's rays.

(c) I'art of the 'Tree.-Bark-scorching only affects the clear bole of a tree, and generally its lower part from the base upwards. The portion of the stem which is immediately above the root-stock suffer's most where there is no underrood, owing to the heat reflected from the ground; the taller the stem and the higher the crown above the ground, the more exposed is a

* Hartig states that in September, with an air temperature of $69.5 \mathrm{~F}$, the temperatures on $S . \mathrm{K}_{\text {. }}$ side of thin-barked hech and spruce were $98^{\circ} 6^{\circ} \mathrm{F}$. and S.2 $4^{\circ} \mathrm{F}$., while that of Scotch pine was $65^{\circ} \mathrm{F}$. 
tree to scorching. Large lnots or low branches localize the injury to the part of the stem which is below them, and stems covered with moss or lichens resist insolation, and so do trees which are branched down to the ground.

An example of the bad effects of pruning trees exposed to insolation may be seen in the Mirwart Estate in the Belgian Ardennes, where a number of spruce trees planted to give shelter along the eastern side of a meadow have been pruned of all their lower branches, and are all badly scorched.

(d) Age of Tree.- The trees mentioned above are exposed to injuries by bark-scorching from the age of poles upwards, but large trees suffer more than smaller ones; the latter, owing to the greater curvature of their stems, do not receive so much direct heat as the former, and they radiate heat more freely than large trees. In forests where bark-scorching is frequent, 60 to 70 -year-old beech trees suffer most.

(e) Position of 'Trees.-Bark-scorching only attacks trees standing in the open, and especially those which have been recently exposed, after standing in a dense wood; also trees along the westerly and south-westerly boundaries of a forest. Trees forming a dense leaf-canopy are never attacked, as their bark cannot become heated like that of exposed trees.

(f) Sundry causes farouring Bark-scorcling.-The locality and its surroundings, and the nature of the soil-covering, may be here considered. As westerly and south-westerly aspects are most exposed to danger, any woods forming protective zones in these directions prevent or reduce the effects of insolation. Undergrowth and soil-covering are also useful, as the reflection of the sun's heat from the ground is much greater when the soil, and especially calcareous or sandy soil, is fully exposed. The malady is most frequent during the hot months in beech forests.

\section{Protective Rules.}

(a) Avoid fellings by which beech- or spruce-woods may become exposed to the west or south-west.

(b) Mix oak, elm, birch or conifers with beech.

(c) Allow the trees on the western and sonth-western border's of it beech or spruce forest to branch freely down to the ground; 
this may be secured by making timely thinnings in young woods.

(d) Avoid high prunings in the case of beech standard-trees, or any pruning of beech or spruce trees growing in hedgerows.

(e) Protect the soil-covering of dead leaves, moss, Sc., and preserve the undergrowth along the borders of a forest.

(f) For the protection of specially valuable arenue trees, their bark may be smeared with a mixture of whitewash, clay and water, cow-dung and water, sc.

Trees which have been scorched should not be removed, as they shelter trees behind them which would otherwise be attacked; it is better to form a protective belt of some shadebearing species, and not to remove the injured trees till this has attained a sufficient height.

\section{Section III.-Heat-crack.}

Beling states that cracks in trees have been caused by insolation; this happens in the spring (April and May), when there are considerable differences between the day- and nighttemperatures, and the ground being still cold, the centre of the tree does not expand so much as the bark. Cracks are thus formed on trees standing on southerly or south-westerly slopes, chiefly on beech 30 to 70 years old, but also on sycamore, hornbeam, oak and ash. The splits extend up the stem from near the level of the ground to 20 and more feet in height. Owing to the drying and loosening of the bark, local decay may be introduced into the wood, but small cracks usually close up again without any permanent injury resulting.

Schlich observed in the early part of 1895 , during severe frost, that the bark of beech-standards cracked or split when the sun rose in the morning. All such cracks or splits occurred in the south-east or south side of the trees, the cracking being followed by an outflow of sap. Trees which had thus been injured in previous years showed a considerable amount of decay in the wood, having the appearance or bark-scorched trees. 


\section{CHAPTER III.}

PROTECTION AGAINST WINDS.

Wrnds may be classified in rarious ways, by their speed, as winds and storms; their origin, land-or sea-winds; their direction according to the point of the compass from which they blow; the damage they inflict on forests, by drying up the soil impeding height-growth and the formation of a regularlyshaped crown in trees, or by breaking and orerthrowing individual stems or whole woods, the last injury being cansed only by storms.

Wind by blowing caterpillars from older trees on to young growth, may also increase the damage done by insects; this has been frequently observed in the case of attacks by the num moth. Winds also spread the spores of fungi.

\section{Section I.-Prevalent Winds.}

South-westerly winds are most prevalent in central Europe, especially during autumn and early winter. They blow as cool winds during summer, and are comparatively warm in winter, and bring much moisture and rain-clouds from the ocean. Dry winds from the north-east and east generally prevail during the spring, the cutting north-east wind on the coasts of the Adriatic being termed borc. In Switzerland, a hot dry wind from the south frequently prevails during the summer months and is termed föhn.

\section{Damage done.}

(a) General Account.-Winds dry up and disperse the soilcovering, blowing dead leaves from slopes and ridges, and heaping them uselessly in hollows; they hinder the formation of dew, and spread the spores of fungi, and the seeds of forestweeds. Easterly and north-easterly winds dry up the soil and

VOL. IV. 
young plants, and injure the foliage and fructification of trees. Strong south-westerly winds cause a misshapen growth of the crowns of trees, especially near the sea-coast and on the southwesterly borders of forests, where the trees are stunted in height and have their crowns hent over towards the east; they also break off blossoms and tender shoots, whilst damp winds near the sea-coast also injure trees by the salt they carry, which the rain washes from their leaves into the soil rendering it salt and unsuitable for certain kinds of vegetation.

The results of these injurious influences are ;-impoverishment of the soil, a rank growth of weeds, failure of reproduction, languishing of young growth, loss of increment and forking of old trees, spread of fungi, \&c.

(b) According to Species. - Broad-leaved trees suffer more from dry winds than conifers, the tender young foliage and inflorescence of beech and hornbeam being frequently so dried up by the north-east wind that it appears to have been frozen or scorched by summer heat. The elm, oak, lime and birch are less liable to damage and still less the Scotch pine. Where the larch is exposed to south-westerly gales, it becomes sabreshaped, curving outwards and upwards from its base, especially on shallow soils; this is due to the wind from its seedling stage continually blowing the tree out of the vertical direction, which it strives to regain by continued upward growth; orchard-trees are similarly affected, whilst poplars, willows, and birch grow with their stems bending towards the east. The shrub-like mountain-pine (Pinus montana var. uncinata Rand.) withstands the action of winds along the sea-coast, and so do the Corsican variety of I'inus Laricio, the cluster or maritime pine, and of broad-leaved species, sycamore, Norway-maple and white poplar.

(c) Age of Trecs.-Seedlings and little plants, especially in sowings and plantations, and young coppice shoots suffer most severely from cutting winds, until the ground is completely covered by their interlacing branches. Coppice suffers more than high forest, when the rotations are short, and high forest suffer's the less, the closer is the leaf-canopy.

(d) Locaility.-The most exposed localities are coast forests, cultivated plains with hedgerow trees, ridges and tops of mountains and hills, valleys running east and west, easterly aspects 
unprotected by higher hills, unsheltered plateaux, \&c. The drier and less wooded is the land, the greater the damage. Late spring and early summer are the most dangerous seasons.

\section{Protective Rules.}

The chief rules consist in the maintenance of a good leafcanopy, especially in localities exposed to prevailing winds. Along sea-consts, therefore, and in high mountainous regions and other exposed places, natural regeneration, selection fellings and the formation of protective belts are adrisable.

Fig. 22?.

$\boldsymbol{N}$.

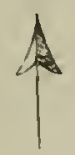

The following special rules should also be observed :-

(a) Sowings should rum from north-east to sonth-west, and soil should be heaped up on $.1 . E . \quad$ the south-east side of the lines;

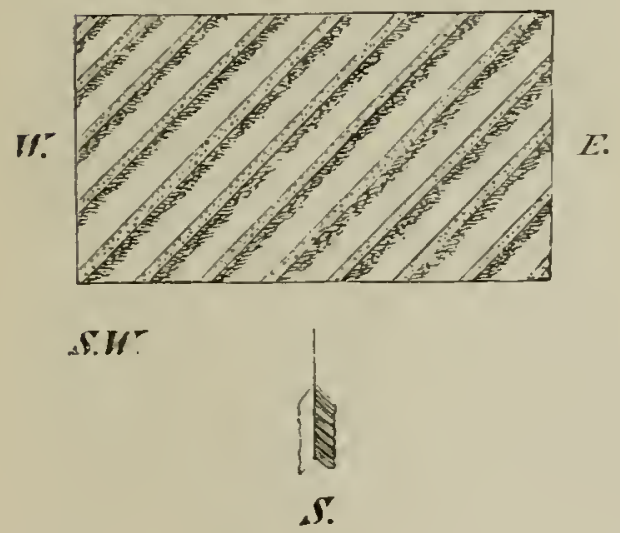

Fร. 223.

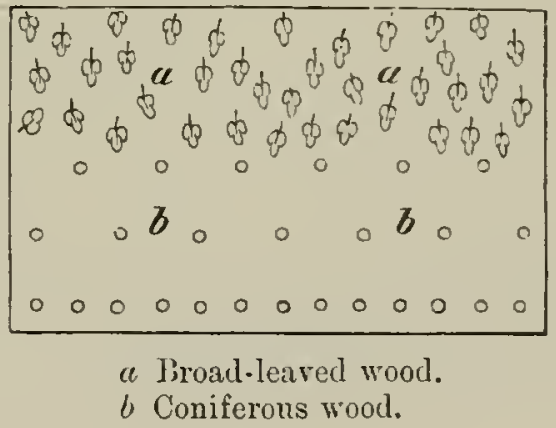

this secures the young plants against frost and heat and is also the best protection against dry winds from the east and sonth. It can, however, be employed only on flat ground, for sowings on slopes must always be horizontal, in order to prevent the soil and seeds from being washed away by rain.

(b) Planting with balls of earth is advisable; if planting is being done during a dry east wind, the plants' roots should not be exposed even for ten minutes, unless they are covered by damp moss.

(c) Belts of conifers 20 to 30 feet wide as in fig. 223 should intervene between broad-leaved forests and cultivated land, and should be established along forest roads. Spruce and silver-fir 
are the best specios for the purpose, but if the soil is too dry for them, Scotch or black pines may be used. These protective belts are extremely useful in sheltering woods from drought and prevent the remoral of dead leaves by the wind, damage by frost, \&c.; the external trees should be allowed to branch down to the ground, and along forest roads there should be a strip of land free from trees beyond the belt, to prevent the roads from being kept moist by the drip from overhanging trees. This is greatly preferable to lopping the border trees along a road-side, which, besides its unsightly appearance, admits the wind into the forest, and exposes the bark to sun-scorehing.

(d) All undergrowth which springs up along easterly and north-easterly forest boundaries affords a natural protection belt and should be carefully preserved.

(e) Coppice should be cut from the west-sonth-rrest or northwest towards the opposite bearings. In High Forests this is only permissible on plains which are exposed to the east and for storm-firm trees such as the oak.

\section{Section II.-Storis.}

\section{Origin of Storms.}

All winds are caused by differences in atmospheric pressure which result from unequal temperatures of the air in different localities. Whenerer the equilibrinm of the atmosphere is thus disturbed, a current of wind sets in to restore it.

A line joining all places having the same atmospheric pressure, as indicated by the height of the barometric column of mercury, after compensation for the eleration of the place above sea-level and for temperature, is termed an isobar. If maps are drawn, as in the 'Times' weather reports, showing the different isobars for every tenth of an inch, it will be noticed that they surround tracts from which either the pressure decreases in all directions, termed barometric maxima or anticyclones; or, from which the pressure similarly increases, which are termed centres of depression, barometric minima or cyclones.

The wind always blows from the regions of high pressure towards the depressions, i.e., from an anticyclonic region towards a centre of depression; it does not, however, blow in direction 
normal or perpendicular to the isobars, but greatly inclined to this, owing to the effects of the earth's rotation, which gives it a twist to the right in the northerly hemisphere. The strength of the wind varies with the barometric gradient, or difference in atmospheric pressure at places distant one geographical mile normal to the isobar's. The closer, therefore, the isobars are for any difference in the height of mercurial column, the greater is the gradient and the stronger the wind.

The isobars become crowded together whererer the pressure is lowest, and this fact, combined with the twist to the right of the winds rushing in from all directions to fill a depression, causes the revolving storms also termed cycloncs, the absolute axes of which are more or less calm. Thus on the southern side of a depression, the wind blows from the S.TV., on its western side from N.W., on its northern side from N.E., and on its eastern side from S.E.

The isobars are closest together on the western sides of depressions, so that the strongest storms come from a westerly direction (S.W. to N.W.). The depressions nsually pass to the north of Central Enrope, and traverse the continent from west to east, so that storms usually begin blowing from S.E. and gradually change to S., S.W., W., and N.W. Most of these storms travel across the British Isles, haring originated in the Atlantic ocean or Gulf of Mexico, but the south-easterly direction of the wind before a cyclone is not rery noticeable here.

Powerful storms therefore depend on the existence of barometric depressions, which may be only partial or irregular interruptions of an isobar, in which case the storm only extends over a limited area. Violent storms of limited extent, but with steep gradients which do considerable damage orer a narrow zone of country, are termed tornados.

The direction of winds may be considerably modified in mountainous countries, by the spurs of the mountains as well as the directions of the valleys. Thus, a rest wind may be converted into a north or sonth wind during its progress through a valley.

It is a still more frequent case for a sonth-west wind to become a south wind, and a north-west wind, west. 
The rates of storms are given as follows by Rouse:-

\begin{tabular}{|c|c|c|}
\hline & $\begin{array}{c}\text { Yards } \\
\text { per second. }\end{array}$ & $\begin{array}{l}\text { Miles } \\
\text { per hout }\end{array}$ \\
\hline Storm, or tempest & 24 & 50 \\
\hline Great storm & 29 & 60 \\
\hline Hurricane. & 39 & 80 \\
\hline Destructive hurricane & 49 & 100 \\
\hline
\end{tabular}

\section{Damage done.}

(a) General Nature.-Storms shake the roots of trees up and down in the ground and may either give a tree a decided leaning in a particular direction, or tear it ont of the ground by its roots and with the earth adhering to them, or break its stem or branches. Such uprooted or broken trees are termed uindfalls.

Whether the tree is blown down or broken depends partly on the intensity of the storm, and partly on the relative power of resistance of its roots or stem. Breakage happens when the roots resist better than the stem, windfall when the roots are the weaker. Breakage may also be due to one tree falling on others. The amount of resistance to storms which the roots or stem of a tree offers, depends on the vertical and lateral extent of the root-system, the nature of the soil, the length of the stem, the species of tree, the kind of crown it possesses, the condition of soundness or unsoundness of its wood, the density of the crop, mode in which the wood has been formed, itc.; each of these factors will be considered separately.

Storms not only overthrow single trees, but also whole woods. A wood may have narrow clearings cut into it by storms corresponding to their direction, or large blanks mily be made.

Breakage may be of stem, fork, crown, or branches; the stem may be broken off close to the ground, or at some distance above it, and whirlwinds frequently twist the entire crown off trees.

The damage done by storms may be direct or indirect.

To the former class belong:-Loss of increment and breakage of timber, which may become only fit for firewood; damage to young growth owing to the breakage of underwood by trees standing over it which have been blown down; increased cost of 
exploitation or of reproduction of woods; reduced prices, owing to an excess of material being suddenly thrown on the market; irregularities in age-classes and in carrying out working-plans, also disorder in thinnings and in preparatory fellings.

The disturbance of a forest working-plan may be so great, that it may become necessary to recalculate the annual yield of a forest, and to prepare a new table of amnual felling-areas. Indirect damage done by storms is chiefly confined to invasions of bark-beetles and of weeds in the blanks and regeneration-areas, where the trees have been blown down.

(b) Species of Tree.-Forests of conifers are far more exposed to damage than those of broad-leaved species, where extensive destruction by storms is comparatively rare. It would be difficult to draw up a comparative table of trees of different species according to their capacity to withstand storms, as the amount of damage done is greatly modified by local circumstances; but evergreen foliage and shallow ront-systems render trees liable to be broken or blown over. As these two qualities are mited in the spruce, this species is specially liable to damage by storms, as experience has proved. If, at any time, other trees suffer more than the spruce, this is clue to the nature of the soil, to the extraordinary violence of the storm, or some other special circumstance. If, however, species such as silverfir, or Scotch pine, with strong root-systems, are hindered from developing them normally, owing to the nature of the subsoil, they are exposed to danger equally with the spruce, and eren more so; for in such cases, they are compelled to have shallow root-systems which, unlike the spruce, they rarely develop evenly in all directions. Danger is also increased in the case of the Scotch pine, by the higher centre of gravity it possesses than the spruce.

A list of species arranged in ascending order of stormfirmness can therefore be drawn up only after allowing for the effects of local circumstances on each species, and presupposing a rational treatment in accordance with sylvicultural requirements.

From this point of view, conifers are arranged in the following 
order:-Spruce, silver-fir, pines and larch. Of the pines, the mountain and Cembran pines are most storm firm, then the Corsican variety of the black pine, and the cluster, Weymouth and Scotch pines. As regards broad-leaved species, those which are shallow-rooted, such as aspen, birch, beech, and hornbeam, are least storm-firm. The beech is more frequently blown-down than any of these species, because it is most abundantly grown. The following trees are fairly storm-firm:-ash, sycamore, Norway-maple, elm, alder, lime, and walnut; the deep-rooted oaks withstand storms best of all.

(c) Age of Tree.-Storms chiefly damage woods of aclvanced age, the second half or last third of a rotation being most endangered. Extensive damage is rare in woods under sixty years of age, and occurs only under exceptional conditions, such as shallow-rootedness of young woods, soil without much consistency owing to saturation by rain, woods in very exposed localities, or when assailed by exceptionally violent storms.

Damage to young trees consists more in causing them to deviate from the vertical position, less by uprooting, and less still in brealiage.

In the storm on the Baltic coast in 1872, in the Greifswald, 25-years-old Scotch pines were affected. In 1876, 15 to 20years-old spruce and Scotch pines were seriously damaged. In some pole-woods 25 to $30 \%$ of the stems were bent at an angle of $30^{\circ}$ towards the east and north-east.

(d) System of Management.-High forests are most exposed to danger from storms. It is still an open question, whether uneven-aged and irregular Selection forests suffer more from storms than the even-aged woods of the Clear-Cutting system, which can only be answered after thoroughly considering the modifying influence of localities, and the degree of skill with which the woods have been treated. Among the coppice systems, that of lopping side branches is the rorst, as trees so treated hare long narrow crowns, on which the wind can exert leverage. Pollards suffer less, and ordinary coppice least of all. Coppicewith-Standards is also storm-firm, as only the standards suffer, and damage to these is incousiderable, owing to their strong root 
development and the uniformity of their crowns, due to their growth in the open.

(e) Nature of Stem.--Long, cylindrical stems with elevated and expanded crowns, having high centres of gravity, and affording strong leverage to the winds, are greatly exposed to damage by storns. Thus standards in high forest above young growth are peculiarly liable to be thrown or broken. Damaged or sickly trees, such as those with decayed roots; trees injured by game, insects, canliers, fungi, cup-shake, barkscorching, \&c., are readily broken at the damaged place.

Uprooting of the tree with the soil attached to its roots is most frequent in the case of spruce or beech. Breakage of crown or branches is most common in the case of Scotch pine, alder, ash and robinia. The forked branches and crown of the two latter species are frequently broken by storms.

In the case of oaks it is chiefly the dry branches of stagheaded crowns which are blown off by storms.

(f) Locality.-In Germany, forests on hills and low mountainchains are more affected by storms than those in higher mountainous regions. During the ten years, $1870-80$, in the Thüringer-Trald and the Harz, damage by storms was chiefly at altitudes of between 800 and 1,800 feet; but in 1876, extended to 2,300 feet. This is because at higher altitudes spruce trees are shorter in the stem than those growing lower down, are also grown less crowded with low crowns in Selection forests, and have thus greater power's of resistance against storms than the crowded lanky stems of lower altitudes.

The configuration of the ground has a marked influence on the amount of damage done to forests by storms; thus, gentle westerly slopes bordering on extensive plains or plateaux suffer greatly, and so do outlying hills and mountrin ridges; also, narrow valleys running from the west or south-west towards the east or north-east, hills lying transversely at the end of, or partly across such ralleys, and steep slopes directly in the way of the storm. Whenerer south-westerly winds prevail, a storm, after crossing a mountain ridge, must descend its north-easterly slope; if then the wind has to find its way across the ridge through narrow felling-areas between ligh woods, or by funnel- 
shaped ravines, the damage done on the north-easterly slope will be increased, as the confined space in which it mores increases the violence of the storm. It is found that storms do more damage down-hill than up-hill, and for the following reasons :-

(i) Trees have stronger branches and roots down-hill, as they get more light, and consequently more nourishment in that direction; they, therefore, have a natural tendency to fall

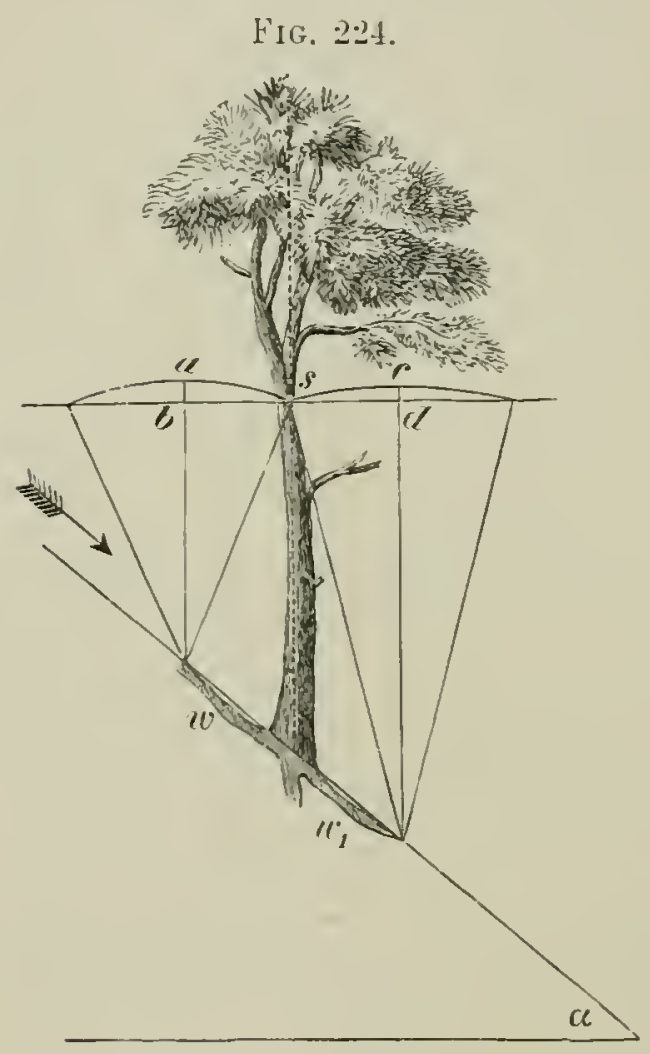
down-hill, whilst their hold on the ground is also less effective against strong winds which blow down-hill.

(ii) Winds which are blowing up-hill are continually losing force by their friction with the soil and crowns of the trees.

(iii) The centre of gravity of a tree has to be raised less when blown over from above than from below, as the annexed diagram shows :-

Here $s$ is the centre of gravity of the tree, and $u$, $u_{1}$, two roots, and if the tree is to be thrown uphill by the wind, $s$ must be raised through $a b$, if down-hill, throngh $c d$ which is less than a $b$. The greater the gradient of the slope, the more endangered is the tree.

Shallow, loose, spongy soil affords a bad root-hold; this explains the great amount of windfall which occurs on moors and sandy soils, or when the subsoil is a loose clay, into which the trees' roots do not penetrate. It has been observed that windfall in the Schwarzwald is more freqnent on the red sandstone formation than on gneiss, granite, basalt or porphyry.

In woods which have been planted on the sites of old fields, windfall is frequent, oring to the looseness and comparative 
poverty of the soil. Soils in which root-rot frequently occurs, such as calcareous soil, or land with a wet subsoil, are liable to windfall; a high soil-covering, such as heather, broom, thorny or shrubby undergrowth, is here beneficial, as these plants bind together the particles of soil.

Heavy rain-fall accompanying a storm greatly diminishes the coherence of the soil, and increases the danger of up-rooting, its effects vary of course with the nature of the soil. Frost, on the contrary, greatly increases the coherence of the soil, especially when the ground is covered with snow.

(g) Density of Crop.-- Trees grown in the open, owing to their well-developed root-sytems and low pyramidal crowns, withstand storms much better than stems which have been drawn up in dense woods and then recently exposed in thimnings and regeneration fellings. The latter improve in their powers of resistance, as they get accustomed to their open position. 'Their root-systems become enlarged; in crowded woods, however, the stems afford one another mutual protection against the wind.

(h) Season.-Storms may occur at any season of the year, but the most destructive storms are during winter; autumn storms accompanied by heary rain are also frequently rery disastrous to forests.

\section{Re?ister of Storms.}

During the past century, the following are the dates of the most wide-spread and disastrous storms :-

1800 (3rd and 9th November).

1801 (29th and 30th January).

1833 (17th and 18th December).

1834 (4th January).

1836 (29th November and 24th-26th December).

1842. (3rd May).

1853 (14th and 15th December from S.E.).

1866 (16th Norember).

1867 (8th April).

1868 (7th, 11th, and 29th December).

1869 (17th December).

1870 (26th and 27th October). 
1872 (12th and 13th November).

1875 (8th and 13th November).

1876 (12th and 13th Narch). In this storm, about thirty million cubic feet of timber were blown down in the State and Communal forests of Hesse, or 84 cubic feet per acre, being $125 \mathrm{per}$ cent. of the total amual yield of the forests. The same storm cleared 24 cubic feet per acre in the Saxon forests, or 40 per cent. of their fixed annual yield.

1877 (30th and 31st January, and 10th and 12th February).

1879 (20th and 21st February, 25th .June, 20th November and 5th December).

1880 (21st October).

1881 (14th and 15th October).

1884 (20th and.28th January).

1885 (15th October).

1890 (23rd, 24th and 27th January).

1893 (8th and 12th December). 'Terrific storms over the north of England and Scotland accompanied by violent rain, the wind blowing at 90 miles an hour in the Orkneys. 1,850,000 trees, valued at $\$ 282,263$, were blown down in Perthshire and Forfarshire, the only conifers resisting the gale being Corsican and maritime pines.

1894 (22nd December). A similar storm to the above, which only did less damage to the Highland woods becanse there were fewer trees left to be blown down. Great numbers of rooks, starlings and other birds were entangled in the branches of trees and liilled, or blown into the sea.

Taking a general view of the storms in Central Europe, during the present century, the years 1801, 1833, 1868, 1876 and 1893, have been the worst, and there has been on the average one destructive storm-year every four years.

Whirlwinds are of rare occurrence in Central Europe, and are usually only of limited extent and short duration. On the 1st August, 1877, a whirlwind fifty miles to the north of Berlin destroyed three-and-a-half million cubic feet of standing timber over a breadth of two-and-a-half miles. The coast districts between the mouths of the Mississippi river and Charleston are subject to terrific hurricanes, and in August, 1893, scarcely a tree was left standing in the islands there, nearly 2,000 people 
were killed, and $\mathfrak{E} 1,000,000$ worth of property destroyed, the wind having blown at the rate of 125 miles per hour.*

\section{Protective Rules.}

(a) During the Formation of Woods.

(i) Favour the cultivation of broad-leared species wherever this is possible. The damage done by storms during the last ten years is a warning to foresters who are so ready to convert broad-leaved into coniferous forests; this should only be done in cases of extreme urgency.

(ii) Drain damp localities before making regeneration-fellings.

(iii) Use strong transplants 4 to 6 feet apart, so as to ensure the growth of sturdy trees. Planting spruce gires better results than sowing it.

(iv) Mix deep-rooted species with shallow-rooted ones; for instance, mix oak, ash, sycamore, larch, or Scotch pine with beech and silver fir, and larch with spruce.

(v) Maintain protective belts aloug the boundaries of a forest, where prevailing winds are to be feared. Boundary ditches should not be dug along these boundaries, as they cut through the roots of the nearest trees.

\section{(b) During Tending.}

(i) Early, frequent and moderate thinnings should be made, so as to ensure normal root-systems, sturdy stems, and regularly shaped crowns. During the thinnings, all trees should be removed which have suffered injury to their bark, or which are forked, diseased or affected with fungi. It is better in thimning young spruce-rroods not to dig up stumps, as in so doing the roots of neighbouring trees may be cut through. Heavy thinnings in lanky and hitherto densely growing woods are dangerous.

(ii) Trees along the borders of a forest should be allowed to branch low down the stem.

(iii) Endangered border trees standing over young growth may be temporarily preserved by thinning ont their crowns, and cutting those branches which extend at right angles to the direction of the prevailing wind. This has been successfully carried out with spruce at Stammheim, in Württemberg.

\footnotetext{
* "Scribner's Magazine," February, 1s9t.
} 
(iv) Carefully avoid all causes leading to defects in trees; thus, resin-tapping should be stopped in spruce forests, deer which peel trees should be shot, and careful forest protection secured.

\section{(c) During Fellings.}

(i) Avoid very long rotations, as the area of a forest exposed to danger from storms increases in proportion to the length of the rotation. Thus, considering that danger from storm commences when the trees are fifty years old, we have :-

With 120 year's' rotation isths of the area endangered.

\begin{tabular}{|c|c|c|c|c|}
\hline 90 & , & , & $\frac{1}{1}$ ths & ," \\
\hline 60 & , &, & $\frac{1}{6}$ thes & , \\
\hline
\end{tabular}

(ii) All greatly exposed places in mountainous regions should FIF, 225.

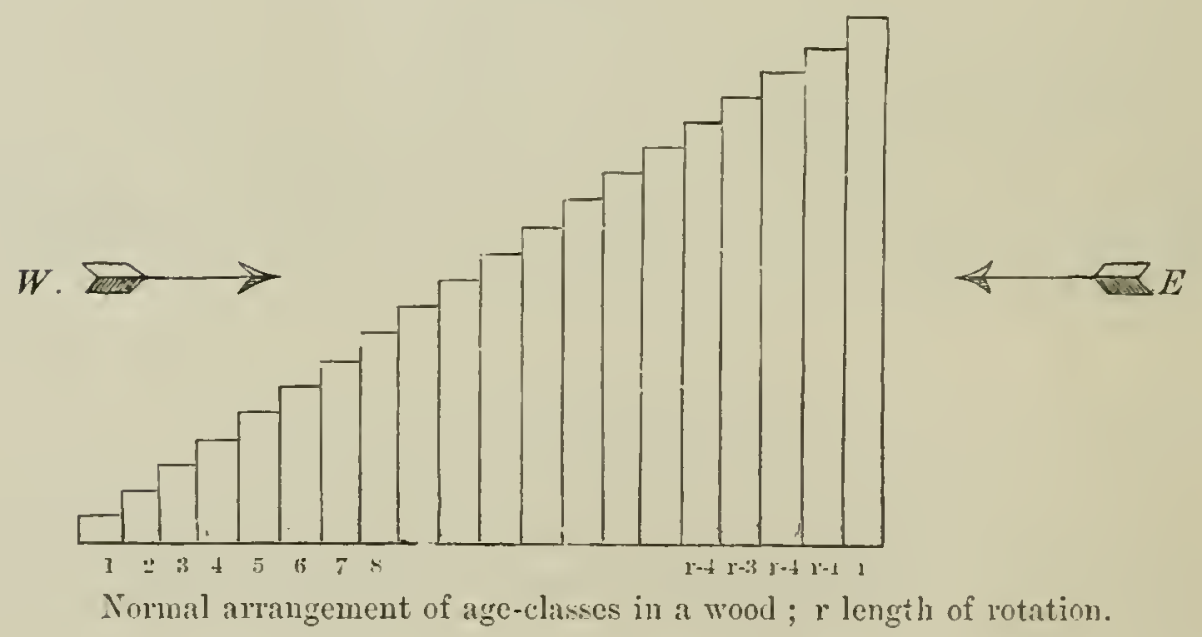

be regenerated by the Selection system, and the slopes shoukt not be tonched till the summit lias been regenerated.

(iii) Regeneration in narrow strips commencing in the direction opposed to the prevailing wind, should be substituted for regeneration extending at once over a whole compartment, especially in spruce forest.

(iv) Woods should always be regenerated in the direction opposed to the prevailing winds, which is generally from east or north-east to west or south-west, so as to secure a constantly graduated succession of young woods on the windy side of the older woods. Nothing can ward oft storms better than such a slope of trees as is shown in fig. 225 . 
As such a succession of felling-areas may encourage insect attacks and would not be practicable over the whole area of a forest, it is usual to arrange the age-classes in a number of cutting-series, running more or less parallel to one another through the forest from east or north-east to west and southwest. Age-classes are, horrever, seldom so arranged that an old rood will not occasionally be found directly opposed to the force of the wind, after it has been exposed by felling another mature rood to the west of it, and in such cases, a sererancefelling is required.

This is a narrow clearing made through a wood, to strengthen the border trees on its weather side, so that by the extension of their crowns and root-systems, they may protect the dense wood beyond them from storms. Sererance-fellings should be forty to fifty feet broad, and as nearly as possible at right-angles to the direction of the prevailing wind; they must be made before the trees are too old to respond to the increased exposure to light. The cleared space should be at once planted up, and thus itself form a protective zone whon the woods beyond it have been felled.

Figs. 226 and 227 show the arrangement of the age-classes in a forest at Sternberg, in Thuringia. If it is wished to fell the 70 -year-old rood without endangering that 50 year's old, which it at present shelters from the rest mind, it becomes necessary to separate the two woods by a sererance-felling. This, as the diagrams show, has been already done six Jears ago, when the strip was planted with 4-years-old spruce transplants, which now form a 10 -year-old protection belt to the 50 -yearold trees. The westerly border-trees of the latter, hare now become so wind-firm that the sererance-felling (b) might be ridened. Another sererance-felling (a) has also been made between the 30 and 50-years-old woods, because the latter is to the west of the former and will first be mature. The proposed widening of $(a)$ is marked in fig. 226 by a line, and in fig. 227 by shading, but it camnot be carried out until the younger wood has become more wind-firm. There is no apparent necessity for the sererance-felling $(c)$, as the woods on both sides of it are of the same age, but it has been cut, in order that the large 50-rears-old wood may be divided into tro cutting 
series, both begimning from the east in order to avoid the necessity of having too large felling areas.

Fis:2.24

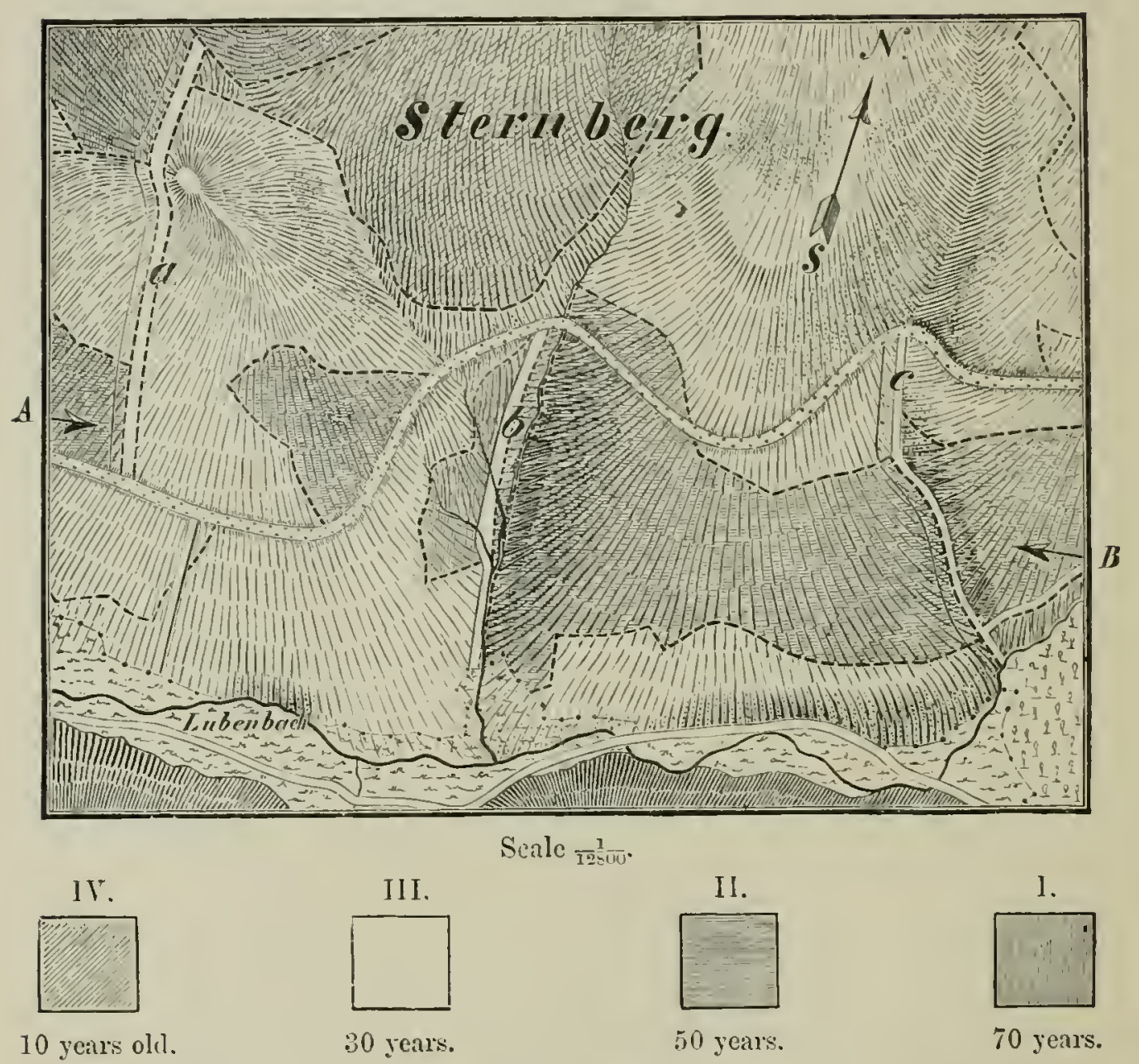

Plan of part of the Zellaer Forest, with 3 scrermec-fellings, $a<c$.

FIr, 22:-

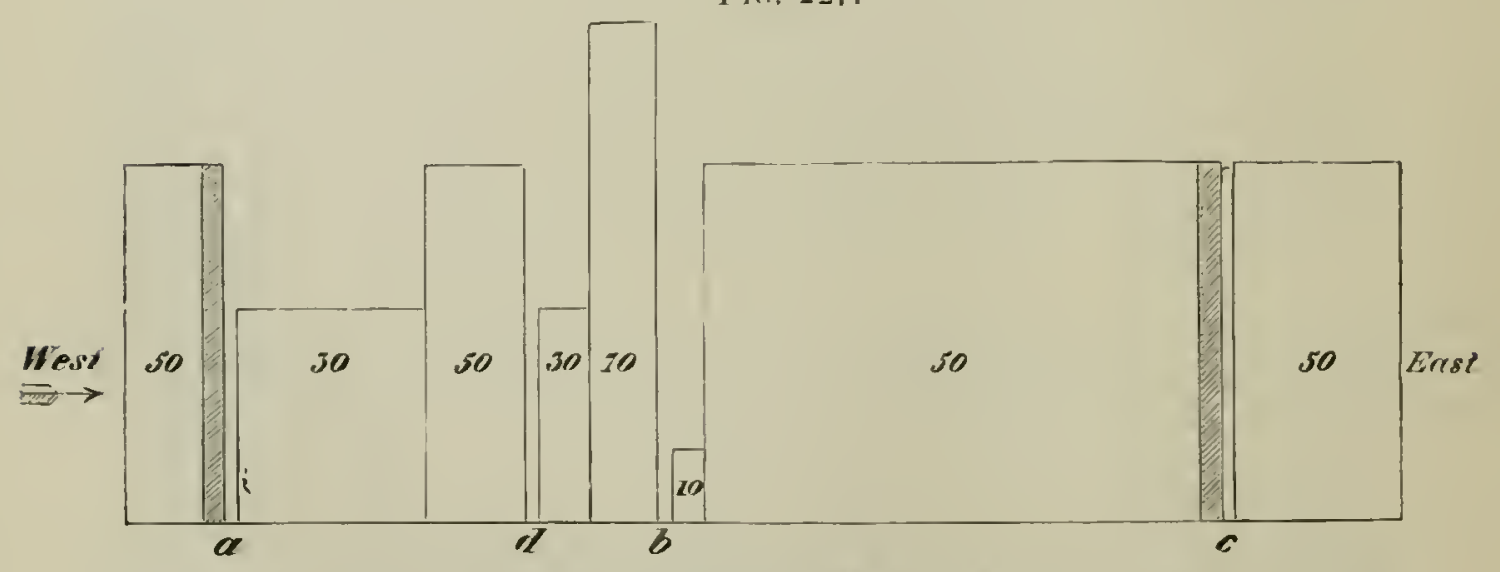

Section of the wood along A P.

The numbers refer to the arerage age of the wood. $a b c$ Sevcrance-fellings. $d$ Road. The 10-year-old wool is a protective pluntation. 
When felling actually commences in the 70-years-old wood, a protective belt should be left along its eastern border, consisting of a double or treble row of trees, the crowns of which have been thinned by lopping away some of their branches, as shown in fig. 228. Severance-fellings are extensively used in the Thüringian forest belonging to Saxony and other States, where the erop is chiefly spruce.

(v) Felling-areas should have long straight boundaries, as fellings in outlying corners of a forest may easily admit storms.

(vi) A system of rides with storm-firm borders should be laid out, which affords protection against storms; the principal

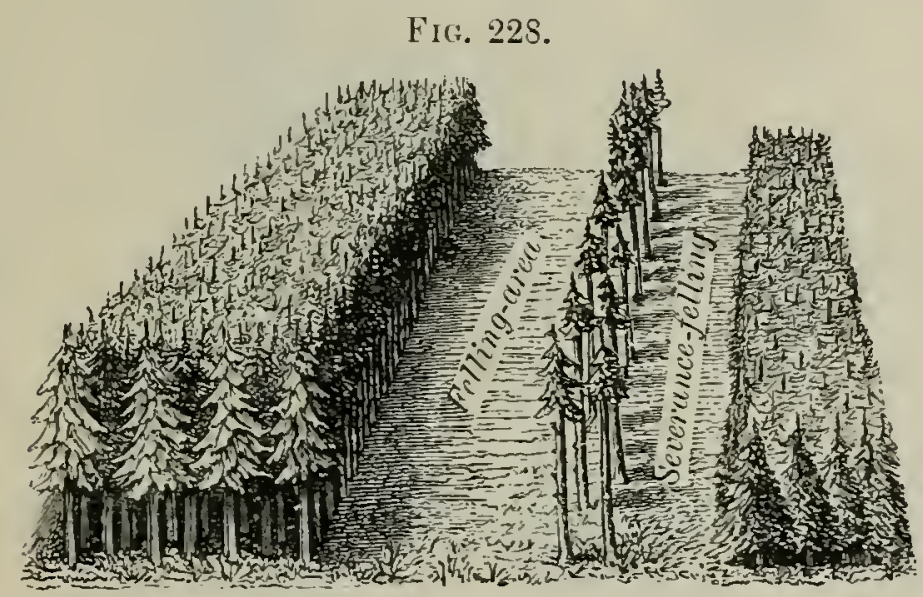

rides should be parallel to the storm-direction, and the secondary rides at right angles to it.

(vii) Fellings in high forest follow one another from east or north-east to west or south-west according as a compartment is cleared in several years, or in one year.

Fig. 229 represents a normal arrangement of age-classes in a forest, * the periodic blocks being variously shaded, and the compartments drawn square instead of oblong, so as to take up less room. The white compartments are the youngest, forming the woods of the fifth period, and the darkest compartments are those of the first period, where fellings will be at once

* A period is an integral part of a rotation, and a periodic block is the area of forest which will be felled during any period. Thus a rotation of 100 years may be divided into 5 periods of 20 years each, and a working-section of a forest into five periodic blocks, the trees in which are aged respectively $0-20,21-40$ $41-60,61-80$ and $81-100$ years.

VOL. IV. 
commenced. The intermediate shades represent the second, third, and fourth periodic blocks.
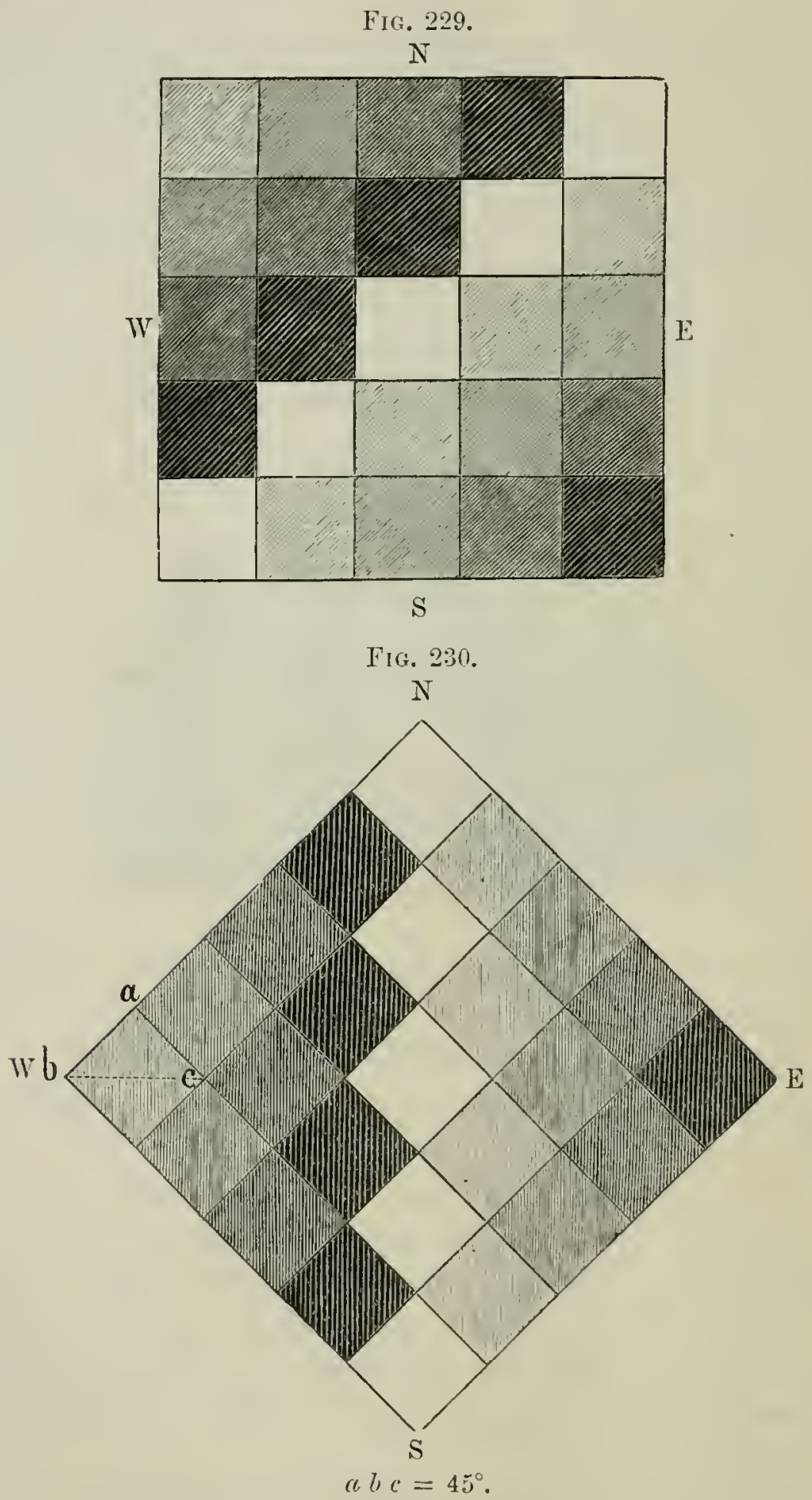

Denzin has, howerer, proposed that this arrangement of fellings, which is the one usually employed, should make way 
for that shown in fig. 230 which he considers to afford better protection to woods of second period against south-west, west south-west, and south-south-west winds.

The objection to this arrangement is that, although the woods of the second period are better protected against west and southwest winds, yet they are completely exposed to the cutting north-east winds with the accompanying danger from rime. Hess thinks that further experience is necessary before deciding between these two arrangements, and also as regards the shape of compartments, whether square* or rectangular, as this may also affect the amount of damage done by storms.

Fig. 231.

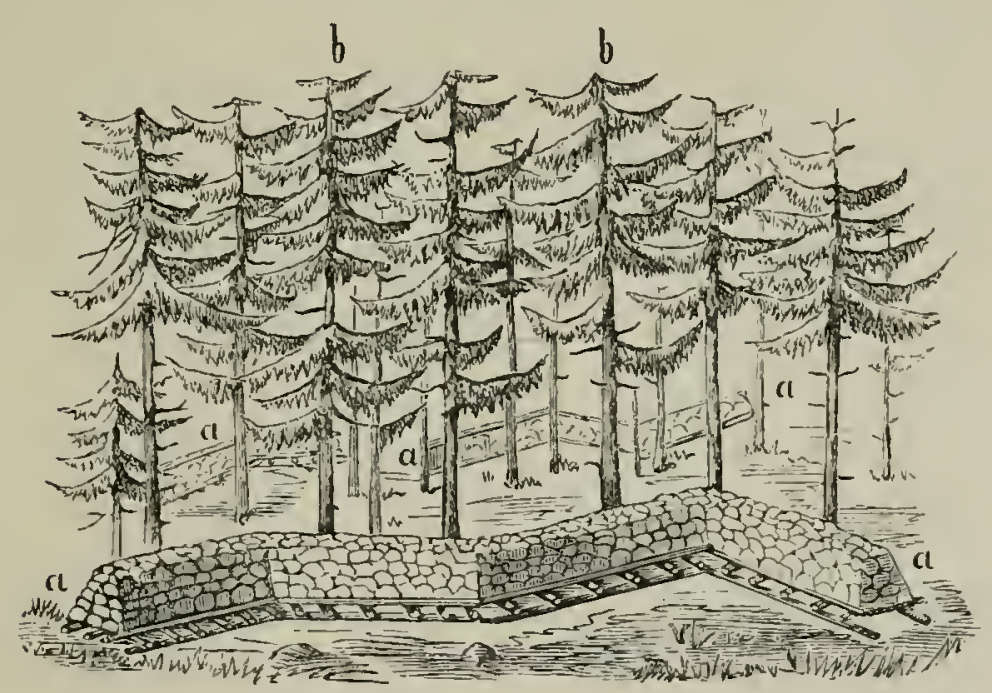

a. Heaps of stones. b. Pruned and topped spruce trees.

(viii) It is useless leaving standards of shallow-rooted species, such as spruce, in exposed places.

(ix) Stumps should not be dug up in preparatory and seeding fellings, where storms are to be feared. After storms have damaged valuable middle-aged woods, further damage may be prevented by thinning out the crowns of trees left standing on the exposed sides of woods, and lading their roots with stones if they are easily procurable.

* The question of the direction of fellings in mountainous districts, and of the proper shape of compartments, is cliscussed in detail by Karl Heyer; in der Waldbau, 1878, p. 52 et seq. 


\section{Treatment of Windfalls and Wood-mealiage.}

On account of danger from bark-beetles, which follow extensive breakage in a wood, prompt measures must be taken after damage has been done by a storm.

(a) Convert the broken material and transport it from the wood as soon as possible, after stripping the bark from all stems and broken pieces, at any rate of conifers.

(b) All wood unfit for timber should be split and the stacks of fuel should be set up in well aërated places. All rubbish may be made into charcoal or even burned, if necessary.

(c) Stumps and roots of coniferons trees should be grubbed out and split up, even if a pecuniary loss is involved. In broadleared roods, on the contrary, up-rooted stumps should be replaced in the ground, or at any rate, the earth lnocked from the roots and the holes filled up. Ordinary cart-jacks may be used to replace the stumps; they cost about $45 \mathrm{~s}$. each, and two jacks are required for each stump. In a beech-rrood, fiftyone men at two shillings a day replaced 422 stumps in this way at a cost of fourpence a stump.

(d) Farourable conditions of sale should be offered so that all broken wood may be sold as soon as possible. All intended fellings should be postponed until the volume of the broken wood has been calculated, and deducted from the annual yield. If there is more wood broken than the fixed annual yield, all principal fellings should be postponed for a year or more. Some idea of the large quantity of wood which is blown down may be gained from the fact that in the spruce and silver-fir State forests in Württemberg, about one third of the fixed amnual yield comes from windfalls and breakage.

\section{Treatment of Woods which hare been Damarged by}

Storms.

When we consider the great variety of local circumstances which influence the degree of damage done by storms, it is impossible to draw up special rules for the treatment of injured woods which will meet all cases that may occur.

A few general rules will, however, be given which are applicable 
to the commoner cases for trees and poles, no damage being done by storms to thickets of saplings or to coppice-shoots.

\section{(a) Injured T'rees.}

All mature or nearly mature woods which have been badly invaded by storms should be felled earlier than was otherwise intended; this is especially true for woods which have thus become full of blanks. If, however, the storm has only caused a few blanks, the date fixed for fellings need not be anticipated. Small blanks due to the fall of single trees, or small groups of trees, camnot well be planted up, as plantations succeed badly in such places, and within ten or fifteen years the crowns of the surrounding trees will close them again. Large blanks, however, should be at once planted, before they become covered with weeds, unless natural regeneration can be secured.

In planting blanks, about 20 to 25 feet should be left mplanted round them, as plants within this strip would suffer from the shade of the surrounding trees.

In filling blanks in spruce and silver-fir woods, beech, hornbeam, sycamore, or silver-fir are preferable; but if the forest contains red deer', silver-fir plants will require fencing with hurdles. Scotch pine and larch-woods when damaged by storms may be filled up with spruce, Weymouth or Corsican pines; beech-roods, where the soil is deep, with oak, and on good but stony soil with sycamore, in wet places with ash, or alder. When the next felling takes place, these groups of young wood will be carried on for another rotation, but will be thinned and pruned where they endanger the future young beech. They will eventually yield fine timber trees.

\section{(b) Injured Poles.}

It is very difficult to decide on the proper treatment of polewoods when broken into by storms. Premature fellings would be undertaken only when the damage done is on a large scale, or when these woods interrupt the normal cutting-series, or when they would not expose neighbouring woods to the rest. In general it is not adrisable to fell damaged pole-woods, but their treatment will rary according to species, locality, area of blanks, de. Small blanks could be left unplanted for the same 
reason as that given for older woods. Larger blanks could be planted with large transplants of beech, hornbeam, or sycamore.

Larch and Weymouth pine owing to their rapid growth would soon fill up the blanks, but the larch does not thrive everywhere, and the Weymouth pine does badly in mountainous districts. Here also 12 to 18 feet interval should be left between the plantation and the still standing poles. Woods intended for natural regeneration may be trained up by means of heavy thinnings to produce seed earlier than usual. 


\section{CHAPTER IV. \\ PROTECTION AGAINST VIOLENT FAIN.}

\section{Damage done.}

HEAvY and prolonged rainfall and occasionally water-spouts, damage forests by carrying away the dead leaves, the soil, and seeds; by up-rooting young plants, the roots of which are not sufficiently developed, such as seedlings and nursery transplants recently put out; by causing local swamps, destroying roads and ditches, loosening the roots of trees, preventing fruit from ripening, and breaking it off.

The results are impoverishment of the soil, failure of sorwings, blanks in plantations, liability to windfall, loss of seed, \&c. As regards the locality, steep slopes with loose light soil, which are neither covered with woody growth, nor with herbage, moss or dead leares are most liable to damage. Loose soil when saturated with rain renders the roots of trees less secure against windfall. Clay soils are also injuriously affected by heary rains, as a crust forms on their surface, excluding air from the roots of plants.

\section{Protectire Iiules.}

(a) Maintain the forest growth and natural soil-corering of herbage, moss, and dead leaves on all steep slopes exposed to flooding. In high forest, it is best to have natural regeneration under a shelter-wood, but on slopes, coppice is less heavy than high forest, and protects the soil as well.

In planting up such localities, the slopes may be terraced with advantage, and planting, which is preferable to sowing, should be in horizontal lines commencing at the top of the slope. For dry calcareous slopes the black pine is most suitable.

(b) Establish a system of horizontal trenches on dry slopes; 
these may be of two kinds, the one designed to arrest the descent of the rain-water, and the other to catch the dead leaves which would otherwise be washed or blown down the slopes. The former trenches are from 10 to 12 inches deep and 25 to 30 feet apart; they should be in lengths of 12 to 30 feet, to prevent the formation of drains. These trenches retain the excess water after heary rain, and part with it gradually to the soil. Leaves are washed and blown into them and the soil is thus improved. In oak and beech forests, they catch the acorns and beech-nuts which are rolling downhill, and thus natural regeneration may be secured. If the trenches are intended merely to retain the dead leaves, they are made narrower than before, and closer together.

(c) All measures which cause or favour loosening of the soil should be abandoned in such places; these are;-extraction of stumps, pasturing cattle, trenching the soil, \&c.

(d) In order to protect forest roads from the effects of violent rainfall, ditches and culverts should be constantly kept free from weeds, silt and dead leaves. Where the road passes through a sandy cutting, the banks on either side may be terraced and fixed by wattle-work fencing, stakes of living willows being used, and sand-fixing species planted between the fences. 


\section{CHAPTER V.}

PROTECTION AGAINST HAIL.

\section{Damage done.}

HAIL completely beats down young plants, and injures saplings, poles and young trees by breaking off leaves, blossom, fruits, young twigs, and leading shoots, and by stripping off flakes of bark, either in little patches or short strips, and thus exposing the cambium-zone. The marks of the wounds made by hail in the bark of trees are often noticeable for a long time, the amount of damage done depending on the size of the hailstones.

In consequence of damage by hail, there is a loss of increment, in certain cases deformed growth, decreased production of seed, and even death of trees. Through the wounds made by hail, spores of species of Nectria and other fungi may gain admission to the tree.

Conifers suffer more from hail than broad-leaved trees, especially the Scotch, Austrian, and Weymouth pines, the sprnce and silver-fir somewhat less; the larch soon recovers from injuries to its shoots or bark.

Among broad-leaved species, those with less power of occluding wounds, and with thin bark, such as the beech, suffer most, but the oak, robinia and other trees when young may be seriously injured; the birch owing to its elastic shoots and leathery bark does not suffer much from hail.

Young plants 1 to 15 -years-old are most endangered, yearlings being often destroyed by a hail-storm; and sowings, especially when on a large scale, suffer more than plantations. Poles 15 to 30 -years-old suffer less than younger plants, while serions damage is rarely done to trees over 30 years old. The later in 
the spring the hail occurs, the greater is the damage, especially to smooth-barked, weakly plants.

Oak-coppice for bark and osier-beds may suffer severely from hail, and in high forest, open woods suffer more than dense woods, and isolated trees and those along the borders of the forest suffer most.

\section{Preralence of Hail-storms.}

Hail-storms are not very common in Europe, they occur only in late spring or summer and generally during the day-time. They are very severe in northern India, occurring generally during April and May, and the stones are then frequently as large as wahnuts, and batter stucco buildings as if they had been subjected to a volley of musketry and even penetrate corrugated iron roofs. Such hail-storms may completely strip the young shoots from trees and tea-bushes, in the latter case causing damage which may be estimated at thousauds of pounds for a tea district.

In Germany there are, on the arerage, only about fire hail-storms a year, but on the west coast of Europe there are about fifteen. These are sometimes very local, extending only over small areas. Thus, in Cambridgeshire, within ten miles around the village of Chatteris, double the usual rates of insurance for agricultural crops against hail are charged.

Hail-storms are very prevalent in Württemberg, where thousands of acres of cultivated land are annually laid waste by hail; a record of them has been kept since 1828, which shows that forests reduce the velocity of the wind and neutralize electricity, but does not show that these influences are effective in preventing hail-storms, or in limiting their range. Observations have also been made at the Meteorological Office at Zurich in Switzerland, between 1883 and 1893, and in discussing these, Dr. C. Hess* states that hail is more frequent in valleys than on mountains, where it is often transformed into sleet or rain. Near marshes and lakes, hail is more frequent than

* Extract from "Nature," Jinuary 3, 1895. Translated from "Naturwissenschaftlich Wochenschrift" for December $9,1894$. 
over woods. On passing over cultivated lands or hill forests, there is a tendency to a decrease in the intensity and at times an entire cessation of the hail-storms.

3. Protection and Remedial Rules.

All blanks in forests should be filled with strong transplants.

Broad-leaved species badly injured by hail should be cut back if young enough to shoot out again from the stool. 


\section{CHAP'TER VI. \\ PROTECTION AGAINST SNOW.}

\section{Damage done.}

\section{(a) General Account.}

SNow injures forest plants by its downward pressure when lying on their branches, by which they may be bent, or broken; even entire stems, or woods, may be bent, broken, or partially mprooted by the weight of snow resting on their crowns. The term snou-brcak is used to denote the breakage of stems or branches, and chiefly occurs when the ground is frozen, and bending when it is soft.

A special form of injury arises when masses of snow sliding down hill-sides fall on undergrowth and crush it; this is not uncommon on cold aspects. The results of damage by snow resemble wind-break. Other indirect damage is done, when the ground becomes soft and yielding after a rapid spring thaw, which occasions floods and landslips.

\section{(b) Species of Tree.}

Trees with pendulous or flexible leaders or branches, such as birch, larch, deodar, and others with a tendency to a squat shrublike habit and to form side-shoots into leaders, such as the mountain-pine, green alder, and most rhododendrons, are adapted to grow in regions where much snow fills annually. On the contrary; trees with brittle attachment of the branches to the stem, such as Pinus rigida, Mill, and some Euculypti may withstand frost, but are broken to pieces by the snow.

Most European trees withstand snow fairly well, but evergreen conifers suffer most from it, in the following order:black, Scotch and Teymouth pines, spruce and silver-fir.

The lareh suffers much less from snow than other conifers owing to its having no needles in winter for snow to rest on, but it may be injured when snow falls in autumn before it has lost 
its needles. Pinus Cembra is another tree found at high altitudes; though growing slowly, it attains a great age, and resists the snow owing to its tufted foliage and tendency to form new leaders, which the silver-fir also possesses.

The black pine does not resist snow well owing to its long needles, which allow much snow to rest on its crown. The spruce generally suffers more than Scotch pine, as it grows at altitudes and on aspects where snow is most frequent and least liable to thaw; the Scotch pine on the other hand, is chiefly grown in plains where snow is less frequent and thars sooner and cannot therefore accumulate in masses on the crowns of the trees. Whererer the spruce and Scotch pine grow together in mixed woods, it is found that the latter is less resisting owing to the brittle nature of its wood; the spruce being more elastic and splitting less readily can support a greater weight of snow than pines. The silrer-fir is more resisting than the spruce, owing to the greater depth of its root-system and the more upward insertion of its branches.

Among broad-leaved trees, the beech suffers most from snow, as this tree ascends higher in mountains than other important broad-leared species.

Alder, robinial, aspen, and Salix fragilis suffer on account of their brittle branches, and even the birch is broken badly if snow should fall before it has lost its leaves. Hornbeam stands the danger better, and so do ash, maple and oak.

The lower part of stems growing on mountain slopes exposed to heavy snow-fall curres outwards before becoming vertical owing to the pressure of the snow which accumulates behind it, especially during the youth of the tree. In hollow depressions on steep slopes, the weight of the descending snow is so great, that masses of it slide down erery year and crush all the seedlings they meet. Such places in the Himalayas are bordered by species of maple and horse-chesnut which apparently withstand the sliding action of the snow better than conifers, or evergreen oaks, which are the chief components of the Himalayan forests between $\tau, 000$ and 9,000 feet altitude.

(c) Part of Tree.

Young trees may be bent down, by snow, individually or in 
masses, inclusive or exclusive of the ball of earth around their roots.

Tearing out of branches from the stem, as shown in the annexed diagram, is a less common form of

Fic. 232.

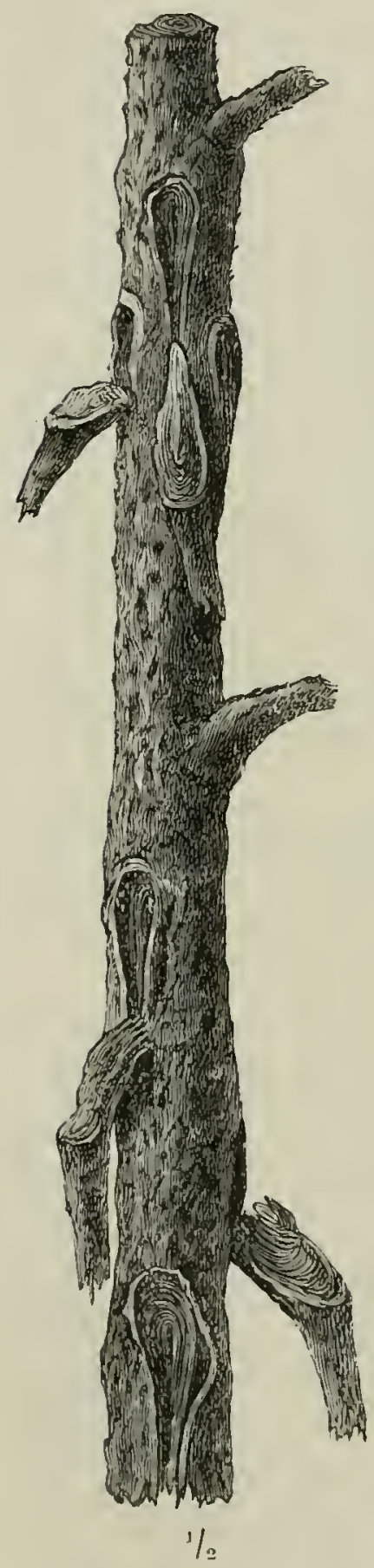

Portion of the leading shoot of a spruce, six branches of which have been torn oft' by snow. damage, by which the stem becomes almost worthless for timber, and more liable to fresh breakage. If all the branches of a rerticil are thus torn ont, the leading shoot invariably dies. This form of injury is common with pines, and branches up to $2 \frac{1}{2}$ inches thick are thus torn out, the holes becoming filled with resin, and the torm branches eventually falling off, so that the damage done to the tree may escape notice. In the case of spruce, the branches thus torn out are not generally more than $1 \frac{1}{2}$ inches thick.

Amongst broad - leaved species, soft woods, including birch, suffer most in this way, then ash; maples and beech and oaks less, though much similar damage was done by snow to oaks in Windsor Forest, in October, 1878, when they were in full leaf.

According to the age of roods so affected, sometimes the leaders and branches, at other's, the stem at different heights above the ground, are more subject to snow break.

The former mode of injury is commonest in seed-yenr's among older conifer's, as the cones increase the weight on the crown of the tree.

Stem-breakage usually occurs in the case of trees injured by resin-tapping, or trees which are forked or cankered at or above the seat of injury.

The following table gives von Seelen's 
observations on damage by snow in December, 1883, in the Hasselfeld forest range.

\begin{tabular}{|c|c|c|c|}
\hline \multirow{2}{*}{ Place of Breakage. } & \multicolumn{2}{|c|}{$\begin{array}{l}\text { Percentage of } \\
\text { Breakage. }\end{array}$} & \multirow{2}{*}{ Remarkis. } \\
\hline & $\begin{array}{l}30-40 \text {-year- } \\
\text { old trees. }\end{array}$ & $\begin{array}{l}\text { Over } 40 \\
\text { years old. }\end{array}$ & \\
\hline Root-collum ................... & 6 & 17 & \\
\hline $\begin{array}{l}6 \text { feet up the stem ............... } \\
\text { (Of these at a place where bark } \\
\text { was injured) ................. }\end{array}$ & $(60)$ & (1) & $\begin{array}{l}\text { Altitude 1, } 800 \text { feet, } \\
\text { site nearly level. The } \\
\text { younger wood had } \\
\text { been hearily thinned. }\end{array}$ \\
\hline Over 6 feet up stem to crom & 20 & 30 & $\begin{array}{l}1,030 \text { stems were } \\
\text { counted. }\end{array}$ \\
\hline Within the crown ............. & 12 & 50 & \\
\hline
\end{tabular}

(d) System of Management.

As the species which suffer most from snow are grown in high forest, that system is most liable to snow-break. Woods, where the trees in each compartment are of even age and height, suffer more than uneren-aged woods, such as those gromn under the Selection system; in the former case snow may lie in masses like a roof over the crowns of the trees, especially when the wood is densely stocked, whilst in uneven-aged roods more snow reaches the ground by falling between the crowns of the trees.

In the second case the wind also enters the wood more freely and shakes the snow from the crowns of the trees. Hence, in localities liable to snow-break, the Selection and Group systems are more suitable than other high forest systems. In coppicewith-standards, the lanky tellers occasionally suffer soon after a felling, but pure coppice is rarely injured by snow.

(e) Age of Wood.

Slowly growing species such as silver-fir, spruce and beech are most endangered by snow between the ages of 20 and 60 years; quickly growing species such as Scotch pine and larch between the ages of 20 and 25 years. Thickets 1 to 20 years-old withstand snow better owing to their elasticity, and woods over 60-years-old suffer less, on account of the greater size of the trees; a distinction must, horrever, be 
made between bending and breakage. Bending owing to snow is most frequent in woods 20 to 40 -years-old, and occurs generally in patches. Snow-break, on the contrary, is most frequent in woods 40 to 60 -years-old and even in older woods the crown and leading shoots of the trees are chiefly broken in woods up to 60 -years-old, whilst in older woods branches are broken off the stem. In otherwise minjured woods, stembreakage is generally near the base of the crown and occurs here and there to individual trees. Younger drawn-up stems are often broken in groups, and sometimes in strips, owing to the action of wind during or after the fall of snow.

In the extensive snow-break which happened in the Harz forests, in December, 1883, trees of the following categories were injured in following proportion for the whole area affected :-

\section{Age of Woods}

in Years.

$20-30$

$30-40$.

$40-50$

$50-60$

$60-70$

$70-80$

80 and over Percentage of
Breakage.

10

25

25

20

12

5

3

\section{(f) Locality.}

Mountain-forests are more affected by snow-break than forests of the plains and lowlands. The localities in Germany most exposed to snow-break lie between altitudes of 1,200 and 2,400 feet; the snow falls more abundantly at higher elevations, but then the flakes are smaller and drier, and do not become so readily attached to the trees; lower down, on the other hand, the fall of snow frequently changes into rain. In Switzerland, in 1885 damage by snow extended to an altitude of 6,560 feet above sealevel.

No aspect is absolutely safe against snow-break; most snow in central Europe comes from a westerly direction, from which quarter also the strongest winds blow. The sonth-easterly, easterly and north-easterly aspects, especially just below the 
crest of the hills suffer most; the snow falling most abundantly in such places and being less easily shaken from the trees by the wind, accumulates on their crowns. Since, also, freezing winds blow chiefly from the east, a frozen crust is then formed over the snow, on which more snow lodges when there is a subsequent snow-storm. North and north-westerly aspects suffer less, and westerly, south-westerly and southerly aspects least of all. Depressions and sheltered spots in valleys are much exposed to snow-break, as the wind camnot free the crowns of the trees from snow in such places.

\section{(g) Mode of Formation.}

Under otherwise equal conditions young pole-woods which have grown up in dense thickets, suffer most from snow, their scanty root-systems and slender drawn-up stems exposing them to danger. Poles resulting from sowings suffer more than plantations where from the first each individual plant has had sufficient room for its development. Planting two or more plants in each planting spot, termed multiple-planting, is also less favourable where snow is to be feared than planting single plants. The distance between the planting-spots is also important, as plants with stronger roots, and crowns, capable of resisting the pressure of the snow, result from wide planting. Such plants may, however, be uprooted, at least at high altitudes, owing to the large surface of their crowns, so that wherever this danger is to be feared, planting-spots must not be too far apart.

Observations made in the Harz forests in December, 1883, after the disastrous snow-storm already referred to, gave the following per-centages in 100 acres of spruce woods which were bent down and broken by the snow :

$$
\begin{aligned}
& \text { Single-planting, 18, } \\
& \text { Multiple-planting, 26, }
\end{aligned}
$$

so that the single-planting suffered about one-third less than multiple-planting.

Mixed woods consisting of broad-leaved trees and conifer's suffer less than pure coniferous woods, as less snow rests on the trees, and the broad-leaved species are less liable to injury. Beech, sycamore and hornbeam. should therefore be mixed with spruce or silver-fir. The larch has not succeeded in German

VOL. IV.

L L 
mountain-forests, but it grows admirably in the British Isles when mixed with beech and other conifers, provided the soil is suitable, and such mixtures are admirably adapted to withstand heavy falls of snow.

\section{(h) Effect of Thinnings.}

Woods which have been properly thinned are generally less liable to damage than unthinned woods, not only on account of the sturdier forms of the trees and their more regular crowns, but also because more snow reaches the ground in thinned roods, and the weight of the snow which rests on the crowns of the trees is less than when the woods are very dense. The wind is also more effective in thinned woods in shaking the trees free from snow. Extensive snow-break has indeed been observed at times in thinned woods, but this does not invalidate the above reasoning, for sometimes thinnings are put off too long, and if excessive snow should fall on weakly stems just set free by a strong thimning, it is evident that much damage may be done. It is therefore to a certain extent an affair of chance, as regards the first thimning in a dense thicket, whether damage by snow occurs or not, but the longer the wood escapes damage after the thimning has been effected, the better it will resist, should a serere snow-storm occur.

In thinned roods, individual stems are more liable to breakage, whilst in unthinned woods whole patches of poles may be crushed. Bühler* has undertaken some very interesting experiments on the effects of thinning in snow-break, which show that heavy thimnings are less affected by snow than light thinnings; it is not the dominant poles with regularly shaped crowns which are so much endangered by the snow as the badly grown poles with lop-sided crowns, and these are removed in heavy thimnings as well as dead, dying and dominated poles. A heary thimning somewhat interrupts the leaf-canopy, and thus allows more snow to reach the ground than in a densepole-wood.

(i) State of the Weather.

The snow is the more destructive, the wetter and larger

* Schneedrück u. Durchforstungsgrad. Practischer Forstwirth, 1890. No. 3-6. 
the flakes and the more quietly it has fallen. Small flakes pass more easily between the branches of the trees, and dry snow is more easily shaken off them by the wind than damp snow. During a frost, however, wood is more brittle and consequently breakage is easier. The greatest damage is done when a thaw sets in after a fall of snow, and is followed by a frost, a fresh fall of snow and a strong breeze. Such a combination of circumstances will cause extensive snow-breakage in woods of all ages, whether sown or planted, thinned or unthinned, forming a sad picture of devastation for the forester, who sees the results of his care at once nullified.

\section{Record of Damage done by Snou.}

Snow-break being only of a local nature, the occurrence of serious damage in the Harz mountains may be cited. During the sixty-six years ending with 1890, there have been serenteen disastrous years of snow-breal, or one year in every four, the worst of which were as follows:-

In January and February, 1844, in Hamnorer, two million stems were broken by snow, orer 95 per cent. of which were under 7 inches in diameter. In November, 1872, in Brunswick, 2,878,000 cubic feet of timber were broken by snow on 89,362 acres, being at the rate of 28 cubic feet per acre, about half the fixed annual yield of the forests. Again, in November and December, 1875, in the same forests, 80 cubic feet per acre were broken by snow, and in some of them as much as 185 cubic feet per acre. The chief damage was done on the northern side of the mountains. From the 10th to the 13th December, 1883, and from the 11th to the 27th January, 1854, 22,500,000 cubic feet of timber were broken in the Hannorerian Harz, and about 7,000,000 cubic feet in the Brunswick State forests.

\section{Protective Rules.}

Protective rules against damage to forests by snow should be drawn up, either on the principle of reducing the porrer of attachment of the snow to the trees, or of strengthening the latter. The question will be discussed under the heads of formation, tending, and utilization of the woods. 
(a) Formation of Woods.

(i) Species endangered by snow should not be planted, especially in pure forests, or in snow localities. Scotch pine is the worst species for such places, and broad-leaved trees, such as beech, sycamore or hornbeam, should be mixed with spruce and silver-fir'; larch may also be introduced, wherever it is likely to succeed.

(ii) Natural regeneration will give better results than regular plantations; it produces the trees in groups and with a mixture of broad-leaved species which should be encouraged.

(iii) Where the clear-cutting system is followed, strong nursery-trained transplants should be used to re-stock the felling-areas, the plantations being made in lines parallel to the direction of the prevailing wind, so that the snow may fall between the plants. The plants should be somewhat closely planted wherever heavy snow is to be feared, so that they may afford one another mutual support against the snow.

(iv) An excessive growth of grass, bracken or other weeds should be removed from young growth, as it may be pressed down by the snow over the plants and lill them.

\section{(b) Protection during Thimmings.}

(i) The most efficient measure to protect roods against snow-break is to make timely thinnings, in accordance with sylvicultural rules, and suitable to the circumstances of each case. In woods endangered by suow-break, thinnings should commence early, be frequently repeated, and increase in intensity with the age of the trees. At the same time great care must be taken in the first thimning of densely stocked pole-woods.

(ii) All injuries to the bark of trees must be avoided.

(iii) In specially valuable young pole-woods, the snow may be shaken from the trees; this measure was snccessfully applied to 10 to 20-year-old s'sotch pines in Württemberg and Silesia in 1868, but can evidently be carried out only on a small scale.

\section{(c) During the Principal Fellings.}

(i) Felling by the selection method should be followed in 
high mountain regions, on peaks and ridges, as this farours uneren heights in the trees.

(ii) Wherever clear-cuttings are practised, the felling-areas should be of small extent, so that areas of even-aged wood should not be too extensive; several series of felling-areas should therefore be established.

(iii) In coppice-with-standards only strong tellers should be reserved.

\section{Treatment of Injured Wroods.}

The treatment of injured woods will depend on their age and the species of which they are composed, and the lind of damage they have experienced.

If extensive damage has been done by snow, the first duty of the forester is to remedy matters as soon as possible; in coniferous woods especially, all bent and broken wood should be at once worked up and sold. Trees on which three or four rerticils of living branches have been spared may be left standing, after carefully pruning off their broken branches. Stems which hare been bent over from the ground may recover their erect position owing to their elasticity and striving torards the light, and in any case, they assist in keeping the soil covered. The woodcutters who are removing broken stems may be directed to set the bent stems upright, and, if necessary, attach them by string or wire to stems which are still erect.

Young coniferous woods which have been broken in patches and strips should be replanted with large transplants of beech, sycamore, larch; spruce, silver-fir, or Weymonth-pine may also be used. Older woods, when greatly thinned by snow-break, should be under-planted; spruce-woods with beech. The remarks * already made regarding repairs of damage done by wind are also applicable here.

Injured broad-leaved woods, especially beech pole-woods, may be repaired by cutting back the bent stems at heights of 12 to 18 feet from the ground, the stems being bent straight. In case of very serious damage, however, the injured woods, if not too old for reproduction from the stool, must be cut back close to the ground, and the thinned wood underplanted with 
FIr. 233.

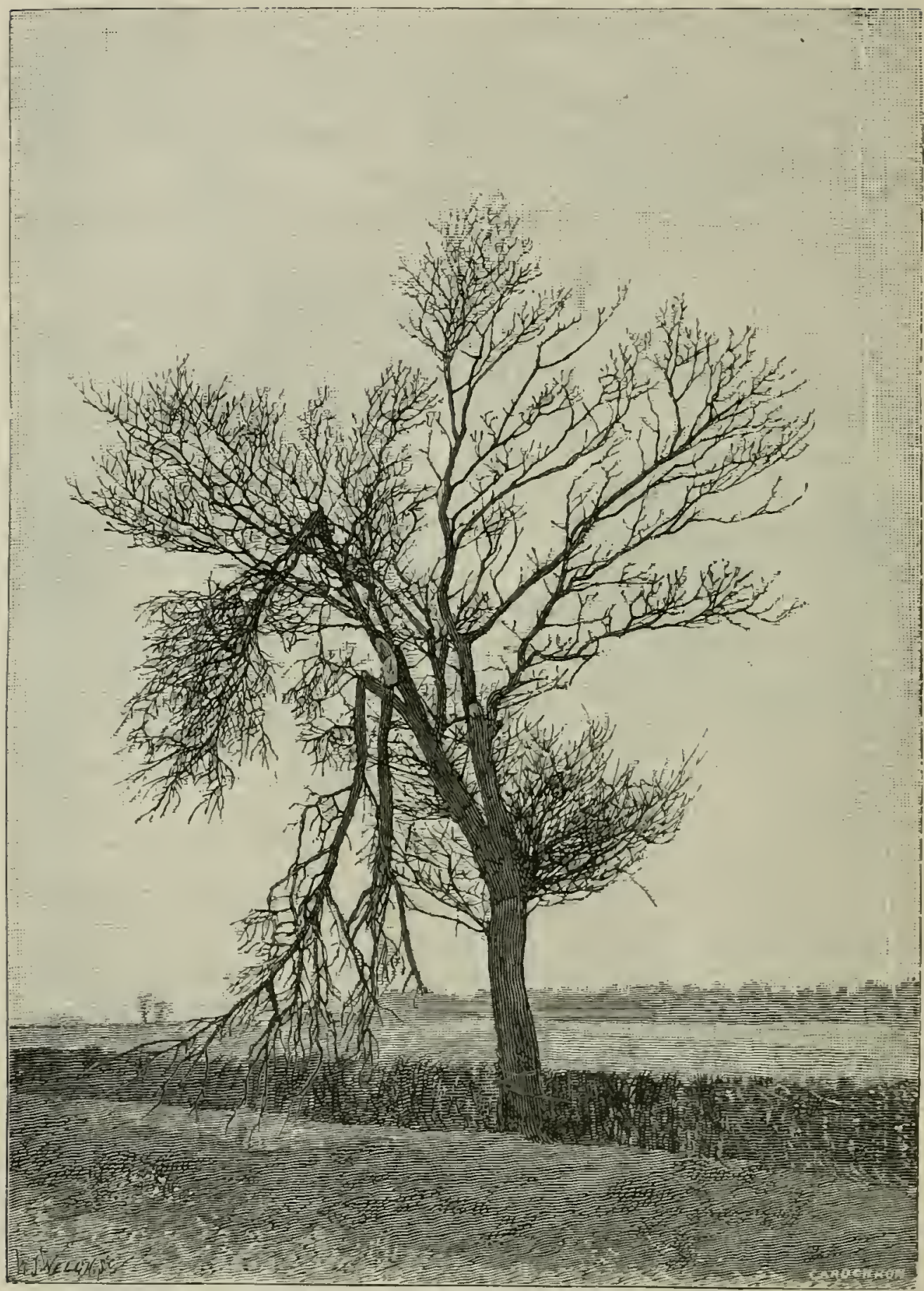

Oak tree, branches broken by rime. From rol. xiii. Journal of R. Hort. Soc., Notes on Hoar Frost, Plowright.

beech or silver-fir; woods like coppice-with-standards will result, which owing to their mnevemness in age, height and rate of growth, will be better able to withstand future falls of snow. 


\section{CHAP'TER VII.}

PROTECTION AGAINST RIME.**

\section{Damage done.}

Rine and ice may incrust and overlade stems, crowns and branches, and thus break or uproot trees. Rime, unless accompanied by snow, seldom seriously damages trees, but this is not the case with ice, and when this is followed by snow and a stiff gale, forests may suffer very considerably.

The damage done resembles that effected by snow, but whilst suow-break chiefly occurs in younger woods, rime and ice will damage middle-aged and even mature woods.

Scotch pine and larch-woods thirty to sixty years old and beech-woods from forty to eighty years are most liable to injury. Pole-woods are generally bent, but may be sometimes crushed by the weight of ice they bear, as if by a gigantic roller. The damage done by rime and ice, in Central and Northern Germany, chiefly occurs at altitudes between 1,600 and 2,600 feet. Northerly, north-easterly and easterly aspects suffer most, especially steep slopes and depressions exposed to the north-east wind. Woods suffer on both sides of valleys running east and west, whilst in valleys running north and south only the east aspect suffers.

Isolated trees suffer more from rime and ice than trees growing in dense woods, as they have a larger surface exposed, and this applies to avenue trees, seed-bearers in regenerationfellings and standards over coppice, and also to trees along the easterly and northerly borders of a wood, or of an exposed felling-area. Trees afford one another mutual protection in a dense wood. Most of the damage is done in January and February during the continuance of northerly or north-easterly winds.

* Vire Totes on Hoar Frost: C. B. Plowright, Jommal of R. Hort. Soc., March. 1891. 


\section{Record of Bad Years.}

The damage done by rime and ice as well as by snow is of a local nature, and in the Harz mountains there were nine bad years between $1821-1875$, which were also the years in which much snow-break occurred.

The weight of ice on the trees is sometimes cousiderable, as much as fifty pounds on six pounds of wood. A most destructive ice-break occurred between the 18th and 25th of November, 1858, in the Spessart, Odenwald, part of the Bavarian Palatiuate and Rhenish Prussia, in which the ice-crust was eighteen to

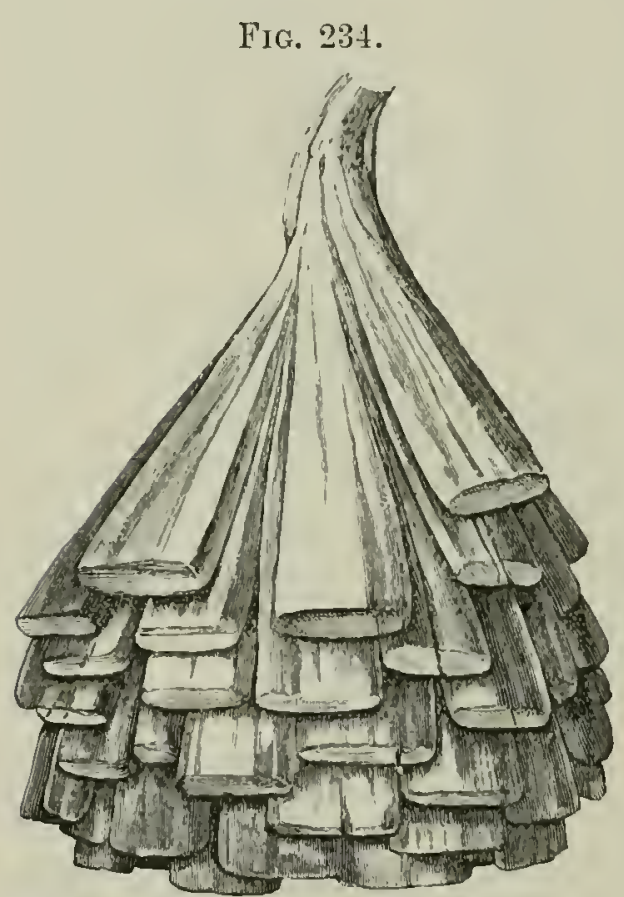

Needles of Scotch pine encrusted with ice. twenty times the thickness of the wood on which it rested. In the Spessart 2,750,000 cubic feet of wood was broken; in the Odenwald nearly $2,000,000$ cubic feet; in the State forests of the Palatinate $11,000,000$ cubic feet, and about half as much in the Communal forests. Observations shored that a spruce plant $3 \frac{1}{2}$ feet liigh had to support 165 lbs., and single Scotch pine-needles, orer half an ounce of ice. The picturesque forms of the ice-incrustations are shown in figs. 234 and 235.

In France and Central Germany, from the $22 \mathrm{nd}$ to the $24 \mathrm{th}$ of January, 1879, there was most extensive breakage of woods by ice, which is described by Janin in the Revue des Deux Mondes. In certain broad-leaved forests, about 50 per cent. of the stems were broken, and in carefully thinned Scotch pine-roods, 70 per cent. In the forest of Fontainebleau, about 5,300,000 staclied cubic feet of wood were broken, thin twigs of wood and telegraph wires being incrusted with ice to a thickness of 8 inches. Living larks were found frozen to the ground by their teet and tails, and in the Champagne district dead partridges were picked up covered with 
ice. Great damage by rime to elm and other trees is described by Plowright as having occurred in Norfolk on Jan. 7th, 1889.

\section{Protective Riules.}

(a) Formation of strong young growth. Where danger from rime and ice is feared, the Scotch pine must be excluded or mixed with other species.

(b) Maintenance of the leaf-canopy even in old woods.

(c) Isolated standards should not be reserved.

(d) A protective belt should be maintained on the northeastern and eastern border's of woods.

(e) Wherever danger from rime-frost is greater than from storms, cuttings should be made in woods from south-east to FiG. 235.

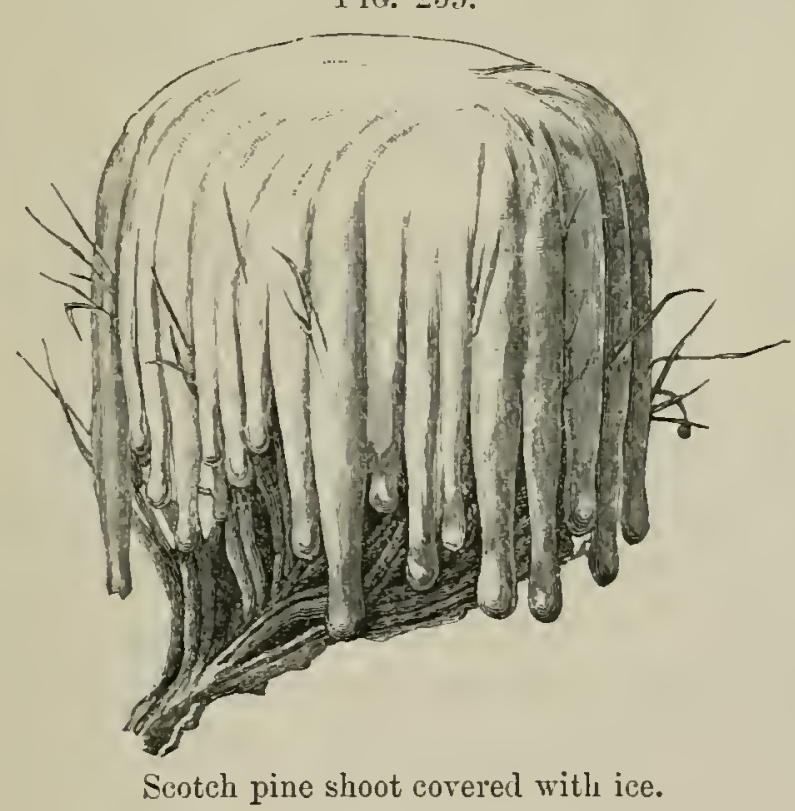

north-west, when the south-westerly gales merely blow along the face of the felling-areas, and endanger only a few border-trees. The correct direction for felling-series can be decided only after a thorough knowledge has been acquired of the configuration of the ground and of the local factors.

\section{Treatment of Injured Woods.}

Reference is here invited to Chapter III., p. 474, and Chapter VI., p. 491, dealing with woods damaged by storms and snow, as those which have been injured by ice will require similar treatment. 


\section{PAR'T V.}

PROTECTION AGAINST NON-ATMOSPHERIC PHENOMENA.

THE chief non-atmospheric phenomena to which forests are exposed are swamps, floods and torrents, avalanches, shifting sands, and forest fires.

\section{CHAPTER I.}

\section{PROTECTION AGAINST DAMAGE BY SWAMPS, FLOODS AND TORRENTS. *}

Water acts either as a meteoric phenomenon, or as stagnant or flowing water on the surface of the ground, or in the soil; its effects are partly mechanical and partly physiological. The chief mechanical effects consist in soil-denudation, landslips, or floods. Physiological damage is done to plant life and to the soil by stagnant water causing bogs and marshes. Damage to forests by heavy rain has already been dealt with.

\section{Section I.-Soil-Denudation.}

\section{Description.}

Soil-denudation on steep slopes may be due either to subsoilor surface-water, or to torrents.

Subsoil- or surface-water on hill-sides may cause landslips, which bring down the soil with the vegetation growing on it, and expose the subjacent rock; this may occur either when the slope of the hill-side is excessive, or when there is an imper-

* Firaft, Gustar. Ijeitrage zm forstl. Wasserbankunde. Hannover, 1862. 
meable substratum which prevents the further descent of the water into the hill. Excavations of pits or quarries at the base of a hill may have a similar effect.

Torrents, especially in mountainous regions, may canse soildenudation, or form ravines by deepening their beds, and by wearing away their banks. The latter effect chiefly occurs at sharp turns in the course of the torrent, when one bank is formed of rock and the other of loose material.

The force of the water increases with its velocity, and may be assumed to be proportional to the sixth power of the velocity of the stream.

To cite an example, a formidable landslip occurred on the 15th November, 1879, at Vitznau, on Lake Lucerne. Here, at the foot of the Rigi, a mass of earth exceeding 35,000 cubic feet, and covered with trees, fell down the mountain side and filled a depression, burying a chapel with mud to a depth of twenty feet.

Landslips occur frequently in all mountain chains, and in the Himalayas attain vast proportions; the Golma landslip, in 1893, for instance, brought down enormous quantities of rock across a valley, damming up a tributary of the River Ganges. This led to the formation of a lake 10 miles long and 500 feet deep, which eventually burst the dam in August, 1894, causing a flood 30 feet deep to rush down the Ganges valley and flood the town of Hardwar. Owing to the establishment of telegraphic communication, and to careful watching at the dam, all the inhabitants of the valley received timely warning of the probable bursting of the dam, and no lives were lost.

\section{Damage done to Forests.}

Soil-denudation reduces the forest area, buries plantations and young growth in mud, injures and destroys forest roads and other works, and fills up ditches; ravines are formed on hill-sides, which become constantly enlarged by surface drainage, whilst the beds of water-courses are raised, interrnpted and altered by the material brought down by the water, and inundations are thus caused. The amount of damage done increases, the steeper the slope and the more broken its contour, and the looser the soil and the greater the weight of the woody growth. 
Localities where landslips are likely to occur may be recognised beforehand in wet years by cracks forming in the soil.

\section{Protectire Rules.}

The best protective rules to adopt against these dangers are :-

(a) Careful maintenumce of a continnous woody growth on mountain-peaks, ridges and all dangerous slopes. Forests in such places are protection forests, and should be managed either by selection or as coppice. For mountain tops and plateanx, the selection system is best, when accompanied by the timely planting up of all gaps which may occur in the wood, but on steep slopes, high forest presses too heavily on the soil, and should make way for coppice with short rotations.

(b) Wherever a land-slip is to be feared, the bank should be liept up by wattle fences, by protection of the soil-covering, and by not extracting the stumps of felled trees. The various protective measures which may be adopted, depend on the cause of the danger and the circumstances of the locality. Surface- or mnderground-water, for instance, may be conducted away from above the endangered place by ditches or drains. All quarrying below the threatened hill-side must be stopped.

(c) The following measures provide against damage by a mountain torrent:-

(i) Securing its sides and bed by revetments from its collecting area downwards.

(ii) Reducing the force of the stream by terracing its bed, and constructing across the stream wattle-work fences or masonry works which keep stones and silt from accumulating in the lower parts of the stream.

(iii) 'Terracing the slopes of the valley on either side of the stream, and fixing them by means of sowings or plantations.

(iv) Reafforesting the collecting-area of the stream; the methods to be adopted for this object are described further on.

\section{Remerlial Measures.}

When, in spite of every care, landslips or ravines have been cansed by ubuormally heary rain, or by melting snow, protective 
works should at once be constructed. A revetment made of wattle-work, or of logs fixed in position by piles driven into the ground, may prevent the occurrence of further damage. If, however, the landslip is extensive, several such revetments, one above the other, must be made, and the earth between them be bronght to a uniform slope and planted up. In certain cases, complicated masonry revetments are required.

\section{Section II.-Inundations.}

\section{Causes of Inundations.}

Inundations originate in valleys and plains owing to the sudden thaw of masses of snow in the mountains or plateaux above them, or to prolonged or heavy rainfall, or to the interruption of water-courses by landslips. The last of these causes is frequently due to clearing forests from mountain sides, and to bad management of protection forests. When, on hillsides, the effects of rain and surface-drainage are not reduced by a full leaf-canopy and by the binding effects of the roots of the trees on the soil, as well as the sponge-like action of the natural soil-covering of dead leaves and moss on the surfacewater, the latter runs down unimpeded into the valleys, bringing with it quantities of boulders, gravel, silt and mud; this raises the beds of the water-courses, and causes them to overflow and spread destruction far and wide into the lower country, especially by leaving cultivated lands covered with gravel and silt after the floods have subsirled. Where floods merely cover riverside meadows and osier beds, or woods of alder and other moistureloving trees, they may actually prove beneficial by the deposition of a fine mud containing useful mineral constituents. In many parts of India the cultivation of rice is carried out on land which is either naturally or artificially flooded.

Most inundations in Central Europe occur in April, when they are due to the general melting of the mountain snow, or in August or November, owing to heavy rainfall.

\section{Damage done.}

Inundations carry away the soil-covering and humus from forests, causing swamps and cold soil; they destroy young 
plants, hinder the formation of coppice-shoots, interrupt fellings and the export of forest produce, and often carry away timber to great distances. In spring floods, trees growing along the banks of streams may suffer from the friction of the ice which is carried down. The mud brought down by the flood, however, richly compensates for the loss of soil covering and humus. River mud not only contains nutritive mineral salts, but yields lime in a fine state of division, which is therefore readily absorbed by plants, and is an excellent manure for lands which are poor in lime.

Dr. Schulze of Darmstadt gives the following per-centages for the constituents of Rhine mud :-

\begin{tabular}{|c|c|c|}
\hline Potash & $\begin{array}{c}1871 . \\
0.43\end{array}$ & $\begin{array}{l}1872 . \\
0.19\end{array}$ \\
\hline Lime & $14 \cdot 06$ & $15 \cdot 65$ \\
\hline Phosphoric acid & $0 \cdot 13$ & $0 \cdot 11$ \\
\hline Humus . . & $2 \cdot 86$ & $2 \cdot 12$ \\
\hline
\end{tabular}

The per-centages of potash and phosphoric acid are small, but always greater than in ordinary agricultural soil.

The greatest recent floods in Central Europe in 1856, 1868, 1879, 1882, and 1888, chiefly affected the Alpine districts, the countries adjoining them, and Hungary.

In 1856 the Rhone caused fearful floods, which drowned numbers of people and damaged property to the extent of $£ 8,000,000$. One of the results of these floods was the enactment by the French Legislature of the laws for the reboisement of the denuded mountain-sides, of the 28th July, 1860, and of the 8th June, 1864, for regazonnement, or restocking them with grass.*

Terrible floods occurred in Switzerland in 1868, and in Hungary in the valley of the River Theiss, in March, 1879. In September, 1882, damage estimated at $\$ 1,000,000$ was caused by floods in Carinthia and the Tyrol, and there were serious floods in the Rhine valley in 1882, and in the regions of the Elbe and Oder in 1858. Extensive floods occurred in the Thames and Severn valleys, and other districts in the South of England, in November, 1894.

* Forest Law, Baden-Powell, 1S93, p. 248. Laws for the protection of momntain forests in Germany, Switzerland, and Italy are also referred to. 
Serions floods* occur in Northern India nearly every year between July and September, after the commencement of the summer monsoon, and owing to the great damage thus caused to irrigation canals fed by the Ganges and Jumna river's, the forests on the southern slopes of the Siwalik Hills are now managed as protection forests. The Indian forest officials $\uparrow$ have for years recommended the adoption of similar measures to the lower hills between the Jumna and Sutlej rivers, as the first burst of the monsoon on the anmually grazed and burned sandy hills above the Hoshiarpur district causes most disastrous inundations every year, besides bringing down quantities of sand, gravel, and boulders which have encroached considerably on the agricultural land below the hills, so that by 1891, lands belonging to 914 villages were affected, and 30,000 acres of richly fertile and long cultivated land laid waste, besides immense damage being done annually to railway and road embankments, \&e. The hills were formerly covered with forest growth, but during the last thirty years, flocks of goats and herds of buffaloes belonging to about eighty hamlets of squatters have been allowed to browse down and destroy the forest growth which formerly fixed the soil on the hills, and would spring up again were the annual grazing and burning of the undergrowth restricted.

\section{Protectire Rules.}

Private agency can usually do little or nothing to prevent floods. The action of the State is indispensable, as the cost of the erection and maintenance of the worlis necessary to secure this object is quite out of proportion to the value of the property on which they must be erected, and the work of fixing the beds of mountain torrents and hill-sides in process of denudation must be carried out over a large area. The most effective measures depend on the management of the collecting areas of dangerous water-courses, the main principle being to meet the danger at its source.

Although observant + people discovered these facts and wrote

* Vide Indian Forester, vol. xii., p. 418.

† Ibicl., vol. v., p. 3. Baden-Powell's Report. Moir's Report, vol. x., p. 271 ; vol. xiii., p. 525 ; vol. xvii., p. 216.

+ Ton Auersberg, Innspruck, 1779. 
about them a century ago, a long time elapsed before improved forest management and the erection of the necessary works were undertaken in regions which were threatened in this way. Serious and successful action, however, is being taken in France, Switzerland and the Tyrol, to counteract the causes of floods.

The chief rules to be followed are:-

(a) Revetment of torrents and their feeders. By this means earth, gravel, and boulders are retained in the mountains. Works of the following nature should be designed in accordance with the nature of the locality, the characters of the torrents, the area of the collecting ground, and the funds available:-

(i) Barricades of trees with their entire crowns thrown across torrents.

(ii) Wattle fences across the bed of torrents.

(iii) Dams made of fascines or masonry, to cause the deposition of coarse material, to be constructed across torrents at suitable distances.

(iv) Paving the bed of the torrent.

(v) Wattle-fencing on revetments along the banks of torrents, to moderate the cutting action of the water.

The above works are only intended to moderate the action of the torrents, but in connection with them, the gradient of slopes above the banks of the torrent may be lessened by terracing, and a system of horizontal drains laid ont, so as to distribute the surface and underground drainage over a large area.

The local forest staff will be best able to carry out these protective measures, as they should possess the necessary technical and local knowledge.

(b) All waste land on the higher ground above the torrents should be planted up, and all woods within that region should be carefully maintained. Sewell, as far back as 1841, argued that the maintenance of and jncrease in the area of mountain forests would regulate torrents.

A treatise on forest protection cannot go very far into the question of the regulation of mountain torrents, which has a literature* all to itself. Here, only the chief points can be

* Demontzey, Etude sur les Travanx de Reboisement et de Gazonnement des Montagnes. Paris, 1878. Id. Traité Pratique, 1882. Von Senkendorf, Ve?bannung der Wildbäche. Vienna, 1884. Landolt, Die Bäche, Schneelawinen und Steinschläge. Zirieh, 1856. 
attended to, and reference made to standard works on the subject. Protection forests must be managed on the Selection system. Planting is the best way of restocking blanks, the mountain and Cembran pines, larch, and spruce being the most suitable species. The lines of plants should be inclined at an augle of $45^{\circ}$ to the axis of the torrent, and grass should be sown under their shelter. Pasture, use of litter, and other destructive usages must be disallowed, and the soil-covering strictly preserved.

Readers are referred to works on Forest Utilization for an account of the regulation of the lower part of streams, as the procedure required to make them serviceable for water-transport will also tend to prevent floods.

\section{Management of Forests on Land liable to Inundations.}

The management of forests on land liable to be flooded includes much that is special to the circumstances of the case. Species should be chosen which can withstand a good deal of moisture in the soil and occasional submersion; such are the pedunculate oak, elms, alder, willows, black and white poplars, and the ash. In the wettest places the common alder and willows are found; ash is more sensitive to soil-moisture than poplars and the pedunculate oak.

Pollarding, the Selection system, and Coppice-with-standards rich in standards, are suitable systems of management. Treewillows may be pollarded, but poplars are best managed by cutting only their side branches, as pollarded poplars soon decay. Both poplars and willows speedily reproduce the bark, which has been rubbed off by ice; they are generally grown from strong cuttings. Oak and ash may be grown in High Forest. Reproduction is then effected by planting saplings, as natural regeneration is difficult to obtain on areas liable to floods. In the case of Coppice-with-standards, a much larger number of tellers is reserved at each felling than is usually the case under this system, in order to keep down inferior species such as blackthorn. Osier beds, chiefly of Salix riminalis, S. purpurea, \&c., may be planted by means of cuttings, and cut over annually.

VOL. IV. 
In the case of High Forest, or Coppice-with-standards, the felling-areas should be arranged at an oblique angle with the course of the stream as shown in figs. 236 and 237 , I. being the youngest and VIII. the oldest wood.

Such an arrangement affords shelter to the young growth and

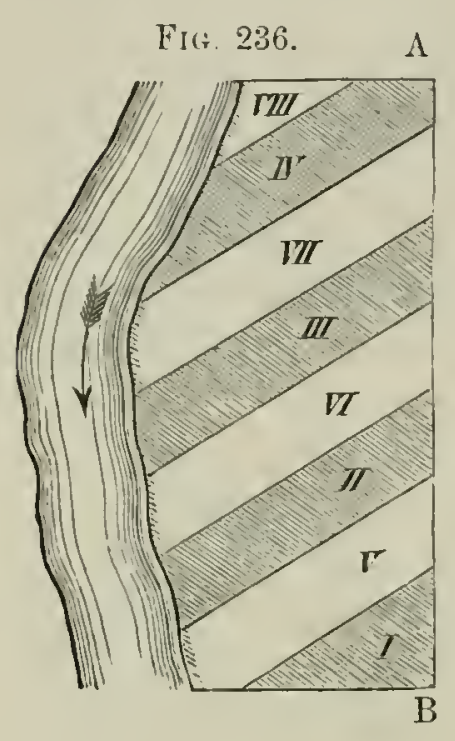
prevents floods from carrying away the $A$ felled timber lying on any area beyond the next strip of rood.

Fellings should take place when the water is lowest, or when it is frozen. Grass-cutting and removal of litter may

FIG. 237.

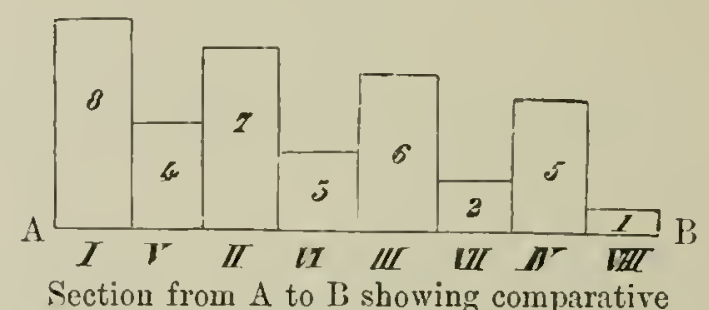

heights of wood.

be carried on freely in such forests, without danger of impoverishing the soil, which is enriched by the annual floods; pasture, however, should not be allowed.

\section{SECTION III.-SwaMIPS.}

\section{Formation of Swamps.}

The soil of a locality becomes wet when the drainage-water has not a sufficient outlet, and if there be no ontlet for the water, swamps or bogs may be formed. Rain, snow- or springwater, or water from rivers and ponds may cause the formation of a swamp, if the water cannot escape superficially owing to an insufficient fall of the ground, or by penetration into the subsoil owing to an impermeable substratum of clay, turf, clayey or marly loam, soil encrusted with iron, or massive rock, especially in horizontal layers. Sometimes both these causes are at work, when the harm done is intensified. The following specific peculiarities may occur:-

(a) In low-lying plains, swampiness is generally caused by 
flowing water, owing to a slight depression in the ground and a stiff soil.

(b) In basin-shaped valleys along watercourses, swamps may be caused by surface-water, or by underground infiltration from the stream ; the former happens after floods, when the overflow cannot find its way back into the stream, owing to the presence of high land along its bank. Part of the overflow must then remain on the low land, especially wheu the subsoil prevents the descent of the water. Lagoons along the sea-coast are formed in this way.

(c) Water may spring through permeable soil from neighbouring watercourses, and when it thus appears in depressions, it denotes a high level of water in the stream and complete saturation of the soil.

(d) In high plateaux, swampiness is due to heavy rainfall, or to snowfall with subsequent thaw, or to saturation of the air

FIG. 23S.

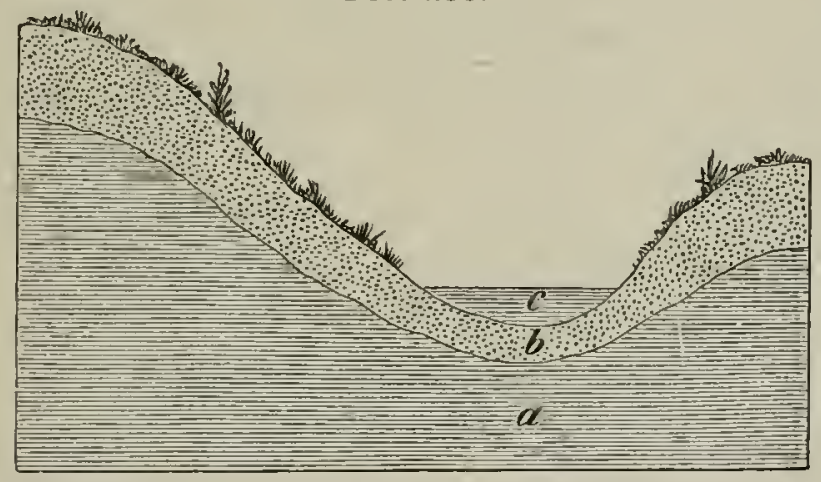

a. Impermeable stratum. b. Permeable stratum. c. Watex.

combined with an impermeable subsoil accompanied by the growth of swamp-forming mosses or other plants.

(c) Swamps at the base of a hill are generally caused by springs, the water from which cannot penetrate into the ground on account of a subsoil of clay or of horizontal rocky strata. If the soil on a hillside should be permeable above and impermeable below, all the water in it descends to the base of the hill, where it rises above the ground-surface and forms a swamp. If, however, the permeable stratum terminates in the slope, drainage-water will spring out of the hill-side, along the line where the two strata coalesce. 


\section{Jamage done by Suamps.}

(a) General Account.

The damage done by swampy ground is as follows:-

(i) Instability of the trees, which favour's windfall, especially of the spruce.

(ii) Stunted growth and liability to decay in the roots and stems of trees, and consequent loss of increment and sometimes death of the trees. The bad growth of trees on wet soil is due to the exclusion of oxygen from the roots and to the low temperatures of the soil and air, as wet soil may reduce air-temperature by $9^{\circ}$ to $14^{\circ}$ Fahr., or to the formation of acid compounds in the soil; healthy growth and action of roots is consequently much impaired.

(iii) Increased damage by frost, sometimes lilling off young plants.

(iv) Difficulties in forest management in regeneration and harvesting, also in trausport. The wetness of the soil increases the difficulty of cultivating it, and often renders spring-planting quite impossible; seeds do not germinate in too wet a soil, and young plants often perish.

(v) The tendency of a swamp to increase in area is another cause of danger to the forest.

\section{(b) According to Species.}

Hardly any forest species can withstand continuous stagnant wetness of the soil, but the degree of resistance to it shown by different species differ's considerably. Experiments made in the Palatinate, where there is an impermeable subsoil, show that trees resisted a very wet soil in the following order:-

Pedunculate oak, elm, poplars, willows, hornbeam, common alder ;

Ash, sessile oak ;

Scotch pine, spruce ;

Beech, silver-fir.

It is strange to find the alder so low in this scale, as other observations tend to prove that this species can withstand more moisture than the elm. The birch, and especially Betult pubescens, Ehr., will withstand much moisture in the soil. 


\section{(c) Age of Wood.}

Young plants are frequently killed by inundations. Poles and trees on swampy ground generally suffer from root-decay, especially the spruce, larch, and Scotch pine.

\section{(d) Locality and Nature of Soil-Covering.}

Swamps are more frequent in lowlands than on hills and in mountain districts, on massive than on stratified rocks, and on heary stiff soil than on loose soil.

Local swamps may occur where the substrata are horizontal, as on the Buntersandstein in the Black Forest. Certain forest weeds, such as sedges, reeds, peat-plants, and especially peatmoss, predispose to swampiness, whilst permanent pasture dries up the surface-soil, but will not thrive on very wet soils.

\section{(e) Density of Standing-Crop.}

Clearance of forests, especially in mountainous regions, favours the formation of swamps; it may be observed as a general rule, that swampy ground, when once stocked with young wood, becomes gradnally drier as the rood grows older and covers the ground. This is especially true for coniferous forest, and the efficacy of the Scotch pine for draining swamps is well known in Ireland, where many bog's have been formed on the former sites of forests, as is proved by the presence in them of bogoak and other woods. The damp, cold London clay at Prince's Coverts near Esher, hardly ever dries up on the roads through the forest, but the ash, hazel, and alder-coppice will be found to have dried up the soil on both sides of an extremely wet road.

Ebermeyer has proved by numerous observations that on a heary clay soil, the root-zone of a spruce forest, from 16 to 32 inches below the surface, is much drier than the corresponding zone on bare fallow land, the opposite being the case as regards the uppermost layer's of soil, which are protected by the leafcanopy of the trees from insolation and the drying action of winds, while the moss and dead needles retain much moisture near the surface of the ground.

The valley of the Upper Rhone affords a waruing example 
of the effects of clearing forests on the formation of swamps; the high land above the river having been cleared of forest at the end of the eighteenth century, in order to afford land for agriculture. Field-crops, however, have made way for pasture, and the quantity of hay produced ammually has decreased, till at last the formerly forest-clad areas have become covered with moss and converted into swamps. Reafforesting the area, as in the Dammersfeld, has been attempted, but is a difficult task.

In explanation it should be noted that in mountain regions with cool, humid atmosphere, which is unfarourable to eraporation, the amount of water taken from the soil is proportional to the extent of leafy surface exposed to the air, and to the surface of the crowns of the trees standing on the area. The greater the amount of leaf-canopy, the more atmospheric precipitation falling on it is evaporated, and so much the less reaches the ground. Broad-leaved trees act in this manner during the season of growth, but evergreen conifers throughout the year. In addition to this the absorptive action of the roots, and the power of transpiration possessed by the foliage of trees must be reckoned. Observations made between 1868 and 1871 at the double Bararian meteorological stations, which are in pairs in the forest and in the open, show that according to the season from $25 \%$ to $32 \%$ of atmospheric precipitation (rain, snow, \&c.), and averaging $26 \%$ for the whole year, did not reach the ground directly, but remained on the crowns of the trees. It is not, however, stated how much of this water may hare subsequently trickled down to the ground.

There are certain localities, for instance, level land with an impermeable substratum and high atmospheric temperature, where swampiness of the soil is, on the contrary, increased by forests. In such cases, the rapidity of evaporation depends on the unimpeded action of the sun's rays and of dry winds, and clearing the ground of forests will increase the effects of these forces.

The action of forests, where the soil-corering of dead leares, moss, and humus is carefully preserved in maintaining moisture near the surface of the ground, and protecting the soil from the effects of insolation and drying wind, is rery raluable on hot 
aspects and steep slopes, especially in hot countries, where water may be thus stored in the spongy soil-covering and maintain a steady supply of water in springs on the hillside, instead of allowing the rain-water to drain rapidly down and cause floods after heary rainfall, while the watercourses may run nearly dry during the hotter months of the year.

\section{(f) Season.}

In countries with heary snowfall, where the snow remains lying on the ground throughout the winter, the soil is wettest in the spring, after the snow has melted.

In the south-east of England, the soil is probably wettest from November till March, and dries up rapidly after the 1st of March till July, owing to the scanty rainfall and the prevalence of dry east winds.

\section{Protective Rules.}

(a) In mountain regions, and in very rainy districts, such as the boggy parts of Ireland, where the formation of swamps is to be feared, forests should be maintained and be completely stocked, and shade-bearing conifers are best for the purpose.

The spruce probably exercises the greatest action in draining soil, the superficial roots of this species acting like drain-pipes; the Scotch and black pines are also very useful in suitable localities, and retain a large proportion of the atmospheric precipitations on their needles and branches.

(b) Marshy plants should be removed from the ground, and in damp low-lying places the circulation of the air should be increased by clearings, thinnings, pruning and removal of undergrowth.

(c) All ditches and watercourses in forests should be kept open, and at least once a year should be cleared of water-plants, dead leaves and mud.

\section{Section IV.-Drainage.}

A superfluity of water in the soil can be thoroughly rectified only by drainage. Before, however, undertaling such a work, a thorough inquiry should be made into all the bearings of the question, as extensive drainage-works, especially in moun- 
tainous districts, may damage a wide tract of country, and thus quite outweigh the advantages which may be gained by affording a larger area for forest-growth and an increased yield of wood. Experience shows that by draining swamps and moorland at high altitudes, the supply of moisture to the soil and atmosphere may become so reduced that forest-growth and agriculture may suffer in districts lower down. This calamity is especially liable to affect older deep-rooted woody species, and woods accustomed to plenty of moisture in the soil. Drainage causes subsidence of the soil, and thus the roots of shallow-rooted trees such as spruce may become exposed, while pedunculate oak and ash may become stag-headed, owing to their roots being less supplied with moisture than was formerly the case. Before, therefore, drainage is attempted, the demands on moisture of the species growing or to be grown on the drained area should be considered.

Neighbouring lands may also be affected by the lowering of the level of the underground water, and drying up of the surfacesoil, which may have bad effects on field-crops.

If the drainage of mountain forests be effected on a large scale, the distribution of atmospheric precipitation may be altered; the drier air may hinder the condensation of watery rapour, and the formation of dew and clouds may be lessened. Instead of frequent gentle showers, irregular heavy rain may fall with disastrous results.

A further disadrantage is the reduction of the quantity of water in brooks and rivers by which timber-floating, watercarriage and works for utilizing water-power, may sufferseriously.

Reuss states that the harm done by ill-advised drainage is most apparent in the Dobris mountain forests of the ColloredoMansfeld family; through the extensive drainage system, over 50 miles in length, effected there between 1858 and 1867, the growth in forest and field fell off to such an extent that it became necessary to fill up most of the drains. In the Harz mountains. also, in 1840 , much harm was done by too extensive drainage, whilst the attempts made since the middle of the present century to drain the peat-bogs in the Hannoverian Harz districts and to plant them with spruce hare prored extremely costly, 
and given such poor results that they have now been abandoned.

On the above grounds, the danger of drying up sources of userni water-supply, and the fear that benefits resulting from forest drainage works may not repay the outlay involved, the construction of such works on a large scale is to be deprecated, and the forester should not as a rule venture beyond draining small local swamps in forests, which may sometimes be rendered innocuous or even useful when converted into fish ponds, by excavating them or constructing a dam.

From a general view, therefore, of the matter, it follows that the advantages of drainage are greatest and the disadvantages least for forests on fairly level ground, whilst the reverse is true

FIG. 239.

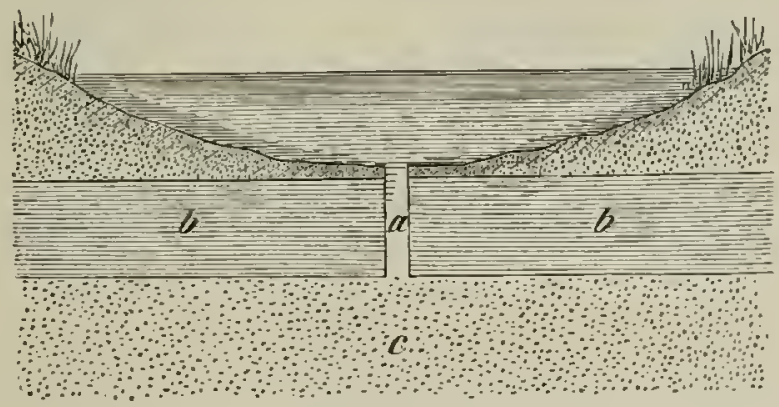

a. Vertical drain. b. Impermeable stratnm. c. Permeable stratum.

for mountain forests. The advantage of draining swamps as regards sanitation, circulation of the air and avoidance of malarial fever, need only be referred to here.

The following methods are employed in drainage:-

1. Vertical drainage.

2. Surface-drainage by open ditches.

3. Underground drainage by covered drains:-

(a) By trenches;

(b) By glazed pipes,

(c) By ordinary draining tiles.

\section{Vertical Drainage.}

Vertical drainage is carried out by piercing an impermeable stratum and thus allowing the water to descend into a lower permeable stratum and be thus drained of ' One or more 
borings of sufficient breadth should be made through the impermeable stratum at its lowest point, as shown in fig. 239.

\section{Drainage by Open Ditches.}

(a) Mode of Laying out a System of Drains.

The mode of laying out a system of drains depends on the nature of the locality. On level ground and in valleys, a complete network of drains is laid out after the land has been

FIG. 240.

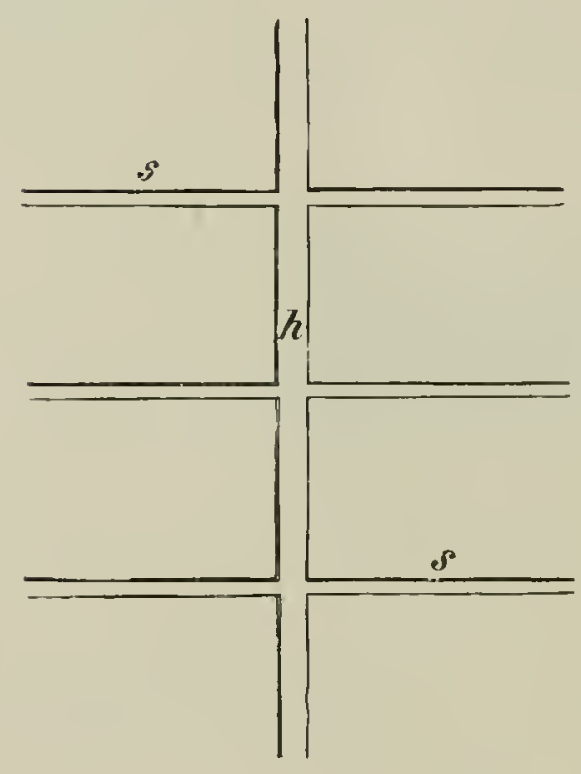

Plan of drainage. h. Main-drain. s. Feedcrs.
FIG. 241.

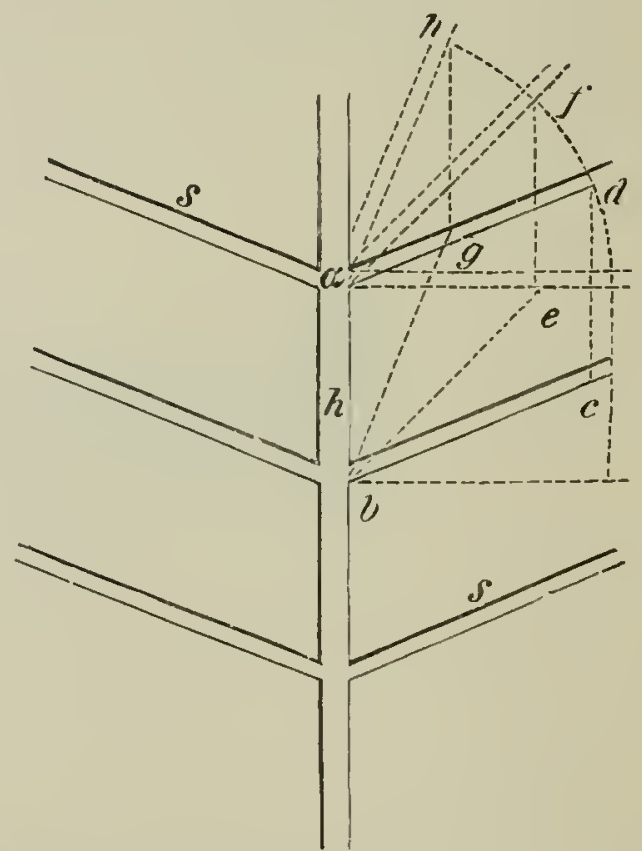

carefully levelled, and consists of main drains, leaders and feeders.

The main drain should run along the lowest part of the area to be drained, necessary excavations being made to give it a uniform gradient between 0.5 and $1 \%$, and to conduct it into the nearest watercourse.

The leader's must carry off the water in the shortest direction from the feeders to the main drain, while the feeders have to collect water from the soil and conduct it to the leaders, the direction of which depends on the gradient of the ground. When the gradient is moderate, the main drains and leader's should run along lines of greatest fall; if it is too steep, their 
length must be increased by causing them to wind or bend so that the drainage water may not wash away the bed or sides of the drains, and cause the formation of ravimes. The best fall for drains is from 0.5 to $1 \%$, but sometimes the lie of the ground may necessitate a certain length of drain of greater gradient.

The feeders should be obliquely inclined to the line of greatest fall in order to collect the maximum amount of water Fir. 243.

FIG. $2 \cdot 12$.
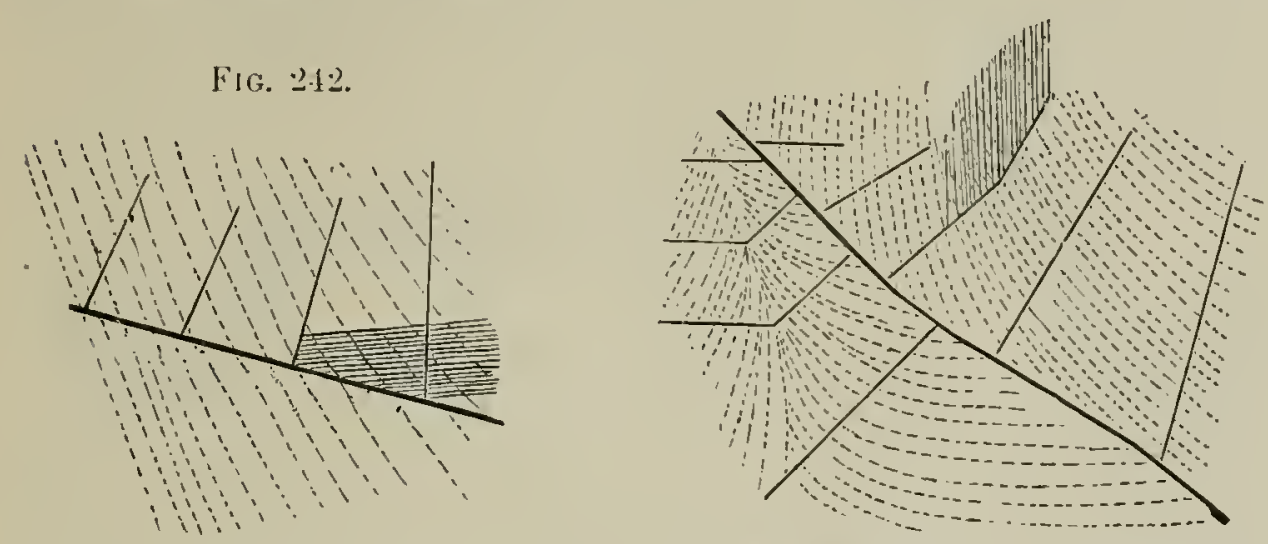

FIG. 244.

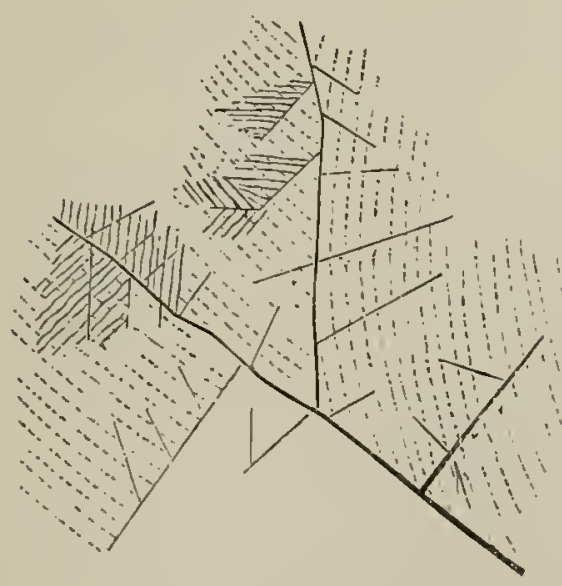

Plans of chainage.

from the soil, and they should conduct the water into the leaders, to which they may be either at right angles or oblique.

The first system, as seen in fig. 240 , has the advantage of draining the largest area with the shortest length of drain, and the more acute the angle between the feeder and leader, the less will be the area drained by a given length of ditches.

$$
\text { Thus } a, b, c, d>a, b, e, f>a, b, g, h \text {. }
$$


The choice of the angle between the feeder's and leaders depends chiefly on the gradient of the ground, the less the gradient the more acute the angle; feeders the bed of which gradually deepens as they approach the leader will be most effective.

Feeders can be laid out parallel to one another only when the gradients are uniform. Figs. 242 to 244 show some interesting networks of drains by G. Koch.

The proper interval between the feeders depends on the quantity of water to be drained array, the configuration of the

FIG. 245.

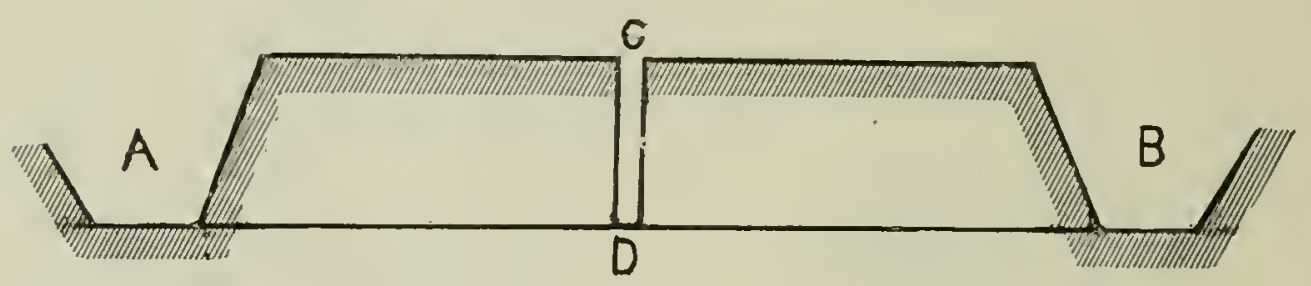

ground and the nature of the soil. The interval between any two feeders will be inversely as the quantity of water in the soil. The looser the soil, the more easily is it drained. On the

FiG. 246.

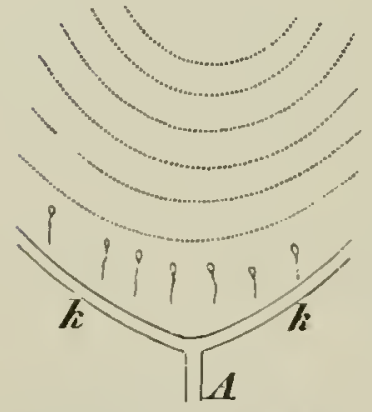

k. Feeder. a. Main drain at the base of a hill. average, according to circumstances, intervals of 16 to 22 yards may be chosen.

A practical method of determining this interval is given by Heyer, as shewn in fig. 245 . Cut a feeder $A$, and another $B$ at different distances from A till the water in the soil at the middle point $\mathrm{C}$ between the two feeder's falls to the depth C D, to which it is required to be drained.

In very wet land, the interval between the feeders may be reduced to 10 yards, whilst on drier land it may be extended to 30 yards.

Water percolating from a river should be collected as near it as possible by deep drains running aloug the river-side, and leading back into the river lower down stream. Orerflow from a stream can only be liept back by the construction of dams, as in the English Fen districts, or along the River Severn.

On slopes, water should be collected at the points of issue from the water-bearing strata, before it can form a swamp. Thus the water should be collected in a drain $k_{i} k_{i}$ running along a contom-line on the hill-side (fig. 246), and then conducted 
down-hill by a leader A along the line of greatest tall, any ontlying swampy places in depressions being connected with the latter. Wherever the fall and the extent of the area to be drained are considerable, several such drains may be constructed, one above the other.

\section{(b) Dimensions of the Drains.}

The breadth of the drains depends on the amount of water in the soil, the gradient of the ground, and the purpose of the drains. The wetter the soil and the slighter the gradient, the broader must the ditches be ; the leaders being broader than the feeder's, and the main drain than the leaders. From 1 to $2 \frac{1}{2}$ feet is a sufficient width for the feeder's, and 3 to 5 feet for the leaders and main drain.

The depth of the drains depends on the depth to which the land is to be drained, and on the physical nature of the soil and subsoil. Clay requires a greater depth of drainage than loam, and this again than sandy loam. In peaty soils, the drains should go down to the mineral subsoil. In practice, the depth of drains is usually half their width, and draining to too great a depth is prejudicial, costing in excess of the requirements of the case, and depriving the subsoil of reserve water which will be required by the trees during dry weather.

The slope of the sides of the drains depends on the degree of coherence of the soil, and on the gradient of the drain; the looser the soil and the steeper the gradient, the gentler must this slope be. Drains on a stiff soil, or on peat, may have steep sides; on loams their slope may be $45^{\circ}$, on clays $60^{\circ}$; and the sides of drains on peat may be almost vertical.

The main drains may be provided with sluices at suitable places, so that they can be closed and the drainage stopped during dry seasons.

\section{(c) Method of Digging the Drains.}

Drainage should precede planting by a few years, so that the ground may besome sufficiently dry and may settle down before the plants are put in ; a dry period of the year should be chosen for the execution of the work.

Operations should be commenced with the main drain at the lowest part of the land, in other respects the system already 
described for digging boundary-trenches should be follored. The earth remored from the drains should not be placed too close to them, as it may then be washed back again by the rain; it should be used for filling-up hollows or spread evenly orer the surface of the ground, which is beneficial in wet places by raising their level. It is most economical to give the work out to be done on contract.

\section{(d) Adrantages of the Method.}

The advantages of the method of draining by open ditches when compared with closed drains are :-

Cheap execution.

Ready discovery of places requiring repair, and cheapness of repair's.

Its disadvantages are :-

Loss to the forest growth of area occupied by the ditches.

Difficulties in transport of produce.

Liability of the ditches to damage by men, cattle, Sc.

Too rapid remoral of water.

The loss of area taken up in open drains is not of any practical importance in forestry, and provided care be taken about the number and dimensions of the ditches, the other disadvantages of the method may be avoided. Hence, for these as well as other reasons which will be giren further on, drainage by open ditches is the chief if not the only available method of draining forests.

\section{Corered Drains.}

(a) Trenches.

Underground drains are usually made as in fig. 247.

The trenches should be about one foot broad at their base, $1 \frac{1}{2}$ to $2 \frac{1}{2}$ feet deep, and with a slope as steep as the nature of the soil will allow. The trench is then half filled with stones, which are corered with brushwood, reeds or sods, and the top is filled in with earth. Another method is to cover the base of the trench with fascines or tied bundles of green osiers, branches of alder, poplar or shrubs, which are used immediately after they have been cut. The racant spaces between the fascines along the sides of the trenches are filled up with moss, and the whole covered with earth, as before. This mode of drainage, known to 
the Romans, was introduced into England by Elkington, and was much practised until 1820. It has the advantage of preventing excessire drainage, and may serve its purpose in places to be planted up, until the roots of the plants can themselves drain the soil.

Brushrood-drains when the fascines are of alder branches will last from 8 to 10 years; they rot sooner on calcareous soil and last longer on clay.

Drains made with stones may last for 50 years, and are

Fig. 247 .

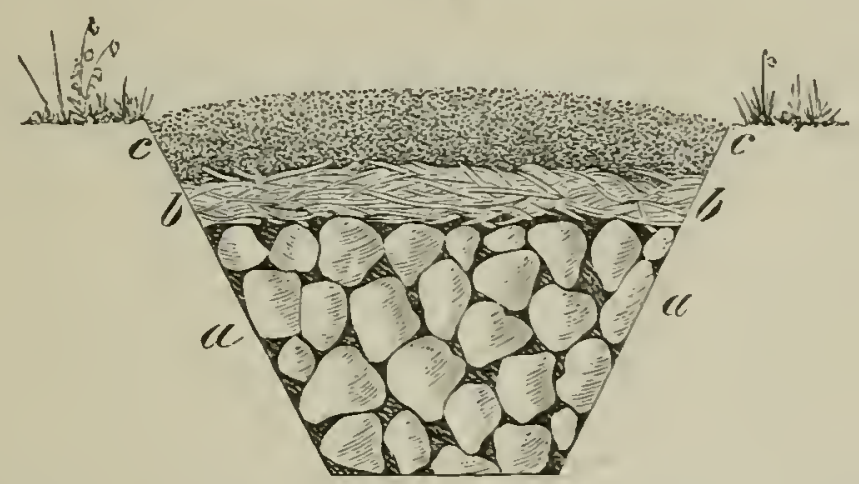

Section of a drain. a. Layer of stones. $b$. Layer of branches. c. Layer of earth.

therefore preferable, unless temporary drains are sufficient for the purpose.

(b) Glazed Drain-pipes.

Drain-pipes made of glazed burned clay or cement and of various dimensions are now generally used for culverts, and unite the advantages of rapid drainage and facility for being cleaned, with that of great durability.

\section{(c) Draining Tiles.}

Draining tiles are cylindrical tubes of burned clay with a circular section. They are generally 1 to $1 \frac{1}{2}$ feet long, $\frac{1}{2}$ to $\frac{3}{4}$ inch thick, and their apertures $1 \frac{1}{2}$ to $4 \frac{1}{2}$ inches across. A good draining tile should be well-burned and smooth within, it should ring when struck, show a clean uniform fracture, and stand sudden changes of temperature without cracking, for which it may be tested by plunging it alternately into hot and cold water. The clay used for these tiles should be fairly pure, and 
contain no lime nor coarse grains of sand. The larger tiles are used for main drains and the smaller ones for collecting drains.

Trenches for the tiles are similar to those in use for open drains, their dimensions depending on the nature of the soil; their sides, however, should be rertical; the main drains have a fall of 2 in 1,000, and the collecting drains a greater fall, and should be from 30 to 80 feet apart according to the nature of the soil. The shortest distance for collecting-drains is chosen when there is much subsoil-water in stiff clay or very fine grained soil with great capillarity; in fact the looser the soil, the further apart the drains shonld be.

The depth of the collecting-trenches should be from 3 to $4 \frac{1}{2}$ feet, and at least $3 \frac{1}{2}$ feet is necessary in cold climates, to prevent damage to the tiles by frost; the main drains should be somewhat deeper.

After the trenches have been dug, which for very wet soils should be in fine weather, and with as little delay as possible, the tiles should be laid carefully, beginning at the upper end of the drains, and placed end to end at the bottom of the trenches; or, if the soil be loose, on a layer of elay or on flat roofing tiles, which will give the bed of the drain an even gradient, to which much attention should be paid. Brown* recommends placing a layer of stones under the tiles, in which ordinary drainage-water may run, while its level will only rise to that of the pipes when the soil happeus to be exceptionally wet. This is because the rootlets of trees are attracted towards wet substances in the soil, and will therefore branch freely among the stones and yet not block up the pipes, which are usually dry. Brown also adrocates placing a layer of clay orer the pipes, so as to lieep the upper rootlets from getting into them.

The size of the aperture of the tiles depends on the degree of wetness and capacity of the soil; the more water there is to be removed and the greater the danger of the tiles becoming choked with soil, the larger the aperture of the tiles, and in sandy soil it sliould be at least two inches.

After laying the tiles, which should be done in dry weather, and as rapidly as possible, the trenches are filled in with eartl,

* The Forester: Brown and Nisbet. Mlackwood \& Co., 1894, Tol. I., 5501. 
and the greatest care should be takell, especially when the soil is stony, that the pipes are neither broken nor displaced.

The durability of the drains depends on the nature of the soil, the quality of the tiles and the care taken in executing the work. Well-burned tiles at depths of $3 \frac{1}{2}$ to $4 \frac{1}{2}$ feet should last for 25 years and more; for instance, draining-tiles laid in 1850, in the Prussian Crown Estates, were in good order in 1880.

(d) Comparison of Draining Tiles with Open Drains.

Drainage improves soils by lowering the level of subsoil water, and exposing a larger area of the soil to the influence of atmospheric air, thus rendering it warmer and accelerating the decomposition of humus. As compared with open drains, draining-tiles waste no productive area, are less subject to damage and drain the soil better, and their use is highly advisable in agricultural lands, but in forests they are much more costly ( $\mathfrak{2} 8$ an acre) to lay out than open drains, and they easily become choked by the rootlets of trees and of weeds such as Equisetum, Arundo, Sc., and also by frogs. Deposits of iron-ochre may also be formed in the pipes, and they may become filled with sand.

Experience has shown that in forests all the disadvantages of underground drainage occur more frequently than in agricultural lands. 


\section{CHAPTER II.}

\section{PROTECTION AGAINST AVALANCHES.*}

1. Origin.

Avalanches are caused by the loosening and fall of masses of snow or ice on steep smooth slopes in mountainous regions; they may consist of loose or massive snow, or both combined, or of ice from broken glaciers.

(a) Aralanches of Loose Snow.

These are locally termed Staublauinen, and occur in November, when fine dust-like snow is falling; they are due to great steepness of the mountain sides, or to overhanging masses of snow falling on to rocks, the snow being separated into dust during its fall. They seldom cause any damage.

(b) Avalanches of Massice Snou.

Movements of the upper layer of massive snow, termed Oberlawinen, occur chiefly from December to February, when thick layers of fresh snow have fallen on to old frozen snow, and become so weighty that they can no longer rest on the smooth base beneath them.

\section{(c) Ground Avalanches.}

When masses of snow which extend down to the surface of the ground, roll or slide down a mountain side, they are termed Grundlawinen, and are extremely dangerous. They generally fall towards the end of winter at midday, during the melting of the snow, and when a Folin, or south wind, is blowing,

* Landolt, El. Die Bache, Schneelawinen u. Steinschläge. Zürich, 1886. 
and frequently during a storm. These are the commonest and most dangerous avalanches, and leave tracks which can be readily observed, as they occur over and orer again at the same places.

In the winter of $1875-76$, in the district of Ragaz, of the Sriss canton Graubünden, 500 avalanches occurred, and in the district Schuls of the same canton, 381 avalanches. The winter of 1887-8S was also distinguished by the number of avalanches which fell. The Swiss Forest Department is now engaged in collecting data regarding avalanches in order to decide when special measures against them are most called for.

\section{(d) Glacier-Avalanches}

Consist of broken fragments of glaciers.

The following remarks apply only to avalanches of massive snow and ground avalanches.

\section{Damage done.}

The damage done to forests by avalanches consists in the breakage of all woods lying in their way, and in the obstruction of streams and roads which they cause. The rush of air which accompanies an avalanche is so great that it breaks many trees up to a distance of several hundred yards from the avalanche. Many ibex are also killed by avalanches. No forest can withstand the rush of a large mass of snow down the mountain side: and the higher, smoother and steeper, and freer from wood a mountain-side is, the greater the danger of avalanches, and the greater the rapidity with which they fall.

A soil-covering of hill grass is a considerable protection.

\section{Protectice Cultural Measures.}

(a) The surface above the tree-limit should be fixed by sowing grass. In order to afford a sufficient obstacle to the sliding down of the snow, the grass should be mown so as to leare a high stubble.

(b) All shrubs, such as alpine roses, mountain-alder, dwarf birch, \&c., should be carefully preserved on steep slopes.

(c) The forest must be maintained up to the tree-limit, and N N 2 
this is the most important rule. Forests which serve to protect the country from aralanches are commonly found in Switzerland, the Tyrol, and the Austrian Alps, and must be properly managed so as to secure the object in view.

The best species for such forests are Pinus Cembra, P.montana, green alder, larch and spruce. The mountain-pine and alder resist the snow action splendidly. The Selection system must be adopted, and all gaps be at once planted up. When a new forest is being formed, sometimes sowing and sometimes planting should be preferred. In stony shallow calcareous soils, pit-sowings are made under the shelter of stones, rocks, dead branches stuck into the ground, or of logs fixed by stakes, all of which protect against the sliding of the snow. In places where there is deeper soil, in depressions, \&c., multiple-planting with three and four plants should be tried. Production of wood is of secondary importance in such forests, and, as a rule, only dead and broken wood should be utilized, and the stumps should then be left in the soil, the felling being high above the ground. Thickets of young wood must be carefully thinned. Neither removal of litter nor pasture, more especially that of the destructive goat, should be allowed, but, unfortunately, in such places browsing by goats is only too common, and the tree-limit is being continually lowered.

\section{Protective Works.}

Protective works consisting either of ditches, rows of wattlefences or walls should be made above and below the line where avalanches begin, which is easily recognized by a sudden change in the gradient of the slope.

(a) Ditches.-Interrupted horizontal ditches, 6 to 16 feet apart, are dug all over the area, being arranged like the wattlefences in fig. 248 ; their construction on rery steep slopes is evidently not unattended with danger.

(b) Rows of Wattle-Fences.-These are set up at intervals of from 20 to 50 feet, their central points being at those of a series of equilateral triangles; they should be 15 to 30 feet long, and of wattle-work with branches plaited between stakes firmly driven into the ground. 
Such a system of wattle-fences allows soil to be formed on a rocky slope, which may afterwards be sown with grass, or planted with trees or shrubs.

(c) Walls.-On stony ground, walls of dry masonry may be

FIG. 218.

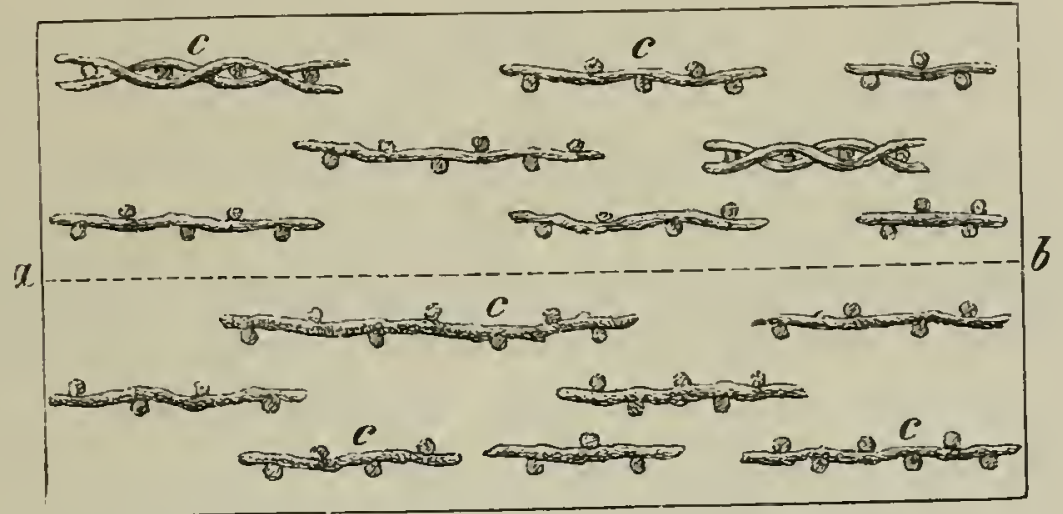

Plan of fences for protection against avalanches.

$a b$. Line where the avalanches commence. $c$. Fences.

FIG. 249.

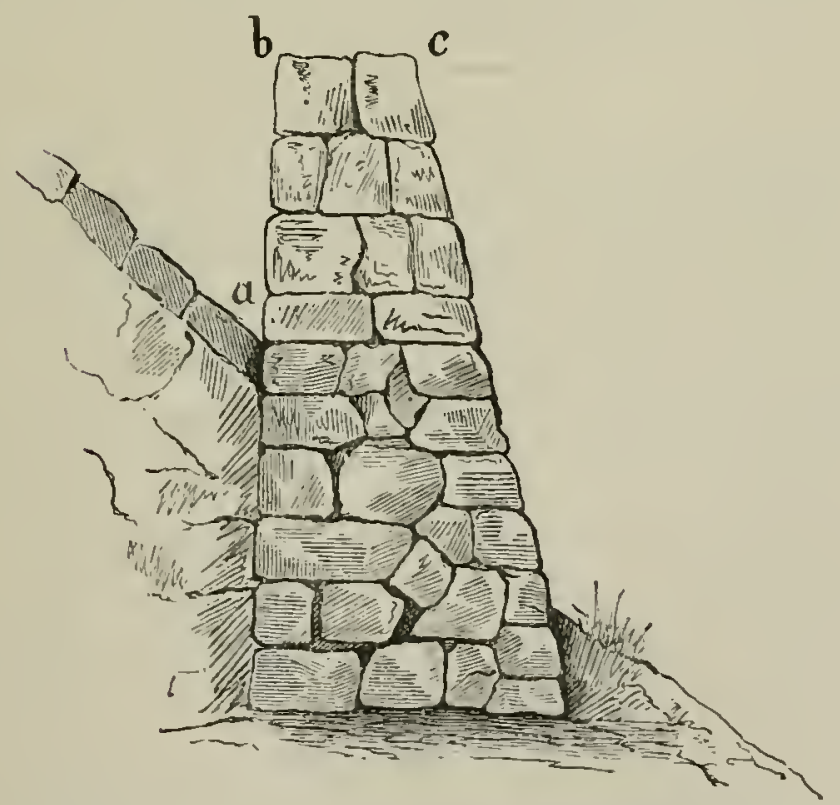

Dry masonry wall for protection against avalanches.

erected instead of wattle-fences; their mode of construction is shewn in fig. 249. On steep rocky slopes, the rock must be cut to admit the foundation of these walls, but this need only be deep enough to prevent the walls from falling, owing to their own weight. Such walls have proved very effective in the Swiss cantons, Uri, Graubünden and Wallis. 


\title{
CHAPTER III.
}

\author{
PROTECTION AGAINST SHIFTING SAND.*
}

UxDEr the term shifting sand is meant a fine-grained sand containing so little clay or humus that when dry and the soil is badly covered with vegetation, it is set in motion by the wind and blown from place to place. Shifting sand is generally found on the sea-coast, but also in the interior of countries. As the productive forest area becomes rapidly reduced by the spread of the sand, the evil must be promptly and rigorously met.

\section{Section I.-Shnd Dunes.}

\section{Description.}

Sand is thrown up by the waves along the sea-coast at high tide, and becomes under certain circumstances heaped up into hillocks, or dunes, and is then carried further into the interior of the country. Vasselot de Régné states that the grains of sand on the Gascon coast are too large to be carried like dust before the wind, but are rolled up the slope of a dune and fall over its ridges, so that the dume naturally attains a slope of about $25^{\circ}$ towards the sea, whilst its slope inland is generally steeper, and may attain $60^{\circ}$. 'The sand is blown away from the ridges or from any eminences in the dune, however slight they may be, and is also carried through depressions made in a ridge to the further side of the dune. 'Two forces are at work on the sand-the sea-breeze which prevails during day-time and drives the sand inland, and the land-breeze by night, which finds the sand firmer owing to the dew, and is not so effectual in blowing it back as the sea-breeze is in blowing it forward.

* Wessely, Josef. Der Europäisehe Flugsand u. seine Cultur. Wien, 1873. Notice sur les Dunes de la Coulure, pa Vasselot de Régné. I'aris, Imp. Nat. 1878. La Dune Littorale, par C. Grandjean. Revue des Eaux et Forêts. July-Decenber, 1887 . 
On the coasts of the North Sea and of the Baltic, in Holstein, Schleswig, Jutland, and in the Baltic islands, and along the westeru coast of France, from the Ile d'Oléron to the mouth of the Adour river, sand-dunes cover extensive areas, and until effective measures were taken to fix them, large tracts of cultivated land were buried in sand. Along the coasts of West and East Prussia, for a distance of 150 miles, dunes extend to a breadth never less than one-sixth of a mile, and unless they are fixed they encroach inland yearly by 50 feet. The area of European dunes is estimated at 21,000 square miles.

The coasts of the British Isles consist chiefly of rocky cliffs, but sand-dunes are found in Norfolk and other points along the coasts of Great Britain.

The dunes along the Bay of Biscay in the French Départements des Landes et le la Gironde extend over a total length of 140 miles, forming a series of parallel ranges about 160 feet high and 4 miles broad. During the constant political troubles of the middle ages, the natural forests of maritime or cluster pine (P. Pinaster, Soland.), which formerly corered this area, were burned and destroyed, and the sand invaded the country at the rate of 60 to 70 feet annually, covering whole towns and villages, cultivated fields, and rineyards. In 1787 , the engineer Brémontier published a treatise showing that the dunes could be fixed by sowing sand-grasses and pines, and the work of fixing the dunes of Gascony was commenced in 1785, and has been continued with complete success up to the present day. In 1810, the French Legislature passed an Act enabling the State to fix dumes belonging to municipalities and private ormers, by mears of plantations, the owners only recovering their property after paying the cost of fixing the sand. This they have only rarely been able to do, owing to the great cost of the operation compared with the value of the reclaimed land.

About 800,000 acres have thus been dealt with, the ammual charge for new work and for maintaining the dunes which hare been already fixed having been $\mathfrak{t} 8,400$ in 1893 . In this way vast areas have been saved for agriculture, and enormous tracts of pine-forests created, which afford work to a large number of people in the extraction of resin and turpentine from the trees, and in timber-works. 


\section{Construction of a Littoral Dune.}

As an embankment along the coast prevents the wind from driving the sand inland, the chief point to be secured is to fix the sand, so as to form what is termed the littoral dune, the mode of construction of which is as follows:-

Two parallel fences are erected along the coast, between and on both sides of which the sand accumulates, the fences being gradually raised till the dune has attained such a height that only inappreciable quantities of sand are blown over it.

The fence facing the sea is a continuous line of paling, from 300 to 600 feet distant from high-water mark; it is made of

FIG. 250.

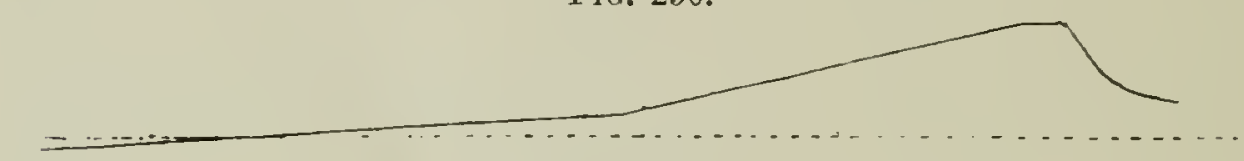

$a$ The Lion Dune.

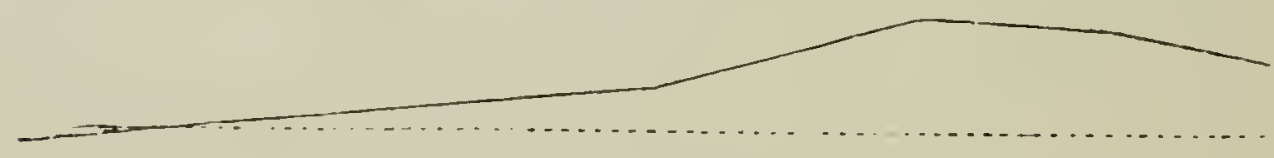

6 The Porge Dune.

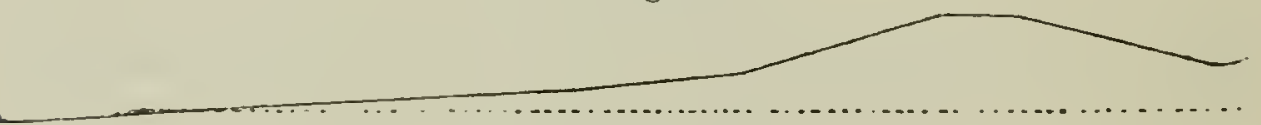

$c$ The Ferret Dune.

inch planks $6 \frac{1}{4}$ feet long, 6 to 8 inches wide, which are pointed below. They are inserted to $\frac{3}{\mathrm{~s}}$ ths of their length into the sand, and 1 inch apart, to allow sand to blow through. When the sand has nearly covered the planks, they are raised three feet by means of levers worked by one man against the next unraised plank, or by a stout rod passed through a chain fastened round the plank and lifted by two men. This operation is repeated until the proper height of the dune is attained, which Grandjean places at 10 metres, or about 33 feet.

The back fence is usually made of wattle-work and prevents the sand which has passed through the front fence from being carried inland, and gives a proper contour to the dune. This fence is replaced by a new one when it has become covered with sand.

The preceding diagrams taken from Grandjean's work repre- 
sent the ordinary sections of the littoral dune, and he consider's $b$ and $c$ preferable to $a$, as being much easier to maintain. They have slopes of $26^{\circ}$ or $27^{\circ}$ facing the sea, which corresponds with De Régné's natural slope of the dunes. Grandjean, in the work already referred to, gives full and satisfactory reasons for the height and gradient he prefers for the littoral dune.

\section{Material for Fixing the Sand.}

The littoral dune can nerer be planted with trees, on account of the salt spray of the waves and the strong sea-wind. In certain places in Holland, masomry works and piles have been erected to protect the dune, but as a rule flexible plants are much more effective than rigid and costly works. Attention is therefore directed to sand-grasses and sedges, and the best of these for the purpose are :-

Sea marram, or matweed (Psamma arenaria, R. \& S.);

Baltic matweed (P. baltica, Schrad.);

Sand lyme-grass (Elymus arenarias, L.) ;

Sand sedge (Carex arenaria, L.).

All these plants are characterised by very long much-divided rhizomes, and can withstand being covered over and buried in sand. The sea marram will only grow where it is continually covered with fresh sand, and dies inland in the shelter of the littoral dune, when no fresh sand covers it. It is termed gourbet in France, and is exclusively used for fixing the littoral dune along the Bay of Biscay. Next to the marram in repute for fixing the sand comes the lyme-grass, and these two species are chiefly used for the purpose in Holland.

Other plants grow in gradually among them, at first lichens and algæ, then grasses, as for instance Arenaria peploides, L., Aira canescens, L., couch-grass (Agropyrum repens, Beaur.), and other plants, such as the sea-poppy, Glaucium luteum, Scop.; Lathyrus maritimus, Bigel; and Hieracium umbellatum, L., \&c. Vasselot de Régné gives a very complete botanical list of dune plants.

Several shrubs then appear on the land side of the dune, as Salix repens, L.; sea-buckthorn (Hippophae rhamnoides, L.) ; Lycium barbarum, L.; Tamarix, \&c. 


\section{Maintenance of the Littoral Dune.}

When once the littoral dune has been raised to a proper height and profile and fixed by means of sea marram, it is necessary to maintain it constantly in the same state, and any undue accumulation of sand in any part of the sea side of the dune at once causes an inland draught of sand on both sides of it, which if not at once attended to will breach the dune.

Nen termed gardes cantonniers are therefore stationed along the littoral dune in Gascony, who cut away all vegetation except the marram from its surface facing the sea, in order to prevent undue accumulation of sand. As the marram grows readily from cuttings during the colder six months in the year, the workmen who cut it away from ridges plant it in depressions, or if the season be too hot or dry for the cuttings to take root, the pieces cut from ridges are merely placed on depressions. In this way, by cutting away the marram where it is too dense, and planting or placing it in depressions, the proper contour of the dune is maintained, as the sand accumulates behind the marram, and is blown away wherever the latter is cut.

In cases where the dune has been neglected and large depressions have been formed, it may be necessary to use wattle fencing to cause an accumulation of sand, but if ordinary care be taken, the marram grass will suffice to keep the littoral dune in good condition, and Grandjean believes that new dunes may be fornied by means of it, withont using the fences described in heading No. 3.

\section{Protective Coast Forest Zone, under the shelter of} the Littoral Dune.

\section{(a) Deseription.}

Under the shelter of the littoral dune, a protective zone of various woody species mixed with gorse, species of genista, heather, Tamarix, \&c., is then allowed to spring up, but is generally planted or sown artificially.

The species chiefly grown near the Baltic coast is the Scotch pine, over 8,000 acres of this species having been planted near Dantzig between 1795 and 1850 .

In Zealand, the uncinata variety of the mountain-pine 
(Pinus montana, Mill.) has been used, and its great success is due to its indifference to soil and climate, and its habit of retaining its lower branches green for long periods. In France the cluster pine is chiefly used, but it is liable to be frozen when grown too firr to the north.

Spruce, birch, or white alder may be mixed with the pines, and in Sonth-West France, Quercus pedunculata and Q. Tozza, D.C. In depressions, the common alder, poplars, and willows may be grown.

The different kinds of Pinus Laricio, Poir., and especially the Corsican variety, maples and the silver poplar, are well able to withstand the force of the strong sea-winds.

As a rule, the growth of protective forests near the sea coast is poor, on account of the strength of the sea breeze and the poor nature of the sand in which the trees grow, and which is being constantly heaped over their roots, but protection and not timber is required in a zone which may extend from 600 to 2,000 feet from the littoral dune and which if left unplanted would be a bare sandy tract tending to spread inland and ruin existing forests.

In coast-protection forests, short terminal-shoots, procumbent stems, one-sided crowns and a leaf-canopy sloping down seawards, are evidences of the struggle these woods carry on with the wind, but it is a forest all the same.

The conditions of growth greatly improve as the distance from the sea becomes greater, so that further inland, especially if the sand contains little flakes of mica, even superior species such as beech or silver-fir may be grown, as in Alsensund in Schleswig. If in any part of the protective zone, a shelving cliff of sand unprotected by vegetation is exposed to the wind, it should be covered with branches of pine, gorse, broom, \&c., placed like slates on a roof, and some sand-fixing grass sown to prevent the sand from being carried inland.

\section{(b) Method of Formation.}

The inequalities of the ground should first be levelled in order to afford the wind as fer points of attack as possible. Sindfixing grasses should then be sown or planted, the former method 
being followed in France and the latter in Germany. Pieces of the grasses should be planted in rows at right angles to the direction of the prevalent wind, holes being made with a spade 1 foot to 2 feet apart, and three or four pieces of rhizome planted in each hole so deeply that only about 6 inches of them appear above the sand. They soon sprout and send out suckers in all directions through the sand, which they fix most effectually.

The cost of fixing sand with grass is that of 70 to 140 days' work at $3 \mathrm{~s}$. a day averaging $£ 15$ an acre. In Prussia long-rooted yearling pines are then planted 1 foot apart in rows distant 3 feet from one another. The work is done with an iron dibble, so as not to loosen the sand unnecessarily. Mountain-pine is the best species in the north for fixing the sand, other trees being erentually planted between the pines.

Cuttings of poplars or willows may be also planted.

In fixing dunes along the Baltic coast, Prussia spent $£ 3,100$ a year, between 1884 and 1887 , during which time 230 acres were fixed with grass and 608 acres stocked with trees.

The planting is usually effected under the protection of the littoral dune, and pine forests in the protective zone are then managed under the Selection system, and broad-leaved species are coppiced.

In the Danish island of Zealand, up to 1866, sowing was preferred to planting, the sand being previously covered with a thin coating of loam which was placed on the ground in heaps in the autumn, and somewhat weathered by the winter's frost before being spread over the area in the spring.

In France the cluster pine is sown with other seeds in the following proportion for an acre:-

Cluster pine seed. . . . . $26 \mathrm{lbs}$.

Furze or gorse • . . . . $2 \frac{1}{2}$,,

Genista . . . . . $2 \frac{1}{2}$,

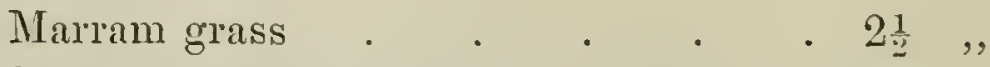

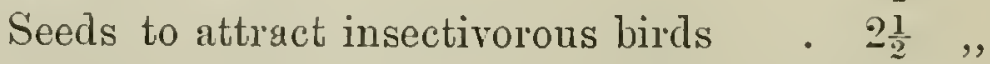

As the seed is sown, it is covered with 1,000 faggots, 3 feet in girth and 5 feet long per acre of furze, broom, heather or pine branches, furze being preferred wherever it is available. The 
fag gots are evenly distributed over the area and opened out, and tho sowing is then commenced on the land side towards the littoral dune under protection of a wattle-fence intended to keep off the sand blown back by the land breeze. Each row of seed is covered by the branches which are placed in rows with their lower ends towards the sea, so that each succeeding row of branches partly covers the preceding one, being arranged like slates on a roof and kept steady by spadefuls of sand thrown on them at intervals of 2 feet.

Areas of about 300 feet long by 60 feet broad are thus sown at one time. Between 1862 and 1874, 5,200 acres were thus sown in the Gironde at a cost of $£ 30,646$.

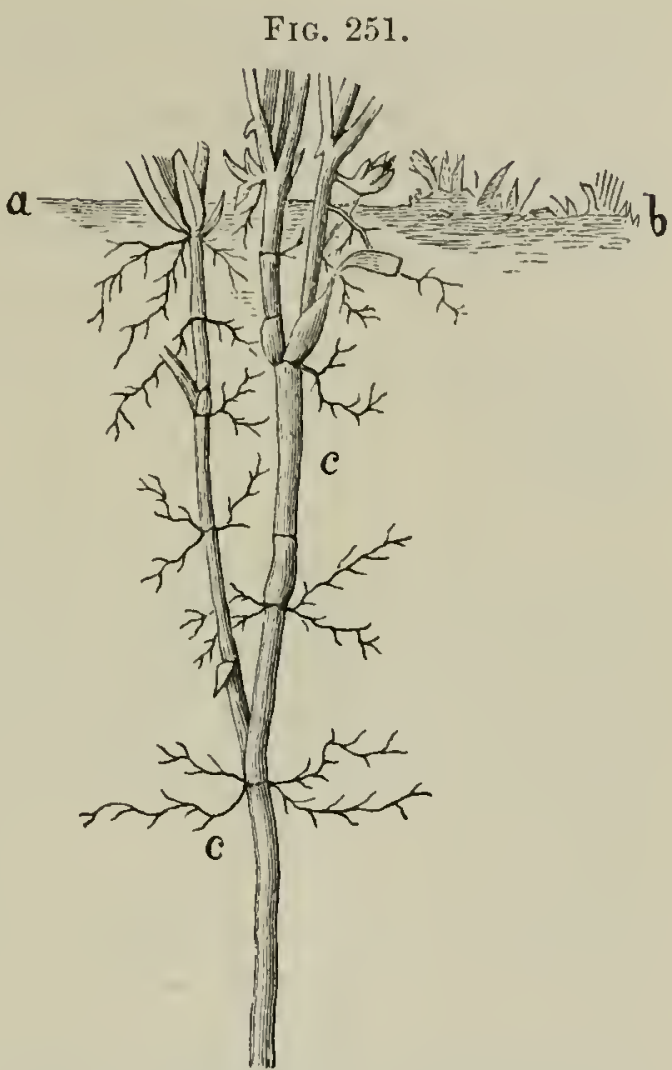

Psamma arenaria, Beauv. a $b$ Surface level of ground. $c$ Rhizomes.

(c) Tending the Woods.

The sand grasses used in fixing the dunes must not be cut or Frg. 252.

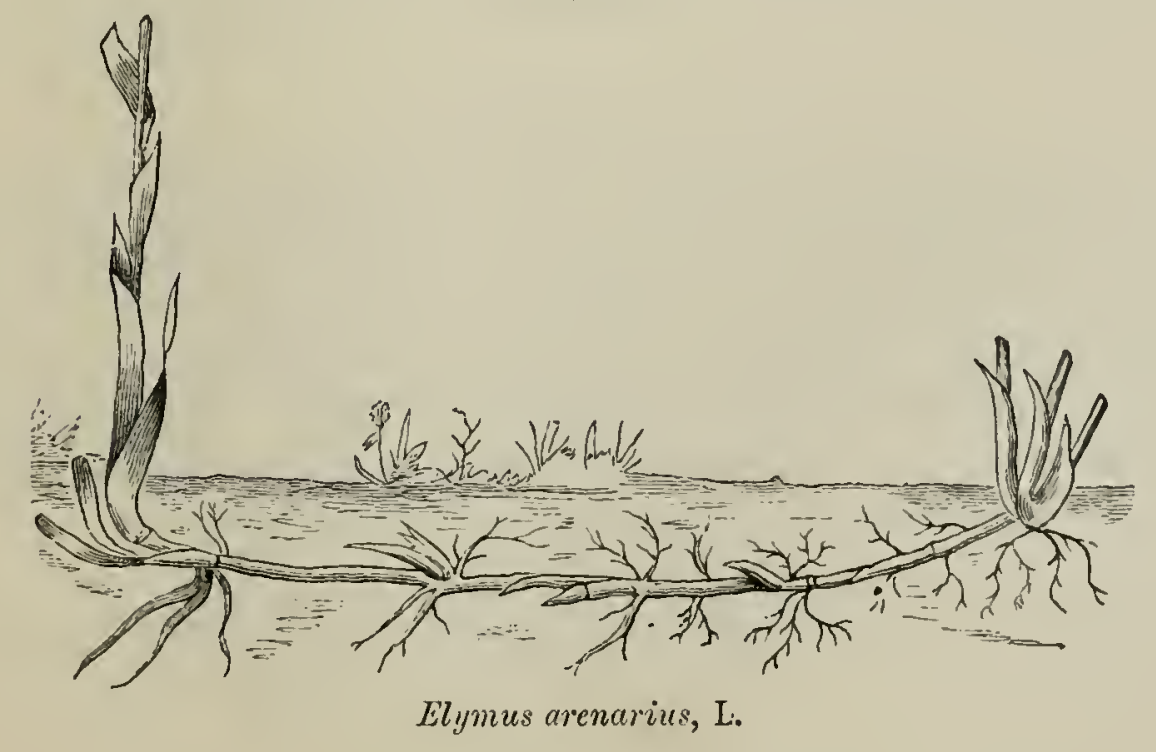


pastured. The water rat and the larve of Polyplyylla fullo, L. are the most dangerous enemies to the grass rhizomes.

Dune forests must be strictly protected against grazing, removal of litter and trespass. Article $366 \mathrm{~A}$ of the German Criminal Code punishes contravention of police regulations regarding dune forests with fines up to $7 l .10 \mathrm{~s}$, or imprisonment, and in Holland, four weeks' imprisonment is inflicted for cutting grass on dunes.

Only dead or dying wood should be removed from the dune forests.

$$
\text { (d) Addenda. }
$$

The best English example of the fixing of shifting sands is on the Holliham sand-hills on the Norfolk coast, belonging to the Earl of Leicester, where, since 1850, sea lime-grass and marram have been used to fix the sands, and several species of pine planted, of which the Corsican pine has proved most successful.

In India, along the Madras coast, extensive plantations of Casuarina equisetifolia, Forster, have been made, and grow with extraordinary rapidity, yielding excellent fuel.

In the Cape Colony, shifting sands are sown with cluster pine and Acacia Pycnantha and decurrens, the seed being mixed with rye seed, which protects the seedlings. A layer of town refuse is first spread over the sand to assist in fixing it and serve as manure.

\section{Section II.-Inland Sand.**}

\section{Description.}

Inland sandy tracts generally originate from sandy hills, and are due chiefly to the clearance or careless management of forests, and especially to removal of litter. Extensive sheep pasture on heather-land also readily sets sand in motion. Large tracts of shifting sands are found in Hannover, Oldenburg, Pommerania, \&c. The greatest areas in Europe of inland shifting sand are, however, in Hungary and South Russia.

* Burkhardt, Dr. H., Zur Kinltur les Flugsandes. Aus dem Walde. 1877, p. 167 . 


\section{Protectice Rules.}

Mainteuance of forests, especially on saudy hills, is the chief protective measure to be adopted. Not only must clearances of forests be prevented, but all destructive practices leading to their imporerishment must be stopped.

The following measures should be adopted in forests which serve as a protection against shifting sand :-

(a) The Selection system should be adopted, or only very small areas under a short rotation be cleared. Extensive clearings must be avoided in any case, but the shelter-wood systems with natural regeneration would be suitable were it always possible to obtain natural regeneration on dry, sandy areas. In the Gascon cluster-pine forests, clear-cutting is adopted, but the pine seed is produced so abundantly by trees adjoining the cleared area and germinates so freely, that good results follow.

(b) In the case of artificial regeneration, planting is preferable to sowing, but the planting-holes should be small, and young plants used.

(c) The borders of the forest to windward must be kept densely stocked and all underwood protected, while the soilcovering is strictly preserved.

(d) Stumps should be left in the ground after fellings, and cultivation of cereal crops in combination with sowings of forest trees must not be undertaken.

(e) No pasturage should be allowed, and all servitudes for pasturage, passage of cattle, usage of grass or litter should be legally annulled.

3. Fixation of the Sand.

The supply of sand must be stopped at its origin by planting up the sandy hills from which it comes. Loose sand may be fixed by means of fences, or by covering it with branches or sods, and both these methods may be combined. Planting sandgrasses is not advisable, as it only increases the difficulty of restoring forest growth to the denuded area.

\section{(a) Fences.}

Fences are generally made by driving into the ground pine 
stakes 6 to 8 feet long and $2 \frac{1}{2}$ to 4 inches in diameter. 'They should be driven 2 to 3 feet deep and supported alternately on either side by means of oblique stakes, as shown in fig. 253 .

Between the stakes, branches of Scotch pine or of broom should be intertwined, leaving sufficiently large interstices for the sand to pass through, or else the fence would be broken by its pressure. Poplar- or willow-cuttings may be used instead of pine-stakes, and their side-shoots may eventually be twined into a fence.

The fences should run at right angles to the direction of the shifting sands, on both sides of roads, or other endangered places, their ends being turned round to serve as a protection against the winds blowing at right angles to the fences. Several

FIs. 253.

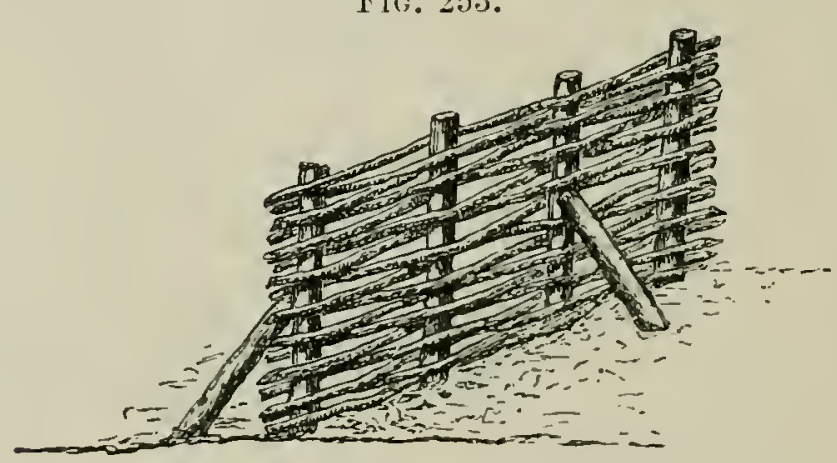

of these horseshoe-shaped fences may be made, at suitable distances, parallel to one another, the distance between them depending on the locality; on level ground a fence will afford shelter for 200 to 230 feet, but on hilly ground, for not more than half these distances, and on steep hill-sides not more than sixty feet.

One man can make from sixty to sixty-six feet of fencing in a day, non-inclusive of the labour of transporting the material. Fence-construction is therefore costly, and fences are not used at present so much as formerly, as they do not thoroughly fulfil their object.

(b) Corering the Sand.

Branches, weeds, grass, seaweed, and sods or straw are the materials used, and for the sake of economy, the nearest available material should be chosen. Branchy stems of Scotch 
pine, juniper-bushes, heather, broom, reeds or rushes form useful material, and sods are cut from grass or heather land.

Covering the ground with sods is the best measure, and is much followed in Hannover and Oldenburg, whilst straw is used in Flanders. The covering is chiefly employed for the most endangered places, such as ridges, the windward side of hills, depressions and roads; other places may be readily stocked with forest growth, provided fresh sand is not blown on to them.

As in the case of dunes, the first measure is to get rid of superficial inequalities in the area to be covered, and

FIs. 254.
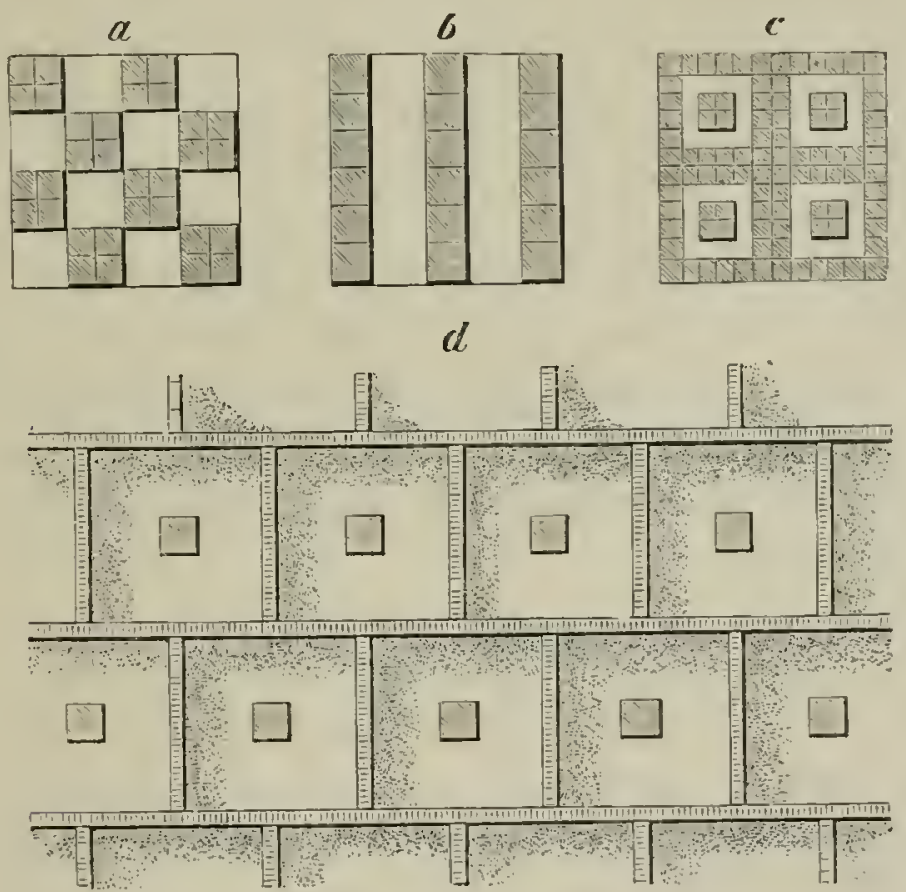

the covering should then be applied from W. or S.W. to E. or N.E., the ground being either entirely or partially covered. Roads are generally covered completely, but, in other cases, partial covering is adopted on account of the high cost of complete covering. The looser the sand, the more complete should be the covering, and it is always more prudent to do too much than too little in this respect.

Branches are either placed on the surface of the ground, or stuck into the sand, with the bushy end inclined away from the wind, the rows partially covering one another, but their use is not recommended on account of the difficulty in VOL. IV. 
stocking an area which has been completely corered with branches, whilst if they are isolated, they are liable to be blown away.

Heather and broom can be used only on level ground in pieces $1 \frac{1}{2}$ to $2 \frac{1}{2}$ feet long, and should be tossed equably orer the area by means of hay-forks, after it has been sown up with Scotch pine seed. Sowings thus carried out will generally prove successful if the spring be moderately wet.

Sods are always laid with the earthy side downwards, and should be firmly pressed down.

The diagrams on the previous page show how the sods may be arranged. Where a sod is laid in the middle of each patch, it should be larger than the other's, and that form of sodding is preferable, as the loose sand within the patches cannot get out. The lines of sods should be at right angles to the direction of the prevailing wind. The work of sodding should be done during autumn, after the sand has been well soaked by rain, or in the spring, and the ground should be at once sown or planted.

In Germany, partial sodding of the ground costs from $1 l$. to $3 l$. an acre, with daily labour at $1 s .10 d$. Covering with branches takes about forty or fifty cartloads per acre, and costs somewhat less than sodding.

\section{Stocking the Area.}

Fixing the sand should be followed by stocking the area, unless the two operations have been done simultaneously.

The most suitable species are Scotch or mountain pines, also robinia or birch. The three first species are very hardy, and yield plenty of humus. The mountain pine covers the ground admirably, and the robinia, owing to its faculty for producing suckers, rapidly fixes the sand, and has given excellent results in Hungary.

For damp places, poplars and willows should be used, the Canadian white and black poplars being most usual. Salix arenaria, L., the Caspian willow (S. acutifolia, Willd.) or S. cinerea, L., may also be planted, the latter rapidly covering the soil with its creeping lateral branches, and it easily grows through any sand which may be blown over it.

In south Russia, near Odessa, Ailanthus glandulosa, Desf. is 
used on sand-dunes, and also in the south of France. This very accommodating species grows rapidly and sends out numerous suclier's, and thrives on the hot southern slopes of the Siwalik Hills in India, as well as in smoky London. The cluster pine may also be used as in Gascony. Sowing is still employed in restocking bare sandy tracts in France, 15 to $20 \mathrm{lbs}$. of seed being used per acre: but in Germany 3 to 4-year-old transplants with balls of earth are now planted in rows at right angles to the prevailing wind. The plants are put in deeply to prevent exposure of the roots, and because they suffer in summer from the heating of the sand. Scotch pines do not suffer at all from this deep planting. In order to get the area stocked as soon as possible, intervals of only $2 \frac{1}{2}$ to 3 feet are left between the rows, and the plants are 1 to $1 \frac{1}{2}$ feet apart in the rows. In Hannover they are planted with a heavy planting iron, termed Buttlar's iron,* and a mixture of $\frac{2}{3}$ peat with $2 \%$ unslaked lime and $\frac{1}{3}$ sand is used to fill the holes round the roots. The peat is hygroscopic and retains moisture near the plants' roots.

Robinias, poplars and willows are put in as cuttings in little clumps or in furrows. Sometimes the ground is cultirated before the cuttings are put in, and Scotch pine seed sown in the depressions. Hubert recommends that grass seed should be strewn over the plantations. In Austria, Jerusalem artichokes (IIclianthus tuberosus) are frequently planted to shelter the woody plants against heat and cold.

In case the sandy tract is so extensive that it cannot be conveniently planted up in one year, a plan of operations extending orer a series of years should be drawn up. A commencement should then be made on the windy side of the area, and the cultivation carried on in strips under shelter of the first year's work. In the Landes of Gascony, shelter-fences are erected to the leeward of each year's strip to protect the plants from sand blown back by land breezes. Whenever the work is thus gradually done, great care must be taken to fill up all gaps in the areas to windward before commencing the work beyond it.

At Lingen, in Hannover, work has been carried out gradually since 1818 , when there were 3,327 acres to be stocked, of which

* Vide Schlich's Manual of Forestry, Vol. II., 1. 124. 
$75 \%$ was shifting sand, and the balance cultivated land. Between 1818 and 1832, 2,279 acres had been planted successfully, and the balance of 1,048 acres was fairly well stocked by 1837 , the total cost up to 1832 being $1 l$. 18s. an acre.

Forests on shifting sand must be managed most carefully. Scotch pine are regenerated under the Selection or Strip systems, and broad-leaved species by coppice. No pasture or removal of litter can be allowed. 


\section{CHAPTER IV. \\ PROTECTION AGAINST FOREST FIRES.**}

Forest fires are nearly always caused by human agency, generally owing to carelessness, but are sometimes intentional; they are also occasionally due to lightning.

It is intended to treat the subject according to these causes, taken in order.

\section{Section I.-Forest Fires caused by Human Agency.}

1. Causes.

The following acts, omissions or occupations may cause forest fires :-

Kindling a fire without permission, in a forest, or by the side of a forest road, in order to warm themselves or to cook their food, by travellers, or men engaged in felling trees, roadmaking, \&c.

Leaving a fire, which has been lighted by permission of the forest manager, without completely extinguishing it.

Carelessness of charcoal-burner's whilst burning their kiln, or extracting charcoal from it.

Burning branches or weeds whilst cultivating crops on forestland or on fields adjoining forests, also burning moor-, heatheror grass-land.

Burning bark to destroy beetles, \&c.

Night-fires by poacher's after fish or game. Burning out wild bees. The collection of wild honey and wax is common in East Prussia and in Russia and India, and frequently gives rise to forest fires.

* Gerding, Fires in the Lïneberger Haide. Frstl. Blttr., 1886, p. 241. Fernandez, Notes on Indian Sylviculture. 2nd cdition, 189:. 'This book gives a very detailed account of the measures for combating forest fires. 
Shooting in forests with rag or paper wads.

Carrying on dangerous industries in or near forests, such as the manufacture of pitch or turpentine, and also iron-smelting furnaces, or foundries.

Sparks from locomotive engines, especially when burning turf or lignite, and unprovided with spark-extinguishing apparatus.

Intentional firing of forests for selfish motires, as when shepherds or farmer's burm extensive forest areas to obtain fresh grass for their flocks and herds, as it grows up luxuriantly after a forest fire.

Motives of revenge, or superstition, as in India, where a deodar forest was burned to propitiate the goddess of small-pox.

It follows from a consideration of the numerous causes of forest fires that the forester must be wide awake to prevent such calamities. Private resources are here quite insufficient, and the State must assist by framing suitable laws, and by instructing officials to be active in enforcing them.

\section{Finds of Forest Fires.}

Forest fires may be in the ground, in the soil-covering, or in the crowns or stems of the trees.

(a) Ground-fires.

These occur in peat, lignite, or coal; they proceed slowly unless they come to the surface, when they partake of the character of fires in the soil-covering. Ground-fires rarely occur in forests.

\section{(b) Surface-fires.}

These are the commonest and most important fires the forester has to deal-with, burning the dead leaves, heather, grass and other soil-covering of a forest.

\section{(c) Fires in the Crouns of Forest Trees.}

These are less frequent in Central Europe, though common in North America and not unfrequent in India. They generally arise from surface-fires, which spread to the crowns of the trees. 
A dense coating of lichens on the trees increases the danger of the occurrence of crown-fires.

(d) Fires in Stems.

Green trees seldom catch fire, and when a whole stem is burned, there is generally some decay present, and the trunk or branches of the tree are hollow.

\section{Damage done.}

\section{(a) General Account.}

Forest fires damage or destroy whole woods, and especially young growth. Reproduction may be stopped for the year by the destruction of blossom or fruit, while owing to repeated fires, broad-leaved trees which are not killed become misshapen and weakly.

The burning of the dead leaves or needles on the ground prevents the accumulation of humus and the improvement of the soil, and renders it poor, hard and unsuitable for reproduction.

The annual burning of the soil-covering on hill-sides may cause soil-denudation when it is followed by heary rain; this was the case in the Siwalik hill-range, extending for fifty miles between the rivers Ganges and Jumna, and its protection from fire was demanded by the Indian Irrigation Department to prevent their canals from silting up.

Game may be killed by forest fires, especially fawns in heather, and apiaries may be burned. Indirectly, forests suffer by disturbance of their working-plans, by increased tendency to breakage and to damage by insects, also to growth of weeds and consequent increased cost of sowing and planting.

After fires in Scotch pine woods the following insects may become extremely abundant and destructive: Hylurgus piniperda, L., in England and Germany, in Germany only, Bostrichus bidens, Fabr., B. Laricis, Fabr., Hylastes palliatus, Gyll., and Hylurgus minor, Hrtg.

\section{(b) According to Species.}

In Central Europe, conifers suffer from fire much more than broad-leaved species, owing to their resinous nature, and to the 
inflammable evergreen needles, which favour the spread of the fires. The Scotch pine is the most exposed to danger, after it the spruce, then the silver-fir, and, last, the larch. 'The greater danger the Scotch pine experiences from fire is due to the early drying up of its lower branches and to the dry nature of the soil-covering, owing to the imperfect leaf-canopy of this tree and to the nature of the localities (heather lands) on which extensive pine forests occur.

Amongst broad-leaved species rough-barked trees withstand fire better than smooth-barked trees, such as the beech. Fires are evidently more frequent and dangerous in High Forests than in coppices.

\section{(c) Age of Trees.}

Young woods up to thirty years old are most exposed to fire, as the struggle for existence is strongest, and there is usually most dead wood at this period.

Well stocked woods between $30-60$ years of age withstand fires best of all, as middle-aged coniferous woods after the earlier thinnings contain least combustible material, such as dead wood, grass or heather undergrowth.

Woods over 60 years of age where grasses and other weeds spring up, again become more endangered.

'The following average figures, taken from a list of forest fires in Hannover between 1864-84, support the above conclusions. Out of 1,000 acres of forest, there were burned annually during these twenty years:-

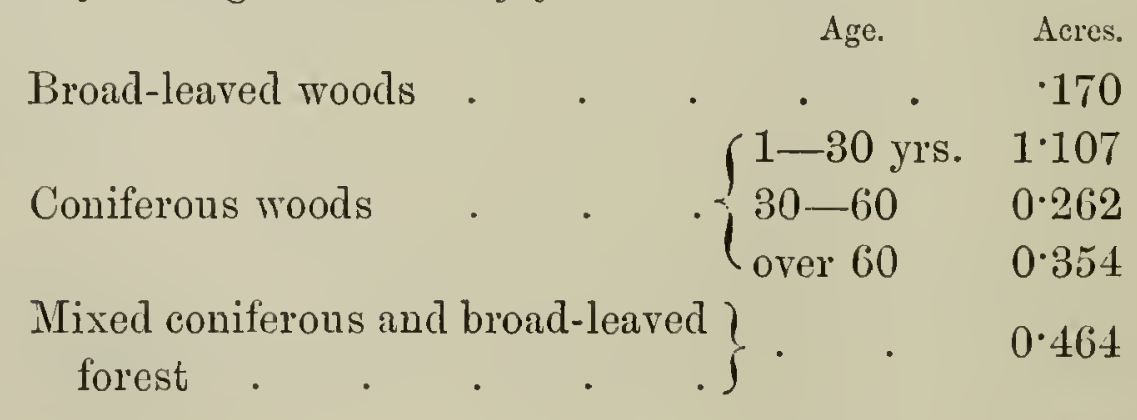

\section{(d) Locality.}

Forests in plains, on account of the greater dryness of the air, and frequently of the soil, suffer more than mountain-forests. On sunny aspects fires spread much more rapidly than on cool 
northerly slopes. A dry sandy soil increases the danger. Fire burns more slowly down-hill than up-hill, and the more so the steeper the slope and the stiller the air. As a slow fire is more easily regulated than a fast one, in jhums, or cultivations on forest clearings, where the branches and undergrowth are burned, it is better to burn down-hill.

\section{(e) Soil-Corering.}

A tall growth of heather, genista, broom, or grass, \&c., increases the danger of fire, and so does an undergrowth of juniper or of sundry conifers. A mossy covering is prejudicial only in seasons of drought, and a covering of dead leaves or needles is usually a bad combustible, though fire in it may smoulder on for days. Whenever much branch-wood, refuse of fellings and dead fallen wood lie on the ground, the danger is increased.

Above all, Scotch pine woods on heather-land with dry soil and soil-covering and combustible foliage are most exposed to forest fires.

In India the grass, in badly stocked forests, is frequently 6-8 feet in height, and in the open in Assam, the flowering stems of reeds may attain a height of 24 feet. The fierceness with which a fire passes through tall grass during the dry season must be seen to be believed, the sparks and flames sometimes crossing rivers one hundred yards broad.

The leaves of many of the Indian forest trees, sucli as the teak (Tectoria grandis, L. fil.) and the Sál (Shorea robusta, Gaertn.) fall in March and April during the dry season and when dead are very inflammable.

\section{(f) Density of Growth and Extent of Forest-Area.}

In so far as density of growth lills down heather, grass and other inflammable undergrowth, and provided all dead wood is removed in the thinnings, a densely stocked wood is less liable to be ignited than a thin wood with inflammable undergrowth. Once, however, that a dense forest is ignited, and especially if the fire is in the crowns of the trees, it can generally be extinguished only by a fall of rain, or a sufficiently wide gap in the 
wood caused by a road, river, fields, \&c., or by purposely counter-firing or felling trees across its path.

If a forest is liable to be burned, it is better to subdivide it into small areas by fairly numerous rides and roads.

\section{(g) Season.}

Most fires in Central Enrope occur in dry springs from March to May when east winds prevail and the dry grass, leaves, and weeds under the trees and the presence of numerous workmen in the woods increase the danger.

Forest-fires also occur in hot summers, they generally fall off in riolence during the night, but recover force again after sunrise, this being due to the daily rariation in the strength of the wind, and sometimes to the nightly dew, which may extinguish a fire.

In tropical and semi-tropical countries forest-fires occur during the dry or hot seasons, and are very rare during the more or less prolonged summer monsoon. Thus in the North-West Himalayan coniferous forests, there may be fires in Norember and December, until snow has fallen, aud then again from ApriI till the monsoon breaks early in July, after the melting of the snow.

In the extensive Sál forests at the foot of the Himalaya mountains, extending from the Jumna river to the Borelli river in Assam, there is danger from fire from February till July, and this danger is increased by the fall of the dead Sál leares in March and April. In the western part of these forests the danger from fire is probably greatest in May and June, whilst in the eastern parts in Bengal and Assam, where spring rains occur, the forests are fairly safe from fire in May, owing to the growth of fresh grass, which is incombustible.

\section{Register of Fires.}

Forest fires are of frequent occurrence in the heather-lands of Berkshire, Surrey and Hampshire. They are not unfrequent in Germany in spite of the great care taken to prevent them, but their extent and frequency are inconsiderable when compared with Austria, the South of France, Sweden, Norway, Russia, Greece, 
India and North America. In this last country, forest fires frequently extend orer hundreds of square miles of forest, and little or no trouble is taken to extinguish or prevent them. The most disastrous forest fires which have occurred in Germany during the present century are given below:-

1800,4 th to 21 st August, 5,675 acres in the Black Forest near the Katzenkopf in Württemberg.

1857, 28th to 30th August, 3,300 acres near Königsbruch in IT. Prussia.

1880, 1st to 3rd May, 3,250 acres on the Lüneburg heath.

There were on the average, between 1860 and 1880, 29 forest fires annually in the Prussian State forests, extending over an area of 1,335 acres. In Austria, in December, 1872, the whole line of the Carpathians in Hungary was burned, extending for 24 miles from Kakora.

In France, between 1865 and 1870, about 25,000 acres of cluster-pine forest was burned in Gascony, and a large area was burned in 1893, including 1,200 acres near Arcachon in the forest de la Teste. The worst districts in France, however, for forest fires are the Départements of the Maures and Esterel, north of Marseilles, where large areas of forest, chiefly consisting of Quercus Ilex, L. and Pinus halepensis, Mill. are burned every year, and a special law has been enacted for their protection from fire.

Extensire forest fires occur every year in Russia. In Canada, in 1868, it was estimated that $400,000,000$ dollars worth of standing timber was destroyed by fire.

The forest fires in September, 1851, and again in 1894 in the States Minnesota, Wisconsin and Michigan of the United States of North America were of enormous extent, hundreds of human beings being burned with their houses and cattle. Statistics are wanting to give some idea of the enormous annual destruction of forests in N. America by fire, and especially of the pitch pine (Pinus australis, Michaux) which yields the best coniferous timber known in the whole world.

Protection from fire of the State forests in British India has been seriously undertaken diuring the last thirty years, and measures with this object in view are carried out on a large scale and at considerable cost to the State. Thus, in 1891-92, 
measures were taken to protect from fire 27,938 square miles of State forest, which were successful in the case of 24,046 square miles, whilst 3,892 square miles were burned. This gives $14 \%$ of failure, showing how difficult it is to protect forests from fire in hot countries. The cost of protection averaged 10 rupees a square mile, or at $1 s .2 d$. per rupee $11 s .8 d$., being as low as 2.. 4 $d$. in the Bombay Presidency. Besides the above, there are 31,805 square miles of State forest, in which either the forest is of such a character as to demand no special protective measures against fire, or its protection has not yet been undertaken.

Professor Wallace,* in his book on Indian Agriculture, states "that periodical forest fires cause a natural process of healthy retardation, cleaning and thinning, under which the magnificent forests of India have been mursed and reared;" this and many other of Wallace's statements regarding forestry are quite erroneous, and show complete ignorance of the lamentably crippled state to which the extensive sál, teak and other valuable Indian forests have been reduced by the amnual fires, and of the wonderful manner in which they are recovering, wherever the absence of forest fires renders natural regeneration possible.

\section{Protective Measures.}

From what has been already said, it is clear that for Central Europe, protective measures against fire have chiefly to be carried out in coniferous forests. The following rules will serve for private forests :-

(a) Mixture of broad-leaved species in coniferous forests, either by single trees, groups, or in whole compartments, or as protective belts round the coniferous woods. Such protection is specially needed along the borders and roads through Scotch pine forests.

Birch, oak, beech, black poplar, and robinia are suitable species, and the belts should be 25 to 35 feet broad, and may be either High Forest or Coppice. Such belts are largely used in the Landes of Gascony to protect the cluster pine from fire, and should be liept free from heather, ferns, dead leaves, and underwood, which are readily sold for litter.

* India in 1887. Edinburgh, Oliver and Boyd, p. 303. 
Except in coniferous mountain forests, belts of broad-leaved trees are practically useless in India, as most trees which retain their foliage during the dangerous months will only grow well in moist places. In Assam, however, belts of evergreen forest growing in low ground on either side of watercourses frequently act as protective belts to the drier deciduous Sál forest on either side of them.

\section{(b) Fire-Traces.}

Wherever forests are surrounded by inflammable undergrowth such as heather, grass, \&c., fire-traces of sufficient breadth should be made along their boundaries, and internal fire-traces are also required for all extensive inflammable forest areas, to limit the extent of the damage done, in case a fire should cross the boundary, or break out within it. The number of internal fire-traces required for a forest must be left to local experience, but the forest manager should remember that a considerable area of forest is reudered unproductive when the length or breadth of the internal fire-traces are excossive, and that the cost of protection is thus greatly enhanced, so that he will limit the number and breadth of the fire-traces to the minima compatible with efficiency.

Fire-traces in Europe are broadest for coniferous forest, but rarely exceed 100 feet in breadth, while in India they are sometimes 400 feet broad.

Whenever the soil-covering on the traces can be utilized for thatching material, litter or fodder, it should be cut and removed. This may often be done by concessioners at no cost to the owner of the forest, or even on payment to him of a certain sum. It frequently happens, however, that the soil-covering has no local value, and must then be carefully burned to avoid the greater expense of cutting it.

Before burning fire-traces, the soil-covering is usually cut on guide-lines on either side of the trace, their breadth being about three feet more than the height of the covering. For greater safety, cross lines as broad as the guide-line are sometimes cut at intervals across the trace itself, so as to divide it into segments, each of which may be burned separately.

The guide-lines should be cut some time before the fire-trace 
is to be burned, and the cut material thrown on the trace, where it will dry, and facilitate the burning. A broad short scythe or a sickle may be used to cut the grass, heather, \&c., from the guidelines.

In burning the traces, it is a golden rule to remember that grass and heather in the open become dry sooner than under cover of the forest, so that border fire-traces may be burned before the internal ones. In firing a trace, a still afternoon should be chosen and men placed on either side of it, two of whom fire the edges of the traces up to a cross line, if one has been cleared, or if not, to a sufficient distance for the other men to be able to beat out the return fire which rums along the ground in the stubble towards the forest. The other men, armed rith evergreen boughs, which they can use to protect their faces from the heat of the fire, keep back on the guide-lines, or eren in the forest beyond them, until they see the return fire approaching too near the edge of the forest, when they rush forward and beat it out, leaving the flames from either side to meet in the trace, and burn all the standing grass or heather within it.

It should be noted that however still the air may be, before firing a trace has commenced, the ascent of hot air due to the fire will draw in colder air from all sides to fill up the vacuum thus produced, and if the wind be blowing in the faces of the men on one side of a fire trace, lighting in the middle of the trace, as well as along its sides, will clraw in the flame away from the men on the dangerous side, in spite of the wind, and will thus greatly facilitate their work.

Very full details as regards the practice of burning fire-traces are given in Fernandez' Indian Sylviculture, and need not be repeated here, as in Europe the worli of burning fire-lines is much simpler than in hot countries.

In every case, however, one or two trustworthy men should follow the firing gang on either side of the trace, and should carefully extinguish all smouldering embers on the guide-lines, and throw all burning twigs and pieces of wood from the latter on to the middle of the trace, so that there may be no possibility of the forest catching fire from the very means which are taken to protect it.

On hill-sides, fire-traces should run along ridges, and they 
may be made zigzag when the hill-sides are steep, and are burned downhill. In forests where numerous fire-traces are cleared annually, it is often adrisable to mark off the limits of the guide.lines by a simple trench of the breadth and depth of a plantation-hoe.

Where the soil-covering is very dense and tall, it is better to burn the traces twice, at first before they are completely dry, and again whenerer dead leaves fall on the traces after the grass has been burned; dead leares should be swept away or burned, in order to render the trace impassable by fire. This leaf-burning is, however, a simple operation which may be carried out by three or four men, whilst the first burning in dense tall grass may require 20 men, or more.

If by accident, during the burning of a fire-trace, the fire should get into the forest on either side of it, the further burning of the trace must be suspended until the fire in the forest has been extinguished, and to do this it must be attacked on both sides by the gang of men, and driven into the shape of a wedge.

\section{(c) Watching the Forests.}

During the dry season, after all the fire-traces have been cleared, and until sufficient rain has fallen to render the forest safe from fire, it is often necessary to appoint special patrols to watch the forest, in addition to the ordinary protective establishment. These men warn all passengers along the roads of the danger from fire, sweep off or burn dead leaves on the fire-traces, relieve one another in night-watching, and instantly report all cases of fire to the forester and forest guards, when organized measures can be taken to extinguish it. In some cases, seats are made for the fire-watchers in trees, with ladders for ascending them, in order that any outbreak of fire may at once be detected.

\section{(d) Trenches round Pcat-Deposits.}

Wherever peat occurs in the forest soil, deep trenches should be dug round the peat-deposits to isolate them from possible forest fires.

(e) Conduct of Thinnings.

Early and careful thinnings should be made in young 
coniferous woods, and all dead branches should be pruned off and removed. The least that can be done is to clear the boundaries of all compartments of dead wood to a breadth of 30 to 45 feet.

\section{(f) Along Railuay-Lines.}

Fire-traces must be kept clear of woody growth, and of dead leaves, heather, and other inflammable material along all railwaylines passing through forests. Most forest fires due to sparks from locomotives break out within 30 feet of a railway-line, but to render the fire-traces quite effective, they should be 60 feet broad. The French law regarding forest-fires in the Maures and Esterel, makes such fire-traces compulsory along all railwaylines running through the forests of those Départements.

\section{(g) Roads and Rides in the Frorest.}

The net-work of forest roads and rides may afford considerable assistance against fires. In order to protect the forest on either side of roads from any risk of fire from sparks from pipes, \&e., of travellers, or cartmen, all inflammable undergrowth and dead leaves should be cleared from the roads, and from a strip 10 to 15 feet broad on either side of them.

Some of the rides may be cleared as fire-traces, and where the prevalent winds are from the west, it is better that rides to be cleared as fire-traces should be at an angle of about $75^{\circ}$ to the wind direction, as it is easier to burn them, and they afford a broader barrier to a fire coming from the west than if they were simply at right angles to the direction of the wind.

Besides roads and rides, watercourses often form effective firetraces when the undergrowth is cleared away and bumed on only one side of the watercourse at a time, but crossing the watercourse at its bends, so as to form a uniformly broad trace.

\section{(h) Size of Working Sections.}

Where forest fires are to be feared, the working-sections should be comparatively small, so that there may not be extensive tracts of young woods, in which the danger from fire is greatest over large areas. 
(i) Clearance of Felling-Areas.

The felling-areas should be rapidly cleared of all refuse, and the produce of the thimmings also removed quickly, especially in the case of faggots from coniferous trees.

When workmen sleep on the felling-areas, great care must be taken as regards smoking, and fires should be allowed only inside their huts, which should be surrounded by broad fire-traces, as the wind might otherwise blow sparks into the forest. In parts of Northern India during the hot dry months of May and June, it has been customary to suspend all timber works owing to the risk of fire from the woodmen and carters, but these men can easily be taught to guard the forest from fire, and it is doubtful whether this restriction is necessary.

\section{(j) Other Measures of Protection.}

Regulations restricting fires and smoking in forests in dry seasons, and also regarding the use of fire-arms, should be made by the State. The most complete State-regulations regarding forest fires are those enacted in 1893 by the French Legislature. Somewhat similar rules are enforced in British India, except as regards railways, but they apply only to certain State forests. The private forest-manager must see that all State regulations regarding forest fires are observed, and should instruct the workmen engaged in occupations endangering the forest, such as charcoal or lime-burning, what protective measures they must adopt, and should see that his instructions are followed.

During the dangerous season, the forest guards must be constantly on the watch against fires, as well as the fire-patrols, if it has been found necessary to engage additional men. All contraventions of the State regulations regarding forest fires should be at once reported to the police, or to a magistrate.

In order to prevent intentional firing of a forest, no privileges to cut grass, or to graze, should be conceded on an area which has been burned.

Difficulties arise in India with sportsmen, when from fear of fires the forests are closed to shooting during a season which would be otherwise open. Special permission is some-

voL. IV. 
times given by Government to forest officers to open the forest temporarily to shooting after a heavy shower of rain, during the dry season, or in order to shoot tigers, or other destructive beasts. The shelter afforded to game or noxious animals by high grass near villages may become a great nuisauce to the villagers, and the forest officer should not carry the practice of protection from fire too far in such cases, and it may even be advisable to burn off worthless tracts of scrub forest or grass-land for pasturage, so as to lieep public opinion on the side of the forester. On the other hand, State forest officers have frequently direct power to arrest offenders, and to call on all forest right-holders and workmen to assist in extinguishing a fire, and in certain cases, privileges and rights to forest produce may be temporarily suspended by the Government, in cases of wilful firing of a forest by villagers, or their refusing assistance when once a fire has broken out.

In Belgium, there are so many small private forests that insurance against damage to forests by fire can be effected at reasonable rates.*

\section{Rules for Extinguishing Forest Fires.}

(a) General Rules.

If a fire should break out in a forest, the manager must call on all available labourers from the nearest villages, as well as the forest workmen, to hurry to the site of the fire, and carry out the necessary measures for extinguishing it. The workmen should bring bill-hooks, hoes, iron-rakes, and axes, and provide themselves with saplings or branches to beat out the fire. The chief object should be to limit the progress of the fire at the smallest possible sacrifice of still unburnt woods. This is best done by attacking the fire on both sides nearly parallel to the direction of the wind, and gradually beating it out in the shape of a wedge. The burned area must be abandoned to the flames. The result depends on the presence of mind, courage, energy, decision of character, and practical directions of the head forester present, and on the obedience, zeal and skill of the men. The chief forester present must be thoroughly acquainted with

* 60 centimes per 1,000 francs for broad-leaved woods. 6 francs 5 , conifers under 20 years.

, over ," 
the locality, as it may be necessary to sacrifice an area of unburned forest by counterfiring. In order to detect at once any fires arising from sparks which may cross fire-traces, men must be posted at all threatened points around the actual fire. As it may take several days to extinguish an extensive forest fire, arrangements may be required to work the available labour force by relays, and to supply the men at work with food and drink.

In countries like India, where forest fires are common, wherever the villager's willingly come forward to help in extinguishing fires, concessions may be made to them of dead firewood or thatching grass, and in case of the fire burning the houses of a village, situated near the forest, the manager should be ready to help with building and thatching material, either free or at cheap rates.

In such localities more than half the battle against forest fires is won, when the protection of the forest from fire meets with sympathy from the neighbouring rillagers.

In France and Germany, it is usual to call out the soldiers of a regiment quartered near the forest to assist in extinguishing extensive forest fires.

\section{(b) Against Ground Fires.}

The burning area must be isolated by digging trenches, which must be deep enough to prevent the fire from finding its way below them. Water should be poured on the burning turf, or soil from the trenches heaped on to it.

\section{(c) Against Surface Fires.}

The fire should be beaten ont with green branches as already explained. Wherever there is a dense undergrowth, as in the case of heather, it is better to beat down the fire rertically, but where the soil-covering is low, the branches should be ased backwarks and forwards like brooms to sweep it ont.

At the spot where the fire commenced, workmen shouid clear away a strip of the soil-covering in order to isolate the fire. Iron rakes, fig. 255, of a special kind can be used for this purpose with advantage, and unburned litter may thus be drawn by the teeth of the rakes towards the workmen, or burning litter be pushed away by using the rake reversed. 
Freshly dug up earth may be thrown on the fire.

A clearance, or fire-trace, may be made in front of the fire to stop its further progress. The distance of this from the fire should be so chosen that the fire-trace may be completed before the fire reaches it. In making this fire-trace, all the soilcovering should be cut and removed, and if there is time, a trench may be dug, and the earth from it piled up towards the fire.

It may be necessary to counterfire from a road, stream, ride or fire-trace; the soil-covering is then burned, and this fire directed so as to meet the advancing forest fire, when the two fires meet and become extinguished for want of fuel. This is a very efficacious remedy, but demands great care, and can be carried out only when the air is fairly still, and the undergrowth

Fis: 255.

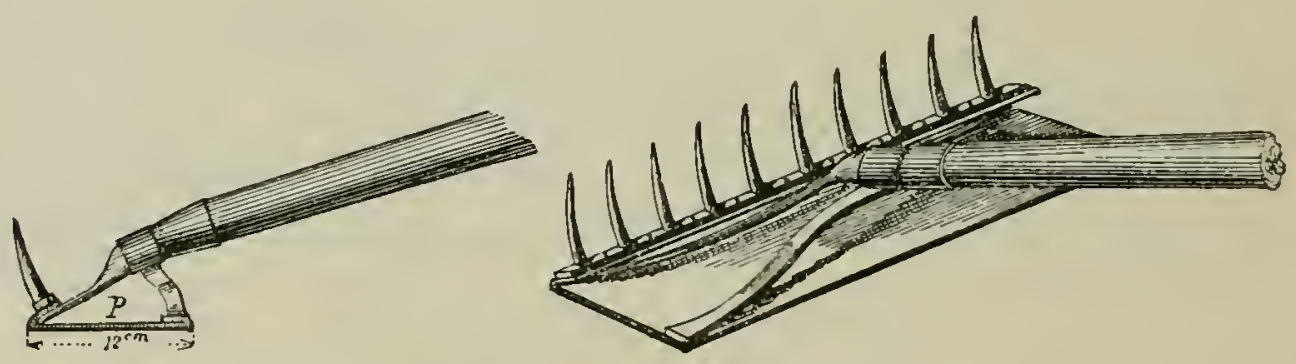

Rake used in protection against fire.

not too high, or fire may ignite the crowns of the trees; it will evidently be resorted to only in extreme cases.

\section{(d) Against Croun Fires.}

The wooded area must be interrupted by felling a strip of trees in front of the fire, which is best done along a road or ride. The smaller trees should be dragged away, if there is time to do so, taller trees should be felled towards the fire and their crowns lopped off, if possible.

Counterfiring is of little use against crown-fires, but may be tried, if only young growth is burning.

\section{(e) Against Stems on Fire.}

When a solitary hollow tree is burning, the hole may be stopped with sods or earth. If, however, the hollow extends to the top of the tree or through one of its main branches, the tree 
must be felled, after clearing away the undergrowth and soilcovering all round it, and the fire shonld then be extinguished with water or soil.

\section{Watching the Site of the Fire.}

In order to guard against a fresh outbreak of a forest fire, its site should be carefully watched by trustworthy persons until all further danger is over. This may not be the case in a coniferous forest, where the soil is deeply covered with dead needles, for a week or more after the fire has been extinguished, unless rain falls. The manager should go completely round the burned area and see that it is properly isolated from the surrounding forest by clearings of the soil-covering and trenches. All burning pieces of fallen wood on the site of the fire should be covered with earth, and wherever any fire reappears, it shonld be at once beaten out.

\section{Treatment of Woods Injuied by Fire.}

The treatment of burned woods depends on their age, the extent of the fire and the amount of injury done to the trees.

Burned young coniferous woods should almost always be dug up and the area at once restocked. Occasionally young Scotch pines may put out fresh needles and recover. Older woods with uninjured crowns and with merely their bark singed may be left standing. If, however, the bast and sapwood should be seriously affected, it will be necessary to fell the trees, and especially if it is subsequently found that they have been attacked by beetles, as for instance, Hylurgus piniperda, L., which will breed in the summer in pine woods which have been burned in the spring, and proceed in the autumn to thin ont the crowns of all the trees around the site of the fire. Where this is to be feared, it is better to fell all trees likely to be so weakened by the fire as to encourage the breeding of these destructive insects.

We should not, however, be very ready to fell broad-leaved trees, as oak-woods, for instance, sometimes recover after being burned, especially the dominating trees, but beech are more susceptible to damage by fire. It is better in doubtful cases to 
await the next season of vegetation before deciding what is to be done. Foung broad-leaved woods may be cut back if seriously injured, but eren this operation may be put off till the ensuing spring as it may then prove unnecessary.

\section{Section II.-Effects of Ijightning on Trees.}

\section{Mode of Striling.}

When lightning strikes a tree, the wet cambium-zone conducts the electrical discharge, and the contained water is suddenly converted into vapour. The expansion thus caused strips off the bark at the points of least resistance, and if the bark be smooth and thin, large pieces of it may be removed. The wood may also be split from the top of the tree downwards, the lightning entering at the fine twigs on the top of the tree and rumning down the stem straight or spirally according to the direction of the fibres.

\section{Damage done.}

(a) General Account.

The effects of lightning on a tree are very various; if the tree be split, the bark is usually remored only in a narrow strip on either side of the tree, otherwise occasionally in large flakes. Even in the former case the tree generally dies, it may be after a few years.

In other cases, pieces of wood are split off the stem, of all sizes up to several yards in length. The lightning has even been known to enter a tree horizontally and then strike down through its axis as shewn in fig. 256. Sometimes large arms of a tree, or its whole crown, have been broken off by lightning. As a rule, the lightning runs down the tree into the ground, but in $3 \%$ of the cases cbserved it passed off to other trees before doing so.

The cambium, wood, and pith of a tree struck by lightning become discoloured, and often the topmost leares turn brown, those below remaining green; the wood becomes soft and weak.

Wood-and bark-beetles, sawflies and fungi speedily attack the injured tree, which should therefore be felled as soon as possible. 
When an unsound tree is struck by lightning it is sometimes set on fire, and the fire may then spread to the surrounding forest.

It has also been repeatedly observed that sometimes a whole group of trees may die from the effects of lightning, the marks of which may only be visible on one of the trees. This talies place some time after the occurrence, and leares an ugly gap in a fine wood. This has been observed only in woods of spruce,

FIG, 256.

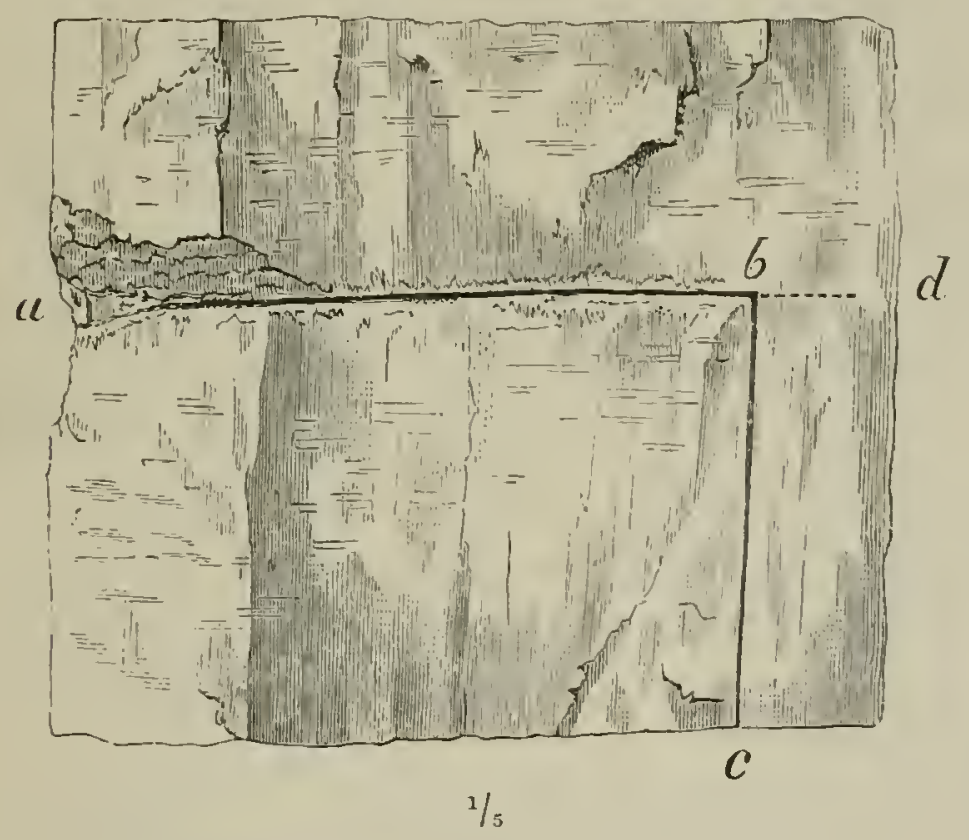

Lightning-stroke along $a b c$ on a beech tree.

silver-fir, Scotch pine and larch, and is probably due to the badly conducting nature of the soil, after a tree has been struck.

(b) According to Species.

All species of trees are liable to be struck by lightning, but oaks and other species with deep roots appear to be most liable to this danger, perhaps on account of their roots forming better conductor's to the moist subsoil than those of shallow-rooted species.

According to the valuable observations made amually since 1874 in the forests of Lippe-Detmold* the Scotch pine suffers most frequently after the oak, then the spruce and beech. The birch, poplar, ash, alder, and larch only suffer exceptionally.

* Ztschret. fr. Frst. u. Jgdw., 1579-18s9. 
Other observations by Collodon,* Hellmann, $\uparrow$ Cohn, and Caspary give somewhat different results.

Thus Hellmann, considering danger for the beech from lightning as 1 , gives-

Conifers . . . 15

Oaks . . . . 54

Other broad-leaved trees . 40

Cohn-Oalis . . . 14 ) out of 40 trees

Poplars. . . 12$\}$ struck.

Caspary-Oaks. . . 15 \} out of 93 trees

Poplars . . . 34$\}$ struck.

According to Collodon, near the Lake of Geneva poplars rarely suffer from lightning.

In the Revue des Eaux et Forêts, + the resuits are given of 15 year's' experience in a forest composed as follows :-

Oak. Beech. Sprnce. Pine. Others.

$\begin{array}{lrrrrrr}\text { Per-centage of trees } & \text {. } & 11 & 70 & 13 & 6 & - \\ \text { Trees struck by lightning } & . & 159 & 21 & 20 & 59 & 20 \\ \text { Relative frequency } & . & 48 & 1 & 5 & 33 & -\end{array}$

This agrees with the results obtained in Detmold, except as regards the beech.

On the whole, from these observations it is evident that local circumstances such as dampness of soil, density of growth, healthy or unhealthy condition of tree, affect the question whether one species will be more liable to attack than another in any particular locality.

Some experiments as regards the conductivity of electricity by wood have been recently made by Janesco Dimitric of the Württemburg Society of Natural Science. In these Holz's electric machine was used.

1 turn passed the spark through oakwood.

12 to 20 turns through beech.

5 turns through poplars and willows.

The use of heartwood or sapwood and state of dryness of the wood made no difference in the results, but the richness of beech in oil prevents its being a good conductor.

* Allg. Frst. u. Jgdztg., 1875, p. 440.

†. Frstl. Blttrn., 1889, p. 26.

‡ February, 1894, p. 78 . 
After the oil had been extracted from beech-rood, it became as good a conductor as oak.

Pine is rich in oil in winter, but not in summer, when it becomes a good conductor of electricity.

It is evident that more observations must be made as regards the comparative frequency with which trees of different species are struck by lightning, before any certainty can be arrived at.

It is probable that when sound well-conducting trees growing on damp soil are struck, the lightning passes rapidly down to the earth without causing much breakage, but that when rotten wood is met with, which is a bad conductor, the crown or branches may be broken, or even the tree set on fire.

\section{(c) Locality.}

Damp soils conduct electricity well, but in dry places when the lightning has reached the ground, it may spread from root to root of neighbouring trees and cause them to die in groups.

The relative frequency with which trees are struck on different soils in Lippe-Detmold is given below :-

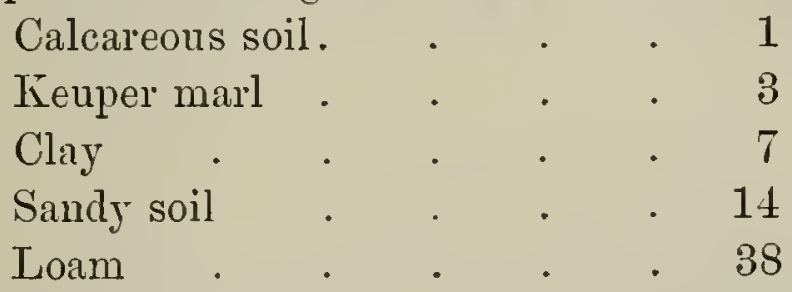

This may explain the greater danger to trees from lightning in North Germany as compared with South Germany and Austria.

Trees are said to be more frequently struck by lightning in badly-wooded plains, than in well-wooded mountain districts.

It is supposed that dense forests act as conductors and allow electricity to pass gradually from the earth to the clouds, whilst clearing the land of forests increases the heat of summer and hinders the neutralization of the electricity of the clouds.

\section{(d) Density of Crop and Condition of Trees.}

Lightning, according to Hess, strikes in preference trees standing free from their neighbours, those in avenues and on 
the border of a wood and also trees dominating over the rest of a rood.

Sound trees are more frequently injured than unsound trees, but dry trees may be struck, and stag-headed oaks are frequently smashed to pieces by lightning. Thus, a positively electrified cloud induces the separation of the electricity in a tree, driving the positive electricity into its roots and the earth, whilst the tree becomes charged with negative electricity. The strength of this charge becomes weakened by gradual discharge into the atmosphere from the numerous twigs and leaves in the crown of a vigorous tree. On the contrary, a tree with many dry branches and scanty foliage becomes thoroughly charged with negative electricity, and when struck by lightning receives a more violent shock than a sound tree.

\section{(e) Season.}

In Central and Western Europe the most frequent thunderstorms are in June and July, between 3 and 5 p.m., or 1 and 2 a.m. These storms usually pass from S.W. to N.E. or from W. to E.

In the case of heary rain before the lightning-stroke, the trees become better conductors, and are more liable to be struck.

\section{Register of Damage by Liglutning.}

The frequency of thunder-storms in Central Europe decreases as the latitude increases and in proximity to the Atlantic Ocean, as the following average figures show :-

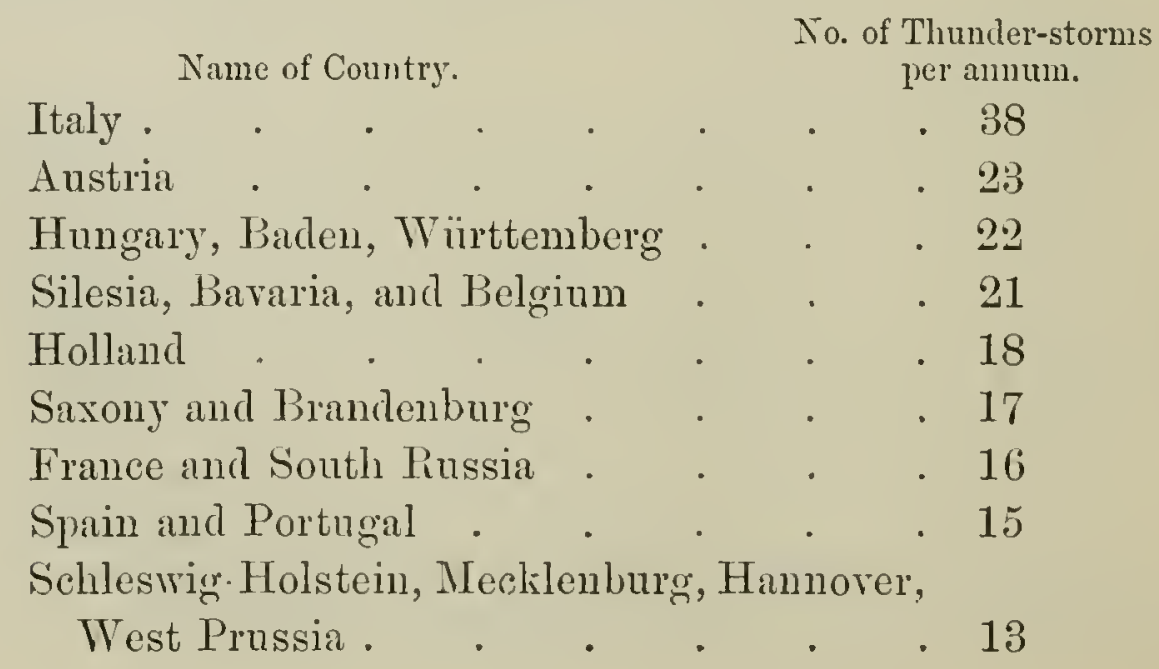


Name of Country.

North Pussia

Sweden and Finland

England and Switzerlan

Norway
No. of 'Thunder'storms per annum.

9

8

7

There has been no increase of late years in the number of thunder-storms in Germany, Austria and Sivitzerland, but in most other European countries their frequency has increased almost three-fold, and this is considered to be due to increase of railways, metallic roofs and pipes for gas, water, sc., inside houses.

Some interesting facts regarding trees lilled by lightning are given below.

1848 (early in July) : 52 Scotch pines about 125 years old were killed by lightning at Sprillgehörge in Hannover, only one of them being directly struck.

1865 (spring) : 70 sixty-year-old spruce trees, only one of which was struck, were lilled by lightning in the Harz Mountains.

1868 (11th May): A green spruce tree struck and burned in Köthenwald in Reuss.

1876 (17th July): After a long drought, a dried-up moor stocked with a thicket of 11-year-old Scotch pines and spruce was fired by lightning at Aurich near Neuenwald.

1887 (summer): Two lightning strokes about 70 feet apart killed all the trees on about $\frac{1}{5}$ th of an acre stocked with Scotch pine and a few beech near Neustadt.

1887 (15th July): 72 large spruce trees were killed by one stroke of lightning at Brïckenberg. It was clearly seen from marks on the branches that the lightning liad passed from tree to tree. 


\section{PART VI.}

PROTECTION AGAINST CERTAIN DISEASES OF FOREST TREES

\section{CHAPTER I.}

\section{GENERAL ACCOUNT.*}

\section{Definition.}

A Forest plant is said to be diseased when owing to disturbances in the functions of its organs and of the chemical or physical processes going on within them, it assumes such a condition that it is hindered from further useful development and may consequently die, either wholly or in part. Disease therefore causes blanks in woods of all ages, and also loss of woodincrement and consequent reduction in their value.

\section{Causes of Disease.}

Many different causes of disease in forest trees may occur, for instance, old age, injuries by men and animals, or by atmospheric agencies; also owing to certain local circumstances, such as soils too poor in the chemical compounds which are necessary for plant-life, soils too dry or very wet, insufficiently porous, \&c.

Although much progress has been made during the last twenty years in the study of the diseases of forest trees, a wide field is still open for discovery in this respect.

3. Classification of Diseases.

The diseases of forest plants may be grouped according to

* A capital account of the conditions of environment which enconrage disease in a plant is given in the Proceedings of the Royl. Soc., vol. 47, "The Croonian Lecture," by H. Marshall Ward. 
their origin, the nature of the organs which are attacked, the progress of the disease and its importance in forestry. These four headings have been considered in the following list :-

1. Diseases arising from physical agency (frost crack, bark blister, \&c.) and those from pllysiological causes, such as red and white-rot.

2. Loeal discases, such as of the roots, or of the stem, bark, buds, leaves or shoots, or of the inflorescence and fruits of the trees.

3. Acute, or rapidly developing diseases, or chronic diseases which develop slowly.

4. Diseases which merely cause loss of increment, and other's which affect the technical value of the wood, the latter consisting either in an abnormal growth of otherwise healthy, woody tissue, such as burrs, twisted fibre, \&c., or in an unhealthy state of the tissues, as in red or white-rot.

The worst kinds of damage to forest plants by men, animals, plants, and atmospheric agencies have been already dealt with in the preceding chapter's of this book. For the study of abnormal growth in healthy wood-tissues, the reader is referred to treatises on Forest Utilization. In the following pages certain diseased conditions will be described which could not well be classified under any of the foregoing heads and are limited to the following:-red-rot, white-rot, stag-hendedness, abnormal needle-shedding, and damage by factory-smoke. 


\title{
CHAPTER II.
}

\author{
RED-ROT.*
}

\section{Description.}

RED-ROT is a decomposition of wood, by which its elementary organs are gradually detached from one another and it becomes

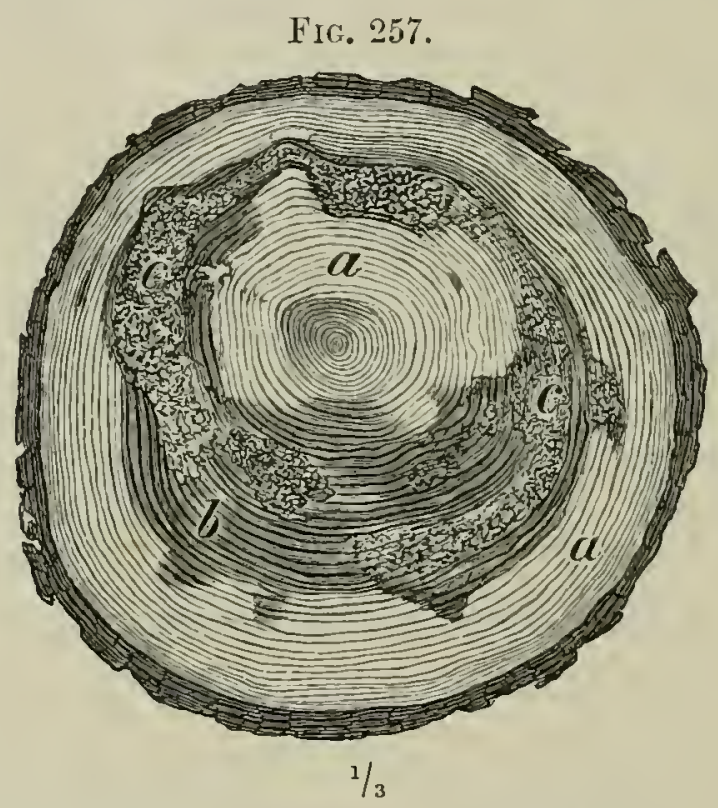

Section of a spruce suffering from red-rot. $\quad$. Sound wood. $\quad b$. Discoloured wood where decay has commenced. c. Rotten wookl.

eventually converted into a loose-textured mass, at first reddishbrown and passing through a dark brown condition into a peaty substance resembling humus. Frequently whitish mycelia may be noticed traversing the wood longitudinally.

Red-rot occurs, according to its position, as root, stump, stem, or branch-rot. A transverse section through the rotting wood

* Willkomm, Dr. Moritz, Die Mikropischen Feinde des Waldes. Dresden, 1866, pp. 31 and 219. Hartig, Dr. R., Die Rotfäule der Fichte. Monatschrift fr. das Forst und Jagdwesen, 1877, p. 97, an excellent and cornprehensive work. 
shows a great variety in the phenomena and course of this disease, often in the same tree. Either certain anmual zones, or groups of annual zones of wood between the heart and sapwood are attacked,* or the disease occurs in patches, or attacks merely the central zones of the tree or branch. The sapwood is never attacked by red-rot. The rotten wood may eventually be completely decomposed, when it disappear's, leaving a hollow cylinder, in place of the heart wood, and this frequently without involving the death of the tree. Sometimes the innermost portion of the stem remains, forming a thin columnal, hard strand of wood united with the sapwood here and there by similar strands where branches have been enclosed in the wood.

The commencement of the disease may be recognized by a light violet or reddish colour of the wood, and by the porous spring zones being attacked before the harder autumn zones.

\section{Modifying Factors.}

(a) Species.

Red-rot occurs in almost every species of forest tree. Among broad-leaved species, oaks and elms suffer most, and among conifers, the spruce and Scotch pine. The disease usually commences at the roots of spruce trees.

Root-rot usually spreads upwards through the heart-wood to the branches. It may, however, on the contrary, gradually descend from the branches through the stem to the roots.

\section{(b) Age of Tree.}

Red-rot is a normal condition of very old trees, but a disease in the case of young trees. It has been observed in the spruce from the age of ten years and upwards.

\section{(c) Locality.}

Wood may become rotten in all linds of localities, but certain conditions of the soil predispose trees to this disease, such are:- Soils very rich in humus, calcareous soils, soils very compact or wet and cold, such as clays and peats which are not properly aërated, or where an impermeable substratum occurs

* Termed Mondring in German and lunure in French. 
at an inconsiderable depth below the surface of the ground. Wood also readily rots in places much frequented by cattle.

\section{(d) Treatment of Woods.}

A dense condition of a wood, especially in moist or wet localities, favours the evil. Tapping for turpentine, barking by game, and other injuries, such as pruning living branches without tarring, frequently give rise to the first symptoms of red-rot in wood, especially when the trees are growing in localities predisposing them to disease.

\section{Causes.}

Widely differing and frequently contradictory hypotheses have been started to explain the origin of red-rot. Usually it is attributed to external circumstances, such as unfavourable localities, injuries, \&c., without further enquiry into its possible causes.

The first scientific enquiry into the cause of red-rot is found in the works of Willkomm (1866), who designated a microscopic fungus as the sole origin of the disease. He named this fungus Ienedochus ligniperda, and another allied form which springs from it, Rhynchomyces violaceus, which causes the bluish colour in rotting wood.

The question as to the origin of red-rot was not by any means solved by Willkomm's researches, as he merely proved the presence of the above fungi in rotten wood, but did not make experiments to infect sound wood by means of their spores, so that it remained doubtful whether the fungi were the causes or merely the consequences of red-rot.

Robert Hartig, in 1874, solved this question, by proving that red-rot in the case of spruce, Scotch pine, oaks, \&c., really arose from infection by parasitic fungi. Later on, in 1877, he further proved that, at least for the spruce, unfavourable soils and external injuries also induced the disease. As we have already in Chapter III., Part II., discussed the infection of trees by fungi, we have now only to deal with the two latter cases.

(a) Unsuitable Soils.

The kinds of soil which induce red-rot in the roots of trees, 
and chiefly in their deeper-lying roots, are generally peaty humus, soils containing pans or impenetrable substrata of ochrous iron ore, lignite, clay or loam, also very fine sand, not infrequently found in the Lias formations in Germany. Such subsoils interfere with aëration of the surface-soil, the oxygen so necessary for the roots of trees being unable to reach them in sufficient quantity. This is due to the fact that the air in too compact or waterlogged soils is gradually deprived of its oxygen by the roots of the plants growing on it, and by the decomposition of the litter, and this loss of oxygen is not sufficiently replaced by the admission of fresh air to the soil. The denser the wood, the faster the evil progresses ; fungi also accelerate the disease. This form of red-rot is more prevalent with larch, and sometimes with Scotch pine, than with spruce, as the roots of the larch, as well as those of Scotch pine, penetrate more deeply into the soil, and therefore rot more readily than those of spruce, which spread in all directions in the npper layer's of the soil.

Scotch pine, howerer, can produce superficial roots like those of spruce when grown on shallow soils, whilst experience in Windsor Forest shows that larch growing on a gravelly soil above a pan always gets red-rot, and this is confirmed by A. D. Webster, who states that larch always gets red-rot when grown on gravelly soils.

\section{(b) External Injuries.}

Trees are frequently wounded during the felling, conversion, and transport of timber. Wounds also arise owing to forest pasture, game, mice, insects, from pruning green branches, or from meteoric influences, frost-crack, bark-scorehing, wind or snow-break, hail, lc. Wherever the living tissues of the wood are exposed, especially where the wounds are not clean-cut, moisture penetrates into them, unless they are protected by antiseptic substances, such as a natural flow of turpentine, or by tar. With the entrance of water into the tissues, certain chemical changes take place in their contents, and local disease may arise. Spores of fingi also penetrate the tissues, such as of species of Iolyporus in the upper parts of the tree, or of Agaricus mellens, de., in its roots.

* Practical Forestry. William lider and Son. London: 2nd edition, 1595. VOL. IY. 


\section{Damage done.}

Red-rot affects the techmical value of wood in proportion to its extent and degree of development, and to the immate value of the tree which is attacked. Wood affected by red-rot camnot be used as timber, and is only of slight value as fuel. The worst form of this disease is when it attacks a tree's roots, as it then generally affects the whole stem; the least dangerons form is in the branches.

It is not rare in spruce-woods $60-70$ years old to find that 10 per cent. of the trees are rotten, whilst the liability of rotten trees to wind and snow-break is another canse of disaster.

\section{Treatment of the Disease.}

The rules for combating red-rot depend on the cause of the disease.

(a) When due to Unsuitable Soils.

Great care should be taken in planting to allot the species of trees to soils suitable for their welfare.

Remove deusely growing mosses and other unfavourable regetation from damp mountain soils.

Drain and work up the superficial layers of compact soils.

In wet soils which camnot be drained, plantations should be made on mounds or ridges.

Broad-leaved species should be intermixed with Scotel pine and spruce on calcareous soils; low rotations should be adopted for spruce, 60 years can liardly be exceeded with safety.

\section{(b) When due to Injuries.}

Great care should be taken during timber-fellings and transport.

Pruning of green branches should if possible be avoided, or restricted to branches under 4 inches in diameter; all wounds made by pruning should be smeared with tar.

All rotten trees and stumps should be speedily removed from the forest.

All measures dictated by forest protection should be strietly followed in order to prevent injuries to the trees. 


\section{CHAPTER III.}

\section{WHITE-ROT. *}

White-rot is distinguished from red-rot by the colour of the decomposing wood, which is of a whitish instead of a reddish hue. It is commoner among broad-leaved species (beech, hornbeam, maple, oak, chestunt, poplars, and willows) than among conifers, and appears to be due chiefly to fungi, I'nlyporus lenealis on the spruce, $I$ '. finlrus on the silver-fir, I'. dryarleus, I'. igniarens, and IMymum dirersidens on the oak, and I'. lerigatus on the birch. White-rot is rarer than red-rot, and its course less rapid. The irotective measures to be taken are similar to those against red-rot.

* Bnoks referrerl to under red-rot, a!so see page 390 of present work. 


\title{
CHAPTER IV.
}

\author{
STAG-HEADEDNESS.
}

\section{Description and Causes.}

IT has been already stated that red-rot frequently attacks very old trees, rendering their stems hollow, but another sign of excessive old age is the death of some of the topmost branches of a tree, which has wo longer sufficient vigour to pump water so far. The death of these branches causes them eventually to break off, and atmospheric moisture is then admitted into the trunk, and rot commences and penetrates downwards towards the roots. Stag-headedness may, however; occur in immature trees, and is then due to one of the following causes:-

(a) When trees which have been growing in a dense wood are suddenly exposed as standards, as in natural regeneration in High Forest, or after the felling of the underwood in Coppicewith-Standards, the surface-moisture of the soil may be reduced and the trees consequently become stag-headed. In some cases such trees, and especially oalss, having comparatively soft bark, owing to their formerly protected state in a dense rood, put out numerous epicormic branches from the dormant buds along their stems, which absorb the sap that would otherwise reach their crowns. This tends to cause stag-headedness, which may, however, be obviated by one or two prunings of the epicormic branches, until the bark becomes too hard for them to form.

(b) In forests of light-demander's such as oak, larch, ash, Scotch pine, the soil may be completely sheltered by the crop, up to a certain age, but after $40-60$ years, the leaf-canopy ceases to be sufficiently close to protect the soil from the sum, which gradually dries it up, and thus canses stag-headedness in the trees, unless the soil be protected by an underwood of shade-bearers. 'T'his result follows more rapidly on hot aspects, and the more superficial the soil, and the more porous the subjacent rock, 
such as chalk or coarse gravel, and the less the rainfall and relatire humidity of the air in the locality.

(c) Any interruption of the leaf-canopy in forests of all kinds may cause deterioration of the soil and eonsequent stag-headedness.

(d) Drainage also, by lowering the lerel of water in the soil of a forest, may deprive formerly thriving trees of sufficient moisture, which their roots, adapted to reach water near the surface, can no longer absorb in sufficient quantity. 'Irees thus affeeted may become stag-headed. 'T'his happened on a large scale with oaks growing in the IFild Parli at Carlsruhe, owing to the rectification of the eourse of the Rhine, and consequent lowering of the water-level in the soil. A similar result followed drainage in Windsor Park, with regard to some of the elms in the Long Walk arenue, and it is not uncommon with alder-woods, after drainage. Continual and exeessive removal of litter from a forest may eause stag-headedness in immature beech forest.* It has been noticed in eertain two-storied coniferous forests in N. Ameriea, after the upper stage of trees har been felled, and the sum allowed to dry up the soil-corering, that the lower stage, the roots of which had spread superfieially in the layer of dead leaves and humus, became liable to stag-headedness and death.

(e) Stag-headedness in the Scoteh pine may be caused, as stated on p. 391, by the fungus l'eridermium I'ini, such trees being termed "foxy."

It is found that though in the case of eonifers, stagheadedness is speedily followed by the death of the tree, and beech also speedily suecumbs when similarly affeeted, yet that some other broad-leaved species, and espeeially oak, may remain stag-headed for many deeades without dying, although the teehnical ralue of their timber rapidly deteriorates, and their trunks may become completely hollow.

\section{Treatment.}

(a) Prerentire.

(i) Maintain the soil-covering of dead leaves, moss, \&c., in order that the soil may not lose its moisture.

* Fürst's Waldschut\%, translated by J. Nisbet, 1. 59. Edinburgh, 1893. 
(ii) Keep up a dense leaf-canopy, especially where the soil is shallow and liable to dry up, and where the subjacent rock is of a porous nature (chalk, gravel, \&c.).

(iii) Under-plant all High Forests of light-demanders with in shade-bearer, such as beech or silver-fir, as soon as grass or other herbage appear's on the soil, and fill up with shade-bearers any gaps which may have occurred in a forest owing to rrindfall, or other injurious causes. Under-planting oak forest with spruce may cause stag-headedness, on account of the quantity of moisture the spruce absorbs.

(iv) Do not plant spruce, alder, ash or pedunculate oak in dry localities. 'The sessile oak will thrive on well drained hillsides, where it is hopeless to plant the pedunculate oak.

(v) Avoid draining, mess it is absolutely necessary.

(vi) High Forest is more suitable than Coppice-with-Standards in dry localities and those with superficial soil, or above in porous rock.

(vii) When epicormic branches appear on oaks and other standards in Coppice-with-Standards, or on standards left after regeneration in High Forest, they shonld be pruned off before the next spring. It may be necessary to repeat the operation, but after two seasons in the open, the bark of the standards becomes hardened and the epicormic branches do not generally reappear. In any case, the stems of the standards will be gradually sheltered again by the rising underwood, which will effectually lill any epicormic branches still on the tree.

A growth of epicormic branches on oak trees growing in a dense forest is a sign of disease, and such trees should be gradually removed in the fellings, as they will certainly become stag-headed.

\section{(b) Remedial.}

As a rule no remedy can be adopted when forest trees become stag-headed, the only measure to be followed being to fell them and utilize their timber before it becomes further deteriorated. Slightly stag-headed ornamental trees in parks or avenues may, however, be given a fresh start in life, by trenching the sround under their crowns, breaking up any impermeable stratum under their roots, and manuring them with rich leafmould. 


\title{
CHAPTER V.
}

\author{
ABNOIIIAL NEEDLE-SHEDDING.*
}

\section{Deseription.}

Since the end of the eighteenth century, a disease termed in German Sichiitte, has been remarked on young pines, the external signs of which consist in the gradual reddish or reddishbrowu discoloration of their one or two-year-old needles, which eventually die and fall off the plants. As a rule these symptoms appear first in the spring, but not unfrequently also in the autumn and early winter, and in Sonth Germany the latter often happens in years when the ground is free from snow. A steelblue or violet colour of the one-year-old pine-needles in autumn is no sign of disease, provided yellow or reddish-coloured spots do not also occur; this is an instance of the normal wintercolour of many evergreen plants, which disappears as the thermometer rises in the spring, and gives place to the ordinary green colouring of the needles. The reddish discolouration and death of the needles proceeds from their tips downwards, and chiefly affects the lower parts of the plant near the ground. Pines thus affected resemble those injured by drought, but at the commencement of the disease, more or less regularly distributed dark spots and stripes appear, and later, in May, small black sporangia of the fungus Hysterium Pinastri, Schrad.t Also resin collects on the sickly needles. The rorst form of the disease may be recognized when the buds become encrusted with resin and dry-up, and then no recovery is possible for the diseased plants.

* Freiherr ron Lijffelholz, beitrag zu einer kritischen Nachweisung ïher die Schiitte-krankheit der Kiefer. Porlin, 1S65. Holzner, Dr. Georg, Die Beobachtungen über die Sehuitte der Kiefer und die Winterfärbung inmergriner Gen ächse. Freising, $187 \pi$.

t see p. 407. 


\section{Modifying Factors.}

(a) Species.

The Scotch pine suffers most from this disease; also the black, cluster and mountain pines, and eren exotic pines, but the disease does not appear to have been as yet, observed in the case of the Wermonth pine.

\section{(b) Age of Plants.}

Two-year-old plants suffer most from this disease, but three to four-year-old plants may also be attacked, though the danger becomes less every year. In years when the disease is very prevalent, weakly plants may suffer up to the age of fifteen years, but only up to about six feet from the ground.

(c) Locality.

Pines growing in all linds of localities are subject to this disease, but it is chiefly prevalent in damp or wet places exposed to frequent fogs. Thus valleys and plains suffer more than hills and mountains, where the snow protects the plants during winter. In depressions and in cold valleys, the disease is often very destructive. As regards aspect, southern and western slopes are most endangered, eastern slopes also suffer, but northern slopes either not at all or only exceptionally.

The soil appears to have some influence on the disease, but its effects bave not yet been clearly explained. Stein* states that Scotch pine suffers most on pure sandy soils, but after all it is on such soils that most indigenous Scotch pine-woods are found. Von Löffelholzt has observed that plants suffer less on thoroughly cultivated soil than when the land has not been previously broken up, and this may be due to the better rootsystems and superior hardiness of the plants in such cases. It also appears that on peaty soil, needle-shedding is little to be feared, which fact may be due rather to the treatment of the pine-forests on such localities than to the nature of the soil. Emmerling $\ddagger$ states that sowings of one-year-old pines in the

* Ueber dic Schiitte, Dr. F. Stein. Tharandter Jahrbuch, vol. viii., 1852, pp. 208-225.

$\dagger$ The same, p. 41.

¥ Untersuchung über die Ursache der Kiefernschiitte in Schleswig-Holstein, von Dr. A. Emmerling und Dr. G. Loges. Allg. Frst. n. Jgdztg. 1882, 1. ] 35. 
North German heather-land suffer severely every year from needle-shedding, whilst those on the more farourable, sandy loam are not affected by it.

It is clear that no very useful conclusions ean be drawn from the abore observations.

\section{(d) Soil-corering.}

It is not ret decided what influence the nature of the soilcovering has on the disease, though it may be laid down as a general rule that ground covered with grass or weeds is less liable to it than bare localities, but the favourable influence of the soil-corering may be counterbalanced by other causes.

\section{(e) System of Management.}

Under a shelter-wood, the young pines may entirely escape the disease, or suffer only slightly, and lateral shelter from old pine-woods acts farourably by reducing insolation and radiation of heat from the ground. On large clearings, pines are almost always subject to needle-shedding. Areas densely sown late in the year suffer most of all, when the individual plants have very small root-systems and thin elongated stems.

\section{(f) Weather.}

The disease is most frequent in March, April and May, and a wide range of temperature, such as warm sumny days and cold nights with rime, favours it. Cold, dry easterly or northeasterly winds increase the evil. During cloudy, rainy weather in spring, the disease may not appear at all, or only slightly. It is also more frequent after damp winters with light snowfall than after the ground has been well corered with snow.

\section{Geographical Range.}

The disease occurs wherever the Scotch pine is cultivated, but is less common in colder countries, such as Russia. It is not prevalent in the British Isles. In Germany it appears to be comnected with the extension of clear-cutting and planting, which, since the end of the eighteenth century, has so largely replaced the system of natural regeneration of the Scotch pine. 
In the damp, cold years 1850 to 185.2 it was widespread and very destructive in North Germany, and again in 1881 to 1884 . Pine-plants which have once suffered from it are liable to be again attacked, as they are greatly weakened by the disease.

\section{Callses.}

\section{(a) Introductory.}

Numerous and contradictory reasons have been given for the needle-shedding disease as quoted by both Yon Löffelholz and Holzner. The nature of the soil, the state of the weather, and combinations of these have been cited. Some think that Iysterium Pincestri is the sole cause of the evil, whilst others hold it to be due to a more rapid transpiration of water by the needles than the roots of the plants can supply. It is therefore probable that we have here to deal with many causes acting in combination, one with another, but these may be reduced to the three following:-

Pine-scab, Hysterium Pinastri, Schrad.

Frost, and especially early frosts in autumn.

Insufficient absorption of water to supply that transpired by the plants.

It is difficult to distinguish these canses from one another, as the pine-scab is always present, though frequently it may be only secondary.

(b) I'ine-scab.

The necessary account of this disease has been given above on p. 407. Hartig, * Prantl, and 'T'ursley have supported the fingus theory, but many phenomena appear which contradict it, for example, from the disease beginning at the points of the needles, and the lower parts of plants suffering most, and awove all from the fact that the disease frequently appears in a single night, and is much commoner in broadcast-sowings than in natural regeneration-areas. Hess has frequently observed the needles to have been attacked in every plant on a nursery-bed, after one night's hoar-frost succeeded by a sunny day, and this altogether excludes the action of the

* Vüle Hartigr, Lehrluch der Bammkrankheiten. 2nd edition. Berlin, 1ss9, 1. 103. 
pine-scab as cause of the disease. Moreover, infection by the scab, which is faroured by heat and damp, would be casier under a shelter-wood than in the open, which is not the case. The Hysterium is, however, widely spread as a saprophyte on dead needles of pines, ats well as on those of the spruce and juniper.

\section{(c) Frost.}

G. Alers* and Nordlinger $\uparrow$ have proved that the disease is frequently due to refirigeration of the plants on unprotecied soil fiee from snow by radiation from the soil-covering, and this opinion has been adopted by most practical men. Generally antummal frost is the canse, and early frost is not injurious, except when there is a great difference between the nightand day-temperatures. The fact that on older plants only the lower branches lose their needles, points to frost as the cause.

Needle-shedding due to frost is common after wet, cold summers, during which the young shoots of the plants have not been properly lignified. Only late frosts can account for the needles turning red in the spring, but experience has shown that they are not nearly so destructive as early frosts. The fact that needle-shedding is so prevalent on clearings, in depressions and valleys, and on uncovered ground where there is no obstacle to radiation, renders it probable that in many cases frost is the cause of the disease.

\section{(d) Drying-up of Neelles.}

The drying-up theory of the origin of the needle-shedding disease was first published by Ebermayer, ${ }_{+}^{+}$who, during the progress of his observations of soil-temperatures in the Bararian Forest meteorological stations, was led to adopt this view of the matter. His theory is, shortly, as follows:-The young Scotch pine-plants, owing to the frequently high atmospheric temperature in Narch and April $\left(66^{\circ}\right.$ to $77^{\circ}$ Falnr. in the shade), are on sumny days compelled to transpire freely.

\footnotetext{
* Alers, Centrllul fr. das ges. Frstw., 187S, 1. 132; 189:3, p. S1. Mlivo 1SS0, p. $156 ; 1882,1$. $159 ; 1883,1 \% 259$.

+ Nördlinger, krit. Blttr. fr. Frst. u. Jglw., rol. xlvi., 1£63, p. 185.

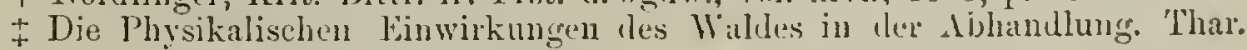
Frstl. Jhrbeh., vol. xxive, 1884, 1. 158.
} 
The loss of water by transpiration cannot be thoroughly replaced, as the action of the roots is restricted by the cold soil, the temperature of which may be only $40^{\circ}$ Fahr., or less, down to a depth of $3 \frac{3}{4}$ feet. Hence the little plants wilt and the needles dry-up and die. This is not due, as in dry summers, to the absence of moisture in the soil, but to the inability of the roots to absorb water in the cold ground, and therefore an abuormal drying-up of the needle ensues.

This theory will not explain needle-shedding in antumn, when the soil is warmer than the air, but when the needles are shed in the spring, it is in complete accordance with the observations recorded on pl. 574-5, under the headings locality and weather. Sandy soils cool down at night to lower temperatures, under similar conditions, than clays, and wet soils become colder than dry soils. Insolation is greatest on bare southern aspects.

\section{Damage done.}

As a rule needle-shedding is not fatal to the plants, and those which have been attacked may recover, provided their terminal buds are still minjured. Naturally, however, the injured plants languish for some time and are very liable to be attacked by insects. If, however, the disease recurs, and the terminal buds of the plants suffer, they hare no chance of recovering.

\section{Trertment.}

As the proper treatment of the disease will depend on its origin, the present section will be divided into headings according as the disease is due to a fungus, frost or the dryingup of the plants. The method of contending with the attacks of the fungus has been already described on p. 407, and only the two latter causes will be dealt with here.

\section{(a) First.}

(i) Regenerate Scotch pine-rroods under a shelter-wood. Aroid large felling-areas in clearing Scotch pine-woods, and wherever, owing to circumstances, natural regeneration is impracticable, narrow strip-fellings should be effected, in order to afford the young plants lateral shelter against the sun. 
(ii) Aroid sowings, and especially broad-cast sowings, in artificial reproduction of Scotch pine. When transplants are scarce it is preferable to sow early in the year, in drills 10 to 12 inches apart. Densely growing seedlings should be thinned, and a mixture of spruce with Scotch pine-seed acts farourably, the spruce protecting the pines.

(iii) Yearling pines are best planted out with balls of earth, by means of Heyer's circular spade, so that all injuries to the roots are aroided.

(iv) Sowings of Scotch pine should be abandoned in narrow deep valleys and in depressions.

As regards forest-nurseries, the following rules hold good:-

(v) Beds of seedlings should be covered with dead leaves, needles, or moss, leaving only the tops of the plants tree.

(vi) The beds may be protected by coverings, which should not be too dense. They should be pliced at about a yard from the ground, towards the end of September, and before the first early frosts, and may be remored as soon as late frosts in spring are no longer to be feared. Throughout the winter, the coverings may be partially removed during bright days, but should be replaced before sunset. If the coverings are placed lower down, the plants suffer from insufficient aëration, but coverings such as are here described have proved very efficacious in different parts of N. Germany.

(vii) Seedlings may be sprinkled with fine dry soil, at the beginning of September, so that only the needles remain uncovered. In case the earth should be washed away by rain, it must be replaced.

(viii) The nursery-beds should be manured with decomposed beech leaf-mould. This has been strongly recommended by sereral foresters, and a coating of about 1 to $1 \frac{1}{2}$ inches appears to be sufficient. This prevents sudden wide ranges of temper:lture in the surface-soil, though it is not clear on this accomnt why beech leaf-mould is preferable to other similar manure. It is stated, however, that heather-humus does not prevent needleshedding, when used instead of beech leaf-mould.

(ix) When two-year-old plants are used, the yearlings should be trausplanted into nursery-lines. 


\section{(b) Dryinu-up of Nectles.}

The principles to be followed in the case of this rariety of the disease should consist in plans for raising the temperature of the soil, and reducing the intensity of the light, in order to increase the activity of the roots and reduce transpiration.

Soil-temperature is increased by the following measures :-

(i) Draining wet soils.

(ii) Deep cultiration and manuring, for instance with burned turf, but these measures can be undertaken only in permanent. nurseries.

(iii) Raising the level of the soil in places prepared for sorring or planting. This method is useful for other reasous, and especially in the case of compact or wet soils.

(iv) Covering the intervals between rows of plants in the beds with substances which are bad conductors of heat, such as moss, clead leaves, \&c.

Iutensity of liyllt is reduced as follows :-

(r) Reproduction of Scotch pine under shelter-woods, or with lateral shelter.

(vi) Sowing Scotcl pine witl leguminous fodder-crops, such as lucerne or saintfoin. This has given splendid results in Brandenburg and Mecklenburg.

(vii) The hardiness of the plants is increased by giving them plenty of space from the first, by carefully preserving the fibrous rootlets during transplanting, and by using transplants with balls of earth round their roots.

\section{(c) Conclusion.}

From the above it is evident that the two rarieties of the necdle-shedding disease may be treated similarly. Needleshedding, oring to the fungus, would indeed be favoured by some of the rules giren under (a) and (b) ; for instance, reproduction under sliclter, and manuring and covering with Scotch pine-branches.

Two other methods of protection have recently been suggested, lut Hess las no experience of his own regarding their efficacy. They are as follows:-

(i) One or two-year-old plants may be carefully dug up 
at the end of September or begiming of October, when they have assumed their normal winter-colour, and placed in rows in a bed of loose earth raised 27 to 30 inclies from the ground, and then covered loosely with a few dead leaves. The plants will be green and in good order for planting in the spring, when other plants left in the nursery-beds have become quite red.

(ii) According to the other method, trenches are dug 24 to 27 inches broad, and 30 to 40 inches deep, and the plants placed in rows at the bottom of the trench with earth between the rows, either in autumn or in early spring. Sticks are placed across the top of the trench at distances of six to eight inches, which are then corered with branches of Scotch pine, or of silver-fir. Spruce branches will not do, as the needles drop off too readily. The density of the covering must be regulated according to the state of the weather, and it should be denser when there is a considerable range of temperature between the day and night in the spring. In case of prolonged drought the plants should be lightly sprinkled with water.

This method has been followed with advantage in certain forest ranges in Prussia. A trench 10 feet long will contain about 5,000 one to two-year-old pine-seedlings. It has not, however, always prored successful, and it is doubtful whether trenching plants in autumn may not be prejudicial. More experience is necessary before it can be contidently recommended. 


\section{CHAPTER VI.}

DAMAGE TO TREES BY ACID FUMES FROM FURNACES, \&C.

\section{Description of Injury.*}

Woons long exposed to acid fumes from iron-smelting furnaces, alkali and other chemical works and brickfields, or to excessive coal-smoke in crowded cities, become continually more and more sickly, and may eventually die.

The needles of coniferous trees become discoloured at first on the side from which the fumes come, turning yellowish, then reddish, and finally falling off, probably owing to the action of the acids on the chlorophyll. The buds at first escape injury, but the twigs of the trees gradually die from the summit of the trees downwards. In this way the crowns of the trees get continually thimner, as if they had been attacked by the pinc beetle, and they eventually die.

Broad-leaved trees suffer in a similar way, the damage to the leaves showing itself by larger or smaller reddish blotches, which uradually spread over the leaf till it dies and falls off the tree. The fact that most broad-leaved trees are leafless during winter, when there is most smolie, accounts for their comparative immunity in London, whilst in Lancashire, large coal-fires go on burning all the year round. 'Then, in proportion to the area, there is ten times as mncl coal burned at St. Helen's as in London, and consequently vegretation suffers much more in the former place.

Fruit-trees exposed to acid fumes cease bearing fruit before

* Viele Journal of the Society of Chemical Industry, pp. 202-206 and pp. 342345. Lmuge's Mannfaetule of Sulphurie Acill Alkali, vol. i., p. 110; vol. ii., 1'. 1S2-190. Air and Rain, by Dr. R. Angus Sunith, 1872. Husenelever, Cliemisehe Industrie, 1579. Von Sehroeder, Dr. Julius, and Renss, Carl, liesehtädignum der Vegretation dureh lianeh und alie Oberharzer Hüttenranel. whiden. Berlin, 1SS3. The hest monograph on the subject._Journal of Royal Hort. Soe, March, 1891, "l'rees and Shrubs for Large Towns," Maxwell T'

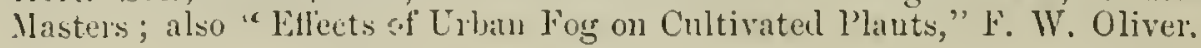


the foliage is seriously injured, and St. Helen's was formerly famed for its fruit; but since 1867, owing to the chemical works in its neighbourhood, no fruit has been produced there. Crops of wheat exposed to acid fumes may to all appearance be ripe and full, when scarcely a grain is to be found in the ears. Root-crops, such as potatoes and turnips, suffer less, and on the whole trees suffer much more than grass or agricultural crops. In some cases pasture may be poisoned by fumes of arsenic, \&c., and sheep and other animals eating the grass may be killed.

In 1861, extensive damage was found to have been done to coniferous woods by the fumes from the Works at Freiburg in Saxony, in some of which sulphuric acid is made from iron pyrites. Stöckhardt* and Schröder, $\dagger$ at the Tharandt laboratory, investigated the chemical components of the smoke which cause the damage, and Hamburger ${ }_{+}^{+}$has done the same more recently. Subsequent notices $\$$ have appeared about damage in the Oberharz owing to acid fumes, and the area of forest damaged by three Iron-Works, in 1881, was about 11,250 acres. In the Altenau forest-range this damage has become noticeable since American ores have been smelted, which contain more sulphur than the native ores.

\section{Injurious Components of Smoke.}

It has been proved by observations made at Tharandt, that of the components of the fumes from the Saxon Works, lead, arsenic, and sulphur compounds, soot, \&c., only sulphur dioxide is hurtful to woody growth, and a similar result has been arrived at in the case of coal-smoke. In order to ascertain the fact, various species of woody plants have been subjected to frequent and prolonged exposure to artificially produced fumes of each of the separate components of the smoke. Sulpliur dioxide in the soil has no prejudicial effects on plants, as has been proved by watering them with diluted sulphur dioxide solntion, for the gas speedily becomes converted into sulphuric acid, and forms harmless compounds with alkalies in the soil.

* Tharandter Jhrbch., vol. ix., 1S53, p. 169 ; also vol. xxi., 1871, 1. 21 S.

+ Id., vol. xxii., p. 185 ; rol. xxiii., p. 217.

¥ Id., 1885, p. 144.

$\$$ Reuss, Ztschirf. fr. Frst. u. Jgdwsn., 1881, p. 65. Also Cntrlbltt. fr. d. ges. Frstw., 1SS1, p. 267 ; id., 1882, p. 443.

VOL. IV.

R $\mathrm{R}$ 
The action of the sulphur dioxide, when the air is moist, or the leaves moistened with dew or rain, is rapid and decisive; it is probably absorbed by the plants in the form of sulphuric acid, being taken up in variable quantities by the leaves or needles of different species of trees. It then proceeds from the leaves into the twigs. The leaves or needles gradually turn brown, owing to the decomposition of the chlorophyll and the tissues of the leaf.

Sulphur dioxide finds its way into the atmosphere by the roasting of minerals containing sulphur, and from coal-fires; coal containing about $1.5 \%$ of sulphur chiefly in the form of iron-pyrites. What minute quantities of tisis gas suffice to kill plants was proved in 1864 , by experiments with spruce plants which were exposed to air containing only one-millionth part of sulphur dioxide. After 335 puffs of the air, the points of the needles began to turu brown, and eventually turned completely brown.

It has also been supposed that the soot in smoke might injure forest trees by blocking up their stomata, but this mode of injury is not admitted by Stöckhart.

As injurious compounds of the smoke of other Works may be reckoned, vapours of mercury, * hydrochloric acid gas, oxides of nitrogen, and chlorine. Also steam containing soda particles from cellulose-factories. The influence of bydrochloric acid from alkali-works is shown whenever the air contains 0.1 per cent., by a considerable increase in the chlorine in the leaves. They get brown or red edges, and eventually dry-up and fall. Chlorine acts similarly, but more energetically. Hydrochloric acid is very destructive to vegetation, sometimes forming dense clouds which, after escaping from Alkali-Works, settle on fields and kill whole patches of the crops in them; it is, however, on the whole less hurtful to woods and crops on a large scale, than sulphur dioxide, and the same may be said of the similar action of the oxides of nitrogen, and chlorine. Dr. Angus Smith gives the following comparative statement of acidity of air at different places in England:- 


\begin{tabular}{|c|c|c|c|c|}
\hline \multicolumn{2}{|r|}{ Locality. } & $\mathrm{HCl}$. & $\mathrm{SO}=$ & Reuırks. \\
\hline \multicolumn{2}{|c|}{ Blackpool, on the Lancashire eoast } & 100 & 100 & \multirow{5}{*}{$\begin{array}{l}\text { Dr. Sinith } \\
\text { gave the pro- } \\
\text { portions in } \\
\mathrm{SO}_{3} \text {, and } \pm \text { ths } \\
\text { of these are } \\
\text { giren here as } \\
\mathrm{SO}_{2} \text {. }\end{array}$} \\
\hline London & . & 320 & 282 & \\
\hline Minchester & $\cdot \quad \cdot$ & 396 & 410 & \\
\hline St. Helen's & $\cdot$ & 516 & 387 & \\
\hline Undergrounc & Railway (London) & 974 & 1243 & \\
\hline
\end{tabular}

In a field near Blackpool he found 20.27 grains of hydrochloric acid and $155^{\circ} 30$ grains of sulphur dioxide in $1,000,000$ cubic feet of air, and the quantities in the other places may be calculated from these figures.

Dr. Hamburger* states that he exposed leaves to the action of $n, \frac{n}{10}, \frac{n}{100}, \frac{n}{1000}$, and $\frac{n}{2000}$ of sulphuric and hydrochloric acids of equivalent strength, $n$ being a normal solution of 49 grammes of sulphuric acid, or $36 \frac{1}{2}$ grammes of hydrochloric acid in one litre of water.

The normal solution produced discoloration in about half an hour, yellowish-brown spots appearing in the middle of the leares and extending gradually over the whole surface. The $\frac{n}{10}$ took three hours before signs of destruction appeared. The $\frac{n}{100}$ acted in about a day, but the action of the sulphuric acid was stronger than that of hydrochloric acid. The $\frac{n}{1000}$ sulphuric acid produced discoloration in about a week, while the $\frac{n}{1000}$ hydrochloric acid required ten days to do so.

The $\frac{n}{2000}$ acid, equivalent to $24 \frac{1}{2}$ grammes of sulphuric acid or $18 \frac{1}{4}$ grammes of hydrochloric acid in 1,000,000 parts of water, seemed to have no action. Two greenhouse-plants were submitted to a daily spray of the $\frac{n}{2000}$ acid for a month, but showed no colrosion.

* Journal of the Society of Chemical Industry, 18s4, p. 205. 


\section{Damage done.}

(a) General Account.

Among the direct kinds of damage done by acid fumes to trees are:-loss of increment, thinning out of woods and formation of blanks, injury to fruit, especially in the case of orchardtrees, loss of fodder by destruction of grass in a forest; damage is done indirectly by rendering the woods liable to insectattacks, to fire and other dangers.

\section{(b) According to Species.}

Conifers suffer more from smoke than broad-leared species, even although the needles under similar conditions absorb less sulphur dioxide, and are in themselves less sensitive and hardier than other leaves. This is due to the longer duration of the needles and their consequently increased exposure to the bad influence of the gas, and to the greater powers of recorery possessed by broad-leaved species.

Thus, evergreen conifer's are not only longer exposed each year, but the evil accumulates from year to year, as long as the needles remain on the tree, whilst broad-leaved trees annually throw off their leaves.

Schröder* found that 1000 square centineters of leaf-surface, containing double that quantity above and below, will, within thirty-six hours, absorb sulphuric dioxide as follows:-

$$
\begin{aligned}
& \text { Silver-fir meedles (young) . . . . . } 1.8
\end{aligned}
$$

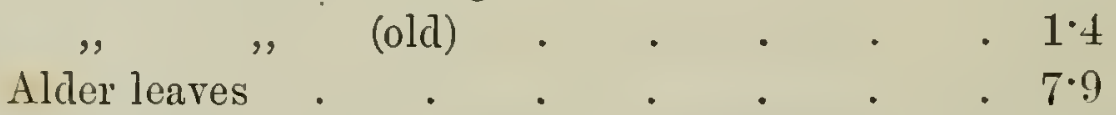

When exposed a second time the silver-fir needles absorbed $1 \cdot 6 \mathrm{c} . \mathrm{cm}$.

The following list gives the order of the sensibility of conifers to damage by smolie and fumes in Germany:-

Silver-fir, most susceptible.

Spruce.

Scotch pine.

Larch. In the British Isles, larch appears to suffer more than Scotch pine.

* Thar. Frstl. Jhrbch., vol. xxii., 1872, p. 193. 


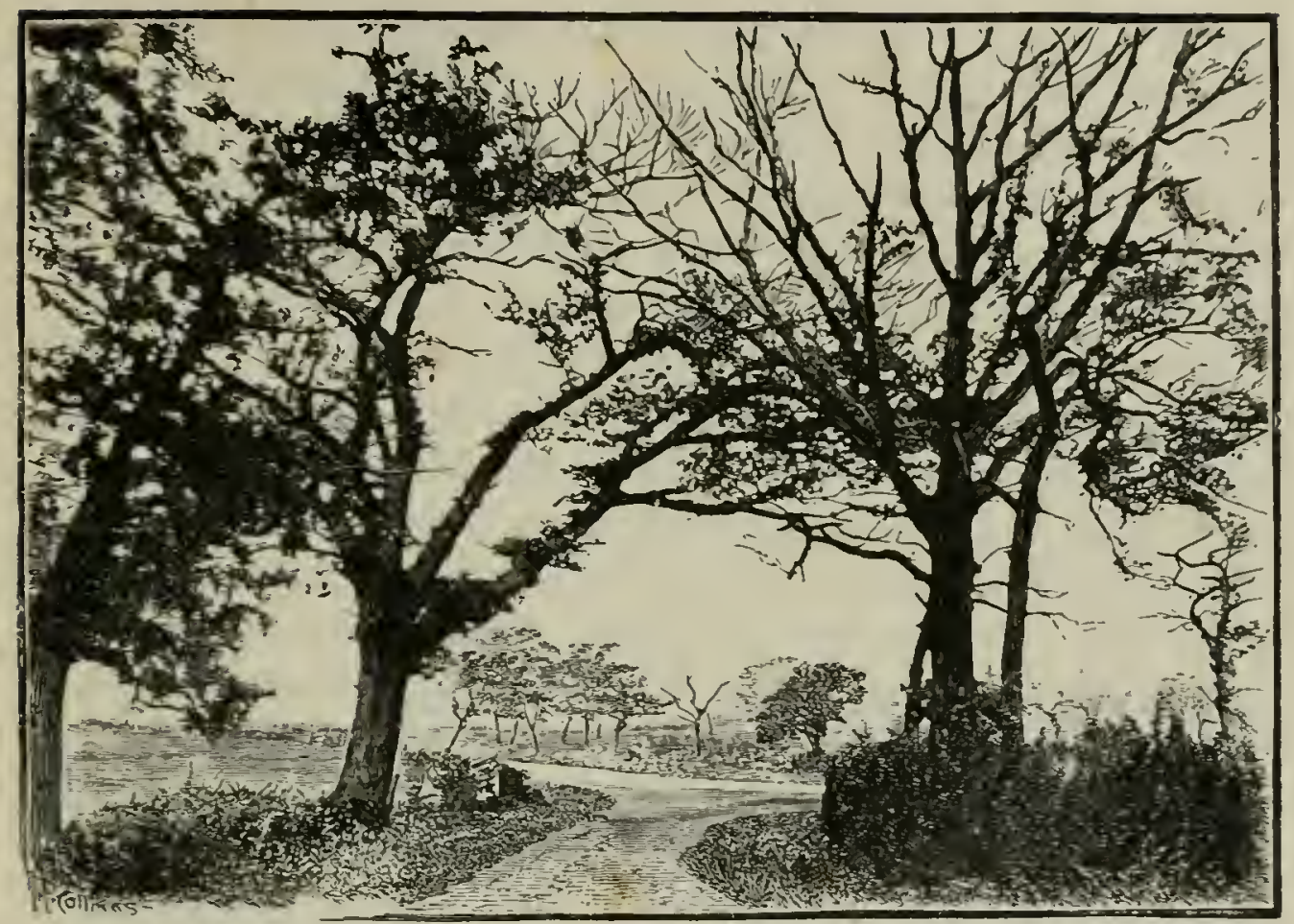

FIg. 258.-Oaks neur a manufacturing town, the foliage damaged by acid fumes. Photngraphed August, 1582.*

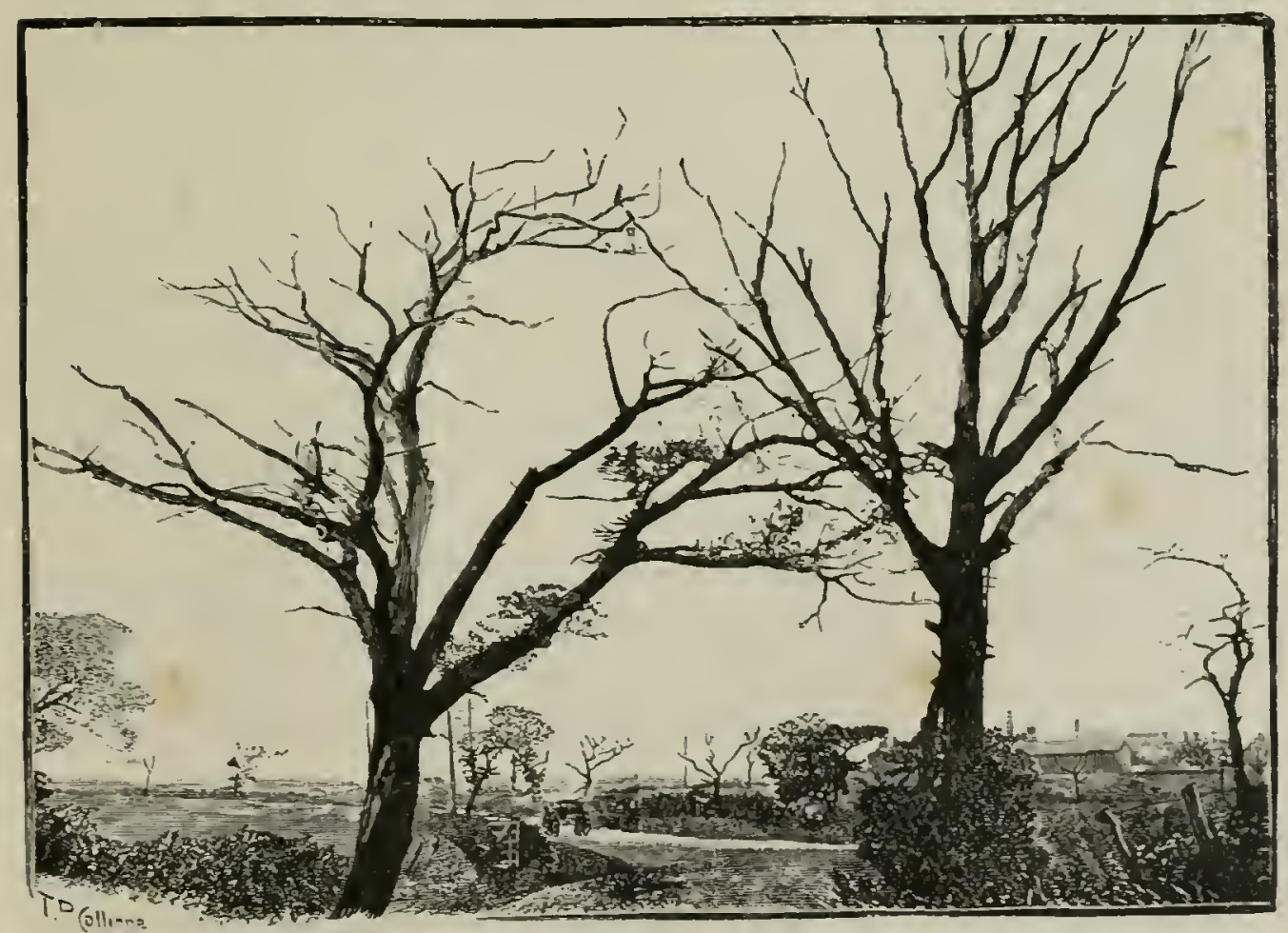

FIG. 259. - Same Oaks photograpined July, 1S88. Several years' cumulative injury having killed the trees.*

* From Croonian Lecture by Marshall Ward (vile p. 562). 
Webster* gives a list of trees and shrubs suitable for townplanting, but among conifers only mentions the deciduous Ginliyo biloba, or maidenhair tree, as flourishing in the worst smolie-infected parts of London, and Retinospor a plumosa anrea which has stood for seven year's in one of the most smoky districts of Glasgow, and looks almost as well as when brought from the country.

Miasters also recommends Ginligo biloba and Pinus excelsa.

J. W. Sowerby, the Secretary to the Royal Botanic Society of London, who has resided in the Botanic Gardens, Regent's Park, since 1842 , states that when the gardens were first laid out (1839-45), special mounds were made and planted with nearly all hardy species of conifers, and although the natural soil of the Gardens is a stiff yellow clay, suitable soil was furnished for the different trees: but at present (1595) only a few miserable plants remain, including five or six deodar's, and some yews, which last longest, but are now looking very bad.

The amount of damage done to broad-leaved trees depends not only on the susceptibility of the leaves, but also on the powers of recovery of each species, so that trees which unite least susceptibility to greatest powers of recovery will suffer least.

Schröder has drawn up the following list :-

Very susceptible: the beech.

Moderately so: hornbeam and birch.

Least: maples, ash, alder, and oak.

The immunity of oak is not, however, confirmed by English experience, and Marshall Ward states that oaks suffer greatly from acid fumes. Perhaps the German authorities refer to sessile oak, which is rare in England, where the pedunculate oak abounds.

A Belgian $t$ official report also considers the hombeam and oak as suffering most of all broad-leaved species from acid fumes and even places them above the larch in this respect.

Borggreve at Münden drew up a similar table to that of Schröder, in the following order :-

1. Silver-fir, spruce, Scotch pine.

* Practical Forestry, by Angus D. Webster. Rider and Son. 2nd edition. London 1895.

+ Rapport par la Commission d'Enquête relative à l'influence des Emanations acides sur la Végétation. Quoted by Dr. Angus Smith in an Appendix to Air and Rain. 
2. Beech, lime, poplar, alder, maples and ash.

3. Horubeam, aspen.

4. Oak (least susceptible).

According to Hess's * orn experiments elms (Ulmus montana and campestris) must be reckoued among resisting species.

The above grouping cannot always be relied on, as there are too many modifying factors in particular cases. London, with its constant coal-smoke and numerous factories and frequent dense sulphurous fogs, should gire better practical results as to the comparative powers of resistance of trees than any merely artificial laboratory experiments.

There are fine large flourishing plane-trees (Platanus orientalis, $\dagger$ L.) in Cheapside and on Ludgate Hill, which are entirely surrounded by tall buildings, and the plane is growing well on the Thames Embankment and in many parts of London. The fact that the plane-tree sheds large flakes of its bark annually, and that its buds are sheltered by its sheathing petioles probably contribute to its immunity.

The following account of the trees and shrubs which flourish in the Botanic Garden in Regent's Park, London, has been kindly supplied by J. W. Sowerby.

"Platanus occidentalis and several varieties between it and $P$. orientalis. Of the former there are many rery large trees. Maples of sereral species and varieties. Horse-chestnuts flower and fruit as well as in the country. Poplars of many species.: Elms, of which a belt surrounds the Gardens, and one old elm which was on the ground in 1838 is still healthy.

"Lime withstands smoke but suffers from green aphis and other pests, and looks shabby in early autumn, as the leaves fall early. Robinia thrives for $30-40$ years, but then dies gradually, perhaps owing to the cold clay soil of the Gardens. Two oaks remain small and scarcely grow, but have kept alive for over 50 years. Laburnum does well, and so do white and red thorns.

* Frstl. Blttr., 1574, p. 31.

$\dagger$ Masters and Webster recommend for town planting $P$. oricntalis accrifolic, which has less deeply divided leaves than the normal plant, and may be distinguished from $P$. occidcntalis, L. by the many fruit balls attached to its peduncles.

$\ddagger$ Populus canadensis, Desf. has a reputation in the Black Country for immunity from the effects of fumes. P. balsamiferc is growing well in St. James' l'ark. 
"Of shrubs Aucuba japonica is best and fruits freely, and so do several varieties of privet. Lilacs and box do well, and Mahonias fairly."

Webster adds the following to this list: species of Rhus and Cotoneaster, Virginia-creeper, ivy and the vine, besides Daplunc Laureola, L., Slimmea japonica, Ribes sanguineus, and Jasminum nudiflorum. He also gives a list of trees suitable for town-planting, which generally agrees with Sowerby's list, but also contains the following: Ailanthus glandulosa, Desf., Magnolia acuminata, Liriodendron tulipifera, Catalpa bigmonioides, Morus nigra, L. He states, however, that horsechestnuts, limes and elms soon show signs of distress when grown in smoky localities.

According to the Belgian official report, the black alder (Alnus glutinosa, Gaertn.), may be seen growing close to chemical works, and in situations very much exposed to acid fumes, but apparently suffering very little from them.

In planting avenues, or parks, in a crowded city, however, not only immunity from fumes has to be considered, but also the nature of the soil, the desirability of the tree and the amount of shade it gives, and whether it bears radiation of heat from the houses and streets. The poplar having a straggling crown and its branches being very brittle is not suitable, while limes, except Tilia argentia, and some other species, are liable to lose their foliage prematurely in hot dry summers. Probably the plane and sycamore are the best trees for the purpose. Of oaks probably the Turkey oak (Quercus Cerris, L.) is the only deciduous species which can at all resist the smoke of a large city. Quercus Ilex is termed by Masters a good town tree.

In the Black Country, near Wolverhampton, Dudley and Bilston, the air is at present not nearly so impure as was formerly the case when the shafts of the smelting furnaces were open, and the furnaces themselres much more numerous than at present. Dudley Park is exposed on the east to the acid fumes of smelting furnaces, and yet ash, poplar and sycamore trees are growing there fairly well with elder, white-thorn and hazel undergrowth, and beech appears on the western slopes of the Park, which are exposed to open comntry where there are no 
furnaces. Grass grows well enough in the Black Conntry, and there can be no reason why the large extent of uneven grassy land near Bilston (about 14,000 acres), where the coalfields have been worked out, the soil being weathered shale, should not be planted with trees, instead of remaining, as it is at present, a dreary waste. It is said that to level this land would. cost 100 per acre, but no levelling would be necessary, if it were to be planted up with trees, which grow well enough on similar land in Belgium.

There are Works at Bilston for galvanizing iron, and the molten zinc in which the sheets of iron are plunged is covered with chloride of ammonium to prevent its oxidising. The fumes given off during the process are said to kill all leaves of trees near the Works by June every year, but these fumes probably extend only for a short distance from the Works.

\section{(c) Age of Trees.}

Woods suffer from acid fumes at all ages, but poles 15-30 years old appear to suffer most.

\section{(d) Locality.}

The influence of the locality makes itself felt chiefly by the direction of the prevailing winds which bring the fumes towards the trees.

The Belgian Commission mentions 2000 meters as the greatest distance from chemical worlss, in the direction of the prevailing winds, at which damage was observed. In certain cases, however, woods have been injured at distances of $4 \frac{1}{2}$ miles from the Works, but naturally the amount of injury done varies inversely with the distance. Trees bordering on the wood, and especially on woods to the east and north-east of the Works, will suffer most. Even the smoke of locomotives in narrow valleys has proved prejudicial to trees on either side of a railway. Oliver states that the effects of London fog extend to 35 miles westward and that seedlings of Cucurbite and Tomatoes are thus killed at even that distance from London.

It has been observed, chiefly in the Oberharz, that woods growing on fertile soil resist acid fumes better than those on poor soils.

VOL. IV. 


\section{(e) Climate.}

Exposure to light and moisture are not without influence on the action of acid fumes. More damage is done by day than by night, when assimilation is arrested. Leaves suffer more when dew is resting on them than when they are dry. Thus the damage will be at its maximum after rain at midday, and at its minimum with cool nights and dry days. The damage during rainy weather, though more severe than in dry weather, does not extend far from the Works, as the rain speedily dissolves the fumes.

\section{(f) Sundry Circumstances.}

When older woods overshade an underwood, the former may protect the latter from damage by fumes, and trees standing above the general leaf-canopy of the wood, such as standards in High Forest or above Coppice, suffer most. The shelter afforded to crops and orchards by walls and hedges is also considerable.

\section{Remedial Measures.}

No thoroughly efficient measures have been devised against this evil. Tall chimneys, sometimes 500 feet high, indeed carry the fumes into the higher strata of the atmosphere, but it has been found that hydrochloric acid descends from them to the ground in dense clouds, and lays waste the vegetation at greater distances from the Works than before.

The best protective measure against hydrochloric acid is to get it condensed, as is now done in the British Isles under the Allkali Acts of 1863 and 1870, so that less than 1 per cent. of the acid generated in the Works escapes into the air.

There is more difficulty in dealing with the sulphur dioxide, and even the most perfect smoke-combustion cannot, free the air of it. Attempts have been made in Germany to convert it into sulphuric acid, but this removes only one-third of the injurious gas, and at Clausthal in Germany 1,250 tons of sulphur are annually sent into the air, greatly damaging the coniferous woods in the neighbourhood.

The forester in districts where hurtful fumes exist can therefore act only by planting protective belts of strong transplants 
of the most resisting trees in the direction of the factories, and managing them entirely by the Selection system. Under the shelter of these belts it will be better, if possible, to grow Coppice, or Coppice-with-Standards, which do not attain the height of High Forest.

As owners of woods injured by factory fumes can claim compensation in the Courts of Law, the question of estimating the damage done is of great importance.

In 1864 the Freiburg Worlss had to pay $£ 2,750$ compensation for damage done to vegetation. Estimates of the value of the damage must be made in accordance with the principles of Forest Valuation, and involve much difficulty. More will not be said on this subject here, but references are given below* to German books specially dealing with it.

* Kraft, Ueber die Berechnung der durch Hüttenrauch veranlassten Schädigung von Holzbeständen. Ztschrft. fr. Frst. 1.. Jgdw., 1887, p. 270. Rudnick, Id., 1889 , p. 417 .

END OF VOLUME IV. 



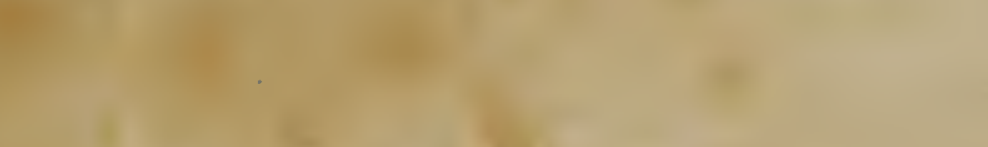

$4+5,1+2$

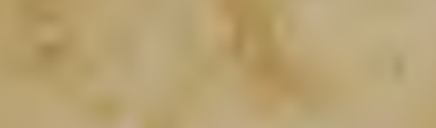

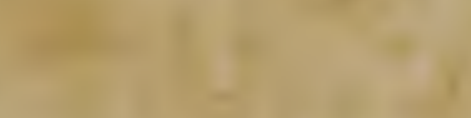
7

(1)

$4+5-1=0$

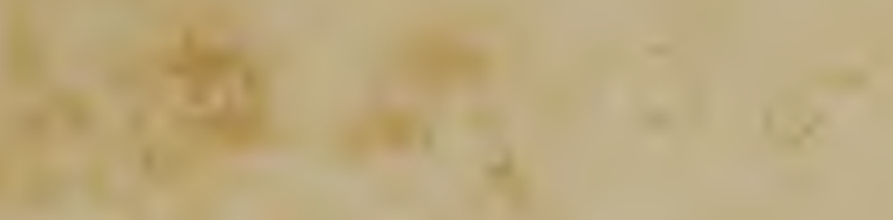
(1)
$\sqrt{2}$

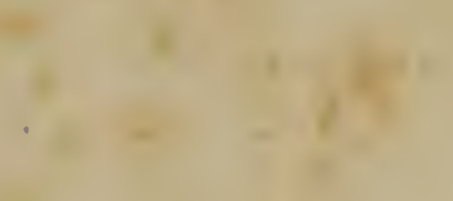

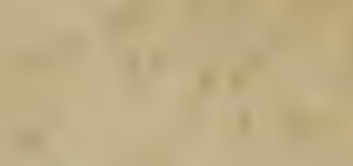

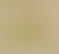

s.
$\sqrt{2+2}+2+2$
$4=$
$=$

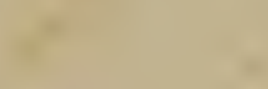

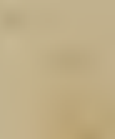

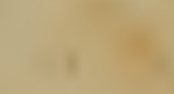
rent

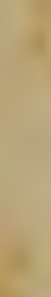

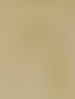

$+2$

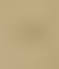

$x+20$

$-$

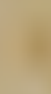

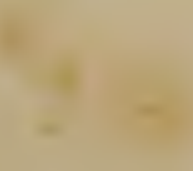

$\sqrt{2}$

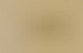

1

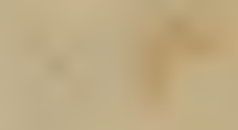

i

$=1+x+10$

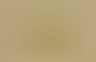

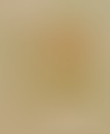

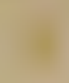

and - n 
S.

5.

1.

3.

3.

10.

M

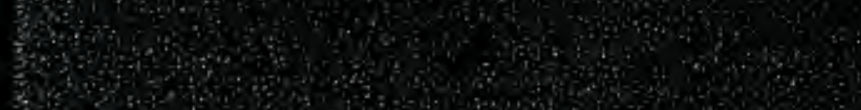

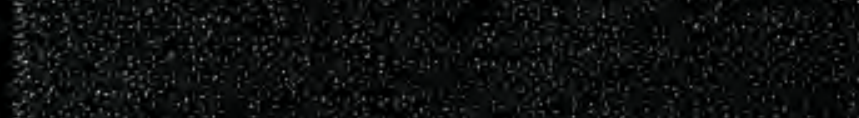

3. 0 -

40 are

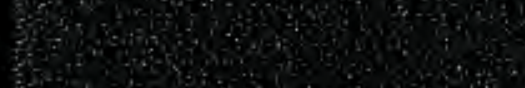

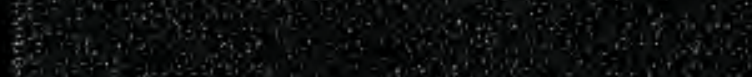

30 .

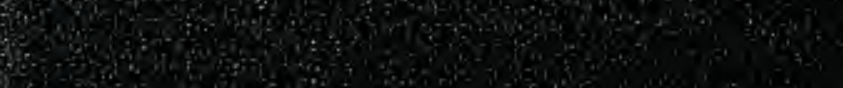

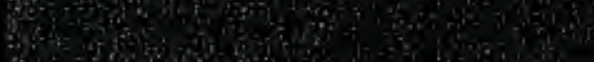

20.

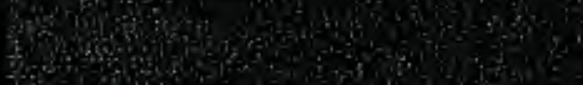

Whe

H. 